Waldemar Paruch

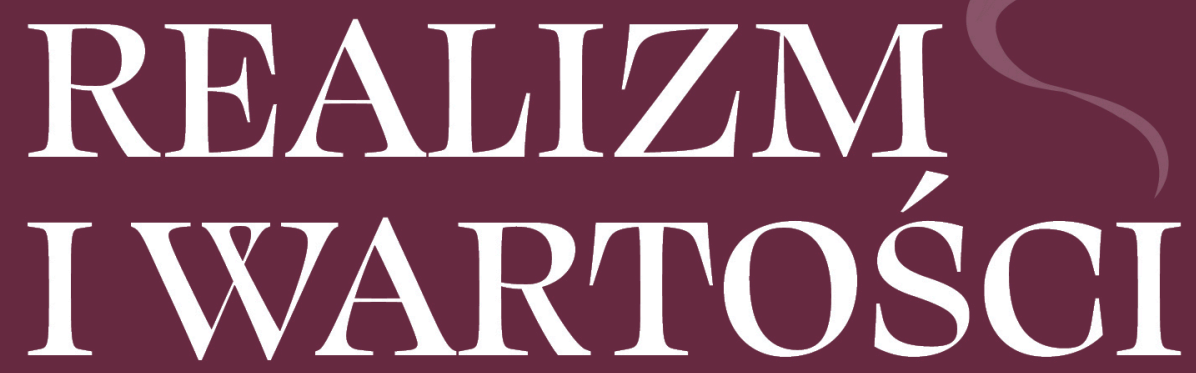

\title{
Prawo i Sprawiedliwość o polityce zagranicznej
}





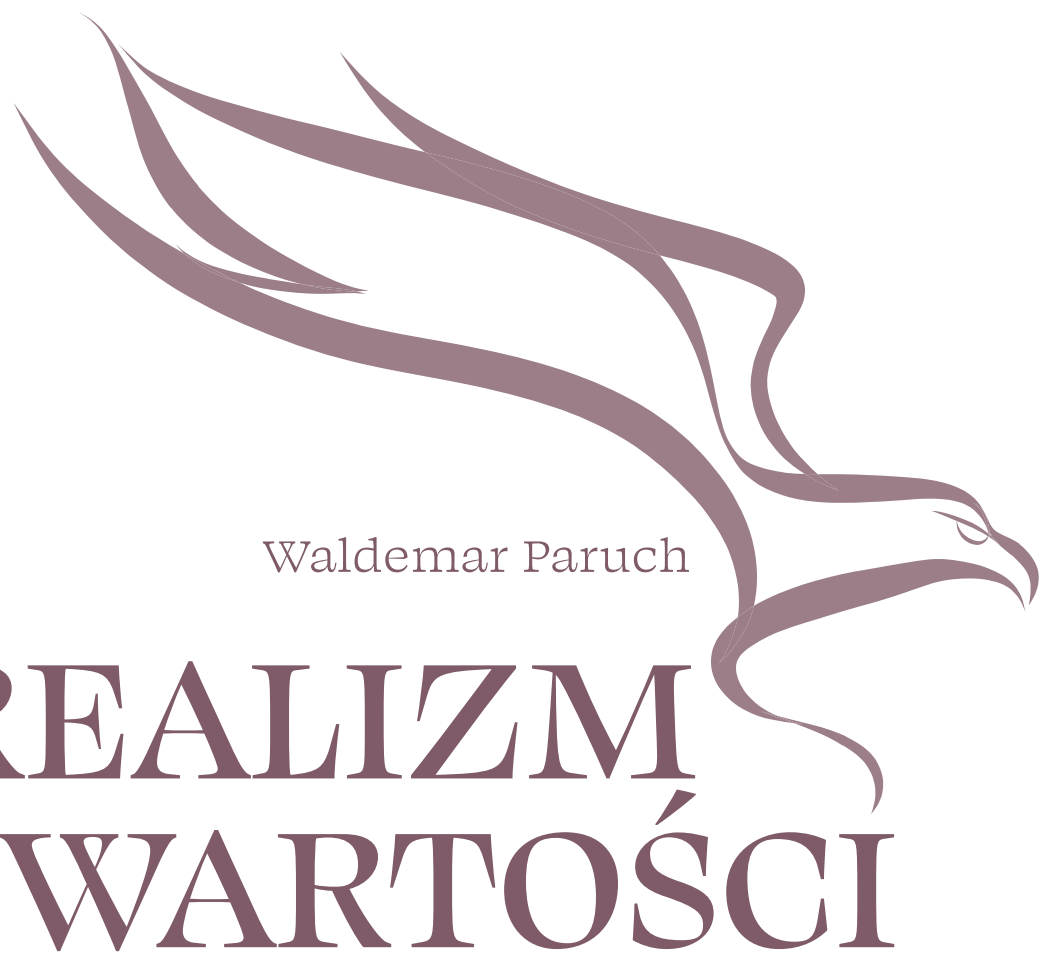

Prawo i Sprawiedliwość
o polityce zagranicznej 

Mojej Mamie w 90. rocznicę Jej urodzin 



\section{Spis treści}

Wstęp

Rozdzial 1

Paradygmat myśli politycznej

Prawa i Sprawiedliwości

1.1. Myślenie polityczne: polityczność i polityka 35

1.2. Przestanki teoretyczne i ideowe $\quad 89$

Rozdzial 2

\section{Polityka transatlantycka}

rzadów Prawa i Sprawiedliwości

2.1. Orientacja transatlantycka

2.2. Krytyka przeciwników politycznych

2.3. Zasady polityki transatlantyckiej

Rozdzial 3

\section{„Wprowadzenie sojuszu}

\section{Pólnocnoatlantyckiego do Polski”}

3.1. I faza polityki transatlantyckiej Prawa i Sprawiedliwości (2015-2016)

3.2. Il faza polityki transatlantyckiej Prawa i Sprawiedliwości (2017-2019)

Rozdzial 4

\section{Eurorealizm}

4.1. Podstawy eurorealizmu

4.2. Przestanki polityki europejskiej

4.3. Koncepcja Unii Europejskiej

\section{Zakończenie}

Bibliografia 
„Po pierwsze, miej zdefiniowany, jasno określony cel (ideal, zadanie). Po drugie, zdobadź potrzebne zasoby by do niego dojść; wiedzę, pieniądze, materialy, metody. Po trzecie, skieruj wszystkie te zasoby na osiagnnięcie celu".

Arystoteles

„Nigdy nie zmieniasz rzeczy, walcząc z istniejąca rzeczywistościa. Aby coś zmienić, zbuduj nowy model, który sprawi,że istniejący model stanie się przestarzaly".

Buckminster Fuller 


\section{Wstęp}

Dla myśli politycznej Prawa i Sprawiedliwości właściwy był odnoszący się do polityki dylemat, który ujął Lech Kaczyński: „polityka bywa sztuką dawania świadectwa, ale częściej jest sztuką osiągania realnych celów"1. Z analizy tych słów zrodził się tytuł tego opracowania - Realizm i wartości. Oddaje on istotę ważnego dla Prawa i Sprawiedliwości problemu o złożonym charakterze: aksjologicznym, politycznym i pragmatycznym, zawartym w pytaniu - kiedy następuje kolizja między wartościami tworzącymi paradygmat ideologii a wynikami analiz i diagnoz, w oparciu o które formułuje się cele możliwe do zrealizowania, oraz co powinien wybrać polityk identyfikujący się jako konserwatysta? Świadomość tej kolizji mieli i Jarosław Kaczyński, i Lech Kaczyński - liderzy tego stronnictwa. Ten pierwszy mówił do Jana Olszewskiego w okresie jego krótkich i burzliwych rządów w III Rzeczypospolitej: „Chcesz rządzić czy zdobywać sztandar?", tym samym zachęcając go do pragmatyzmu. Natomiast ten drugi w wywiadzie zastrzegał: „Nie można iść z dwiema chorągwiami przeciw transporterom opancerzonym" ${ }^{2}$, co było wezwaniem do realizmu. Jakże wiele w tych wypowiedziach tonów podobnych do przeświadczeń Józefa Piłsudskiego.

\footnotetext{
Ł. Warzecha, Lech Kaczyński. Ostatni wywiad, Prószyński i S-ka, Warszawa 2010, s. 273.

2 P. Zaremba, O jednym takim... Biografia Jarosława Kaczyńskiego, Czerwone i Czarne, Warszawa 2010, s. 362; O dwóch takich... Alfabet braci Kaczyńskich. Rozmawiali Michat Karnowski i Piotr Zaremba, Wydawnictwo M, Kraków 2010, s. 160.
} 
Wartości, bez konieczności rozważania kontrowersji definicyjnych, na użytek tej monografii zostały określone jako trwałe przekonania na temat pożądanych stanów końcowych lub zachowań, porządkujące je co do ważności. Tym samym stanowią one uogólnione i ustrukturyzowane standardy służące do wyboru między rozwiązaniami alternatywnymi, a także do usprawiedliwiania i oceniania ludzi, podmiotów, działań i wydarzeń ${ }^{3}$. Są niezbędne w polityce co najmniej z czterech powodów. Po pierwsze, warunkują dokonywanie skutecznej konsolidacji politycznej danej zbiorowości (współcześnie - narodu lub wyborców partii politycznej), co pozwala reprezentującemu ją państwu lub partii politycznej na uzyskanie statusu podmiotu politycznego zdolnego do podnoszenia swojego potencjału politycznego i przejmowania nowych zasobów zarówno na arenie wewnętrznej, jak i w środowisku międzynarodowym. Po drugie, wartości składają się na paradygmat ideologii, stanowiący rdzeń myśli politycznej, bez której dany podmiot nie uzyska trwałej tożsamości politycznej, lecz będzie sezonowym jedynie uczestnikiem gry politycznej. Ułatwiają także polityczne komunikowanie oraz rywalizację. Po trzecie, wartości przeniesione do polityki przez dany podmiot polityczny uzyskują cechę polityczności, czyli stają się polityczne, co nadaje im wyjątkową rolę - pozwalają dokonywać rozróżnienia na wrogów i sojuszników. Po czwarte, obrona wartości jest w polityce priorytetowa, chroni przed kapitulacją i nadaje sens polityce oraz pozwala kreować emocje. Jednak nie można zapominać o rachunku zysków i strat, a przede wszystkim należy uwzględnić możliwość poniesienia klęski, co chroni przed nadmiernym dogmatyzmem. Najprościej byłoby uznać, że pożą-

3 Definiowanie wartości politycznych (oraz w polityce), w tym o kontrowersjach, w: S. Feldman, Wartości, ideologia i strukturyzacja postaw politycznych, [w:] Psychologia polityczna, red. D. O. Sears, L. Huddy, R. Jervis, Wydawnictwo Uniwersytetu Jagiellońskiego, Kraków 2008, s. 435-461; J. H. Kołodziej, Wartości polityczne. Rozpoznanie, rozumienie, komunikowanie, Księgarnia Akademicka, Kraków 2011; C. Maj, Wartości polityczne w stosunkach międzynarodowych, Wydawnictwo UMCS, Lublin 1992. Analiza znaczenia wartości w myśli politycznej vide W. Paruch, Między wyobrażeniami a dziataniami. Wybrane aspekty przedmiotowe badań politologicznych nad myślą polityczna, „Polityka i Społeczeństwo” 2004, nr 1, s. 9-38. 
danym stanem jest sytuacja, kiedy cele wynikają z wartości, czyli politycy, formułując te pierwsze, kierują się przesłankami aksjologicznymi.

Niestety nie ma jednego porządku i hierarchii wartości, a dodatkowo we współczesnym świecie rozmyciu uległa definicja prawdy, nazywana przez Lecha Kaczyńskiego „dawaniem świadectwa”. Uznanie w naukach społecznych i humanistycznych znalazły tezy na temat prawdy Robina George'a Collingwooda i Ludwiga Wittgensteina, uzależniające ją od kontekstu historycznego (temporalnego), kulturowego, podmiotowego, a nawet sytuacyjnego i politycznego. Takie podejście oznacza faktycznie niepoznawalność rzeczywistości, w tym przypadku faktów. Przedmiotem poznania jest tylko percepcja, co nasyca nauki humanistyczne i społeczne subiektywizmem, a świat faktów czyni jedynie presupozycją myślową, własnymi wywodami autora - jak sugerował to już w XVIII wieku Giambattista Vico. Każdy fakt, a więc również każde zjawisko polityczne, jest opisywany z puntu widzenia autora opisu; ten punkt widzenia jest zawsze zewnętrzny wobec przedmiotu opisu. Nie jest możliwe oderwanie się ani od przedmiotu opisu, ani od własnych myśli .

Cechą charakterystyczną ładu aksjologicznego PiS, mającego fundamentalne znaczenie w myśli politycznej tego stronnictwa, jest przyjęcie założenia kanonicznego dla konserwatyzmu, że wartości należy chronić, gdyż są nieprzemijającym i obiektywnym składnikiem rzeczywistości politycznej, w której przychodzi żyć współczesnym. Chronić je przed nierzeczywistością, projektowaną przez różnego rodzaju rewolucjonistów, będących nosicielami nihilizmu ${ }^{5}$. Według J. Kaczyńskiego, patrząc z tej perspektywy, należy uznać, że ani państwo, ani prawo nie mogą być neutralne w sensie aksjologicznym. Jest to stan ułudy, sprzeczny z cechą polityczności, jaką charakteryzuje się rzeczywistość ${ }^{6}$.

4 Vide F. Fernández-Armesto, Historia prawdy, Wydawnictwo Zysk i S-ka, Poznań 1999, s. 207-246; R. G. Collingwood, Istota i cele filozofii historii, „Roczniki Filozoficzne” 2018, nr 4(66), s. 153-173; B. Kaluziński, Idea prawdy jako korespondencji w filozofli późnego Wittgensteina, „Diametros”, wrzesień 2012, nr 33, s. 20-39; M. Stelmach, Charakter i podstawy "metanauki" Ludwiga Wittgensteina, "Zagadnienia Naukoznawstwa” 2011, nr 1, s. 75-85.

5 R. Legutko, Trzy konserwatyzmy, http://www.omp.pl, dostęp 11 VI 2020.

6 Konwencja konstytucyjna Prawa i Sprawiedliwości, PiS, Warszawa 2003, s. 6. 
Chcąc zrozumieć rolę wartości w myśli politycznej PiS, należałoby odnieść się do polityki w sensie arystotelesowskim, kiedy przypisuje się jej walory edukacyjne, obywatelskie i etyczne, można by rzec republikańskie. Polityka ma być ukierunkowana na dobro publiczne i ma wynikać z wartości. Katalog wartości jest zaś „transcendentny” dla jednostki, pochodzi z przeszłości, został przekazany przez poprzednie pokolenia, podobnie jak to mniemali starożytni Rzymianie. Wszelkie nowości w tej materii są co najmniej podejrzane, mogą bowiem oznaczać chaos i upadek, a na pewno rozchwianie ładu społecznego i porządku moralnego, które są ostoją dla wspólnoty. Klasyczne myślenie o polityce zostało zaburzone w myśli politycznej PiS przez recypowanie do niej polityczności, co stało się przyczyną sięgnięcia po paradygmat realistyczny, gdyż to on wydawał się najlepszym narzędziem do opisywania rzeczywistości politycznej zdominowanej przez konflikty, polaryzację i konsolidację. Jak pisał Zdzisław Krasnodębski: „To nie Jürgen Habermas, lecz Carl Schmitt wyraża obecnie ducha czasu. Obserwujemy nie tyle kształtowanie się "postnarodowej konstelacji «, co ożywienie relacji "wróg-przyjaciel» jako podstawowej zasady strukturalizującej polityczne działania"7. Nacisk na przywrócenie w Polsce polityczności do debaty publicznej jest wyróżnikiem myśli politycznej PiS, co stawia ją na przeciwległym biegunie do współczesnego liberalizmu, opowiadającego się za depolityzacją społeczeństwa, wyeliminowaniem ideologii, religii i prawdy z polityki, a to jest istotą postpolityki oraz podstawową przesłanką dla antypolityki. Ten biegunowy podział dobrze scharakteryzował Krasnodębski, pisząc o dwóch grupach polityków: jedna traktuje Polaków jako wspólnotę polityczną, uprawnioną do decydowania o sprawach wewnętrznych, i suwerenną poprzez swoje państwo w stosunkach międzynarodowych, druga postrzega Polaków jako grupę etnicznokulturową, zamieszkującą określone europejskie terytorium i działającą poprzez Unię i wewnątrz Unii ${ }^{8}$.

Z. Krasnodębski, Drzemka rozsądnych. Zebrane eseje i szkice, Ośrodek Myśli Politycznej - Wyższa Szkoła Europejska im. ks. Józefa Tischnera, Kraków 2006, s. 268-269.

8 Ważny tekst prof. Krasnodębskiego w "Rzeczach Wspólnych”. Wielkie spetnienie, czyli postliberalizm po polsku, 8 II 2012, http://www.wpolityce.pl, dostęp 12 VI 2020; 
Trudno jest także zaakceptować dwa poglądy ocenne obecne w piśmiennictwie. Pierwszy, że wierność wartościom jest utożsamiana z idealizmem i wyklucza pragmatyzm. Drugi, że myśl polityczna w zakresie polityki zagranicznej danego podmiotu politycznego może być syntezą realizmu i idealizmu. Odrzucam oba poglądy. Realizm jest na kursie kolizyjnym z idealizmem. Czy uznanie państwa i jego racji stanu za podstawowe wartości ukierunkowujące politykę zagraniczną, czy też poszukiwanie w rzeczywistości politycznej jej istoty oraz mechanizmów rozwoju ukrytych przed zmysłami może być przejawem idealizmu? Odpowiedź na oba pytania musi być negatywna. Kluczem do rozwiązania tych zależności jest zdefiniowanie realizmu w odniesieniu do środowiska i stosunków międzynarodowych. Politycy realiści wykluczają bowiem dogmatyzm, a kładą nacisk na kwestie poznawcze i ontologiczne, czyli odpowiadają na pytania: co poznawać i jak poznawać? Przyjąłem, że realizm (podejście realistyczne) jest sposobem ustosunkowania się podmiotu do rzeczywistości, czyli zestawem poglądów. Ma charakter zawsze normatywny - ukierunkowuje myślenie, w tym polityczne, niekiedy perswazyjny - wyjaśnia i interpretuje oraz racjonalizuje sądy o rzeczywistości i stosunkach społecznych.

Złożoność opisanych zależności powodowała, że cechą charakterystyczną myśli politycznej PiS było bardzo trudne balansowanie między realizmem a wartościami, zwłaszcza w sytuacjach międzynarodowych oraz z zakresu decydowania politycznego, uznawanych przez politologów za niepewne. Z jednej strony z założeń poznawczych i ontologicznych wynikał swoisty kult realizmu, gdyż tylko taką postawę intelektualną uważano w PiS za racjonalną, a z drugiej strony z konserwatywnego podejścia do przeszłości Rzeczypospolitej i historii Polaków powstał imperatyw kierowania się w polityce wartościami. PiS chciało być w nowych warunkach depozytariuszem wielkich polskich czynów niepodległościowych, w tym tradycji solidarnościowej. Dlatego też wielokrotnie mówiono, że obowiązkiem III Rzeczypospolitej jest sięgnięcie po misję 
ukształtowaną w przeszłości zarówno staropolskiej, jak i najnowszej, antykomunistycznej. Powstała więc dysharmonia w myśleniu politycznym PiS. Przekonaniu, że w poliarchicznym środowisku międzynarodowym państwa kierują się racją stanu i interesem narodowym towarzyszyło oczekiwanie, że stosunki międzynarodowe będą oparte na takich wartościach, jak solidarność, godność i prawda. W tym tkwi sprzeczność.

Problemem zasadniczym dla badań politologicznych myśli politycznej PiS są skutki rywalizacji politycznej w Polsce, zwłaszcza po 2005 roku, kiedy wyjątkowo ważnym składnikiem bezpardonowej walki o władzę było kreowanie przez stronnictwa wrogie wobec partii Jarosława Kaczyńskiego, przy zasadniczej roli środków komunikacji społecznej o proweniencji liberalno-lewicowej, jaźni odzwierciedlonej tej partii, niemającej żadnego osadzenia w danych źródłowych. Główne cztery cechy tejże jaźni wskazał badacz systemu partyjnego w Polsce Artur Lipiński: 1) oskarżanie PiS o autorytaryzm i łamanie zasad demokracji oraz dążenie do monopolu władzy, mające swoje uzasadnienie w osobowości prezesa Kaczyńskiego; 2) narzucanie przez lidera stronnictwa oraz innych czołowych przywódców konfliktowości debacie publicznej, generującej podziały społeczne; 3) przypisywanie PiS populizmu i nacjonalizmu; 4) postrzeganie licznych programów partii jako przejawów ulegania ideologii socjalistycznej ${ }^{9}$. Należałoby jeszcze dodać dwie kolejne cechy. Piątą odnoszącą się do polityki zagranicznej postulowanej i realizowanej przez PiS - przypisywanie jej takich przymiotów, jak: antyeuropejskość, dyletanctwo, konfliktowość, antyrosyjskość, antyniemieckość. Rzecz wielce charakterystyczna, że w kontekście wyjaśniania okoliczności katastrofy smoleńskiej oraz po 2015 roku, kiedy PiS przejęło odpowiedzialność za politykę zagraniczną Rzeczypospolitej, antyrosyjskość w jaźni odzwierciedlonej kreowanej w odniesieniu do PiS przez tzw. opozycję totalną została zastąpiona oskarżeniami o prorosyjskość. Polityka zagraniczna prowadzona przez rządy Zjednoczonej Prawicy miała być korzystna dla Putina i interesów rosyjskich oraz miała być realizacją „scenariuszy ro-

9 A. Lipiński, Prawica na polskiej scenie politycznej w latach 1989-2011. Historia, organizacja, tożsamość, Dom Wydawniczy Elipsa, Warszawa 2016, s. 336-337. 
syjskich"10. Przytoczone określenia, o ile oddają charakter unicestwiający konfliktów politycznych we współczesnej Polsce, o tyle ich obecność w opracowaniach naukowych wyklucza naukowość takich sądów, ponieważ nie tylko, że nie mają żadnego osadzenia w źródłach adekwatnych do badania myśli politycznej i decydowania politycznego w odniesieniu do PiS, ale również przeczą logice i racjonalności, będąc wyrazem przede wszystkim emocji. Szóstą cechą przypisywaną myśli politycznej PiS, zwłaszcza w kontekście międzynarodowym, jest anachroniczność w postaci posługiwania się kategoriami dziewiętnastowiecznymi. W tej kwestii pojawia się jednak zasadniczy problem - w myśli politycznej PiS jest wiele zapożyczeń z wiedzy politologicznej i socjologicznej i to całkiem współczesnej. Te zapożyczenia dezawuują opinie o anachroniczności.

Opisany problem można by zapewne uznać jedynie za wyraz walki politycznej toczonej w Polsce w ramach reguł demokratycznych i systemu partyjnego silnie spolaryzowanego o rywalizacji odśrodkowej, gdyby nie dwa następstwa: pierwsze - polityczne, drugie - poznawcze. Kreśląc taką jaźń odzwierciedloną PiS, politycy liberalni najpierw w latach 2007-2015 dążyli za jej pomocą do zmarginalizowania stronnictwa, a następnie w okresie 2015-2019 wypracowali formułę opozycji totalnej wobec legalnych władz Rzeczypospolitej z nominacji PiS, dezawuując je na arenie międzynarodowej (strategia „ulica i zagranica"11). Następstwem tych działań liberałów (przede wszystkim polityków reprezentujących Platformę Obywatelską i Nowoczesną - dwie partie uznające się

10 Vide wypowiedź Tomasza Nałęcza „PiS realizuje rosyjski scenariusz", 20 I 2011, http:// www.wprost.pl, dostęp 9 VIII 2020.

11 Rodowód i rozwój określenia „ulica i zagranica” w: Z. Nosowski, Zawrotna kariera „ulicy i zagranicy", 5 IV 2018, http://www.wiez.com.pl, dostęp 15 VI 2020. Niestety autor błędnie (nierzetelnie i wyraźnie intencjonalnie) przypisał politykom prawicy sięgnięcie po stowa Zenona Kliszki. Pierwszym miał być w marcu 2016 roku Marek Jurek. Autor całkowicie pominął programowe wystąpienie Grzegorza Schetyny z 2015 roku, który mówit do aktywistów PO przed wyborem na przewodniczącego partii: „naszą aktywnością będzie ulica na pewno. A także Europa". Uczynił z tych słów dewizę swojej strategii przeciwko PiS oraz wobec innych partnerów politycznych. Zachowanie w tej kwestii polityków PiS było wtórne. "Newsweek" ma nagrania Schetyny. "Naszą aktywnością będzie ulica, wyprowadzimy milion ludzi", 3 | 2016, http://wiadomosci.wp.pl, dostęp $12 \mathrm{VI} 2020$. 
za liberalne) było spetryfikowanie myślenia ich wyborców o PiS (także wielu naukowców zaliczających się otwarcie do tego elektoratu). Drugie następstwo jest widoczne w licznych opracowaniach naukowych, których autorzy, wbrew zasadom kwerendy i interpretacji źródeł, opisują PiS, albo w ogóle nie korzystając ze źródeł prymarnych, a jednocześnie woluntarystycznie podchodząc do rzeczywistości politycznej, albo sięgając jedynie do źródeł wytworzonych przez polityków i dziennikarzy będących w skrajnej opozycji wobec PiS. Wartość poznawcza takich opracowań jest znikoma, niemniej są one wykorzystywane w rywalizacji politycznej. Potwierdzają jak najbardziej tezę Michała Wendlanda, że każdy badacz przynależy do określonej zbiorowości, w tym politycznej, co determinuje jego decyzję o wyborze bazy źródłowej oraz interpretacji źródeł, a tym samym powiela on (a niekiedy uzasadnia) wyobrażenia zbiorowe $^{12}$. Do chlubnych wyjątków w nielicznej literaturze przedmiotu z zakresu współczesnej polskiej konserwatywnej myśli politycznej (pomijam publikacje o polityce zagranicznej Polski w pierwszych dekadach XXI wieku) mogę zaliczyć opracowania: Joanny Saneckiej-Tyczyńskiej, Krzysztofa Zuby, Andrzeja Nowaka, Agnieszki Orzelskiej-Stączek, Krzysztofa Szczerskiego, Jacka Kloczkowskiego, Pawła Kowala, Lecha Rubisza, Przemysława Żurawskiego vel Grajewskiego ${ }^{13}$.

Natomiast źródła różnego typu wykorzystane w tej monografii (podział w Bibliografii) pozwoliły na analizowanie faktów i procesów politycznych, w tym konkretnym przypadku myśli politycznej - ideologii, koncepcji i programów, oczywiście zgodnie z ograniczeniami wynikającymi z danych czasów historycznych, w których żyją twórcy i nosiciele myśli politycznej PiS oraz jej badacze, w tym autor. W przyszłości kolejne pokolenia naukowców będą je odczytywać odmiennie, bogatsi o wiedzę co do następstw określonych zjawisk politycznych oraz wyposażeni w nowe metody i środki poznania. W procesie badawczym uzyskujemy więc dostęp do przeszłości w drodze analitycznej, wbrew temu,

12 M. Wendland, Filozoficzne i metodologiczne podstawy historii komunikacji, Wydawnictwo Naukowe UAM, Poznań 2014, s. 365.

13 Wykaz publikacji wymienionych autorów w dziale Bibliografia. 
co sądzą zwolennicy postnowoczesności, narratywizmu i interpretacjonizmu $^{14}$. Dokonany w naukoznawstwie w ostatnich dekadach XX wieku "zwrot lingwistyczny" należy traktować jako jedynie nakierowanie uwagi na znaczenie interpretacji tekstu oraz rolę czynników subiektywnych w badaniu naukowym, np. przynależności grupowej naukowców. Nadal obowiązuje dyrektywa sformułowana w połowie poprzedniego wieku przez Carla G. Hempla, że naukowe wyjaśnianie polega na stawianiu hipotez podlegających argumentacji i falsyfikacji oraz teorii mających moc wyjaśniającą i prognostyczną. Opracowanie naukowe nie jest - jak chciałby Hayden White - jedynie „werbalną fikcją", ale - jak pisał Henryk Samsonowicz - weryfikacją faktów za pośrednictwem źródeł w sposób jak najdokładniejszy, wiarygodny i ścisły, z wykorzystaniem technik uznawanych w danym czasie za naukowe ${ }^{15}$. Gdyby nauka była jedynie konstruktem o charakterze narracyjnym, to straciłaby walory prognostyczne i utylitarne, a politologia stosowana nie miałaby sensu - natomiast w ostatnich dekadach odgrywa coraz ważniejszą rolę w polityce, w procesach wyborczych i decyzyjnych.

W odniesieniu do myślenia politycznego, którego owocem są idee, wiedza jest jedynie prawdopodobna, gdyż przedmiot poznania często wymyka się analizie, jednocześnie jest bowiem tworzeniem polityki oraz refleksją nad nią, czyli ma podwójny charakter - przedmiotowy (polityka w sensie ogólnym i szczegółowym) i metaprzedmiotowy (polityka w sensie filozoficznym). Taka jest jego natura, którą dobrze uchwycił

14 Czołowi twórcy narratywizmu Franklin Ankersmit i Hayden White vide K. Gaczot, Narratywizm historyczny Haydena White'a w badaniach nad historią prawa, "Folia luridica Universitatis Wratislaviensis" 2018, vol. 2(7), s. 87-110; E. Domańska, Historia egzystencjalna. Krytyczne studium narratywizmu i humanistyki zaangażowanej, Wydawnictwo Naukowe PWN, Warszawa 2012; J. Węgrzecki, Teoria polityki - powszechność interpretacjonizmu na przykładzie rekonstrukcji, „Teoria Polityki” 2020, nr 4, s. 109-120; F. Ankersmit, Narracja, reprezentacja, doświadczenie. Studia z teorii historiografii, Universitas, Kraków 2004; H. White, Poetyka pisarstwa historycznego, red. E. Domańska, M. Wilczyński, Universitas, Kraków 2000.

15 H. Samsonowicz, O "historii prawdziwej". Mity, legendy i podania jak źródło historyczne, Novus Orbis, Sopot 1997, s. 15. 
Glenn Tinder w klasycznym już opracowaniu Myślenie polityczne ${ }^{16}$. Bardzo wiele zależy od interpretacji śladów i świadectw myśli politycznej; ta interpretacja może być stronnicza. Decyduje w tej kwestii jedno ważne założenie, będące odpowiedzią na pytanie: czy twórca myśli politycznej, wytwarzając źródła, nadawał im sens przede wszystkim socjotechniczny i propagandowy, czy raczej przekazywał swoje poglądy? O ile takie założenie można przyjąć co do świadectw (programy, oficjalne wystąpienia, pamiętniki, wspomnienia, wywiady), o tyle jest ono błędne wobec śladów, czyli opisów podjętych decyzji. Oczywiście musimy pamiętać, że świadectwa mogą charakteryzować się niską wiarygodnością, dla polityków są bowiem środkiem wykorzystywanym w komunikowaniu politycznym z wyborcami i potomnymi. Mają więc charakter znaków w komunikowaniu politycznym, niekiedy są intencjonalnie mocno skażone albo chęcią zwiększenia poparcia społecznego w kontekście wyborów i sondaży (np. programy i wywiady), albo wolą oddziaływania na pisarstwo historyczne (np. wspomnienia i pamiętniki). Poprzez świadectwa politycy opowiadają o własnych poglądach, dokonują autoidentyfikacji, prezentują swoje opinie na dany temat, ale przede wszystkim starają się oddziaływać na potencjalnych czytelników. W odniesieniu do PiS źródeł typu świadectwa jest stosunkowo dużo. Bardzo często czołowi politycy PiS, tacy jak Jarosław Kaczyński, Lech Kaczyński, Andrzej Duda, Krzysztof Szczerski, Anna Fotyga, Witold Waszczykowski, Zdzisław Krasnodębski, Jacek Czaputowicz, Marek Kuchciński, Antoni Macierewicz, wypowiadali się o stosunkach międzynarodowych i polityce zagranicznej. Partia starała się także przed każdymi wyborami prezentować kolejne odsłony programów politycznych, które bardzo często były pogłębionymi analizami rzeczywistości politycznej, zawierały odwołania do wartości, zapis de-

16 G. Tinder, Myślenie polityczne. Odwieczne pytania, Wydawnictwo Naukowe PWN, Warszawa 2003, passim. Confer rozważania: J. Reykowski, Myślenie polityczne, [w:] Podstawy psychologii politycznej, red. K. Skarżyńska, Wydawnictwo Zysk i S-ka, Poznań 2002, s. 110; S. Gałkowski, Barbarzyńcy i obywatele. Myślenie polityczne wobec wartości, Wydawnictwo KUL - Krakowska Akademia im. Andrzeja Frycza Modrzewskiego, Lublin 2012, s. 8. 
klarowanych celów, a zarazem propozycje podjęcia stosownych działań w stosunkach społecznych.

Natomiast w odniesieniu do PiS mamy również do dyspozycji ślady po działalności tej formacji (oznaki), kiedy ugrupowanie to dwukrotnie sprawowało w Polsce władzę, w tym realizowało politykę zagraniczną (2005-2007, 2015-2019). Między tymi dwoma okresami jest ścisła łączność. Owszem, oznak, w odróżnieniu od znaków myśli politycznej PiS, nie ma zbyt dużo z powodów politycznych, gdyż nadal nie są ujawniane okoliczności podejmowanych wówczas decyzji, tym bardziej że czołowi liderzy formacji wciąż uczestniczą w bieżącej polityce (chociażby J. Kaczyński, M. Kuchciński, K. Szczerski, A. Duda, A. Fotyga). Nie można zrozumieć polityki zagranicznej Polski realizowanej przez prezydenta Andrzeja Dudę oraz kolejne gabinety Beaty Szydło i Mateusza Morawieckiego, nie odwołując się do dorobku prezydenta Lecha Kaczyńskiego oraz dwóch kolejnych rządów z okresu 2005-2007: Kazimierza Marcinkiewicza oraz Jarosława Kaczyńskiego ${ }^{17}$. W odniesieniu do polityki zagranicznej projektowanej przez PiS dominowała kontynuacja, nie zaś zmiana, a na pewno nie było zerwania. PiS nie kierowało się w tej materii także wynikami sondaży, czy też poglądami przypisywanymi większości Polaków. Koncepcja polityki zagranicznej realizowanej w latach 2005-2007 została znacznie uszczegółowiona w czasie bycia w opozycji, zwłaszcza w latach 2010-2015, kiedy wokół prezesa Kaczyńskiego powstało środowisko analityczno-eksperckie, później wchłonięte w sensie politycznym przez obóz rządzący po wygranej w 2015 roku.

17 Biorąc pod uwagę cztery gabinety tworzone przez PiS w okresach 2005-2007 i 20152019 oraz szefów tych gabinetów i właściwych im ministrów spraw zagranicznych, należy zauważyć znaczne dysproporcje we wpływie na koncepcję PiS dotyczącą polityki zagranicznej Polski istniejące między poszczególnymi premierami i ministrami spraw zagranicznych. O ile M. Morawieckiego, B. Szydto, A. Fotygę, W. Waszczykowskiego i J. Czaputowicza można uznać za miarodajnych wyrazicieli myśli politycznej PiS, o tyle nie można tego powiedzieć ani o K. Marcinkiewiczu, ani o S. Mellerze, którzy byli raczej wykonawcami linii strategicznej partii niż jej istotnymi kreatorami. Z perspektywy lat prawdopodobny jest wniosek, że dwaj ostatni z wymienionych bardzo stabo identyfikowali się z działalnością ideotwórczą całej formacji. 
W odniesieniu do analizy myśli politycznej PiS obowiązywała w tej pracy dyrektywa metodologiczna, którą trafnie wyraził Janusz Węgrzecki: „selekcja tekstów dotyczących wybranego przedmiotu badań, jak i wydobycie sensu poszczególnych tekstów oraz całościowego sensu zanalizowanej myśli wiąże się ściśle z interpretacją. [...] koncepcja interpretacji jako rekonstrukcji ma charakter krytycznego ujęcia badanego przedmiotu. Sytuuje się zatem w ramach korespondencyjnej teorii prawdy. To przedmiot - prawda - wytycza kierunek badań i jest przynajmniej częściowo osiągalna"18. Niech moja autorska interpretacja dokonana w monografii stworzy przestrzeń do kolejnych interpretacji, co pozwoli lepiej poznać przedmiot - myśl polityczną PiS. Ustalenia dokonane w tym opracowaniu nie mogą być traktowane jako definitywne, wymagają bowiem dalszych pogłębionych badań. Są pierwszą kompleksową propozycją odpowiedzi na kilka ważnych pod względem poznawczym pytań.

Stosunkowo mało użyteczne dla badania myśli politycznej PiS są opracowania biograficzne, a konkretnie jedno o Lechu Kaczyńskim, autorstwa zespołu powstałego wokół Sławomira Cenckiewicza. Autorzy skoncentrowali swoją uwagę na danych biograficznych, natomiast niemal całkowicie pominęli myślenie polityczne oraz jego efekty w odniesieniu do "swojego" bohatera ${ }^{19}$. W polskim piśmiennictwie naukowym zastanawiający jest też brak solidnych opracowań tego typu o Jarosławie Kaczyńskim ${ }^{20}$.

Zajmujące poznawczo byłyby również studia nad tzw. przemysłem pogardy, który miał znaczenie nie tylko dla polityki, ale także dla badań naukowych. Liberałowie, inspiratorzy stosowania tego rozwiązania w strategii politycznej, zaostrzali swój stosunek do partii kierowanej przez J. Kaczyńskiego ze względu na jej pozycję w systemie politycznym

18 J. Węgrzecki, op. cit., s. 120.

19 Lech Kaczyński. Biografia polityczna 1949-2005, S. Cenckiewicz i inni, Wydawnictwo Zysk i S-ka, Poznań 2013; S. Cenckiewicz, A. Chmielecki, Prezydent. Lech Kaczyński 2005-2010, Wydawnictwo Fronda, Warszawa 2016.

20 Trudno za takie opracowania uznać: M. Krzymowski, Jarosław. Tajemnice Kaczyńskiego, Ringier Axel Springer Polska, Warszawa 2015; R. Krasowski, Czas Kaczyńskiego. Polityka jako wieczny konflikt, Czerwone i Czarne, Warszawa 2016. 
(rządzenie-opozycja). Kiedy Kaczyński był w opozycji, niekiedy głębokiej po przegranych wyborach prezydenckich i parlamentarnych w latach 2010-2011, negowano wygłaszane przez niego parezje - wypowiedzi trafnie opisujące rzeczywistość polityczną, ale uderzające w liberalną formułę legitymizacji władzy w Polsce, tym bardziej że po kilku latach wyrażane przez niego opinie stawały się obowiązujące w diagnozowaniu stosunków społecznych. Natomiast po wygraniu wyborów przez PiS i przejęciu władzy w 2005 i w 2015 roku, liberałowie przechodzili do opozycji, która dezawuowała prawomocność rządów, mimo ich demokratycznej legitymacji, odrzucali bowiem zasadę alternacji władzy. Bracia Kaczyńscy oraz inni politycy PiS nie ukrywali w kampaniach wyborczych w latach 2001-2005 i 2009-2019, że ich celem było podważenie status quo w postaci III Rzeczypospolitej i „systemu Tuska”, budowa IV Rzeczypospolitej i dokonanie „dobrej zmiany”; opisywana w programach rzeczywistość była bowiem przez nich oceniana jako zło, które należy odrzucić.

Ważnym wyjaśnieniem kategorialnym jest przyjęcie w monografii trzech tez (bez przeprowadzania dowodu). Pierwsza - identyfikacja partii politycznych w oparciu o kwestionariusz prawicowości i lewicowości najlepiej objaśnia rywalizację polityczną we współczesnej demokracji między stronnictwami politycznymi oraz strukturalizuje myślenie polityczne uczestników stosunków społecznych, w tym grup wyborców. Druga - PiS należy zaliczyć do konserwatywnej rodziny ideologiczno-programowej partii politycznych, dlatego też dość często politycy PiS są określani w tym opracowaniu jako konserwatyści. Taka klasyfikacja stronnictwa może być dyskusyjna z dwóch powodów, o których będzie mowa. Trzecia teza - na poziomie członków partii, jej sympatyków i wyborców identyfikacja ideologiczno-programowa według podziału lewica-centrum-prawica petryfikuje trzy odmienne style politycznego myślenia, a także poznawania i opisywania rzeczywistości społecznej, w tym polityki, co podnosi poziom wzajemnej wrogości oraz obniża zdolność do zawierania kompromisów zgodnie z podziałem wróg-sojusznik.

Wracając do dwóch wątpliwości w sprawie uznania PiS za partię konserwatywną, to należy je zasygnalizować. Primo - w programach partyj- 
nych nie dokonano identyfikacji ideologiczno-programowej w sposób jednoznaczny, wręcz przeciwnie - pisano o wielonurtowości. Jednak liderzy PiS nie ukrywali swojej prawicowej identyfikacji w formule konserwatywnej, czyniąc to na dwa sposoby: 1) mówiąc o tym wprost - „Mówię to ja, który jestem umiarkowanym konserwatystą" (L. Kaczyński); 2) odrzucając najważniejszą historycznie postać prawicowości w dziejach Polski - ruch narodowodemokratyczny, ponieważ "[...] Polsce potrzebna jest prawa strona, ale tradycję polskiej prawicy trzeba mocno zweryfikować, że to nie może być tradycja endecka" (J. Kaczyński) ${ }^{21}$. Secundo - w wielu opracowaniach naukowych na temat ruchów i partii politycznych dokonuje się bardzo anachronicznego definiowania konserwatyzmu. Badacze systemów partyjnych oraz kryteriów lewicowości i prawicowości niejednokrotnie abstrahują od ustaleń dokonanych przez specjalistów w zakresie myśli politycznej i postrzegają konserwatyzm w oparciu o kwestionariusz analityczny odnoszący się faktycznie do tego nurtu ideowego, ale istniejącego w II połowie XIX wieku i w I połowie XX stulecia. Nie uwzględnia się zmian, jakie zaszły w II połowie XX wieku, a których swoistym ukoronowaniem jest "konserwatyzm współczujący" (compassionate conservatism). Ten typ konserwatyzmu spełnia rolę obrzeży, za pośrednictwem których dokonuje się modernizacja paradygmatu konserwatywnego. Za dewizę nowoczesnego konserwatyzmu można uznać słowa Irvinga Kristola: „Konserwatyści powinni zająć się przede wszystkim poszukiwaniem takiej formy państwa opiekuńczego, która byłaby zgodna z podstawowymi zasadami moralnymi naszej cywilizacji i podstawowymi zasadami politycznymi naszego państwa"22. Można tę dewizę odnieść do myśli politycznej dla okresu 2015-2019, kiedy PiS zaczęło poszukiwać polskiego modelu państwa opiekuńczego, opartego na moralności, tradycji i demokracji.

Recypowanie w Europie „konserwatyzmu współczującego” otworzyło drogę do nasycenia myśli konserwatywnej solidaryzmem społecznym,

21 O dwóch takich... Alfabet braci Kaczyńskich..., s. 157, 196.

22 I. Kristol, Konserwatywne państwo opiekuńcze, [w:] Neokonserwatyzm, oprac. I. Stelzer, Wydawnictwa Akademickie i Profesjonalne, Warszawa 2007, s. 180. 
zgodnie z którym państwo ma obowiązki wobec słabszych grup społecznych, ale powinno działać w ramach zasady pomocniczości wtedy, kiedy nie radzą sobie rodzina i wspólnota lokalna ${ }^{23}$. W tym aspekcie jest zasadnicza różnica między konserwatystami w II Rzeczypospolitej, wpływowymi w rządzącym autorytarnie obozie piłsudczykowskim, a konserwatystami w III Rzeczypospolitej, rywalizującymi w warunkach demokracji parlamentarnej. PiS wykorzystało w Polsce kryzys zarówno lewicy, wynikający z jej postkomunistycznego charakteru, dokonania zwrotu w kierunku liberalizmu za czasów Aleksandra Kwaśniewskiego i Leszka Millera, słabości programów społecznych rządów zdominowanych przez Sojusz Lewicy Demokratycznej, jak również kondycji liberalizmu reprezentowanego przez Platformę Obywatelską RP, która przyjęła model rozwoju gospodarczego polaryzacyjno-dyfuzyjny z bardzo rozległymi negatywnymi skutkami społecznymi. $Z$ tych zasadniczych powodów solidaryzm społeczny zaprezentowany w programie PiS z 2014 roku oraz w dwóch kampaniach wyborczych w 2015 roku doprowadził stronnictwo Jarosława Kaczyńskiego do wygranej.

Cechą przesądzającą o konserwatywnym charakterze myśli politycznej PiS jest warstwa ideologiczna, oparta na religii, co w polskich warunkach oznaczało chrześcijaństwo. Przynajmniej cztery składniki ideologicznej tożsamości o rodowodzie religijnym są kluczowe:1) uznanie godności człowieka za źródło myślenia o polityce; 2) realistyczne przekonanie o grzesznej naturze człowieka; 3) pochodzenie transcendentne praw człowieka, niebędących kreacją ani jednostki, ani społeczeństwa; 4) wiara w istnienie obiektywnego porządku ograniczającego ludzką aktywność. Stosując także strukturę wartości Shaloma H. Schwartza do analizy myśli politycznej PiS, zauważamy, że charakteryzują ją dwie grupy wartości: zachowawczość oraz umacnianie siebie, które wyróżniają prawicę. Nacisk jest położony na: tradycję, bezpieczeństwo, władzę, osią-

23 Vide M. du Vall, Neokonserwatyzm w Stanach Zjednoczonych. Od Żywotnego Centrum do epoki Reagana, Krakowskie Towarzystwo Edukacyjne sp. z o. o. - Oficyna Wydawnicza AFM, Kraków 2011, s. 41 i n. 
gnięcia, tożsamość polityczną zarówno państwa, jak i partii politycznej²4. Elita partyjna PiS nie ma charakteru kompradorskiego i nie poszukuje zewnętrznej legitymizacji swojej społecznej pozycji.

Słuszność takiej klasyfikacji pokazują badania Anity Filipczak-Białkowskiej, Pawła Chmielnickiego i Dobrochny Minich, z których wynika, że profil ideologiczny PiS spełnia zasadniczo kryteria paradygmatu konserwatywnego, a to właśnie ten element przesądza o charakterze myśli politycznej ${ }^{25}$. Na konserwatywny profil ideologiczny PiS składają się takie cechy warstwy ideologicznej myśli politycznej, jak: silny rząd, paternalizm państwa, suwerenność państwa, więź międzypokoleniowa, społeczna odpowiedzialność władzy, aktywne państwo w gospodarce, solidaryzm społeczny. Towarzyszy temu odrzucenie wartości liberalnych.

Powód unikania przez PiS samoidentyfikacji miał charakter wyborczy, który opisał Ludwik Dorn, przywołując badania przeprowadzone w czasach Porozumienia Centrum, z których wynikało, że konserwatyzm nie jest w Polsce „lewarem" wyborczym ${ }^{26}$. Do podobnych wniosków doszedł też Jarosław Kaczyński, który przy tworzeniu PiS odszedł także od samookreślania się partii jako chadeckiej czy też umieszczonej w centrum areny politycznej. Nazwa „Prawo i Sprawiedliwość" była w tej kwestii neutralna i okazała się marką przysparzającą wyborców, co potwierdziły

24 Vide P. Maj, Lewicowość, centrowość i prawicowość w nauce o polityce, Wydawnictwo Uniwersytetu Rzeszowskiego, Rzeszów 2018, s. 142 i n. Nie jest zrozumiałe, dlaczego autor uznat chrześcijańską demokrację za modelowy przykład realizacji wartości prawicowych w zestawieniu z liberalizmem jako przykładem urzeczywistniania wartości lewicowych. Wspótczesna chadecja znacznie oddaliła się od prawicowości.

25 Według Anity Filipczak-Białkowskiej sądy ideologiczne PiS w 48 proc. korelują ze znacznikami konserwatyzmu. W rzeczywistości jest to jednak zdecydowanie więcej, ponieważ cechy wspótczesnej ideologii konserwatywnej przyjęte przez autorkę wymagają modernizacji, są bowiem nadmiernie zdominowane przez elementy gospodarcze z pominięciem społecznych, np. autorka nie zauważyła, że solidaryzm społeczny jest cechą konserwatywną, a nie socjalistyczną. A. Filipczak-Białkowska, Mechanizmy manifestowania orientacji ideologicznej w dyskursie politycznym, Wydawnictwo Uniwersytetu Łódzkiego, Łódź 2018, s. 155 i n.; P. Chmielnicki, D. Minich, Gorzki smak kietbasy wyborczej. Obietnice wyborcze $i$ ich realizacja ustawami w latach 2015-2016, Wolters Kluwer, Warszawa 2019, s. 504 i n.

26 R. Krasowski, Dwie formuty prawicowości, [w:] Partie i zmiany granic polityki, Fundacja im. Stefana Batorego, Warszawa 2009, s. 70. 
badania stosunku emocjonalnego wyborców do logotypów partyjnych. Oczywiście uznanie PiS za partię konserwatywną jednocześnie pozycjonuje ją na osi lewica-centrum-prawica, niezależnie od definiowania tych pojęć i zawartości kwestionariusza lewicowości i prawicowości. O dokonaniu takiego wyboru przesądziły trzy przesłanki. Pierwsza - położenie nacisku w myśli politycznej na zjawisko polityczności w ujęciu klasycznym oraz określony sposób definiowania polityki, jak najbardziej zbliżony do paradygmatu konserwatywnego. Druga - powoływanie się przez polityków PiS na polski republikanizm oraz wielki dystans liderów partii do prawicy narodowej. Trzecia - przejęcie z konserwatyzmu najważniejszych przemyśleń na temat państwa, władzy, narodu, a także oficjalne sięgnięcie w drugiej dekadzie XXI wieku po solidaryzm społeczny charakterystyczny dla nowoczesnego konserwatyzmu, a nie dla myśli socjalistycznej, jak głosili liberałowie. Należy też podkreślić, że na poziomach przejawiania się myśli politycznej: teorie naukowe wykorzystywane w myśleniu politycznym, paradygmat ideologii, idee przybierające postać koncepcji i programów, przekształcanie wartości w decyzje polityczne, postrzeganie partii przez jej wyborców, w odniesieniu do PiS identyfikacja stronnictwa jest prawicowa o charakterze konserwatywnym.

Uznając PiS za partię prawicową typu konserwatywnego, zdecydowanie odmówiono takiej identyfikacji Platformie Obywatelskiej RP, przynajmniej po 2006 roku, a na pewno w latach 2015-2019. Jak to ustalili P. Chmielnicki i D. Minich, wartości „ze znacznikami ideologicznymi konserwatyzmu" mają w jej myśli politycznej minimalne znaczenie, na poziomie 5 proc. ${ }^{27} \mathrm{~W}$ pewnym sensie podobny trend zauważył Przemysław Maj, jednak trudno się zgodzić ze sformułowanymi przez niego wnioskami, że PO konsekwentnie lokowała się w centrum areny politycznej w Polsce. Natomiast z dokonanego przez niego przeglądu programów PO wynika, że w 2015 roku PO zaczęła wyraźnie opierać etykę i moralność na oświeceniowym racjonalizmie, pluralizmie systemów wartości, wynikających z akceptacji postprawdy, oraz na progresywi-

27 P. Chmielnicki, D. Minich, op. cit., s. 512. 
zmie, odchodząc jednocześnie od religii i tradycji obecnych w poprzednich programach. Ewolucja w tym kierunku otworzyła przestrzeń do wchłonięcia partii Nowoczesna.pl. Te zmiany były dość symptomatyczne i zaczynały separować PO od centrum, które w Polsce bynajmniej nie jest progresywistyczne. Jednak o tej separacji zadecydowały inne cechy obecne w myśli politycznej PO badanej w oparciu o jej świadectwa wyjątkowa konfliktowość i dążenie do likwidacji PiS, przy odrzuceniu poszukiwania kompromisu ${ }^{28}$. Wojowniczość tego typu stała się barierą odgradzającą PO od centrowych wyborców, co stało u podstaw klęsk wyborczych w latach 2018-2019. Pojmowanie liberalizmu przez Donalda Tuska i Ewę Kopacz spychało partię w lewą stronę areny politycznej. Nie chodziło bynajmniej o wybór ideologiczno-programowy, ale o zajęcie postawy anty-PiS. Decyzja podjęta w 2006 roku o przejściu do twardej opozycji, a w 2015 roku o uznaniu się za opozycję totalną zdeterminowały umiejscowienie PO w systemie partyjnym Polski, zwłaszcza kiedy w Sejmie VIII kadencji zabrakło ugrupowań lewicowych. Przesuwaniu się PO na lewą stronę areny partyjnej w Polsce w okresie 2007-2015 będzie także towarzyszyć populizm, mający na celu utrzymanie się u władzy, co utrudnia analizę świadectw myśli politycznej tego stronnictwa, albowiem ślady stoją z nimi w sprzeczności. Inaczej wyglądały obietnice wyborcze, a inaczej podejmowane przez rząd decyzje.

Lokalizacja monografii wymaga wyjaśnień. Po pierwsze, w ujęciu chronologicznym jej dwie cezury - początkowa i końcowa - stanowią lata 2015 i 2019, czyli okres, kiedy PiS przejęło odpowiedzialność za Rzeczpospolitą. W pewnym sensie wybór roku 2019 może wydawać się dyskusyjny, gdyż PiS wygrało wybory parlamentarne w tym roku i nadal jest odpowiedzialne za politykę zagraniczną Polski, ale w okresie październik 2019 - lipiec 2020 formacja rządząca pozostawała w pewnym zawieszeniu, mimo wygranych kilka miesięcy wcześniej wyborów do Sejmu i Senatu. Zawieszenie wynikało przede wszystkim z: 1) oczekiwania na wynik wyborów prezydenckich, kluczowych w kontekście międzynarodowym oraz w warunkach dezawuowania przez kontrkandydatów A. Dudy pro-

28 P. Maj, op. cit., s. 267-268. 
wadzonej przez niego polityki oraz 2) widocznego „zatrzymania się" w sensie strategicznym i koncepcyjno-programowym rządu Zjednoczonej Prawicy, zadyszki spotęgowanej kryzysem pandemicznym oraz kalkulacjami w perspektywie średniookresowej. Kryzys pandemiczny w 2020 roku został uznany za czynnik, który może wywołać znaczne przewartościowania nie tylko w sytuacji wewnętrznej wielu państw, ale także w stosunkach międzynarodowych, zważywszy na nierównomiernie rozłożone w skali globalnej negatywne skutki tego zjawiska.

Badając lata 2015-2019, uzyskałem unikatową możliwość udzielenia odpowiedzi na ważne pytania: o źródła myśli politycznej PiS, o kontynuację i zmianę, o wpływ zmiany statusu partii na arenie politycznej z opozycyjnego na rządzący, o spójność śladów i świadectw myśli politycznej. Chcąc na te pytania odpowiedzieć, musiałem niejednokrotnie sięgać do okresów poprzednich: bycia w opozycji w latach 2001-2005 i 20072015 (a nawet do czasów istnienia Porozumienia Centrum) oraz sprawowania rządów w okresie 2005-2007. Spojrzenie procesualne wynikało także z charakteru polityki zagranicznej jako typu polityki szczegółowej, która nie podlega tak intensywnym i koniunkturalnym zmianom, jak w przypadku innych polityk szczegółowych. To do niej odnosi się historyczne długie i średnie trwanie.

Po drugie, w ujęciu podmiotowym odnoszącym się do twórców myśli politycznej w aspekcie personalnym nie kierowałem się formalizmem, bo on w tej materii byłby szkodliwy. Dlatego też przyjąłem, że Lech Kaczyński i Andrzej Duda po objęciu urzędu prezydenta RP nadal pozostawali wyrazicielami myśli politycznej PiS, zwłaszcza w polityce zagranicznej. Podobną uwagę należy odnieść do doradców i ekspertów PiS, tworzących krąg bliskich współpracowników prezesa Jarosława Kaczyńskiego, mających znaczny wpływ na myślenie polityczne w tej partii, szczególnie w latach 2011-2019.

W drugiej dekadzie XXI wieku został ostatecznie przełamany podział na dwa obozy: postsolidarnościowy i postkomunistyczny, który był niejednokrotnie fałszywie interpretowany jako zniesienie podziału lewica-centrum-prawica. To odrodzenie naturalnej dla demokracji rywalizacji międzypartyjnej oraz identyfikacji jej uczestników w sensie 
ideologiczno-programowym wynikało przede wszystkim z dwóch procesów: przesunięcia się PO w kierunku lewicowym, zgodnie z trendem odnoszącym się do współczesnego liberalizmu, który przestał rościć sobie prawa do bycia kolejnym wariantem prawicy; udanego przejęcia przez PiS tradycji solidarnościowej, mimo iż w pierwszej dekadzie XXI wieku PO próbowała o ten spadek rywalizować, wykorzystując przynajmniej takie symbole, jak Lech Wałęsa, Tadeusz Mazowiecki i Gdańsk, zdominowany politycznie przez liberałów.

Po trzecie, przedmiotem zainteresowania w monografii była polityka zagraniczna projektowana przez PiS dla Rzeczypospolitej, ale bez roszczeń do jej całościowego opracowania. Na tym etapie badań nad współczesną myślą polityczną, polityką zagraniczną Polski i stosunkami dwustronnymi Polski z innymi państwami w okresie 2015-2019 byłoby to zadanie karkołomne, brakuje bowiem prac szczegółowych, w których rzetelnie opracowano by wybrane zagadnienia w oparciu o kwerendę, krytykę i interpretację źródeł prymarnych ${ }^{29}$. Przedmiotem moich zainteresowań było kilka kluczowych kwestii pozycjonujących organizację i planowanie kolejnych badań: paradygmat myśli politycznej PiS, ze szczególnym zwróceniem uwagi na myślenie polityczne, przesłanki teoretyczne i ideowe; podstawy polityki transatlantyckiej, zdecydowanie wyróżniającej to stronnictwo na arenie politycznej III Rzeczypospolitej; koncepcje PiS polityki transatlantyckieji europejskiej realizowanej przez

29 Oceniając niedostatki piśmiennictwa o polityce zagranicznej Polski w myśli politycznej PiS, można by wskazać chlubne wyjątki, jeśli chodzi o wartościowe opracowania kwestii szczegółowych. Stosunkowo dobrze zostały przeanalizowane chociażby: inicjatywa Trójmorza (A. Orzelska-Stączek, Inicjatywa Trójmorza w świetle teorii realizmu. Polityczne aspekty nowej formy wspótpracy dwunastu państw, „Sprawy Międzynarodowe" 2019, nr 1, s. 131-155; M. Sienkiewicz, Koncepcja Trójmorza w polityce zagranicznej Polski po 2015 r., „Dyplomacja i Bezpieczeństwo” 2016, nr 1(4), s. 139-151; T. Stępniewski, Inicjatywa Trójmorza. Uwarunkowania geopolityczne i nowy model regionalnej wspótpracy, "Studia Europejskie” 2018, nr 2, s. 33-43) oraz relacje Polski z Ukrainą (P. Żurawski vel Grajewski, Specyfika relacji polsko-ukraińskich po 2015 roku, „Sprawy Międzynarodowe" 2018, nr 1, s. 41-92). Jednak należy sformułować ocenny wniosek - całościowa rzetelna ocena polityki zagranicznej w myśli politycznej PiS wymaga wielu kolejnych opracowań takich zagadnień, jak kwestie (w ujęciu geograficznym): unijna, amerykańska, chińska, niemiecka, francuska, brytyjska, litewska, turecka, węgierska, rumuńska, środkowoeuropejska, bałkańska, kaukaska, izraelsko-żydowska. 
Polskę w okresie 2015-2019. Wymienione obszary zostały wybrane celowo, gdyż cechowały myśl polityczną PiS, nadając jej swoiste wyróżniki ${ }^{30}$. Przedmiotem zainteresowania nie były koncepcje i programy stosunków ani dwustronnych, ani odnoszących się do najważniejszych dla Polski regionów, takich jak Europa Zachodnia, Środkowa i Wschodnia oraz Ameryka Północna i Azja. Moim zamiarem nie było także analizowanie konkretnych wydarzeń ze stosunków międzynarodowych, o ile nie korespondowały z wybranymi polami refleksji. Wydarzenia z zakresu bieżącej polityki zagranicznej zasadniczo były poza moim zainteresowaniem, np. kryzys migracyjny w Unii Europejskiej czy też spór o praworządność między Polską a Wspólnotą.

Oprócz zasygnalizowanych już pytań związanych z deskrypcją myśli politycznej PiS, badania miały przynieść odpowiedzi także na kilka pytań wyjaśniających na temat koncepcji polityki zagranicznej tej formacji: 1) Ślady jakich teorii naukowych, źródeł ideowych i paradygmatów ideologicznych są widoczne w myśli politycznej PiS? 2) W jaki sposób wartości prymarne oraz realistyczna ocena rzeczywistości politycznej kształtowały koncepcję PiS polityki zagranicznej Polski? 3) Jak wyglądały zależności między różnymi segmentami (kierunkami) „geograficznymi" w myśli politycznej PiS? 4) Jakie czynniki zadecydowały o przyjęciu przez PiS określonych rozwiązań składających się na koncepcję polityki zagranicznej Polski? 5) W jaki sposób kurs transatlantycki i eurorealizm

30 Wybrane problemy z myśli politycznej PiS były już przedmiotem opracowań mojego autorstwa, ale w formie zarysowej, wtaściwej dla artykutów. Vide W. Paruch, Źródta orientacji eurorealistycznej w Polsce. O myśli politycznej Prawa i Sprawiedliwości, [w:] Integracja europejska. Polska perspektywa, red. Z. Czachór, T. Grosse, W. Paruch, Wydawnictwo Sejmowe, Warszawa 2018, s. 213-242; idem, Przesztość w myśli politycznej Prawa i Sprawiedliwości: polska wersja neorealistycznej doktryny stosunków międzynarodowych, [w:] Pomiędzy pamięcią zbiorową a historią. Rekonstrukcje przesztości w Europie Środkowo-Wschodniej, red. P. Bałdys, I. Jakimowicz-Ostrowska, J. Charuta-Kojkot, Wydawnictwo Naukowe Katedra, Gdańsk 2016, s. 483-498; idem, Polska w Sojuszu Pótnocnoatlantyckim. Koncepcja Prawa i Sprawiedliwości bezpieczeństwa państwa (20152019), [w:] Sojusz Pótnocnoatlantycki w środowisku niepewności i zmiany. Dwadzieścia lat członkostwa Polski, red. W. Paruch, M. Pietraś, B. Surmacz, Wydawnictwo Sejmowe, Warszawa 2020, s. 340-380; idem, „Wprowadzenie Sojuszu Pótnocnoatlantyckiego do Polski". Studium o polityce transatlantyckiej większości parlamentarnej Zjednoczonej Prawicy (2015-2019), „Przegląd Sejmowy” 2020, nr 2, s. 97-124. 
przekładały się na koncepcje roli Sojuszu Północnoatlantyckiego i zmian systemu politycznego Unii Europejskiej?

Sfalsyfikowania wymagały również hipotezy formułowane w różnych źródłach, najczęściej w wytworach prasowych, oraz powtarzane w piśmiennictwie naukowym, a odnoszące się do myśli politycznej PiS. Cztery z nich wyraźnie dominowały. Pierwsza - myśl polityczna PiS nosi charakter nacjonalistyczny i jest skażona autorytaryzmem, a jej cechą charakterystyczną jest eurosceptycyzm, który może przekształcić się w projekt wyjścia Polski z Unii Europejskiej. Druga - koncepcja PiS polityki zagranicznej Polski nie jest dostosowana do współczesnych trendów, lecz zawiera rozwiązania ukierunkowane na historię, której prawa wraz z integracją, globalizacją i demokratyzacją przestały obowiązywać. Trzecia - dwukrotna realizacja polityki zagranicznej przez gabinety z nominacji PiS doprowadziła do utraty przez Polskę pozycji i pozytywnego wizerunku w środowisku międzynarodowym. Czwarta - najważniejszymi cechami koncepcji PiS polityki zagranicznej Polski jest antyniemieckość i antyrosyjskość, wynikające $\mathrm{z}$ fobii i emocji przeniesionych do współczesności z przeszłości.

Uznaję za konieczne wyjaśnienie kilku kwestii metodologicznych. Przygotowując dla Czytelników studium o myśli politycznej, musiałem przyjąć określony sposób rozumowania o tym segmencie rzeczywistości politycznej. Pisałem o pojęciu „myśl polityczna” oraz o podstawach metodologicznych tej subdyscypliny politologicznej stosunkowo wiele, ograniczę się więc do wyłożenia kluczowej dla tej monografii definicji. Myśl polityczna jest to wszelka forma refleksji o rzeczywistości politycznej (a więc nie tylko o polityce), niezależnie od stopnia rozwoju, wewnętrznej spójności i systematyzacji oraz uteoretyzowania i konkretyzacji131.

31 Rozważania autorskie na temat myśli politycznej w: W. Paruch, K. Trembicka, Wprowadzenie, [w:] Wizje i realia. Studia nad realizacją polskiej myśli politycznej XX wieku, red. W. Paruch, K. Trembicka, Wydawnictwo UMCS, Lublin 2002 s. 7-15; J. Jachymek, W. Paruch, Wstęp, [w:] Więcej niż niepodlegtość. Polska myśl polityczna 1918-1939, red. J. Jachymek, W. Paruch, Wydawnictwo UMCS, Lublin 2001, s. 9-14; W. Paruch, Myśl polityczna obozu pitsudczykowskiego 1926-1939, Wydawnictwo UMCS, Lublin 2005, S. 1011; idem, Myśl polityczna - refleksje metodologiczne o pojęciu, „Annales Universitatis 
Przyjmując taką definicję myśli politycznej, zauważamy, że w odniesieniu do PiS jest ona wdzięcznym przedmiotem badań, w odróżnieniu od piłsudczykowskiej myśli politycznej, z jednego powodu - jest spójna, całościowa, scentralizowana, skonkretyzowana. W odróżnieniu od piłsudczykowskiej myśli politycznej, nie ma w niej sfery bezdyrektywnej, czyli pozostającej poza oddziaływaniem prezesa J. Kaczyńskiego, a kształtowanej przez innych polityków przynależnych do formacji. Natomiast J. Piłsudski pozostawiał swoim współpracownikom bardzo szerokie pole do samodzielnej aktywności koncepcyjno-programowej, zwanej sferą bezdyrektywną, np. w odniesieniu do wielu polityk szczegółowych, wobec których - nie zawsze - formułował jedynie generalne wytyczne.

Nadałem monografii strukturę rzeczową w odniesieniu zarówno do rozdziałów, jak i podrozdziałów, z wyjątkiem rozdziału 3 pt. „Wprowadzenie Sojuszu Północnoatlantyckiego do Polski", w którym dwa podrozdziały zostały wydzielone $\mathrm{z}$ wykorzystaniem kryterium chronologicznego (cezurą pomiędzy podrozdziałami jest rok 2016 - data szczytu północnoatlantyckiego w Warszawie). Zawartość wszystkich czterech rozdziałów jest podporządkowana głównemu celowi poznawczemu pracy - przeanalizowaniu myśli politycznej PiS w odniesieniu do polityki zagranicznej Polski w oparciu o cechy konstytutywne myśli politycznej tego stronnictwa, tworzące paradygmat ideologii, będący kośćcem każdego podmiotu politycznego, który chce być trwałym składnikiem rzeczywistości politycznej. Bez paradygmatu ideologii nie uzyska bowiem tożsamości politycznej, koniecznej do udziału w rywalizacji politycznej, mającej między innymi na celu ochronę swojej egzystencji i podmiotowości, a następnie rozszerzanie własnej bazy społecznej, aby wygrać przetarg o władzę, co jest warunkiem realizacji własnych koncepcji i programów.

W odniesieniu do PiS na paradygmat ideologii składają się dwa kluczowe elementy: 1) styl myślenia politycznego, oparty na powiązaniu polityki jako działalności społecznej z politycznością jako cechą rzeczywistości społecznej oraz 2) zbiór przesłanek teoretycznych i ideowych 
stanowiących fundament myśli politycznej ugrupowania. Obie te kwestie są przedmiotem rozważań w rozdziale 1. Jednak w odniesieniu do koncepcji PiS polityki zagranicznej Polski za kluczowy uznałem także dorobek ideowy składający się na dwie polityki szczegółowe: transatlantycką (rozdziały 2 i 3 ) i europejską (rozdział 4). To właśnie opcja atlantycka i eurorealizm wyróżniały środowisko skupione wokół J. Kaczyńskiego i L. Kaczyńskiego na arenie rywalizacji politycznej III Rzeczypospolitej. Obie orientacje: transatlantycka i eurorealistyczna kształtowały się w opozycji do myśli politycznej i praktyki politycznej najważniejszych konkurentów: liberałów, lewicy, narodowców. Dwukrotnie przejmując władzę w Polsce, PiS oparło politykę zagraniczną na tych orientacjach, co najczęściej oznaczało dokonywanie głębokiej korekty aktywności międzynarodowej Rzeczypospolitej i stawało się przyczyną licznych napięć. Tak się stało i w 2005, i w 2015 roku, kiedy PiS zasadniczo poddało korekcie kurs międzynarodowy realizowany w polityce przez koalicję lewicowo-ludowcową oraz zdezawuowało linię strategiczną rządów liberalno-ludowcowych. PiS konsekwentnie prezentowało wypracowywane przez siebie zasady polityki transatlantyckiej (podrozdział 2.3) i koncepcję Unii Europejskiej (podrozdział 4.3). Należy podkreślić, że oba te komponenty myśli politycznej PiS były konkretyzowane przez dwie dekady istnienia stronnictwa w XXI stuleciu. Wraz z nawarstwiającymi się doświadczeniami oraz wynikami analiz ewolucji środowiska międzynarodowego, politycy PiS konsekwentnie rozbudowywali kolejne warstwy polityki transatlantyckiej i europejskiej (unijnej). Te problemy były przedmiotem rozważań w rozdziałach 2 i 4.

W monografii została wykorzystana metoda analizy systemowej na poziomie średnim, wspomagana dwoma innymi metodami - decyzyjną i porównawczą. To właśnie analiza systemowa, zgodnie z założeniem poczynionym przez Ludwiga von Bertalanffy'ego, pozwoliła sformułować uogólnienia na temat myśli politycznej $\mathrm{PiS}^{32}$. Stworzyła również możli-

32 L. von Bertalanffy, Ogólna teoria systemów. Podstawy, rozwój, zastosowanie, Wydawnictwo Naukowe PWN, Warszawa 1984, passim. Interesujące rozważania na temat stosowania analizy systemowej w: A. Huczek, Zastosowanie analizy systemowej jako metody 
wości wyjaśnienia działalności ideotwórczej i decydowania politycznego tej formacji przez odwołanie się do: celów strategicznych; specyficznych i unikatowych właściwości; ewolucji wewnętrznej o charakterze koncepcyjno-programowym (w niewielkim stopniu ideologicznej); oraz paradygmatu ideologii w postaci zhierarchizowanych wartości. Jest to więc wyjaśnianie wielopłaszczyznowe i kompleksowe.

Strukturą traktowaną jako system badany jest myśl polityczna PiS, oczywiście na użytek publikacji „zredukowana” do wybranych spraw międzynarodowych, które zostały potraktowane jako podsystem. Nie można mieć żadnych wątpliwości, że ów podsystem był poddawany oddziaływaniom wobec niego zewnętrznym z dwóch stron: 1) innych podsystemów myśli politycznej PiS, chociażby zespół poglądów o: wartościach (prawda, państwo, naród), polityce w sensie ogólnym, ważnych politykach szczegółowych - przede wszystkim wewnętrznej, bezpieczeństwa, obronnej oraz w zakresie komunikowania politycznego, wyjątkowo ważnego w odniesieniu do strategii i taktyki wyborczej; 2) analizy i diagnozy zmian w środowisku międzynarodowym w badanym okresie, tym bardziej że w PiS dominowało przekonanie, iż w otoczeniu Rzeczypospolitej dochodzi do dość głębokich zmian, na które powinna mieć wpływ. To właśnie na tych dwóch wejściach dokonywały się korekty poglądów na temat polityki zagranicznej. Jesteśmy w stanie je zauważyć, porównując dwa okresy sprawowania rządów: 2005-2007 i 2015-2019.

Wewnątrz wyodrębnionego podsystemu są zauważalne oddziaływania między jego poszczególnymi elementami. W koncepcji PiS polityki zagranicznej Polski obserwujemy ścisłe zależności między jej poszczególnymi "geograficznymi" trzema segmentami: 1) środkowoeuropejskim, 2) rosyjskim i niemieckim, 3) północnoatlantyckim, europejskim (unijnym) iamerykańskim. Drugi segment jest wyraźnie pierwotny wobec pierwszego i trzeciego, gdyż to właśnie rozwiązanie historycznego dramatu położenia geopolitycznego Polski między Niemcami a Rosją przesądzało o polityce regionalnej (konieczność budowy powiązań sieciowych w Europie Środ-

badawczej w naukach politycznych - perspektywa porównawcza, s. 120-137, http://bibliotekacyfrowa.pl, dostęp 10 VI 2020. 
kowej) oraz o polityce północnoatlantyckiej, unijnej i amerykańskiej, które przynieść miały reasekurację wobec zagrożenia rosyjskiego dla regionu i aspiracji niemieckich na kontynencie. Jednak tylko aktywna polityka w Europie Środkowej stwarzała nadzieję, że te czynniki reasekuracji powstaną i będą efektywne, gdyż potencjał polityczny wyizolowanej Polski był przez PiS oceniany jako zbyt słaby, żeby uczynić z Rzeczypospolitej ważnego gracza w skali kontynentalnej i wobec Stanów Zjednoczonych. Natomiast bez osiągnięcia statusu państwa średniego pivotalnego Polska mogła stanąć przed zagrożeniem jeśli nie swojej niepodległości, to na pewno suwerenności i podmiotowości, co pociągałoby za sobą destrukcję polskiego kodu kulturowego ukształtowanego przez wieki.

Zastosowanie metody decyzyjnej i porównawczej pozwoliło dokonać zjednej strony analizy kluczowych decyzji podejmowanych przez liderów PiS w odniesieniu do polityki zagranicznej - chodzi przede wszystkim o najważniejsze rozstrzygnięcia o charakterze ideowym i programowym, a z drugiej strony porównania tych samych segmentów w konserwatywnej myśli politycznej (PiS) i lewicowej (SLD, prezydent Aleksander Kwaśniewski, gabinety Leszka Millera i Marka Belki) oraz liberalnej (PO, gabinety Donalda Tuska i Ewy Kopacz, prezydent Bronisław Komorowski). Porównanie było o tyle istotne, że krytyka koncepcji polityki zagranicznej Polski realizowanej przez rządy lewicowo-ludowcowe i liberalno-ludowcowe była jednym z czynników przyczyniających się do krystalizacji myśli politycznej PiS, a na pewno pozwalała na prezentowanie własnych idei w debacie publicznej.

Książka oddawana do rąk Czytelników powstawała w okolicznościach niekiedy trudnych lub bardzo nietypowych. Dziękuję wszystkim moim Przyjaciołom i Znajomym, którzy przyczynili się do powstania tej monografii, stwarzając mi jak najlepsze warunki pisarskie. Dziękuję również dr. hab., prof. Uniwersytetu Łódzkiego Przemysławowi Żurawskiemu vel Grajewskiemu za wnikliwe uwagi recenzyjne, które pozwoliły wzbogacić moje rozważania o nowe wątki merytoryczne, oraz Instytutowi Europy Środkowej za opublikowanie monografii. 


\section{Paradygmat myśli politycznej Prawa i Sprawiedliwości}

\subsection{Myślenie polityczne: polityczność i polityka}

Standardem współczesnej politologii jest rozróżnianie polityki i polityczności, co w odniesieniu do badań myśli politycznej pociąga za sobą potrzebę przeanalizowania dla danego twórcy idei (podmiotu politycznego) jego poglądów na te dwie podstawowe kategorie. To właśnie poglądy na te kategorie wchodzą w skład paradygmatu danej orientacji ideowej, determinują bowiem rozważania nad innymi kluczowymi elementami składającymi się na kwestionariusz badań myśli politycznej, takimi jak: wartości, państwo, naród, władza, ład polityczny, stosunki społeczne, gospodarowanie. O ile w odniesieniu do polityki można odpowiedzieć na pytanie o jej definiowanie przez podmiot polityczny, o tyle polityczność stwarza problemy, gdyż w rozumieniu potocznym jest to rzeczownik odprzymiotnikowy, a więc niesamodzielny, wyprowadzany z definicji polityki, podczas gdy faktycznie „polityczność" jest rzeczownikiem odprzymiotnikowym, ale pochodzącym od przymiotnika "polityczny". Tylko w bardzo rozwiniętej myśli politycznej jej twórcy odnoszą się do kwestii polityczności. Taka refleksja jest rzadkością, przynajmniej z jednego zasadniczego powodu - twórca myśli politycznej także jest podmiotem o charakterze politycznym ${ }^{1}$.

K. Minkner, Problem polityczności jako metateoretyczne wyzwanie dla politologii, „Athenaeum. Polskie Studia Politologiczne" 2014, vol. 43, s. 9-14. 
Prawo i Sprawiedliwość jest partią polityczną, która działalność ideotwórczą, a w konsekwencji także decydowanie polityczne, oparła na klasycznym rozumieniu polityczności, którego podstawę stanowią trzy kryteria: 1) odróżnianie podmiotów politycznych od środków politycznych w odniesieniu do stosunków wewnętrznych oraz środowiska międzynarodowego; 2) projektowanie środków w celu przekształcania rzeczywistości zgodnie z własną myślą polityczną; 3) rozróżnianie wrogów i sojuszników na wewnętrznej arenie politycznej oraz w środowisku międzynarodowym ${ }^{2}$. Przyjęcie tych kryteriów determinowało także podejście liderów stronnictwa do polityki, którą traktowano jako działalność społeczną o charakterze teleologicznym, czyli ukierunkowaną na realizację celów. Przywrócenie do debaty publicznej myślenia politycznego opartego na polityczności było w ostrej kontrze do tez upowszechnianych przez lewicę i liberałów o triumfie postpolityki jako cechy postnowoczesności. PiS zdecydowanie odrzucało taki sposób podejścia do stosunków społecznych i rzeczywistości politycznej³. Dla skupionych w tej partii konserwatystów myślenie postpolityczne, będące konstytutywną cechą postmodernizmu, należało do tego samego zbioru poglądów i idei, co postkomunizm. W ten sposób wyjaśniali chociażby szybką w Polsce ewolucję poglądów liberałów z PO w kierunku lewicowości i akceptacji "historycznego kompromisu" po okrągłym stole, zawartego pomiędzy postkomunistami a częścią ugrupowań postsolidarnościowych. Sposób postrzegania postkomunizmu i postmodernizmu przez PiS dobrze oddaje opinia politologa Marka Chodakiewicza, że oba nurty łączyły

2 C. Schmitt, Teologia polityczna i inne pisma, Wydawnictwo Aletheia, Warszawa 2012, s. 245-314; R. Skarzyński, Mobilizacja polityczna. Współpraca i rywalizacja człowieka wspótczesnego w wielkiej przestrzeni $i$ długim czasie, Dom Wydawniczy Elipsa, Warszawa 2011, s. 37-53, 301-333; idem, Anarchia i policentryzm. Elementy teorii stosunków międzynarodowych, Wydawnictwo Wyższej Szkoły Ekonomicznej w Białymstoku, Białystok 2006, s. 103-110, 165-230; idem, Podstawowy dylemat politologii: dyscyplina nauki czy potoczna wiedza o społeczeństwie? O tradycji uniwersytetu i demarkacji wiedzy, Wydawnictwo Temida 2, Białystok 2012, s. 25-49, 239-334.

3 Vide M. A. Cichocki, Prawica, sfera polityczności iztudzenia, [w:] Partie i zmiany granic polityki..., s. 78; opinia w kwestii stosunku L. Kaczyńskiego do postpolityki w: Z. Krasnodębski, Lech Kaczyński - niepokorny polityk w świecie „postpolityki”, [w:] Lech Kaczyński - portret, oprac. M. Karnowski, Wydawnictwo M, Kraków 2010, s. 308. 
wspólne cechy: 1) rzeczywistość jest jedynie konstruktem społecznym zrealizowanym przez „klasę panującą" w odniesieniu do ludu; 2) nie ma prawdy, więc nie można w sposób obiektywny odróżnić dobra od zła, fałszu od słuszności, gdyż istnieją tylko narracje teoretycznie równoważne, o ile akceptują reguły politycznej poprawności; 3) czas ideologii przeminął, a polityka oparta na klasycznej polityczności skończyła się na rzecz bezalternatywnego ładu aksjologicznego i politycznego, jedynie słusznego ${ }^{4}$. Z powodu zasadniczej postawy w opisanej kwestii ugrupowanie (zarówno PC, jak i PiS) kierowane przez J. Kaczyńskiego (oraz jego lider) stało się obiektem akcji dyfamacyjnej, uderzało bowiem w proponowany przez nurt lewicowo-liberalny ład poznawczy i aksjologiczny. Jakże często pisano o formacji Kaczyńskiego, że jest opozycją antysystemową, czyli faktycznie antydemokratyczną i niemal antypaństwową, którą należy konsekwentnie eliminować z przestrzeni publicznej wszelkimi dostępnymi metodami, w tym nielegalnymi ${ }^{5}$.

Warto podkreślić, że stosunek liberałów do PiS podważał faktycznie istotę postmodernizmu i postpolityki, trudno przecież pogodzić dogmat o dezideologizacji polityki i retorykę debaty politycznej z takimi zjawiskami właściwymi dla PO, jak: ostre, oparte na emocjach i negatywnych uczuciach, wykluczanie PiS i wyborców tego stronnictwa z przestrzeni publicznej; akcja dyfamacyjna wobec polityków konserwatywnych („przemysł pogardy”); czy też opozycję totalną ogłoszoną niemal nazajutrz po wygraniu przez PiS wyborów w 2015 roku. Okazało się, że w latach 2015-2019 najważniejszym spoiwem dla liberałów był tzw. anty-PiS, czyli jednoznaczne definiowanie wroga, którego należy wykluczyć z życia politycznego, a na pewno odrzucić wszystkie idee przez niego głoszone.

Poznanie myśli politycznej partii kierowanej przez Jarosława Kaczyńskiego jest niezbędne do zrozumienia jej aktywności w przestrzeni publicznej co najmniej z trzech powodów.

M. J. Chodakiewicz, Międzymorze, 3S Media, Warszawa 2017, s. 279-281.

Vide A. Chmielecki, Antykomunizm praktyczny, czyli zarys historii i programu Porozumienia Centrum, [w:] Nowe państwo. Porozumienie Centrum w dokumentach (1990-2001), wstęp, wybór i oprac. A. Chmielecki, Patria Media, Gdańsk 2020, s. 18. 
Po pierwsze, politycy PiS bardzo często wypowiadali się o podstawach aksjologicznych i ideologicznych własnej formacji oraz o celach strategicznych, a także prezentowali uzasadnienia dla projektowanych decyzji politycznych - zarówno rządząc, jak i będąc w opozycji. W tej materii dla PiS wielce charakterystyczne były trzy zjawiska: 1) oficjalne definiowanie w programach politycznych celów strategicznych, które partia zamierza realizować; 2) kontynuacja i konsekwencja o charakterze aksjologicznym i teleologicznym; 3) wyjątkowe zdyscyplinowanie na trzech poziomach myśli politycznej: teoretycznym, ideologicznym i koncepcyjnym. Na tych poziomach stanowisko rozstrzygające należało do prezesa stronnictwa Jarosława Kaczyńskiego i jego brata - Lecha. Natomiast na poziomie programowym można dostrzec znaczną elastyczność w myśli politycznej PiS, wynikającą z analizowania rzeczywistości politycznej i dynamiki stosunków społecznych. Podmiot polityczny może wykazywać znaczną elastyczność programową bez uszczerbku dla własnej tożsamości politycznej pod warunkiem, że ma ściśle określoną warstwę ideologiczną, z zakotwiczeniem w wartościach oraz w teoriach społecznych, $w$ tym naukowych. PiS jak najbardziej spełniało te kryteria w całym okresie swojego dotychczasowego istnienia, gdyż lider J. Kaczyński położył znaczny nacisk na ofertę programową, zawsze poprzedzoną diagnozą sytuacji oraz rozważaniami politycznymi. Niemal tradycją stało się przygotowywanie obszernego programu partii przed nadchodzącymi wyborami prezydenckimi, parlamentarnymi, europejskimi i samorządowymi.

Po drugie, poddając krytyce i interpretacji źródła do badania myśli politycznej PiS, można odnaleźć w nich projektowane środki polityczne służące do osiągania celów, a także odczytać taktykę polityczną, niejednokrotnie wymuszoną przez okoliczności. Te okoliczności były odmienne w dwóch okresach wydzielonych ze względu na sprawowanie władzy. Partia zawierała kompromisy, kiedy rządziła, zwłaszcza w latach 20052007, będąc w koalicji z odmiennymi w sensie ideologiczno-programowym partnerami (Liga Polskich Rodzin, Samoobrona RP) oraz w latach 2015-2019, zabiegając o utrzymanie wysokiego poparcia sondażowego niezbędnego do prowadzenia polityki „dobrej zmiany” w warunkach zjawiska tzw. opozycji totalnej, ogłoszonej 26 lutego 2016 roku przez 
przewodniczącego Platformy Obywatelskiej RP Grzegorza Schetynę . Inne okoliczności towarzyszyły PiS w czasach bycia w opozycji: 20012005 i 2007-2015. W tych dwóch okresach należy wyróżnić trzy fazy, specyficzne dla wyrażanej przez PiS opozycyjności : 1) 2004-2005, kiedy realna wydawała się powyborcza koalicja z PO i należało ten projekt uwzględniać w śladach myśli politycznej, przede wszystkim w publicznych wystąpieniach, a w mniejszym stopniu w oficjalnych programach partyjnych; 2) 2007-2010, kiedy prezydent Lech Kaczyński nie tylko starał się być depozytariuszem idei z okresu sprawowania władzy przez jego brata, ale także próbował realizować myśl polityczną PiS, wbrew koalicji liberalno-ludowcowej, zwłaszcza w polityce zagranicznej; 3) 2013-2015, kiedy J. Kaczyński i jego partia przyjęli realny kurs na wygranie wyborów, czyli przejęcie władzy w Polsce, zaczęli więc zabiegać o maksymalizację poparcia społecznego i poszukiwanie elektoratu "miękkiego", który uzupełniłby elektorat „żelazny” partii, wierny liderowi w okresie poprzednim (2010-2012).

Po trzecie, PiS poświęcało wiele uwagi strukturalizacji stosunków politycznych krajowych i międzynarodowych za pomocą ostatecznego rozróżnienia politycznego opisanego przez Carla Schmitta, czyli definiowania wroga i sojusznika. Obie kategorie w myśli politycznej PiS były w latach 2001-2019 stosunkowo stabilne zarówno dla areny wewnętrznej, jak i dla środowiska międzynarodowego. Kategorii „wróg” poświęcano wiele miejsca w źródłach myśli politycznej oraz koncentrowano się na wyjaśnieniu opinii publicznej dokonanego wyboru, prezentując różne argumenty. Rozumowanie w kategoriach wróg-sojusznik stało się kryterium konstytuującym tożsamość polityczną formacji.

Przyjęcie klasycznego myślenia o polityczności miało swoje konsekwencje dla postrzegania przez PiS innej bardzo ważnej kategorii politycznej (i politologicznej) - władzy. Politykom PiS znacznie bliżej jest do

6 Schetyna mówit na Radzie Krajowej PO: „Będziemy opozycją totalną, najtwardszą z możliwych. Będziemy w sposób totalny walczyć z totalną wtadzą. [...] Będziemy totalną zaporą w niszczeniu polskiego dorobku od 1989 roku". P. Radwanowicz, Grzegorz Schetyna: Będziemy opozycją totalną. Będziemy przeszkadzać w niszczeniu kraju, 26 II 2016, https://polskatimes.pl, dostęp 20 III 2020. 
stylu definiowania tego pojęcia przez Thomasa Hobbesa i Maxa Webera niż Johna Locke'a i Talcotta Parsonsa7 . Ten wybór przynosił ważne konsekwencje.

Primo, dla PiS władza jest przede wszystkim zdolnością do podejmowania suwerennych decyzji, poprzez które realizuje się własną wolę i osiąga wyznaczone strategiczne cele, poddane ocenie w czasie wyborów, nawet wbrew oporowi innych uczestników stosunków społecznych, w tym w skali międzynarodowej (opozycja na arenie wewnętrznej, państwa w środowisku międzynarodowym). Odrzucono więc myślenie, konstytuujące liberalizm, o władzy w kategoriach umowy społecznej, dającej uprawnienia (zdolność) do stanowienia i egzekwowania prawa będącego wyrazem celów wyznaczonych w wyniku zawarcia kompromisu, obejmującego jak największą ilość uczestników stosunków społecznych. Prezydent czy rząd, powołani z rekomendacji PiS, w trakcie sprawowania władzy starali się realizować myśl polityczną własnej formacji, niezależnie od fluktuacji sondażowych. Dla polityków PiS determinanta programowa była wyjątkowo ważna w sprawowaniu władzy. Tej ostatniej nie postrzegano w kategoriach uprzywilejowania i godności, uprawniających do zaszczytów.

Secundo, władza dla PiS jest nie tylko właściwością danych organów państwowych (ujęcie substancjalne), ale przede wszystkim zdolnością kształtowania stosunków społecznych (ujęcie relacyjne), w tym wywoływania procesów politycznych korzystnych dla danego podmiotu politycznego. Myśląc w tych kategoriach, należy uznać, że to władza jawi się jako zdolność zarządzania konfliktami i kryzysami, które często są postrzegane jako środki do realizacji celów strategicznych, a przede wszystkim kształtowania rzeczywistości ${ }^{8}$. Z tych zasadniczych powodów J. Kaczyński, sprawując władzę, ale także będąc w opozycji, niejednokrotnie nadawał stosunkom społecznym w Polsce nową dynamikę, wprowadzając

\footnotetext{
7 VideS. Wróbel, Wtadza i rozum. Studia rozwojowe krytycznej teorii społecznej, Wydawnictwo Naukowe UAM, Poznań 2002, s. 27-28; A. Czajowski, Wtadza polityczna: analiza pojęcia, [w:] Studia z teorii polityki, t. 1, red. A. W. Jabłoński, L. Sobkowiak, Wydawnictwo Uniwersytetu Wroctawskiego, Wroctaw 1999, s. 33-36.

8 Vide Ł. Warzecha, Lech Kaczyński. Ostatni wywiad..., s. 15.
} 
do debaty publicznej różne podziały społeczne: zwolennicy kontraktu okrągłostołowego-zwolennicy przyspieszenia, postkomuna-obóz solidarnościowy, Polska liberalna-Polska solidarna, III Rzeczpospolita-IV Rzeczpospolita, obóz "dobrej zmiany"-opozycja totalna. W ten sposób lider PiS stawał się "panem pola gry”, wymuszając na innych uczestnikach defensywne dostosowywanie się do niej. Inicjatywa należała do niego, co oczywiście nie zawsze oznaczało wygraną, ale wielokrotnie o niej przesądziło: elekcje prezydenckie Lecha Wałęsy, Lecha Kaczyńskiego i Andrzeja Dudy, wygrane w wyborach parlamentarnych w 2005, 2015 i 2019 roku.

Tertio, władza polityczna spełnia wyjątkowo ważną rolę w ujęciu historycznym, gdyż spoczywają na niej dwa obowiązki: 1) dokonywania koncentracji i konsolidacji politycznej w odniesieniu do państwa oraz 2) nadawania danemu podmiotowi tożsamości politycznej, między innymi przez politykę w odniesieniu do symboli, interesów, historii, afektów i emocji. Te obowiązki stawały się priorytetowe dla władz RP, które w wyniku wygranych wyborów były obsadzane przez polityków $\mathrm{PiS}$ zarówno w latach 2005-2007, jak i w okresie 2015-2019. Nie wyobrażano sobie skutecznej polityki zagranicznej bez konsolidacji politycznej wokół Rzeczypospolitej, jej racji stanu oraz interesów narodowych. Chcąc realizować cele w środowisku międzynarodowym, należało utrwalić tożsamość polityczną państwa. Zamierzano ją budować poprzez wywoływanie pozytywnych emocji, zwłaszcza przez odwoływanie się do rocznic historycznych, które postrzegano jako kamienie milowe polityki historycznej. Właśnie z tej perspektywy poznawczej należy interpretować wypowiedź Grażyny Gęsickiej na III Kongresie PiS w 2010 roku, która powiedziała: „Wspólnotę narodową buduje się wokół historii, ale także wokół celów i wizji przyszłości" ${ }^{\prime}$. PiS zaproponowało w swoich licznych programach partyjnych spójną, opartą na aksjologii interpretację i ocenę przeszłości oraz sprecyzowaną wizję przyszłości. Jarosław Kaczyński nie miał wątpliwości, że aktywność założonej przez niego partii będzie kon-

9 Nowoczesna Polska 2020. Materiaty i dokumenty [III Kongres Prawa i Sprawiedliwości. Zespół Pracy Państwowej], PiS, Poznań 2010, s. 35. 
fliktogenna w wielu wymiarach i na licznych polach. Do takiej sytuacji przygotowywał kierowaną przez siebie partię.

Wskazane kryteria polityczności zostały wywiedzione przez PiS z czterech założeń o charakterze ogólnym.

1. Cele polityczne realizuje się tylko w ujęciu długookresowym, dlatego też sprawowaniu władzy w państwie musi towarzyszyć możliwość podejmowania działań strategicznych. Tym samym prezesa PiS nigdy nie interesowała władza połowiczna, czyli rządy powstałe w wyniku kompromisu z przeciwnikami jego wizji politycznej. Podsumowując stosunek J. Kaczyńskiego do sprawowania władzy po okresie krótkich rządów 2005-2007, Rafał A. Ziemkiewicz stwierdzał: „[...] nie jest już zainteresowany normalnym wygrywaniem wyborów i przejęciem władzy w koalicji z kimkolwiek [...]. Czeka na kompletny upadek systemu i wzięcie całej puli". Ów zapowiadany przez Ziemkiewicza system, poddawany konsekwentnej dekonstrukcji, został przez PiS w 2014 roku nazwany, opisany i zdiagnozowany jako „system Tuska”, który najogólniej polegał na: restauracji postkomunizmu przefiltrowanego przez liberalizm, zawłaszczeniu państwa przez PO, naruszeniu standardów demokracji, niskiej efektywności rozwojowej oraz traktowaniu „utrzymania władzy jako celu nadrzędnego". O tym systemie pisano, że jest „wypaczeniem istoty demokracji zarówno w odniesieniu do jej treści, jak również procedur i mechanizmów charakteryzujących ten ustrój polityczny"10. Ziemkiewicz uznał więc prezesa PiS za „człowieka, który niezłomnie obstawia na ruletce zero"11. Tym zerem było przejęcie pełni władzy w wyniku demokratycznych wyborów w następstwie załamania się „systemu Tuska". Jarosław Kaczyński był pewien prognozowanego załamania przynajmniej z jednego powodu - ten system był antyrozwojowy, dlatego musiał doprowadzić do wyczerpania zasobów i zablokowania jego zdolności autopojetycznych (reprodukcyjnych).

10 Zdrowie, praca, rodzina. Program Prawa i Sprawiedliwości 2014, PiS, Warszawa 2014, S. 15, $18,44$.

11 Ziemkiewicz użył określenia „gra w zero" w 2008 roku w odniesieniu do J. Kaczyńskiego w publikacji Czas wrzeszczących staruszków. Vide R. A. Ziemkiewicz, Myśli nowoczesnego endeka, Fabryka Słów, Lublin-Warszawa 2017, passim. 
Strategiczny ogląd celów politycznych spowodował, że w myśli politycznej PiS duże znaczenie przypisano historii oraz polityce historycznej, polegającej na świadomym wieloletnim kształtowaniu tożsamości politycznej. Według PiS posiadanie tożsamości politycznej konstytuuje podmioty w polityce, dlatego jest przedmiotem szczególnej troski. Ta postawa odnosiła się i do partii politycznej, i do państwa. Łatwo więc zrozumieć dwa zjawiska charakterystyczne dla PiS. Pierwsze - zdecydowanie negatywny stosunek lidera partii do wszelkich prób podważania w PiS linii strategicznej, co pociągało za sobą liczne secesje i rozłamy oraz odejście wielu wpływowych polityków. Drugie - negatywne odniesienie się do interpretowania integracji europejskiej w kategoriach federalistycznych lub konfederacyjnych, pogłębiania procesu kształtowania ładu paneuropejskiego, zmierzającego do przekształcenia Unii Europejskiej w jeden organizm państwowy, który przejąłby atrybuty suwerenności państw członkowskich. Polityka na rzecz kształtowania tożsamości politycznej w środowisku międzynarodowym powinna być zmonopolizowana przez państwa narodowe, a nie instytucje wspólnotowe. Dość interesujące wyjaśnienie takiego podejścia zaprezentował L. Kaczyński, mówiąc w wywiadzie, że najłatwiej jest kontrolować państwo w sposób demokratyczny, czego nie można zrobić wobec innych podmiotów politycznych ${ }^{12}$. We współczesnym świecie demokracja jest praktykowana tylko w formacie państwowym, trudno dostrzec jej przejawy w środowisku międzynarodowym czy w organizacji wewnętrznej niepaństwowych uczestników stosunków międzynarodowych.

2. Każdy podmiot polityczny, a najważniejszym dla PiS była Rzeczpospolita, dąży do zagwarantowania sobie dostępu do nowych zasobów, które wzmacniają jego potencjał. Uważano jednak w tej partii, że powiększanie potencjału wykorzystywanego w polityce zagranicznej jest zależne od jakości wewnętrznego ładu politycznego, gospodarczego i społecznego. Natomiast w opinii polityków PiS, III Rzeczpospolita została owładnięta przez imposybilizm w postaci niezdolności państwa do skutecznego działania w wielu kluczowych dziedzinach. Nawet zdefinio-

12 Ł. Warzecha, Lech Kaczyński. Ostatni wywiad..., s. 196. 
wano to pojęcie jako ideologię i praktykę. Pisano, że jest to "programowa niemożność podejmowania przez państwo wielu działań koniecznych z punktu widzenia ochrony jego interesów i dobra obywateli". Podawano jego przejawy, takie jak: brak możliwości legalnego zwalczania patologii, niezdolność państwa do mobilizowania sił i środków w celu rozwiązywania problemów społecznych, nadanie państwu konstrukcji ustrojowej maksymalnie go osłabiającej, opaczne rozumienie państwa prawa w postaci idealistycznego pojmowania podziału i równowagi władz.

W opinii PiS imposybilizm III Rzeczypospolitej stawał się wyjątkowo niebezpieczny w aspekcie międzynarodowym z dwóch zasadniczych powodów. Taki wniosek można sformułować na podstawie analizy Strategii bezpieczeństwa narodowego Rzeczypospolitej Polskiej z 2007 roku, przygotowanej przez rząd J. Kaczyńskiego. Po pierwsze - „W życiu narodów, podobnie jak w życiu jednostek, nic nie jest dane raz na zawsze. Porządek międzynarodowy nie jest zastygłą, niewzruszalną formą". Po drugie - „Rzeczpospolita Polska, będąc państwem granicznym NATO iUE, zajmuje ważne miejsce w europejskim środowisku bezpieczeństwa, a jej terytorium stanowi obszar o istotnym znaczeniu strategicznym"13. Po roku 2008 (odrodzenie się polityki imperialnej Rosji) w myśli politycznej PiS pojawił się trzeci powód koniecznego odrzucenia imposybilizmu. O ile jeszcze w 2007 roku we wspomnianej strategii rząd PiS oceniał, że w pierwszej dekadzie nowego stulecia Polska jest państwem bezpiecznym, ale jednocześnie przestrzegał przed zmiennością właściwą dla środowiska międzynarodowego oraz przed pojawieniem się nowych wyzwań zmuszających do wysiłku, o tyle po inwazji rosyjskiej na Gruzję politycy PiS dostrzegli z całą wyrazistością dokonanie się wręcz rewolucyjnej i niekorzystnej zmiany w najbliższym otoczeniu Rzeczypospolitej i w jej środowisku bezpieczeństwa. Wszelkie dane napływające z Rosji potwierdzały słuszność nowej diagnozy.

Używano pojęcia „imposybilizm” w programach partyjnych PiS z lat 2009 i 2011, zapowiadając jednocześnie przełamanie tak nazywanej

13 Strategia bezpieczeństwa narodowego Rzeczypospolitej Polskiej, [b.o.w.], Warszawa 2007, s. 3-4. 
niemocy. We wcześniejszych programach partyjnych pisano o bojaźliwości i pasywizmie w odniesieniu do sfery polityki. Natomiast w programie z 2014 roku nie było już mowy o imposybilizmie, dokonano wtedy personalizacji patologii III Rzeczypospolitej w pojęciu „system Tuska”, który nazwano „i restauracyjną odbudową, i jednocześnie kolejną mutacją klasycznego wydania III Rzeczypospolitej z jej wszystkimi negatywnymi cechami"14. Zanim jednak pojęcie „system Tuska” się pojawiło, to w wyborach prezydenckich i parlamentarnych w 2005 roku sformułowano hasło oraz program budowy IV Rzeczypospolitej, a także przedłożono projekt konstytucji tej nowej formy polskiej państwowości ${ }^{15}$. Reminiscencje imposybilizmu możemy jeszcze odnaleźć w wystąpieniu sejmowym K. Szczerskiego w 2015 roku, kiedy mówił o polityce rządu E. Kopacz: „Nie możemy ciągle bać się własnego cienia i być sparaliżowani w momencie podejmowania decyzji. Jak powiemy coś zdecydowanie, to nie możemy potem bać się własnych słów. Nie możemy czekać na zdanie innych, żeby wiedzieć, co sami mamy powiedzieć. Nie możemy czekać na rozwój wypadków. Polska nie może być państwem przeczekującym sytuacje" ${ }^{\prime \prime}$.

W PiS postrzegano stosunki międzynarodowe przede wszystkim jako przestrzeń rywalizacji między państwami, które wykorzystują do swoich celów organizacje międzynarodowe, np. Sojusz Północnoatlantycki, Unię Europejską, oraz organizacje regionalne. Państwa obowiązuje bowiem reprezentowanie interesów narodowych, a "konkurencja między narodami jest zjawiskiem trwałym i obejmuje wiele dziedzin życia", Polacy powinni w niej uczestniczyć i odnosić sukcesy ${ }^{17}$. Oceniając negatywnie możliwość zbudowania jednego państwa i ludu paneuropejskiego, PiS traktowało pogłębianie integracji jako proces przejmowania władzy

14 Zdrowie, praca, rodzina..., s. 43; Polska nowoczesna, Polska solidarna, Polska bezpieczna. Program Prawa i Sprawiedliwości 2009, 2011, PiS, Warszawa 2011, s. 17.

15 Konstytucja Rzeczypospolitej Polskiej. Projekt Prawa i Sprawiedliwości, PiS, Warszawa 2005.

16 K.Szczerski, Wypowiedź, [w:] Wypowiedzi na posiedzeniu Sejmu [dalej: WNP Sejm], 7 kadencja, 91 pos., 23 IV 2015, http://www.sejm.gov.pl, dostęp 22 V 2020.

17 Dokumenty programowe i ideowe. Kongres założycielski Prawo i Sprawiedliwość, Falęty 1-2 grudnia 2001 r., PiS, [b.m.w.] 2001, s. 11. 
w Unii Europejskiej przez najsilniejszych jej członków, dążących do opanowania zasobów kontynentalnych oraz uzależnienia od siebie państw małych i słabych ${ }^{18}$. Chcąc temu przeciwdziałać, lider stronnictwa zaproponował w 2003 roku dokonanie zasadniczej zmiany w świadomości polskiej elity politycznej, w której zostało zakodowane i przeniesione z PRL "ciągłe poczucie małości” w odniesieniu do państwa i narodu, a "to nieprawda, to trzeba czynnie odrzucić". Drogą do odrzucenia było skoncentrowanie uwagi na opracowaniu koncepcji wykorzystania organizacji międzynarodowych w polityce polskiej jako narzędzi „lewarowania" pozycji Rzeczypospolitej w środowisku międzynarodowym. Prezes Kaczyński różnie opisywał takie zachowanie, które można uznać za przemyślaną taktykę o znaczeniu niemal strategicznym:

1) „[...] walka o znaczenie Rzeczypospolitej”, żeby: „Warszawa stała się jedną z najważniejszych europejskich stolic" i nikt "nie miał wątpliwości, że nasz kraj należy do najważniejszych europejskich państw";

2) „Trzeba licytować w górę. Trzeba walczyć o status wielkiego europejskiego narodu - nawet nieco na wyrost"19.

Jego brat - Lech, nazywał tę politykę „licytowaniem Polski w górę" w odniesieniu do statusu, pozycji i bezpieczeństwa ${ }^{20}$. Jednocześnie na rzecz szerzenia demokracji odrzucono wszelkie złudzenia typu pacyfistycznego i integracyjnego o budowie wspólnego europejskiego domu oraz sojuszu zideologizowanego.

Skoro stosunki międzynarodowe są przestrzenią rywalizacji między państwami, reprezentującymi interesy narodowe, to racjonalne było sformułowanie warunku właściwego dla myśli politycznej PiS, bardzo ważnego w kontekście polityki zagranicznej, niemal ją determinującego. Zanim opiszemy ów warunek, należy wskazać przesłankę, z której wynikał. Można ją zawrzeć w cytacie: „Polacy znajdują się gdzieś

\footnotetext{
18 IV Rzeczpospolita-Sprawiedliwość dla Wszystkich. Program 2005, PiS, [b.m.w.] 2005, s. 9.

19 J. Kaczyński, Wystąpienie w czasie dyskusji na temat informacji rządu na temat polskiej polityki zagranicznej w2003 roku, [w:] Sprawozdania stenograficzne z posiedzeń Sejmu RP [dalej: SS Sejm], 4 kadencja, 40 pos., 22 I 2003, http://orka2.sejm.gov.pl, dostęp 14 IX 2008; O dwóch takich... Alfabet braci Kaczyńskich..., s. 13.

20 Ł. Warzecha, Lech Kaczyński. Ostatni wywiad..., s. 246.
} 
pośrodku, między narodami wielkimi a małymi". Ten stan miał swoje konsekwencje. O ile dla małych narodów dominujących w Europie Środkowej historycznym sukcesem jest trwanie i dostosowywanie się do trendów światowych, o tyle dla narodów zawieszonych w "prześwicie ontologicznym", czyli między wielkością a małością, celem jest zdobycie i poszerzanie podmiotowości, którą może zapewnić jedynie suwerenne państwo, zdolne do bycia producentem idei, w tym o zasięgu kontynentalnym, a nawet globalnym ${ }^{21}$. Dla narodów małych państwo suwerenne o wysokiej podmiotowości było w sferze marzeń, natomiast dla narodów średnich - realnym celem politycznym, ukierunkowującym niemal całą aktywność międzynarodową, gdyż państwa średnie tracące podmiotowość bardzo szybko wkraczają w okres upadku i są likwidowane przez silniejszych sąsiadów zainteresowanych ich zasobami, których mają wiele przynajmniej z racji swojego statusu.

Dla PiS wspomnianym warunkiem realizacji polskich interesów w środowisku międzynarodowym było sprawne państwo, wzmacniające stale i konsekwentnie swoją podmiotowość polityczną oraz dysponujące rozbudowanymi zasobami użytecznymi dla osiągania sukcesów w rywalizacji międzypaństwowej. Jak już zostało wspomniane, jednymi z takich zasobów były tożsamość polityczna państwa oraz zrozumienie interesów narodowych. Budowę tożsamości politycznej uznano za obowiązek władz państwowych, wypełniany przede wszystkim za pomocą polityki historycznej, odwołującej się do sfery symbolicznej, emocjonalnej i afektywnej. Oczywiście każde państwo powinno bronić swoich racji na arenie międzynarodowej, ale także prezentować własną interpretację wydarzeń minionych oraz zestaw symboli państwowo-narodowych: „Każdy naród polityczny musi mieć sfery tzw. świeckiego sacrum, sfery, w których to, co polityczne, ma pewien rytuał i symbol. [...] Szacunek dla przeszłości, poważne traktowanie rytuałów narodowych i symboli

21 D. Gawin, Przekleństwo 1709 roku. Czy Polacy mogą wybić się na podmiotowość?, „Teologia Polityczna" 2009-2010, nr 5, s. 36, 40-41. 
nie wyklucza nowoczesności, wręcz przeciwnie [... $]^{\text {222 }}$. Przed tego typu polityką szczegółową wyznaczono trzy cele: 1) przechowywanie i utrwalanie w świadomości zbiorowej symboliki konsolidującej społeczeństwo; 2) upowszechnianie wartości pozwalających rozpoznawać przeciwników i zagrożenia międzynarodowe; 3) nadawanie polityce zagranicznej cech efektywności i racjonalności w urzeczywistnianiu celów i zaspokajaniu interesów. Tym samym polityka zagraniczna RP powinna wynikać z realizmu, ale jednocześnie powinna być służebna wobec wartości.

Po 2010 roku, ze szczególną wyrazistością w latach 2015-2019, sfera symboliczna, emocjonalna i afektywna nie tylko polityki historycznej, ale polityki w ogóle została zdominowana przez postać Lecha Kaczyńskiego, a raczej przez jego mit ${ }^{23}$. Wykorzystując typologię mitów Janiny Hajduk-Nijakowskiej ${ }^{24}$, można sformułować dwa wnioski: pierwszy z zakresu mitotwórstwa - mit nieżyjącego prezydenta uzyskał w latach 20102019 charakter pełny; drugi - wszystkie komponenty tego mitu miały znaczenie dla koncepcji polityki zagranicznej PiS. Stronnictwo chciało na dwa sposoby uczynić z mitu Lecha Kaczyńskiego jedną z podstaw konsolidacji politycznej polskiej wspólnoty narodowej oraz tożsamości politycznej Rzeczypospolitej. Z jednej strony szczegółowa symbolika mitu (urząd, śmierć, pochówek, upamiętnienie, emocje, żałoba, konsekwencje) miała stanowić pomost między teraźniejszością a dawnymi czasami i przeżyciami narodowymi z okresu Rzeczypospolitej Obojga Narodów i II Rzeczypospolitej, związanymi z królami, Józefem Piłsudskim, Władysławem Sikorskim, Janem Pawłem II. Tak jak niegdyś Piłsudski, Kaczyński przypominał wielkich zmarłych będących w służbie Rzeczypospolitej, których niejednokrotnie w kraju nie rozumiano (elity) i zwalczano (rząd PO-PSL, środowiska medialne). Stawał się łącznikiem

22 Wypowiedź Dariusza Gawina w: Seminaria lucieńskie 2006-2007. Referaty wprowadzające do dyskusji, Kancelaria Prezydenta RP, Warszawa 2008, s. 75.

23 Pierwsze bardzo zarysowe opracowanie na temat mitu L. Kaczyńskiego videP. Lewandowski, Mit polityczny Lecha Kaczyńskiego, Wydawnictwo Adam Marszałek, Toruń 2014, passim.

24 J. Hajduk-Nijakowska, Proces mityzacji wspótczesnych bohaterów, [w:] Mit, prawda, imaginacja, red. P. Kowalski, Uniwersytet Wroctawski, Wroctaw 2011, s. 217. 
między przeszłością i przyszłością, brakującym ogniwem w ustanowieniu III Rzeczypospolitej, mimo iż paradoksalnie z L. Kaczyńskim łączyło się jej zanegowanie w postaci hasła „Prezydent IV Rzeczypospolitej” (PiS przejęło to hasło z debaty naukowej i publicystycznej toczonej na przełomie XX i XXI wieku). Z drugiej strony jawił się jako ucieleśnienie racji stanu i interesu narodowego, ich współczesnej interpretacji. Sprzyjały temu chociażby miejsce tragedii - Katyń, jej okoliczności - 70. rocznica zbrodni, przyczyna - niewyjaśniona rola Rosji i rządu D. Tuska, wielkie przemówienia (wygłoszone na Westerplatte w 2009 roku i niewygłoszone w Katyniu w 2010 roku) - o prawdzie w historii. Bardzo szybko polityka zagraniczna prezydenta została uznana za jej symboliczne „złote czasy”, kiedy określono jej najważniejsze wektory i założenia, tym bardziej że po katastrofie ówczesny obóz rządzący odcinał się od niej i zacierał jej wszelkie ślady.

Rzecz znamienna, w myśli politycznej PiS rozróżniano status i pozycję międzynarodową państwa. Przesądził o tym prezes Kaczyński, i kwestię tę określono w programach z lat 2009 i 2011. Status został zdefiniowany jako stan trwały w danym czasie historycznym, składający się z: formalnej suwerenności, podmiotowości w stosunkach międzynarodowych, roli państwa w organizacjach międzynarodowych. Natomiast pod pojęciem "pozycja międzynarodowa" państwa rozumiano zmienne możliwości realizacji interesów państwa w środowisku międzynarodowym oraz towarzyszącą temu jaźń odzwierciedloną (czyli opinię o państwie na arenie międzynarodowej) $)^{25}$.

3. Myślenie polityczne właściwe dla PiS było mocno zdeterminowane przez geopolitykę, co nie oznaczało sięgnięcia po jakąkolwiek teorię geopolityczną. Jeszcze w programach partyjnych z okresu 2001-2007 ta determinanta polityki zagranicznej nie była eksponowana. Zmiana jest widoczna w programie z 2009 roku, w którym odniesiono się do geopo-

\footnotetext{
25 J. Kaczyński, Bardzo potężne sity dążą do tego, żeby Polska nie była tym, czym mogłaby być. Trzeba się temu przeciwstawić [Rozmowa Jerzego Kubraka z Jarosławem Kaczyńskim], 7 VI 2014, https://wpolityce.pl, dostęp 20 V 2020; Polska nowoczesna, Polska solidarna, Polska bezpieczna..., s. 216-218.
} 
lityki, a w kolejnych programach, ogłoszonych w latach 2011, 2014 i 2019, rozważania i wyjaśnienia geopolityczne zaczęły zajmować coraz więcej miejsca. W programie przypisano geopolityce kluczową rolę w kształtowaniu relacji międzynarodowych w XXI stuleciu ${ }^{26}$. Odrzucono pogląd, że państwa są w stanie łatwo uwolnić się od balastu geopolitycznego i czynników cywilizacyjno-kulturowych. Wróciła natomiast, po przerwie w latach dziewięćdziesiątych XX wieku, polityka realizowana w kategoriach stref wpływów, hierarchizacji państw, imperializmu. Wpływ geopolityki na myślenie polityczne w $\mathrm{PiS}$ pociągał za sobą rozumowanie także w kategoriach systemu międzynarodowego, którego istota została określona już w XVII wieku na konferencjach westfalskich kończących wojnę trzydziestoletnią (ład westfalski, korygowany w następnych wiekach na konferencjach/kongresach wiedeńskim, berlińskim i paryskim). Tą istotą było przypisywanie wyjątkowej roli w systemie międzynarodowym państwom jako jedynym podmiotom nacechowanym suwerennością. Inną cechą ładu westfalskiego było zdezawuowanie reliktów średniowiecza o istnieniu suprapaństw (w tamtych czasach chodziło o Święte Cesarstwo Rzymskie Narodu Niemieckiego) i rozumowania o środowisku międzynarodowym w kategoriach suzeren-wasal ${ }^{27}$. Zależność wasalna, czyli w sensie nowożytnym klientystyczna, była utożsamiana z obniżeniem podmiotowości prowadzącym do utraty realnej, a nie formalnej suwe-

26 Program Prawa i Sprawiedliwości 2014, PiS, [b.m.w.] 2014, s. 153.

27 W monografii używane jest określenie "suprapaństwo" dla takich bytów politycznych o uniwersalnych ambicjach, które roszczą sobie pretensje do zwierzchnictwa nad państwami, na podobieństwo rozwiązań systemowych wtaściwych przede wszystkim dla średniowiecza europejskiego. Unia Europejska w XXI wieku zaczęła zmierzać do osiągnięcia statusu takiego suprapaństwa. Zrezygnowano więc w monografii z pojęcia „superpaństwo" na określenie aktualnego stanu Unii, żeby celowo podkreślić odmienność takich podmiotów politycznych - bez bazy społecznej i zdolności przeprowadzenia koncentracji politycznej, z silnie zarysowanymi tendencjami uniwersalistycznymi, wprowadzającymi nowe podziały polityczne oraz nowy typ konsolidacji politycznej. Suprapaństwo nie jest państwem klasycznym, ale także nie może być superpaństwem, ponieważ nie spełnia obiektywnie najważniejszych kryteriów państwa, w tym nie posiada instrumentów władczych (policja, wojsko, urzędy skarbowe), lecz jedynie wysuwa roszczenia typu państwowego. 
renności. Państwo sprowadzone do roli wasalnej traci wtedy zdolność realizacji racji stanu oraz interesu narodowego, a także ulega penetracji.

Prawo i Sprawiedliwość przypisywało systemowi międzynarodowemu sześć konstytutywnych cech:1) anarchiczność definiowaną jako przeciwieństwo istnienia jednego ośrodka dyspozycji politycznej w środowisku międzynarodowym; 2) złożoność widoczną na wielu obszarach stosunków międzynarodowych;3) dychotomię polegającą na funkcjonowaniu obok siebie strefy bezpiecznej, opartej na prawie międzynarodowym i strefy chaosu, opartej na zależnościach klientystycznych; 4) dynamikę właściwą stosunkom międzynarodowym, premiującą aktywność, samodzielność i kreatywność; 5) zróżnicowanie widoczne w środowisku międzynarodowym, wynikające z różnicy potencjałów między państwami; 6) rywalizacjęjako stan naturalny i odwieczną cechę stosunków międzynarodowych ${ }^{28}$.

Względy geopolityczne narzucały obiektywne ograniczenia polityce zagranicznej Rzeczypospolitej, determinując dwa główne pola aktywności. Pierwszym było ostateczne zniesienie pozostałości po przynależności do radzieckiej strefy wpływów, co mogło się dokonać przede wszystkim przez wzmacnianie podmiotowości Polski oraz jej roli w Sojuszu Północnoatlantyckim, postrzeganym jako jedyny możliwy czynnik zapewnienia suwerenności i bezpieczeństwa Rzeczypospolitej. Drugim polem było podnoszenie statusu Polski w Unii Europejskiej. Takie przemyślenia w pełni uzasadniały priorytetowe zainteresowanie PiS regionem Europy Środkowej i Wschodniej, ponieważ „Polska czerpie swą siłę z siły regionu Europy Środkowej i Wschodniej i poprzez to wzmacnia potencjał całej Europy"29. Słowa te stanowią klucz do zrozumienia koncepcji PiS polityki zagranicznej Polski.

Jednak żeby taka sytuacja zaistniała, należy uprzednio dokonać ważnej dekompozycji o charakterze geopolitycznym i mentalnym w skali globalnej, świat przyzwyczaił się bowiem do nieistnienia Europy Środ-

28 J. Sanecka-Tyczyńska, Racja stanu we wspótczesnej polskiej myśli politycznej 2001-2015, Wydawnictwo UMCS, Lublin 2019, s. 291-293.

29 Program Prawa i Sprawiedliwości 2014..., s. 155. 
kowej ${ }^{30}$, a posłannictwem Polski jest ją odbudować. Klęska tego planu będzie prowadziła do utraty przez Rzeczpospolitą swojego bytu. Tego zadania nie można zrealizować, zapominając o historii, bo: „W naszej części Europy wakacje od historii nigdy nie trwały długo" ${ }^{31}$. Marek Chodakiewicz w swojej wybitnej monografii Międzymorze określił dwa warunki udanej rekonstrukcji Europy Środkowej: 1) przezwyciężenie postkomunizmu, będącego dziedzictwem zasadniczej większości ziem środkowoeuropejskich oraz 2) okcydentalizacja, polegająca na oryginalnej (a nie adaptacyjnej) recepcji dorobku Zachodu w powiązaniu z wpływami Wschodu. Dwoma cechami tejże okcydentalizacji są pluralizm w regionie w odniesieniu do zróżnicowania jego mieszkańców pod wieloma względami oraz odbudowa wolności, w tym znaczenia religii w konstytuowaniu przestrzeni publicznej ${ }^{32}$. Bez cienia wątpliwości ten sposób myślenia o Europie Środkowej odzwierciedlał sposób pojmowania rekonstrukcji regionu w myśli politycznej PiS.

Polska, jako członek Sojuszu Północnoatlantyckiego i Unii Europejskiej, a zarazem największe państwo w regionie, kierując się własną racją stanu, powinna zająć się rekonstruowaniem regionu jako realnej przestrzeni politycznej. Było to dla Polski zadanie nie tylko konieczne, ale również wykonalne, a na pewno decydujące o bycie politycznym Rzeczypospolitej. PiS tym samym prezentowało kolejne historyczne wcielenie dylematu właściwego dla polskich dziejów - budowy państwa o średnim potencjale, słaby organizm polityczny odizolowany od swojego otoczenia w tych realiach geopolitycznych nie ma bowiem szans na przetrwanie.

30 W okresie rywalizacji amerykańsko-radzieckiej nastąpit podziat Europy Środkowej na zachodnią i wschodnią wzdtuż żelaznej kurtyny. Jednak już Rosja carska i II Rzesza zwalczały wszelkie rozumowanie o odrębności ich ziem środkowoeuropejskich. Dopiero w ostatniej fazie Wielkiej Wojny Niemcy sięgnęty do pomystu oderwania ziem zachodnich imperium rosyjskiego w celu utworzenia klientystycznej wobec nich Europy Centralnej, skazanej na podporządkowanie Berlinowi, będącej jednak odrębną od Rzeszy przestrzenią stabych państw narodowych: polskiego, białoruskiego, litewskiego, ukraińskiego, totewskiego i estońskiego. Trudno jednak ten projekt uznać za odbudowę Europy Środkowej w jej znaczeniu z XVI stulecia.

31 M. A. Cichocki, Szkice z polskiej podmiotowości, "Teologia Polityczna" 2009-2010, nr 5, s. 65, 68.

32 M. J. Chodakiewicz, op. cit., s. 278. 
Bezwzględnie chciano uniknąć epizodu Księstwa Warszawskiego - „małe państwo wielkich nadziei" ${ }^{33}$, ponieważ jego upadek skazał następne pokolenia na powstania narodowe, które bardziej kształtowały naród, niż były szansą na odzyskanie Rzeczypospolitej.

4. Podział na sojuszników i wrogów nie może być zredukowany do rywalizacji innego typu, np. ekonomicznej lub społecznej. Ten pogląd w pełni oddaje wzorzec myślenia o polityczności właściwy dla PiS. Z tego powodu państwo powinno dbać o kształtowanie świadomości społecznej w duchu identyfikacji racji stanu i interesów narodowych: „Polacy mają prawo wiedzieć, kto służył Moskwie, a kto walczył o niepodległą Ojczyznę. Kto był katem, a kto ofiarą" ${ }^{34}$. W oparciu o te kategorie (wróg i sojusznik) wyznaczano cele w stosunkach dwustronnych międzypaństwowych. Wypowiedziano się przeciwko modelowi polityki zagranicznej polegającym na zakładaniu niezdolności Polski do samodzielnego działania w środowisku międzynarodowym, co miało uzasadniać poszukiwanie oparcia w mocarstwach europejskich lub w strukturach Unii Europejskiej. W zamian postulowano politykę podmiotową, polegającą na wywoływaniu pożądanych faktów i procesów w środowisku międzynarodowym "przy użyciu wszystkich dostępnych instrumentów, także wielostronnych" ${ }^{35}$.

W myśleniu politycznym wiele uwagi poświęcano w PiS zdolności z jednej strony do rozpoznawania własnej sytuacji w kontekście rywalizacyjnym, a z drugiej strony do tworzenia warstwy symbolicznej, afektywnej i emocjonalnej. Jarosław Kaczyński, twórca i niekwestionowany lider formacji, sprecyzował podejście PiS do polityki. Powiedział w Sejmie: "[...] zacząć trzeba od pewnej generalnej dyrektywy, dyrektywy aktywności, poszukiwania sojuszników, nieustannego aktywnego uczestniczenia w grze, która jest dla polityki zagranicznej czymś immanentnym, czymś, co nigdy nie ustaje". W tak opisywanej grze trzeba unikać ograniczania

33 B. Grochulska, Mate państwo wielkich nadziei, KAW RSW „Prasa-Książka-Ruch", Warszawa 1987.

34 IV Rzeczpospolita - Sprawiedliwość dla Wszystkich..., s. 18.

35 Program Prawa i Sprawiedliwości 2014..., s. 154. 
podmiotowości i nie należy rezygnować z zachowań typowo politycznych, czyli obrony swoich racji, nawet wbrew silniejszym partnerom ${ }^{36}$.

W myśli politycznej PiS dokonano dość jasnego, podstawowego rozróżnienia na podmioty i środki polityczne. Dla J. Kaczyńskiego i jego zwolenników, Polska i Polacy są podmiotami politycznymi, które posługują się środkami politycznymi. To właśnie w ten sposób tym drugim jest nadawany status polityczny. Prezes PiS pisał we wstępie do programu z 2005 roku: „Polska jest wartością” oraz „warto być Polakiem i trzeba uczynić wszystko, by nasz naród rozwijał się"37. W konsekwencji wprowadzono do debaty politycznej pojęcie "polonizm”, odrywając je od nacjonalizmu, ale także pisząc o jego kryzysie. Dwie cechy były wielce charakterystyczne dla PiS w kwestii postrzegania polskości. Po pierwsze, niezrozumiałe dla PiS było unikanie przez dominujące w III Rzeczypospolitej stronnictwa identyfikacji z polskością, a wyraźna była skłonność do przyjmowania zagranicznych ocen polskich dziejów. Dostrzegano niezdolność do wykorzystywania polskich sukcesów, przy jednoczesnej tendencji do nieustannego przypominania narodowi o klęskach lub domniemanych historycznych winach. Takie oceny zostały zawarte w pierwszym programie partii, napisanym w 2001 roku. To w nim zdefiniowano pojęcie "polonizm” jako przywiązanie do wartości związanych z polską przynależnością narodową. Za przejawy opisywanego kryzysu uznano prezentowanie kilku postaw negatywnych - od postawy opisywanej jako „lęk wobec Wschodu i poczucie niższości wobec Zachodu” poprzez przyjmowanie poglądu o nieistotnym znaczeniu przynależności narodowej we współczesnym świecie do odrzucenia polskiej tożsamości, a zaakceptowania kategorii „Europejczyk" jako podmiotu odniesienia ${ }^{38}$. Nosiciele takich przekonań lokowali się niemal automatycznie wśród politycznych przeciwników. Po drugie, jeśli traktować polonizm jako tożsamość polityczną, to L. Kaczyński, a za nim cała formacja odrzucili

\footnotetext{
36 J. Kaczyński, Wystąpienie w czasie dyskusji na temat informacji rządu na temat polskiej polityki zagranicznej w 2003 roku...

37 IV Rzeczpospolita - Sprawiedliwość dla Wszystkich..., s. 4.

38 Dokumenty programowe i ideowe. Kongres założycielski Prawo i Sprawiedliwość..., s. 25.
} 
jej postrzeganie w kategoriach przełomu dokonanego w 1989 roku, jakby chcieli liberałowie i lewica (hasła „wybierzmy przyszłość" i „polskość to nienormalność"). Tożsamość polska jest trwała, ukształtowana przez wieki, „zdefiniowana” przez historię, nie wymaga transformacji kulturowej w związku z wejściem do sfery euroatlantyckiej ${ }^{39}$.

Natomiast 14 lat później, w 2019 roku spojrzenie na tę kwestię zdominowało inne pojęcie - antypolonizm. Sięgnięcie po to określenie w znacznym stopniu wynikało z analizy myśli politycznej PO, w której polskość była traktowana jako obciążenie na drodze do europeizacji polskiego społeczeństwa i jego modernizacji. PiS zobowiązywało się do "przeciwdziałania antypolonizmowi", wiążąc go z fałszowaniem historii w odniesieniu przede wszystkim do II wojny światowej. Chodziło wtedy o przeciwdziałanie propagandzie, głównie rosyjskiej i żydowskiej, oskarżającej Polskę o bycie albo sprawcą wybuchu tej wojny, albo kolaborantem Niemiec w polityce zagłady Żydów ${ }^{40}$. Był jeszcze drugi powód walki z antypolonizmem, związany ze stanem polskiej świadomości. Opisał go Zdzisław Krasnodębski: „[...] największymi polofobami są sami Polacy. Pełni kompleksów [...] bardzo często mają negatywny autostereotyp i zdecydowanie zaniżone oceny swego kraju" ${ }^{41}$. Władze RP powinny przeciwdziałać tym zjawiskom, bo one uderzają w konsolidację polityczną, niezbędną dla realizacji polityki zagranicznej.

Cechami polonizmu miały być obowiązki zarówno Polski wobec swoich obywateli, jak i Polaków wobec własnego państwa. W opracowaniu na temat myśli politycznej Lecha Kaczyńskiego za credo polityczne prezydenta uznano zasadę protego ergo obligo, czyli "państwo zobowiązuje, bo chroni", dlatego też "obowiązki obywateli wobec państwa pozostają w najściślejszym związku z wypełnianiem przez państwo jego obowiąz-

39 A. Waśko, Patriotyzm Lecha Kaczyńskiego, [w:] Lech Kaczyński. Pamięć i zobowiązanie, PiS, Warszawa 2011, s. 32.

40 IV Rzeczpospolita-Sprawiedliwość dla Wszystkich..., s. 10; Dobryczas dla Polski. Program 2019 Prawa i Sprawiedliwości, PiS, [b.m.w.] 2019, s. 181-182.

${ }_{41}$ Z. Krasnodębski, Drzemka rozsądnych..., s. 72-73. 
ków"42. Uznano wtedy, że powinnością każdej władzy w Rzeczypospolitej jest nie tylko kreowanie podstaw aksjologicznych koncentracji politycznej, ale również dysponowanie istniejącymi zasobami, aby przejąć panowanie nad kolejnymi w celu maksymalizacji potencjału politycznego państwa: „[...] chcemy, by Polska stawała się, w sposób niemożliwy do zakwestionowania przez nikogo, jednym z najbardziej znaczących krajów naszego kontynentu. Powinniśmy chcieć być wielkim narodem"43. To była klisza, którą przykładano do oceny wszystkich ugrupowań sprawujących władzę w Polsce.

W PiS liczono, zwłaszcza po wejściu do Unii Europejskiej i związanej z tym fali wielkiej migracji, że zasobem możliwym do wykorzystania będzie diaspora polska, jeśli państwo umiejętnie będzie dbało o utrzymywanie migrantów w sferze kultury polskiej i w lojalności wobec Polski. Z tego powodu w programach przyjmowanych przez partię były umieszczane specjalne rozdziały (punkty) na temat Polonii. W programach z lat 2009 i 2011 temu fragmentowi nadano wielce wymowny tytuł Solidarnie z rodakami za granica oraz deklarowano: „Polacy rozsiani po całym świecie stanowią część naszej wielkiej wspólnoty narodowej. Są dla naszej polityki zarówno cennym kapitałem, jak i zobowiązaniem". Także w programie wcześniejszym z 2005 roku pojawił się krótki fragment Troska o Polonię, a dla gabinetu J. Kaczyńskiego był to jeden z ważniejszych kierunków aktywności międzynarodowej ${ }^{44}$. W kolejnym programie z 2014 roku zrezygnowano z odrębnej części o Polonii, ale pisząc o statusie i pozycji Polski w Europie i świecie, zaliczono regulowanie tego problemu do założeń polityki zagranicznej RP. Podkreślano: „siłą Polski są Polacy rozsiani po całym świecie", a celem państwa jest działanie na rzecz tych rodaków, gdyż jest to podmiot troski wynikający z więzi na-

42 Warto być Polakiem. Idea i myśl Lecha Kaczyńskiego, oprac. M. Łopiński, Kancelaria Prezydenta RP, Warszawa 2010, s. 6.

43 Ibidem.

44 Nowoczesna, solidarna, bezpieczna Polska. Program Prawa i Sprawiedliwości, PiS, Kraków 2009, s. 168, 210; IV Rzeczpospolita - Sprawiedliwość dla Wszystkich..., s. 50. Vide Rząd Premiera Jarosława Kaczyńskiego. 365 dni lipiec 2006-lipiec 2007, CIR, Warszawa 2007, s. 56-57. 
rodowej, która "przekracza granice państw" ${ }^{45}$. Podobne treści możemy odnaleźć w programie z 2019 roku; powrócono w nim do umieszczenia specjalnego punktu zatytułowanego w sposób dla tej partii niemal tradycyjny Polacy poza granicami kraju i Polonia siłą Polski oraz zamieszczono go w dziale Polityka zagraniczna i obronna ${ }^{46}$.

Jest dość charakterystyczne, że PiS rozróżniało Polaków zamieszkujących poza granicami Rzeczypospolitej w wyniku kurczenia się jej państwowego terytorium od Polonii będącej dziedzictwem trwającej przez dekady emigracji. Zdecydowanie jednak przeceniano zarówno wolę i zdolność emigracji polskiej po 2004 roku do wspierania Polski, zwłaszcza rządzonej przez konserwatywne PiS, jak również jej skłonność do powrotu do ojczyzny w przypadku osiągnięcia przez nią rozwojowych sukcesów. Nie doceniano, że dla wielu osób, które wyjechały z Polski, był to także wybór niemal cywilizacyjny, ponieważ ojczyzna „zmęczyła” ich trudnościami życia codziennego, w tym fatalną organizacją przestrzeni publicznej oraz usługami społecznymi na niskim poziomie (ochrona zdrowia, opieka społeczna). Nie starano się zrozumieć, że zasadnicza większość migrantów dość szybko dobrze zaadaptowała się w nowych państwach osiedlenia i jedynie przechowywała w świadomość sentyment do krainy swojego dzieciństwa, co nie czyniło z nich zasobu, który można by wykorzystać w umacnianiu statusu międzynarodowego Rzeczypospolitej.

Jednocześnie, według PiS, zmianie powinna ulec perspektywa patrzenia na Polskę przez jej obywateli, zwłaszcza elitę społeczną. Jarosław Kaczyński podkreślił w 2006 roku, że Polacy nie cenią Rzeczypospolitej, a dyskurs polityczny „nieustannie obraca się wokół tego, że właściwie to państwo nie ma żadnego znaczenia". Natomiast, jeśli chce się mieć państwo, „to po prostu kosztuje" i trzeba swoje państwo szanować ${ }^{47}$. Liderzy PiS wskazywali na niewielkie znaczenie w polskim myśleniu

\footnotetext{
45 Program Prawa i Sprawiedliwości 2014..., s. 136.

46 Dobry czas dla Polski..., s. 173-174, 183.

47 J. Kaczyński, Bezpieczeństwo kosztuje [Rozmowa Jacka Karnowskiego z Jarosławem Kaczyńskim], 19 IX 2006, http://www.polskieradio.pl, dostęp 18 XII 2009.
} 
politycznym kategorii państwa, ale jednocześnie odrzucali łączenie patriotyzmu z nacjonalizmem w sensie utrwalonym historycznie w latach międzywojennych. Podmiotem odniesienia dla patriotyzmu było państwo, a nie etnos, nacjonalizm zaś był uważany za szkodliwą płaszczyznę konsolidacji politycznej. $\mathrm{Z}$ tego powodu, według liderów PiS, należało wyeliminować nacjonalizm ze stosunków międzynarodowych jako ideologię prowadzącą do wojen.

W licznych wypowiedziach liderów PiS można zauważyć postrzeganie polityki zgodne z tradycją romantyczną, przeniesioną do niej skutecznie w Polsce przez Józefa Piłsudskiego, który traktował romantyzm jako styl myślenia polegający na wizjonerstwie w odniesieniu do kreowania celów politycznych. Powinny być one historycznie doniosłe, zgodne z wielką przeszłością i maksymalistyczne, gdyż tylko wtedy mobilizują społeczeństwo do aktywności. A ta aktywność jest kluczowa dla przeprowadzenia konsolidacji politycznej. Piłsudski w całej swojej karierze politycznej zdezawuował przeciwstawianie realizmu romantyzmowi ${ }^{48}$, zaprzeczając, jakoby to pozytywizm był postawą realistyczną. Kiedy odrodzenie Rzeczypospolitej wydawało się jedynie mrzonką, on konsekwentnie twierdził, że ten cel z epoki romantyzmu jest jak najbardziej realny, chodzi tylko o zastosowanie środków politycznych adekwatnych do danych czasów historycznych. Porównując ze sobą najbardziej rozbudowane programy PiS, powstałe przed dwukrotnym zdobyciem władzy - z lat 2005 i 2014, można wskazać w nich konsekwencje recepcji romantyzmu w sensie piłsudczykowskim. Było to odczytywanie tej tradycji ideowej w sposób nowoczesny. W programie PiS z 2005 roku przywołano demokratyczny dorobek wielokulturowej I Rzeczypospolitej, uczestnictwo Polaków w walkach wolnościowych w Europie, moralny protest ruchu

48 Zdzisław Krasnodębski, zastanawiając się nad losami paradygmatu romantycznego w czasach najnowszych, nie dostrzegt, że już Piłsudski i jego współpracownicy potrafili wpisać romantyzm we współczesność. PiS nie było pierwszym ugrupowaniem, które w nowoczesny sposób sięgnęło do romantyzmu, powtórzyło po prostu manewr wykonany wiele lat wcześniej przez piłsudczyków. Z. Krasnodębski, Drzemka rozsądnych..., s. 21 i n. 
solidarnościowego przeciwko komunizmowi ${ }^{49}$. Natomiast w 2014 roku zaproponowano wypracowanie syntezy bytu jednostki w ujęciu indywidualnym ze wspólnotowym. Dokonano tego przedsięwzięcia na trzech płaszczyznach: 1) pomocniczości wspólnoty (rodziny i narodu) wobec jednostki w eliminowaniu zagrożeń dla życia wynikających z czynników zewnętrznych; 2) symbiozy między życiem codziennym a wartościami heroicznymi; 3) współistnienia wolności jednostki i solidarności wspólnoty. Wyraźnie widać przezwyciężanie antynomii właściwych dla klasycznego romantyzmu.

Wyjątkowe sympatie do romantyzmu powodują zamieszanie w ocenie myśli politycznej PiS oraz liderów tej formacji - czy bliżej im było do romantycznych złudzeń sprzed przewartościowań piłsudczykowskich, znajdujących się przez lata u podstaw czynów powstańczych, czy raczej byli zdecydowanymi realistami w odniesieniu do polityki w duchu piłsudczykowskim, a kult romantyzmu wynikał jedynie z chęci skutecznego oddziaływania na społeczeństwo ${ }^{50}$. Tak jak w piłsudczykowskiej myśli politycznej, również w myśli politycznej PiS nie ma ani sakralizacji historii, lecz dominuje rzeczowy do niej stosunek, ani apoteozy cierpienia i ofiary, tylko konieczność ich upamiętnienia; brak też radykalnego podejścia do środków politycznych, ale jest ostrożność i sięganie po te sprawdzone w przeszłości i oparte na diagnozie rzeczywistości. Piłsudczykowskie przewartościowanie romantyzmu miało trzy wyjątkowo ważne konteksty. Pierwszy - przejęli z romantyzmu potrzebę wyznaczania w polityce ambitnych, doniosłych historycznie celów; ich realizacja zasadniczo zmieniłaby losy sprawy polskiej, prowadząc do niepodległości i przezwyciężając skutki rozbiorów. Drugi - wybór taktyki w polityce oraz środków politycznych musi mieć charakter realistyczny (w polskiej tradycji pozytywistyczny) oraz oparty na: analizowaniu rzeczywistości politycznej, stosunków międzynarodowych, nastrojów społecznych;

\footnotetext{
49 IV Rzeczpospolita-Sprawiedliwość dla Wszystkich..., s. 42-43.

50 Opis problemu relacji romantyzm-realizm w odniesieniu do L. Kaczyńskiego w: P. Semka, Lech Kaczyński. Opowieść arcypolska, Czerwone i Czarne, Warszawa 2010, s. 11-12; Lech Kaczyński. Biografia polityczna..., s. 11.
} 
myśleniu wielowariantowym (scenariuszowym); działalności rozpisanej na etapy. Trzeci - odmówiono realizmu postawom lojalistycznym wobec zaborców, uważając je za niepatriotyczne, sprzeczne z interesem narodowym oraz godzące w polską tożsamość polityczną. Należy zgodzić się z opinią biografa Lecha Kaczyńskiego - Sławomira Cenckiewicza, że prezydent podzielał ten sposób myślenia historycznego, z jedną uwagą. W roli lojalistów obsadził komunistów oraz ich sojuszników z okresu Polski Ludowej, odmawiając im miana rzeczników realizmu, a widząc w nich w wariancie ostrym - zdrajców, w wariancie łagodnym - oportunistów ${ }^{51}$.

Całościowej rozprawy ze stereotypowym podejściem do polskiego romantyzmu, odziedziczonym po PRL i utrwalanym w III Rzeczypospolitej, dokonał Przemysław Żurawski vel Grajewski na łamach najpierw "Teologii Politycznej”, a następnie w konserwatywnym tygodniku „Sieci". Ten tekst możemy uznać za dobrą wykładnię przewartościowań romantyzmu w wydaniu konserwatywnego PiS. Członkom partii daleko było do krakowskich konserwatystów z II połowy XIX stulecia, gdyż przyjęli mniemanie, że zachowania romantyczne w XIX i XX wieku wynikały z charakteru staropolskiej wspólnoty politycznej oraz właściwej dla niej wolnościowej kultury politycznej, która w odniesieniu chociażby do powstań - począwszy od konfederacji dzikowskiej w 1732 roku i konfederacji barskiej w 1768 roku, a skończywszy na powstaniu warszawskim w 1944 roku - miała charakter deterministycznego czynnika. Owe „nierealistyczne" przejawy romantyzmu, według Żurawskiego vel Grajewskiego, przyniosły konkretne efekty: 1) utrzymanie polskości, która nie została wchłonięta ani przez kulturę i tożsamość niemiecką, ani przez rosyjską; 2) uniknięcie znacznie większych strat demograficznych w przypadku zajęcia postawy kapitulanckiej wobec wrogów, gdyż wtedy znacznie więcej Polaków zginęłoby w wojnach imperialnych; 3) narodziny przekonania, że podbój Polski jest przedsięwzięciem dość ryzykownym i kosztownym w każdym wymiarze ${ }^{52}$.

51 Ibidem.

52 P. Żurawski vel Grajewski, Bić się czy nie bić? Oczywiście bić, „Sieci”, 8-14 VI 2020, nr 24, s. 44-47. 
W dokumentach partyjnych PiS zaproponowano także definicję narodu wywiedzioną z polskiego procesu narodowotwórczego. Zrobiono to w tym samym roku, w którym powstała partia, bo w 2001, definiując naród jako wspólnotę kultury i doświadczenia historycznego oraz wspólnotę losu; dla tych cech spoiwem było państwo jako czynnik narodowotwórczy. W tym duchu wypowiedział się także prezydent Kaczyński w Sejmie (orędzie z 1 kwietnia 2008 roku na temat ratyfikacji traktatu lizbońskiego): „Naród polski to wspólnota pokoleń - tych żyjących na naszej ziemi tu i teraz, tych, które odeszły, i tych, które przyjdą po nas" ${ }^{23}$. Jakże wiele w tej wypowiedzi reminiscencji piłsudczykowskich, a jakże mało narodowodemokratycznych, a na pewno brak nacjonalistycznych. Zupełnie świadomie dawano w PiS pierwszeństwo czynnikom kulturowym i historycznym, a nie etnicznym i wyznaniowym, mimo akcentowania znaczenia idei chrześcijańskich i nauczania społecznego Kościoła katolickiego. Wiele lat później napisano, że narodu "nie definiujemy w sensie etnicznym", lecz ponadetnicznym jako "demokratyczną wspólnotę polityczną" oraz „wspólnotę kultury, języka, doświadczenia historycznego, tradycji politycznej i wartości cywilizacyjnych, przeżywanego losu" ${ }^{54}$. Zdzisław Krasnodębski wywodził definiowanie narodu z tradycji republikańskiej i wolnościowej, która odrzucała kryterium etniczne i biologiczne ${ }^{55}$. W polskich realiach sporów politycznych takie podejście do kategorii "naród" oznaczało odcięcie się od myśli narodowodemokratycznej oraz nacjonalistycznej. W dokumentach partyjnych nie odnajdziemy rezyduów właściwych dla tego nurtu polskiej myśli politycznej.

Według PiS naród polski powstał w wyniku wielowiekowego procesu, w którym kluczową rolę odegrał kod kulturowy i cywilizacyjny, ukształtowany w okresie staropolskim. Wtedy naród stanowiły stany uprzywilejowane, a w XIX i XX wieku dokonało się unarodowienie warstw plebejskich, domknięte w II Rzeczypospolitej. Nie identyfikując

\footnotetext{
53 Polityka zagraniczna. Bezpieczeństwo, [w:] Lech Kaczyński. Pamięći zobowiązanie..., s. 139

54 Dokumenty programowe i ideowe. Kongres zatożycielski Prawo i Sprawiedliwość..., s. 10; Program Prawa i Sprawiedliwości 2014..., s. 9.

55 Z. Krasnodębski, Jaki model prawicowości?, [w:] Partie i zmiany granic polityki..., s. 93.
} 
się z myśleniem nacjonalistycznym o narodzie, PiS także odrzucało lewicowy konstruktywizm w odniesieniu do procesu narodowotwórczego, sprowadzający się do zanegowania roli przeszłości i tradycji na rzecz przekonania, że ze wspólnoty narodowej można uczynić nowy i dowolny konstrukt, o ile sprawuje się władzę i monopolizuje język debaty publicznej. Definiując tak naród, PiS odróżniało się nie tylko od narodowców, ale również od lewicy i liberałów. W XXI wieku wyjątkowo wyraźne były rozbieżności między PiS a PO, odpowiednio wyostrzane w komunikowaniu politycznym przez oba stronnictwa. Politycy PO mieli olbrzymie kłopoty z kategorią "naród” - nie mogąc zanegować jej znaczenia, unikali wypowiadania się na ten temat. Odrzucali rolę dziedzictwa historycznego i więzi międzypokoleniowej dla tej ludzkiej zbiorowości. Naród jawił się jako społeczność istniejąca w danym czasie w wyniku umowy społecznej niezależnych podmiotów, realizujących w ten sposób swoje interesy. Odrzucając wszelkie historyczne ograniczenia i zobowiązania, widzieli możliwość swobodnego kształtowania ludzi tworzących naród, dlatego też tak wielką wagę przywiązywano do monizmu medialnego oraz panowania nad językiem debaty publicznej5 ${ }^{56}$

Stronnictwo J. Kaczyńskiego nie eksponowało w tym kontekście znaczenia etnosu i więzów krwi oraz identyfikacji religijno-wyznaniowej, lecz odwrotnie, doceniając znaczenie Kościoła katolickiego, przywoływało wkład do kultury polskiej także innych wyznań i religii. Postrzegano Kościół jako ostoję polskości oraz surogat państwa polskiego w warunkach jego nieistnienia lub utraty suwerenności. W takich okolicznościach Kościół przez dekady, oprócz tego, że głosił naukę moralną, był równocześnie depozytariuszem polskich wartości: wolności, równości i godności, stając się tym samym instytucją budującą patriotyzm. Jednak to nie etnos, lecz "wolność współtworzy sens bycia Polakiem" ${ }^{57}$. W tym samym duchu rozumował Lech Kaczyński. Dla niego wspólnotę polską konstytuują: pamięć historyczna, dziedzictwo kulturowe i zaangażo-

56 Vide rozważania w: idem, Demokracja peryferii, Wydawnictwo stowo/obraz, terytoria, Gdańsk 2005, s. 239-241.

57 Dobry czas dla Polski..., s. 13-14. 
wanie w sprawy ojczyzny ${ }^{58}$. W oparciu o dokumenty programowe PiS możemy ustalić trzy podstawowe elementy dla myśli politycznej stronnictwa: 1) definicję polskości wywiedzioną z przeszłości oraz opartą na emocjach i uczuciach; 2) pożądaną wizję ładu społecznego w przestrzeni geograficznej; 3) wykaz środków niezbędnych do zrealizowania celów politycznych.

O ile sięganie przez PiS do zmodernizowanego romantyzmu nie jest zbyt problematyczne i można go wskazać jako źródło myśli politycznej stronnictwa, o tyle stosunek tego stronnictwa do realizmu jest bardziej złożony. Nie chodzi bynajmniej o refleksję na temat tego, z którym nurtem realizmu należy się utożsamiać: klasycznym czy też strukturalnym (neorealizm), ofensywnym czy raczej defensywnym. Takich niuansów teoretycznych na próżno szukalibyśmy w źródłach, po prostu ich nie ma. Jeśli zaś zestawimy główne kontrowersje między zwolennikami różnych nurtów realizmu z myślą polityczną PiS, to możemy sformułować trzy wnioski. Pierwszy - reguły myślenia o środowisku międzynarodowym niewątpliwie zostały przejęte z realizmu klasycznego, z jednym, ale bardzo ważnym wyjątkiem. W myśli politycznej stronnictwa było mocno zakorzenione przekonanie, że wartości należy bronić w stosunkach międzynarodowych. Nie można stale dawać pierwszeństwa egoizmowi, skuteczności i interesom. Drugi - wiele miejsca w refleksji na temat polityki zagranicznej przypisywano systemowi międzynarodowemu i jego strukturze, która narzuca państwom różne ograniczenia w ich działalności, gdyż kieruje się własną racją stanu i interesem narodowym. W systemie międzynarodowym w danym czasie historycznym występuje także określony zmienny rozkład potęgi między państwami. Trzeci - dany system międzynarodowy poprzez swoją istotę i mechanizm mu właściwy wpływa na zachowania państw, ich skłonność do wywoływania wojen i konfliktów. Może również eliminować działania ryzykowne i radykalne, ukierunkowane na zburzenie istniejącego ładu międzynarodowego lub odwrotnie - zachęcać do ich podejmowania. Każdy system międzynarodowy charakteryzuje określony stosunek do norm prawnych, któ-

58 Warto być Polakiem..., s. 39. 
re mogą ograniczać jego uczestników, skłaniając ich do podejmowania negocjacji i zawierania kompromisów ${ }^{59}$.

W PiS odrzucono utożsamianie postawy realistycznej z dostosowywaniem strategii do posiadanych środków politycznych. Taki redukcjonizm dla polityków PiS nie był realizmem, lecz błędnym pojmowaniem sensu polityki oraz rezygnacją z jej czynnego charakteru na rzecz bezrefleksyjnego kultu bierności. Łukasz Warzecha dość trafnie określił istotę poglądów PiS w tej kwestii, pisząc, że w opinii tej partii realizm polegał na połączeniu czterech elementów: 1) kierowania się przez państwo racjonalizmem i egoizmem w ocenie okoliczności, metod, celów i środków; 2) uznania państwa za główny podmiot polityczny zorientowany na zaspokojenie własnych interesów; 3) wartościowania celów przy wzięciu pod uwagę możliwości realizacyjnych w danym czasie historycznym; 4) wyznaczania strategii opartej na wielowariantowości uzależnionej od rozwoju sytuacji ${ }^{60}$.

W PiS odrzucono pozytywistyczne mniemanie, że polityka jest jedynie bezideową, niemal techniczną, realizacją zadań minimalnych - tzw. wygrywanie wyborów, prowadzące do przejęcia władzy, podobnie jak sama władza traktowane jako środki polityczne, konieczne w demokracji do osiągania celów, wyznaczonych w oparciu o wartości. Według E. Warzechy, utożsamianie realizmu z pozytywizmem jest podejściem fałszywym, ale wielce charakterystycznym dla polskiej debaty publicznej. W tym kontekście możemy odwołać się do analogii historycznych między J. Kaczyńskim i L. Kaczyńskim a J. Piłsudskim. Takie porównanie jest uprawomocnione, zważywszy na stosunek obu braci do Marszałka.

59 Wnikliwa analiza problematyki realizmu i neorealizmu w: R. Jackson, G. Sørensen, Wprowadzenie do stosunków międzynarodowych. Teorie i kierunki badawcze, Wydawnictwo Uniwersytetu Jagiellońskiego, Kraków 2006; S. Burchill i in., Teorie stosunków międzynarodowych, Książka i Wiedza, Warszawa 2006; J. Czaputowicz, Teorie stosunków międzynarodowych, Wydawnictwo Naukowe PWN, Warszawa 2008.

60 Ł. Warzecha, Czy możliwa jest realistyczna polityka zagraniczna nie na kolanach, czyli o fatszywej interpretacji realizmu, [w:] Rzeczpospolita na arenie międzynarodowej. Idee i praktyczne dylematy polityki zagranicznej, red. J. Kloczkowski, T. Żukowski, Kancelaria Prezydenta Rzeczypospolitej Polskiej - Ośrodek Myśli Politycznej, Warszawa 2010, s. 105-109. 
W jednym ze swoich listów politycznych Jarosław Kaczyński pisał: „Nie tylko upatrywaliśmy w nim jedną z najznakomitszych postaci europejskiego życia politycznego pierwszych dekad XX w. oraz najwybitniejszego Polaka [...], ale także uważaliśmy się - w jakiejś mierze, rzecz jasna, w zasadniczo odmiennych warunkach - za kontynuatorów jego myśli" ${ }^{\prime 1}$.

Natomiast Lech Kaczyński, już jako prezydent, oświadczył w wielce charakterystycznym wywiadzie udzielonym w 80 . rocznicę zamachu majowego, że w tamtych czasach poparłby ten czyn Komendanta, gdyż bliska jest mu postawa państwowca, a nie narodowca. Tej samej identyfikacji dokonał w wywiadzie dla czasopisma „Arcana”: „Byłem piłsudczykiem od wczesnej młodości. I w tej sprawie niewiele się zmieniło do dziś". Była to wyjątkowa deklaracja, zważywszy na znaczenie w polskiej myśli politycznej rozstrzygnięcia relacji państwo-naród oraz ocenę Romana Dmowskiego dokonaną w tym samym wywiadzie: „Bardziej złożoną kwestią jest ocena Romana Dmowskiego. [...] wprowadził on polską myśl polityczną, a zwłaszcza świadomość potoczną na obszar, z którego gorzkie owoce przychodzi nam spożywać do dzisiaj"62. Cztery lata po wywiadzie dla „Arcanów” L. Kaczyński scharakteryzował stosunek swojego brata do nurtu nacjonalistycznego: „[...] mój brat nie jest endekiem i nie chciałby polskiej endecji"63. Sam Jarosław Kaczyński już w 1992 roku zdezawuował endecję w sposób bardzo mocny, uznając ten nurt polskiej myśli politycznej za niezgodny z konserwatyzmem i katolicyzmem. Jej rodowód spostrzegał w darwinizmie społecznym, a samemu Dmowskiemu przypisywał koniunkturalizm polityczny. Lider ruchu narodowego dokonał zwrotu ku Kościołowi i katolicyzmowi z powodów politycznych. Natomiast ugrupowania identyfikujące się z chrześcijaństwem nie mogą być ani kosmopolityczne, ani nacjonalistyczne ${ }^{64}$.

61 Kaczyński o Pitsudskim: Ja i mój brat uważaliśmy się za kontynuatorów jego myśli, 27 XI 2017, https://wiadomosci.dziennik.pl, dostęp 20 III 2020.

62 P. Semka, op. cit., s. 212-214; L. Kaczyński, Historia stosowana, „Arcana” 2006, nr 70-71, cyt. za: Tożsamość i pamięć, [w:] Lech Kaczyński. Pamięć i zobowiązanie..., s. 113.

63 Ł. Warzecha, Lech Kaczyński. Ostatni wywiad..., s. 167.

64 J. Kaczyński, Chrześcijańska demokracja w Polsce dzisiaj, 28 III 1992, [w:] Nowe państwo. Porozumienie Centrum w dokumentach..., s. 108-109. 
Raczej nie można mieć wątpliwości, że w tych wypowiedziach chodziło o narodowodemokratyczne (nacjonalistyczne) definiowanie narodu oraz wynikającą zeń koncepcję rozwiązania kwestii narodowościowej na ziemiach Rzeczypospolitej. Podobne przekonania były właściwe dla elity partyjnej PiS. Najpełniejsze ich potwierdzenie możemy znaleźć w przemówieniu prezydenta Andrzeja Dudy na odsłonięciu w Warszawie pomnika Lecha Kaczyńskiego. Dnia 10 listopada 2018 roku prezydent dość jednoznacznie stwierdził: „Od czasów marszałka Józefa Piłsudskiego nie było tak wielkiego przywódcy Państwa Polskiego jak Lech Kaczyński"65. W tym porównaniu nie chodziło o wielkość czynów i ich historyczny sens, bo to było z zasady dyskusyjne, ale o sposób myślenia politycznego, tzw. państwowego, opartego na realizmie. W opinii zarówno J. Piłsudskiego, jak i J. Kaczyńskiego realizm powinien mieć sens niepozytywistyczny, czyli nie powinien odnosić się do działalności ideotwórczej, lecz jedynie do analitycznej i wykonawczej. W myśleniu realistycznym położono nacisk na interesy, potęgę, podmiotowość, egzystencję, strategię i taktykę. Przypisano stosunkom politycznym takie cechy, jak konfliktowość i rywalizację między podmiotami. Natomiast za główny podmiot polityczny zostało uznane państwo, którego egzystencję należy chronić.

Podczas gdy „Podstawową funkcją państwa jest zapewnienie bezpieczeństwa i ochrona interesów narodowych", to demokratyczne państwo polskie jest wartością prymarną ${ }^{66}$. Zastrzegano jednocześnie, że jego istnienie i działanie "musi być osadzone zarówno w sferze wartości, jak i w historii", mieć uprawomocnienie aksjologiczne i historyczne. Taki status może uzyskać tylko państwo demokratyczne. Jednak pisząc o relacjach państwo-naród w 2001 roku, stwierdzono, że: „Demokracja nie może służyć jako usprawiedliwienie dla zdarzających się w historii narodów, także i w naszej historii, załamań moralnych jednostek i grupy". Wyraźnie w tym osądzie pobrzmiewają poglądy piłsudczykowskie

\footnotetext{
65 Prezydent Duda: Od czasów marszatka Józefa Pitsudskiego nie byto tak wielkiego przywódcy Państwa Polskiego jak Lech Kaczyński, 10 XI 2018, https://wpolityce.pl, dostęp 20 III 2020.

66 Program Prawa i Sprawiedliwości 2014..., s. 11.
} 
z lat międzywojennych, niezwykle krytyczne wobec stanu moralnego i dojrzałości politycznej Polaków ${ }^{67}$. W programach PiS wskazywano dwa powody uzasadniające uznanie państwa za wartość najwyższą w hierarchii aksjologicznej. Pierwszy powód był pragmatyczny - tylko państwo demokratyczne zapewnia realizację fundamentalnych praw jednostki i narodowej zbiorowości. Drugi miał znaczenie historyczne - Polacy nie dysponowali przez wiele lat własnym suwerennym państwem, dlatego podważanie jego istnienia i suwerenności jest „niemożliwe do przyjęcia i zgubne dla narodu oraz zagrażające polskości w wymiarze teraźniejszym i historycznym" ${ }^{\prime 68}$. W tych warunkach wspieranie federalistycznych tendencji w integracji europejskiej lub preferowanie postawy klientystycznej w stosunkach międzynarodowych, np. wobec Niemiec lub Rosji, były postrzegane jako zagrożenie dla Polaków o znaczeniu strategicznym, naród bowiem nie wypracował mocnej identyfikacji z własnym suwerennym państwem, co było uwarunkowane przez komunistyczne zniewolenie oraz wynegocjowaną transformację systemową. Warto do tych wyjaśnień dodać tradycje dziewiętnastowiecznej ugody z zaborcami. Utrata suwerennego państwa na rzecz suprapaństwa europejskiego będzie zagrażała wolności, demokracji i polskości.

Zaspokajanie interesów Rzeczypospolitej zostało potraktowane w myśli politycznej PiS jako miernik patriotyzmu i profesjonalizmu w polityce. Realizm odnosił się do środków politycznych, które należy wybierać, kierując się kryterium efektywności i adekwatności. Środki polityczne miały służyć zapewnieniu egzystencji podmiotu politycznego, a następnie rozszerzeniu jego podmiotowości oraz skuteczności w przejmowaniu zasobów istniejących w stosunkach społecznych, tak aby osłabić twórców i nosicieli konkurencyjnych idei ${ }^{69}$. Zdaniem J. Kaczyńskiego „w Europie

67 PiS konsekwentniełączyło państwo z moralnościąi historią. To one decydowały, że naród identyfikował się z państwem i zajmował postawy patriotyczne. Pisano: „Nie ma dobrego państwa poza moralnością [...]". Confer Dokumenty programowe i ideowe. Kongres zatożycielski Prawo i Sprawiedliwość..., s. 12; Dobry czas dla Polski..., s. 15.

68 Program Prawa i Sprawiedliwości 2014..., s. 11.

69 T. Łoś-Nowak, Paradygmat realistyczny - projekcje porządku międzynarodowego u progu XXI wieku, [w:] Porządek międzynarodowy u progu XXI wieku. Wizje, koncepcje, paradygmaty, red. R. Kuźniar, Wydawnictwa Uniwersytetu Warszawskiego, Warsza- 
i świecie mamy do czynienia z konkurencją", którą należy „umieć łączyć ze współdziałaniem, ale trzeba twardo, w przemyślany i długoterminowy sposób bronić swoich interesów"70. To przekonanie należy uznać za rdzeń myśli państwowej zarówno prezesa PiS, jak i prezydenta Kaczyńskiego.

Realistycznie projektowano w polityce instrumentarium działania i posługiwanie się nim w celu realizacji własnych wizji, nie można bowiem polityki ani opierać na teoretyzowaniu oraz na woli wykorzystywania środków niesprawdzonych, ani zredukować jej do poziomu gry medialnej, marketingu politycznego oraz działań socjotechnicznych i propagandowych. Polityka jest sposobem odnoszenia się podmiotu politycznego do środowiska, aby dokonywać w nim zmian w wyznaczonym kierunku, zgodnie z własną myślą polityczną. W stylu myślenia właściwego dla PiS realizm przejawiał się również w analizowaniu rzeczywistości politycznej. Stronnictwo odrzuciło przeświadczenie właściwe dla wielu polskich ugrupowań politycznych lewicowych i liberalnych, że we współczesności dokonała się zmiana polityki wraz z sukcesami kolejnych fal demokratyzacji. W przeciwieństwie do takich opinii pisano: „Mamy więc państwo słabe, nieodporne na korupcję i partykularne interesy grupowe oraz upartyjnione, z szarą strefą podejmowania decyzji i redystrybucje pieniądza publicznego [...]"71. Tezy liberałów i lewicy zanegowano jako błędne na rzecz przekonania, że polityka ma swoją niezmienną istotę, natomiast postpolityka powinna być traktowana albo jako chwilowa przemijająca moda intelektualna, albo jako kategoria właściwa dla kwestionariusza lewicowości po skompromitowaniu się marksizmu. W ocenie PiS negowanie wiedzy politologicznej doprowadziło do ustanowienia "sytemu Tuska", czyli - jak już pisano - traktowania utrzymania władzy jako celu nadrzędnego. W efekcie władze zdecydowały się naru-

wa 2006, s. 21-58; S. P. Sałajczyk, Wizje rzeczywistości międzynarodowej, [w:] Stosunki międzynarodowe. Geneza, struktura, dynamika, red. E. Haliżak, R. Kuźniar, Wydawnictwa Uniwersytetu Warszawskiego, Warszawa 2006, s. 41.

70 J. Kaczyński, Polityka zagraniczna jest twardą grą [Rozmowa Pawła Lisickiego i Małgorzaty Subotić z premierem Jarosławem Kaczyńskim], 16 XII 2006, www.rzeczpospolita.pl, dostęp 12 I 2008.

71 IV Rzeczpospolita - Sprawiedliwość dla Wszystkich..., s. 7-8. 
szyć procedury demokratyczne i racjonalność ekonomiczną ${ }^{72}$. W polityce chodzi zaś o narzucenie w sposób trwały własnej wizji politycznej na maksymalnie dużym terytorium i uzależnienie innych uczestników stosunków politycznych. Z tego powodu w wypowiedziach J. Kaczyńskiego tak często są przywoływane w charakterze przeciwieństw suwerenność i klientelizm, traktowane jako antytezy w zakresie odnoszenia się do środowiska międzynarodowego.

Celem działalności politycznej było rozszerzenie suwerenności Polski, a faktycznie jej podmiotowości w środowisku międzynarodowym, stronnictwa zaś na arenie wewnętrznej, podczas gdy klientelizm, przypisywany przeciwnikom politycznym, był opisywany negatywnie, jako naganny moralnie i nieskuteczny politycznie, gdyż wywoływał lekceważenie interesów podmiotu politycznego (państwa, stronnictwa). Przykładem mogła być negatywna ocena Sojuszu Lewicy Demokratycznej i Platformy Obywatelskiej oraz polityki zagranicznej Polski prowadzonej przez rząd Leszka Millera i dwa kolejne gabinety Donalda Tuska. Jarosław Kaczyński w 2004 roku zwracał uwagę na „niezrozumiałą nieśmiałość czy wręcz lękliwość" polskich decydentów, przypisując im „żywą tradycję serwilizmu wobec silniejszych". Wcześniej w deklaracji programowej z 2001 roku pisano o "paradygmacie wasalnym”, któremu towarzyszy "syndrom bojaźliwości" wobec Wschodu i Zachodu ${ }^{73}$. To miała być cecha konstytutywna III Rzeczypospolitej od początku jej narodzin. Ciekawą ocenę klientelizmu sformułował Marek Cichocki: „To jest ucieczka od własnej podmiotowości w dekonstrukcję przez integrację. Taka dekonstrukcja zwalnia od wysiłku, od odpowiedzialności, od samodzielnego myślenia, od ryzyka"74.

72 Program Prawa i Sprawiedliwości 2014..., s. 18.

73 J. Kaczyński, Polityka zagraniczna jest twardą grą...; idem, Wystąpienie w debacie nad informacją ministra spraw zagranicznych o podstawowych kierunkach politykizagranicznej Polski w 2004 roku, [w:] SS Sejm, 4 kadencja, 67 pos., 21 I 2004, [b.p.], http://orka2.sejm. gov.pl, dostęp 14 IX 2008; Deklaracja polityczna Prawo i Sprawiedliwość, PiS, Warszawa 2001, s. 19.

74 M. A. Cichocki, Polska polityka musi być świadoma własnej podmiotowości [Rozmowa Wojciecha Przybylskiego z Markiem Cichockim], http://www.teologiapolityczna.pl, dostęp 1 XI 2015. 
Politycy PiS niejednokrotnie oskarżali PO (w mniejszej skali również SLD) o zależność albo od zagranicznych ośrodków dyspozycji politycznej (Niemcy, Rosja), albo od patologicznych grup społecznych (tzw. układ, polityka transakcyjna). Z serwilizmu preferowanego przez PO wynikał minimalizm w polityce zagranicznej, który doprowadził do autodestrukcji widocznej w stosunkach z Rosją i Niemcami w postaci polityki resetu z Moskwą i asymetrii z Berlinem ${ }^{75}$. PiS prezentowało przez cały okres swojego istnienia - w czasie rządzenia i bycia w opozycji - inne podejście do statusu politycznego Polski. Zdaniem J. Kaczyńskiego: „Polityka międzynarodowa jest bezwzględna. Jeżeli ktoś się zgadza na gorszy status, to nikt go poważnie nie traktuje" ${ }^{\text {76 }}$. Anna Fotyga skonkretyzowała podejście PiS do polityki zagranicznej w 2007 roku: „[...] jesteśmy na tyle ważnym graczem w regionie, na tyle dużym i historycznie związanym ze Stanami Zjednoczonymi, że możemy się pokusić o indywidualną drogę"77.

W swoich diagnozach PiS także wielokrotnie pokazywało w sposób klarowny negatywne tendencje międzynarodowe i wewnętrzne. Przestrzegano przed kryzysami na obu arenach, wymieniając imperializm rosyjski, potęgę Niemiec, federalizację Unii Europejskiej, pułapkę średniego rozwoju. W programach z lat 2003 i 2005 wyborcy byli ostrzegani przed kontynuacją polityczną jako prowadzącą do wszechogarniającego kryzysu oraz nadania Polsce statusu peryferii Europy i zagrożenia podstaw narodowego bytu. Pisano wprost, że polityka kontynuacji oznacza sprowadzenie Rzeczypospolitej „do roli niewiele znaczącego państwa o peryferyjnej gospodarce" oraz przekształcenie jej w "głęboką europejską prowincję". Według PiS na ten stan składały się wieloletnie negatywne i nakładające się na siebie procesy: 1) transformacja systemowa oparta na dziedzictwie PRL, która doprowadziła do postkomunizmu we wszystkich sferach życia społecznego; 2) budowa państwa słabego, nieodpornego na korupcję, lobbing i upartyjnienie; 3) polityka gospodarcza

\footnotetext{
75 Polska nowoczesna, Polska solidarna, Polska bezpieczna..., s. 220.

76 J. Kaczyński, I co dalej, Panie Premierze? [Rozmowa Ewy Milewicz z Jarosławem Kaczyńskim], „Gazeta Wyborcza”, 23 IX 2005, nr 222, s. 4.

77 Rozmowa z Anną Fotygą na tamach "Przekroju”, 19 IV 2007, http://www.pis.org.pl, dostęp 30 IX 2008.
} 
i społeczna, oparta nie na wizji rozwoju, lecz zaspokajaniu wybranych grup interesu; 4) fiasko budowy państwa prawa i społeczeństwa obywatelskiego na rzecz bezprawia i zaniku sprawiedliwości; 5) rosnące bieda, ubóstwo i wykluczenie, prowadzące do kryzysu patriotyzmu i polonizmu; 6) załamanie demograficzne połączone ze starzeniem się społeczeństwa oraz z olbrzymią migracją ekonomiczną. Polityka realizowana w III Rzeczypospolitej doprowadziła do pustki moralnej, skrajnego oportunizmu, wybujałego indywidualizmu, odrzucenia idei prawdy w życiu publicznym oraz marazmu intelektualnego ${ }^{78}$.

Przy tak szerokiej i głębokiej negacji zasadna była propozycja budowy nowej formy polskiej państwowości, która miała być i zaprzeczeniem III Rzeczypospolitej, i antidotum na jej wszystkie bolączki, a także nowym kompleksowym projektem uporządkowania systemu politycznego, stosunków społecznych i ładu gospodarczego. Pomysł na skonkretyzowanie nowego modelu państwa wyklarował się między 2003 a 2005 rokiem. Jeszcze w 2003 roku pisano ogólnie o naprawie państwa, a dwa lata później przejęto z publicystyki politycznej i debaty intelektualnej hasło „IV Rzeczpospolita"79. Kontekst publicystyczny wydawał się wówczas zbliżony do zapisanego później w programie PiS. Paweł Śpiewak ogłaszał, że: „[...] III Rzeczpospolita wyczerpała swoje możliwości samonaprawy. Czas zacząć myśleć o IV Rzeczypospolitej". Natomiast Rafał Matyja uzasadniał w 2004 roku projekt IV Rzeczypospolitej potrzebą posiadania

78 Program Prawa iSprawiedliwości, PiS, Warszawa 2003, s. 3-11; IV Rzeczpospolita-Sprawiedliwość dla Wszystkich..., s. 7-10.

79 Za pierwotnych autorów hasła „IV Rzeczpospolita” w publicystyce politycznej i debacie intelektualnej uważa się Rafała Matyję (lata 1997-1998) i Pawła Śpiewaka (2003 rok). Obaj niezależnie od siebie, wychodząc z innych przestanek ideologicznych (konserwatyzm versus liberalizm), zdiagnozowali ówczesną rzeczywistość. Wieszczyli wyczerpanie się formuły III Rzeczypospolitej oraz ogłaszali koniec złudzeń lub potrzebę powstania obozu IV Rzeczypospolitej. Konserwatywny publicysta ogtosit swoje poglądy, kiedy w Polsce rządzita prawicowa koalicja AWS-UW, a liberalny naukowiec w warunkach rządów lewicy przybierającej coraz bardziej liberalne oblicze. Można w tej zbieżności dostrzec pośrednie kwestionowanie prawicowości AWS i lewicowości SLD, a na pewno racjonalności systemu partyjnego i ksztattu w Polsce rodzin ideologiczno-programowych partii politycznych. Vide IV Rzeczpospolita, 15 XII 2005, http://www.wiadomosci. wp.pl, dostęp 20 III 2020. 
przez Polaków silnego i sprawnego państwa z dwóch powodów: tylko ono zagwarantuje 1) „zdolność partycypowania w konstrukcji europejskiej z pożytkiem dla przyszłych pokoleń" oraz 2) zaprowadzi „możliwość sensownego i pożytecznego dla ogółu uprawiania polityki". Co ciekawe, oba powody miały wysoko polityczny charakter i kontekst międzynarodowy. W swoich tekstach Matyja udowadniał, że postulat zasadniczej zmiany można wywieść z ideologii konserwatywnej, a nie z liberalnej, czy z lewicowej - jak to czynił Śpiewak - co zepchnęło w latach 20052019 te ugrupowania na pozycje defensywne, zwłaszcza PO, która stała się, według PiS, obrońcą ancien régime'u (postkomunizmu).

Konserwatywne co do wartości PiS zajęło pozycje rewolucyjne wobec zastanej rzeczywistości. W sensie ideologiczno-politycznym powstała sytuacja paradoksalna, wręcz heretycka - konserwatywne stronnictwo zajęło postawę niemal rewolucyjną. Partia ze swej istoty zachowawcza zaczęła być posądzana o radykalizm, a na pewno dążyła do zmian natury zasadniczej we wszystkich segmentach życia społecznego. Wyjaśnił to Lech Rubisz: ten rewolucjonizm miał być jedynie środkiem, a nie celem. Posłużenie się nim miało przywrócić przerwany stan naturalny, sens i znaczenie wielu wartości, a nawet słów. Natomiast na pewno nie należało go wiązać z szerzeniem postępu ${ }^{80}$.

Rafał Matyja jednocześnie sformułował w debacie intelektualnej problem odbudowy (lub raczej budowy) wspólnoty politycznej, nieznanej od okresu "pierwszej Solidarności". Ten publicysta i zarazem politolog wskazywał wtedy na potrzebę zaistnienia takiego wydarzenia historycznego, które nadałoby instytucjom państwa nowy kierunek działania. Ten nowy kierunek miał polegać na przyjęciu „nadrzędnych punktów odniesienia”, które pozwolą państwu zidentyfikować "przeciwnika czy śmiertelnego wroga"81.

80 L. Rubisz, Prawo i Sprawiedliwość - konserwatyzm tu iteraz, [w:] Prawo i Sprawiedliwość, red. M. Migalski, Wydawnictwo Adam Marszałek, Toruń 2010, s. 70.

81 P. Śpiewak, Koniec ztudzeń, „Rzeczpospolita”, 23 I 2003, nr 19; R. Matyja, Konserwatyści - rzecznicy zmian, „Debata” 1998, s. 3; idem, Druga..., trzecia..., czwarta..., czyli o państwie Polaków, 7 VIII 2004, http://www.newsweek.pl, dostęp 20 III 2020; vide G. Markiewicz, Kontrowersje wokót „numeracji” Rzeczypospolitej Polskiej - zarys 
Podobne cele generalne PiS postawiło przed sobą, dwukrotnie można było zauważyć takie oczekiwania, ale okazały się ułudne. Wydarzeniem przełomowym najpierw miało być zwycięstwo wyborcze w 2005 roku "obozu IV Rzeczypospolitej”, po którym miała dokonać się niemal rewolucja aksjologiczna w odniesieniu do organów władzy państwowej. Postrzegano ją także jako przeniesiony efekt żałoby po śmierci Jana Pawła II. Pięć lat później spodziewano się, że odnowa życia społecznego dokona się pod wpływem ofiary smoleńskiej. W obu przypadkach do sanacji nie doszło, zwyciężyła optyka liberalna - odrzucenie IV Rzeczypospolitej i "przemysł pogardy" wobec nieżyjącego prezydenta ${ }^{82}$. Radykalizm tego typu okazał się słabym „lewarem" pozycji politycznej PiS, mógł natomiast przyczynić się do przegranych w wyborach w latach 2007, 2010 i 2011.

Prawo i Sprawiedliwość sformułowało w swoich programach w okresie 2003-2005 wstępny warunek zmian - realizację celów strategicznych należało poprzedzić naprawą państwa, polegającą na jego oczyszczeniu z pozostałości komunizmu i cech postkomunizmu: „Sytuacja wewnętrzna państwa zasadniczo wpływa na jego pozycję międzynarodową" pisano w tezach konstytucyjnych ${ }^{83}$. Naprawę państwa widziano jako stworzenie silnego i sprawnego aparatu państwowego. Podano także uzasadnienie dla tej naprawy: „Dopiero silne, sprawne, nie marnotrawiące publicznego grosza państwo będzie mogło rozwiązać podstawowe problemy Polaków i odsunąć zagrożenia stojące przed naszym narodem". Cechami zapowiadanej IV Rzeczypospolitej miały być: umowa społeczna, odrodzenie poczucia wspólnoty, solidarność społeczna, wartości chrze-

problematyki, [w:] Idea ustrojowa a rzeczywistość „IV Rzeczypospolitej”, red. J. Kornaś, Wydawnictwo Uniwersytetu Ekonomicznego, Kraków 2010, „Studia i Prace Uniwersytetu Ekonomicznego w Krakowie", 2010, nr 9, s. 19-20.

82 Analiza „przemystu pogardy” i jego znaczenia dla kształtu rzeczywistości politycznej w III Rzeczypospolitej w XXI wieku w: S. Kmiecik, Przemyst pogardy: niszczenie wizerunku prezydenta Lecha Kaczyńskiego w latach 2005-2010 oraz po jego śmierci, Wydawnictwo Prohibita, Warszawa 2013; Z. Krasnodębski, Już nie przeszkadza. Szkice polityczne III, Ośrodek Myśli Politycznej, Kraków 2010; R. Legutko, Antykaczyzm, Wydawnictwo M, Kraków 2013.

83 IV Rzeczpospolita-dwanaście tez konstytucyjnych. Program Prawa iSprawiedliwości, PiS, [b.m.w., b.r.w.], s. 18. 
ścijańskie, w tym miłość bliźniego, prawo i sprawiedliwość. Zakładano więc przeprowadzenie koncentracji politycznej wokół sfery aksjologicznej, która miała być odbudowana przez państwo poddane uprzedniej sanacji (takiego określenia użyto w programie z 2003 roku). Za cechę zapowiadanej sanacji uznano oparcie państwa na moralnej i historycznej legitymacji ${ }^{84}$.

Warto zauważyć, że w drugiej dekadzie XXI wieku hasło „IV Rzeczpospolita" prawie znikło z dokumentów programowych partii. Jeszcze w programie z 2011 roku incydentalnie było przywoływane (dwukrotnie) w kontekście podkreślenia jego aktualności oraz wskazania potrzeby naprawy państwa, podczas gdy w następnych programach z lat 2014 i 2019 próżno go szukać. Wielce prawdopodobne, że uznano ten projekt już za wyczerpany, nadmiernie kojarzył się bowiem z okresem 2005-2007 oraz prezydenturą L. Kaczyńskiego.

W latach 2014-2019 przyjęto w PiS inne rozwiązanie polityczne. W dwóch programach przygotowanych wtedy na wybory wyodrębniono rozbudowane części na temat wartości i zasad ${ }^{85}$. To one poprzedzały tzw. diagnozę, stając się jakby aksjologiczną perspektywą w pierwszej kolejności oceny rzeczywistości społecznej, a następnie podstawą, z której wywiedziono cele polityczne. W obu wspomnianych programach (z 2014 i 2019 roku) prezentowane swoiste wykłady na temat wartości nie tylko są bardzo spójne wewnętrznie i logiczne, ale również korespondują ze sobą co do zawartych w nich treści. Wyrastają bowiem z tych samych inspiracji i źródeł ideowych.

Przejąwszy odpowiedzialność za państwo po wygranych wyborach w 2005 roku, rada ministrów i prezydent z rekomendacji PiS negatywnie ocenili dotychczasowe gwarancje bezpieczeństwa Polski i mimo krótkiego czasu sprawowania rządów premier J. Kaczyński zdecydował się przedstawić prezydentowi w listopadzie 2007 roku Strategię bezpieczeństwa narodowego Rzeczypospolitej Polskiej. Można ją uznać za "testament" polityczny odchodzącego rządu. Dokument był pierwszą kompleksową,

84 Ibidem, s. 12-13.

85 Vide Zdrowie, praca, rodzina..., s. 7-14; Dobry czas dla Polski..., s. 6-21. 
realistyczną koncepcją bezpieczeństwa państwa - bez złudzeń. W opracowaniu tym wskazano na podstawowe interesy narodowe, o charakterze niezmiennym, uzasadnione aksjologicznie i zapisane w konstytucji. Przyjęto typowo realistyczną perspektywę poznawczą przy określaniu celów strategicznych państwa - wyeliminowanie zewnętrznych i wewnętrznych zagrożeń, redukcję ryzyka, oszacowanie wyzwań i szans. Wszystkie zadania strategiczne wymienione w koncepcji miały kontekst państwowy i obywatelski. Państwo przyjmowało na siebie obowiązek zapewnienia: 1) niepodległości, suwerenności i nienaruszalności terytorialnej Rzeczypospolitej; 2) warunków rozwoju cywilizacyjnego, gospodarczego i społecznego; 3) możliwości korzystania przez obywateli z konstytucyjnych wolności, praw, opieki i ochrony; 4) obrony racji stanu i interesów narodowych w środowisku międzynarodowym; 5) ochrony własnego dziedzictwa państwowego i narodowego ${ }^{86}$. Charakterystyczny jest brak mrzonek ideologicznych o nowej naturze stosunków międzynarodowych, która sama ze swej istoty poprawiłaby bezpieczeństwo państwa.

Jeśli wziąć pod uwagę stosunki polityczne na dwóch arenach: wewnętrznej i międzynarodowej, to dla PiS polityka była działalnością na rzecz podmiotowości politycznej. Na pierwszej z nich aktywność ukierunkowano na partię polityczną, na drugiej dążono do wzmocnienia podmiotowości politycznej Rzeczypospolitej. Takie pojmowanie polityki było widoczne na pięciu płaszczyznach: 1) genetyczno-historycznej; 2) ideowo-koncepcyjnej; 3) temporalnej; 4) emocjonalno-afektywnej; 5) symbolicznej. Na polu konkretnego działania politycznego PiS przywiązywało uwagę do wyjaśniania z odwołaniem się do historii, dlatego tak wiele miejsca w dokumentach programowych zajmowały rozważania na temat rodowodu postsolidarnościowego stronnictwa; wskazywano na źródła myśli politycznej PiS, przywołując tradycję chrześcijańską, powstańczą, ludową, piłsudczykowską. Typowy rodowodowy eklektyzm, z istotnymi wykluczeniami, jak tradycja socjalistyczna i narodowodemokratyczna, ale także konserwatywna z minionych czasów. Tak jak już zostało wspomniane, PiS chciało uchodzić zarówno za kontynuatora

86 Strategia bezpieczeństwa narodowego Rzeczypospolitej Polskiej..., s. 5-6. 
i zarazem strażnika aktywności niepodległościowej w odniesieniu do powstań listopadowego, styczniowego, warszawskiego oraz legionistów i żołnierzy wyklętych, jak i za spadkobiercę, a także wykonawcę posłannictwa ruchu solidarnościowego z lat 1980-1981. Trudno zaś te wydarzenia wpisać w dzieje jednego nurtu ideowo-politycznego, gdyż wydawały się mieć charakter suprapolityczny, czyli polaryzujący Polaków, ale nie na płaszczyźnie typowo partyjnej.

Ta cecha strategii politycznej PiS uwidoczniła się z racji odcięcia się lewicy postkomunistycznej (z powodów rodowodowych i współczesnego kwestionariusza lewicowości) i liberałów (ze stosunku generalnego do historii) od wymienionych tradycji. Lewica broniła dziedzictwa PRL, a liberałowie, na pewno po 2006 roku, byli w tej kwestii zwolennikami kompromisu historycznego między stronami toczącego się w latach osiemdziesiątych XX wieku konfliktu politycznego, którego zdecydowanym orędownikiem było środowisko "Gazety Wyborczej". Lewica i liberałowie utrwalali też stosowny wizerunek Rzeczypospolitej, który opisał Zdzisław Krasnodębski: „[...] III Rzeczpospolita została tak zbudowana, że niewiele z dziedzictwa Solidarności znalazło w niej swe ucieleśnienie. [...] dawniejsi luminarze intelektualni i polityczni Solidarności odrzucili jej dziedzictwo po 1989 roku"87.

W dokumentach partyjnych przyjmowanych przez kongresy PiS jako programy polityczne lub platformy wyborcze zawsze prezentowano własną wizję Polski, co widoczne było chociażby w tak nośnych społecznie projektach, jak „IV Rzeczypospolita”, , Polska solidarna” i „Europa solidarnych narodów” oraz "dobra zmiana”. PiS celowało w takim rozwiązaniu, odziedziczyło także tę cechę niejako po Porozumieniu Centrum, kiedy to wystąpiono z hasłem „Nowe Państwo" ${ }^{88}$. We wszystkich przypadkach, kiedy PiS było w opozycji, struktura dokumentów była niemal identyczna - negatywna ocena rzeczywistości oraz partii rządzących, wizja nowego państwa oraz bardzo liczne konkretne postulaty programowe. Wizja państwa zawsze była poprzedzona wnikliwą analizą rzeczywistości

87 Z. Krasnodębski, Demokracja peryferii..., s. 227.

88 A. Chmielecki, op. cit., s. 19. 
politycznej w całej jej złożoności, z wykorzystaniem wiedzy z różnych nauk społecznych oraz publicystyki politycznej. Tym samym niejako naturalnie wynikała z postawionej diagnozy. Natomiast postulaty programowe miały zakorzenienie w założeniach ideologicznych oraz prezentowanych koncepcjach, tworzyły spójną całość nie tylko adresowaną do różnych grup społecznych, ale też pokazującą zakres i zasięg postulowanych zmian, które musiały być podporządkowane wyartykułowanym wcześniej celom. Opinii publicznej prezentowano z jednej strony własną docelową i alternatywną wizję rzeczywistości politycznej, a z drugiej strony wykaz zasobów stwarzających możliwość osiągnięcia celów, ale w perspektywie długookresowej. PiS konsekwentnie odrzucało politykę kontynuacji, proponując zerwanie z tradycją III Rzeczypospolitej, uważało bowiem, że postawa kompromisowa byłaby wyrazem naiwności i błędem politycznym, dlatego też należało ją odrzucić. Liderzy PiS, a przede wszystkim J. Kaczyński, traktowali politykę jako działalność wielofazową, ale również opartą na myśleniu zero-jedynkowym. Jak już wspomniano, konsekwentnie chciano zrealizować wyznaczone cele, a nie jedynie sprawować władzę w Polsce. Przejawem takiej postawy było fiasko negocjacji koalicyjnych z Platformą Obywatelską w 2005/2006 roku oraz decyzja o samorozwiązaniu Sejmu w 2007 roku.

Na poziomie ideologii, PiS zaproponowało podstawy aksjologiczne działań na rzecz podmiotowości politycznej. Relacje między polityką a historią określił L. Kaczyński: „Nie można przeciwstawiać odkrywania prawdy o przeszłości budowaniu przyszłości. Pomyślna przyszłość zależy od uczciwej wiedzy o przeszłości" ${ }^{89}$. Znaczenie tego zdania wzmacniał zasadniczo stosunek prezydenta do definiowania prawdy, który stwierdził: „[...] stoję zdecydowanie przy klasycznej, arystotelesowskiej teorii prawdy", polegającej na zgodności sądu z rzeczywistością ${ }^{90}$. To podejście oznaczało odrzucenie teorii alternatywnych, takich jak teoria koherencji

89 L. Kaczyński, Wystawimy rachunek za krzywdy [Rozmowa Jarosława Kurskiego z Lechem Kaczyńskim], 11 III 2005, „Gazeta Wyborcza”, 21-22 V 2005, nr 117, s. 13.

90 Ł. Warzecha, Lech Kaczyński. Ostatni wywiad..., s. 196. 
(poszukiwanie prawdy w obrębie języka) czy też konsensusu (utożsamianie prawdy z użytecznością).

Postrzeganie przeszłości przez PiS było oparte na dualizmie. Żadne ze stronnictw we współczesnej Polsce nie eksponowało tak zdecydowanie tej cechy własnej myśli politycznej. Już w pierwszych dokumentach programowych PiS z 2001 roku podzielono historię Polski na dwa, istniejące od 300 lat, nurty: pozytywny i patriotyczny (buntowniczo-insurekcyjny) oraz negatywny i zdradziecki (ugodowo-kapitulancki). Państwo polskie musi być jednoznacznie osadzone w tym pierwszym nurcie. Jego nosicielami byli: twórcy poprzednich dwóch państwowości - I i II Rzeczypospolitej; powstańcy z XIX i XX wieku; uczestnicy walk z dwoma okupantami w czasie II wojny światowej - niemieckim i sowieckim, oraz ruchu solidarnościowego, skierowanego przeciwko komunizmowi. PiS chciało się jawić Polakom jako kontynuator tradycji insurekcyjnej, irredentystycznej, niepodległościowej i solidarnościowej. Ten dualizm został opisany w programie z 2003 roku: „Nie ma takiej polskiej tradycji, w której mieszczą się jednocześnie Piłsudski i Bierut, Witos i Wycech, niepodległościowa PPS i PPR, Dmowski i Piasecki". Zaproponowano więc rozróżnienie zdrady i służby Polsce, odwagi i tchórzostwa, mądrości i głupoty ${ }^{91}$. O tym dualizmie mówił 16 lat później w Sejmie Witold Waszczykowski. Pokazywał wówczas różnicę między tymi dwoma tradycjami, wynikającą z geopolitycznego dylematu sandwicza - położenia Polski między Niemcami a Rosją. Mówił: „Obóz niepodległościowy stawiał na własne, narodowe wysiłki w zakresie utrzymania suwerenności”. Jego adwersarze zakładali inaczej: „Polska może przetrwać tylko wtedy, gdy podporządkuje się jednemu z silnych sąsiadów ze Wschodu czy z Zachodu"92. Nietrudno się domyśleć, że w warunkach politycznych lat 2015-2019 współczesnymi wyrazicielami tej drugiej tradycji jawiły się opozycyjne wobec PiS ugrupowania liberalne i lewicowe.

Program Prawa i Sprawiedliwości [2003]..., s. 7.

92 W. Waszczykowski, Wypowiedź, [w:] WNP Sejm, 8 kadencja, 78 pos., 14 III 2019, http:// www.sejm.pl, dostęp 14 II 2020. 
Czasom komunistycznym, kiedy dominował nurt ugodowo-kapitulancki, przypisywano dokonanie bardzo trwałego przewartościowania w świadomości społecznej, czego skutkiem był kryzys polonizmu. Odrzucono wówczas tradycyjne polskie wartości ${ }^{93}$. W tych odziedziczonych warunkach część narodu była gotowa do rezygnacji z własnej tożsamości na rzecz obcej. Chcąc temu przeciwdziałać, J. Kaczyński postulował zerwanie z jednej strony z serwilizmem władzy państwowej wobec wybranych, wpływowych grup nacisku (tzw. polityka transakcyjna), a z drugiej strony z podporządkowaniem polityki zagranicznej Polski interesom silnych państw europejskich. Zamiast wzmacniania podmiotowości państwa polskiego nastąpił proces jego degradacji, a zamiast rozwoju wspólnoty narodowej doszło do powstania zespołu rywalizujących ze sobą grup społecznych. Objawem tego były najpierw rządy Leszka Millera, zakończone kilkoma aferami, a następnie „system Tuska”. W konsekwencji nastąpiło znaczne pogorszenie statusu Rzeczypospolitej w środowisku międzynarodowym.

Płaszczyzny emocjonalno-afektywna oraz symboliczna w polityce niejednokrotnie się przenikają, wiadomo bowiem, że skutecznie można oddziaływać na emocje i uczucia społeczne za pomocą symboli. Weźmy pod uwagę kilka z nich. PiS w rywalizacji o tradycję solidarnościową sięgnęło po przywódców tzw. pierwszej „Solidarności” - Annę Walentynowicz i Andrzeja Gwiazdę. Przeciwstawiono ich roli Lecha Wałęsy. To w Prawie i Sprawiedliwości była podtrzymywana legenda o „rządzie przełomu" premiera Jana Olszewskiego, opisywanego w kategoriach "premiera tysiąclecia" i niezłomnego polityka, obalonego w wyniku spisku spadkobierców systemu komunistycznego („lewy czerwcowy”). Po katastrofie rządowego samolotu w 2010 roku pod Smoleńskiem podstawową funkcję w oddziaływaniu na emocje i uczucia PiS przypisało tragedii, która stała się politycznym testem, za pomocą którego zaczęto testować patriotyzm. Czyniono tak w stosunku do niejasnych okoliczności tragedii smoleńskiej, postępowania ówczesnych władz Polski - rządu

93 Gtosuj na Prawo i Sprawiedliwość. Program, PiS, Warszawa 2001, s. 7; Deklaracja polityczna Prawo i Sprawiedliwość..., s. 13-14. 
Donalda Tuska i p.o. prezydenta Bronisława Komorowskiego, intencji czołowych polityków PO, sposobu prowadzenia śledztwa oraz oceny konsekwencji katastrofy. Dla polityków PiS nie tylko kuriozalnie, ale wręcz absurdalnie brzmiały słowa ministra spraw zagranicznych w rządzie PO-PSL wypowiedziane w Sejmie dwa dni przed katastrofą. Mówił on wtedy: „Jesteśmy za odpolitycznieniem problemu katyńskiego oraz innych białych i czarnych plam w historii stosunków polsko-rosyjskich" ${ }^{14}$.

W programie PiS z 2011 roku wskazano zaś na taki charakter tragedii smoleńskiej, pokazując ów dualizm - albo początek politycznego katharsis, albo rozwój postawy wasalnej wobec Rosji ${ }^{95}$. Stan pośredni nie był wskazywany, w ten sposób wzmacniano polaryzację polityczną oraz formułowano oś podziału sojusznicy-wrogowie z wykorzystaniem kategorii prawdy historycznej i racji moralnych. PiS zaczęło wysuwać tezę, że życie społeczne należy budować na prawdzie, podczas gdy obóz rządzący wybrał drogę kłamstwa i manipulacji. Ponieważ oczekiwania PiS wobec całego społeczeństwa się nie spełniły, mit smoleński został wykorzystany przez to ugrupowanie do konsolidacji własnego zaplecza politycznego oraz wyimpregnowania go na oddziaływanie propagandy w warunkach nieistnienia pluralizmu medialnego, który został zastąpiony w latach 2010-2015 przez monizm, kiedy wszystkie media głównego nurtu były zaangażowane w potwierdzanie słuszności działań podejmowanych przez koalicję PO-PSL oraz w dezawuowanie PiS, co naruszało standardy demokracji, przede wszystkim prawo obywateli do rzetelnej informacji przed podjęciem decyzji np. wyborczych lub sondażowych. W kontekście katastrofy smoleńskiej niejednokrotnie oznaczało to kreowanie i powielanie kłamstw oraz ośmieszanie środowisk zgłaszających bardzo istotne wątpliwości co do rezultatów rosyjskiego i polskiego (rządowego) śledztwa. Nie nastąpiło więc polityczne katharsis.

Równolegle do kształtowania symbolicznej roli katastrofy smoleńskiej budowano konsekwentnie drugi symbol - prezydenta L. Kaczyń-

94 Cyt. za: M. Stolarczyk, Rosja w polityce zagranicznej Polski w latach 1992-2015, Wydawnictwo Uniwersytetu Śląskiego, Katowice 2016, s. 218.

95 Polska nowoczesna, Polska solidarna, Polska bezpieczna..., s. 54. 
skiego, który nie tylko poległ w katastrofie, ale również wykonywał bardzo dobrze urząd prezydenta Rzeczypospolitej jako jedyny z polityków na tym stanowisku, co wywołało nienawiść wszystkich przeciwników sanacji państwa. Decyzje, które podjął L. Kaczyński, ulegały stopniowo mitologizacji poprzez odrywanie ich od kontekstu sytuacyjnego i związanego z ówczesną oceną polityczną. W myśleniu politycznym PiS, zmarły prezydent stał się równocześnie symbolem kolejnej historycznej ofiary złożonej dla Ojczyzny, niezłomności wobec Rosji w obronie polskiej racji stanu oraz samodzielności Europy Środkowej, a także obrońcą polskości przed oszczercami, kreowanymi na współczesnych targowiczan. Te przesłanki zaczęto wykorzystywać w ostrych polemikach medialnych o legitymację wawelskiego pochówku Lecha i Marii Kaczyńskich oraz uzasadnianiu działań mających na celu budowę pomnika prezydenta w Warszawie.

Można przyjąć za Michaelem Fleischerem, że katastrofa smoleńska, a przede wszystkim prezydent Kaczyński stali się najpierw symbolami dyskursywnymi (w latach 2010-2011), czyli właściwymi dla kultury politycznej PiS oraz zdeklarowanych wyborców tej partii. Potwierdzeniem opisanej sytuacji było utworzenie Ruchu Społecznego im. Prezydenta Lecha Kaczyńskiego w 2011 roku oraz przyjęcie przez to stowarzyszenie 10 kwietnia deklaracji ideowej, w której stwierdzano, że "depozytariuszem spuścizny ideowej, myśli politycznej i działań państwowych” patrona ruchu jest „jego brat Jarosław Kaczyński" ${ }^{96}$. Tworzono wrażenie kontynuacji "przerwanej prezydentury” i jej dorobku ideowego, jednoznacznie pokazując jego źródła w postaci myśli państwowej, chrześcijańskiej i solidarnościowej. PiS dość umiejętnie w latach 20112015 zawłaszczyło te trzy tradycje ideowe. Druga strona sporu politycznego w Polsce (PO i jej elektorat) prezentowała całkowicie odmienne oceny tych ważnych symboli - Lecha Kaczyńskiego i katastrofy smoleńskiej. Po przejęciu w 2015 roku przez PiS władzy w Polsce stronnictwo za pośrednictwem organów państwa wykonało wiele działań upamiętniających,

96 Oto deklaracja ideowa Ruchu im. Lecha Kaczyńskiego, 10 IV 2011, http://www.wiadomosci.dziennik.pl, dostęp 20 III 2020. 
aby nadać obu tym symbolom znaczenie kolektywne dla całej polskiej wspólnoty politycznej. Dopełnieniem było odsłonięcie na placu Piłsudskiego w Warszawie dwóch pomników: ofiar katastrofy oraz prezydenta Kaczyńskiego. Zaczęto nadawać dorobkowi ideowemu zmarłego prezydenta, zwłaszcza w zakresie polityki zagranicznej, nadznaczenie. Lech Kaczyński, ze swoją piękną biografią i dorobkiem w opozycji antykomunistycznej, w ruchu solidarnościowym i pracy państwowej, miał być wykorzystany jako symbol nadający systemowi politycznemu spoistośćc7. Sanacja państwa uzyskała swojego "patrona” - polityka zasłużonego dla Rzeczypospolitej.

Myślenie polityczne charakterystyczne dla polityków PiS koncentrowało się bardziej wokół polityczności i jej rozlicznych aspektów niż polityki jako zjawiska politycznego. Polityka była postrzegana w kategoriach zmieniania rzeczywistości nie tylko politycznej, ale szerzej-społecznej, a przede wszystkim realizacji celów strategicznych, wynikających z wartości stojących najwyżej w hierarchii aksjologicznej. Do zmian rzeczywistości społecznej za pomocą polityki Prawo i Sprawiedliwość zaliczało również przekształcanie świadomości społecznej, polegające na korekcie wyobraźni zbiorowej, reinterpretowaniu historii, wzmacnianiu tożsamości politycznej, przywracaniu poczucia godności i wartości oraz dumy z własnych osiągnięć przeszłych i teraźniejszych. Tym samym, podobnie jak u piłsudczyków, polityka była działalnością o cechach historiozoficznych i nosiła znamiona metapolityczne. $Z$ tego powodu PiS podjęło spór o tradycję powstańczą, niepodległościową i solidarnościową, odrzucając kanony historyczne upowszechniane przez dominujące środki komunikacji społecznej w pierwszej dekadzie III Rzeczypospolitej.

Polityka nie była natomiast działalnością polegającą na zawieraniu kompromisów, które miałyby służyć np. utrzymaniu władzy sprowadzonej do administrowania państwem. $Z$ tych powodów tak wielkie znaczenie przypisywano działalności ideotwórczej, ale opartej na diagnozie procesów politycznych, między innymi w ujęciu historycznym,

97 M. Fleischer, Polska symbolika kolektywna, Dolnośląska Szkota Wyższa Fundacji TWP, Wroctaw 2003, s. 28. 
oraz stosunków społecznych widzianych z perspektywy konfliktów i ich dynamiki ${ }^{98}$. Myślenie polityczne określało także model polityki, w tym model polityki zagranicznej, właściwy dla PiS. Na tym etapie badań myśli politycznej PiS trudno jest zaprezentować pogłębiony model polityki w kategoriach ogólnych. Niewątpliwie określili go obaj bracia Kaczyńscy. Można się opierać głównie na opracowaniach publicystycznych, gdyż teksty biograficzne nie wnoszą istotnych ustaleń ${ }^{99}$.

Model polityki właściwy dla PiS wynikał nie tylko z poglądów (w tym naukowych) Jarosława Kaczyńskiego i jego brata Lecha, ale także z dość konsekwentnych przemyśleń na temat prawdy. Tak więc pierwszym źródłem modelu polityki był stosunek do prawdy. Jak już zostało to wspomniane w odniesieniu do prezydenta Kaczyńskiego, był on zwolennikiem klasycznego definiowania prawdy, odrzucał alternatywne sposoby postrzegania tej kategorii, co w praktyce politycznej miało doniosłe konsekwencje. PiS uznało postrzeganie prawdy właściwe dla liberalizmu za niemożliwe do przyjęcia co najmniej z trzech powodów: po pierwsze - było sprzeczne z chrześcijańskim postrzeganiem prawdy; po drugie - było niebezpieczne dla kształtu rzeczywistości politycznej, po trzecie - nie dawało szans na rozwiązywanie problemów społecznych w państwie oraz realizację racji stanu Rzeczypospolitej w środowisku międzynarodowym. Stronnictwo PiS odwoływało się do chrześcijaństwa jako jednego z głównych źródeł własnej myśli politycznej, sięgało po nauczanie społeczne Kościoła katolickiego, ale mocno odcinało się od konfesyjnego modelu partii politycznej.

98 W postrzeganiu stosunków społecznych poprzez konflikty i ich dynamikę można zauważyć wpływy ustaleń naukowych Stanisława Ehrlicha - promotora pracy doktorskiej Jarosława Kaczyńskiego. Mimo że Ehrlich swoich ustaleń dokonat stosunkowo dawno, to zachowują one zdolność wyjaśniającą także wspótcześnie. VideS. Ehrlich, Dynamika norm. Podstawowe zagadnienia wiążących wzorów zachowań, Wydawnictwa Szkolne i Pedagogiczne, Warszawa 1994, passim; idem, Dynamika norm, Wydawnictwo Naukowe PWN, Warszawa 1988, passim. Ciekawa analiza w: M. Pękala, Stanisława Ehrlicha decyzyjna koncepcja prawa: próba rekonstrukcji, „Państwo i Prawo” 2012, nr 10, s. 5-20.

99 Pomocne w opisaniu modelu polityki są przede wszystkim trzy opracowania, które wymagają krytyki źródtowej. P. Zaremba, op. cit.; O dwóch takich... Alfabet braci Kaczyńskich...; R. Krasowski, Czas Kaczyńskiego... 
Drugi powód był bardziej skomplikowany, składały się na niego dwie refleksje. Liberalne definiowanie prawdy z jednej strony o charakterze uniwersalnym prowadziło do zakwestionowania demokracji poprzez likwidację pluralizmu, różnorodności oraz sprawiedliwości i było „poza rzeczywistością polityczną", czyli w niezgodzie z prawdą faktualną (ustalanie faktów w oparciu o dane o nich, niezależne od poglądów politycznych), a z drugiej strony o charakterze szczegółowym odnoszącym się do Polski stało się podstawą akcji dyfamacyjnej przeciwko PiS, prezydentowi L. Kaczyńskiemu i prezesowi J. Kaczyńskiemu, gdyż nie akceptowali liberalnego paradygmatu prawdy. Akcja dyfamacyjna wynikała ze zjawiska, które Ryszard Legutko nazwał antykaczyzmem, a w sensie rywalizacji politycznej używane jest określenie anty-PiS, o którym „Gazeta Wyborcza” napisała: „Anty-PiS jest koniecznością" ${ }^{100}$. Antykaczyzm był odbierany przez polityków PiS, a także przez wyborców tego stronnictwa, jako bezprzykładne naruszanie podstawowych standardów życia publicznego w imię wykluczenia obu braci Kaczyńskich z polityki z powodu zasadniczej, ideologicznej dezaprobaty dla ich diagnoz i przekonań, w tym stosunku do prawdy. Jedną z ofiar antykaczyzmu jako schematu myślowego stała się właśnie prawda, która w odniesieniu do tego stronnictwa i jego liderów uległa „zawieszeniu”. Propaganda wyprodukowana przez anty-PiS uczyniła ze stronnictwa „ideologiczne monstrum będące ucieleśnieniem wszystkich demonów", zarówno tych współczesnych, jak i historycznych ${ }^{101}$.

Trzecia przesłanka pociągała za sobą fikcyjność wyborów w jednym aspekcie - stronnictwa liberalne obietnice wyborcze traktowały tylko jako środek do przejęcia władzy, a nie jako kontrakt z wyborcami, który należy próbować zrealizować w trakcie sprawowania władzy. PiS chciało postępować odmiennie, co w szerokiej skali zostało zaprezentowane wlatach 2015-2019. Według PiS obietnice wyborcze powinny nosić cechy prawdziwości i słuszności, czyli powinny być ogłaszane w dobrej wierze

100 Anty-PiS jest koniecznościa, http://www.wyborcza.pl, dostęp 10 VI 2020.

101 R. Legutko, Antykaczyzm..., s. 9, 41, 43, 132. 
i powinny być możliwe do zrealizowania, nie mogą zaś stanowić jedynie środka socjotechnicznego ${ }^{102}$.

Za filary modelu polityki możemy uznać sześć elementów.

1. O naturze polityki decyduje polityczność, a więc konflikt jako stan naturalny stosunków społecznych, mający swoją dynamikę. Konfliktowość jest zaś pochodną polaryzacji i konsolidacji politycznej, które są "dziełem" polityków, dlatego też w polityce chodzi o narzucanie takiej polaryzacji, żeby przynosiła dwa sprzężone ze sobą skutki. Wygraną w wyborach, która w demokracji daje możliwość zmieniania rzeczywistości na wszystkich jej poziomach - od aksjologicznego i historycznego do ekonomicznego. Wygrawszy wybory, uzyskuje się legitymację do realizacji własnych koncepcji, czyli przekształcania rzeczywistości zgodnie z własnymi wyobrażeniami.

2. Istota polityki jest poza poznaniem empirycznym, składają się na nią bowiem mechanizmy nieobserwowalne, lecz dostępne poznaniu rozumowemu, np. rywalizacja grup interesów. Należy się tymi mechanizmami posługiwać adekwatnie do zastanych okoliczności, dlatego tak ważna jest gra polityczna, którą można postrzegać jako taktykę i łączyć $\mathrm{z}$ wolą polityczną. Nie można jednak taktyki uznawać za definiowanie polityki w kategoriach zawierania kompromisów. Kompromisy uprawdopodabniają przyszłe zwycięstwo, są wyrazem podjętej gry i zarazem tylko etapami prowadzącymi do wygranej.

3. Polityka musi opierać się na prawdzie, a nie na uzgadnianiu opinii, którą akceptuje większość obywateli, mimo jej sprzeczności z rzeczywistością (faktami społecznymi). Legitymacja władzy wynika z prawdy, a nie z kompromisu zawartego między rywalizującymi podmiotami politycznymi. Rozumowanie w kategoriach prawdy i fałszu nie może zostać wypchnięte z przestrzeni publicznej do sfery prywatnej na rzecz tzw. pluralizmu narracji politycznych, jak chcieliby liberałowie i lewica, uznając ten pluralizm narracji za metaprawdę, która realnie ogranicza pluralizm, gdyż decyduje o dopuszczalności wybranych narracji do deba-

102 Rozważania na temat prawdy w polityce w wybitnym opracowaniu: T. Buksiński, Prawdy w polityce, Oficyna Wydawnicza Epigram, Bydgoszcz 2018, passim. 
ty publicznej na zasadzie równości, a nie anihilacji. Liberalna metaprawda przechodzi w postprawdę, której istotą jest wyeliminowanie prawdy z polityki, co faktycznie prowadzi najpierw do ideologizacji pamięci i prawdy, a następnie do niewiedzy, a nawet antywiedzy na temat polityki, którą traktuje się jako działalność wizerunkową i granie nastrojami, bynajmniej nie chodzi zaś o realizację programu ${ }^{103}$. Taka polityka jest postrzegana przez PiS nie jako polityka, tylko co najwyżej działalność socjotechniczna. W tych warunkach, według liberałów, polityka oparta na klasycznej prawdzie powinna być traktowana wrogo - jako niszowa, ponieważ kultura polityczna czasów postnowoczesnych jest ambiwalentna wobec prawdy, co otwiera drogę do zdominowania polityki przez kłamstwo ${ }^{104}$. Świadomość takiego liberalno-lewicowego stylu myślenia charakteryzującego III Rzeczpospolitą była obecna w poglądach obu braci Kaczyńskich. Ujawnił ją J. Kaczyński: „Oszołomy były poza sferą dialogu. Z nimi się nie dyskutowało, i "oszołomy“ nie miały prawa dyskutować. Ta strona była całkowicie dezawuowana. [...] W głównym obiegu medialnym "oszołomów» nie było. Ta jednonurtowość głównej części mediów to ważna cecha charakterystyczna tego okresu"105. PiS nie uznawało dogmatów liberalnych jako metaprawdy, lecz jako składnik jednej z wielu konkurencyjnych myśli politycznych.

4. W polityce nie chodzi o rządzenie w rozumieniu sprawowania władzy lub administrowania, lecz o możliwość realizacji własnej myśli politycznej, w tym odnoszącej się do metapolityki i do przyszłości, czyli dokonywania rozstrzygnięć na temat:1) natury polityki i jej ograniczeń, wynikających z definicji prawdy oraz 2) przyszłego kształtu podstawowego bytu, będącego podmiotem odniesienia w polityce (państwo). Dlatego potrzebna jest pełna wygrana. $Z$ tego powodu PiS generowało konflikty suprapolityczne, prowadzące do wyparcia innych konfliktów typowo politycznych. Najważniejszym konfliktem suprapolitycznym stał się

\footnotetext{
103 Z. Krasnodębski, Już nie przeszkadza..., s. 394.

104 M. d'Ancona, Postprawda, Wydawnictwo Krytyki Politycznej, Warszawa 2018, s. 1316; P. Ricoeur, Pamięć, historia, zapomnienie, Universitas, Kraków 2006, s. 590.

105 O dwóch takich... Alfabet braci Kaczyńskich..., s. 169.
} 
stosunek do lidera partii - Jarosława Kaczyńskiego, i jego pozycji w systemie politycznym. W tych warunkach elektorat partii był wierny jej prezesowi, a nie strukturom partyjnym czy też programowi. Ten stosunek niejednokrotnie zastępował spory programowe między stronnictwami.

5. Polityką można zmieniać rzeczywistość, ale wybór taktyki zależy od dynamiki sytuacji, czyli od analizy rzeczywistości: „W polityce czasem opłaca się ryzykować, a czasem nie. [...] Trzeba wyczuć dynamikę sytuacji" (L. Kaczyński) ${ }^{106}$. Kluczowa w tej materii jest zdolność definiowania konfliktów i wprowadzania własnej diagnozy do debaty publicznej w oczekiwaniu, że dokona się korzystnego przemodelowania sceny politycznej, w której PiS stanie się hegemonem. Jarosław Kaczyński w XXI wieku dwukrotnie doprowadził do wykreowania zwycięstwa wyborczego, chociażby w 2005 roku (Polska liberalna versus Polska solidarna) i w 2015 roku ("dobra zmiana” versus „system Tuska”). W tym kontekście instytucje publiczne zostają sprowadzone do środków politycznych podporządkowanych celom strategicznym, tracą swoją autonomię i ulegają polityzacji.

6. Polityka państwa średniego, takiego jak Polska, nie może być reaktywna, lecz co najmniej adaptacyjna, a najlepiej wyprzedzająca. Taki wniosek wyciągnięto z historii poprzednich polskich państwowości, których los zakończył się tragicznie dla narodu. W takim położeniu geopolitycznym bierność i oczekiwanie zostały uznane za błędną postawę, gdyż nie przygotowywały państwa na stan niepewności i na kryzysy, głównie międzynarodowe. Trendy międzynarodowe PiS postrzegało jako ciąg wyzwań, na które Rzeczpospolita powinna próbować oddziaływać, modyfikując je w korzystnym dla siebie kierunku. Aby to było możliwe, należało spełnić jeden warunek - uznać politykę za dobrą w sensie aksjologicznym i prakseologicznym. Chodziło o dokonywanie koncentracji politycznej wspólnoty narodowej; tę konsolidację należało oprzeć na prawdzie o Polsce w ujęciu historycznym i teraźniejszym.

Joanna Sanecka-Tyczyńska wskazała trafnie trzy cechy modelu polityki zagranicznej: 1) aktywność na arenie międzynarodowej zarówno 
w sensie ideotwórczym, jak również w ujęciu decyzyjnym; 2) podmiotowość państwa polskiego warunkowaną jego kondycją, potencjałem politycznym oraz konsolidacją polityczną; 3) równowagę rozumianą w kategoriach geograficznych, ale przede wszystkim polegającą na unikaniu niesprawdzonych rozwiązań, będących jedynie konstruktami intelektualnymi ${ }^{107}$. Do wymienionych trzech cech można dodać cztery kolejne, wynikające z konserwatywnego charakteru myśli politycznej stronnictwa: 4) unikanie eksperymentów w polityce zagranicznej, niemających osadzenia ani w doświadczeniu historycznym, ani w diagnozie rzeczywistości politycznej, oczywiście dokonywanej w oparciu o przyjęty paradygmat analizy; 5) odwoływanie się do patriotyzmu, racji stanu i interesu narodowego; 6) podejście z dużą ostrożnością do organizacji i instytucji międzynarodowych podporządkowanych państwom dominującym w środowisku międzynarodowym; 7) stosowanie w polityce zagranicznej podstawowego rozróżnienia politycznego na sojuszników i wrogów ${ }^{108}$.

Model polityki zagranicznej wypracowany przez PiS można próbować wyjaśnić za pomocą narzędzia, które zaproponował Krzysztof Szczerski, rozpatrując to według czterech przecinających się osi: politycznej, ekonomicznej, wizerunkowej i militarnej. Przecięcie się tych osi powoduje powstanie czterech pól: geopolitycznego (polityka i zasoby militarne), geoekonomicznego (polityka i zasoby ekonomiczne), soft power (wizerunek i zasoby ekonomiczne) oraz neogeopolitycznego (wizerunek i zasoby militarne $)^{109}$. Dokonywana przez PiS ocena położenia III Rzeczypospolitej na tych czterech polach miała charakter negatywny. Rozwijający się przez cały okres jej trwania potencjał gospodarczy nie pociągał za sobą ani zwiększenia zasobów militarnych, ani kształtowania dobrego wizerunku na arenie międzynarodowej, ani też zdolności kreowania faktów politycznych w środowisku międzynarodowym. Polska stosowała za-

\footnotetext{
107 J. Sanecka-Tyczyńska, Racja stanu we wspótczesnej polskiej myśli politycznej..., s. 266267.

108 Vide I. Kristol, Neokonserwatywne przekonania, [w:] Neokonserwatyzm..., s. 75-76.

109 K. Szczerski, Utopia europejska. Kryzys integracji i polska inicjatywa naprawy, Wydawnictwo Biały Kruk, Kraków 2017, s. 172-173.
} 
sadniczo strategię adaptacji pasywnej, przyjmując fałszywie, że dobry czas w środowisku międzynarodowym będzie stanem trwałym. Polska nie potrafiła również kształtować wokół siebie przyjaznego otoczenia, mimo iż zrezygnowała z dbałości o własny wizerunek, nie prowadząc chociażby polityki historycznej dyskontującej polski wkład w dzieje powszechne. W opinii PiS stosowany przez dwie dekady model polityki zagranicznej, rozpatrywany za pomocą wymienionych czterech osi, doprowadził do słabego statusu Polski w środowisku międzynarodowym, nieodzwierciedlającego jej możliwości, co utrudniało realizację polityki bieżącej. Zaproponowano więc w latach 2015-2019 trwałą zmianę polityki zagranicznej Polski.

\subsection{Przestanki teoretyczne i ideowe}

Polityka zagraniczna rządów PiS oraz ogląd spraw międzynarodowych tej partii politycznej wynikały z realizmu poznawczego i politycznego ${ }^{110}$. To doktryna realistyczna, zwana paradygmatem, stała się instrumentem teoretycznym stosowanym w rozpoznawaniu środowiska i stosunków międzynarodowych, a zarazem przesłanką do budowania koncepcji polityki zagranicznej Polski, w tym w zakresie bezpieczeństwa państwa ${ }^{111}$.

110 O realizmie politycznym i poznawczym PiS vide W. Paruch, Źródła orientacji eurorealistycznej w Polsce..., s. 213-242; idem, Przesztość w myśli politycznej Prawa i Sprawiedliwości..., s. 483-498; idem, Regionalne czynniki bezpieczeństwa Polski. Powrót do doktryny realistycznej w myśleniu politycznym, [w:] Wspótczesne bezpieczeństwo ekonomiczne ispoteczno-kulturowe. Wymiar międzynarodowy, red. M. Gębska, Wydawnictwo Akademii Sztuki Wojennej, Warszawa 2017, s. 53-79. Joanna Sanecka-Tyczyńska wymienita sześć "symptomów" realistycznego myślenia PiS o polityce zagranicznej, ale mają one charakter opisowy, a nie enumeratywny. Vide J. Sanecka-Tyczyńska, Racja stanu we wspótczesnej polskiej myśli politycznej..., s. 263-265.

111 Dwie kwestie wymagają wyjaśnienia. Pierwsza - realizm należy tączyć z doktryną, a nie z teorią stosunków międzynarodowych. W tej materii przekonujące są argumenty przytoczone przez Ryszarda Skarzyńskiego w kilku opracowaniach, w tym: R. Skarzyński, Geoekonomia. Kryzys czy upadek teorii stosunków międzynarodowych?, Instytut Badań nad Bezpieczeństwem, Energetyką i Klimatem, Warszawa 2017, s. 45-75. Druga kwestia - PiS przypomina, a raczej kontynuuje myśl polityczną obozu piłsudczykowskiego, który także odwoływał się do realizmu, dokonując uprzednio jego przewartościowania w postaci oderwania od pozytywizmu. O problematyce idealizm-realizm w: S. Bieleń, 
Jeśli przyjąć także, że na poziomie teoretycznym na myśl polityczną wpływa odniesienie się (świadome lub nieświadome) jej twórców do dwóch wariantów filozofii politycznej - egzystencjonalistycznego i normatywistycznego ${ }^{112}$, to liderom PiS -J. Kaczyńskiemu i L. Kaczyńskiemu - znacznie bliżej było do wariantu pierwszego.

Zwrot w stronę filozofii egzystencjonalistycznej dokonany przez PiS znalazł w drugiej dekadzie XXI wieku wyraz w tworzeniu przez stronnictwo przesłanek do jego samoidentyfikacji z republikanizmem, definiowanym w ujęciu typowo polskim, czyli wywiedzionym z okresu staropolskiego oraz czasów „pierwszej Solidarności” (a nie ze współczesnej tradycji zachodnioeuropejskiej komunitaryzmu i multikulturalizmu), ale także przeciwstawianego liberalizmowi, zwłaszcza w wydaniu PO. Próbę zdefiniowania republikanizmu podjął Zdzisław Krasnodębski - europoseł PiS oraz naukowiec związany ideowo z PiS. Najpierw odniósł go nie tylko do nurtu myślenia politycznego w czasach staropolskich, ale również do tradycji solidarnościowej, pisząc już w 2003 roku, że ten ruch sięgnął po republikańską tradycję myślenia o polityce, która „osadziła się przez wieki w polskiej kulturze". Następnie - przy okazji wspomnień o L. Kaczyńskim - w 2011 roku kreślił istotę ruchu w ten sposób: "[...] uznaje się, że wolność państwa jest warunkiem wolności jednostek i [...] wolność jednostek nie jest możliwa bez solidarności obywateli, bez solidarności obywateli republiki, którzy dbają o jej suwerenność, czasami nawet kosztem dobra własnego. [...] Bez wolnej Rzeczypospolitej nie będzie wolnych Polaków [...]". Według tego polityka wolność jednostki może uzyskać pełny zakres i zasięg (w tym wolności negatywne) tylko w wolnym i suwerennym państwie, którego istnienie jest warunkiem koniecznym oraz powinnością dla obywateli, upoważniającym do nakładania ograniczeń na wolności negatywne. Państwo jest przyjacielem wolności, a nie jej wrogiem. Krasnodębski wnioskował, że wolność

Pozycja geopolityczna Polski, [w:] Polska wstosunkach międzynarodowych, red. S. Bieleń, Wydawnictwo Aspra-JR, Warszawa 2007, s. 23-24.

112 VideT. Buksiński, Racjonalność wspótdziałań. Szkice z filozofii polityki, Wydawnictwo Naukowe Instytutu Filozofii UAM, Poznań 1996, passim; idem, Prawdy w polityce..., passim. 
nie polega na swobodzie wyboru indywidualnego, ale na niezawisłości wspólnoty (współcześnie narodu) reprezentowanej przez państwo. Bez niezawisłego państwa nie ma wolności, ponieważ „wolność publiczna warunkuje wolność prywatną [...] nie znajdziemy wolności w domu, w sferze prywatnej, gdy nie będzie jej w ojczyźnie". W tej koncepcji wolności nie akceptowano dwóch dogmatów liberałów: 1) państwo jest zagrożeniem dla wolności jednostki, dlatego należy ją przed nim chronić, osłabiając państwo i jego instytucje; 2) państwo powinno być neutralne w sensie aksjologicznym, z tego powodu rządzenie dokonuje się w wyniku zawarcia kompromisu między wszystkimi siłami politycznymi stojącymi na gruncie takiego postrzegania państwa ${ }^{113}$.

Wykorzystując wyniki badań Elżbiety Ciżewskiej nad republikanizmem solidarnościowym, można wskazać zapożyczenia dokonane przez PiS z etosu republikańskiego tego związku zawodowego. Były to: znaczenie wspólnoty i pomocniczości, wolność traktowana jako konstytutywny składnik polskiej kultury politycznej i narodowej mitologii, znaczenie emocji w kształtowaniu patriotyzmu, postrzeganie religii jako czynnika wychowawczego i narodowotwórczego ${ }^{114}$. Takie zapożyczenia stały się możliwe, gdyż "Solidarność" nie była ruchem liberalnym, była wręcz bardzo od niego odległym, lecz kolejnym polskim uosobieniem republikanizmu, co ją impregnowało na związki z PO. W działalności „Solidarności" w latach 1980-1981 łatwiej można dostrzec kolejne wcielenie polskich rokoszów przeciwko władzy nielegitymowanej, inspirowanej chrześcijaństwem niż powtórzenie liberalnej Wiosny Ludów przeciwko ładowi konserwatywnemu.

W przytoczonych wypowiedziach Krasnodębskiego pobrzmiewa odrzucenie credo liberalizmu - absolutyzacji wolności jednostki na niemal

113 Z. Krasnodębski, Demokracja peryferii..., s. 281-282, 300; idem, Prezydent nowoczesnego republikanizmu, [w:] Lech Kaczyński. Pamięć i zobowiązanie..., s. 40-42; idem, Republikanizm po komunizmie - utopia czy alternatywa?, [w:] Władza w polskiej tradycji politycznej. Idee i praktyka, red. J. Kloczkowski, Ośrodek Myśli Politycznej, Kraków 2010, s. 205-206. Vide D. Pietrzyk-Reeves, Tradycja republikańska, respublica, republikanizm, „Horyzonty Polityki" 2013, nr 7, s. 47-66.

114 E. Ciżewska, Filozofia publiczna Solidarności. Solidarność 1980-1981 z perspektywy republikańskiej tradycji politycznej, Narodowe Centrum Kultury, Warszawa 2010, s. 331. 
wszystkich płaszczyznach (od moralnej do ekonomicznej). Dobro Rzeczypospolitej - jej egzystencja oraz racja stanu - zostało postawione ponad wolność jednostki i grupy interesu. Według Krasnodębskiego wolność w polskiej tradycji wywodzi się z republikanizmu, a nie z liberalizmu, dlatego też znacznie ważniejszy jest jej aspekt pozytywny (wolność do) niż negatywny (wolność od). Jedną z miar wolności jest wykorzystywanie przez jednostki przestrzeni publicznej do uczestnictwa w polityce na rzecz Rzeczypospolitej. Takie podejście miało istotne konsekwencje dla poglądów generalnych na politykę. Po pierwsze, polityka była definiowana jako działalność społeczna, której celem jest zapewnienie i ochrona bytu podmiotu politycznego; tym podmiotem było państwo polskie - Rzeczpospolita, a w warunkach wewnątrzpaństwowej rywalizacji politycznej - stronnictwo, którego byli założycielami. Po drugie, normy i wizje dobrego ładu, kreowane w wyniku działalności ideotwórczej, odgrywały rolę drugorzędną; zasadniczo wzmacniał się wymiar pragmatyczny polityki i rola wartości ${ }^{115}$.

W rozważaniach o państwie w świadectwach i śladach myśli politycznej PiS jest bardzo wiele na temat twardych czynników bezpieczeństwa państwa oraz jednocześnie na temat wartości. Te dwie kwestie niejednokrotnie ze sobą „sąsiadują”. Należy podkreślić, że i dla bezpieczeństwa, i dla wartości podmiotem odniesienia było państwo. To Rzeczypospolitej należało zapewnić bezpieczeństwo oraz to ona była nosicielem wartości w stosunkach międzynarodowych. W debacie nad pierwszym exposé ministra spraw zagranicznych po wygranych wyborach w 2015 roku Dominik Tarczyński - jeden z polityków PiS często udzielający się medialnie, ogłosił z trybuny sejmowej: „Oparcie polityki na podstawowych wartościach zawsze prowadzi do pozytywnych skutków, nawet wtedy gdy spotyka się z początkową krytyką [... $]^{\prime 116}$. W dokumencie rządowym

115 Szerzej vide W. Paruch, Między romantyzmem a realizmem - Prawo i Sprawiedliwość o polityczności, „Annales Universitatis Paedagogicae Cracoviensis”, Studia Politologica, 2015, nr 15, s. 78-88.

116 D. Tarczyński, Wypowiedź, [w:] WNP Sejm, 8 kadencja, 10 pos., 29 I 2016, http://www. sejm.pl, dostęp 14 II 2020. 
pisano zaś o znaczeniu "miękkiej siły"117. Pod tym pojęciem rozumiano w odniesieniu do państwa właśnie „postawę wobec wartości”, ale także wiarygodność i wizerunek. One się ze sobą ściśle łączą oraz przesądzają o skuteczności innych środków politycznych będących w dyspozycji państwa, a także zwiększają efektywność w polityce zagranicznej. Ciekawe jest rozstrzygnięcie relacji między wartościami-wiarygodnościąwizerunkiem. Uznano, że wiarygodność jest to "podejmowanie działań na rzecz realizacji wyznawanych wartości i podjętych zobowiązań". Ma znaczenie zarówno dla skuteczności, jak i dla autorytetu międzynarodowego państwa i jego zdolności koalicyjnych. Natomiast do wizerunku przypisano "wymierną wartość" oraz rolę wpływania na otoczenie międzynarodowe i międzynarodową pozycję Polski.

W odniesieniu do roli wartości to PiS chciało jawić się opinii publicznej krajowej i międzynarodowej jako sukcesor ruchu solidarnościowego z okresu 1980-1981, kiedy ówczesny związek zawodowy upomniał się o wolność narodów poddanych radzieckiemu zniewoleniu. Na takie stanowisko oddziaływała także recepcja nauczania społecznego Jana Pawła II - wielkiego orędownika oparcia polityki na wartościach mocno osadzonych w polskich doświadczeniach lat 1980-1981. W Strategii Polskiej Polityki Zagranicznej 2017-2021 zaprezentowano katalog takich wartości o różnym charakterze: uniwersalnych (typu demokracja) i komunikacyjnych (typu wizerunek), ale odwołano się też do najbardziej reprezentatywnych dla PiS: chrześcijaństwa, polskości (tożsamość narodowa) i suwerenności. O tej ostatniej pisano: „Suwerenność pozostaje w XXI wieku najpowszechniejszym punktem odniesienia dla wszystkich istniejących współcześnie państw, niezależnie od rosnącej liczby różnych projektów integracyjnych". To bardzo ważne stanowisko. Jednak w czasie debaty sejmowej nad polityką zagraniczną Polski w 2016 roku inne wartości wymienił poseł PiS Dominik Tarczyński. Była to triada: solidarność, wolność i prawo. Nazwał je realnymi wartościami, przeciwstawionymi wartościom fasadowym i pozornym. Pierwsza z nich została uznana za szczególną, obowiązkową dla Polski i „adresowaną" do śro-

117 Strategia Polskiej Polityki Zagranicznej 2017-2021, MSZ, [b.m.w., b.r.w.], s. 21. 
dowiska międzynarodowego ${ }^{118}$. Niezależnie od pojemności i zawartości katalogu wartości, wszystkie one niewątpliwie były definiowane za pośrednictwem kategorii „państwo". To ono miało być: chrześcijańskie, polskie, suwerenne, solidarne, wolne i prawe.

Kategorię wartości odniesiono także do Unii Europejskiej, uznając ją za związek suwerennych państw połączonych wartościami. Wskazano też na jedną z wartości o charakterze międzynarodowym - „Polska powinna dążyć do osiągnięcia statusu kraju, który w sposób jednoznaczny postrzegany jest jako dostarczyciel "międzynarodowych dóbr publicznych", państwa, które jest nie tylko "biorcą", ale również "dawcą" stabilności"119. W integrującym się świecie, w warunkach globalizacji, to właśnie służba wobec wartości miała budować status Rzeczypospolitej na arenie międzynarodowej, w tym w organizacjach międzynarodowych, takich jak Unia Europejska i Pakt Północnoatlantycki. W PiS oczekiwano, że wierność wartościom uczyni z Polski lidera państw średnich i małych na kontynencie oraz $\mathrm{w}$ regionie środkowoeuropejskim. Takie postrzeganie roli wartości było w kolizji z recepcją realistycznej doktryny stosunków międzynarodowych i groziło powstaniem dylematu: wartości czy interesy. PiS próbowało zniwelować zagrożenie wynikające z tego problemu, przyjmując, że interesy należy definiować z odwołaniem się do wartości.

Wielce charakterystyczne dla PiS w myśleniu politycznym o wartościach było powiązanie między nimi a "twardą" polityką, ponieważ "obrona zasad i wartości bywa skuteczna wyłącznie wtedy, gdy poparta jest siłą - nie tylko siłą moralną, ale także wojskową, siłą sojuszy"120. Biorąc pod uwagę koncepcje polityki zagranicznej Polski, to w tej materii były zasadnicze różnice między dwoma partiami: Prawem i Sprawiedliwością oraz Platformą Obywatelską RP, których rywalizacja zdeterminowała

118 D. Tarczyński, Wypowiedź, [w:] WNP Sejm, 8 kadencja, 10 pos., 29 | 2016, http://www. sejm.pl, dostęp 14 II 2020.

119 Ibidem.

120 Informacja Ministra Spraw Zagranicznych o zadaniach polskiej polityki w 2017 roku, 9 |l 2017, http://www.msz.gov.pl, dostęp 12 || 2020. 
dzieje Polski w pierwszych dwóch dekadach XXI wieku ${ }^{121}$. Przejawem paradygmatu idealistyczno-neoliberalnego w myśli politycznej oraz w działalności PO w odniesieniu do środowiska międzynarodowego było koncentrowanie się na cechach i zasadach określających politykę, a nie na wartościach i interesach, których nosicielami są podmioty polityczne, przede wszystkim państwa ${ }^{122}$. Myślenie w tym stylu zaczęło dominować w PO w 2006 roku. Zasadniczo wtedy zrezygnowano z analizowania stosunków międzynarodowych za pośrednictwem takich kategorii, jak suwerenność, podmiotowość, racja stanu, interesy narodowe, coraz częściej twierdząc, że Polski nie stać na urzeczywistnianie tych kategorii, które należy postrzegać jako relikt historyczny ${ }^{123}$.

Takie podejście do polityki zagranicznej w wydaniu liderów PO przyniosło Polsce niekorzystne skutki w latach 2007-2015. Polska nie opracowała wtedy wielkich projektów będących efektem analizy zmian w stosunkach międzynarodowych; brak też przejawów działalności ideotwórczej w tym obszarze. W tym segmencie myśli politycznej (ale nie tylko w tym) PO stała się partią bezideową. Kiedy konflikty międzynarodowe zaczęły się uzewnętrzniać i eskalować, nie zajmowano się ich rozwiązywaniem, lecz koncentrowano uwagę na zabiegach wizerunkowych, adresowanych do międzynarodowej opinii publicznej. Za ocenę może posłużyć wypowiedź sejmowa Grażyny Gęsickiej (PiS): „[...] minimum działania - maksimum dobrego wrażenia. Polską politykę zagraniczną realizowaną od czasu dojścia koalicji PO-PSL do władzy cechuje bierność w inicjowaniu projektów zgodnych z polską racją stanu i pozycją Polski w świecie, ograniczanie działań i redukcja zasobów - instrumentów zwiększania pozycji, prestiżu, roli Polski na scenie międzynarodo-

121 Najbardziej wnikliwa analiza problemu genezy rywalizacji PiS-PO w: J. K. Sokołowski, Od sojuszu do skrajnej wrogości. Ewolucja zachowań parlamentarnych Platformy Obywatelskiej i Prawa i Sprawiedliwości w latach 2001-2013, „Annales Universitatis Paedagogicae Cracoviensis", Studia Politologica, 2015, nr 15, s. 118 i n.

122 L. Rubisz, Platforma Obywatelska - tradycje i inspiracje światopoglądowe, [w:] Platforma Obywatelska, red. M. Migalski, Wydawnictwo Adam Marszatek, Toruń 2009, s. 90-92.

123 Vide Zasadnicze cele naprawy Państwa [III Krajowa Konwencja Platformy Obywatelskiej RP, 21 V 2006], PO, Warszawa 2006, s. 12. 
wej"124. Jeszcze mocniej politykę zagraniczną koalicji PO-PSL określił w 2016 roku Krzysztof Szczerski: „Polska przez ostatnie 8 lat [2007-2015W.P.] traciła aktywa w polityce zagranicznej", tkwiąc w sferze utopii „marzeń, wizji i przechwałek". Kiedy trzy lata wcześniej, będąc jeszcze w opozycji, porównywał styl prowadzenia polityki zagranicznej PiS i PO, doszedł do wniosku, że jego własny obóz nie akceptuje poddawania się biegowi wypadków, jak to czyniła PO, lecz optuje za stwarzaniem faktów dokonanych w stosunkach międzynarodowych; odrzuca bycie statystą, który „nosi halabardę przy innych rycerzach”, na rzecz gry aktorskiej na scenie międzynarodowej ${ }^{125}$.

W kontrze do paradygmatu idealistyczno-neoliberalnego PiS zaproponowało doktrynę realistyczną, co niemal automatycznie oznaczało odrzucenie także wszelkich przejawów konstruktywizmu w odnoszeniu się do świata oraz definiowanie deliberatywne polityki. Jak to ujął Szczerski: „Chodzi o to, by politykę zagraniczną sprowadzić do realiów"126. Należałoby postawić pytanie, czy w myśli politycznej PiS można odnaleźć recepcję nowej szkoły metodologicznej, jaką jest Foreign Policy Analysis, której znaczenie w XXI wieku zaczęło się umacniać ${ }^{127}$. Bezpośrednich odniesień do tego sposobu analizowania polityki zagranicznej nie odnajdujemy w źródłach. Wydaje się, że zadecydowały trzy powody: 1) niewielkie oddziaływanie na piśmiennictwo naukowe w Polsce, które można by zastosować w działalności ideotwórczej; 2) skromne możliwości wykorzystania w rywalizacji politycznej w Polsce, w której zasadniczą przewagę, przynajmniej do 2015 roku, mieli zwolennicy dok-

124 G. Gęsicka, Wystąpienie w czasie dyskusji na temat informacji ministra spraw zagranicznych o zatożeniach polskiej polityki zagranicznej w 2010 roku, [w:] SS Sejm, 6 kadencja, 64 pos., 8 IV 2010, s. 147, http://orka2.www.sejm.gov.pl, dostęp 4 V 2019.

125 K. Szczerski, Chodzi o to, by politykę zagraniczną sprowadzić do realiów, 29 | 2016, http:// www.wprost.pl, dostęp 16 II 2020; idem, Wystąpienie w czasie dyskusji na temat informacji ministra spraw zagranicznych o założeniach polskiej polityki zagranicznej w 2013 roku, [w:] SS Sejm, 7 kadencja, 36 pos., 20 III 2013, s. 36, http://orka2.sejm.gov.pl, dostęp 15 III 2020.

126 Ibidem.

127 Vide M. Breuning, Foreign Policy Analysis. A Comparative Introduction, Palgrave Macmillan, [b.m.w.] 2007, passim; C. Alden, A. Aran, Foreign Policy Analysis. New approaches, Routledge, London-New York 2017, passim. 
tryny liberalnej - główni oponenci w sporach politycznych; 3) kłopoty ze sformułowaniem doktryny tej szkoły metodologicznej użytecznej w działalności ideotwórczej. Można jednak znaleźć pewne oddziaływania, ale o charakterze nieświadomym, wynikające raczej z własnych przemyśleń niż zapożyczenia wiedzy naukowej. Są to: ścisłe powiązanie polityki zagranicznej z wewnętrzną; traktowanie państw jako aktorów mających spójne konstytutywne cechy oraz sposoby zachowywania się w środowisku międzynarodowym; postrzeganie procesualne polityki zagranicznej; rozpatrywanie polityki zagranicznej na różnych poziomach - decydentów, państw, systemu międzynarodowego; podział czynników kształtujących politykę na subiektywne i obiektywne (zależne i niezależne); wykorzystywanie w polityce zagranicznej zarówno racji stanu i interesów narodowych, jak również gry politycznej. Dla Prawa i Sprawiedliwości politycy, ich wola i determinacja kształtują w sposób dość istotny politykę zagraniczną państw oraz powodują zmiany w systemie międzynarodowym. $Z$ tego powodu tak wielką wagę przywiązuje się tu do aktywności Rzeczypospolitej w środowisku międzynarodowym.

W sensie poznawczym teoria realistyczna recypowana do myśli politycznej PiS nosiła podwójny charakter - epistemologiczny i ontologiczny ${ }^{128}$. Aspekt epistemologiczny miał dwa wymiary. Pierwszy polegał na odrzuceniu pozytywizmu poznawczego. Jak to ujął Lech Kaczyński w wywiadzie: „jestem skrajnym antypozytywistą". Jego wykładnia polegała na tym, że uważał, iż podmiot badania ma wpływ na przedmiot. Jednak antypozytywizm właściwy dla myśli politycznej PiS miał jeszcze

128 Vide R. Zięba, Gtówne kierunki polityki zagranicznej Polski po zimnej wojnie, Wydawnictwa Akademickie i Profesjonalne, Warszawa 2010, s. 18; J. Czaputowicz, Teorie stosunków międzynarodowych. Krytyka i systematyka, Wydawnictwo Naukowe PWN, Warszawa 2007, passim; M. Kaczmarski, Realizm neoklasyczny, [w:] Teorie i podejścia badawcze w nauce o stosunkach międzynarodowych, red. R. Zięba, S. Bieleń, J. Zając, Wydziat Dziennikarstwa i Nauk Politycznych Uniwersytetu Warszawskiego, Warszawa 2015, s. 13-23; K. Szczerski, Analiza neogeopolityczna (neo-geo), [w:] Podmiotowość geopolityczna. Studia nad polską polityką zagraniczną, red. K. Szczerski, KSAP, Warszawa 2009, s. 25; B. Sajduk, Tradycyjne metody analizy polityki zagranicznej, [w:] Podmiotowość geopolityczna. Studia nad polską polityką zagraniczną..., s. 80. 
inny sens, wydaje się ważniejszy ${ }^{129}$. Politycy PiS nie zadowalali się tak jak pozytywiści pozorami rzeczywistości, rejestrowanymi przez zmysły, lecz zawsze poszukiwali jej ukrytej istoty i mechanizmu, pozostających poza empirycznym poznaniem, ale dostępnych rozumowi. Z tego powodu w programach oficjalnych tego stronnictwa starano się recypować różne teorie społeczne, podchodząc do nich w sposób eklektyczny.

Realizm polegał na nacechowaniu myślenia politycznego PiS, które opierało się na przekonaniu o konieczności analizowania: rzeczywistości politycznej, poliarchii charakterystycznej dla środowiska międzynarodowego, czasów historycznych, uwarunkowań geopolitycznych oraz procesów i zjawisk nadających stosunkom międzynarodowym dynami$\mathrm{kę}^{130}$. Gdyby przypisywać do tego modelu analizowania cechy optymizmu i pesymizmu, to byłoby w nim znacznie więcej tego drugiego. Uważano, że wprawdzie stan stosunków międzynarodowych w określonym czasie jest dany zewnętrznie i zdeterminowany przez konsekwencje geopolityczne i historyczne ${ }^{131}$, ale oprócz czynników zmiennych, zakładano istnienie czynników niezmiennych, ukształtowanych w wyniku dziejów. Zaliczano do nich: stratyfikację państw w zależności od ich potencjału politycznego, relacje typu wróg-sojusznik oraz podział na centrum i peryferie. Jednak w założeniach polskiej polityki zagranicznej rząd PiS w 2006 roku wskazywał także na zmienność w stosunkach międzynarodowych. Pisano, że "nietradycyjne czynniki” postawiły pod znakiem zapytania „to, co wydawało się rozstrzygnięte raz na zawsze”, co rodzi „potrzebę odmiennego stawiania dawnych pytań i wzięcia pod rozwagę nowych dylematów"132.

Inną cechą stosunków międzynarodowych jest ich naturalna konfliktowość, wynikająca chociażby z cech poliarchii oraz uznania suwerenno-

129 Ł. Warzecha, Lech Kaczyński. Ostatni wywiad..., s. 46.

130 Vide Archiwum KPRM, „Założenia polskiej polityki zagranicznej w 2006 r.”, luty 2006, SKM 450-1/06, t. 1292/1, s. 6.

131 L. Sykulski, Ku Nowej Europie: perspektywa związku Unii Europejskiej i Rosji. Spojrzenie geopolityczne z Polski, Wydawnictwo Instytutu Geopolityki „Alfa 24”, Częstochowa 2011, s. 8-10.

132 Archiwum KPRM, „Założenia polskiej polityki zagranicznej w 2006 r.”, luty 2006, SKM 450-1/06, t. 1292/1, s. 6-7. 
ści państw. Konfliktowość mogła być czynnikiem sprawczym dominacji pesymizmu nad optymizmem, ale przekonaniu o nieuchronności konfliktów towarzyszył także pogląd o możliwości ich rozwiązywania w sposób pokojowy i zinstytucjonalizowany, co wymagało aktywności na arenie międzynarodowej ${ }^{133}$. O wyjaśnienie tego pesymistycznego podejścia do rzeczywistości pokusił się sam L. Kaczyński. Odnalazł go w swoich poglądach na naturę ludzką: „nie wierzę w idealną naturę ludzką", ponieważ "grzeszność jest nieunikniona"134. Rzecz wielce charakterystyczna, kwestią natury ludzkiej zajęto się dość obszernie w jednym z materiałów do dyskusji na konferencji PC w 1990 roku. Pisano: „Nasza wizja człowieka nie jest wizją skłaniającą do łatwego optymizmu. Tego również uczy nas chrześcijaństwo. Kościół mówi o grzechu pierworodnym. W języku świeckim powiedzielibyśmy o pewnej skazie w naturze człowieka". Ta skaza powoduje, że człowiek jest omylny, jest skłonny i do rzeczy wielkich, i do ulegania rzeczom złym ${ }^{135}$.

Dla polityków PiS, będących admiratorami doktryny realistycznej w odniesieniu do polityki, w tym zagranicznej, bardzo istotnym dylematem w stosunku do XXI wieku było poszukiwanie odpowiedzi na pytanie, czy we współczesności dokonuje się upadek porządku międzynarodowego w skali globalnej, zbudowanego po II wojnie światowej i opartego na przekonaniu, że celem społeczności międzynarodowej było uchronić przyszłe pokolenia od klęski wojny. Paradoksalne, ale system biegunowej równowagi Stany Zjednoczone-Związek Radziecki zapewniał światu pokój przez wiele dekad. Po upadku ZSRR raczej dominowało przekonanie, że ten stan się utrwali. Taki pogląd przez jednych był wyprowadzany z przesłanki, że dokonał się „koniec historii”, zarazem triumf liberalizmu i demokracji, przez innych z przekonania, że potęga Stanów Zjednoczonych jest gwarantem porządku międzynarodowego. Jednak według jednego z analityków: „Nie nadszedł koniec historii, nie nastąpił koniec geopolityki i geostrategii; geopolityki nie wyparła geo-

\footnotetext{
Z. Krasnodębski, Prezydent nowoczesnego republikanizmu..., s. 40.

Ł. Warzecha, Lech Kaczyński. Ostatni wywiad..., s. 196.

Nowe państwo. Porozumienie Centrum w dokumentach..., s. 41.
} 
ekonomika. Wbrew prognozom, po świecie nie krąży widmo pokoju i demokracji"136.

Dla konserwatywnego ugrupowania, jakim jest PiS, pytanie o trwanie i zmienność w historii stawało się kluczowe. Nie chodziło bynajmniej o "powrót historii", rozumowanie w kategoriach „końca historii” było bowiem dla polityków PiS albo przykładem fałszywej świadomości, albo kolejnym kryterium identyfikacji nowej lewicy i liberałów. Z doktryny realistycznej, niezależnie od jej wariantów teoretycznych, wynikało, że rywalizacja międzynarodowa jest oparta na tym samym mechanizmie konkurencji między państwami, a o jej wynikach decydują zasoby przez nie zgromadzone oraz umiejętności ich pomnażania i posługiwania się nimi (polityka zagraniczna i wewnętrzna). Niemniej z bieżącej analizy środowiska międzynarodowego, a zwłaszcza najbliższego otoczenia Polski, wynikały wnioski, że stan spokoju przypisywany latom dziewięćdziesiątym definitywnie się zakończył i należy o tym mówić zarówno Polakom, jak i sojusznikom oraz partnerom.

Według polityków PiS stosunki międzynarodowe stabilizował nie tylko mechanizm rywalizacji, ale również wartości, takie jak: suwerenność państw, integralność terytorialna, nienaruszalność granic, poszanowanie praw człowieka. Wyróżnikiem XXI stulecia jest ich odrzucenie przez te państwa, które dążą do podważenia ładu międzynarodowego na nich opartego. Ta tendencja jest postrzegana jako groźna, ponieważ nie spotyka się z mocną kontrreakcją środowiska międzynarodowego ${ }^{137}$. We wspomnianych założeniach polskiej polityki zagranicznej na rok 2006 rząd PiS sformułował przestrogę oddającą charakter stosunków międzynarodowych: „Powinniśmy uzmysłowić sobie istotę nierzadko rozbieżnych interesów naszych kluczowych partnerów i sojuszników na Zachodzie, utrudniających realizację naszych celów strategicznych"138.

\footnotetext{
36 B. Balcerowicz, Powrót sity, „Rocznik Strategiczny” 2006/2007, s. 20.

137 Zob. Informacja Ministra Spraw Zagranicznych o zadaniach polskiej polityki w 2017 roku...

138 Archiwum KPRM, „Założenia polskiej polityki zagranicznej w 2006 r.”, luty 2006, SKM 450-1/06, t. 1292/1, s. 7.
} 
Aspekt ontologiczny realizmu przejawiał się w przekonaniu, że w środowisku międzynarodowym kreatorami polityki zagranicznej oraz nosicielami interesów są przede wszystkim państwa; są to jedyne podmioty polityczne obdarzone suwerennością i zmienną podmiotowością. Ta perspektywa determinowała postrzeganie organizacji międzynarodowych, w tym Sojuszu Północnoatlantyckiego i Unii Europejskiej. Definiowano je jako środki polityczne, które mają służyć rozszerzeniu i umocnieniu podmiotowości Rzeczypospolitej, zagwarantowaniu jej suwerenności i niepodległości oraz uzyskaniu przez nią optymalnych warunków do realizacji racji stanu i interesów narodowych. Mówił o tym w Sejmie politolog i zarazem poseł PiS Włodzimierz Bernacki: „Można przynależeć do różnych struktur, można należeć do różnych organizacji, ale one mają być tylko i wyłącznie instrumentem działania w wymiarze zewnętrznym, nie mogą stać się fetyszem [...]", który krępuje możliwości działania i przeszkadza w realizacji podmiotowości, suwerenności i niepodległości. W podobnym duchu wypowiedział się także inny poseł PiS W. Waszczykowski, uznając, że wejście Polski do Sojuszu i Unii: „[...] nie było spełnieniem celów strategicznych, ale raczej zdobyciem nowych instrumentów realizowania naszej racji stanu. Tym interesem narodowym było i nadal jest bezpieczeństwo i rozwój"139.

W konsekwencji w Strategii Polskiej Polityki Zagranicznej 20172021 zapisano: „Podstawową jej przesłanką jest założenie, że stosunki międzynarodowe są sferą działania suwerennych państw. Niezależnie od współpracy w różnych formach państwa zachowują swoją podmiotowość" ${ }^{140}$. Korespondowała z tym stanowiskiem opinia W. Waszczykowskiego, ministra spraw zagranicznych w rządach Zjednoczonej Prawicy Beaty Szydło i Mateusza Morawieckiego: „Członkostwo w UE i NATO też nie jest celem samym w sobie, tylko narzędziem. Naszym celem jest

139 W. Bernacki, Wypowiedź, [w:] WNP Sejm, 8 kadencja, 60 pos., 21 III 2018, http://www. sejm.pl, dostęp 14 II 2020; W. Waszczykowski, Wystąienie w czasie dyskusji na temat informacji ministra spraw zagranicznych o zatożeniach polskiej polityki zagranicznej w2014 roku, [w:] SS Sejm, 7 kadencja, 67 pos., 8 V 2014, s. 194, http://orka2.sejm.gov.pl, dostęp 15 III 2020.

140 Strategia Polskiej Polityki Zagranicznej 2017-2021..., s. 4. 
upodmiotowienie Polski, zdobycie wpływów w tych instytucjach, dzięki którym możemy współdecydować [...]"141. Podstawę tego typu sądów można odnaleźć w programie z 2019 roku, w którym zaprezentowano wyniki analizy i ogłoszono: „Nie sprawdziły się poglądy o zanikaniu funkcji państwa narodowego, o jedynym możliwym modelu integracji europejskiej wykluczającej obronę interesów narodowych, o kapitale bez narodowości niosącym jedynie postęp i rozwój". Z tej diagnozy wyciągnięto wniosek, że o statusie państwa decyduje nadal jego potencjał polityczny, oparty na sile militarnej, efektywnej gospodarce i wewnętrznym ładzie społecznym ${ }^{142}$.

Robert Krasowski sprowadził realizm polityczny PiS do myślenia w kategoriach lokalnych, czyli stosowania perspektywy państwa narodowego, poszukiwania w jego dziejach wielkich idei, które byłyby nośne społecznie i dawały szansę nie tylko na wygranie wyborów, ale przede wszystkim na przeprowadzenie tak pożądanej konsolidacji politycznej, niezbędnej, aby państwo mogło prowadzić aktywną politykę zagraniczną, ukierunkowaną na zawłaszczanie kolejnych zasobów w celu powiększenia potencjału politycznego. To wymiar lokalny czynił z polityki działalność realistyczną, współczesny świat został bowiem zdominowany przez egoizmy narodowe, które między innymi są zaspokajane w organizacjach międzynarodowych oraz z ich wykorzystaniem jako środków politycznych ${ }^{143}$. Lokalność Krasowskiego pośrednio objaśnił Zdzisław Krasnodębski, zdaniem którego to właśnie suwerenne państwo polskie ma rozwiązywać najważniejsze problemy społeczne, a nie jakakolwiek organizacja międzynarodowa, czy też inny podmiot polityczny, ponieważ Polska nie jest tworem kulturowym, krainą geograficzną lub prowincją unijną ${ }^{144}$.

Przytoczone poglądy pokazują, że Prawu i Sprawiedliwości bliskie było rozumowanie realistów/neorealistów, że wyjątkowe znaczenie dla

\footnotetext{
141 W. Waszczykowski, Chcę się ułożyć z Białorusią [Rozmowa Elizy Olczyk i Jakuba Mielnika z Witoldem Waszczykowskim], „Wprost”, 8 I 2017, nr 1, s. 35.

142 Dobry czas dla Polski..., s. 171.

143 R. Krasowski, Dwie formuty prawicowości..., s. 71-72.

144 Z. Krasnodębski, Jaki model prawicowości?..., s. 92.
} 
każdego państwa w systemie międzynarodowym ma rozkład potęgi, pomnażanie własnych zasobów oraz konsolidacja polityczna wewnątrz państwa, umożliwiająca skuteczną reakcję na bodźce płynące ze środowiska międzynarodowego ${ }^{145}$. W opinii tego stronnictwa Polska pod rządami ugrupowań liberalnych, lewicowych i ludowcowych nie spełniała tych kryteriów. Potrzebna była gruntowna zmiana - "dobra zmiana", nawiązując do hasła wyborczego PiS z 2015 roku. Małgorzata Gosiewska, przemawiając w Sejmie w imieniu Klubu Parlamentarnego PiS, dokonała wykładni określenia "polityka zagraniczna” jako działania, które „odpowiada na rzeczywistość, a nie ją ignoruje" ${ }^{\text {"146. }}$. PiS wyraźnie podkreślało różnice w postrzeganiu polityki zagranicznej w zestawieniu z opcją liberalno-lewicową. Precyzyjnie, a nawet naukowo, te różnice uchwycił W. Bernacki, który w Sejmie VIII kadencji mówił: „Zjednej strony jest język konkretu, język realizmu politycznego i realizmu również w wymiarze metodologicznym, $\mathrm{z}$ drugiej zaś strony mamy do czynienia z narracją, która jest narracją o charakterze ideologicznym"147.

Najgłębszy pokład sporu między liberałami a realistami w Polsce dotyczył stosunku do dziedzictwa poprzednich polskich państwowości - Rzeczypospolitej Obojga Narodów i II Rzeczypospolitej w trzech głównych obszarach: 1) roli polskiego państwa w regionie środkowoeuropejskim; 2) polityki wschodniej; 3) rywalizacji z germanizmem i rosyjskością. W odniesieniu do tych obszarów PiS formułowało pozytywne oceny dziedzictwa i podstawowych koncepcji wówczas realizowanych. Poglądy, właściwe dla tej formacji, w tej sprawie wyartykułował Janusz Kurtyka, mówiąc o tym w dyskusji na temat polityki historycznej. Eksponował utworzenie przez Rzeczpospolitą odrębnego kręgu kulturowego i cywilizacyjnego na znacznych obszarach między Krakowem, Wilnem i Kijo-

145 Na ten temat: M. Kozub-Karkut, Realizm neoklasyczny - gtówne zatożenia i możliwości, [w:] Mapa wspótczesnego realizmu. Założenia i zastosowania badawcze, red. E. Haliżak, J. Czaputowicz, Wydawnictwo Rambler, Warszawa 2014, s. 43-44.

146 M. Gosiewska, Wypowiedź, [w:] WNPSejm, 8 kadencja, 78 pos., 14 III 2019, http://www. sejm.pl, dostęp 14 II 2020.

147 W. Bernacki, Wypowiedź, [w:] WNP Sejm, 8 kadencja, 60 pos., 21 III 2018, http://www. sejm.pl, dostęp 14 II 2020. 
wem. Egzystencja staropolskiego państwa została przerwana w wyniku klęski w starciu z imperium rosyjskim. Jednak " $[. .$.$] tradycja ta w sensie$ kulturowym i "mitycznym" nie została wykorzeniona i [...] pozostaje również tęsknotą na terenach poza naszymi wschodnimi granicami"148.

Istotę odrębnego kręgu kulturowego i cywilizacyjnego, jaki stanowiła I Rzeczpospolita, PiS opisało w programie z 2019 roku. Przywołano jego dwie główne cechy: 1) symbiozę wolności i równości oraz 2) republikanizm, przeciwstawiony absolutyzmowi i warunkujący demokrację $e^{149}$. Takie poglądy stanowiły wystarczające przesłanki do przyjęcia stanowiska zaprezentowanego w Sejmie przez Michała K. Ujazdowskiego: „Naszym obowiązkiem jest także troska o zachowanie polskiego dziedzictwa kulturowego na obszarze I i II Rzeczypospolitej"150.

Politycy PiS przypisywali pozostałościom historycznym I Rzeczypospolitej znaczenie dla współczesnych losów Europy Środkowej i Wschodniej. Dlatego stronnictwo J. Kaczyńskiego chciało nawiązywać do dorobku Jagiellonów, Rzeczypospolitej wielu narodów, haseł powstań narodowych i programu na emigracji ks. Adama Jerzego Czartoryskiego, idei Piłsudskiego i myślenia strategicznego Jerzego Giedroycia i Juliusza Mieroszewskiego oraz historycznego Oskara Haleckiego, podniesionego w polskiej historiografii czasów najnowszych przez Andrzeja Nowaka ${ }^{151}$. Takie podejście miało mocne zakorzenienie w nurcie badań historycznych prowadzonych w czasach III Rzeczypospolitej, reprezentowanych przez takich luminarzy historii, jak Jan Kieniewicz, Jerzy Kłoczowski, Bohdan Cywiński i Andrzej Nowak ${ }^{152}$, którzy opisywali i analizowali dzieje państwa staropolskiego w kategoriach cywilizacyjno-kulturowego starcia z ro-

\footnotetext{
148 Polska polityka historyczna, „Biuletyn Instytutu Pamięci Narodowej”, maj 2006, nr 5, s. 16.

149 Dobry czas dla Polski..., s. 12.

150 K. M. Ujazdowski, Wystąpienie, [w:] SS Sejm, 4 kadencja, 16 pos., 14 III 2002, s. 73, http:// orka2.sejm.gov.pl, dostęp 4 V 2019.

151 VideA. Nowak, Idea jagiellońska w polskiej pamięci i wyobraźni politycznej, http://studylibpl.com/doc/1243941, dostęp 2 VI 2020.

152 Najpetniej problem starcia cywilizacyjnego na Wschodzie przeanalizowat: B. Cywiński, Szańce kultur. Szkice z dziejów narodów Europy Wschodniej, Wydawnictwo Trio-Centrum Europejskie Natolin, Warszawa 2013.
} 
syjskością na ziemiach środkowoeuropejskich i wschodnioeuropejskich. Po przegranym przez Polaków procesie narodowotwórczym nie udało się bowiem stworzyć narodu politycznego ze wszystkich mieszkańców I Rzeczypospolitej, lecz powstały nowe plebejskie i niehistoryczne narody. Po misji Rzeczypospolitej pozostało jedno zadanie. Nazwali je historyk Jan Kieniewicz i politolog Włodzimierz Marciniak. Pierwszy pisał: „Albo jako naród wesprzemy procesy narodowe i europejskość na wschodzie, albo Rosja wprowadzi tam swoją wersję relacji międzyludzkich". Według drugiego: „W pożądanej przyszłości Rosja będzie traktować ten obszar nie jako strefę wpływów, ale jako "areał cywilizacyjny"153. Oczywiście jako przestrzeń cywilizacyjną, której składnikami będą: rosyjska kultura polityczna, model państwa, język rosyjski, prawosławie, misja odziedziczona po poprzednich rosyjskich państwowościach, kod geopolityczny. Rzeczpospolita nie mogła wobec tych zamierzeń zachowywać obojętności, „uspokojona” akcesją do hemisfery zachodniej.

"Obiekty" pozostałe w wyniku procesów historycznych w kategoriach spadku i podlegające recepcji do najnowszych dziejów Polski wskazał w wystąpieniu sejmowym wspomniany już poseł Bernacki. Po pierwsze definiowanie narodu, które było odmienne od zachodnioeuropejskiego, jako wspólnoty obiektywnej, wyznaczonej przez cechy etniczne i kulturowe („więzy krwi”), a nie przez wolę polityczną. Po drugie - traktowanie wolności jako wartości podstawowej, która konstytuuje polski republikanizm. Po trzecie - własna tradycja prawna, polegająca na rozdzielaniu lex civilis od nadrzędnego lex aeterna; to ta tradycja była fundamentem historycznego modelu "polskiej” demokracji. Podsumowaniem była konkluzja, która najlepiej oddawała stosunek PiS do rodzimej historii: „tak naprawdę I Rzeczpospolita mogła być i była wzorcem dla całej Europy, tylko z tego wzorca wtedy po prostu nie skorzystano"154. Na doniosłość historii w polityce zagranicznej Polski wskazał także zbliżony w tej ma-

153 W. Marciniak, Rosja w Europie: utopia i antyutopia modernizacji, [w:] Polska w grze międzynarodowej. Geopolityka i sprawy wewnętrzne, red. J. Kloczkowski, Ośrodek Myśli Politycznej, Kraków 2010, s. 32-33.

154 W. Bernacki, Wypowiedź, [w:] WNP Sejm, 8 kadencja, 78 pos., 14 III 2019, http://www. sejm.pl, dostęp 14 II 2020. 
terii do PiS - Kornel Morawiecki, mówiąc w 2017 roku: „Jesteśmy dziedzicami wielkiej przeszłości"155.

Na stosunek do przeszłości polskiej państwowości PiS nałożyło dychotomiczne postrzeganie jej statusu i podmiotowości w środowisku międzynarodowym. Poseł PiS M. Gosiewska w imieniu Klubu Parlamentarnego PiS wyróżniła dwie tradycje "prowadzenia wolnej i suwerennej polityki zagranicznej". W jej opinii pierwszą tradycją, której realizatorem stała się PO, było wywodzenie z polskich kompleksów modelu polityki podporządkowania się woli mocarstw, rezygnacji z własnej tożsamości i interesów, lekceważenia państw małych i średnich, odwracania się od regionu środkowoeuropejskiego. Tej tradycji przeciwstawiła inną, właściwą dla własnego obozu, a opartą na przesłance, że Polska jest państwem o największym potencjale politycznym, militarnym, demograficznym i gospodarczym w Europie Środkowej, co zobowiązywało ją do budowania własnej tożsamości w oparciu o położenie geopolityczne, odrzucenia kompleksów, determinacji do walki o własne interesy i nieulegania trudnościom ${ }^{156}$.

Można powiedzieć, że w myśli politycznej PiS mamy do czynienia z afirmacją przeszłości państwowości polskiej, którą przywołano w Strategii Polskiej Polityki Zagranicznej 2017-2021: „Odrębnym zadaniem jest zwalczanie używania w odniesieniu do Polski terminu "nowa demokracja». Rzeczpospolita ma bowiem jedne z najstarszych, choć przerywanych obcą przemocą, tradycji demokratycznych i parlamentarnych na świecie. Polacy byli jednym z pierwszych politycznych narodów obywatelskich w czasach nowożytnych, dzieląc tę tradycję z innymi narodami I Rzeczypospolitej"157. Potwierdzeniem tej deklaracji w latach 2015-2019 były obchody państwowe ważnych rocznic historycznych (związanych z dawnymi dziejami): chrztu Polski, początków parlamentaryzmu, odrodzenia Polski i unii lubelskiej - promieniujące na otoczenie międzynarodowe

155 K. Morawiecki, Wypowiedź, [w:] WNP Sejm, 8 kadencja, 35 pos., 9 II 2017, http://www. sejm.pl, dostęp 24 II 2020.

156 M. Gosiewska, Wypowiedź, [w:] WNPSejm, 8 kadencja, 60 pos., 21 III 2018, http://www. sejm.pl, dostęp 14 II 2020.

157 Strategia Polskiej Polityki Zagranicznej 2017-2021..., s. 26. 
III Rzeczypospolitej. Obchody każdej z nich odbywały się według oczekiwań wyartykułowanych przez poseł Gosiewską w imieniu KP PiS: „W polityce zagranicznej każda z tych rocznic powinna stać się symbolem wartości, które przyświecają naszym rodakom, spraw, o które w przeszłości walczyli, przesłaniem politycznym dla wszystkich naszych partnerów". Zadaniem zaś rządu powinno być przypominanie innym tego dziedzictwa jako wkładu Polski i Polaków w teraźniejszość i przyszłość ${ }^{158}$. Takie podejście do historii oznaczało, że losy Polski postrzegano jako sprzęgnięte z dziejami państw i narodów Europy Środkowej, przede wszystkim sukcesyjnych wobec dziedzictwa państwa polsko-litewskiego. Konsekwencją tego myślenia było przekonanie, że budowanie relacji Polski z Rosją nie może odbywać się kosztem interesów Ukrainy, Białorusi i państw bałtyckich.

W rozważaniach na temat kształtu narodu w PiS, po zestawieniu przytoczonych wypowiedzi Bernackiego i Gosiewskiej, widoczne były niekonsekwencje. Z jednej strony Bernacki wskazywał, zgodnie ze standardami wiedzy politologicznej, że polski naród, tak jak wszystkie w tej części kontynentu, ukształtował się jako wspólnota etniczno-kulturowa, z drugiej strony Gosiewska głosiła odmienny pogląd, że mamy do czynienia ze wspólnotą polityczną - jedną z pierwszych. Mniemania Gosiewskiej były życzeniowe, gdyż proces narodowotwórczy na ziemiach polskich zakończył się w połowie XX wieku ukształtowaniem się narodu etniczno-kulturowego. Piłsudski, epigon usiłujący przestawić zwroty historii jako ostatni i zbudować naród polityczny II Rzeczypospolitej, poniósł porażkę. Wydaje się, że obiektywnie jego wizja nie miała szans na realizację w istniejących uwarunkowaniach regionalnych, kiedy rodziły się narody plebejskie oraz nadal toczyła się rywalizacja polsko-rosyjska i polsko-niemiecka o identyfikację narodową zbiorowości bez tożsamości tego typu. Ostatecznie II wojna światowa przesądziła o etniczno-kulturowym charakterze wspólnoty polskiej. W tym aspekcie rzeczywistość polityczna na przełomie XX i XXI wieku bardziej przypominała wizje

158 M. Gosiewska, Wypowiedź, [w:] WNP Sejm, 8 kadencja, 78 pos., 14 III 2019, http://www. sejm.pl, dostęp 14 II 2020. 
narodowych demokratów niż piłsudczyków, co nie korespondowało $\mathrm{z}$ definiowaniem narodu przez elitę partyjną PiS.

Uważano w tej partii, że nowoczesne, odrodzone i suwerenne polskie państwo jest naturalnym spadkobiercą swoich poprzedniczek i ma obowiązki „środkowoeuropejskie" $i$ „wschodnioeuropejskie". Jak to ujął Józef Fiszer, akceptowano, że Polska ma być "ambasadorem Zachodu na Wschodzie i Wschodu na Zachodzie"159. Na pewno PiS nie patrzyło przychylnie na kierunek ewolucji kultury zachodnioeuropejskiej w ostatnich dekadach, przeciwstawiając mu wartości rodzime, wywiedzione $\mathrm{z}$ historii, w której krzyżowały się różne wpływy kulturowe. Uważano, że odwrócenie się Polski od Europy Środkowej i Wschodniej zakończy się kolejną katastrofą geopolityczną, na podobieństwo rozbiorów w latach 1772-1795 i 1939. Chcąc tego uniknąć, przyjęto określony paradygmat myślenia politycznego o aktywności międzynarodowej Polski, który został dobrze scharakteryzowany w odniesieniu do prezydenta Kaczyńskiego: „Głęboko rozumiał, że tyle będzie znaczyć Polska na Zachodzie, ile potrafi wytworzyć więzów współpracy na Wschodzie, i na tyle będzie ceniona na Wschodzie, na ile okaże się wiarygodnym partnerem i adwokatem w popieraniu na forum UE i NATO uzasadnionych interesów naszego regionu"160. Tym samym status i pozycja Polski rozstrzygają się w jej obecności regionalnej, a nie w Unii Europejskiej, postrzeganej jako odrębna wspólnota integracyjna.

Wychodząc z tych ogólnych przesłanek, prezydent Andrzej Duda zapowiedział w orędziu inauguracyjnym 6 sierpnia 2015 roku w Zgromadzeniu Narodowym: „Polska polityka zagraniczna, która nie powinna podlegać rewolucji, bo polityka zagraniczna rewolucji nie lubi, potrzebuje dzisiaj korekty". Zapowiadana korekta miała obejmować: zwiększenie aktywności, upublicznianie celów, artykułowanie aspiracji, komunikowanie partnerom własnego punktu widzenia. Prezydent odcinał się od rewolucji, nawiązując do poglądów swojego mentora L. Kaczyńskiego, że

159 J. M. Fiszer, Polityka zagraniczna Polski wXXI wieku: cele, wyzwania, kierunki, szanse izagrożenia, „Myśl Ekonomiczna i Polityczna” 2019, nr 2(65), s. 158.

160 Warto być Polakiem..., s. 50. 
w polityce zagranicznej nie powinny mieć miejsca zakręty, jej podstawową cechą należy bowiem uczynić stabilność, gdyż efekty można osiągnąć poza horyzontem jednego roku ${ }^{161}$. Jednak w odniesieniu do prezydentury jego poprzednika - B. Komorowskiego, i rządów koalicji PO-PSL zmiany po 2015 roku miały być znacznie głębsze niż tylko korekta.

Jednak ów rewolucjonizm w odniesieniu do polityki zagranicznej został stępiony przez możliwość nawiązywania do dorobku prezydenta L. Kaczyńskiego i rządów z okresu "pierwszego PiS" (2005-2007). Najpełniejsze credo zapowiadanych przewartościowań możemy odnaleźć już w programie przedwyborczym w 2011 roku: „[...] Polska może prowadzić skuteczną politykę zagraniczną, jeżeli jest ona oparta na realizmie - zamiast naiwnego idealizmu, podmiotowości - zamiast klientyzmu, zdobywaniu realnego statusu i silnej pozycji - zamiast zabiegania o protekcjonalne traktowanie przez "głównych rozgrywających", aktywnej obronie polskiego interesu narodowego - zamiast udawania, że działania innych są z nim w pełni zgodne, wierności sprawdzonym zasadom - zamiast koniunkturalizmu i politycznej poprawności, aktywności-zamiast bezradności"162. Realizację tych zasadniczych przewartościowań zapowiadała debata sejmowa 29 stycznia 2016 roku nad Informacją ministra spraw zagranicznych o zadaniach polskiej polityki zagranicznej w 2016 roku - pierwszym dokumentem tego typu przygotowanym przez Radę Ministrów utworzoną przez Zjednoczoną Prawicę. W wypowiedziach polityków PiS zabierających wtedy głos w imieniu Klubu Parlamentarnego (między innymi Małgorzata Gosiewska, Dominik Tarczyński, Konrad Głębocki, Piotr Pyzik, Włodzimierz Bernacki) pojawiła się wizja polityki zagranicznej odmienna od realizowanej przez koalicję PO-PSL. Zapowiadane przewartościowania były stosunkowo duże w sensie strategicznym oraz taktycznym. Partia to potwierdziła w programie z 2019 roku: „W latach 2015-2019 rząd powołany przez Prawo i Sprawiedliwość zmienił

161 Ł. Warzecha, Lech Kaczyński. Ostatni wywiad..., s. 179.

162 Nowoczesna, solidarna, bezpieczna Polska..., s. 173. 
wektory myślenia politycznego o roli Polski w środowisku międzynarodowym"163.

Przewartościowania w polityce zagranicznej stały się widoczne przede wszystkim w odniesieniu do przyjętych imperatywów. Zostały one określone w 2012 roku w wystąpieniu sejmowym K. Szczerskiego, przemawiającego w imieniu Klubu Parlamentarnego Prawa i Sprawiedliwości. Późniejszy doradca prezydenta Dudy wskazał ich pięć.

Za pierwszy przyjął, co należy uznać za bardzo wymowne, że skoro Polska "czerpie swą siłę z siły regionu Europy Środkowej i Europy Wschodniej" - jak pisano w programie z 2014 roku - to jej obowiązkiem jest budować podmiotowość i wolność państw położonych w tym regionie w taki sposób, aby Polska była „zwornikiem” czterech kręgów koncentrycznych: zachodnioeuropejskiego, bałtycko-nordyckiego, wschodniego i południowo-bałkańskiego. Formą organizacyjną bycia „zwornikiem” miały być powiązania sieciowe w różnych formalnych konfiguracjach subregionalnych. Kierując się tym imperatywem, Polska miała się opowiadać za rozszerzeniem wschodnim i południowym Unii Europejskiej. Jednak dla Szczerskiego ważne były cztery założenia takiej konstrukcji politycznej. Po pierwsze, Europa Środkowa nie może być utożsamiana z państwami postkomunistycznymi, tylko definiowana w ujęciu geopolitycznym. Po drugie, powiązania sieciowe w tej części kontynentu nie mogą mieć ostrza antyniemieckiego. Po trzecie, Europa Środkowa musi być oddzielona w sposób czytelny od Rosji w sensie cywilizacyjnym. Po czwarte, Polska nie może dążyć do bycia mocarstwem regionalnym, ponieważ wówczas wejdzie w ostry konflikt z Niemcami i Rosją. Założenia te są wyjątkowo ważne, pokazują bowiem bezpodstawność opinii ferowanych przez przeciwników PiS oraz popierające je media, że PiS reprezentuje fobię antyniemiecką oraz szaleńczą mocarstwowość.

Jednoznacznie też Szczerski uznał, iż: „Polska zakorzenia swoje bezpieczeństwo w sojuszu transatlantyckim” (drugi imperatyw). Z tego powodu tworzenie europejskiej polityki współdziałania obronnego może byćjedynie dopełnieniem roli Paktu Północnoatlantyckiego, gdyż główną

163 Dobry czas dla Polski..., s. 173. 
siłą obronną na kontynencie powinien być Sojusz. Trzecim imperatywem było przekonanie, że: „Polska ma potencjał, który upoważnia ją do prowadzenia polityki globalnej obecności". Natomiast czwarty odnosił się do sfery aksjologicznej. Szczerski mówił: „Polska w polityce międzynarodowej powinna być promotorem takich wartości jak sprawiedliwość, solidarność i prawda". Znaczenie tej ostatniej wartości podkreślił w odniesieniu do państw, z którymi relacje wykazują jej zdecydowany deficyt; zamiennikiem dla prawdy nie może być zjawisko resetu. Ostatni (piąty) imperatyw został wyrażony w poglądzie, że „siłą Polski są Polacy rozsiani po całym świecie"164.

Po ponad roku rządów Zjednoczonej Prawicy minister W. Waszczykowski w informacji przedstawionej Sejmowi odniósł się do zapowiadanej kilka lat wcześniej rewizji polityki zagranicznej: „Polska polityka zagraniczna zmieniła też swój charakter. Przywróciliśmy jej podmiotowość i właściwą hierarchię priorytetów, przyjmując za punkt wyjścia szeroko pojęte interesy naszego kraju". Nie bez powodu wiele miejsca budowaniu wspólnoty środkowoeuropejskiej poświęcił w swojej mowie inauguracyjnej również nowy prezydent - „na północ od basenu Morza Bałtyckiego aż po Adriatyk". Zapowiadał wzmożoną aktywność na tym kierunku w postaci „odnowienia Grupy Wyszehradzkiej” $i$ „przyciągania nowych partnerów"165. Został więc wyznaczony najważniejszy kierunek aktywności Polski w środowisku międzynarodowym - kierunek środkowoeuropejski. W 2018 roku minister spraw zagranicznych Jacek Czaputowicz w informacji o zadaniach polskiej polityki zagranicznej uznał go za obszar o pierwszoplanowych wyzwaniach, najważniejszych celach oraz przesądzający o naturze polityki zagranicznej Rzeczypospolitej. Wyraźnie podkreślił, że Polska, chcąc oddziaływać na procesy decyzyjne w Sojuszu Północnoatlantyckim i w Unii Europejskiej, powinna nabyć „zdolność do artykułowania interesów państw naszego regionu i dzia-

164 K. Szczerski, Wystapienie w czasie dyskusji na temat informacji ministra spraw zagranicznych o zatożeniach polskiej polityki zagranicznej w 2012 roku, [w:] SS Sejm, 7 kadencja, 11 pos., 29 III 2012, s. 179, http://orka2.sejm.gov.pl, dostęp 15 III 2020.

165 Orędzie nowego prezydenta, 6 VIII 2015, http://www.tvn24.pl, dostęp 5 II 2020; Informacja Ministra Spraw Zagranicznych o zadaniach polskiej polityki w 2017 roku... 
łania w roli ich adwokata". Minister nie dzielił państw zgodnie z granicą unijną czy też północnoatlantycką, przechodzącą przez Europę Środkową. Jednak zastrzegał, że na Polsce ciążą dwa zobowiązania: 1) poszanowanie podmiotowości politycznej środkowoeuropejskich partnerów; 2) odpowiedzialność za promocję i obronę tychże państw ${ }^{166}$. Należy zgodzić się z oceną Grzegorza Piwnickiego, że koncepcja "dobrej zmiany" pociągnęła za sobą „najpoważniejszą od ćwierćwiecza reorientację w sferze polityki zagranicznej", polegającą na odejściu od kilku kluczowych założeń w tym obszarze przyjętych w poprzednich latach III Rzeczypospolitej, zwłaszcza przez rządy lewicowe i liberalne ${ }^{167}$.

Biorąc pod uwagę aspekty geopolityczne w myśli politycznej PiS i PO, należy zauważyć, że między oboma partiami istniała też inna fundamentalna różnica. Obie partie polityczne podchodziły odmiennie do konsekwencji, jakie geopolityka narzuca polityce. PiS oskarżało PO o lekceważenie geopolityki. Poseł PiS W. Bernacki pytał w Sejmie o świadomość geopolityczną liberałów, a konkretnie o charakter zagrożeń stojących przed Polską: „Czy te zagrożenia wynikają z przestrzeni kosmicznej, a może wynikają z tej przestrzeni, w której się znajdujemy, przestrzeni geograficznej ukształtowanej w procesie historycznym? Radzę sięgnąc do podstawowych opracowań" ${ }^{168}$. Wskazaną różnicę między PiS a PO zasygnalizował pośrednio w swoim orędziu prezydent Duda. Politycy PO starali się rozwiązywać polskie dylematy geopolityczne, rozumując w kategoriach Wschód-Zachód, budując mocne powiązania z tym drugim, oparte na regule podporządkowania, a w odniesieniu do Wscho-

166

J. Czaputowicz, Informacja ministra spraw zagranicznych o zadaniach polskiej politykizagranicznej w 2018 roku, [w:] SS Sejm, 8 kadencja, 60 pos., 21 III 2018, s. 82, http://orka2. sejm.gov.pl, dostęp 4 VI 2019.

167 Jako kierunki zmian w polityce zagranicznej Polski Grzegorz Piwnicki wskazat trzy: 1) prymat polityki wewnętrznej nad zagraniczną, a konkretnie konieczności zmian w systemie politycznym i stosunkach społecznych nad relacjami międzynarodowymi, np. w Unii Europejskiej; 2) głęboki pesymizm w ocenie przyszłości integracji europejskiej; 3) redefinicja Europy, która przestała być jedynie szansą, a stała się także zagrożeniem i ryzykiem. G. Piwnicki, Syndrom reintegracji w stosunkach Polski z Unia Europejską po roku 2015, „Środkowoeuropejskie Studia Polityczne” 2017, nr 3, s. 36.

168 W. Bernacki, Wypowiedź, [w:] WNP Sejm, 8 kadencja, 78 pos., 14 III 2019, http://www. sejm.pl, dostęp 14 II 2020. 
du - szukając porozumienia z Rosją. Dla PiS położenie geopolityczne Polski było bardziej skomplikowane. Na oś Wschód-Zachód nakładała się druga oś Północ-Południe. W Strategii Polskiej Polityki Zagranicznej 2017-2021 ujęto ten problem dość obrazowo: „Polska jest usytuowana w newralgicznym punkcie Europy na styku dwóch geopolitycznych płyt tektonicznych [...]". Dlatego też Rzeczpospolita pełni rolę „zwornika na osi Północ-Południe - między szeroko pojętym regionem Morza Bałtyckiego i Europą Środkową i dalej - państwami bałkańskimi i obszarem adriatyckim i czarnomorskim" ${ }^{169}$. Widziano w tym położeniu oczywiście źródło problemów, ale także unikatową szansę wzmocnienia pozycji międzynarodowej Polski. Należy dodać - szansę na przezwyciężenie słabości na linii Wschód-Zachód. Oznak takiego rozumowania na próżno szukać w śladach i świadectwach myśli politycznej PO.

Polska aktywność międzynarodowa, zwłaszcza w regionie, była postrzegana jako niezbędny czynnik do zniwelowania scenariuszy negatywnych. Tym samym PiS było gotowe uwikłać Polskę w rywalizację z Niemcami i Rosją na polu kulturowym, społecznym i gospodarczym, uważając taką aktywność za historycznie i geopolitycznie uzasadnioną. Zdecydowanie dla stronnictwa J. Kaczyńskiego była nie do przyjęcia opinia Mieroszewskiego: „Tysiącletni bilans Polski jest ujemny, po dziesięciu wiekach jesteśmy w punkcie wyjścia. Utraciliśmy wszystko, co można było utracić. Z Rzeczpospolitej Obojga Narodów, idei jagiellońskiej, z misji przedmurza pozostał popiół"170. Nawet jeśli te zdania uznać za prowokację intelektualną, to w myśli politycznej PiS obecne było jej całkowite odrzucenie, co znajdowało najpełniejszy wyraz w polityce historycznej realizowanej przez wszystkie cztery gabinety rządowe powołane przez tę partię w latach 2005-2007 i 2015-2019 oraz przez prezydenta Lecha Kaczyńskiego. Fundamentem tej polityki było przekonanie, że rezydua minionych wieków wpływają pozytywnie na współczesnych Polaków, a przede wszystkim określają ich tożsamość polityczną oraz stanowią

170 Cyt. za: P. Maciążek, Za Kijów nikt nie chciatby niszczyć świata?, http://www.psz.pl, 21 IX 2010, dostęp 24 I 2020. 
kod kulturowy. Dlatego z własnej historii należy być dumnym - to zasadnicza dewiza rządów PiS.

Dla PO takie podejście do polityki zagranicznej Polski było co najmniej wyrazem nonszalancji, błędnego tradycjonalizmu, ignorowania trendów kontynentalnych. PO opowiadała się za odejściem od takiego postrzegania roli międzynarodowej Polski, uważając, że jej potencjał polityczny wyklucza: zachowania ofensywne w regionie, tworzenie alternatywnej wobec niemieckiej polityki środkowoeuropejskiej oraz drażnienie Rosji zaangażowaniem na terytoriach jej „bliskiej zagranicy”. Proponowano w tej materii pasywizm oraz uczestnictwo jedynie w akcjach podejmowanych przez Unię Europejską. Polska miała wejść do hemisfery zachodnioeuropejskiej, czyli uznać, że założenia strategiczne Warszawy powinny być zgodne z Brukselą, gdzie dominowało niemieckie i francuskie postrzeganie Rosji, Europy Środkowej i Wschodniej. Takie podejście do Unii Europejskiej skomentowała Grażyna Gęsicka w Sejmie: „Obudźcie się! Nie jesteśmy już w okresie ubiegania się o akcesję. Polska jest członkiem Unii Europejskiej. Nie musimy przyjmować bezrefleksyjnie wszystkiego, co z Unii przychodzi, ale powinniśmy kształtować politykę Unii Europejskiej"171.

Reprezentatywne dla orientacji liberalnej były wręcz kanoniczne teksty na temat polityki zagranicznej takich polityków jak Bartłomiej Sienkiewicz i Radosław Sikorski. Ten pierwszy w tekstach o wielce wymownych tytułach Pochwała minimalizmu i Pożegnanie z Giedroyciem na łamach prasy ogłosił dezaktualizację w nowych okolicznościach międzynarodowych polityki wschodniej, której podstawy formułowali Piłsudski i Giedroyc, a ujął je dość klarownie Jan Nowak-Jeziorański: „Zabezpieczeniem przed zagrożeniami płynącymi ze wschodu jest przyznanie niezależności państwowej Ukrainy, Białorusi i państw bałtyckich. Dzisiejsza Rosja nie pogodziła się w pełni z oderwaniem się tych krajów od Moskwy"172. W tej wypowiedzi kluczowe dla realnej polityki było zda-

171 G. Gęsicka, Wystąpienie w czasie dyskusji..., s. 149.

172 J. Nowak-Jeziorański, Rzeczpospolita atlantycka. Czym jest polska racja stanu?, [w:] Polska polityka wschodnia. Materiaty konferencji zorganizowanej w dniach 28-29 paździer- 
nie drugie - determinantą stosunków polsko-rosyjskich była niezgoda Kremla na niepodległość i zarazem suwerenność wymienionych państw, leżących na obszarze „bliskiej zagranicy” imperium. Wszelkie polskie projekty porozumienia z Rosją oparte na uznaniu trwałości skutków Jesieni Ludów 1989-1991 były więc iluzoryczne i niewykonalne, mogły być tylko krótkotrwałym epizodem, z którego zyski czerpała jedynie Rosja.

Jeśli nawet opinia o odrzuceniu wskazanego strategicznego założenia polityki zagranicznej Polski byłaby przeinterpretowaniem intencji B. Sienkiewicza, to jednak ten polityk co najmniej wzywał do przemyślenia strategii międzynarodowej Polski ukształtowanej w latach międzywojennych, głównie przez obóz belwederski (1918-1921) i piłsudczykowski (1926-1939), oraz przechowanej w okresie komunizmu przez środowisko emigracyjne w Stanach Zjednoczonych i w Europie Zachodniej (między innymi krąg paryskiej „Kultury”). Polityk PO uznał taką strategię za nierealistyczną i anachroniczną. Sienkiewiczowi chodziło przede wszystkim o obalenie tezy o tym, że „klucz do pozycji międzynarodowej Polski" znajduje się na Wschodzie, na rzecz tworzenia podstaw pod porozumienie z Rosją i rezygnację z polityki wschodniej, którą Kreml postrzegałby jako antyrosyjską ${ }^{173}$.

Natomiast drugi z wymienionych polityków, będąc już ministrem spraw zagranicznych w rządzie Donalda Tuska, ogłosił w 2009 roku na łamach prasy ("Gazeta Wyborcza”, „Nasz Dziennik") w 70. rocznicę wybuchu II wojny światowej porzucenie polityki „jagiellońskiej”, w domniemaniu koncepcji realizowanej przez PiS, na rzecz polityki "piastowskiej", którą autor zinterpretował jako modernizację państwa polegającą na wkomponowaniu się w Unię Europejską, przy jednoczesnej rezygnacji z podmiotowej polityki wschodniej, będącej realizacją własnych interesów. W wywiadzie uwypuklił różnicę między obu koncepcjami: „realizacją idei piastowskiej jest zakorzenienie Polski w strukturach zachodnich,

nika 2005 roku we Wroctawiu, Kolegium Europy Wschodniej, Wroctaw 2005, s. 10.

173 B. Sienkiewicz, Pochwata minimalizmu, "Tygodnik Powszechny", 24-31 XII 2000, nr 52-53, s. 12; idem, Pożegnanie z Giedroyciem, "Rzeczpospolita”, 29-30 V 2010, nr 124, s. 12. 
a promieniowanie stabilnością, wartościami i kulturą europejską na wschód - to realizacja idei jagiellońskiej". Co ciekawe, ten zdeklarowany liberał jako uzasadnienie przywoływał racje z myśli politycznej narodowej demokracji. Sikorski zanegował tym samym wyjątkowe znaczenie dla Polski tej przestrzeni geopolitycznej ${ }^{174}$.

Kolejnymi dwoma wyróżnikami polityki zagranicznej przyjętej przez PO w latach 2007-2015 było traktowanie jej z jednej strony jako pola konfrontacji wewnętrznej z przeciwnikami orientacji realistycznej, a faktycznie z PiS, a z drugiej strony jako ścieżki, która pozwoliłaby liberałom objąć intratne stanowiska w strukturach międzynarodowych (taka postawa odnosiła się przede wszystkim do D. Tuska i R. Sikorskiego, zabiegających o takie usadowienie na arenie międzynarodowej w Unii Europejskiej bądź w Sojuszu Północnoatlantyckim). Dokonało się odrzucenie wszelkich płaszczyzn współpracy w celu zawarcia strategicznego porozumienia co do celów i interesów Rzeczypospolitej na arenie międzynarodowej. Najpełniej ten model przejawiał się w wykonywaniu urzędu ministra spraw zagranicznych przez Radosława Sikorskiego. Jak to ujęła badaczka tej problematyki Agnieszka Orzelska-Stączek, było to ministerium konfrontacyjne ${ }^{175}$.

Za podsumowanie propozycji polityków $\mathrm{PO}$ w zakresie polityki zagranicznej może posłużyć też ocena sformułowana przez historyka Marka Kornata na temat resetu polsko-rosyjskiego: „W sferze realnych intere-

174 R. Sikorski, Lekcje historii, modernizacja i integracja, "Gazeta Wyborcza", 29 VIII 2009, nr 202, s. 3; M. Bober, Nie czekamyna nagrodę pocieszenia [Wywiad Mariusza Bobera z Radosławem Sikorskim], „,Nasz Dziennik", 31 X-1 XI 2009, http://www.naszdziennik.pl, dostęp 12 V 2012. Dogtębnej charakterystyki nurtu przewartościowania polskiej polityki wschodniej dokonali Mieczystaw Stolarczyk i Konrad Szpak. Wedtug tego drugiego różnice między PiS a PO przypominały spory piłsudczyków z endekami w I połowie XX wieku o linię strategiczną Rzeczypospolitej w polityce zagranicznej. Vide M. Stolarczyk, Rosja w polityce zagranicznej Polski..., s. 229-234; K. Szpak, Założenia programowe polityki zagranicznej koalicji rządowej PO-PSL w latach 2007-2011, [w:] Gtówne kierunki polityki zagranicznej rządu Donalda Tuska w latach 2007-2011, red. P. Musiatek, Wydawnictwo eSPe, Kraków 2012, s. 11-21.

175 A. Orzelska-Stączek, Ministrowie spraw zagranicznych Polski w latach 2005-2015. Stefan Meller, Anna Fotyga, Radostaw Sikorski, Instytut Studiów Politycznych PAN, Warszawa 2016, s. 8. 
sów Polskę i Rosję dzieli dużo - zbyt dużo, by mówić o przełomie". Ten wybitny naukowiec przypominał w 2010 roku, że polityki zagranicznej nie można redukować jedynie do warstwy symbolicznej, emocjonalnej i narracyjnej, polega ona bowiem na „załatwianiu spraw”. Napominał także: „Skuteczność w polityce międzynarodowej jest najważniejszym kryterium oceny jej wartości, ale nie należy zapominać, że wielkie idee polityczne osiągają cel na przestrzeni "długiego trwania“"176. W Sejmie VI kadencji politycy PiS występujący w imieniu Klubu Parlamentarnego swojej partii niemal rytualnie podkreślali, że politykę koalicji PO-PSL cechuje jedynie dbałość o wizerunek i pompatyczna forma, bez treści i skuteczności, a przede wszystkim bez jakiejkolwiek wizji.

Realizm polityczny PiS polegał na: 1) postrzeganiu rzeczywistości politycznej jako powiązanych ze sobą procesów, w których należy poszukiwać zmienności i koniunktur; 2) rozważaniu wariantowych scenariuszy rozwoju rzeczywistości uwarunkowanych przez liczne czynniki, między innymi historyczne, geopolityczne i społeczne ${ }^{177}$. W strategii polityki zagranicznej przygotowanej przez rząd Zjednoczonej Prawicy napisano wprost: „Podstawową przesłanką polskiej polityki zagranicznej jest realizm polityczny”, czyli dążenie do „szukania rozwiązań pragmatycznych, zgodnych z polską racją stanu"178. Realizm polityczny PiS wynikał z przemyśleń Jarosława Kaczyńskiego i Lecha Kaczyńskiego, a jego rodowodu należy poszukiwać w recepcji tradycji staropolskiej (nazywanej często jagiellońską, ale chodziło o okres dziejów polskiej państwowości od XIV do XVIII wieku). Taki obraz myśli politycznej w odniesieniu do L. Kaczyńskiego zaczęto upowszechniać na szeroką skalę po katastrofie smoleńskiej. W opracowaniu Warto być Polakiem pisano, że ta tradycja realizmu politycznego oznaczała posługiwanie się w polityce zagranicznej racją stanu i publiczną rozumnością, co w praktyce odnosiło się do podejmowania "gry z największymi potęgami ówczesnego świata" oraz

\footnotetext{
176 M. Kornat, Nie wyrzekajmy się „doktryny Giedroycia”, "Nowa Europa Wschodnia” 2010, t. 5, s. 179-180.

177 J. Kloczkowski, T. Żukowski, Polityka polska: czas na poważną debatę, [w:] Rzeczpospolita na arenie międzynarodowej..., s. 13-14.

178 Strategia Polskiej Polityki Zagranicznej 2017-2021.., s. 21.
} 
poszukiwania istoty polityki, a nie kierowania się pozorami. Odrzucano przeciwstawianie realizmu politycznego romantyzmowi, lecz odczytywano go jako walkę w imię wolności, która miała dwa źródła historyczne dla Europy Środkowej - wynikała 1) z tradycji wielonarodowej Rzeczypospolitej Obojga Narodów oraz 2) z procesu wyzwalania się spod władzy reżimów totalitarnych. Wtedy nastąpiło połączenie wspólnoty wartości ze wspólnotą interesów. Z tych powodów uogólniano w Strategii Polskiej Polityki Zagranicznej 2017-2021: „Solidarność z bliższymi i dalszymi sąsiadami jest zatem nie tylko nakazem moralnym, ale leży także w dobrze pojętym interesie Rzeczypospolitej"179.

Realizm - jak pisał Maciej Łopiński, minister-szef Gabinetu Prezydenta L. Kaczyńskiego - w warunkach integracji miał polegać na: dumie z własnej tradycji i tożsamości, walce o jak najlepsze warunki obecności Polski w organizacjach międzynarodowych (Unia, Sojusz), zapewnianiu dogodnych warunków do rozwoju własnego potencjału, wykonywaniu "polityki bez kompleksów". Przeciwieństwem realizmu było idealizowanie, którego współczesny przejaw to życie w „postpolitycznych obłokach” i mniemanie, że integracja europejska zniosła w stosunkach międzynarodowych: odmienność tradycji i interesów państw narodowych, imperialne dążenia i narodowy protekcjonizm ${ }^{180}$.

W literaturze politologicznej za realizm polityczny uznaje się myślenie, w którym istnienie i bezpieczeństwo państwa są wartościami podstawowymi; odrzuca sięjednocześnie rozumowanie idealistyczne, a uwagę koncentruje się na środkach realizacji celów wynikających z hierarchii wartości. Według politologa Ryszarda Zięby: „Realiści twierdzą, że dążenie do umacniania własnego bezpieczeństwa narodowego jest stałym celem polityki zagranicznej państwa [...] zapewnienie bezpieczeństwa jest zredukowane do zapewnienia przetrwania". W identyczny sposób są także oceniani inni suwerenni uczestnicy stosunków międzynarodowych. Potęga państwa jest rozumiana w kategoriach potencjalnych i relatywnych możliwości. Pierwszeństwo przypisuje się środkom typu

79 Ibidem, s. 5.

180 Warto być Polakiem..., s. 6-8. 
hard power ${ }^{181}$. Uznając państwo za najważniejszy podmiot w środowisku międzynarodowym, przyjmuje się również trzy konsekwencje: 1) system międzynarodowy tworzą państwa o różnym znaczeniu i potencjale; 2) uczestnicy systemu międzynarodowego są zróżnicowani i pełnią różne role; 3) w środowisku międzynarodowym jest różny rozkład potęgi między jego uczestnikami. PiS jako podmiot polityczny spełnia niewątpliwie tę definicję. W konsekwencji w myśli politycznej tego stronnictwa kluczowe miejsce zajmuje refleksja nad potencjałem Rzeczypospolitej, jej możliwościami działania w środowisku międzynarodowym oraz rozkładem relacji sojusznik-wróg w stosunkach międzynarodowych. Jednocześnie PiS przypisywało przeciwnikom liberalno-lewicowym skrajnie odmienne podejście do kwestii podmiotowości w stosunkach międzynarodowych, uważając, że zaakceptowali oni reguły postnowoczesności i przenieśli podmiotowość z instytucji państwa na organizację międzynarodową - Unię Europejską ${ }^{182}$.

Analizując myśl polityczną PiS w odniesieniu do polityki zagranicznej z wykorzystaniem modeli teoretycznych realistycznego i liberalnego, należy pamiętać, że: „Żadna teoria stosunków międzynarodowych nie wyznacza konkretnych rozwiązań politycznych, ale wybór określonej teorii przez decydentów najprawdopodobniej wpłynie na kształt ich polityki i pomoże wyjaśnić podejmowane przez nich decyzje" ${ }^{183}$. Jedynie w takiej roli możemy więc wykorzystywać teorię/doktrynę (neo)realistyczną żeby zrozumieć myślenie polityczne polityków stronnictwa J. Kaczyńskiego o środowisku i stosunkach międzynarodowych.

Na poziomie analizy politycznej przyjęto, że Polska jest państwem średnim pivotalnym i „nigdy nie powinna pełnić w Europie roli pośledniej"184. Z uwarunkowań dziejowych wynikało zaś, że sytuacją alterna-

181 Vide R. Zięba, Teoria bezpieczeństwa państwa w ujęciu neorealistycznym, „Studia Politologiczne" 2018, vol. 49, s. 16-21. Tam też jest przegląd literatury na temat realizmu/ neorealizmu.

182 W. Bernacki, Wypowiedź, [w:] WNP Sejm, 8 kadencja, 78 pos., 14 III 2019, http://www. sejm.pl, dostęp 14 II 2020.

183 A. Orzelska-Stączek, Ministrowie spraw zagranicznych..., s. 52.

184 Vide K. N. Waltz, Structural Realism after the Cold War, „International Security”, Summer 2000, vol. 25, no. 1, s. 38. Cyt. za: Warto być Polakiem..., s. 8. 
tywną dla Polski jest utrata bytu państwowego. Tym samym odrzucono scenariusz istnienia Rzeczypospolitej jako państwa o niskim potencjale politycznym, spenetrowanego i podporządkowanego w sensie klientystycznym swoim sąsiadom - Niemcom i Rosji. Miało to swoje uzasadnienie w dziejach Rzeczypospolitej Obojga Narodów w XVIII wieku, Królestwa Polskiego w latach 1815-1864 oraz Polski Ludowej (1944-1989). Dlatego też J. Kaczyński wnioskował, że Polska swój potencjał musi „zwiększać do rozmiarów stosownych dla państwa naszej wielkości i to musi być ostra gra"185. Należy w tej wypowiedzi widzieć dwa konteksty: obiektywny - pomnażanie zasobów zarówno politycznych, jak również militarnych i gospodarczych; subiektywny - prowadzenie aktywnej polityki zagranicznej, ukierunkowanej między innymi na pozyskiwanie sojuszników ${ }^{186}$. Oba te konteksty tworzyły perspektywę, przez którą w PiS patrzono na rolę Sojuszu Północnoatlantyckiego i Unii Europejskiej wobec Polski, Europy Środkowej i całego kontynentu.

Odrzucając "rolę poślednią", PiS musiało zdefiniować inne potencjalne role Rzeczypospolitej w środowisku międzynarodowym. Określono je w okresie pozostawania w opozycji w latach 2007-2015. Można ich wyróżnić pięć:

1) „rzecznika interesów państw regionu” w trzech znaczeniach: a) w Sojuszu Północnoatlantyckim i Unii Europejskiej; b) państw postkomunistycznych; c) państw położonych na obszarze o charakterze osiowym w aspekcie strategicznym;

2) „współdecydenta" w sprawach wschodnich w organizacjach międzynarodowych hemisfery zachodniej - w Unii Europejskiej i w Sojuszu Północnoatlantyckim;

185 J. Kaczyński, Polska naszych marzeń, Wydawnictwo „Drukarnia Akapit”, Lublin 2011, s. 122.

186 Vide kontrowersyjne opinie w: M. Klatt, Polska-jako „średnie państwo": możliwości iperspektywy, [w:] Polska na arenie międzynarodowej - wspótczesne wyzwania, red. J. J. Piątek, R. Podgórzańska, Wydawnictwo Adam Marszałek, Toruń 2009, s. 127-131. Inny pogląd w: P. Żurawski vel Grajewski, Geopolityka-siła - wola. Rzeczypospolitej zmagania z losem, Ośrodek Myśli Politycznej, Kraków 2010, s. 18-19; R. Łoś, Siła wspótczesnych państw. Ujęcie teoretyczne, „Przegląd Politologiczny” 2018, nr 2, s. 31-44. 
3) „obrońcy suwerenności państw narodowych" w Unii Europejskiej na rzecz Europy ojczyzn;

4) „promotora wartości”, takich jak prawda i solidarność;

5) "promotora pokoju i przestrzegania prawa międzynarodowego"187.

Jednak dla myśli politycznej PiS w okresie jego bycia w opozycji bardziej charakterystyczne było nie tyle deklarowanie ról międzynarodowych, do jakich powinna aspirować Rzeczpospolita, ile opisywanie zasad, na jakich powinna być oparta jej polityka zagraniczna. Najbardziej zwięźle zaprezentował je 4 marca 2013 roku P. Żurawski vel Grajewski, występujący wtedy jako ekspert Piotra Glińskiego, wskazanego przez PiS jako kandydat na premiera "technicznego". Współpracujący z PiS politolog wymienił wówczas siedem zasad:

1) podmiotowość, czyli „nic o nas bez nas" w międzynarodowych organizacjach, do których Polska przynależy;

2) sprzeciw wobec "koncertu mocarstw” (i uczestnictwa w nim Polski) jako systemu ograniczającego suwerenność i podmiotowość państw małych i słabych;

3) solidarność regionalna, polegająca na wyjątkowej odpowiedzialności Polski za Europę Środkową i wspieraniu leżących na tym obszarze państw;

4) nieuznawanie stref wpływów w „polu bezpieczeństwa Polski”, obejmującym Europę Środkową od Finlandii do Gruzji;

5) wzajemność w stosunkach dwustronnych, wykluczająca przyznanie jakiemukolwiek partnerowi jednostronnego uprawnienia do wpływania na ład polityczny w Rzeczypospolitej;

6) maksymalizacja kosztów lekceważenia interesów Rzeczypospolitej przez państwa trzecie;

7) odpersonalizowanie celów polskiej polityki zagranicznej, które zostało zdefiniowane jako postrzeganie polityki zagranicznej w kategoriach

187 Opis ról dla Rzeczypospolitej w środowisku międzynarodowym jest rozproszony w różnych źródtach do badania myśli politycznej PiS. Nie dokonano ich syntetycznego ujęcia. VideW. Waszczykowski, Wypowiedź, [w:] WNP Sejm, 7 kadencja, 36 pos., 20 III 2013, http://www.sejm.gov.pl; J. Kaczyński, Testament polityczny prezydenta, „Nasz Dziennik”, 9 IV 2013, nr 83, s. 19. 
środka służącego do objęcia eksponowanych stanowisk w organizacjach międzynarodowych ${ }^{188}$.

Zestawiając postulowane przez PiS role międzynarodowe Polski oraz zasady rządzące jej polityką zagraniczną, otrzymujemy podstawy aksjologiczne polityki zagranicznej opartej na paradygmacie realistycznym, które miały być drogowskazem po przejęciu władzy. Tworzyły model polityki zagranicznej, w którym kluczowe były status, pozycja i interesy Rzeczypospolitej w środowisku międzynarodowym.

Stronnictwu Kaczyńskiego obce było przecenianie znaczenia soft power w stosunkach międzynarodowych, mimo iż doceniano znaczenie jaźni odzwierciedlonej Polski w środowisku międzynarodowym, stąd tak wielką wagę przywiązywano do polityki historycznej oraz dbałości o Polaków poza Rzeczpospolitą i o Polonię. Politykę historyczną zaproponowaną przez PiS należy odczytywać w dwóch kontekstach: działalności ideotwórczej i decydowania politycznego. Z polityki historycznej PiS zamierzało uczynić (i uczyniło w latach 2005-2007 i 2015-2019) z jednej strony czynnik soft power w stosunkach międzynarodowych, a z drugiej strony środek koncentracji politycznej, opowiadając się jednocześnie za otwartą polityzacją historii (chociażby na podobieństwo Niemiec i Rosji). Historia stała się użyteczna w: 1) przywracaniu wymiaru geopolitycznego aktywności międzynarodowej Polski; 2) urzeczywistnianiu w środowisku międzynarodowym celów strategicznych; 3) promocji własnego dziedzictwa na arenie międzynarodowej oraz w świadomości społecznej Polaków ${ }^{189}$. PiS zaproponowało odbudowę polskiej pamięci historycznej, „zniszczonej" i „zdeformowanej" przez komunizm i postkomunizm ${ }^{190}$. Jak to ujął Lech Kaczyński: „Charakterystyczną cechą polskiego postkomunizmu była próba likwidacji historii", ale „nasze państwo musi mieć korze-

188 P. Żurawski vel Grajewski, Zasady polskiej polityki zagranicznej, 7 III 2013, http://www. niezalezna.pl, dostęp 9 VIII 2020; Nic o nas bez nas - zasady polskiej polityki zagranicznej, 6 III 2013, http://www.salon24.pl, dostęp 9 VIII 2020.

189 Vide D. Gawin, P. Kowal, Polska polityka historyczna, [w:] Polityka historyczna. Historycy, politycy, prasa. Konferencja pod honorowym patronatem Jana Nowaka-Jeziorańskiego, Patac Raczyńskich w Warszawie, 15 grudnia 2004 roku, red. A. Panecka, Muzeum Powstania Warszawskiego, Warszawa 2005, s. 11-13; Polska polityka historyczna..., s. 2-34.

190 IV Rzeczpospolita-Sprawiedliwość dla Wszystkich..., s. 17. 
nie". Działania na rzecz wykorzenienia historycznego Polski Kaczyński tłumaczył nałożeniem się takich dwóch tendencji jak „tożsamość osób i tożsamość losów"191. To właśnie z tych tendencji wynikało, że likwidacja historii była korzystna dla formacji postkomunistycznych (SLD i PSL), ale w latach 2005-2007 na te pozycje przeszła także PO. W tym przypadku decydowała tożsamość idei, polegająca na deprecjonowaniu znaczenia historii, ale także przejmowanie wyborców, którzy uprzednio głosowali na lewicę. Polityka historyczna miała wzmocnić tożsamość polityczną Polaków, aby ich wyraźnie oddzielić od innych wspólnot narodowych tworzących Unię Europejską ${ }^{192}$. Jak podkreślił bowiem L. Kaczyński: "narody, tracąc pamięć, tracą życie”, dlatego też: „Potwierdzanie własnej pamięci to ciągłe zadanie stojące przed narodami Europy. Tę pamięć trzeba przecież przekazywać kolejnym pokoleniom" ${ }^{193}$.

Stojąc twardo na gruncie przynależności Polski do Unii Europejskiej, PiS jednocześnie poszukiwało zabezpieczeń przed roztopieniem się polskości w uniwersalnym kodzie europejskim. Uważano, że tylko wzmacnianie polskości zagwarantuje na poziomie mentalnym i świadomościowym utrwalenie niepodległości Rzeczypospolitej w warunkach integracji i europeizacji. PiS nie ukrywało też kontekstu antyrosyjskiego nowoczesnej polskiej pamięci historycznej, znacznie słabiej przywoływało zaś kontekst antyniemiecki. Przypominano tradycję walki Rzeczypospolitej i Polaków z różnymi formami państwowości rosyjskiej (Rosja carska, Rosji radziecka, ZSRR) oraz sprawę mordu katyńskiego ${ }^{194}$.

Po przegranych wyborach w 2007 roku PiS uczyniło z koncepcji polityki historycznej ważny wyróżnik własnej myśli politycznej. W sferze rządzenia prezydent Kaczyński pozostał jej „depozytariuszem” w zakresie

191 Ł. Warzecha, Lech Kaczyński. Ostatni wywiad..., s. 116-117.

192 J. von Wedel, Polska polityka wobec Niemiec 2005-2007: polityka historyczna czy nowa polityka europejska?, [w:] Polityka zagraniczna Polski w warunkach członkostwa w Unii Europejskiej, red. R. Podgórzańska, Wydawnictwo Adam Marszałek, Toruń 2009, s. 44.

193 L. Kaczyński, Pojednanie możliwe tylko dzięki prawdzie, „Rzeczpospolita”, 1 IX 2009, nr 204, s. 3.

194 Vide Rozmowy w "Faktach" 15 I 2002, http://www.pis.org.pl, dostęp 2 III 2009; Rozmowa Doroty Gawryluk z Markiem Jurkiem, 4 VIII 2004, http://www.pis.org.pl, dostęp 5 II 2009. 
polityki zagranicznej i wewnętrznej, doprowadzając do konfrontacji nie tylko z podmiotami politycznymi działającymi w środowisku międzynarodowym (Rosja, Niemcy), ale również z PO i rządem D. Tuska, którzy stali się wykonawcami innej koncepcji polityki zagranicznej Polski oraz nosicielami alternatywnych idei w odniesieniu do historii. Przede wszystkim zaś zanegowali oni znaczenie polityki historycznej dla skutecznej aktywności Polski na arenie międzynarodowej, zwłaszcza na odcinku rosyjskim, niemieckim i unijnym.

Z przesłankami, z których PiS wywiodło swoją politykę transatlantycką i europejską, mocno wiązały się kwestie rodowodowe. Poprzedniczką genetyczną PiS była partia Porozumienie Centrum, którą u progu III Rzeczypospolitej można było uznać za najbardziej zorientowaną na promowanie polityki szybkiego wejścia Polski do Sojuszu i do Wspólnot Europejskich. Dla tej orientacji mitem założycielskim stał się stosunek do rządu Jana Olszewskiego. W PiS, po powstaniu partii, niemal powszechnie uważano, że był to pierwszy gabinet w III Rzeczypospolitej, którego szef w swoim exposé 21 grudnia 1991 roku zapowiedział podjęcie przez Polskę starań o członkostwo w Organizacji Traktatu, wbrew innym ówczesnym siłom politycznym zarówno o rodowodzie postsolidarnościowym (Unia Demokratyczna, ruch narodowy), jak i o przeszłości postkomunistycznej (socjaldemokraci, ludowcy). Eksponowaniu roli Olszewskiego "sprzyjała" jego śmierć w 2019 roku oraz 20. rocznica akcesji Polski do Sojuszu. To o zmarłym premierze w tym kontekście mówił minister obrony narodowej Mariusz Błaszczak, że „wytyczał kierunek drogi do NATO” dla kolejnych rządów, które realizowały ten strategiczny cel $^{195}$. Jest natomiast zastanawiające, że kiedy obchodzono 10. rocznicę wejścia Polski do Sojuszu, to politycy PiS, w tym prezydent L. Kaczyński, nie podkreślali już tak mocno roli rządu Olszewskiego. Prezydent w wystąpieniu oko-

195 Spotkanie z żotnierzami w bazie w Mińsku Mazowieckim, 9 III 2019, http://www.pap.pl, dostęp 22 XII 2019. 
licznościowym 12 marca 2009 roku ograniczył się do ocen generalnych, uznając rok 1999 za "drugi przełom po roku 1989"196.

Faktycznie Olszewski sformułował taki cel oraz zaprezentował jego podwójne uzasadnienie. Mówił, że:1) Sojusz jest filarem bezpieczeństwa europejskiego; 2) obecność w Europie wojsk Stanów Zjednoczonych Ameryki jest czynnikiem stabilizacji ${ }^{197}$. W dyskusji sejmowej nad exposé premiera w imieniu PC zabrał głos poseł Marek Dziubka, który ocenił program rządu Olszewskiego jako "dokonywanie zasadniczej korekty polityki prowadzonej od 1989 r." ${ }^{198}$. Tę korektę widział w kategoriach alternatywnego rozwiązania dla dominujących wówczas pomysłów. Była to opinia reprezentatywna dla całego środowiska politycznego. Politycy PC odrzucali projekty: paneuropejskiego kooperatywnego systemu bezpieczeństwa opartego na KBWE/OBWE; utworzenia NATO-bis, czyli środkowoeuropejskiego systemu bezpieczeństwa; budowy Północnoatlantyckiej Rady Współpracy połączonej z Partnerstwem dla Pokoju. Wszystkie one były interpretowane jako celowe tworzenie w Europie Środkowej „szarej strefy” między Sojuszem Północnoatlantyckim obecnym w Europie Zachodniej a Federacją Rosyjską przejmującą sukcesję po ZSRR, co faktycznie oznaczało pozostawienie tej części kontynentu otwartą na penetrację rosyjską („bliska zagranica”) i uzależnienie od zjednoczonych Niemiec (Mitteleuropa) ${ }^{199}$.

W PC wyraźnie odczuwalne było odrzucenie dominującego w latach dziewięćdziesiątych XX wieku liberalnego myślenia o statusie i roli Sojuszu w środowisku międzynarodowym. Zwolennicy liberalnej doktryny uważali, że należy zasadniczo przekształcić Organizację Paktu lub nawet ją zlikwidować, ponieważ wraz z upadkiem ZSRR i systemu biegunowego bezpieczeństwa dokonały się rewolucyjne zmiany w świecie,

196 Prezydent: NATO musi zostać paktem obronnym, 12 III 2009, http://www.newsweek.pl, dostęp 1 II 2020.

197 Exposé premiera Jana Olszewskiego - fragment dotyczący polityki zagranicznej - 21 grudnia 1991 r., http://stosunki-miedzynarodowe.pl, dostęp 4 V 2019.

198 M. Dziubka, Wystąienie, [w:] SS Sejm, 1 kadencja, 4 pos., 23 XII 1991, s. 14, http://orka2. sejm.gov.pl, dostęp 4 V 2019.

199 W. Waszczykowski, O trudnej drodze do NATO. Kilka wspomnień i refleksji, 12 III 2019, http://wiadomosci.onet.pl, dostęp 3 V 2019. 
które uzasadniały podjęcie takich decyzji ${ }^{200}$. Dla PC takie rozumowanie było nie do przyjęcia. Jednocześnie z myśli politycznej PC do PiS został przeniesiony inny istotny pogląd, że akcesja do Sojuszu (także do Wspólnot Europejskich) nie może oznaczać rezygnacji z suwerennej polityki wschodniej oraz w regionie Europy Środkowej (środkowoeuropejskiej). Opcji euroatlantyckiej nie można było traktować jako odizolowania się od najbliższego środowiska międzynarodowego na rzecz westernizacji. Polska nie mogła postrzegać swojego wejścia do Sojuszu i Wspólnot jako zerwania powiązań regionalnych - środkowoeuropejskich i wschodnioeuropejskich - na rzecz budowania relacji z państwami zachodnioeuropejskimi. Raczej odwrotnie - uważano, że akcesja do tych organizacji poszerzy możliwości dla aktywności regionalnej Polski, gdyż Warszawa stanie się wówczas atrakcyjnym partnerem w regionie.

Wraz z upływającym czasem pozytywny wizerunek "transatlantyckiego" rządu Olszewskiego się utrwalał, przechodząc z poziomu faktów w sferę mitów. Przypisywano temu gabinetowi, a konkretnie ministrowi obrony narodowej w jego składzie Janowi Parysowi, propozycję natychmiastowych rozmów o wejściu Polski do Paktu ${ }^{201}$. Najbardziej ilustratywnym przykładem była wystawa zorganizowana z okazji warszawskiego szczytu Paktu w 2016 roku, kiedy mocno wyeksponowano rolę tego premiera. Jednak to nie dobór zdjęć był najważniejszy, ale wyjaśnienia złożone przez ministra obrony narodowej Antoniego Macierewicza. Mówił: „Chcieliśmy pokazać na tych zdjęciach tych ludzi, o których nie było wiadomo, że odegrali rolę przełomową w tym, żeby Polska była w NATO". To właśnie premier Olszewski był pierwszym, który „postawił sprawę wejścia Polski do NATO jako kluczową", a chciano go wykreślić "gumką myszką". Według Macierewicza, było to przywracanie historycznej równowagi i sprawiedliwości, ponieważ przez poprzednie lata

200 R. Zięba, Główne kierunki polityki zagranicznej..., s. 18.

201 Vide Wypowiedź A. Macierewicza w: Konferencja z okazji rocznicy wstąpienia do NATO, 13 III 2017, http://www.pap.pl, dostęp 22 XII 2019. 
III Rzeczypospolitej w tym kontekście byli obecni jedynie politycy opcji lewicowo-liberalnej, a pomijano prawicowych ${ }^{202}$.

W 20. rocznicę akcesji Polski do Sojuszu Północnoatlantyckiego zdecydowano się na zaprezentowanie opinii publicznej poglądu, że na początku lat dziewięćdziesiątych stosunek do Sojuszu Północnoatlantyckiego strukturalizował arenę polityczną na obóz niepodległościowy, optujący za wejściem do Sojuszu, i jego przeciwników, proponujących alternatywne, niejasne rozwiązania, faktycznie korzystne dla Rosji. Swoistym patronem tych drugich był prezydent Wałęsa. Taki obraz ówczesnej areny politycznej nakreślił W. Waszczykowski w tekście rocznicowym na 20-lecie członkostwa, pisząc o lewicowych i liberalnych oraz wojskowych przeciwnikach wejścia Polski do Sojuszu. Niemal identycznej strukturalizacji ówczesnej areny politycznej dokonała z trybuny sejmowej M. Gosiewska, dodając jeszcze, że przeciwnicy zwrotu transatlantyckiego straszyli pogorszeniem stosunków z Rosją i z Zachodem. Minister zaś wyeksponował w sposób bezpośredni także to, co było reprezentatywne dla PiS, że jedną z przyczyn obalenia rządu Olszewskiego był brak zgody w ówczesnej elicie politycznej na kurs transatlantycki premiera ${ }^{203}$.

W drugiej dekadzie XXI wieku Jarosław Kaczyński zaczął intensywnie przypominać dorobek rządu Olszewskiego w kontrze do opinii o tym rządzie polityków PO. W 2012 roku oceniał: „[...] opcja natowska w okresie rządów Tadeusza Mazowieckiego, a także Krzysztofa Bieleckiego wcale nie była przyjmowana. [...] Pierwszym rządem, który tę sprawę postawił twardo i jednoznacznie [...] był rząd Jana Olszewskiego i to jest jego ogromna zasługa, bo ta opcja nie mogła być już później podważona, i została przyjęta z oporami także przez rządy komunistyczne, które przyszły w roku 1993"204. Podobną opinię sformułował siedem lat później:

202 A. Macierewicz, Konferencja z okazji szczytu NATO, 9 VII 2016, http://www.pap.pl, dostęp 29 XII 2019.

203 W. Waszczykowski, O trudnej drodze do NATO...; M. Gosiewska, Wypowiedź, [w:] WNP Sejm, 8 kadencja, 78 pos., 14 III 2019, http://www.sejm.pl, dostęp 14 II 2020.

204 WypowiedźJ. Kaczyńskiego na konferencji w20. rocznicę „Nocnejzmiany", 7 VI 2012, http:// www.tvn24.pl, dostęp 1 V 2019. 
„[...] gdyby nie rząd Olszewskiego, Polska nie przystąpiłaby do NATO w 1999 roku. [...] Odbyłoby się to znacznie później"205.

Oceniając Olszewskiego, zapominano o uwarunkowaniach globalnych i wewnętrznych tego czasu, a zwłaszcza o relacjach Stany Zjednoczone-Federacja Rosyjska po upadku ZSRR oraz o decyzjach szczytu Sojuszu podjętych w Rzymie 7-8 listopada 1991 roku w postaci Nowej koncepcji strategicznej Sojuszu. W tej strategii wyraźnie odbierano Sojuszowi cechę antyradziecką/antyrosyjską oraz wspierano tworzenie paneuropejskiego systemu bezpieczeństwa ${ }^{206}$. W Waszyngtonie dominowali zwolennicy bliskiej współpracy z Moskwą, odrzucający scenariusze konfrontacyjne, gdyż przede wszystkim obawiano się chaosu na obszarach postradzieckich, ale także w postkomunistycznej Europie Środkowej. Rewolucja i radykalizm nie były stanami pożądanymi i oczekiwanymi w Białym Domu za prezydentury George’a H. Busha. Natomiast osłabione władze na Kremlu - najpierw Michaił Gorbaczow, a potem Borys Jelcyn, gwarantowały względną stabilizację.

205 Wywiad J. Kaczyńskiego w "Sygnałach dnia”, 15 II 2019, http://www.polskieradio.pl, dostęp 10 V 2019; vide Wystąpienie M. Błaszczaka w bazie lotnictwa z okazji pikniku NATO, 9 III 2019, http://www.tvp.info, dostęp 8 V 2019.

206 R. Zięba, Gtówne kierunki polityki zagranicznej..., s. 32. 


\subsection{Orientacja transatlantycka}

Wstępem do rozważań na temat polityki transatlantyckiej rządów Prawa i Sprawiedliwości w latach 2015-2019 mogą być słowa prezydenta Lecha Kaczyńskiego: „NATO czyni świat lepszym. Być może nie jest to organizacja idealna, ale bez niej świat byłby gorszy"1. Kierując się tą opinią oraz realizmem, a także odrzucając koncepcję polityki zagranicznej Polski realizowaną przez rząd PO-PSL, znajdujące się w latach 2007-2015 w opozycji PiS zapowiadało nową politykę transatlantycką w przypadku przejęcia władzy w Rzeczypospolitej. Zamierzano nawiązać do dorobku własnych rządów w latach 2005-2007 (oraz prezydentury Kaczyńskiego w okresie 2005-2010), kiedy to - jak napisano w programie Dbamy o Polskę. Dbamy o Polaków - „Zdecydowanie przewartościowaliśmy polską politykę zagraniczną"2.

Innym refleksem realizmu w odniesieniu do orientacji transatlantyckiej PiS była ocena zapisana w 2001 roku: „Zostaliśmy przyjęci do Sojuszu niejako na kredyt i bez zmiany tego stanu rzeczy nie będziemy mogli wykorzystać możliwości, jakie nam daje położenie geograficzne i potencjał ludnościowy [...]". Dwa lata później w kolejnym programie

Wypowiedź prezydenta L. Kaczyńskiego dla polskiego radia, 13 III 2009, http://wiadomosci.dziennik.pl, dostęp 1 VI 2019.

2 Dbamyo Polskę. Dbamy o Polaków, PiS, [Warszawa] 2007, s. 49. 
wskazano jedną z przyczyn obecności na kredyt w Sojuszu. Był nią stan sił zbrojnych Rzeczypospolitej, który nie pozwalał na wykonywanie zobowiązań w sferze militarnej, co zasadniczo ogranicza podmiotowość Polski w Pakcie ${ }^{3}$. Trudno było w Polsce o większy sceptycyzm co do znaczenia obecności w Pakcie, ponieważ - w opinii PiS - samo członkostwo w nim nie prowadziło do rewolucyjnych zmian w zakresie bezpieczeństwa Rzeczypospolitej. Stwarzało jedynie szansę na zmianę w tej kwestii, która mogła doprowadzić do przekształceń o charakterze rewolucyjnym, czyli znieść dramatyczne ciążenie położenia geopolitycznego nad losami Polaków przez ostatnie trzy wieki.

Nowa polityka transatlantycka PiS była pochodną poglądu, że w środowisku międzynarodowym istnieją obok siebie dwa różne porządki: "świat bezpieczny" oparty na obronie kolektywnej jego uczestników oraz „świat regionalnej przemocy" ze strony mocarstw w stosunku do państw małych i średnich" Wyróżnienie tych dwóch światów nie wynikało z czynnika ideologicznego (demokracja-dyktatury), ale z oceny uczestnictwa Stanów Zjednoczonych Ameryki, które jako jedyne są zdolne do przeciwstawienia się przemocy i agresji w stosunkach międzynarodowych. Taka ocena kontrastowała z opinią wyrażoną pięć lat później w Priorytetach Polskiej Polityki Zagranicznej 2012-2016, przygotowanych przez rząd PO-PSL. W tym dokumencie konstatowano schyłek „świata jednobiegunowego" i „niepewność co do trwałości ładu światowego" oraz prognozowano, że decydujące dla stosunków międzynarodowych będą

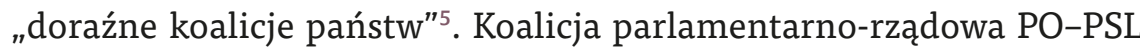
przyjęła więc założenie, że status Stanów Zjednoczonych będzie się zmieniał w kierunku utraty roli jedynego kreatora systemu bezpieczeństwa w skali globalnej na rzecz bycia jednym z mocarstw (prawdopodobnie najsilniejszym), skazanym jednak na porozumiewanie się z innymi państwami o podobnym statusie, nie tylko w tematach ogólnoświatowych,

3 Dokumenty programowe i ideowe. Kongres założycielski Prawo i Sprawiedliwość..., s. 74; Program Prawa i Sprawiedliwości [2003]..., s. 26.

4 Dbamyo Polskę. Dbamyo Polaków..., s. 49.

5 Priorytety Polskiej Polityki Zagranicznej 2012-2016, MSZ, Warszawa 2012, s. 4. 
ale także w kwestiach regionalnych, np. europejskich i środkowoeuropejskich. Następstwem takiego podejścia do problemu kształtu i efektywności systemu bezpieczeństwa było dowartościowywanie znaczenia Niemiec i Rosji oraz Unii Europejskiej, które mogły przejąć zadania dotychczas wykonywane przez Waszyngton czy to bezpośrednio, czy za pośrednictwem Paktu Północnoatlantyckiego. Rząd D. Tuska postanowił rozluźnić więc związki ze Stanami Zjednoczonymi na rzecz zacieśnienia współpracy z Niemcami i porozumienia się z Rosją. Dla PiS taki kierunek był nie do przyjęcia ze względów strategicznych. Nie akceptowano takich prognoz oraz formułowano odmienny wniosek - zacieśnienie współpracy ze Stanami Zjednoczonymi i jak najpełniejsze ich uwikłanie w sprawy środkowoeuropejskie.

Była jeszcze inna płaszczyzna rozbieżności. O ile PiS uważało, że globalizm i integracja nie są skutecznymi gwarantami bezpieczeństwa dla państw małych i średnich, a wręcz odwrotnie - niosą ze sobą uprzedmiotowienie wobec silniejszych partnerów, o tyle $\mathrm{PO}$ poszukiwała gwarancji bezpieczeństwa $\mathrm{w}$ ustanowieniu europejskiego systemu bezpieczeństwa jako pochodnego pogłębionej integracji, bowiem „żadne z państw Unii nie jest w stanie samodzielnie kształtować zdarzeń globalnych ani istotnie wpływać na ich rozwój [...]" ${ }^{\prime}$. O ile PiS wiązało bezpieczeństwo Polski z utrzymaniem się hegemonii globalnej Stanów Zjednoczonych i ich trwałej obecności w Europie, nawet w wersji rozszerzonej na region środkowoeuropejski, o tyle $\mathrm{PO}$ optowała za poszukiwaniem bezpieczeństwa w warunkach osłabienia pozycji międzynarodowej Stanów Zjednoczonych oraz podjęcia przez Unię Europejską ciężaru zbudowania kontynentalnego systemu bezpieczeństwa. Podejścia strategiczne były więc zasadniczo odmienne - rozbieżność wynikała z oceny zdolności Waszyngtonu do spełniania swojej roli w systemie międzynarodowym i z oceny zdolności Unii Europejskiej do chociażby częściowego zastąpienia Stanów Zjednoczonych w roli stabilizatora bezpieczeństwa militarnego w Europie. W tej materii politycy PiS byli raczej optymistami, 
podczas gdy liberałowie nie wierzyli w utrzymanie dotychczasowego ładu międzynarodowego opartego na hegemonii.

Tworząc własną wizję Sojuszu Północnoatlantyckiego i jego roli w postzimnowojennym świecie, PiS przyjęło założenie, że w interesie Rzeczypospolitej jest utrzymanie się amerykańskiej hegemonii, gdyż wszelkie projekty budowy koncertu mocarstw są bardzo niebezpieczne z racji geopolitycznych i historycznych (położenie między Rosją a Niemcami, doświadczenia lat międzywojennych i II wojny światowej). Złożoność sytuacji wynikającą z położenia geopolitycznego Polski Witold Waszczykowski określił jako „dylemat sandwicha”, który mimo wejścia do Sojuszu i Unii nie został rozwiązany. Wskazywał dwa połączone ze sobą powody: rosyjski imperializm oraz brak adekwatnej reakcji europejskiego Zachodu na to zagrożenie. Amerykańską hegemonię konkretyzowano w odniesieniu do Paktu Północnoatlantyckiego - jak to ujął minister Waszczykowski: „Przywództwo polityczne i zaangażowanie wojskowe Stanów Zjednoczonych jest niezbędne dla zachowania wiarygodności i spójności NATO"7.

Z historii wynikało, że powstanie koncertu mocarstw oznaczało nie tylko zbiorową odpowiedzialność kilku państw za kształt systemu międzynarodowego, ale również utworzenie stref wpływów. Zastrzeżenia wobec takiego kierunku ewolucji systemu międzynarodowego formułowano na dwóch poziomach: globalnym i regionalnym. O pierwszym mówił Andrzej Duda 24 sierpnia 2016 roku: „Doświadczenie przeszłości dobitnie przekonuje, że system równoważących się potęg nigdy nie był w stanie trwale zapewnić pokoju w Europie. Osiągano go jedynie chwilowo, zazwyczaj poprzez poświęcenie niepodległości słabszych państw"8. Mechanizm był jednak bardziej skomplikowany niż opis dokonany przez

Informacja Ministra Spraw Zagranicznych o zadaniach polskiej polityki w 2017 roku...; W. Waszczykowski, Wypowiedź, [w:] WNP Sejm, 8 kadencja, 78 pos., 14 III 2019, http:// www.sejm.pl, dostęp 14 II 2020. Szerzej vide J. Sanecka-Tyczyńska, Racja stanu we wspótczesnej polskiej myśli politycznej..., s. 384-387; eadem, Model bezpieczeństwa zewnętrznego państwa w myśli politycznej Prawa i Sprawiedliwości, „Zeszyty Naukowe WSOWL" 2011, nr 3(161), s. 219.

8 Archiwum Prezydenta RP, https://www.prezydent.pl, „Wystąpienie Prezydenta RP na dorocznej naradzie ambasadorów Ukrainy", 24 VIII 2016, dostęp 12 VI 2020. 
prezydenta. Owszem, to koncert mocarstw solidarnie decydował o zakresie podmiotowości i istnieniu państw małych, a nawet średnich, ale faktycznie tymczasowo współdziałające mocarstwa gwarantowały efektywną adaptację i unikanie wojen. Zagrożenie wojną następowało wówczas, kiedy koncert mocarstw w wyniku sprzeczności zaczynał się dzielić na bloki. Istotą blokowego systemu bezpieczeństwa jest bowiem strategiczne dążenie do wojny między blokami mocarstw, które w okresie przejściowym podporządkowują sobie na zasadzie klientelizmu innych uczestników stosunków międzynarodowych.

Co do poziomu regionalnego w PiS obawiano się, że w przypadku Europy Środkowej koncert mocarstw pociągnie za sobą budowę w tej części kontynentu rosyjskiej strefy wpływów, na którą mogą się zgodzić mocarstwa zachodnioeuropejskie. Nie bez powodu minister W. Waszczykowski niemal wykrzyczał z trybuny sejmowej w 2017 roku: „Nigdy więcej Monachium i Jałty". W obu przypadkach Zachód pozostawiał Europę Środkową albo Niemcom, albo Rosji. Zestawienie było czytelne zarówno dla Moskwy, jak i dla stolic zachodnioeuropejskich, w tym dla Berlina ${ }^{9}$. Chcąc temu przeciwdziałać, PiS, a faktycznie Lech Kaczyński w czasie swojej prezydentury, zaproponowało alternatywne rozwiązanie geopolityczne. Po latach w wywiadzie opisał je Zdzisław Krasnodębski (europoseł z rekomendacji PiS), mówiąc o prezydencie: „On zamiast opierać się na Berlinie czy Brukseli, chciał budować sojusz mniejszych i większych państw Europy Środkowej, które prowadziłyby suwerenną politykę nie tylko wobec Rosji, ale też wobec Niemiec czy Brukseli"10.

Oceny znaczenia historycznego i politycznego Sojuszu dokonano w latach 2005-2007 w dwóch dokumentach tzw. ramowych: programie IV Rzeczpospolita - Sprawiedliwość dla Wszystkich (2005) oraz Strategii bezpieczeństwa narodowego Rzeczypospolitej Polskiej (2007). W pierwszym z nich o charakterze partyjnym (PiS) stwierdzano: „Pakt Północ-

Informacja Ministra Spraw Zagranicznych o zadaniach polskiej polityki w 2017 roku...

10 Z. Krasnodębski, Putin niejest szaleńcem [Rozmowa Tomasza Terlikowskiego ze Zdzisławem Krasnodębskim], „Do Rzeczy”, 24-30 III 2014, nr 13(61), s. 26. Trudno w myśleniu politycznym właściwym dla PiS nie widzieć inspiracji piłsudczykowskich w odczytywaniu czynników geopolitycznych. 
noatlantycki jest jedynym skutecznym i wiarygodnym sojuszem. Na tę wiarygodność składa się przede wszystkim fakt, że należy doń największa potęga wojskowa świata i główny militarny sojusznik Polski - Stany Zjednoczone Ameryki Północnej [tak w oryginale - W.P.]"11. Natomiast w drugim, mającym charakter rządowy (rząd J. Kaczyńskiego), pisano: „Sojusz Północnoatlantycki [podkr. w oryginale - W.P.] jest dla Polski najważniejszą formą współpracy wielostronnej w polityczno-wojskowym wymiarze bezpieczeństwa oraz filarem stabilności na kontynencie, a także główną płaszczyzną stosunków transatlantyckich"12.

Będąc już w opozycji, PiS doprecyzowało rolę Sojuszu w koncepcji bezpieczeństwa państwa. Uczyniono to w programie z 2009 roku. Określono w nim trzy filary kształtujące pozycję międzynarodową Polski. Były to: 1) członkostwo w Sojuszu; 2) partnerskie relacje ze Stanami Zjednoczonymi; 3) bliskie stosunki z niepodległymi państwami "położonymi na wschód od Unii Europejskiej"13. Rzecz znamienna, nie wymieniono wśród tych atutów ani członkostwa w Unii z jej polityką obronną i bezpieczeństwa, ani bliskich relacji z wybranymi państwami zachodnioeuropejskimi (w domniemaniu z Niemcami). Posunięto się o krok dalej - otóż uznano te trzy czynniki za „lewary” pozycji Polski w Unii Europejskiej, a także widziano między nimi sprzężenia. Nie traktowano ich więc w oderwaniu, uważano, że Sojusz będzie gwarantem bezpieczeństwa Polski tylko w warunkach jego asekurowania bezpośrednimi stosunkami sojuszniczymi z Waszyngtonem oraz w ujęciu regionalnym, czyli uznania Rzeczypospolitej w Białym Domu za państwo podstawowe dla bezpieczeństwa tej części Europy. W PiS nie miano żadnych złudzeń, że o strategii polityczno-wojskowej w Pakcie decydują Stany Zjednoczone i to od ich kalkulacji zależy koncepcja rozwoju organizacji. Taki sposób myślenia strategicznego zasadniczo odróżniał PiS od rządzącej wówczas PO.

Te wszystkie stwierdzenia zostały niemal powtórzone w kolejnych głównych dokumentach PiS, powstałych w późniejszym okresie trwa-

\footnotetext{
IV Rzeczpospolita - Sprawiedliwość dla Wszystkich..., s. 41.

Strategia bezpieczeństwa narodowego Rzeczypospolitej Polskiej..., s. 11.

Nowoczesna, solidarna, bezpieczna Polska..., s. 173.
} 
nia w opozycji (2011-2014). W programie wyborczym z 2011 roku odnotowano: „W sferze polityczno-militarnej głównym naszym celem jest utrzymanie i rozwijanie zdolności Sojuszu Północnoatlantyckiego do skutecznego działania. Postrzegamy NATO jako gwarancję integralności terytorialnej wszystkich państw członkowskich i ich zabezpieczenie przed atakiem”. W kolejnym programie z 2014 roku pisano: „Za fundament naszego bezpieczeństwa międzynarodowego uznajemy przynależność do Paktu Północnoatlantyckiego i naszą aktywność w jego ramach. Dla Polski szczególnie jest istotne, aby nasze - zakładamy, iż nie ostateczne - obecne położenie jako państwa brzegowego NATO, bezpośrednio konfrontowanego ze wzrostem potencjału militarnego innych aktorów tuż u swoich granic, stanowiło przesłankę do zwiększenia poziomu gwarancji bezpieczeństwa NATO dla Polski" ${ }^{14}$. Należy zauważyć, porównując świadectwa myśli politycznej PiS powstałe w dwóch różnych okresach: 2005-2007 i 2011-2014, że na stosunek Polski do roli Sojuszu Północnoatlantyckiego nie miały wpływu ani pogłębianie się obecności Polski w Unii Europejskiej, ani inicjatywy strategiczno-wojskowe tej organizacji, podobnie jak to, czy PiS sprawowało władzę, czy też było w opozycji. PiS jako główny czynnik bezpieczeństwa Polski konsekwentnie uznawało Sojusz, nie zaś Unię.

Programy z lat 2011-2014 miały jednak odmienny wydźwięk polityczny od oficjalnych dokumentów z okresu poprzedniego (2005-2007), ale także następnego (2015-2019). W programie z 2007 roku rządzące wówczas PiS chwaliło osiągnięcia własnych rządów w polityce transatlantyckiej. Pisano: „Jesteśmy aktywnym i odpowiedzialnym członkiem NATO. Zwiększamy wpływy Polski w tej organizacji [... $]^{15}$. Natomiast programy z 2011 i 2014 roku powstawały w związku z odrzuceniem polityki zagranicznej koalicji PO-PSL. W PiS uważano, że ta właśnie polityka osłabiała powiązania transatlantyckie Polski. Dlatego też stronnictwo zapowiadało, po wygranych wyborach, uruchomienie polityki „zwięk-

14 Program Prawa i Sprawiedliwości 2014..., s. 153; Polska nowoczesna, Polska solidarna, Polska bezpieczna..., s. 216.

15 Dbamyo Polskę. Dbamy o Polaków..., s. 49. 
szenia gwarancji bezpieczeństwa NATO dla Polski". Konkretnie pisano o konieczności podjęcia przez Sojusz prac nad: realnym planem ewentualnościowym dla Polski, budową krytycznej strategicznej infrastruktury obronnej w Polsce oraz tworzeniem regionalnych narzędzi współpracy militarnej, w tym wojskowej, w ramach Sojuszu i Unii. Wyznaczano więc kierunek dla przyszłego rządu tworzonego przez Zjednoczoną Prawicę ${ }^{16}$.

W zakresie zapewniania bezpieczeństwa Polski nastąpiło w myśli politycznej PiS po powrocie do władzy przesunięcie akcentów w porównaniu z opozycyjną przeszłością. W Strategii Polskiej Polityki Zagranicznej 20172021 przyjętej przez rząd Zjednoczonej Prawicy wskazano trzy obszary koniecznych działań: sojuszniczy, regionalny i krajowy. W porównaniu z poprzednim opozycyjnym okresem może zaskakiwać umieszczenie w jednym kompleksie Paktu Północnoatlantyckiego i bliskich stosunków ze Stanami Zjednoczonymi i z Unią Europejską. Nadal duży nacisk kładziono na "zacieśnianie współpracy z państwami naszego regionu", szeroko definiowanego (państwa wyszehradzkie, bałtyckie, nordyckie i Rumunia), oraz na „aktywną politykę wschodnią". Na trzecim miejscu ulokowano „wzmacnianie własnych zdolności obronnych"17.

W myśli politycznej PiS Sojuszowi przypisywano trzy role: pierwszą - stabilizacja systemu bezpieczeństwa w warunkach niepewności właściwej dla środowiska międzynarodowego; drugą - gwarantowanie bezpieczeństwa Polsce i regionowi Europy Środkowej przed Rosją; trzecią - wzmacnianie przemian demokratycznych zachodzących w Europie Środkowej. Wszystkie te role były zdefiniowane realistycznie i oparte na przekonaniu, że Pakt powinien być sojuszem państw powstałym przede wszystkim w celu zbiorowego zapewniania bezpieczeństwa jego członkom $^{18}$. Dla PiS członkostwo Polski w Pakcie Północnoatlantyckim miało znaczenie nie tylko typowo polityczne, ale też jednoznacznie określone

\footnotetext{
16 Program Prawa i Sprawiedliwości 2014..., s. 153-154; Polska nowoczesna, Polska solidarna, Polska bezpieczna..., s. 216-224.

17 Strategia Polskiej Polityki Zagranicznej 2017-2021..., s. 7.

18 R. Zięba, Gtówne kierunki polityki zagranicznej..., s. 31-32.
} 
w sensie bezpieczeństwa. Wskazywano dwa obszary o konkretnych zadaniach Sojuszu - bezpieczeństwo militarne i energetyczne.

Analizując Strategię bezpieczeństwa narodowego Rzeczypospolitej Polskiej, opracowaną na zakończenie misji rządu J. Kaczyńskiego, znajdujemy dwie tezy na temat Sojuszu (nr 55 i 56 ). Obie były wolne od pochwały stanu bezpieczeństwa osiągniętego przez Polskę w wyniku akcesji do Sojuszu i Unii. Wskazywano natomiast, że istnieje groźba wybuchu konfliktów o charakterze regionalnym i lokalnym, które mogą generować sytuację kryzysową wymagającą zastosowania artykułu 5 traktatu waszyngtońskiego o kolektywnej obronie. $Z$ tego powodu postulowano konieczność równoczesnego przystąpienia do intensywnych przygotowań wojskowych w celu reakcji na zaistniałe zagrożenia ${ }^{19}$. Natomiast problem zapewnienia bezpieczeństwa energetycznego został potraktowany odmiennie. Nie oczekiwano uznania go za priorytetowy przez Organizację Paktu, lecz wskazywano, że mógłby stać się instrumentem poszerzania i utrwalania euroatlantyckiej solidarności w kwestiach energetycznych ${ }^{20}$.

W 2006 roku, u progu swoich rządów, jak się okazało krótkich i zarazem "pierwszych", PiS dokonało oceny następstw akcesji Polski do Sojuszu Północnoatlantyckiego. Zrobiono to w dokumencie Założenia polskiej polityki zagranicznej na dany rok. Wskazano w nim cztery skutki:1) dała wejście do systemu bezpieczeństwa „gwarantującego ochronę podstawowych wartości i zdobyczy cywilizacyjnych"; 2) zainspirowa-

19 Strategia bezpieczeństwa narodowego Rzeczypospolitej Polskiej..., s. 14-15.

20 Wydaje się, że z tego powodu projekt „energetyczne NATO”, czyli Europejski Traktat Bezpieczeństwa Energetycznego autorstwa rządu K. Marcinkiewicza z 2006 roku, byt adresowany do Unii Europejskiej, a nie do Sojuszu Północnoatlantyckiego. Jednak ówczesny minister obrony narodowej R. Sikorski proponowat premierowi Kaczyńskiemu w piśmie z 7 grudnia 2006 roku, żeby problem bezpieczeństwa energetycznego uczynić przedmiotem „dalszej aktywności NATO”, z tego powodu Polska powinna podjąć taką inicjatywę na forum Sojuszu. Vide Archiwum KPRM, Pismo minister Anny Fotygi do min. Radostawa Sikorskiego", 16 | 2007, SJK 450-4(1)/07, t. 1291/1, s. 1; Rozmowa z Lechem Kaczyńskim w „Der Spiegel”, 6 III 2006, www.pis.org.pl, dostęp 10 X 2016; Archiwum Rady Ministrów, Sekretariat Prezesa Rady Ministrów, „Pismo ministra obrony narodowej Radostawa Sikorskiego do prezesa Rady Ministrów Jarosława Kaczyńskiego", 7 XII 2006, SJK 450-3(9)/06, s. 1-2; analiza w: Polska polityka zagraniczna w 2006 r., „Rocznik Strategiczny" 2006/2007, s. 299. 
ła do działań „przekraczających regionalne opłotki i miedze”; 3) zapewniła sojusz i strategiczne partnerstwo ze Stanami Zjednoczonymi; 4) wzmocniła pozycję Polski w Unii Europejskiej ${ }^{21}$. Patrzono więc na skutki bardzo kompleksowo, łącząc trzy aspekty geopolityczne: amerykański, środkowoeuropejski i unijny, co było wielce charakterystyczne dla myśli politycznej PiS. Obecność Polski w Pakcie Północnoatlantyckim została bardzo mocno spleciona z dążeniem do utrzymywania jak najbliższych stosunków ze Stanami Zjednoczonymi. Jednocześnie członkostwu w Sojuszu przypisywano rolę środka politycznego wobec Unii Europejskiej. Według rządu utworzonego przez PiS Polska powinna wykorzystywać swoją pozycję w Sojuszu, aby „lewarować” własny status w Unii. Tę zależność tłumaczył prezydent L. Kaczyński w radiu w 2007 roku, mówiąc, że obecność w Sojuszu należy rozpatrywać w kategoriach indywidualnych, a nie obecności zbiorowej państw członkowskich Unii. Jednocześnie wyraził zastrzeżenie: „Jeżeli UE ma tu jakiś wspólny interes, który wszyscy akceptujemy, to wtedy oczywiście występujemy wspólnie i będziemy tak czynić" 22 . Był to wyraźny sygnał, że to nie instytucje unijne będą reprezentowały interesy Polski w strukturach północnoatlantyckich.

Stosunek stronnictwa do Sojuszu można prześledzić, analizując wystąpienia ministrów rządów PiS w latach 2005-2007, czyli Stefana Mellera, Witolda Waszczykowskiego, Radosława Sikorskiego i Anny Fotygi. O ile na początku 2006 roku minister spraw zagranicznych S. Meller w wystąpieniu sejmowym kładł nacisk na trzecią rolę, czyli promowanie demokratyzacji i modernizacji w skali globalnej, o tyle w późniejszych publicznych wypowiedziach trójki pozostałych polityków podkreślano pierwszeństwo ról pierwszej i drugiej. Według nich Sojusz powinien być "tradycyjnym NATO”, ,skutecznym instrumentem zbiorowej obrony", w pełni zdolnym do „zwalczania nowych zagrożeń”, a więc powinien realizować pierwotną funkcję kolektywnej obrony państw członkow-

\footnotetext{
21 Archiwum KPRM, „Założenia polskiej polityki zagranicznej w 2006 r.”, luty 2006, SKM 450-1/06, t. 1292/1, s. 7-8.

22 Wywiad L. Kaczyńskiego dla polskiego radia, 9 VI 2007, http://www.polskieradio.pl, dostęp 10 V 2019.
} 
skich $^{23}$. Można przyjąć, że w tej kwestii minister Meller nie był reprezentatywny, co sam przyznał w swoich wspomnieniach ${ }^{24}$. O eksponowaniu tych dwóch zasadniczych ról przesądziła Strategia bezpieczeństwa narodowego Rzeczypospolitej Polskiej z 2007 roku. Zawarto w niej dwie tzw. tezy o roli Sojuszu w koncepcji polityki transatlantyckiej PiS. Pisano w tym dokumencie: „Priorytetem pozostaje zwiększanie zdolności NATO do pełnienia jego podstawowych funkcji - zbiorowej obrony oraz tworzenia płaszczyzny konsultacji międzysojuszniczych w razie zagrożenia". W innej tezie zaś stwierdzano: „Polska buduje swoją politykę obronną w powiązaniu z zasadą solidarności i lojalności sojuszniczej. Gotowość przyjścia z pomocą każdemu członkowi Sojuszu Północnoatlantyckiego wzmacnia potencjał odstraszania, zapewniający bezpieczeństwo państw członkowskich i NATO jako całości"25.

W latach "pierwszych" rządów PiS (2005-2007) i w pierwszych latach prezydentury Kaczyńskiego (2005-2009) jedna kwestia praktyczna najpełniej ilustrowała stosunek stronnictwa do roli Sojuszu - zainstalowanie w Polsce elementów systemu obrony antyrakietowej, którego gorącym zwolennikiem było stronnictwo, natomiast najważniejszy rywal - PO, miał co najmniej zasadnicze wątpliwości. PiS wskazywało dwa powody uzasadniające zgodę na zainstalowanie w Polsce elementów tarczy antyrakietowej: 1) zwiększenie bezpieczeństwa i poziomu obronności Polski oraz innych członków Sojuszu; 2) zacieśnienie strategicznego partnerstwa ze Stanami Zjednoczonymi poprzez osiągnięcie przez Pol-

23 S. Meller, Informacja ministra spraw zagranicznych o zadaniach polskiej polityki zagranicznej w 2006 r., [w:] SS Sejm, 5 kadencja, 10 pos., 15 II 2006, s. 11-12, http://orka2. sejm.gov.pl, dostęp 4 V 2019; W. Waszczykowski, Refleksje na temat polskiej polityki bezpieczeństwa, [w:] Rzeczpospolita na arenie międzynarodowej..., s. 380; Rozmowa z Radosławem Sikorskim w "Sygnatach dnia", 29 XI 2006, http://www.pis.org.pl, dostęp 7 V 2019; A. Fotyga, Informacja ministra spraw zagranicznych o zadaniach polskiej polityki zagranicznej w 2007 r., [w:] SS Sejm, 5 kadencja, 41 pos., 11 V 2007, s. 363, http://orka2. sejm.gov.pl, dostęp 4 V 2019.

24 Świat według Mellera. Życie i polityka - ku przysztości, t. 2, Rosner \& Wspólnicy, Warszawa 2008, s. 252. Vide A. Orzelska-Stączek, Uwarunkowania polskiej politykizagranicznej wokresie urzędowania ministra Stefana Mellera (31 X 2005-9 V 2006), „,Myśl Ekonomiczna i Polityczna" 2016, nr 2(53), s. 194.

25 Strategia bezpieczeństwa narodowego Rzeczypospolitej Polskiej..., s. 11, 14. 
skę mocniejszej pozycji w relacjach dwustronnych ${ }^{26}$. PiS uznało konieczność budowy strategicznego partnerstwa ze Stanami Zjednoczonymi za cel bezdyskusyjny w istniejącym systemie bezpieczeństwa. Uważano, że między Warszawą a Waszyngtonem istnieje spójność celów strategicznych pozwalająca na długotrwałe współdziałanie. Mniemano, że Polska jako partner zdecydowanie słabszy posiada unikatowe atuty - położenie geopolityczne, filoamerykańskie społeczeństwo, Polonię w Stanach Zjednoczonych. Decydował jednak pierwszy z wymienionych atutów, pozwalał bowiem Stanom Zjednoczonym blokować rosyjski ekspansjonizm oraz groźbę przejęcia obszaru osiowego, jakim była Europa Środkowa. Zająwszy Europę Środkową, Rosja stałaby się realnym sukcesorem imperium carskiego i komunistycznego ${ }^{27}$. Natomiast stosunek PO do strategicznego partnerstwa Polski ze Stanami Zjednoczonymi najpełniej wyraziła wypowiedź Sikorskiego z 2014 roku (już wtedy prominentnego polityka PO o radykalnie antypisowskim nastawieniu), w której podważał sens kooperacji polsko-amerykańskiej w dziedzinie bezpieczeństwa, uznając ją za przejaw "murzyńskości” i „frajerstwa”, stwarzający Polsce "fałszywe poczucie bezpieczeństwa", a wyrastający z "geopolitycznej sympatii" właściwej dla polskiej prawicy, kompletnie nieodwzajemnianej przez Amerykanów ${ }^{28}$.

Negocjacje w sprawie tarczy rząd PO-PSL traktował jako formę przetargu mającą na celu osiągnięcie zysków na innych polach - przede wszystkim modernizacji polskiej armii. Dla PiS była to perspektywa ocenna nie do przyjęcia, oznaczająca prowadzenie nieodpowiedzialnej

26 Dbamyo Polskę. Dbamyo Polaków..., s. 49. Jednak kwestia zainstalowania w Polsce tzw. tarczy antyrakietowej była postrzegana bardziej w kategoriach relacji polsko-amerykańskich niż rozwiązań wewnątrz Sojuszu. Ewentualne następstwa zainstalowania systemu antyrakietowego w Polsce videS. Koziej, Amerykański system obrony przeciwrakietowej, „Rocznik Strategiczny” 2007/2008, s. 28-32; M. Wągrowska, Wraz z tarcząnowe dylematy w polityce bezpieczeństwa, „Rocznik Strategiczny” 2007/2008, s. 35-45. Najważniejsze w tej kwestii były szanse dla Polski, bo one w znacznym stopniu odzwierciedlały kalkulację polityczną polityków PiS.

27 Pojęcie „strategiczne partnerstwo" zdefiniowata Lucyna Czechowska w: L. Czechowska, Wewnątrzunijni partnerzystrategiczni Rzeczypospolitej Polskiej, Wydawnictwo Mado, Toruń 2013, s. 44, 58.

28 A. Orzelska-Stączek, Ministrowie spraw zagranicznych..., s. 95-96. 
gry ze Stanami Zjednoczonymi, a faktycznie frymarczenie polską racją stanu. Strategiczne nastawienie do Waszyngtonu (typu „handlowego") doprowadziło rząd D. Tuska do odrzucenia propozycji udziału w operacji Zachodu w Libii w 2011 roku wespół ze Stanami Zjednoczonymi i Zjednoczonym Królestwem. W tej sprawie Polska rządzona przez koalicję PO-PSL zajęła antyamerykańskie stanowisko, zgodne z postawą Berlina. W opinii PiS był to dowód, że PO rozluźnia więzi łączące Warszawę z Waszyngtonem, dostosowując się do polityki niemieckiej oraz licząc się ze zdaniem Rosji.

Prezydent L. Kaczyński i rząd J. Kaczyńskiego mocno zaangażowali się w negocjacje w sprawie tarczy antyrakietowej. Ten kierunek prac wskazał minister Meller w 2006 roku w swoim sejmowym wystąpieniu, kilka miesięcy później podtrzymała go minister Fotyga, a w następnym roku prezydent Kaczyński ogłosił nawet, że zapadła już w tej kwestii „decyzja kierunkowa"29 a jej materializacją miała być polsko-amerykańska umowa z 20 sierpnia 2008 roku. Umowę tę L. Kaczyński nazwał jednym "z głównych i strategicznych" celów sprawowania przez niego urzędu ${ }^{30}$. Trafnie zauważyła politolog Joanna Sanecka-Tyczyńska, że przy tak dużej determinacji w sprawie tarczy antyrakietowej politycy PiS dawali prymat celom politycznym, a nie wojskowym. Przyznał to niemal wprost minister obrony narodowej Aleksander Szczygło: „Tarcza antyrakietowa gwarantuje nam większe bezpieczeństwo w wymiarze militarnym, a przede wszystkim politycznym" ${ }^{\prime 31}$. Chodziło o zablokowanie dążeń rosyjskich do wasalizacji Europy Środkowej i Wschodniej, a nie o możliwość odparcia konkretnego zagrożenia militarnego. Oczekiwane następstwa

29 Vide Dbamyo Polskę. Dbamyo Polaków..., s. 50; Witold Waszczykowski w” „Poranku Radia TOKFM", 6 VI 2007, http://www.pis.org.pl, dostęp 10 IV 2015; Konferencja L. Kaczyńskiego po powrocie ze Stanów Zjednoczonych, 17 VII 2007, s. 1, http://serwis.pap.pl, dostęp $27 \mathrm{XI} 2009$.

30 S. Meller, Informacja ministra spraw zagranicznych o zadaniach polskiej polityki zagranicznej w 2006 r...., s. 12; A. Fotyga, Polska-USA. Sympatia i mtodość, „Gazeta Wyborcza”, 16 VI 2006, nr 139, s. 9; Archiwum Prezydenta RP, https://www.prezydent.pl, „Wystąpienie Prezydenta na briefingu prasowym po spotkaniu z Sekretarzem Stanu USA", 20 VIII 2008, dostęp $10 \times 2019$.

31 A. Szczygło, Wozi mnie kobieta, „Wprost”, 9-16 VIII 2009, nr 32/33, s. 34. 
przedkładano ponad potencjalne zagrożenia w postaci możliwych ataków terrorystycznych na Polskę, a przede wszystkim ponad groźbę wygenerowania kryzysu w relacjach wewnątrz Sojuszu i Unii oraz znacznego pogorszenia się relacji polsko-rosyjskich (te dwa ostatnie następstwa błyskawicznie się pojawiły) ${ }^{32}$.

Kiedy jednak kwestia zainstalowania tarczy stała się nieaktualna z powodu decyzji administracji Baracka Obamy, L. Kaczyński wyjaśnił stanowisko swoje oraz rządu PiS z okresu 2005-2007 w czasie wizyty w Stanach Zjednoczonych we wrześniu 2009 roku. Mówił, że bynajmniej nie chodziło o zagrożenie ze strony Iranu lub Korei Północnej, ale o to, że „Polska chce obecności Stanów Zjednoczonych na swoim terytorium”, gdyż obawia się „osłabienia swojej pozycji wobec polityki rosyjskiej, która polega już nie na politycznej dominacji, jak to było dawniej, lecz na zdobywaniu olbrzymich wpływów wewnętrznych". Tarcza antyrakietowa miała być "realnym gwarantem strategicznego partnerstwa polsko-amerykańskiego" oraz miała "podnieść je na wyższy poziom”, a stała się „funkcją relacji amerykańsko-rosyjskich" ${ }^{33}$. Niezależnie od tego, że przyczyną niewejścia w życie umowy polsko-amerykańskiej z 20 sierpnia było negatywne stanowisko nowej demokratycznej administracji w Białym Domu, politycy PiS obwiniali rząd PO-PSL za brak determinacji i wadliwą strategię w procesie decyzyjnym w tej sprawie, a także zarzucali mu minimalizm, bierność oraz niezdolność do stwarzania

32 J. Sanecka-Tyczyńska, Model bezpieczeństwa zewnętrznego państwa..., s. 221-222. Vide K. Wodzińska, Polskie dylematy strategiczne. Debata na temat uczestnictwa Polski wamerykańskim systemie obrony rakietowej, [w:] NATO na początku XXI wieku, red. S. Zakrzewski, Wydawnictwo Wyższej Szkoły Nauk Humanistycznych i Dziennikarstwa, Poznań 2008, s. 139-140.

33 Archiwum Prezydenta RP, https://www.prezydent.pl,,,Wystąpienie Prezydenta w nowojorskim Metropolitan Club”, 25 IX 2009, dostęp 10 X 2019; „Decyzję Waszyngtonu przyjątem z niepokojem" [Wywiad prezydenta L. Kaczyńskiego dla czasopisma „Fakt"], 18 IX 2009, http://www.pap.pl, dostęp 10 X 2019; Wypowiedź Prezydenta dla PAP, 23 IX 2009, http://www.pap.pl, dostęp 10 X 2019. Szerzej na temat tarczy antyrakietowej vide P. Witkowski, Plany umieszczenia "tarczy antyrakietowej" na terenie RP a bezpieczeństwo Polski - wptyw, znaczenie, analiza krytyczna, [w:] NATO w dobie transformacji. Sity zbrojne $w$ transatlantyckim systemie bezpieczeństwa początku XXI wieku, red. K. Kubiak, P. Mickiewicz, Wydawnictwo Adam Marszałek, Toruń 2008, s. 158 i n. 
faktów dokonanych, co ułatwiło prezydentowi Obamie wycofanie się z umowy. Pojawił się także zarzut najmocniejszy - rząd PO-PSL brał pod uwagę stanowisko Rosji w kontekście planów antyrakietowych, dlatego zdecydował się na reset w stosunkach z Moskwą. Lech Kaczyński ujął to lapidarnie - „Tusk bał się Rosji" ${ }^{34}$.

Podsumowując, dla PiS sprawującego rządy w Polsce w latach 20052007 Organizacja Paktu miała być przede wszystkim sojuszem polityczno-wojskowym, ukierunkowanym na obronę państw członkowskich przed agresją. Sojusz powinien działać na zasadach solidarności, lojalności i równości. Zgodnie z tą logiką A. Fotyga charakteryzowała politykę rządu J. Kaczyńskiego, w którym zasiadała jako minister spraw zagranicznych: „Konsekwentnie zabiegamy, by Sojusz Północnoatlantycki pozostał skutecznym instrumentem zbiorowej obrony, a zarazem był w pełni zdolny do zwalczania nowych zagrożeń. Zależy nam na utrzymaniu amerykańskiego zaangażowania w Europie, jako siły gwarantującej bezpieczeństwo i stabilizującej relacje polityczno-militarne na kontynencie"35. Kilka lat później, po powrocie PiS do władzy, ministrowie w dwóch kolejnych gabinetach Zjednoczonej Prawicy-Jacek Czaputowicz, spadkobierca Fotygi na urzędzie ministra spraw zagranicznych, oraz Antoni Macierewicz jako minister obrony narodowej, tenże imperatyw polityczny ujęli niemal identycznie. Pierwszy z wymienionych mówił: „[...] wojskowa obecność Stanów Zjednoczonych w Europie i ich silna pozycja w NATO mają fundamentalne znaczenie dla bezpieczeństwa militarnego Polski i całego regionu. W interesie Polski i Europy Środkowo-Wschodniej jest trwałe zaangażowanie Stanów Zjednoczonych i Sojuszu Północnoatlantyckiego w tej części świata. Polska jest jak najżywotniej zainteresowana utrzymaniem silnych więzi transatlantyckich". Natomiast Macierewicz mocno podkreślał: „NATO jest formacją, sojuszem, strukturą obronną,

\footnotetext{
34 Ł. Warzecha, Lech Kaczyński. Ostatni wywiad..., s. 259.

35 A. Fotyga, Informacja ministra spraw zagranicznych o zadaniach polskiej polityki zagranicznej w 2007 r...., s. 363.
} 
defensywną - taką, która jedynie odpowiada na zagrożenia, aby bronić swoich członków"36.

W ten sposób politycy PiS opowiadali się za stylem myślenia o Pakcie Północnoatlantyckim w kategoriach polityczno-wojskowych w odniesieniu do obszaru amerykańsko-europejskiego, a nie polityczno-policyjnych w ujęciu globalnym. Tym samym PiS odrzucało projekty przekształcenia Sojuszu: 1) w porozumienie polityczne bez komponentu wojskowego czy też 2) w "policjanta globalnego" dbającego o porządek w regionach nieistotnych dla państw członkowskich albo 3) w „stróża ładu globalnego” lub 4) w instrument typu soft power i comprehensive approach, czyli wspólnotę cywilizacyjną i organizatora misji ekspedycyjnych (out-of-area). Takie działania postrzegano jako rozpraszanie sił oraz ignorowanie realnych zagrożeń, których nosicielem była Rosja. Z tego powodu te alternatywne scenariusze oceniano negatywnie ze względu na skutki dla Rzeczypospolitej, którym należało przeciwdziałać. W 2009 roku wzywano, żeby rząd wzmocnił aktywność w dyskusjach o kierunkach zmian i reform Paktu, a nawet dalej sugerowano sformułowanie polskiego planu w tej materii. Dwa lata później rozczarowane stronnictwo w następnym programie przypominało, że polityka koalicji PO-PSL doprowadziła do osłabienia transatlantyckiego wymiaru polityki zagranicznej Polski ${ }^{37}$.

Cechą myśli politycznej PiS było nie tylko odrzucanie scenariuszy uznawanych za negatywne, ale również wskazywanie na pożądaną rolę Paktu. Prezydent Kaczyński oceniał więc: „Misje ekspedycyjne, zadania polityczne są istotne, ale obrona przed agresją ma podstawowe i historycznie obecne znaczenie". Jednak we wcześniejszych wystąpieniach zastrzegał, że są dwa najważniejsze wymiary bezpieczeństwa „konstytuujące" istnienie Sojuszu: tradycyjny - międzypaństwowy, i terrorystyczny - transnarodowy; ten ostatni nie odnosi się już do hemisfery północno-

36 J. Czaputowicz, Informacja ministra spraw zagranicznych o zadaniach polskiej polityki zagranicznej w 2018 roku..., s. 82; A. Macierewicz, Konferencja prasowa przed szczytem NATO, 8 VII 2016, http://wiadomoscidziennik.pl, dostęp 28 XII 2019.

37 Program Prawa i Sprawiedliwości 2009..., s. 174; Polska nowoczesna, Polska solidarna, Polska bezpieczna..., s. 216. 
atlantyckiej, ale do globalnej ${ }^{38}$. W podobnym duchu wypowiedziała się partia już po śmierci prezydenta, bo w 2011 roku: „Postrzegamy NATO jako gwarancję integralności terytorialnej wszystkich państw członkowskich i ich zabezpieczenie przed atakiem"39. Te główne komponenty, według PiS, miały się składać na strategiczną rolę Organizacji Paktu Północnoatlantyckiego.

Niemniej PiS chciało podtrzymania udziału Wojska Polskiego w misjach wojskowych Sojuszu realizowanych na świecie: pokojowych, stabilizacyjnych, bojowych (Afganistan, Irak, Kuwejt, Kosowo, Bośnia i Hercegowina, Mołdawia, Gruzja, Ukraina). Decydowały względy zarówno uniwersalne, jak i partykularne - polskie. Prezydent Kaczyński uznał te misje za niezbędne dla „umacniania i poszerzania obszaru wolności i pokoju" ${ }^{\prime 40}$. W programie PiS z 2007 roku, wówczas partii rządzącej, przystępującej do wyborów parlamentarnych, wyjaśniano powody takiej aktywności Polski na arenie międzynarodowej, przywołując następujące argumenty: wzmacnianie międzynarodowej pozycji i znaczenia Rzeczypospolitej oraz jej bezpieczeństwa; wspieranie polityki zagranicznej Polski; zgodność z polską racją stanu; szerzenie wolności i utrzymywanie pokoju. A w konkluzji pisano: „Polska jest jednym z najważniejszych państw wspierających militarne działania stabilizacyjne na świecie" ${ }^{\prime 4}$. Innej argumentacji 10 lat później użył minister spraw zagranicznych Waszczykowski, wyjaśniając w Sejmie: „W XXI wieku bezpieczeństwo coraz bardziej staje się dobrem wspólnym całej ludzkości. Skutki kryzysów wybuchających nawet w najbardziej oddalonych regionach szybko dają znać o sobie w Europie, u granic Rzeczypospolitej. Dlatego Polska angażuje się w inicjatywy na rzecz bezpieczeństwa nie tylko naszego

38 Archiwum Prezydenta RP, https://www.prezydent.pl, dostęp 10 X 2019: „Odprawa rozliczeniowo-koordynacyjna kierowniczej kadry MON i SZ RP”, 8 III 2010; „Wystąpienie Prezydenta na konferencji Foreign Policy Association”, 24 IX 2008; „Wykład Prezydenta w The Chicago Council on Global Affairs", 25 IX 2007.

39 Polska nowoczesna, Polska solidarna, Polska bezpieczna..., s. 218.

40 Archiwum Prezydenta RP, https://www.prezydent.pl „,Decyzję Waszyngtonu przyjątem z niepokojem" [Wywiad prezydenta Kaczyńskiego dla gazety „Fakt"], 18 IX 2009, dostęp 10 X 2019.

41 Dbamyo Polskę. Dbamyo Polaków..., s. 49. 
kraju czy regionu, ale także Europy i świata"42. Te wszystkie wypowiedzi i zapisy potwierdzają, że dla polityków PiS użycie Wojska Polskiego w misjach wojskowych było ważnym czynnikiem w prowadzeniu polityki zagranicznej i nie zamierzano z tego instrumentu rezygnować, niezależnie od politycznej koniunktury. Nie oczekiwano jednak spektakularnych sukcesów, a na pewno nie dostrzegano w tych działaniach realizacji misji Paktu Północnoatlantyckiego.

Natomiast dostrzegano w PiS ścisły związek między międzynarodową wojskową aktywnością Polski w Sojuszu a potencjalnymi decyzjami tej organizacji na rzecz bezpieczeństwa Rzeczypospolitej. Dzięki takiemu zaangażowaniu polskich żołnierzy na świecie można powiedzieć opinii międzynarodowej (głównie amerykańskiej): „nie bierzemy nic za darmo, płacimy krwią i wysiłkiem naszych żołnierzy za waszą służbę tutaj [w Polsce - W.P.]"43. W 2018 roku Polska skierowała własny kontyngent wojskowy także w rejon Morza Śródziemnego w celu zażegnania konfliktu migracyjnego (misja UE „Sophia”). Traktowano taką postawę jako wyraz solidarności z sojusznikami z Unii, ale także z Paktu. Mówił o tym minister obrony narodowej Mariusz Błaszczak (12 lutego 2018) ${ }^{44}$.

Jednak „ekspedycyjnej” roli Sojuszu nie uważano za priorytetową, ale traktowano ją jako uzupełniającą i wynikającą z sytuacji globalnej. Dlatego w programie z 2007 roku Dbamy o Polskę. Dbamy o Polaków konsekwentnie pisano, że te misje wzmacniają międzynarodową pozycję i bezpieczeństwo Polski, a minister Fotyga uzasadniała je w 2007 roku, mówiąc w Sejmie, iż należy eliminować zagrożenia bezpieczeństwa na wczesnym etapie w różnych regionach świata ${ }^{45}$. Prezydent Kaczyński podniósł inny argument - udział Polski w takich misjach wynika ze

42 Informacja Ministra Spraw Zagranicznych o zadaniach polskiej polityki w 2017 roku...

43 Wypowiedź A. Macierewicza do żotnierzy polskich wracających z Afganistanu, 24 VI 2017, http://www.pap.pl, dostęp 5 XII 2019. W 2019 roku minister Błaszczak przypomniat, że w misjach Sojuszu poległo 73 polskich żotnierzy, których uznał za bohaterów. Wystapienie M. Btaszczaka w bazie lotnictwa...

44 Pożegnanie Polskiego Kontyngentu Wojskowego, 12 II 2018, http://www.pap.pl, dostęp 28 XII 2019.

45 Dbamy o Polskę. Dbamy o Polaków..., s. 49; A. Fotyga, Informacja ministra spraw zagranicznych o zadaniach polskiej polityki zagranicznej w 2007 r...., s. 363. 
zobowiązań wobec sojuszników należących do Paktu. Jego następca na tym urzędzie (A. Duda) ujął to odmiennie, że jest to stosowanie i realizacja „zasady 360 stopni, tzn. współodpowiedzialności za zapewnienie bezpieczeństwa w różnych częściach świata”, gdzie „my realizujemy misję niesienia pokoju i budowania świata stabilności”, a „każdy kierunek jest jednakowo ważny" ${ }^{\prime 6}$. W dokumentach programowych powstałych w latach 2005-2010 formułowano także zastrzeżenia. Pierwsze - Polska: „Popiera selektywne zaangażowanie w misje stabilizacyjne na obszarze pozaeuropejskim, jednak pod warunkiem zachowania przez Sojusz wiarygodnego potencjału i pełnej zdolności do zbiorowej obrony państw członkowskich [...]”. Drugie - „Polska powinna uczestniczyć w misjach ekspedycyjnych, o ile stanowi to realną inwestycję w lojalność sojuszniczą, w sposób maksymalnie zwiększający wpływ polityczny i nieumniejszający potencjału do obrony kraju" ${ }^{47}$. Wyraźnie widać było w PiS obawy, że misje północnoatlantyckie mogą prowadzić do rozpraszania potencjału Sojuszu oraz mogą być kompletnie nieefektywne - żadnych zysków politycznych w skali globalnej, a utrata zdolności reagowania na kierunkach o strategicznym znaczeniu. Istniała też świadomość, że Polska musi balansować między realnymi możliwościami własnych Sił Zbrojnych a oczekiwaniami ze strony amerykańskiej i postulatami aksjologicznymi (walka z dyktaturami, ochrona ludności cywilnej). Nie chciano rezygnować z obrony wartości w stosunkach międzynarodowych, mimo skromności polskiego potencjału militarnego, np. morskiego.

Dlatego też w przywołanych wypowiedziach najważniejsze są trzy zastrzeżenia, że to polskie zaangażowanie 1) ma być selektywne, 2) ma stanowić instrument podnoszenia potencjału Polski oraz 3) nie może uszczuplać zasobów Sojuszu na głównych obszarach jego zaangażowania.

46 Wywiad prezydenta Kaczyńskiego, 12 III 2009, http://www.bankier.pl, dostęp 22 XII 2019; Noworoczne spotkanie Pary Prezydenckiej z korpusem dyplomatycznym, 15 I 2020, http:// www.prezydent.pl, dostęp 3 V 2020. Vide Archiwum Prezydenta RP, https://www.prezydent.pl, dostęp 12 VI 2020: „Wypowiedź Prezydenta dla mediów w bazie Bagram”, 26 III 2018; „Wypowiedź Prezydenta dla mediów, w ostatnim dniu wizyty w Davos”, 24 I 2019.

47 Dbamyo Polskę. Dbamy o Polaków..., s. 11; Nowoczesna Polska 2020..., s. 117. 
Powinna zostać także wypracowana zasada równowagi między oboma rodzajami zadań. W kolejnym programie z 2011 roku złagodzono podejście do tej kwestii, pisząc, że istnieje potrzeba znalezienia w strategii Organizacji odpowiedniej równowagi między podtrzymywaniem gotowości do obrony państw członkowskich a działaniami operacyjnymi (stabilizacyjnymi). Jednak nadal kategorycznie twierdzono, że podstawową funkcją jest obrona kolektywna. Postulowano, aby Polska traktowała sprawę przetargowo - poparcie dla działań ekspedycyjnych Sojuszu w zamian za utrzymywanie skutecznych mechanizmów obrony kolektywnej ${ }^{48}$.

Nowa polityka transatlantycka formułowana przez PiS miała być odpowiedzią na wyzwania z zakresu bezpieczeństwa państwa oraz politykę zagraniczną rządów PO-PSL ${ }^{49}$. W tej materii poglądy stronnictwa wyraźnie ewoluowały w okresie 2007-2019. Zasadniczo w PiS dominował pogląd, że w pierwszej dekadzie XXI stulecia bezpieczeństwo Polski zaczęło się systematycznie pogarszać, wraz z końcem „strategicznej pauzy w światowej rywalizacji" ${ }^{50}$. Jednak w strategii bezpieczeństwa państwa z 2007 roku, opracowanej przez rząd J. Kaczyńskiego, nie dawano pierwszeństwa czynnikom militarnym, ponieważ: „W pierwszej dekadzie nowego stulecia Rzeczpospolita Polska jest krajem bezpiecznym" ${ }^{\text {"51. }}$ Z tego powodu w przedmiotowej strategii, mimo zastosowania zintegrowanego podejścia do bezpieczeństwa, eksponowano nade wszystko zagrożenia pozamilitarne. Katalog ich był bardzo szeroki, między innymi: osłabienie więzów transatlantyckich, załamanie się integracji europejskiej, umocnienie się porządków autorytarnych w Europie, konflikty lokalne i regionalne, terroryzm międzynarodowy, zagrożenia ekologiczne, kryzysy gospodarcze, zorganizowana przestępczość międzynarodowa. W kontekście geograficznym wskazywano na takie regiony, jak Bliski

48 Polska nowoczesna, Polska solidarna, Polska bezpieczna..., s. 226.

49 Analiza w: J. Sanecka-Tyczyńska, Racja stanu we wspótczesnej polskiej myśli politycznej..., s. 383 i n.; eadem, Państwo obywatelskie i wspólnota polityczna. Studium o myśli politycznej Prawa i Sprawiedliwości, Wydawnictwo UMCS, Lublin 2011, s. 244-246.

50 W. Waszczykowski, Refleksje na temat polskiej polityki bezpieczeństwa, http://www.omp. org.pl, dostęp 5 VI 2019.

51 Vide opinia w tej sprawie: J. Sanecka-Tyczyńska, Model bezpieczeństwa zewnętrznego państwa..., s. 218. 
i Środkowy Wschód oraz Afryka. Co było wielce charakterystyczne, nie została wymieniona Europa Wschodnia, nie widziano bowiem zagrożenia dla bezpieczeństwa w tej części kontynentu oraz wpływu tego zjawiska na Europę Środkową. Należy przypomnieć, że strategię napisano na kilka miesięcy przed agresją Rosji na Gruzję ${ }^{52}$. Nie spodziewano się, że tak szybko trzeba będzie weryfikować upowszechnione diagnozy.

Badacz tej tematyki Marcin Lasoń ocenił, że także w tej strategii odchodzono od "prymatu ujęcia militarnego", nadal kierowano się diagnozą postawioną w poprzednim wieku „o minimalnym prawdopodobieństwie konfliktu zbrojnego w Europie, który objąłby Polskę"53. W tym aspekcie dokument przygotowany przez rząd J. Kaczyńskiego nie różnił się od analogicznych powstałych z inicjatywy poprzednich gabinetów. Pisano co prawda o Rosji jako zagrożeniu dla Polski, ale lokowano je w sferze energetycznej i surowcowej, a nie militarnej. W następnych latach PiS wskazywało już na wzrost rywalizacji między mocarstwami. Konieczną odpowiedzią ze strony Polski powinna być wzmożona aktywność na arenie międzynarodowej. Według W. Waszczykowskiego: „Nie zabezpieczymy swoich interesów biernie wtapiając się w główny nurt europejski" ${ }^{54}$. To faktycznie było negowanie kursu w polityce zagranicznej rządu D. Tuska.

Dopiero po 2008 roku w Urzędzie Prezydenckim L. Kaczyńskiego uznano jednoznacznie, że Polsce grozi realne niebezpieczeństwo, wynikające przede wszystkim z polityki Rosji. Traktowano to niebezpieczeństwo nie w ujęciu strategicznym i długofalowym, ale w horyzoncie realnym i bieżącym. Była to dość ważna zmiana w zestawieniu z napisaną rok wcześniej przez rząd PiS strategią bezpieczeństwa pań-

52 Strategia bezpieczeństwa narodowego Rzeczypospolitej Polskiej..., s. 9.

53 M. Lasoń, Zagrożenia dla bezpieczeństwa Polski wXXI wieku wświetle analizy porównawczej kolejnych Strategii Bezpieczeństwa Narodowego, „Bezpieczeństwo. Teoria i Praktyka”, Czasopismo Krakowskiej Szkoły Wyższej im. Andrzeja Frycza Modrzewskiego, 2016, nr 10/3, s. 130. Szerzej vide W. Paruch, Dwie koncepcje bezpieczeństwa Polski - neorealistyczne refleksje o narodowych strategiach bezpieczeństwa państwa (2007 i 2014), [w:] Bezpieczeństwo Europy- bezpieczeństwo Polski, red. E. Maj i inni, Wydawnictwo UMCS, Lublin 2016, s. 335-362.

54 W. Waszczykowski, Refleksje na temat polskiej polityki... 
stwa. W 2009 roku Mariusz Handzlik, podsekretarz stanu w Kancelarii Prezydenta L. Kaczyńskiego, był zdania, że Rosja dąży do uzyskiwania instrumentów wpływu na decyzje Sojuszu. Jej celem było rozbijanie solidarności sojuszniczej poprzez rozgrywanie antagonizmów między najważniejszymi państwami członkowskimi, a przede wszystkim na linii Stany Zjednoczone-Europa Zachodnia ${ }^{55}$. Analityk spraw zagranicznych związany z PiS, Przemysław Żurawski vel Grajewski, wskazywał na szczegółowe zagrożenia rosyjskie typu wojennego: pełne uzależnienie Ukrainy od Rosji, prowadzące do znacznego rozszerzenia granicy polsko-rosyjskiej; bezpośrednie uderzenie na Polskę wojsk rosyjskich z północy i ze wschodu; wkroczenie wojsk rosyjskich do państw bałtyckich w celu obrony mniejszości rosyjskiej; załamanie się państwa mołdawskiego ${ }^{56}$.

Dość symptomatyczny był styl myślenia ówczesnego rządu koalicji PO-PSL, dla którego ilustratywne są dwa dokumenty: 1) notatka MSZ z 4 marca 2008 roku i 2) list D. Tuska do W. Putina z czerwca 2008 roku. W pierwszym z nich, czyli w notatce Tezy o polityce RP wobec Rosji i Ukrainy (autorstwa Jarosława Bratkiewicza, dyrektora Departamentu Polityki Wschodniej MSZ), powstałej kilka miesięcy przed notatką M. Handzlika, dokonano fundamentalnego zdezawuowania polityki wschodniej autorstwa PiS, w tym czasie realizowanej przez prezydenta Kaczyńskiego. Nazwano tę linię działania "poprawnością polityczną" i uważano, że nie miała ona żadnego oparcia w analizach i ocenach, lecz wynikała z demagogicznych sądów, by nie powiedzieć z nieznajomości stosunków międzynarodowych. Ocena tego typu była jak najbardziej fałszywa, wręcz przewrotna. Warto przywołać opinię zawartą w „Roczniku Strategicznym" z tego czasu: „W ostatnich latach stosunki Rosji i jej partne-

55 Archiwum KPRM, t. 1535/3, „Notatka informacyjna nt. działań Federacji Rosyjskiej w kwestii pozyskiwania zaawansowanych technologicznie systemów uzbrojenia w kontekście doświadczeń z operacji gruzińskiej", 23 XII 2009, PMH-085-117-09/1, s. 66. Ten dokument jest stosunkowo ważny, wydaje się pierwszym urzędowym wskazaniem na realność rosyjskiego zagrożenia. Ilustruje wnikliwość obserwacji otoczenia prezydenta Kaczyńskiego oraz absurdalność ocen ferowanych przez ówczesny ośrodek rządowy. Należy pamiętać, że rząd PO-PSL zaczynat rozwijać właśnie wtedy politykę resetu z Rosją. Byt całkowicie głuchy na argumenty Pałacu Prezydenckiego.

56 P. Żurawski vel Grajewski, Geopolityka - siła - wola..., s. 114. 
rów euroatlantyckich ulegały stopniowemu zaostrzeniu, wynikającemu z jednej strony z obiektywnie narastającego konfliktu interesów, z drugiej zaś z obustronnej wadliwej percepcji istoty ich relacji, nieuzasadnionych oczekiwań i nadziei żywionych co do kierunku rozwoju współpracy między nimi i na arenie międzynarodowej" ${ }^{57}$. Czołowy analityk koalicji POPSL zasadniczo się mylił w ocenie sytuacji, a co gorsza, jego tezy zostały przyjęte przez ówczesne władze RP jako podstawa polityki zagranicznej.

Rozprawiono się w tezach $\mathrm{z}$ tzw. aksjomatami koncepcji polityki zagranicznej PiS. Do aksjomatów zaliczono: 1) uznanie Rosji za odwiecznego wroga Polski i przypisywanie jej imperializmu, nieobliczalności i nieprzewidywalności; 2) prognozowanie o nieuchronności konfliktu polsko-rosyjskiego z inspiracji Kremla o obszar postradziecki; 3) przypisywanie stosunkom polsko-rosyjskim charakteru gry zero-jedynkowej. Sformułowano także bardzo mocne zarzuty wobec poprzedniego rządu z nominacji PiS, jego politykę rosyjską nazwano przykładem "eskapizmu", wyrazem „małostkowości”, przejawem kompleksów, dyletantyzmu i bojaźni oraz „postawą kamerdynerską”. Primo, politycy PiS wychodzili z założenia, że nie można prowadzić polityki wobec Rosji z powodu braku szans na zwycięstwo oraz w obawie przed "oszustwami i matactwami" oraz „szantażami i groźbami” Rosji. Secundo, PiS nie uwzględniało znaczenia przynależności Polski do Unii i Sojuszu, co zasadniczo zmieniło charakter stosunków polsko-rosyjskich, ponieważ „współczesna Polska nie stoi samotnie" wobec Federacji. Tertio, partia J. Kaczyńskiego absolutyzowała „określone doniosłe wnioski historyczne", których jednak „nie potwierdzają realne współczesne (konkretnohistoryczne) uwarunkowania i okoliczności"58.

Czytając tę notatkę, należy zgodzić się z rekonstrukcją aksjomatów właściwych dla koncepcji PiS polityki „rosyjskiej”, ale wnioski wysnute z tych przesłanek nie wytrzymują żadnej krytyki merytorycznej, są po

\footnotetext{
57 Rosja aspiruje do statusu supermocarstwa i zawiesza CFE, „Rocznik Strategiczny” 2007/2008, s. 100.

58 Tezy o polityce RP wobec Rosji i Ukrainy, 4 III 2008, n-22-2.dcs.redcdn.pl, dostęp $2 \mathrm{~V} 2020$.
} 
prostu fałszywe. Z dokumentów wiemy, że gabinety PiS w latach 20052007 doskonale zdiagnozowały efektywność ewentualnych rozmów polsko-rosyjskich, widząc w nich jedynie propagandową grę Moskwy, bez rozwiązywania żadnych realnych problemów o znaczeniu strategicznym. Skłonność Polski do rozmów była na Kremlu traktowana jako przejaw słabości oraz dowód dla Zachodu, że Rosja jest pokojowo nastawionym uczestnikiem stosunków międzynarodowych. PiS bardzo doceniało znaczenie obecności Polski w Unii i Sojuszu w kontekście rosyjskim, ale było dość dalekie od przeceniania tej partycypacji, zwłaszcza że realne uczestnictwo w Pakcie miało swoje znaczne ograniczenia militarne. W tym czasie bowiem w obu organizacjach zwyciężała koncepcja naiwnych ustępstw wobec Rosji, natomiast brak wówczas wojsk północnoatlantyckich w Europie Środkowej negliżował rolę Paktu w stosunkach polsko-rosyjskich.

Trudno ustosunkować się do odniesienia w notatce do potraktowania znaczenia wiedzy historycznej dla polityki, jako że pozostaje w zdecydowanej kolizji z kanonami działalności ideotwórczej. Natomiast ostateczne wnioski zawarte w tym dokumencie tworzyły przesłanki polityki resetu koalicji PO-PSL wobec Moskwy i mogą nie tylko zastanawiać poziomem ułudy, ale nawet wręcz przerażać ewentualnymi następstwami.

W notatce uznano, że: 1) współczesna Rosja "nie kieruje się mesjanistyczną ideologią"; 2) społeczeństwo rosyjskie cechuje apatia i zmaganie się z codziennością; 3) system polityczny zbliża się do autorytaryzmu, ale jest niesprawny oraz nie generuje celów strategicznych, lecz jest ukierunkowany na przetrwanie; 4) Rosja nie potrafi wykorzystywać swoich zasobów materialnych; 5) w obliczu zagrożenia chińskiego i islamskiego Rosja będzie poszukiwała partnerstwa z Zachodem, dla którego jest także istotnym sojusznikiem. Dość interesujące były dwa uogólnienia. Pierwsze - „możliwości wpływania Moskwy [...] na kraje Europy Środkowo-Wschodniej, przynależące do UE i NATO, są znikome lub zgoła żadne [podkr. w oryginale - W.P.]". Drugie - Moskwa wobec Polski przejawia "swoisty tradycyjny kompleks", w którym „hegemonistyczny protekcjonalizm paradoksalnie ociera się o poczucie swoistego respektu i nawet 
obawy"59. Dość charakterystyczne, że w notatce nie przywołano żadnych argumentów na rzecz tych tez, lecz przyjmowano je apriorycznie jako prawdziwe. Wystarczyło zaś sięgnąć do oficjalnych rosyjskich dokumentów strategicznych oraz danych wojskowych, żeby zacząć przynajmniej powątpiewać w słuszność zaprezentowanych tez.

Z notatki wyłania się nowa koncepcja polityki wobec Rosji, budowana w oparciu o syndrom anty-PiS. Stwierdzano: „ożywiony dialog z Rosją stanowi samorzutną wartość polityczną dla Polski", gdyż dowodzi, że Warszawa przezwyciężyła rusofobię oraz „umacnia Polskę w roli głównego w rodzinie zachodniej znawcy i interpretatora Rosji". Odejście od owej rusofobii miało otworzyć drogę do wpływania na wspólną politykę UE zarówno wobec Rosji, jak również całego obszaru postradzieckiego, w tym Ukrainy. Oczywiście należy mieć świadomość, że zapowiadane polskie interpretowanie Rosji miało się dokonywać w duchu założeń zaprezentowanych w tym dokumencie, czyli negowania zagrożenia rosyjskiego dla Europy. Te ferowane w 2008 roku wnioski są co najmniej zdumiewające. Ciekawe są też stwierdzenia końcowe. Nie zapowiada się przełomu w stosunkach dwustronnych, gdyż „wbrew pozorom, nie są obciążone żadnymi wielkimi spornymi sprawami". Proponuje się Polsce podjęcie dwóch rodzajów działań. Po pierwsze - rezygnację z samodzielnej polityki rosyjskiej na rzecz wkomponowania jej w politykę unijną i północnoatlantycką, żeby nie wywoływać nastawienia antypolskiego na Kremlu. Po drugie - uruchomienie dwustronnego dialogu w celu uwiarygodnienia Warszawy „w oczach zachodnich partnerów i sojuszników"60.

Drugie ze wspomnianych źródeł - list D. Tuska do W. Putina, odzwierciedla ten sam styl myślenia. Jego autor przypisuje Putinowi intencje poszukiwania korzystnych wzajemnie rozwiązań "na wszystkich płaszczyznach kontaktów" oraz "gotowość do podejmowania trudnych tematów z uwzględnieniem wrażliwości strony polskiej". Mnóstwo w tym liście optymizmu co do możliwości współpracy polsko-rosyjskiej oraz 
uregulowania licznych problemów za pomocą różnych dwustronnych form zinstytucjonalizowanych. Znajduje się w nim również zaproszenie dla rosyjskiego premiera do złożenia wizyty w Polsce. Jest natomiast zastanawiające, że zabrakło w tym dokumencie jakichkolwiek polskich oczekiwań wobec polsko-rosyjskiego dialogu oraz wyartykułowania polskich racji ${ }^{61}$. Swoistą odpowiedzią PiS był list przewodniczącego Klubu Parlamentarnego Przemysława Gosiewskiego do D. Tuska z 10 czerwca tego samego roku w sprawie katyńskiej. Na tym przykładzie pokazywano brak dobrej woli ze strony Rosji i zasadniczą rozbieżność między rzeczywistością a „zapowiadanym polepszeniem relacji polsko-rosyjskich". Najważniejszy był wniosek: „Utrzymywanie przyjaznych i bliskich relacji z Federacją Rosyjską powinno być ważnym celem polskiej polityki zagranicznej. Takie relacje możemy zbudować jednak wyłącznie na szacunku do prawdy, możliwości jej badania oraz respektowania zasad praworządności i sprawiedliwości [...]"62.

Wracając do diagnozy M. Handzlika, należy zauważyć, że miała mocne oparcie w faktach w latach 2008-2009, poprzedzone enuncjacjami formułowanymi w okresie 2006-2007 o planowanej zasadniczej korekcie rosyjskiej polityki zagranicznej, ogłoszonej chociażby w Przeglądzie polityki zagranicznej FR z 27 marca. Moskwa stanęła na gruncie jednoznacznego przeciwstawienia się zasadom ładu hegemonicznego, akcentując mocno swoje interesy oraz wyrażając gotowość ich obrony za pomocą różnych dostępnych środków - od ekonomicznych do militarnych. W 2007 roku przyjęto długofalowy plan modernizacji zbrojeń na osiem lat. W związku z tym w latach 2008-2009 Rosja znacząco zwiększyła wydatki budżetowe na cele wojskowe, zorganizowała manewry wojskowe, ćwicząc między innymi uderzenie na Polskę, oraz ogłosiła

61 Archiwum Rady Ministrów, Sekretariat Prezesa Rady Ministrów, „List Donalda Tuska do Wtadimira Putina", czerwiec 2008, s. 155-159. Odpowiedź Putina na list Tuska byta enigmatyczna i zdawkowa, poza przyjęciem zaproszenia do Polski. Archiwum Rady Ministrów, Sekretariat Prezesa Rady Ministrów, „List Wtadimira Putina do Donalda Tuska", 8 VII 2008.

62 Archiwum Rady Ministrów, Sekretariat Prezesa Rady Ministrów, „List Przemystawa Gosiewskiego do Donalda Tuska", 10 VI 2008, s. 165. 
możliwość użycia sił zbrojnych Federacji poza granicami państwa dla obrony Rosjan ${ }^{63}$. Ten okres tworzenia podstaw rosyjskiego imperializmu został zamknięty w 2010 roku. Wtedy Moskwa w swojej doktrynie obronnej uznała Sojusz Północnoatlantycki za największe niebezpieczeństwo dla Rosji ${ }^{64}$.

Refleksy takiego myślenia po stronie PiS są widoczne już w strategii bezpieczeństwa państwa z 2007 roku. Wskazywano w niej jednoznacznie na Rosję jako zagrożenie w trzech kontekstach: 1) strategicznego dążenia imperialnego; 2) polityki dzielenia członków Unii i Sojuszu; 3) stosowania szantażu energetyczno-surowcowego. Nie ograniczono się do oceny tylko rosyjskiego zagrożenia, ale za niebezpieczne uznano również procesy i zjawiska zachodzące w regionie, na kontynencie europejskim i we wspólnocie transatlantyckiej ${ }^{65}$. Diagnoza tego typu uległa wzmocnieniu wraz z oceną sytuacji zaistniałej w Europie Środkowej i Wschodniej w latach 2008-2014, kiedy Rosja zaatakowała najpierw Gruzję, a następnie Ukrainę, niejako realizując zapowiedzi Władimira Putina wypowiedziane 10 lutego 2007 roku na 43. Monachijskiej Konferencji Bezpieczeństwa. Putin zakwestionował wtedy ład hegemoniczny na świecie, zarazem rzucając wyzwanie Stanom Zjednoczonym. Dokonał także zdecydowanie negatywnej interpretacji polityki zagranicznej Stanów Zjednoczonych, między innymi w kontekście rozszerzenia Sojuszu iprojektu tarczy antyrakietowej ${ }^{66}$. Taka reakcja Rosji była następstwem jej

63 W 2007 roku R. Sikorski w wywiadzie dla "Washington Post” przestrzegat, że Rosja „Wydaje obecnie siedem razy więcej na zakupy uzbrojenia i modernizację sprzętu wojskowego niż przed pięcioma laty". R. Sikorski, Nie uważajcie zgody Polski za oczywistość, „Polski Przegląd Dyplomatyczny”, marzec-kwiecień 2007, nr 2(36), s. 58.0 zbrojeniach rosyjskich vide Rosja aspiruje do statusu supermocarstwa i zawiesza CFE..., s. 101 i n.

64 Obszar WNP. W stronę nowego tadu? Rosja: na rozdrożu, "Rocznik Strategiczny” 2009/2010, s. 209; Europa Wschodnia między nostalgią a inercja " Rocznik Strategiczny” 2009/2010, s. 87-88; Obszar WNP: broń gazowa Rosji, „Rocznik Strategiczny” 2006/2007, s. 178.

65 Dbamyo Polskę. Dbamy o Polaków..., s. 3; Strategia bezpieczeństwa narodowego Rzeczypospolitej Polskiej..., s. 6. Vide również Ł. Warzecha, Czy możliwa jest realistyczna polityka zagraniczna..., s. 104.

66 Monachium: Putin atakuje Zachód, Gates nie chce zimnej wojny, 11 II 2007, http:// www.pb.pl, dostęp 2 I 2020; Obszar WNP: dtugi cień Rosji, „Rocznik Strategiczny” 2007/2008, s. 191-192. 
dążenia do przekształcenia globalnej hegemonii Stanów Zjednoczonych w koncert mocarstw, z udziałem na pewno Rosji i Chin oraz Unii Europejskiej, ale co bardziej prawdopodobne Niemiec (przynajmniej w pierwszej fazie, dopóki Rosja nie ulegnie wystarczającemu wzmocnieniu, aby uzależnić od siebie całą Europę), co w praktyce oznaczałoby zepchnięcie Unii Europejskiej na pozycje peryferii poddanych rosyjskiej penetracji i dominacji. Jak to ujął badacz problematyki Józef M. Fiszer, Rosja pod rządami Putina postawiła sobie za cel rozbicie ładu międzynarodowego, którego centrum stanowi wspólnota transatlantycka, co w perspektywie i bliższej, i dalszej zagraża pokojowi na pewno w Europie ${ }^{67}$.

Faktycznie zaś w polityce zagranicznej prezydent Putin kieruje się w XXI wieku doktryną realistyczną, a celem samoistnym Moskwy nie jest utworzenie koncertu mocarstw, lecz maksymalizacja potęgi Rosji i zaspokajanie interesów narodowych. Na Kremlu uważa się, że koncert mocarstw może być najlepszym środkiem, aby to osiągnąć, Moskwa jest bowiem zbyt słaba, żeby sięgnąć po hegemonię lub przywrócić system biegunowy ze Stanami Zjednoczonymi. Z takiego punktu widzenia Zachód jawi się na Kremlu jako burzyciel stabilizacji i w Rosji, i na terenie "bliskiej zagranicy" w wyniku eksportu demokracji oraz realizacji swoich egoistycznych interesów. Natomiast najlepszą metodą obrony jest realizacja strategii ofensywnej, stąd agresja na Gruzję i Ukrainę.

Polityk PiS Paweł Zalewski, obecny na wspomnianej konferencji, skomentował wystąpienie na niej Putina: „[...] sprawiał wrażenie, jakby jego kraj znajdował się w okrążeniu, ponieważ do jego granic zbliżyły się demokratyczne i praworządne kraje. NATO jest traktowane ciągle jako czynnik zagrożenia dla Rosji, chociaż od lat budowane jest przecież partnerstwo między sojuszem a Rosją"68. Trudno uznać ten komentarz za wyraz zrozumienia ofensywnej strategii w polityce zagranicznej Rosji

67 J. M. Fiszer, Polityka zagraniczna Polski w XXI wieku..., s. 151; szerzej na ten temat vide idem, Zadania i cele polityki zagranicznej Wtadimira Putina, "Myśl Ekonomiczna i Polityczna" 2016, nr 1(52), s. 167-201.

68 Konferencja bezpieczeństwa w Monachium, 10 II 2007, http://www.fakty.interia.pl, dostęp 2 III 2020; Putin atakuje Stany Zjednoczone, 10 II 2007, http://www.wprost.pl, dostęp 2 | 2020. 
oraz właściwe odczytanie zamiarów Kremla, między innymi w odniesieniu do Europy Środowej i Wschodniej.

Bardzo mocnym i niejako przesądzającym dla PiS ostrzeżeniem przed imperializmem rosyjskim stała się w 2010 roku katastrofa smoleńska oraz jej następstwa. Po latach znaczenie sprawy smoleńskiej dla myślenia politycznego (charakterystycznego dla $\mathrm{PiS}$ ) o bezpieczeństwie wyjaśnił A. Macierewicz, mówiąc, że był to zwiastun nowej ery w sytuacji zagrożenia dla Europy i dla Polski, który doprowadził do zmiany postaw i przekonań, że „nie chodzi o to, żeby było więcej sił szybkiego reagowania, więcej ćwiczeń, więcej tego samego, tylko że chodzi o historyczną zmianę" ${ }^{\prime 69}$. W środowisku PiS błyskawicznie zaczęły narastać obawy, że nie tylko nie dostrzega się w Sojuszu zagrożenia rosyjskiego, ale również wśród europejskich członków Paktu (RFN, Francja, Włochy) zauważyć można gotowość do porozumienia się z Moskwą kosztem Europy Środkowej ${ }^{70}$. W latach 2010-2014 oczekiwania na historyczną zmianę trafiały w próżnię, dopiero agresja na Ukrainę stała się odpowiednim impulsem do działań. To właśnie z tych przemyśleń wynikały poglądy na rolę Polski w Sojuszu Północnoatlantyckim, której nie można było ograniczać do udziału Wojska Polskiego w misjach ekspedycyjnych Sojuszu.

Powróciwszy do władzy w 2015 roku, politycy PiS nie mieli żadnych wątpliwości, że w ostatnich latach sytuacja międzynarodowa Polski uległa pogorszeniu. Taką diagnozę postawiono w Strategii Polskiej Polityki Zagranicznej 2017-2021, pisząc w niej o świecie mniej przewidywalnym i mniej stabilnym oraz o erozji ładu międzynarodowego, także o kryzysie świata zachodniego. Za główną przyczynę jednoznacznie uznano Rosję, a także brak adekwatnej reakcji na jej politykę imperialną. To właśnie ta bierność stała za jej sukcesami na Ukrainie i podważeniem europejskiej architektury bezpieczeństwa. Oskarżano Rosję o destabilizację sąsiedztwa europejskiego „nie tylko na Wschodzie, ale również na Po-

Spotkanie z internautami, 16 XI 2017, http://www.pap.pl, dostęp 29 I 2020.

70 Vide Archiwum KPRM, t. 1535/3, „Notatka informacyjna z rozmowy telefonicznej Prezydenta RP Pana Lecha Kaczyńskiego z Prezydentem Gruzji Panem Micheilem Saakaszwili", 17 XII 2009, SDT 450-29/09/4, s. 35. 
łudniu"71. W 2018 roku minister Czaputowicz w znacznym stopniu powtórzył i zarazem rozszerzył ocenę skali zagrożeń rosyjskich dla Polski dokonaną w dokumentach partyjnych i rządowych w 2007 roku. Przypisał Rosji cel ogólny w postaci "rewizji porządku politycznego w Europie” ukształtowanego po 1989 roku, co oznaczało bezpośrednio zagrożenie dla podmiotowości Polski w stosunkach międzynarodowych. Jako instrumenty wskazał zaś: 1) destabilizację regionów sąsiednich wobec Polski; 2) wzmacnianie wewnętrznych konfliktów politycznych w wybranych państwach; 3) rozbijanie jedności transatlantyckiej; 4) pogłębianie podziałów wewnątrz Unii Europejskiej ${ }^{72}$. Taki opis stanu środowiska międzynarodowego można było interpretowaćjako imperatyw wzmocnienia polityki zagranicznej wypracowanej w latach 2005-2007 oraz projektowanej w okresie bycia w opozycji.

W okresie rządów sprawowanych przez Zjednoczoną Prawicę z zadań przypisywanych Organizacji Paktu coraz ważniejsza stawała się jego rola na odcinku rosyjskim. Scharakteryzował ją prezes Kaczyński 26 lutego 2016 roku w wywiadzie dla „Financial Times”. Sojusz miał wywierać presję na Rosję o takiej sile, która przyniosłaby efekty dla Polski, Europy i Zachodu. Mówił: „Trzeba, żeby ta droga [Rosji - W.P.] wiodąca do imperializmu stała się całkowicie nieracjonalna i nie doprowadziła do jakichkolwiek sukcesów [...]". Kaczyński użył dwóch porównań - sportowego i historycznego. W pierwszym kontekście proponował bycie bokserem wagi ciężkiej, a nie lekkiej, a w drugim stawiał za wzór prezydenturę Ronalda Reagana, kiedy Sojusz był "organizacją militarną przygotowaną do wojny - defensywnej, ale wciąż wojny [...]"73.

Inną ważną cechą nowej polityki transatlantyckiej sformułowanej przez PiS było uznanie za istotne militarnych czynników bezpieczeństwa. W tej materii PiS było stronnictwem tradycjonalistycznym - negliżowało znaczenie wojskowe międzynarodowych struktur bezpieczeństwa

\footnotetext{
71 Strategia Polskiej Polityki Zagranicznej 2017-2021.., s. 2.

72 J. Czaputowicz, Informacja ministra spraw zagranicznych o zadaniach polskiej polityki zagranicznej w 2018 roku..., s. 82.

73 Cyt. za: Wypowiedź dla „Financial Times”, 26 II 2016, http://www.rfm24.pl, dostęp $30 \mid 2020$.
} 
na rzecz własnych sił zbrojnych ${ }^{74}$. Były dwa zasadnicze powody takiej postawy. Pierwszy wskazał w 2015 roku J. Kaczyński: „Dobry czas, kiedy zagrożeń militarnych nie było, jest już za nami". Z tej konstatacji wynikał imperatyw wyjątkowej dbałości o stan Sił Zbrojnych RP. Prawo i Sprawiedliwość uważało, że polityka zarówno rządów koalicji lewicowo-ludowcowej, jak i gabinetów liberalno-ludowcowych była dla Wojska Polskiego niekorzystna. Natomiast według J. Kaczyńskiego: „Czasy są takie, że musimy mieć silną armię, silniejszą niż ta dzisiejsza, znacznie silniejszą". W programie z 2011 roku sformułowano zadanie dla nowego rządu RP (w domniemaniu prawicowego) - "modernizacja Sił Zbrojnych, aby osiągnęły standardy i możliwości, które pozwolą na obronę integralności terytorialnej w razie ataku potencjalnego agresora"75. Silna armia była potrzebna z trzech powodów: 1) podnosiła bezpieczeństwo państwa; 2) stanowiła atut w pozyskiwaniu sojuszników; 3) zabezpieczała Polskę przed wasalizacją i klientelizmem ${ }^{76}$. Był jeszcze inny powód - Polska, aby mogła dyskontować w Sojuszu oraz w regionie swoje położenie geopolityczne oraz potencjał ludnościowy, musiała wesprzeć wolę polityczną „wykonywaniem zobowiązań w sferze militarnej", czyli podejmować „energiczne działania zmierzające do modernizacji i rewitalizacji naszych sił zbrojnych"77.

Zarówno rządząc w okresie 2005-2007, jak i będąc w opozycji w latach 2007-2015, PiS przywiązywało wielką wagę do własnej koncepcji ukształtowania Sił Zbrojnych RP. Armia unowocześniona i profesjonalna, zdolna zarówno do obrony własnego terytorium, jak i do uczestnictwa w misjach ekspedycyjnych miała wzmocnić pozycję Polski w Sojuszu Północnoatlantyckim oraz zwiększyć jej wpływ na decyzje polityczne podejmowane przez Organizację. Już w 2005 roku postulowano więc opracowanie długofalowej strategii finansowania uzbrojenia (przezbrojenia) Sił Zbrojnych RP, do czego nawiązano 10 lat później, po odzyskaniu

\footnotetext{
74 J. Sanecka-Tyczyńska, Model bezpieczeństwa zewnętrznego państwa..., s. 224.

75 Polska nowoczesna, Polska solidarna, Polska bezpieczna..., s. 228.

76 Kaczyński: musimy mieć silniejszą armię, 14X 2015, http://www.pap.pl, dostęp 8 VI 2019.

77 IV Rzeczpospolita-Sprawiedliwość dla Wszystkich..., s. 19.
} 
władzy w 2015 roku. Pierwszym kompleksowym działaniem w dziedzinie wojskowości, podjętym nazajutrz po sformowaniu rządu Beaty Szydło, było rozpoczęcie tworzenia piątego rodzaju Sił Zbrojnych RP Wojsk Obrony Terytorialnej, obejmujących docelowo 53 tysiące żołnierzy ugrupowanych w 17 brygad podporządkowanych Dowództwu Wojsk Obrony Terytorialnej. Była to reakcja na typ wojny narzuconej Ukrainie przez Rosję w 2014 roku oraz sposób zorganizowania jak najszybciej potencjalnego oporu we wschodniej Polsce, której - według doktryny opracowanej przez rząd PO-PSL - Wojsko Polskie nie zamierzało bronić. Doprowadzono więc faktycznie do likwidacji na tym obszarze dużych jednostek wojskowych ${ }^{78}$. Zmiana stosunku do tzw. wschodniej Polski dawała możliwość opracowania realistycznej doktryny obronnej Rzeczypospolitej. Trudno byłoby sobie wyobrazić bowiem wojnę obronną w kontekście rosyjskim, kiedy zamierzano oddać bez walki terytorium na wschód od Wisły (prawdopodobnie z Warszawą), tracąc tym samym głębię operacyjną i zasób ludzki.

Najpełniej do kwestii modernizacji Sił Zbrojnych RP odniesiono się w programie PiS z 2019 roku, mając już w pełni ugruntowaną wiedzę o możliwościach ich przezbrojenia oraz odpowiednie gwarancje finansowania, wynikające ze znacznie większych dochodów budżetowych. Wychodząc z założenia, że „Polska potrzebuje rozbudowanych i zmodernizowanych Sił Zbrojnych”, aby „zapewnić zdolności obronne na całym terytorium naszego państwa", złożono trzy konkretne obietnice. Pierwsza - zwiększenie liczebności wojsk operacyjnych do 150 tysięcy; druga - realizacja programu wyposażenia wszystkich rodzajów Sił Zbrojnych w nowoczesne środki prowadzenia działań militarnych, który miał być wykonany w latach 2017-2026 na kwotę 185 mld PLN; trzecia - rozbudowa nowoczesnego przemysłu zbrojeniowego w celu zwiększenia jego potencjału, konkurencyjności i zdolności eksportowych oraz gotowość do podniesienia technologicznego Wojska Polskiego. W dokumencie zawarto też wykaz konkretnych programów podlegających kontynuacji i zasadniczo rozpoczętych po 2015 roku, wolę wzmocnienia Polskiej Gru-

78 Obrona terytorialna, MON, Warszawa 2017, http://www.mon.gov.pl, dostęp 2 II 2020. 
py Zbrojeniowej, a także informację o rozszerzeniu programu zakupów wojskowych ${ }^{79}$. Minister obrony narodowej M. Błaszczak szczegółowo wyjaśniał opinii publicznej ścisły związek modernizacji sił zbrojnych z obecnością wojsk sojuszniczych, w tym amerykańskich, w Polsce ${ }^{80}$. W tym sensie kontynuował linię polityczną swojego poprzednika. To właśnie A. Macierewicz stwierdził, że instalacji wojsk sojuszniczych powinna towarzyszyć przebudowa Wojska Polskiego. Obecność sojuszników „[...] to jest warunek wstępny, który jedynie stwarza przesłankę do tego, żeby Polska była silna. Warunkiem prawdziwym i ostatecznym jest wykorzystanie tej osłony zewnętrznej do tego, by stworzyć naprawdę silną armię" 81 .

Podsumowując kwestię roli Sojuszu w polityce bezpieczeństwa Polski w koncepcji PiS, można przywołać opinię J. Kaczyńskiego. Według niego sojusz między państwami, aby był skuteczny, powinien opierać się na wspólnocie zarówno interesów, jak i wartości. Jednoznacznie stwierdzał, że polityka powinna spełniać jeden warunek - „musi być najpierw moralnie słuszna”, dlatego "należy odkurzyć drogowskazy wartości w polityce międzynarodowej”. Jednocześnie: „Należy respektować interesy nie tylko największych, ale też średnich i małych państw". Te przekonania prezesa determinowały politykę transatlantycką $\mathrm{PiS}{ }^{82}$.

\subsection{Krytyka przeciwników politycznych}

Ważną rolę w wypracowaniu przez PiS koncepcji polityki transatlantyckiej dla Polski odegrała nie tylko orientacja transatlantycka tej formacji, przyjęta i dopracowywana konsekwentnie od początku jej powstania jako propozycja strategiczna dla Rzeczypospolitej, ale również krytyka alternatywnych rozwiązań, realizowanych przez przeciwników politycznych

\footnotetext{
79 Dobry czas dla Polski..., s. 187-188.

80 Konferencja prasowa dotycząca umowy o zakupie rakiet Patriot, 28 III 2018, http://www. pap.pl, dostęp 21 | 2020.

81 Spotkanie z internautami, 16 IX 2017, http://www.pap.pl, dostęp 29 I 2020.

82 J. Kaczyński, Sojusznicy i wartości, 30 IX 2010, http://www.old.pis.org.pl, dostęp 8 VI 2019.
} 
- najpierw lewicowych, a następnie liberalnych, rządzących w okresie 2001-2015. Charakter rywalizacji politycznej w tym okresie przesądził o tym, że głównym podmiotem odniesienia w sporze o rolę Paktu w polskiej polityce zagranicznej stała się Platforma Obywatelska, a nie Sojusz Lewicy Demokratycznej. Tym bardziej że główny rywal PiS - PO, formułował własne, odmienne rozwiązania. PO inaczej rozkładała akcenty, co widać w pierwszym oficjalnym dokumencie na temat polityki zagranicznej powstałym po przejęciu władzy w 2007 roku. W Założeniach polskiej polityki zagranicznej w 2008 r. zapisano: „Zabiegamy o utrzymanie równowagi między zdolnością NATO do obrony terytorium państw członkowskich a działaniami ekspedycyjnymi" ${ }^{83}$. W dokumencie nie wskazano jednak żadnych środków, przede wszystkim militarnych, które mogłyby prowadzić do osiągnięcia tego celu, a zwłaszcza do wzmocnienia bezpieczeństwa Europy Środkowej. Nawet nie sugerowano działań na rzecz obecności wojskowej Sojuszu w Polsce, natomiast pisano o rozwijaniu "rzeczowej współpracy NATO-Rosja", budowie partnerstwa strategicznego Sojusz-Unia, harmonizacji i koordynacji działań stabilizacyjno-pomocowych Sojuszu oraz innych organizacji międzynarodowych. Te obszary zainteresowań Sojuszem mogły budzić zaniepokojenie polityków PiS, były bowiem zanegowaniem priorytetów północnoatlantyckich gabinetu J. Kaczyńskiego. Nasuwa się także kolejny jednoznaczny wniosek - PO nie uświadamiała sobie imperatywów ani strategii w polityce zagranicznej Rosji; liderzy tej partii ani nie mieli woli budowy wschodniej flanki Sojuszu, ani nie widzieli takich możliwości, szans i zarazem potrzeb. Relacje Polska-Sojusz były więc w PO postrzegane odmiennie niż w PiS.

W latach 2005-2015, czyli w okresie naznaczonym rywalizacją między Prawem i Sprawiedliwością a Platformą Obywatelską o władzę w Rzeczypospolitej, stronnictwo kierowane przez J. Kaczyńskiego przedstawiło opinii publicznej sześć dokumentów, którym można przypisać znaczenie programowe. Były to programy z lat 2005, 2007, 2009, 2011 i 2014 oraz Raport o stanie Rzeczypospolitej - prezentujący oficjalne stanowisko przy-

83 Archiwum Rady Ministrów, Sekretariat Prezesa Rady Ministrów, „Założenia polskiej polityki zagranicznej w 2008 r.", Warszawa 2008, s. 14. 
jęte przez Radę Polityczną PiS w 2011 roku $^{84}$. Tylko program z 2007 roku powstał wtedy, kiedy partia broniła w kampanii wyborczej swoich rządów sprawowanych w latach 2005-2007, natomiast pozostałe były bardzo krytyczną oceną rzeczywistości politycznej, w tym polityki zagranicznej realizowanej przez gabinety rządowe reprezentujące koalicję lewicowo-ludowcową i liberalno-ludowcową (PO, SLD, PSL), osadzonej przede wszystkim w myśli politycznej lewicowej i liberalnej ${ }^{85}$.

W ocenie generalnej, według PiS, między polityką zagraniczną zarówno rządów Leszka Millera i Marka Belki (2001-2005), jak również gabinetów Donalda Tuska i Ewy Kopacz (2007-2015) nie było fundamentalnej różnicy w warstwie ideologicznej. Opierały się one na fałszywych założeniach poznawczych i doktrynalnych, na doktrynie/teorii liberalnej stosunków międzynarodowych, odrzucanej przez PiS. Jednak w ujęciu szczegółowym zarzuty wobec premierów lewicowych i liberalnych były odmienne. Paradoksalnie znacznie więcej zrozumienia i minimalnej aprobaty PiS wyrażało wobec gabinetów zdominowanych przez SLD oraz wobec prezydenta Aleksandra Kwaśniewskiego niż wobec rządów koalicji PO-PSL i poczynań międzynarodowych prezydenta Bronisława Komorowskiego. O ile w pierwszym przypadku niektóre elementy uznawane były za pozytywne, takie jak polityka ukraińska czy zorientowanie na Stany Zjednoczone, o tyle w odniesieniu do drugiej konstelacji politycznej negacja miała charakter niemal całkowity.

Odnośnie do gabinetów Millera i Belki, PiS prezentowało bardzo rzeczową, ale i zróżnicowaną ocenę. Akceptowano najważniejsze decyzje międzynarodowe związane z przynależnością Polski do Sojuszu Północ-

84 IV Rzeczpospolita - Sprawiedliwość dla Wszystkich...; Nowoczesna, solidarna, bezpieczna Polska...; Polska nowoczesna, Polska solidarna, Polska bezpieczna...; Zdrowie, praca, rodzina...; Raport o stanie Rzeczypospolitej, PiS, Warszawa 2011.

85 Będąc w koalicji najpierw z SLD, a następnie z PO, Polskie Stronnictwo Ludowe miało w tym czasie bardzo ograniczony wpływ na ksztattowanie polityki zagranicznej Polski w jej sensie strategicznym. Oddziaływało tylko na wybrane dziedziny, najczęściej o charakterze gospodarczym, a w odniesieniu do warstwy ideologicznej i poznawczej przyjmowało postawę pasywną. W myśli politycznej ludowców odczuwalny był wówczas brak pogtębionych przemyśleń na temat statusu Polski w środowisku międzynarodowym. 
noatlantyckiego i Unii Europejskiej, podejmowane chociażby w sprawie II wojny w Zatoce Perskiej czy rozmów o akcesji do Unii, ale jednocześnie formułowano inne zarzuty o rozbieżnej treści. Z jednej strony oskarżano rządy SLD o uwikłanie ideologiczne i partyjne związane z przynależnością tej organizacji do ruchu socjaldemokratycznego, zwłaszcza w Unii Europejskiej, kosztem polskich interesów na rzecz wizji integracyjnych ${ }^{86}$, ale z drugiej strony pisano o chaosie i niekonsekwencjach, braku myślenia geopolitycznego, niskim pragmatyzmie i niewielkich zdolnościach adaptacyjnych, nadmiernym nasyceniu fobiami i emocjami ${ }^{87}$.

Te zarzuty wobec lewicy nie były ani spójne, ani jednoznaczne. W czasie debaty sejmowej o polityce zagranicznej Polski w styczniu 2004 roku J. Kaczyński wygłosił zaskakująco pozytywną ocenę polityki zagranicznej rządu L. Millera w czterech jej segmentach: europejskim i amerykańskim oraz regionalnym i rosyjskim. Co do pierwszego powiedział: „[...] chciałbym wyrazić uznanie, więcej: podziękowanie, nieobecnemu tutaj premierowi Leszkowi Millerowi i Włodzimierzowi Cimoszewiczowi, ministrowi spraw zagranicznych, za ich postawę w Brukseli, za ich twardość - w wypadku Leszka Millera także za twardość osobistą związaną z chorobą, z ciężkimi dolegliwościami. Przysłużyliście się panowie Polsce i trzeba, także jeżeli się jest w zdecydowanej opozycji, o tym powiedzieć". W odniesieniu do drugiego segmentu prezes $\mathrm{PiS}$ pochwalił decyzję rządu RP w sprawie Iraku jako odważną i podjętą energicznie, chociaż niepoprzedzoną uzyskaniem przez Polskę odpowiednich decyzji Stanów Zjednoczonych. W tym kontekście wymienił bazy amerykańskie w Polsce jako gwarancję jej pozycji międzynarodowej i niepodległości. Wobec dwóch pozostałych - regionalnego i rosyjskiego, J. Kaczyński zgłosił sugestie i zachęcał do refleksji, ale nie było potępienia ani zmasowanej krytyki. Proponował "głębokie zastanowienie"

\footnotetext{
86 Vide K. M. Ujazdowski, Wystąpienie, [w:] SS Sejm, 4 kadencja, 16 pos., 14 III 2002, s. 73, http://orka2.sejm.gov.pl, dostęp 4 V 2019.

87 Polska polityka zagraniczna - U.S. First, lecz także więcej Europy, "Rocznik Strategiczny” 2004/2005, s. $385,387$.
} 
w sprawach środkowoeuropejskich (sąsiedzkich) oraz podjęcie nowych inicjatyw, a przemyślenie dotychczasowych.

Ocena polityki rosyjskiej rządu Millera była najbardziej surowa. Prezes PiS z jednej strony zaakceptował ofensywę polskiej polityki zagranicznej na tym odcinku, z drugiej strony uznał ją jednak za nieudaną, ale z powodów obiektywnych - porozumienie z Rosją było niemożliwe. Zasugerował więc przejście na pozycje realistyczne, przestrzegając, że w perspektywie krótkoterminowej niewiele można osiągnąć. Oskarżył lewicę o budowanie z Moskwą relacji asymetrycznych, które należy jak najszybciej zlikwidować, ponieważ: „Nic nie dają, do niczego nie prowadzą, a w istocie degradują [...], także w stosunkach z Zachodem" ${ }^{88}$. Ocena polityki rosyjskiej rządów lewicowych była o tyle istotna, że stosunki polsko-rosyjskie weszły już wówczas w fazę nieskrywanej niechęci do Warszawy ze strony Moskwy, która coraz wyraźniej traktowała Polskę jako wroga. Było też już wtedy wiadomo, że akcesja Polski do Unii nie spowoduje żadnych pozytywnych trendów na Kremlu wobec Polski. Natomiast zwrot w stronę Stanów Zjednoczonych, połączony z intensywnym zaangażowaniem w sprawy ukraińskie premiera Millera rozdrażnił ekipę Putina.

Wobec polityki zagranicznej gabinetów D. Tuska i E. Kopacz oraz prezydenta B. Komorowskiego negacja ze strony PiS była kompleksowa, odnosiła się bowiem do całej linii politycznej PO oraz do najważniejszych decyzji podejmowanych w latach 2007-2015. Ryszard Legutko, intelektualista, polityk PiS, pisał nawet o katastrofie w polityce zagranicznej Polski wywołanej przez „triumwirat Tusk-Sikorski-Bartoszewski", tak rozległej, że po zmianie władzy będzie trzeba "wskrzeszać polską politykę zagraniczną"89. Najpełniejszej krytyki polityki zagranicznej koalicji PO-PSL dokonano w programie z 2014 roku oraz w dyskusji nad infor-

\footnotetext{
88 J. Kaczyński, Wystąpienie w debacie nad informacją ministra spraw zagranicznych o podstawowych kierunkach polityki zagranicznej Polski w 2004 roku...

89 Nowoczesna Polska 2020..., S. 50. VideŁ. Warzecha, Czy możliwa jest realistyczna polityka zagraniczna..., s. 102, 105.
} 
macją ministra spraw zagranicznych Grzegorza Schetyny wygłoszonej 23 kwietnia 2015 roku.

Na poziomie ogólnym PiS krytykowało zarówno przesłanki przyjmowane przez PO, jak również skutki, czyli strategię. Według A. Fotygi: „Nie jest prawdą, że Polska i pozostałe kraje Europy Środkowo-Wschodniej są w okresie prosperity, bezpieczeństwa, zainteresowania ze strony świata, i nie muszą się o nic martwić" ${ }^{90}$. Jarosław Kaczyński krytykował strategię przyjętą przez PO, nazywając ją "strategią "krótkiego oddechu"" oraz "strategią konformizmu". W jego opinii miała ona liczne wady, z tego cztery najważniejsze: pierwsza - nie uwzględniano zmienności sytuacji międzynarodowej, zakładając fałszywie jej niezmienność i ciągłą dominację czynników korzystnych dla Polski; druga - nie uwzględniano w myśleniu politycznym scenariuszy alternatywnych, natomiast „Polska musi brać pod uwagę różne scenariusze ewolucji UE i NATO i mieć gotowe rozwiązania na wypadek, gdyby któryś z nich był realizowany"; trzecia - przyjęto model działania schematyczny i nieodpowiadający wyzwaniom stojącym przed Polską; czwarta - prowadzenie polityki opartej na bufonadzie i pozorności. Natomiast - według J. Kaczyńskiego - polityka bezpieczeństwa powinna być "z natury rzeczy" nastawiona na czarne scenariusze, a te wymagają racjonalnego podejścia i rzetelnego przepracowania tematu ${ }^{91}$.

Bardzo pejoratywnie istotę strategii liberalnej opisywała A. Fotyga: „Tymczasem obecne władze [wywodzące się z PO - W.P.] postępują tak, jakby Polska była małym, nieliczącym się krajem, który wisi u klamki wielkich i możnych tego świata. [...] zrezygnowały one ze wszystkich negocjacyjnych atutów" ${ }^{22}$. Na inną perspektywę wskazał R. Legutko: „Wydaje się, że dzieje się coś pozytywnego, podczas gdy naprawdę w świecie rzeczywistym następuje gwałtowna degradacja siły, znaczenia i wagi Polski jako podmiotu relacji międzynarodowych. Jej celem jest robienie

\footnotetext{
90 M. Bober, Rząd przeksztatca Polskę w kolonię [Rozmowa z Anną Fotygą], „Nasz Dziennik", 23 VIII 2010, nr 167, s. 3.

91 J. Kaczyński, Polska naszych marzeń..., S. 19-20; M. Bober, Rząd przeksztatca Polskę w kolonię..., s. 3; Nowoczesna Polska 2020..., s. 50-52.

92 M. Bober, Rząd przeksztatca Polskę w kolonię..., s. 3.
} 
dobrego wrażenia i to bardziej na użytek wewnętrzny"93. Z tych wypowiedzi wyłania się obraz polityki zagranicznej koalicji PO-PSL nastawionej na kreowanie wizerunku, bynajmniej nie Polski, ale własnego i to w odniesieniu do polskiej opinii publicznej.

W 2015 roku, czyli w roku nadchodzących podwójnych wyborów, K. Szczerski poczynił oceny generalne, które można uznać za podsumowanie merytoryczne. Zarzucił rządowi PO-PSL przyjęcie założeń, które zostały zweryfikowane negatywnie przez rzeczywistość („Ta rzeczywistość was dopadła i obaliła na ziemię"), a prowadzoną przez niego politykę zagraniczną wyjaśniał, odwołując się do alternatywy złożonej z trzech elementów: 1) niekompetencji polityków odpowiedzialnych za politykę zagraniczną Polski, którzy „nie potrafią dostrzec nadciągających zagrożeń i nic nie rozumieją z procesów międzynarodowych zachodzących wokół nas"; 2) naiwności polegającej na kierowaniu się myśleniem życzeniowym i nadzieją, że „nie będzie burzy, nawet gdy na horyzoncie widać już błyskawice"; 3) świadomego błądzenia przy unikaniu odpowiedzialności. Ocena dokonana przez polityka i zarazem politologa specjalisty w zakresie stosunków międzynarodowych była miażdżąca. Konkluzją były słowa: „Kierowanie się myśleniem życzeniowym w polityce to grzech ciężki. [...] najbardziej adekwatnym do waszego sposobu myślenia jest opis z piosenki "Imagine»: świat bez granic, bez wojen, a w zamian wolna miłość, tylko że na Kremlu nie zasiada John Lennon, tylko Władimir Putin, a w Berlinie nie rządzi Yoko Ono, tylko Angela Merkel"94.

Jeszcze inaczej politykę zagraniczną koalicji PO-PSL opisywała M. Gosiewska, nazywając ją "doktryną chowania się przed światem do szafy" oraz "doktryną kunktatorstwa, strachu przed narażaniem się europejskiemu establishmentowi, przepraszania wszystkich wokół za to, że przeżyliśmy setki lat między Niemcami i Rosją, że dalej żyjemy, wstydu za własną historię, własną tradycję i kulturę, za fakt, że Polska jest Polską, a nie jakąś podróbką suwerennego państwa małpującą cudze wzor-

Nowoczesna Polska 2020..., s. 50.

94 K. Szczerski, Wypowiedź, [w:] WNP Sejm, 7 kadencja, 91 pos., 23 IV 2015, http://www. sejm.gov.pl, dostęp 21 V 2020. 
ce". Jej wystąpienie w Sejmie było dość ważne, przemawiała bowiem w imieniu Klubu Parlamentarnego PiS w oficjalnej debacie nad polityką zagraniczną Polski ${ }^{95}$.

Po czterech latach rządów, w 2019 roku PiS wyjaśniało wyborcom, że odrzucenie polityki zagranicznej PO-PSL dokonało się we wszystkich jej segmentach: założeń, wartości, celów i środków. Odrzucono więc: klientelizm w postaci „płynięcia w głównym nurcie", naiwność w postrzeganiu Unii Europejskiej, pasywizm w polityce środkowoeuropejskiej i wschodniej, rozluźnianie więzi ze Stanami Zjednoczonymi, pedagogikę wstydu. Ta negacja miała charakter aksjologiczny i pragmatyczny, ponieważ polityka PO-PSL zarówno była w kolizji z prawdą i polskością, jak również przynosiła straty na arenie międzynarodowej, osłabiała potencjał polityczny Polski oraz jej możliwości oddziaływania na procesy międzynarodowe w skali regionalnej, kontynentalnej i globalnej ${ }^{96}$.

Prawo i Sprawiedliwość poruszyło też kilka konkretnych spraw. Zarzucało PO, że podejmuje działania prowadzące do osłabienia spójności przymierza transatlantyckiego (oraz sojuszu ze Stanami Zjednoczonymi) na rzecz: 1) budowy architektury bezpieczeństwa w oparciu o Unię Europejską (Europejska Polityka Bezpieczeństwa i Obrony); 2) polityki typu bandwagoning wobec RFN oraz 3) polityki resetu w stosunkach z Federacją Rosyjską ${ }^{97}$. Według Radosława Sikorskiego miał to być "realizm" polityczny realizowany w opozycji do polityki „jagiellońskiej", którą urzeczywistniało PiS w latach 2005-2007 oraz prezydent L. Kaczyński w czasie swojej kadencji ${ }^{98}$. W opinii PiS polityka ukierunkowana już na przełomie lat 2007/2008 jednocześnie na realizację wskazanych trzech celów była co najmniej błędna, ale zasadniczo traktowano ją jako szkodliwą dla racji stanu i suwerenności Rzeczypospolitej. W 2019 roku

95 M. Gosiewska, Wypowiedź, [w:] WNPSejm, 8 kadencja, 78 pos., 14 III 2019, http://www. sejm.pl, dostęp 14 II 2020.

96 Dobry czas dla Polski..., s. 172.

97 M. Habowski, Platforma Obywatelska wobec zagadnień polityki zagranicznej, [w:] Polityka zagraniczna Polski w latach 2004-2011. Struktury, koncepcje, sąsiedzi, Izrael, red. M. S. Wolański, Dolnośląska Wyższa Szkoła Przedsiębiorczości i Techniki, Polkowice 2013, s. 40, 63.

98 R. Sikorski, Lekcje historii, modernizacja i integracja..., s. 3. 
wypunktowano konkretne negatywne skutki takiej polityki: wyeliminowanie Polski z dyskusji o wojnie rosyjsko-ukraińskiej, wywołanie kryzysu w Grupie Wyszehradzkiej, zrezygnowanie z tarczy antyrakietowej, zgoda na pakiet klimatyczny ${ }^{99}$. Do tego doprowadziły złudzenia europejskie, niemieckie i rosyjskie.

Wyjątkową dezaprobatę stronnictwa J. Kaczyńskiego wywoływał sposób rozwiązywania przez PO strategicznego dla Polski zagadnienia - niemiecko-rosyjskiego. PiS odrzucało budowę „Wspólnoty wartości i interesów" ${ }^{100}$ z Berlinem oraz "nadanie nowej dynamiki stosunkom dwustronnym" ${ }^{101}$ z Moskwą „taką, jaką ona jest"102. Następstwem tych działań był bowiem spadek zainteresowania Stanów Zjednoczonych Europą Środkową oraz zmniejszenie zaangażowania Sojuszu Północnoatlantyckiego w obronę tego regionu, w tym Polski, przed narastającym imperializmem rosyjskim. W stronnictwie taką koncepcję polityki zagranicznej Polski nie tylko zdecydowanie odrzucano, ale też traktowano ją jako niebezpieczną dla Polski, naiwną i fałszywą w swoich założeniach, przynoszącą straty polskim interesom narodowym. PiS, przejąwszy władzę w 2005 roku, stanęło wobec problemu pogarszających się stosunków polsko-niemieckich, co było widoczne już w okresie 2002-2003, czyli za rządów w Polsce koalicji lewicowo-ludowcowej. Wtedy to w odniesieniu do kluczowych wydarzeń międzynarodowych oba państwa znalazły się po dwóch różnych stronach międzynarodowych sporów zarówno globalnych, jak i kontynentalnych. Wejście Polski do Unii nie spowodowało automatycznej zmiany w tej kwestii, lecz jeszcze bardziej skomplikowało polsko-niemieckie relacje, Warszawa musiała bowiem

99 Dobry czas dla Polski..., s. 173.

100 Określenie autorstwa Bogdana Koszela w kontekście wizyty D. Tuska w Berlinie 11 grudnia 2007 roku. B. Koszel, "Nowe otwarcie"? Stosunki polsko-niemieckie w okresie rządów koalicji PO-PSL (2007-2009), Instytut Zachodni, Poznań 2009, s. 12-13.

101 Tym określeniem postużył się minister spraw zagranicznych w rządzie D. Tuska, Radosław Sikorski. Archiwum KPRM, „Założenia polskiej polityki zagranicznej w 2008 r.", t. 1289/l, s. 17.

102 D. Tusk w swoim exposé 23 listopada 2007 roku zapowiedziat dialog z „Rosją, taką, jaką ona jest". M. Habowski, Platforma Obywatelska wobec zagadnień polityki zagranicznej..., s. 63. 
teraz odpowiedzieć na najważniejsze pytanie - w jakim zakresie akceptuje dominującą rolę RFN we Wspólnocie oraz niemieckie postrzeganie obecności Polski w Unii.

Zadaniem rządu utworzonego przez PiS w 2005 roku stało się więc poszukiwanie wyjścia z tej sytuacji. Dla PiS, podobnie jak dla obozu piłsudczykowskiego w latach międzywojennych, kwestie niemiecka i rosyjska się łączyły, mimo że odmiennie postrzegano status międzynarodowy tych dwóch sąsiadów Rzeczypospolitej. Dostrzegano hamulce powstrzymujące Berlin w postaci bycia częścią świata demokratycznego, praworządnego i euroatlantyckiego. Suwerenność Niemiec była ograniczona chociażby przez wojska amerykańskie tam stacjonujące. Jednak nie przeszkadzało to RFN w podjęciu gry z Rosją oraz w realizacji wspólnych interesów, które prowadziły do osaczenia Europy Środkowej i uzależnienia Europy Zachodniej od dostaw rosyjskich surowców. Berlin niemal bezproblemowo akceptował kierowane wobec siebie rosyjskie awanse. Z tego powodu politycy PiS w 2010 roku wprowadzili do obiegu określenie „kondominium niemiecko-rosyjskie” w odniesieniu do Polski rządzonej przez koalicję PO-PSL w kontrze do propozycji R. Sikorskiego dotyczącej powołania federacji europejskiej - według PiS na podobieństwo Świętego Cesarstwa Narodu Niemieckiego, w którym Polska zostałaby zredukowana do „stanu europejskiego". W 2012 roku rozważano ten problem na konferencji, zadając pytanie - kondominium, stan europejski czy wolna Rzeczpospolita, oraz pisano, że wszelkie takie projekty "germanizacji" Unii są łamaniem traktatów europejskich i prowadzą do „zagłady dzisiejszej Unii" ${ }^{103}$. Takie nazywanie zagrożenia wiszącego nad całym regionem wywołało zmasowany atak polityczny,

103 Kaczyński: „Kondominium rosyjsko-niemieckie w Polsce”. PO, SLD i PSD oburzone, zwotują konferencję. Wszyscy przeciw PiS, 8 IX 2010, http://www.wpolityce.pl, dostęp $25 \mathrm{~V}$ 2020; Kondominium, stan europejski czy wolna Rzeczpospolita. „Kwestia suwerenności rozwiązuje się w naszych głowach", 16 I 2012, http://www.wpolityce.pl, dostęp $21 \mathrm{~V}$ 2020; A. Macierewicz, Elity trawi śmiertelna choroba [Rozmowa Dominika Zdorta z Antonim Macierewiczem], „Uważam Rze”, 15-21 X2011, nr 42, s. 65; Nie odtwarzajmy Cesarstwa Niemieckiego. „Polski minister wybrat metodę uzgadniania z rządem Niemiec”, 9 XII 2011, http://www.wpolityce.pl, dostęp 21 V 2020; K. Czabański, Za nic z Rosja, ostrożnie z Niemcami!, „Uważam Rze”, 15-21 X 2013, nr 42, s. 60. 
w tym medialny, na prezesa Kaczyńskiego, mimo że wniosek miał mocne oparcie w analizie geopolitycznej ${ }^{104}$.

W PiS narodził się pomysł "nowego otwarcia” z Niemcami, które wynikało z założenia, że w poprzednich latach: „Polska przeszacowuje znaczenie Niemiec, Niemcy nie doszacowują znaczenia Polski" ${ }^{105}$. Opisał to wyzwanie w 2008 roku Marek Cichocki: „Po 2005 roku przynajmniej podjęto w polskiej polityce próbę zdefiniowania tych podziałów i podmiotowego ustosunkowania się do nich. Ale to oznaczało m.in. całkowitą zmianę dotychczasowej logiki w stosunkach polsko-niemieckich". W opinii polityków PiS ich konkurenci polityczni przeceniali rolę RFN w decyzji o przyjęciu Polski do Unii. Nie chodziło o żadne sentymenty, czy też o idealistyczne mrzonki o wspólnej Europie, ale o interesy. Polska wchodząca do Unii stała się dla niemieckich firm oraz kapitału olbrzymim rynkiem - największym rynkiem konsumenckim w tej części Europy. „Nowe otwarcie” zostało odczytane w Berlinie jako przyjęcie kursu antyniemieckiego, elity niemieckie nie były bowiem gotowe zaakceptować ani wzmacniania podmiotowości Rzeczypospolitej, ani polityki zagranicznej zorientowanej na własne interesy, ani też polskiej polityki historycznej. W Berlinie przypisywano Polsce rolę peryferii Unii, o gospodarce imitacyjnej, nakierowanej na bycie kooperantem dla RFN ${ }^{106}$. Model polityki niemieckiej realizowany przez $\mathrm{PiS}$ w latach 2005-2007 nie przyniósł zmian na lepsze w stosunkach polsko-niemieckich, ale był rozwiązaniem, do którego partia J. Kaczyńskiego mogła nawiązać po 2015 roku.

Dezaprobatę polityków PiS wywoływały następstwa polityki bandwagoningu, realizowanej przez koalicję PO-PSL wobec RFN w latach 2007-2015, której wielkim admiratorem był minister spraw zagranicz-

104 Vide M. J. Chodakiewicz, op. cit., s. 412.

105 M. Stolarczyk, Gtówne problemy w stosunkach polsko-niemieckich na początku XXI wieku, [w:] Problemy polityki zagranicznej Polski i stosunków międzynarodowych na początku XXI wieku. Wybrane aspekty, red. M. Stolarczyk, Wydawnictwo Uniwersytetu Śląskiego, Katowice 2008 , s. 40.

106 Idem, Stosunkipolsko-niemieckie w latach 1998-2009 (wybrane aspektypolsko-niemieckiej wspótpracy), [w:] Stosunki Polski z sąsiadami w pierwszej dekadzie XXI wieku, red. M. Stolarczyk, Wydawnictwo Uniwersytetu Śląskiego, Katowice 2011, s. 10, 29-37; M. A. Cichocki, Polska polityka musi być świadoma własnej podmiotowości... 
nych R. Sikorski. Taką politykę prezydent Kaczyński nazwał „Himalajami politycznej głupoty"107. W 2009 roku Sikorski pisał o sojuszu polsko-niemieckim jako pożądanym, a w 2011 roku w Mowie berlińskiej wezwał Berlin do przejęcia odpowiedzialności za Europę, a nade wszystko za przeprowadzenie procesu jej federalizacji. Co jest wyjątkowo znamienne, dla polityków PiS Mowa berlińska była "hołdem lennym" jednego państwa (Polski) wobec innego (Niemiec), która wywołała najostrzejszą z możliwych dezaprobatę. Odrzucano nie tylko treść, ale także formę wygłoszenie mowy w Berlinie oraz jej przygotowywanie przez byłego ambasadora Wielkiej Brytanii w Polsce Charlesa Crawforda. Uznano taką postawę ministra spraw zagranicznych „za ośmieszanie Polski”, przejaw "ustrojowych fikcji i fiksacji"108. Prezes Kaczyński, odnosząc się do międzynarodowej roli Niemiec, wskazywał na inne konteksty. Po pierwsze, hegemonia RFN w Europie jest nie tylko niepożądana, ale wręcz nieskuteczna i niemożliwa (z powodu braku instrumentów pozwalających na ustanowienie i wykonywanie hegemonii), nie przyczynia się bowiem do rozwiązywania problemów europejskich, lecz wręcz generuje nowe, wywołując niechęć w wielu państwach do instytucji europejskich podporządkowanych niemieckim interesom. Po drugie, to właśnie Niemcy są odpowiedzialne za kryzys Unii, w tym strefy euro, ponieważ kierują się egoizmem państwowym, natomiast gospodarka niemiecka w Eurolandzie zawiodła, nie udźwignęła odpowiedzialności za Europę, nie

107 Ł. Warzecha, Lech Kaczyński. Ostatni wywiad..., s. 249.

108 R. Sikorski, Polska i Niemcy w jednoczącej się Europie, [w:] Modernizacja - Centrum - Peryferie. Księga jubileuszowa z okazji 70. rocznicy urodzin Profesora Ryszarda Stemplowskiego, red. W. Borodziej, S. Dębski, PISM, Warszawa 2009, s. 33-35. Mowę berlińska minister Sikorski wygłosit 28 listopada 2011 roku w Berlinie na forum Niemieckiego Towarzystwa Polityki Zagranicznej. Zaprezentowane tam tezy i wnioski zostały odrzucone przez polityków PiS. Vide tekst mowy - R. Sikorski, Polska a przysztość Unii Europejskiej, Berlin 28 XI 2011, http://www.scribd.com, dostęp 2 XII 2019; informacje o jej powstaniu - F. Memches, Berlińska prowokacja Sikorskiego była potrzebna, 9 XII 2011, http://www.wpolityce.pl, dostęp 18 II 2020; Kto pisat berlińskie przemówienie Sikorskiego?Brytyjskiślad, 5 I 2015, http://www.tvn24.pl, dostęp 18 II 2020; opinie - K. Głębocki, Wypowiedź, [w:] WNP Sejm, 8 kadencja, 78 pos., 14 III 2019, http://www.sejm.pl, dostęp 14 II 2020; Ile kosztuje wolność narodów, 23 | 2012, http://www.naszdziennik.pl, dostęp 21 V 2020. Vide A. Orzelska-Stączek, Ministrowie spraw zagranicznych..., s. 91-92. 
wytworzyła bowiem pożądanych impulsów rozwojowych. Po trzecie, nadmierna pozycja Niemiec na kontynencie dodatkowo wzmacnia scenariusz efektywnego niemiecko-rosyjskiego partnerstwa strategicznego, które dla Europy Środkowej byłoby dziejową katastrofą, na podobieństwo tej z XVIII i XIX wieku oraz z okresu lat międzywojennych. Wniosek dla J. Kaczyńskiego był dość oczywisty, sformułowany na kanwie odrzucenia Mowy berlińskiej Sikorskiego - odtwarzanie Świętego Cesarstwa Narodu Niemieckiego w postaci Stanów Zjednoczonych Europy z centrum w Berlinie będzie końcem Unii Europejskiej ${ }^{109}$.

Politykom PO chodziło o ustanowienie polsko-niemieckiego partnerstwa dla Europy oraz dla świata, definiowanego właśnie w kategoriach wspólnoty, której powstanie miało z jednej strony sprzyjać zmianom w kulturze pamięci o przeszłości w relacjach dwustronnych, a z drugiej strony tworzyć obszary współdziałania, takie jak: Partnerstwo Wschodnie, Europejska Polityka Bezpieczeństwa i Obrony, polityka energetyczna UE, stosunki transatlantyckie. Dla PO (od początku istnienia tej formacji) Niemcy miały być głównym sojusznikiem Polski zarówno na forum Unii, jak i w Sojuszu ${ }^{110}$. Dla PiS uwidaczniały się w tych obszarach rozbieżności interesów między Polską a Niemcami. W tych warunkach partnerstwo oznaczałoby przyjęcie niemieckiego punktu widzenia w wymienionych sprawach, co było postrzegane jako jednoznacznie szkodliwe dla Polski. Dowodem może tu być Partnerstwo Wschodnie, które już L. Kaczyński postrzegał jako projekt, który miał zniweczyć jego politykę wschodnią nastawioną na budowanie przez Polskę sieci powiązań w regionie, a Sikorski zgodził się na projekt unijny o niewielkim znaczeniu strategicznym ${ }^{111}$.

Z badań Lucyny Czechowskiej wynika, że cel wyznaczony przez PO w polityce niemieckiej i realizowany w latach 2007-2015 mijał się z rze-

109 J. Kaczyński, Jaka reforma UE, 8 XII 2011, http://www.rp.pl, dostęp 9 VIII 2020; Europa Środkowa wobec zmian w UE - komentarz Jarosława Kaczyńskiego, 11 V 2012, http://www. youtube.com, 14:30-15:35, dostęp 10 VIII 2020. Szerzej na ten temat w: P. Żurawski vel Grajewski, Polska wobec przywództwa Niemiec w Unii Europejskiej, „Przegląd Zachodni” 2014, nr 1, s. 111-135.

110 Vide Polska obywatelska. Podstawy programu politycznego Platformy Obywatelskiej RP, PO, Warszawa 2007, s. 25, http://www.zientarski.pl, dostęp 16 XII 2009.

111 Ł. Warzecha, Lech Kaczyński. Ostatni wywiad..., s. 247. 
czywistością. Owszem, oba państwa przypisywały relacjom dwustronnym duże znaczenie i często się do nich odnosiły w różnych dokumentach partyjnych i rządowych, ale istniała mnogość rozbieżności i bynajmniej nie chodziło o sprawy mało istotne, jak napisała Czechowska. O ile rząd koalicji PO-PSL (a poprzednio gabinety lewicowo-ludowcowe) ogłaszał istnienie strategicznego partnerstwa, o tyle w Niemczech nie zaistniało takie rozumowanie o wschodnim sąsiedzie. Pojęcie „strategiczne partnerstwo" zostało zarezerwowane w Berlinie dla stosunków z mocarstwami o znaczeniu jednoznacznie globalnym (Rosja, ChRL). Polska nie była postrzegana w tych kategoriach, ani razu nie użyto wobec niej tego określenia ${ }^{112}$.

Nie może więc zaskakiwać, że PiS, przejmując rządy w Rzeczypospolitej, przestało używać takiej frazeologii, ponieważ nie tylko była fałszywa, ale też absolutnie nie wpływała na zrozumienie w Berlinie polskich interesów. W XXI wieku Polska i Niemcy nie przyjęły żadnego spektakularnego dokumentu projektującego jakiekolwiek wspólne działania na arenie międzynarodowej, wynikające ze zbieżności interesów lub takową ustanawiające. W odniesieniu do pierwszego celu (polsko-niemieckie partnerstwo) to PiS go odrzucało, postrzegając politykę Niemiec w kategoriach gry na "przemilczenie, przedawnienie i zapomnienie", jak to ujął w Sejmie poseł Arkadiusz Mularczyk ${ }^{113}$. Dla polskich konserwatystów spod znaku PiS w relacjach polsko-niemieckich istniały bardzo realne rozbieżności w sprawach doniosłych politycznie. PiS dostrzegało te rozbieżności, a politycy formacji głośno mówili o nich publicznie. Można by wymienić: kontrowersje wokół pamięci historycznej na temat II wojny światowej oraz jej skutków; rozbieżne koncepcje Unii Europejskiej; różnice w odniesieniu do Europy Wschodniej, w tym postrzegania Rosji; odmienne traktowanie stosunków transatlantyckich oraz wykonywania przez Stany Zjednoczone roli hegemona w stosunkach międzynarodowych; różnice co do możliwości rozszerzenia Unii o pań-

\footnotetext{
112 L. Czechowska, op. cit., s. 91 i n.

113 A. Mularczyk, Wypowiedź, [w:] WNPSejm, 8 kadencja, 60 pos., 21 III 2018, http://www. sejm.pl, dostęp 14 II 2020.
} 
stwa wschodnioeuropejskie ${ }^{114}$. Lista ta obejmuje kwestie o znaczeniu dla Polski podstawowym.

Natomiast co do drugiego celu (współdziałanie) to politycy PiS właśnie w tych obszarach dostrzegali zasadnicze różnice interesów między Polską a RFN. Przyjmując odmienną od liberalnej generalną perspektywę postrzegania Niemiec jako partnera Polski w stosunkach międzynarodowych, PiS zdecydowało się podnieść na forum parlamentarnym problem nierozliczenia II wojny światowej, a konkretnie sprawę niemieckich reparacji wobec Polski. PiS uczyniło z tej kwestii pole polaryzacji, uznając, że polskie roszczenia wojenne w kontekście materialnym i osobowym ani się nie przedawniły, ani nie zostały uregulowane. Oprócz akcji medialnej na rzecz tego tematu w środkach komunikacji społecznej sprzyjających rządom Zjednoczonej Prawicy, 29 września 2017 roku powołano w Sejmie VIII kadencji Parlamentarny Zespół ds. Oszacowania Wysokości Odszkodowań Należnych Polsce od Niemiec za Szkody Wyrządzone w trakcie II Wojny Światowej. Zakres działań Zespołu miał wyraźne poparcie zarówno prezesa Kaczyńskiego, jak i rządu Morawieckiego, a zajął się przede wszystkim obliczaniem skali polskich roszczeń wobec RFN. Celowo przyjęto więc taktykę lokalizacji tego tematu na forum parlamentarnym, a nie prezydenckim, czy też rządowym, aby nie obciążać nim bieżących relacji Polska-Niemcy ${ }^{115}$.

Prawo i Sprawiedliwość przyjęło dwa założenia w kwestii odszkodowań. Po pierwsze - uważano, że sprawa niemieckich odszkodowań za II wojnę światową jest nieuregulowana. Polska nie otrzymała ani reparacji wojennych przyznanych jej na konferencji w Poczdamie, ani adekwatnych odszkodowań wypłaconych przez RFN na mocy umowy podpisanej przez dwa suwerenne państwa. Takiej regulacji nie dokonano w umowie moskiewskiej w sprawie zjednoczenia Niemiec, zwanej traktatem „2+4". Wniosek dla polityków stronnictwa był jeden: Niemcy nie rozliczyły się z Polską za II wojnę światową, nie został bowiem zawarty żaden traktat

114 M. Stolarczyk, Gtówne problemy w stosunkach polsko-niemieckich..., s. 14-37.

115 Vide Morawiecki domaga się reparacji wojennych od Niemiec: Nie można tego tak zostawić, 22 VIII 2019, http://www.wprost.pl, dostęp 14 II 2020. 
pokojowy wielostronny lub dwustronny kończący tę wojnę. Natomiast po zjednoczeniu Niemiec, odzyskaniu przez Polskę i Niemcy suwerenności, wspólnym członkostwie w Unii i Sojuszu, problem powinien zostać rozwiązany. Członkostwo w obu organizacjach wymuszało uregulowanie tej kwestii przez Berlin na gruncie prawa międzynarodowego. Po drugie - uważano, że podjęcie tego tematu na arenie międzynarodowej przyniesie Rzeczypospolitej zyski zarówno w ujęciu długookresowym potencjalne odszkodowania, jak i w sensie operacyjnym i taktycznym, zwłaszcza w polityce historycznej, przypomni bowiem światu prawdę o tej wojnie w kontekście skutków i strat oraz charakteru niemieckiej polityki okupacyjnej na polskich ziemiach. Zamierzano także przeciwdziałać alternatywnym narracjom: niemieckiej, rosyjskiej i żydowskiej, w których Polska albo jawiła się jako ofiara najazdu nazistów/hitlerowców, bez narodowej i państwowej przynależności, niemal na równi z Niemcami, albo była współsprawcą wojny lub kolaborantem Hitlera, albo uczestnikiem pomocniczym Holokaustu dokonanego na narodzie żydowskim ${ }^{116}$.

Celem prac zespołu powołanego przez Sejm VIII kadencji było opisanie i oszacowanie tychże strat, stanu prawnego oraz wysokości potencjalnych reparacji, a politycy PiS kreślili przed opinią publiczną realność, zasadność i nieprzedawnienie tego typu oczekiwań. Głośnym echem medialnym odbiły się takie wypowiedzi J. Kaczyńskiego jak ta dla „Gazety Polskiej": „[...] dyskusja o reparacjach, a przez to o zniszczeniach wojennych, o tym, kto był katem, kto ofiarą, bardzo nam służy, bo godzi w narrację o beznarodowych nazistach, o symetryczność cierpień. Z tej drogi na pewno nie zejdziemy"117. W swoich wypowiedziach prezes stronnictwa zwracał uwagę także na inne konteksty żądań reparacyjnych. Pierwszy o charakterze utylitarnym: „Nadawanie rozgłosu sprawie reparacji to narzędzie informowania świata, jak wyglądała II wojna światowa". Drugi miał charakter aksjologiczny - rozliczenie się z II wojny światowej to

\footnotetext{
116 Vide A. Mularczyk, Wypowiedź, [w:] WNP Sejm, 8 kadencja, 78 pos., 14 III 2019, http:// www.sejm.pl, dostęp 14 II 2020.

117 Kaczyński o reparacjach: Mamy sygnat, że Niemcy traktują tę sprawę bardzo poważnie, 30 | 2018, http://www.wiadomosci.gazeta.pl, dostęp 14 || 2020.
} 
powinien być standard europejskości i wartość, na której należy budować integrację kontynentalną. Trzeci - odnosił się do postawy zarówno Zachodu, jak i Rosji. Chodziło o skutki działań radzieckich na ziemiach polskich w latach 1939-1945, dlatego Kaczyński mówił: „W żadnym wypadku nie możemy zaakceptować sytuacji, w której nie otrzymaliśmy rekompensaty nie tylko za niemieckie zbrodnie, lecz także za skutki działań ZSRR wobec Polski, na które Zachód się zgadzal"118. Dla całej formacji te słowa brzmiały jak dyrektywa polityczna, zachęcały do determinacji oraz były instrumentem ostrego dezawuowania polityki niemieckiej (i częściowo rosyjskiej) rządów zarówno lewicowych, jak i liberalnych w Polsce. Za podsumowanie racji prawnych podnoszonych przez polityków PiS mogą posłużyć słowa przewodniczącego Zespołu, posła PiS Arkadiusza Mularczyka: „Do dzisiaj Niemcy nie zawarły z Polską traktatu pokojowego, który kończyłby II wojnę światową, ani jakiejkolwiek innej umowy, która całościowo regulowałaby kwestię rozliczeń wynikających z II wojny światowej"119.

W dokumentach programowych PiS stosunki polsko-niemieckie nie były określane jako strategiczne partnerstwo, co zdecydowanie odróżniało tę konserwatywną partię od stronnictw lewicowych i liberalnych kształtujących politykę zagraniczną III Rzeczypospolitej wobec RFN, którą prezes Kaczyński nazwał w 2004 roku „aktem szaleństwa" ${ }^{120}$. Pięć lat później, w rocznicę wybuchu II wojny światowej, jego brat tak opisał stosunki dwustronne Warszawa-Berlin: „w słowach wszystko jest pięknie, no ale istnieją realne fakty". Liderom PiS chodziło przede wszystkim o dwa wielkie tematy: historyczny - odpowiedzialność Niemiec za wybuch II wojny światowej i wyrządzone krzywdy oraz inne skutki; wschodni - nieuwzględnianie przez Berlin polskich interesów na tym

118 Ibidem; Kaczyński mówi wprost: Powinniśmy dogadać się z Żydami ws. odszkodowań od Niemiec, 4 IV 2018, http://www.wiadomosci.radiozet.pl, dostęp 14 II 2020.

119 A. Mularczyk, Wypowiedź, [w:] WNP Sejm, 8 kadencja, 78 pos., 14 III 2019, http://www. sejm.pl, dostęp 14 II 2020.

120 J. Kaczyński, Reperowanie reparacji, „Gazeta Wyborcza”, 1 IX 2004, nr 205, s. 14. 
obszarze geograficznym na forum Unii Europejskiej i Sojuszu Północnoatlantyckiego ${ }^{121}$.

Generalną przyczynę takiego podejścia widocznego w myśli politycznej PiS do kwestii niemieckiej wskazał w 2010 roku Przemysław Żurawski vel Grajewski, pisząc, że w latach 2003-2004 Niemcy dokonały zmiany w polityce środkowoeuropejskiej i zrezygnowały ze wspierania Europy Środkowej na rzecz jej uprzedmiotowienia oraz wyraźnie postawiły na politykę włączania Rosji w sprawy tej części kontynentu i uznania specjalnych interesów Moskwy w Europie Wschodniej. Taka postawa oznaczała z jednej strony niemal automatycznie blokowanie aspiracji euroatlantyckich Ukrainy, Gruzji i Mołdawii, a z drugiej strony narzucanie Unii Europejskiej preferowania partnerstwa z Rosją, a nie z jej zachodnimi sąsiadami. Taką politykę Berlina Krzysztof Malinowski nazwał Russia first.

Według Żurawskiego vel Grajewskiego z tego powodu "polsko-niemiecka wspólnota interesów strategicznych ustała”, a „Niemcy z adwokata spraw polskich stały się przeciwnikiem strategicznych priorytetów Warszawy". Te priorytety dla Warszawy powinny być inne niż niemieckie. Polska jest zobowiązana wspierać politykę „otwartych drzwi" wobec państw wschodnioeuropejskich w odniesieniu do Sojuszu i Unii oraz angażować Brukselę w aktywną politykę na terenie tych państw w celu eliminowania ich związków z Rosją, a przynajmniej pokazywania, że opcja europejska ma sens. W przeciwnym razie społeczeństwa ukraińskie, gruzińskie i mołdawskie zwrócą się ze swoimi nadziejami do Rosji i zwyciężą tam partie filorosyjskie ${ }^{122}$.

W opinii PiS zamazywanie różnic między Berlinem a Warszawą utrudniało uporządkowanie stosunków polsko-niemieckich w odniesieniu do spraw nie tylko bieżących, ale też o znaczeniu strategicznym. Celem priorytetowym Polski powinno być zneutralizowanie skłonności Niemiec

\footnotetext{
121 Idem, Bezpieczeństwo kosztuje...

122 P. Żurawski vel Grajewski, Geopolityka - siła - wola..., s. 63, 367; Vide P. Zalewski, Dyplomacja w imię wartości, „Polski Przegląd Dyplomatyczny”, listopad-grudzień 2006, nr 6(34), s. 6-8; K. Malinowski, Polityka Niemiec wobec Europy Wschodniej: Russia first?, „Przegląd Politologiczny" 2015, nr 4, s. 19-32.
} 
do realizowania własnych interesów narodowych w kooperacji z Rosją z pominięciem Polski oraz jednoczesne opracowanie i zaproponowanie Niemcom koncepcji współpracy atrakcyjniejszej niż rosyjska ${ }^{123}$. Uważano, kierując się chociażby danymi gospodarczymi (wymiana handlowa, rynek pracy, inwestycje), że Polska może być takim partnerem dla Berlina, tylko trzeba nauczyć się wykorzystywać własne atuty.

Warto przywołać tytuł jednego z wywiadów Krzysztofa Szczerskiego, udzielonego po wygraniu wyborów prezydenckich przez Andrzeja Dudę: Nie jesteśmy niemieckim zasobem. W tym określeniu widać oczywiste nawiązywanie do stwierdzenia L. Kaczyńskiego, że Polska nie jest „krajem przybocznym" Niemiec ${ }^{124}$. Natomiast w samym orędziu inauguracyjnym prezydent Duda nie odniósł się w szczególny sposób do relacji polsko-niemieckich, odróżniając się tym samym od swoich poprzedników. W komentarzu do orędzia W. Waszczykowski zapowiedział zaś korektę polityki niemieckiej w wydaniu PiS, a dwa lata później określił istotę tej zmiany: „[...] oczekujemy od drugiej strony [Niemiec - W.P.] większej otwartości i zrozumienia dla polskich racji i naszego prawa do realizowania polskich interesów" ${ }^{\prime 25}$. W PiS uważano także, że współpraca z Niemcami postulowana przez rząd PO-PSL na wskazanych polach spowoduje podwójne, sprzężone ze sobą negatywne następstwa. Pierwsze - rozluźni związki polsko-amerykańskie, co było celem przypisywanym politykom PO. Tym bardziej że w kampanii wyborczej w 2007 roku podkreślali konieczność osiągnięcia równowagi w tym związku co do korzyści i partnerstwa, a zarazem sięgali do nastrojów antyamerykańskich oraz dawali pierwszeństwo współpracy gospodarczej przed polityczno-wojskową ${ }^{126}$.

123 Pawet Zalewski w "Poranku Radia TOK FM", 5 VII 2006, http://www.pis.org.pl, dostęp 12 I 2007.

124 K. Szczerski, Nie jesteśmy niemieckim zasobem [Wywiad Mariusza Staniszewskiego z Krzysztofem Szczerskim], „Wprost”, 17-23 VIII 2015, nr 34, s. 14; Ł. Warzecha, Lech Kaczyński. Ostatni wywiad..., s. 250.

125 Na czym ma polegać korekta Dudy? „Przekonać partnerów, aby zmienili swoją politykę”, 8 VIII 2015, http://www.tvn24.pl, dostęp 5 II 2020; Informacja Ministra Spraw Zagranicznych o zadaniach polskiej polityki w 2017 roku...

126 M. Migalski, Polityka zagraniczna w programie idziatalności Platformy Obywatelskiej, [w:] Platforma Obywatelska..., s. 107. 
Drugie - osłabi bezpieczeństwo Polski, gdyż - jak to ujął J. Kaczyński jest złudzeniem, że „Niemcy czy też Unia Europejska pod niemieckim przewodnictwem mogą nam zapewnić bezpieczeństwo"127.

Politycy PiS nie przywiązywali większej wagi do częściowego zwrotu, jaki dokonał się w Berlinie wobec Rosji po jej agresji na Ukrainę, kiedy rząd Angeli Merkel poparł politykę sankcji wobec Moskwy; niemniej nie porzucił projektu budowy Nord Stream, a to mógłby być test dla stosunków niemiecko-rosyjskich. Natomiast Niemcy zgadzały się, aby Moskwa wspierała ich politykę zagraniczną, w zamian aprobując paraliżowanie Europy Środkowej przez Kreml, przede wszystkim w sensie gospodarczym. Tym samym dla PiS te zmiany były tylko zręcznym taktycznym manewrem, mającym na celu podniesienie na Kremlu wartości partnerstwa niemiecko-rosyjskiego. Prezydent Duda docenił jednak publicznie znaczenie kanclerz Merkel dla polityki rosyjskiej, mówiąc: „[...] jedynym europejskim politykiem, który ma dziś choć minimalny wpływ na działania Władimira Putina, jest Angela Merkel. Jest ona także jednym z nielicznych polityków w Europie, którzy zdają sobie sprawę z zagrożenia, jakie współczesna Rosja stanowi dla Europy"128. W mniemaniu PiS między Warszawą a Berlinem istotną różnicą była reakcja na agresywną politykę Moskwy. Niemcy orędowały za polityką niekonfrontacyjną, podczas gdy według Polski taka słabość prowadziła do eskalacji zachowań Kremla. Ten sceptycyzm został potwierdzony, kiedy Merkel odrzuciła amerykański pomysł znacznego dozbrojenia Ukrainy. Kanclerz Niemiec miała obawy przed antagonizowaniem stosunków z Rosją, której interesy w Europie Wschodniej były uprawdopodobnione. Odmiennie do tej sprawy podchodziła formacja rządząca w Polsce, która optowała za realną pomocą Sojuszu dla Ukrainy. Takie oczekiwania ujawnił minister Macierewicz przed warszawskim szczytem Sojuszu, a dwa lata wcześniej

\footnotetext{
127 J. Kaczyński, Tusk powinien przyznać się do btędu [Rozmowa Jacka i Michała Karnowskich z Jarostawem Kaczyńskim], „Sieci”, 17-30 III 2014, nr 12(68), s. 27.

128 Archiwum Prezydenta RP, https://www.prezydent.pl, „Wywiad w »Polskim Przeglądzie Dyplomatycznym«", 23 X 2016, dostęp 12 VI 2020.
} 
mówił o tym Błaszczak: „Polska i inne kraje NATO powinny sprzedawać Ukrainie broń"129.

Według PiS polityka Berlina wobec Moskwy obiektywnie jest dla niej korzystna, gdyż zachęca ją do rozszerzania dążeń imperialistycznych, zwłaszcza w Europie Środkowej i Wschodniej, oraz uniemożliwia wspólną akcję Zachodu wobec Rosji. Zasadniczo w myśli politycznej PiS nie ma przyzwolenia na politykę zaspokajania Rosji. Takie podejście uważa się za nieefektywne, oparte na fałszywym przeświadczeniu, że wywoła zmiany demokratyczne w Rosji i doprowadzi do porzucenia przez Kreml imperializmu na rzecz wizji pokojowej Europy.

Natomiast w odniesieniu do Rosji PiS wychodziło z odmiennych niż PO przesłanek strategicznych. Stronnictwo J. Kaczyńskiego przypisywało cechę skuteczności polityce wschodniej opartej na dwóch filarach: 1) nieustępliwości wobec Rosji w sprawach o doniosłości strategicznej w stosunkach dwustronnych, na forum Unii Europejskiej i Sojuszu Północnoatlantyckiego, aby zmusić Moskwę do zmian w polityce zagranicznej i jednocześnie utrudnić jej porozumienie z Zachodem kosztem Europy Środkowej; 2) aktywnej polityce regionalnej w Europie Środkowej oraz wobec państw postradzieckich (europejskich i środkowoazjatyckich) w celu wzmocnienia ich podmiotowości, niezależności i suwerenności w relacjach z Rosją. Doświadczenia z okresu rządzenia w latach 20052007 utwierdziły PiS w niemal oczywistym przekonaniu, że bez zmian politycznych w Rosji jej polityka zagraniczna nie ulegnie zasadniczej rewizji, a ten proces nie dokona się w przewidywalnym czasie. Przyczynę tej sytuacji wyjaśniali specjaliści od stosunków polsko-rosyjskich, posługując się pojęciem asymetrii, wynikającej z dwóch powodów: 1) zasadniczej różnicy potencjałów politycznych na korzyść Rosji, która ma liczne możliwości kształtowania środowiska międzynarodowego; 2) twardej, niezmiennej strategii Rosji wobec Polski, opartej na przekonaniu, że suwerenność Polski powinna być ograniczona przez imperialne intere-

129 Vide Konferencja prasowa z sekretarzem generalnym NATO, 15 VI 2016, http://www.pap.pl, dostęp 30 I 2020; M. Błaszczak, Jesteśmy zaporą przed Rosją dla catej Europy, 4 IX 2014, http://www.wiadomosci.dziennik.pl, dostęp 5 II 2020. 
sy Moskwy ${ }^{130}$. Jednak, niezależnie od owej asymetrii, ogólną przyczyną trudności w relacjach dwustronnych była i jest sprzeczność interesów strategicznych między Warszawą a Moskwą.

Natomiast PO uznała konieczność porozumienia z Kremlem rządzonym przez W. Putina, bez żadnych oczekiwań strategicznych wobec Rosji oraz wpisanie się bez zasadniczych wątpliwości w politykę porozumienia Stanów Zjednoczonych i mocarstw europejskich z Moskwą, co oznaczało rezygnację z formułowania własnej polityki na odcinku rosyjskim. Liczono, że taki kierunek strategiczny z jednej strony umożliwi pragmatyczną współpracę polsko-rosyjską, mierzoną przede wszystkim zyskami ekonomicznymi, a z drugiej ograniczy wpływ czynników historycznych i emocjonalnych na stosunki dwustronne. Takie nastawienie otworzyło drogę do resetu polsko-rosyjskiego oraz usprawiedliwiało różne decyzje "rosyjskie" podejmowane przez rząd PO-PSL, a przede wszystkim przez ministra Sikorskiego. Chociażby w sprawach: tarczy antyrakietowej, negocjacji o wstąpienie Rosji do Organizacji Współpracy Gospodarczej i Rozwoju, agresji Rosji na Ukrainę, katastrofy smoleńskiej, wydarzeń symbolicznych, jak uczestnictwo Putina w obchodach 70. rocznicy wybuchu II wojny światowej oraz obecność ministra spraw zagranicznych Rosji Siergieja Ławrowa 2 września 2010 roku na naradzie ambasadorów RP ${ }^{131}$.

Sikorski pokusił się nawet o konceptualizację polityki rosyjskiej koalicji PO-PSL, co uczynił 29 sierpnia 2009 roku na łamach "Gazety Wyborczej" w słynnym artykule Lekcje historii, modernizacja i integracja. Ten tekst, podobnie jak późniejsza o ponad dwa lata (28 listopada 2011 roku) Mowa berlińska, stał się wykładnią polityki zagranicznej PO w odniesieniu do dwóch najsilniejszych sąsiadów: Rosji i Niemiec oraz polityki

130 M. Sabat, Stosunki polsko-rosyjskie. Rozbieżności interesów strategicznych, [w:] Polityka zagraniczna Federacji Rosyjskiej. Wybrane aspekty stosunków z Polską, Ukrainą i Biatorusią, red. L. Zyblikiewicz, M. Czajowski, P. Bajor, Wydawnictwo Uniwersytetu Jagiellońskiego, Kraków 2010, s. 120; S. Weremiuk, Polska wobec Rosji w latach 1992-2014. Od zależności postimperialnych do trudnych relacji. Analiza wybranych aspektów, „Przegląd Bezpieczeństwa Wewnętrznego" 2015, nr 13, s. 99.

131 O polityce rosyjskiej koalicji PO-PSL, a faktycznie premiera Tuska i ministra Sikorskiego, w: P. Żurawski vel Grajewski, Polska polityka wschodnia 1989-2015. Wymiar narodowy i unijny, Ośrodek Myśli Politycznej, Kraków 2016, passim. 
europejskiej w jej trzech segmentach: unijnym, środkowoeuropejskim i wschodnioeuropejskim ${ }^{132}$. Jak już wspomniano, Sikorski odrzucał politykę „,jagiellońską" na rzecz „piastowskiej", wychodząc z założenia, że Polska jest zbyt słaba, aby samodzielnie realizować wielkie cele strategiczne w polityce zagranicznej. Dlatego też powinna rezygnować z niezależnej aktywności w Europie Środkowej i Wschodniej, co uczyni możliwym z jednej strony reset z Rosją, a z drugiej sojusznicze oparcie się na Niemczech. Dokonał także wykładni owej polityki "piastowskiej” jako zacieśniania relacji Polski z Niemcami (w mniejszym stopniu z Francją), czyli przejście na pozycje koncyliacyjne wobec Rosji. Oba przywołane państwa opowiadały się bowiem wówczas za "europeizacją" Rosji i normalizacją relacji z nią, niezależnie od odradzania się rosyjskiego imperializmu. Linia "piastowska” w polityce zagranicznej Polski miała oznaczać orientację strategiczną na sojusz z Berlinem ${ }^{133}$.

Oczywiście pewnym nadużyciem, a na pewno ahistoryzmem, była nadinterpretacja przymiotników „piastowski” i „jagielloński”. Wydaje się, że Sikorski starał się przeciwstawić chrzest z 966 roku, postrzegany jako pierwowzór akcesji do Unii, ekspansji na Wschód, co w kontekście wiedzy historycznej było fałszem. Najwybitniejsi Piastowie prowadzili bowiem ekspansję zarówno na Zachód, jak i na Wschód, czerpiąc z tych dwóch kręgów kulturowych, które wtedy były zasadniczo zbieżne (Ruś Kijowska wchodziła w liczne związki z rzymskim kręgiem kulturowym). Niemal identycznie rzecz się miała z Jagiellonami, prowadzącymi swoją politykę dynastyczną na wszystkich geograficznych azymutach. Sikorskiemu w polityce „jagiellońskiej” na pewno nie pasowały jej dwie cechy: bezdyskusyjna dominacja Królestwa Polskiego nad państwowością prusko-niemiecką oraz wielki rozmach w kreśleniu celów strategicznych w odniesieniu do całej Europy Środkowej. Dla liderów PO nie do przyjęcia była taka linia strategiczna w polityce zagranicznej, o istocie której

\footnotetext{
132 R. Sikorski, Lekcje historii, modernizacja i integracja..., s. 3.

133 J. Kubera, Polska „piastowska” vs. „jagiellońska”. Odmienność wizji relacji z Niemcami jako determinanta poglądów na polską politykę zagraniczna, "Acta Politica Polonica” 2016, nr 4(38), s. 66; D. Pietrzyk-Reeves, The Revivals of the Jagiellonian Idea. Political and Normative Contexts, „Politeja” 2017, nr 51, s. 89-90.
} 
pisał Łukasz Warzecha: „[...] Polska jest graczem na tyle silnym, iż może zadziałać jak ośrodek krystalizacji dla państw o podobnych interesach w naszym regionie oraz dodatkowo stworzyć własną siatkę interesów w dalszych częściach świata - choćby w bogatym energetycznie regionie Kaukazu"134. Tak wzmocniona Polska mogłaby podjąć efektywną grę chociażby w Unii Europejskiej, ale także wobec Rosji i Niemiec.

Jednak ani polityka PiS nie była „jagiellońska", ani polityka PO nie stała się „piastowska”. Natomiast dla J. Kaczyńskiego odrzucenie polityki „jagiellońskiej" w tej formie, w jakiej to uczynił Sikorski, czyli niemal w tym samym czasie, kiedy Putin na Westerplatte zaprezentował rosyjską wykładnię historii, było nie do przyjęcia z trzech bardzo istotnych powodów. Było: 1) uzasadnianiem likwidacji II Rzeczypospolitej; 2) uznaniem Rosji za państwo demokratyczne, uprawnione do kształtowania stosunków w Europie; 3) przyznaniem, że o statusie Europy Środkowej mogą decydować Rosja i Niemcy ${ }^{135}$.

Warto jeszcze zauważyć, że linia strategiczna w polityce zagranicznej proponowana przez Sikorskiego była zasadniczo sprzeczna z teorią stosunków międzynarodowych przynajmniej w czterech kwestiach. Po pierwsze, obowiązkiem każdego państwa jest poszukiwanie wszelkich możliwych środków, aby zwiększać swój potencjał polityczny poprzez zawłaszczanie kolejnych dotychczas niedostępnych zasobów, co oznacza porzucenie minimalizmu w wyznaczaniu celów, gdyż to prowadzi do demobilizacji i dekoncentracji politycznej, której efektem jest popadnięcie w zależności klientystyczne i redukcja podmiotowości. Po drugie, cechą środowiska międzynarodowego jest hierarchizacja i dynamika. $Z$ tego powodu pasywizm w polityce zagranicznej każdego państwa prowadzi do degradacji w hierarchii, która poprzedza utratę pozyskanych już zasobów. Po trzecie, potencjał Polski w porównaniu z innymi państwami położonymi w regionie środkowoeuropejskim niejako wskazywał na

134 Ł. Warzecha, O wypetnianiu przez Polskęjejpotencjału, Ośrodek Myśli Politycznej, http:// omp.org.pl, dostęp 20 V 2020.

135 J. Kaczyński, Piłsudskim nie jestem, zgodzę się na przyśpieszone wybory, [w:] Dwa ognie. Wywiady [przeprowadzili Anita Werner i Paweł Siennicki], Wydawnictwo Literackie, Kraków 2010, s. 135. 
nią jako na lidera. Niepodjęcie tej roli oznaczałoby, że Europa Środkowa utraci swoje znaczenie, ponieważ na nowo zostanie podzielona na dwie części: jedną przynależną do Europy Zachodniej, a drugą do Europy Wschodniej. Po czwarte, rezygnacja przez Polskę z aspiracji w Europie Środkowej i wobec Europy Wschodniej zdecydowanie osłabiała Rzeczpospolitą w stosunkach dwustronnych przede wszystkim ze Stanami Zjednoczonymi, ale również z innymi partnerami, pozbawiała ją bowiem ważnego atutu, możliwego do wykorzystania w bieżącej polityce i rozwiązywaniu sytuacji kryzysowych.

W artykule opublikowanym w "Gazecie Wyborczej" Sikorski sformułował najbardziej kontrowersyjny osąd, że Rosja, na podobieństwo Niemiec, hołduje wartościom właściwym dla demokracji i kieruje się w polityce zasadami demokratycznymi, co miało uzasadniać konieczność dokonania rewizji „autoidentyfikacji politycznej" Polski oraz jej polityki zagranicznej, która w przeszłości wynikała z przesłanek „mocarstwowych i agresywnych"136. Kilka miesięcy wcześniej minister Sikorski ogłosił jeszcze bardziej kontrowersyjny postulat - rozważenia w przyszłości akcesji Rosji do Sojuszu Północnoatlantyckiego. Owszem, zastrzegał, że jest to kwestia hipotetyczna, ale uznał, że Rosja jest potrzebna do rozwiązywania problemów europejskich i globalnych. Uzasadnienie dla swojego konstruktu myślowego ogłosił 5 lutego 2010 roku, w przeddzień 46. Monachijskiej Konferencji o Bezpieczeństwie, mówiąc, że przyjęcie Rosji do Sojuszu przyniesie stabilność i bezpieczeństwo regionom, "gdzie dotychczas nie było ani jednego, ani drugiego", a także będzie „obiecujące" dla Polski ${ }^{137}$. Sprawa była o tyle istotna, że Sikorski aspirował do objęcia stanowiska sekretarza generalnego Paktu Północnoatlantyckiego, i z tego powodu przeszedł na pozycje filorosyjskie. Jego wypowiedzi wskazywały więc potencjalny kierunek ewolucji Paktu Północnoatlantyckiego, sugerowany przez prominentnego polityka PO.

136 R. Sikorski, Lekcje historii, modernizacja i integracja..., s. 3.

137 Idem, Rosja w NATO? Czemu nie, "Gazeta Wyborcza”, 31 III 2009, nr 73, s. 3; Sikorski: Rosja powinna być w NATO, 5 II 2010, http://www.tvn24.pl, dostęp 10 III 2020. 
Jednocześnie rząd koalicji PO-PSL przystał na porozumienia między Rosją a Unią Europejską w latach 2009-2010, na mocy których ustanowiono „partnerstwo dla modernizacji”. Unia wycofała się z krytyki Rosji oraz uznała ograniczoną suwerenność Ukrainy co do jej kursu zachodniego ${ }^{138}$. Porozumienie Rosja-UE w połączeniu z resetem w stosunkach amerykańsko-rosyjskich dawały Moskwie inicjatywę strategiczną oraz stwarzały jej możliwości penetracji Europy Środkowej, przy milczącej aprobacie tzw. Zachodu.

Prawo i Sprawiedliwość nie tylko odrzucało tezy Sikorskiego, ale też zajmowało skrajnie odmienne stanowisko we wszystkich wskazanych sprawach. Stronnictwo uważało, że: 1) polityka zagraniczna Polski powinna być oparta na linii strategicznej wyznaczonej jeszcze w latach międzywojennych oraz na doświadczeniach historycznych poddanych analizie pod kątem stosunków polsko-rosyjskich i polsko-niemieckich; 2) Sojusz Północnoatlantycki miał zapewniać Polsce bezpieczeństwo od strony Rosji, a nie stać się forum uzgadniania z nią sposobów rozwiązywania najważniejszych problemów współczesnego świata; 3) zmiany w Organizacji Paktu powinny iść w kierunku zwiększenia jego zdolności reagowania na rosyjskie zagrożenie dla Europy. Jeśli weźmiemy pod uwagę rozmach polityki zagranicznej Polski projektowanej przez PiS, to była ona i "piastowska", i „jagiellońska", z jedną uwagą - co do podmiotowości politykom PiS było znacznie bliżej do domu Jagiellonów niż Piastów, ale należy pamiętać, że obie dynastie panowały w Królestwie Polskim w odmiennych warunkach systemowych. Pierwsi w monarchii patrymonialnej, kiedy to ród panujący podejmował decyzje międzynarodowe, a drudzy w monarchii stanowej, kiedy został już ukształtowany dogmat Korony Królestwa Polskiego, a rada królewska, sejmiki i sejm walny uzyskały wpływ na konkretyzację racji stanu Królestwa.

Już u progu ogłoszenia przez rząd D. Tuska szybkiej i efektywnej poprawy w stosunkach z Rosją, PiS uznało to za niemożliwe do wykonania. W imieniu Klubu Parlamentarnego PiS poseł Paweł Kowal mówił w tym kontekście w Sejmie 7 maja 2008 roku w czasie dyskusji o informacji

138 S. Weremiuk, op. cit., s. 103. 
ministra Sikorskiego na temat założeń polskiej polityki zagranicznej: „[...] nie można składać obietnic, których potem nie da się spełnić. Nie można stwarzać iluzji"139. Polityka resetu była interpretowana przez PiS jako „konwergencja polskiej polityki z priorytetami polityki Rosji przy jednoczesnym zaniedbywaniu sojuszu ze Stanami Zjednoczonymi" oraz dostosowywanie się do stylu polityki modnego w Niemczech, wywodzącego się z ducha rozbrojenia, co uważano za działanie nie tylko krótkowzroczne, ale również samobójcze, a przede wszystkim bez żadnych realnych skutków. Na niemiecki kontekst resetu zwrócił uwagę też W. Waszczykowski, wskazując, że taka polityka miała spowodować przychylność Niemiec dla Polski jako państwa, które przestało się kierować rusofobią, a może być dopełnieniem osi Berlin-Moskwa. Efekt był odwrotny - Polska nie stała się partnerem w tym trójkącie, a dodatkowo doszło do jej alienacji od regionalnego sąsiedztwa.

W opinii PiS polityka resetu nie przyniosła żadnych pozytywnych skutków ani w sensie ogólnym, ani w odniesieniu do spraw szczegółowych. Jak to ujęła Grażyna Gęsicka w 2010 roku: „Nowy styl polskiej polityki wobec Rosji nie zrobił wielkiego wrażenia na jej przywódcach traktujących Polskę jako drugorzędnego partnera". Natomiast kwestiami szczegółowymi zajął się w 2013 roku poseł Waszczykowski, mówiąc: "Oba rządy, polski i rosyjski, stworzyły iluzję procesu pojednania", a faktycznie konkretne problemy nie są wyjaśniane i regulowane, lecz „zamiatane pod dywan”. Konkludował więc: „Większość dzielących nas spraw nie została rozwiązana i nie widać żadnej perspektywy na pozytywne rozstrzygnięcie". Koronnym przykładem przywołanym przez posła była sprawa zwrotu wraku samolotu z katastrofy smoleńskiej ${ }^{140}$.Zapowiada-

139 P. Kowal, Wystąpienie w czasie dyskusji na temat informacji ministra spraw zagranicznych o założeniach polskiej polityki zagranicznej w 2008 roku, [w:] SS Sejm, 6 kadencja, 15 pos., 7 V 2008, s. 20, http://orka2.sejm.gov.pl, dostęp 15 III 2020.

140 G. Gęsicka, Wystąpienie w czasie dyskusji na temat informacji ministra spraw zagranicznych o założeniach polskiej polityki zagranicznej w 2010 roku, [w:] SS Sejm, 6 kadencja, 64 pos., 8 IV 2010, s. 148, http://orka2.www.sejm.gov.pl, dostęp 4 V 2019; W. Waszczykowski, Wystąpienie w czasie dyskusji na temat informacji ministra spraw zagranicznych o zatożeniach polskiej polityki zagranicznej w 2013 roku, [w:] SS Sejm, 7 kadencja, 36 pos., 20 III 2013, s. 17, http://orka2.sejm.gov.pl, dostęp 15 III 2020. 
ne pozytywne rozstrzygnięcie nie mogło się dokonać również z powodu błędnych ustaleń, które poczynił minister Sikorski. Przyjął, że normalizacja w stosunkach polsko-rosyjskich jest możliwa, jeżeli zaakceptuje się charakterystyczny dla Rosji system wartości, jej tradycję i kod kulturowy ${ }^{141}$. Błąd wynikał z ignorancji na dwóch polach. Po pierwsze, cechą wyróżniającą nacjonalizm i imperializm rosyjski był antypolonizm, w nowoczesnej formie wykrystalizowany w ostatnich dekadach XIX wieku oraz ugruntowany w ZSRR za czasów Józefa Stalina. Po drugie, fundamentem rosyjskiej kultury strategicznej jest zasada, że Rosja prowadzi dialog jedynie w gronie mocarstw, to z nimi stara się uzgadniać skalę realizacji swoich interesów; państwa małe i średnie są na Kremlu ignorowane ${ }^{142}$.

Waszczykowski w wystąpieniu sejmowym przyrównywał politykę prowadzoną przez Tuska i Sikorskiego z jednej strony do zachowań dyplomacji z czasów PRL, a z drugiej strony do naśladowania zachodnioeuropejskiej poprawności politycznej. Pierwszą charakteryzowała uległość wobec zewnętrznego ośrodka dyspozycji - rolę Moskwy przejęły Bruksela i Berlin. Poprawność polityczna zaś dokonała spustoszenia w myśleniu politycznym, zwłaszcza o środowisku międzynarodowym i polityce zagranicznej. W zamian za politykę resetu PiS proponowało konsekwentne zmniejszanie wpływów Moskwy w Polsce w każdej sferze, a jednocześnie oskarżało koalicję PO-PSL o działania w odwrotnym kierunku ${ }^{143}$. Waszczykowski zaprezentował z trybuny sejmowej dwa uzasadnienia dla odrzucenia polityki resetu. Pierwsze w 2016 roku w Sejmie, kiedy jako minister spraw zagranicznych wspominał: „[...] naiwnością była wiara,

\footnotetext{
141 Vide Informacja rządu na temat polskiej polityki zagranicznej w 2008 roku przedstawiona przez ministra spraw zagranicznych Radostawa Sikorskiego na posiedzeniu Sejmu 7 maja 2008 roku, „Roczniki Polskiej Polityki Zagranicznej” 2009, s. 15.

142 VideS. Weremiuk, op. cit., s. 102; A. Walicki, Między polskim mesjanizmem a misjonizmem [Rozmowa z Andrzejem Walickim], „Teologia Polityczna" 2006-2007, nr 4, s. 32, 37-38.

143 W. Waszczykowski, Wypowiedź, [w:] WNP Sejm, 8 kadencja, 78 pos., 14 III 2019, http:// www.sejm.pl, dostęp 14 II 2020; M. Gosiewska, Wypowiedź, [w:] WNPSejm, 8 kadencja, 78 pos., 14 III 2019, http://www.sejm.pl, dostęp 14 II 2020; J. Kaczyński, Polska naszych marzeń..., s. 20; K. Szczerski, Polską rządzą dzicy [Wywiad Jacka i Michała Karnowskich z Krzysztofem Szczerskim], „Sieci”, 27 X-2 XI 2014, nr 44, s. 30.
} 
którą okazywał kilka lat temu jeden z moich poprzedników [Radosław Sikorski - W.P.], że Rosja hołduje wartościom demokratycznym i zasadom prawa międzynarodowego. Postulował wtedy zaproszenie jej do NATO". Drugie w 2019 roku jako poseł w debacie sejmowej: „Nie ulegajmy więc mitom, że poprzez spolegliwe zachowanie wobec Moskwy - ta koncepcja: nasza chata z kraja - zdobędziemy przychylność, korzyści gospodarcze i uznanie w zachodnich stolicach. Tę politykę, nazwijmy ją trochę polityką appeasementu, bez powodzenia ćwiczył poprzedni rząd, PO-PSL"144.

Krytykując politykę PO resetu z Rosją, oprócz stawiania zarzutu naiwności, odwoływano się także do racjonalności i realizmu. Uważano, że reset w wydaniu amerykańskim wynika z kalkulacji politycznych obcych polskim interesom. Chodziło o pozyskanie przez Waszyngton Moskwy do walki z fundamentalistycznym islamem oraz do powstrzymywania dążenia Chin do uzyskania statusu supermocarstwa ${ }^{145}$. Natomiast dominacji takiej linii strategicznej w polityce zagranicznej Stanów Zjednoczonych Polska powinna przeciwdziałać, a nie się do niej dostosowywać, negliżuje ona bowiem zagrożenie rosyjskie dla bezpieczeństwa globalnego. Ani wzrostu międzynarodowego znaczenia ChRL, ani aktywności islamskich ruchów fundamentalistycznych nie postrzegano w kategoriach źródeł bezpośredniego zagrożenia dla Polski. Nie widziano obiektywnych szans na powodzenie polityki resetu, ponieważ Rosja, akceptując ofertę amerykańską, nie zmieniła swojej strategii, istniała natomiast obawa, że wykorzysta odprężenie w stosunkach z Waszyngtonem, tak jak niegdyś ZSRR, do rozbudowy potęgi militarnej i zawłaszczenia kolejnych

144 W. Waszczykowski, Informacja ministra spraw zagranicznych o zadaniach polskiej polityki zagranicznej w 2016 roku, [w:] SS Sejm, 8 kadencja, 10 pos., 29 I 2016, s. 73, http://orka2.sejm.gov.pl, dostęp 4 V 2019; idem, Wypowiedź, [w:] WNP Sejm, 8 kadencja, 78 pos., 14 III 2019, http://www.sejm.pl, dostęp 14 II 2020. W 2010 roku prezydent Kaczyński jednoznacznie odrzucił swoisty pomyst R. Sikorskiego przyjęcia w przyszłości Rosji do Sojuszu. Uczynił tak w rozmowie z Andersem Fogh Rasmussenem 12 marca. Powiedziat, że „Rosja nie powinna być członkiem NATO. [...] Jednocześnie zaznaczyt, że nie neguje konieczności współpracy NATO z Rosją [...]". Archiwum Prezydenta RP, https://www.prezydent.pl, „Rozmowa prezydenta Lecha Kaczyńskiego z Andersem Fogh Rasmussenem", 12 III 2010, dostęp 10 X 2019.

145 P. Żurawski vel Grajewski, Geopolityka - siła - wola..., s. 59. 
zasobów $^{146}$. Istota realizmu PiS wobec Rosji została ujęta przez premiera Morawieckiego w 2018 roku: „[...] chcemy jak najbardziej przyjaznych stosunków ze wszystkimi sąsiadami, również z Rosją, ale nie jesteśmy naiwni. Jesteśmy realistami i te przyjazne stosunki w przyszłości najlepiej jak byłyby wzmocnione poprzez naszą siłę militarną i solidarność Sojuszu Transatlantyckiego"147.

Wychodząc od takich przesłanek, PiS odniosło się bardzo negatywnie do diagnoz stosunków polsko-rosyjskich dokonywanych przez rządy koalicyjne PO-PSL i nie traktowało ich w kategoriach pożądanej normalizacji, lecz nieusprawiedliwionych ustępstw. Zaproponowało zasadniczo odmienną ocenę Rosji. Najbardziej miarodajny był w tym aspekcie dokument z 2017 roku Koncepcja obronna Rzeczypospolitej Polskiej. Został przygotowany przez ministerstwo kierowane przez A. Macierewicza na podstawie strategicznego przeglądu obronnego rozpoczętego w lipcu 2016 roku. Uznano w nim jednoznacznie zagrożenie rosyjskie za pierwszoplanowe i oskarżono poprzedników o nieprzeprowadzenie właściwych analiz i oszacowań ${ }^{148}$. Patrząc z tej perspektywy, Polska nie mogła popierać resetu w stosunkach amerykańsko-rosyjskich. W ten sposób dezawuowano strategię polityczną rządów koalicji PO-PSL. Uczynił to już w 2014 roku w sposób bardzo ostry i niebudzący wątpliwości o kierunku zmiany po ewentualnym przejęciu władzy w Polsce Jarosław Kaczyński: „Byłoby dobre dla przyszłości kraju przyznanie, że teza ekipy Tuska, iż można się dogadać z Rosją na równych prawach, że można ten kraj traktować jak zwykłego sąsiada, była błędna i przyniosła wiele szkód. Polska zmarnowała dużo czasu, osłabiła więzi z innymi państwami regionu". Zamiast resetu PiS zaproponowało inny model polityki wobec Rosji. Jego credo określił we wspomnianym wywiadzie J. Kaczyński: „Widać jak na

146 Archiwum MSZ, sygn. 140/09, w. 2, „Notatka informacyjna nt. polityki zagranicznej Federacji Rosyjskiej w okresie prezydentury Wtadimira Putina", luty 2006, s. 2, 4.

147 Wywiad premiera dla tvp.info, 27 III 2018, http://www.premier.gov.pl, dostęp 2 II 2020.

148 Koncepcja Obronna Rzeczypospolitej Polskiej, MON, Warszawa 2017, s. 6, http://www. mon.gov.pl, dostęp 2 II 2020. Więcej informacji w: A. Legucka, Dylemat bezpieczeństwa w stosunkach polsko-rosyjskich po 2014 roku, "Studia Politologiczne” 2018, vol. 49, s. 97 in. 
dłoni, że nasza diagnoza, iż w tym pokoleniu nie da się dogadać na równych prawach z Rosją, że należy twardo myśleć o własnym bezpieczeństwie [...] była słuszna i dobra dla Polski"149.

To credo wynikało nie tylko z przemyśleń teoretycznych, analizy historycznej i geopolitycznej prezesa partii, ale również z doświadczeń lat 2005-2007, kiedy urząd ministra spraw zagranicznych wykonywali kolejno Stefan Meller i Anna Fotyga, a prezydentem był Lech Kaczyński. O ile pierwszy minister miał za zadanie ustalić możliwość normalizacji stosunków polsko-rosyjskich na warunkach partnerskich i suwerennych, o tyle minister Fotyga nie podejmowała się takiego sondowania. Jarosław Kaczyński uznał bowiem, że taka normalizacja w przewidywalnym czasie historycznym jest niemożliwa. W swoim exposé Kaczyński taką właśnie ocenę sugerował, że ustanowienie partnerskich stosunków Polski z Rosją będzie "prawdopodobnie długotrwałe, tak się po prostu układa historia tej części Europy”. Podobne poglądy można przypisać L. Kaczyńskiemu. Wprawdzie prezydent twierdził, że „nie ma obiektywnych powodów, dla których stosunki polsko-rosyjskie nie mogłyby być dobre", ale już sama forma językowa (podwójne zaprzeczenie i tryb przypuszczający) jednoznacznie wskazywała na małą realność takiego planu ${ }^{150}$.

Pierwszy wariant w stosunkach polsko-rosyjskich realizowany przez Warszawę w latach 2005-2007 zakończył się porażką, czego symbolicznym potwierdzeniem była dymisja Mellera ze stanowiska ministra spraw zagranicznych. Odszedł polityk, który uważał, że dla normalizacji bieżących stosunków na linii Warszawa-Moskwa należy: zrezygnować z kontrowersyjnych tematów historycznych, używać koncyliacyjnego języka, nie eskalować konfliktu z Rosją i jej nie izolować, uzgadniać stanowisko wewnątrz Unii co do polityki wobec Rosji ${ }^{151}$. W ocenie liderów PiS przyjęta strategia nie mogła przynieść żadnych efektów i ich nie przyniosła, niemniej z niej skorzystano, zdobywając istotną wiedzę diagnostyczną. Taka

\footnotetext{
149 J. Kaczyński, Tusk powinien przyznać się do btędu..., s. 27.

150 Idem, Przedstawienie przez prezesa Rady Ministrów programu działania Rady Ministrów z wnioskiem o udzielenie jej wotum zaufania, [w:] SS Sejm, 5 kadencja, 22 pos., 19 VII 2006, s. 175, http://orka2.www.sejm.gov.pl, dostęp 7 V 2019; Warto być Polakiem..., s. 48.

151 A. Orzelska-Stączek, Uwarunkowania polskiej polityki zagranicznej..., s. 206.
} 
opinia z czasem ulegała wzmocnieniu i doprowadziła do pojawienia się w programie z 2011 roku stwierdzenia: „Wydarzenia ostatnich lat i miesięcy umacniają nas jednak w wyrobionym już przedtem realistycznym przekonaniu, że istotna poprawa stosunków polsko-rosyjskich możliwa jest tylko w dłuższej perspektywie". Dość ciekawe było wskazanie szansy na zaistnienie takiej perspektywy - nie zależała ona od demokratyzacji Rosji, ale od wzmacniającej się pozycji Polski w środowisku międzynarodowym ${ }^{152}$.Zmiany polityczne w Rosji nie były traktowane jako warunek konieczny porozumienia polsko-rosyjskiego.

Swoisty eksperyment w postaci "misji Mellera” jest dość istotny, obala bowiem tezę, niepopartą żadnymi danymi źródłowymi, że cechą charakterystyczną, wręcz ideologiczną i emocjonalną, polityki zagranicznej PiS była "programowa antyrosyjskość czy wręcz rusofobia”, oparta na apriorycznym założeniu, że Rosja jest „wrogiem zewnętrznym o ponadczasowym charakterze". Takie przekonania miały charakteryzować polski populizm, którego emanacją miał być $\mathrm{PiS}^{153}$. Tej tezy nie można obronić w kontekście polskich doświadczeń z polityką zagraniczną Rosji w latach 2008-2019. Natomiast oczekiwanie, że obowiązkiem Polski w relacjach z Rosją jest branie pod uwagę jej interesów, jest co najmniej zaskakujące w odniesieniu do stosunków międzynarodowych, zważywszy na ich charakter oraz skłonność Rosji do łamania prawa międzynarodowego. Pośrednio istnienie „misji Mellera” potwierdził Paweł Kowal, który tłumaczył także, jakimi przesłankami kierowało się kierownictwo PiS, próbując dokonać normalizacji w stosunkach z Rosją. Wyjaśniał: „Kaczyński [Lech - W.P.] liczył, że w bardziej bezpośrednim kontakcie, jako polityk nieobciążony skazą PZPR, będzie mógł porozumieć się z Putinem. [...] dopiero po nieudanych próbach porozumienia się z Rosją i określenia na nowo zasad polityki na Wschodzie, Lech Kaczyński zdecydował się na podjęcie gry polegającej na powstrzymaniu ekspansywnej polityki rosyj-

Nowoczesna, solidarna, bezpieczna Polska..., s. 222.

153 M. Stolarczyk, Rosja w polityce zagranicznej Polski..., s. 199-200, 277. Populizm zostat przypisany myśli politycznej PiS przez Ludwika Habudę. Vide L. Habuda, Prawa i Sprawiedliwości Rzeczpospolita Polska. Aksjologia, ustrój, uprawianie polityki, obywatelskie społeczeństwo, Wydawnictwo Uniwersytetu Opolskiego, Opole 2010, passim. 
skiej"154.Z Warszawy na początku 2006 roku były więc wysyłane sygnały o możliwości złożenia przez Putina wizyty w Polsce lub odbycia takiego spotkania w państwie trzecim, jednak Kreml nie podjął tej inicjatywy ${ }^{155}$. Wyjaśnienia P. Kowala są jak najbardziej zasadne i pokazują charakter zwrotu wykonanego przez PiS wobec Rosji w 2006 roku.

Politycy PiS wahali się między uznaniem Rosji za państwo o sprzecznych z Polską interesach albo za mocarstwo nieakceptujące suwerenności, niepodległości i podmiotowości Polski. Po wydarzeniach w Gruzji w 2008 roku zaczynała przeważać w stronnictwie opinia J. Kaczyńskiego: „Póki w Moskwie nie zrozumieją, że idea przywrócenia dominacji w tej części Europy, także dominacji wobec Polski, to jest niebezpieczna także dla Rosji imaginacja, nasz status jako państwa niepodległego, jako podmiotu polityki międzynarodowej nie zostanie do końca wyjaśniony". Według niego Moskwa musi „ostatecznie uświadomić sobie, że o powrocie [...] do jakiejkolwiek formy dominacji nie ma już mowy"156.

Minister Meller w swojej polityce zagranicznej przyjął fałszywe założenie: „w naszych stosunkach z Rosją nie istnieją żadne obiektywne uwarunkowania i przesłanki, które przeszkadzałyby dobrosąsiedzkiej współpracy, opartej na racjonalnie formułowanych interesach państwowych"157. Podobnie prezydent Kaczyński nie doceniał obiektywnych przesłanek determinujących rozwój polsko-rosyjskich relacji w kierunku konfliktowym. Nie było możliwe pogodzenie strategicznych interesów, ukształtowanych historycznie z uwzględnieniem geopolityki, Warszawy i Moskwy ani w ujęciu regionalnym (środkowoeuropejskim), ani kontynentalnym (europejskim i transatlantyckim). Polska i rosyjska racje sta-

154 P. Kowal, Wielki powrót geopolityki iwschodnia idea Lecha Kaczyńskiego, [w:] Polska wgrze międzynarodowej..., s. 54, 68.

155 Możliwość spotkania z Putinem w Warszawie sugerował L. Kaczyński w wywiadzie dla TVN24. Lech Kaczyński dobre stosunki z sąsiadami i USA; wcześniejsze wybory parlamentarne są możliwe, 26 I 2006, http://www.pap.pl, dostęp 12 V 2013; vide S. Cenckiewicz, A. Chmielecki, op. cit., s. 218.

156 J. Kaczyński, Wystąpienie w debacie nad informacją ministra spraw zagranicznych o podstawowych kierunkach polityki zagranicznej Polski w 2004 roku...

157 S. Meller, Informacja ministra spraw zagranicznych o zadaniach polskiej polityki zagranicznej w 2006 r...., s. 12. 
nu, tak jak je interpretowały elity polityczne PiS oraz rosyjskie skupione wokół prezydenta Putina, były kolizyjne, niemożliwe do jednoczesnego urzeczywistnienia. Kurs kolizyjny uwidocznił się wyraźnie w okresie 2005-2007 w kilku fundamentalnych obszarach - w odniesieniu do: 1) wspólnego sąsiedztwa, czyli statusu państw położonych między Polską a Rosją; 2) roli Europy Środkowej w globalnym i kontynentalnym ładzie politycznym; 3) aktywności Polski i Rosji w Europie Środkowej; 4) polityki energetycznej; 5) obecności militarnej Stanów Zjednoczonych w Europie Środkowej; 6) oceny przeszłości, zwłaszcza faktów ze stosunków dwustronnych.

Oprócz kolizji w tych konkretnych obszarach należy również porównać: po pierwsze - dokumenty strategiczne przyjęte przez Rosję i przez Polskę za rządów PiS (2005-2007 i 2015-2019) oraz po drugie - wypowiedzi W. Putina i L. Kaczyńskiego w dniach 31 sierpnia-1 września 2009 roku w związku z 70. rocznicą wybuchu II wojny światowej.

W 2000 roku Rosja konsekwentnie przyjęła kurs na odzyskanie statusu mocarstwa światowego na podobieństwo ZSRR oraz rozbicie systemu euroatlantyckiego. Wtedy to zaktualizowano doktrynę polityki zagranicznej Rosji, dostosowując ją do koncepcji multipolaryzmu, ogłoszonej w 1996 roku przez ówczesnego ministra spraw zagranicznych Jewgienija Primakowa. Rosja uznała też, że może stosować siłę w obronie swoich żywotnych interesów oraz praw Rosjan zamieszkujących w innych państwach, jednocześnie przyznając sobie swobodę w decydowaniu o zaistnieniu takiej sytuacji ${ }^{158}$. Owszem, obaj bracia Kaczyńscy uważali, że

158 R. Zięba, Teoria bezpieczeństwa państwa w ujęciu neorealistycznym..., s. 27. Na temat polityki zagranicznej Rosji po 2000 roku w: J. M. Fiszer, Zadania i cele polityki zagranicznej Wtadimira Putina..., s. 167-201; J. Koralewski, Rozpad ZSRR a powstanie Federacji Rosyjskiej. Mocarstwowość utracona?, [w:] Mocarstwowość na przetomie XX i XXI wieku. Teorie - analizy-prognozy, red. S. Wojciechowski, M. Tomczak, Wyższa Szkoła Nauk Humanistycznych i Dziennikarstwa w Poznaniu, Poznań 2010, s. 129-145; Polityka zagraniczna Rosji, red. S. Bieleń, M. Raś, Wydawnictwo Difin, Warszawa 2008, passim; A. Bryc, Europejska Polityka Sąsiedztwa w perspektywie rosyjskiej, [w:] Europejska Polityka Sąsiedztwa Unii Europejskiej. Geneza, doświadczenia, perspektywy, red. J. M. Fiszer, Dom Wydawniczy Elipsa, Warszawa 2012, s. 128-139; eadem, Cele polityki zagranicznej Federacji Rosyjskiej, Wydawnictwo Adam Marszałek, Toruń 2004, s. 23-34. 
Rosja jest "kluczem do pokojowego i szybkiego rozwoju regionu", ale oczekiwali powstania Rosji demokratycznej, do czego jednak nie doszło w XXI stuleciu. Wydawało się wtedy, że tylko demokratyzacja Rosji mogła przynieść zasadniczą zmianę istoty tego państwa w odniesieniu do środowiska międzynarodowego. Według PiS demokratyzacja Rosji była powiązana z odrzuceniem imperializmu, jak to ujęła poseł M. Gosiewska: „Tylko z tej demokratyzacji może wyniknąć wejście na drogę dobrosąsiedzkiej, przyjaznej współpracy z krajami i narodami dawnego Związku Sowieckiego oraz z Europą Środkową i Zachodnią"159. Nie wyobrażano sobie ukonstytuowania się demokratycznej Rosji, która jednocześnie prowadzi agresywną politykę wobec swojego otoczenia międzynarodowego. Jednak na przełomie XX i XXI wieku nadzieje na demokratyzację Rosji, w opinii braci Kaczyńskich, były tylko iluzją. Otoczenie międzynarodowe nie miało instrumentów, żeby w Rosji uruchomić ten proces. W czasie rządów Putina trudno sobie było wyobrazić taki kierunek zmian na Kremlu, stąd brał się pesymizm w ocenie stosunków polsko-rosyjskich. Politycy PiS uznali, że w Rosji postradzieckiej „Polska ma być przesłanką negatywną budowania rosyjskiej tożsamości". Zalecano więc w polityce wobec Rosji cierpliwość, racjonalność i zdecydowanie, bez złudzeń, że jednorazowe wizyty i rozmowy dwustronne doprowadzą do zmian ${ }^{160}$.

Na przełomie sierpnia i września 2009 roku za sprawą wypowiedzi W. Putina i L. Kaczyńskiego zderzyły się dwie różne perspektywy historyczne oraz narracje historyczne. Putin w opublikowanym w "Gazecie Wyborczej" 31 sierpnia artykule List do Polaków oraz w wystąpieniu na Westerplatte 1 września zaprezentował podstawy historyczne rosyjskiej racji stanu. Dostrzegał genezę II wojny światowej w traktacie wersalskim, który doprowadził „do poniżenia Niemiec", a bezpośrednią przyczynę w umowach podpisanych w latach 1934-1939. Domagał

159 M. Gosiewska, Wypowiedź, [w:] WNPSejm, 8 kadencja, 78 pos., 14 III 2019, http://www. sejm.pl, dostęp 14 II 2020.

160 L. Kaczyński, Wystawimy rachunek za krzywdy [Rozmowa Jarosława Kurskiego z Lechem Kaczyńskim], „Gazeta Wyborcza”, 21 V 2005, nr 117, s. 13; J. Kaczyński, Wstrzymuję się od krytyki PO [Rozmowa Ewy Milewicz z Jarosławem Kaczyńskim], „Gazeta Wyborcza", 25 X 2005, nr 249, s. 5. 
się poddania ich całkowitej krytyce, co było wyraźną sugestią, że polscy politycy powinni potępić polsko-niemiecką deklarację o nieagresji z 1934 roku oraz ultimatum Polski wobec Czechosłowacji z 1938 roku, a mocarstwa zachodnie umowę monachijską z 1938 roku. W przypadku Polski oznaczało to oczekiwanie, że Warszawa odetnie się od pierwszej suwerennej koncepcji polityki zagranicznej nowoczesnego państwa, jaką wypracowali najpierw Józef Piłsudski, a następnie Józef Beck. Formacja konserwatywna, taka jak PiS, nie mogła przyjąć jakichkolwiek sugestii w tej sprawie. Wymienione przez Putina akty zostały zrównane z paktem Ribbentrop-Mołotow z 23 sierpnia 1939 roku, który Putin wyjaśniał jako rozwiązanie konieczne dla ZSRR w warunkach współpracy Zachodu z nazistami. Za realnych sprawców wybuchu wojny zostały uznane przez niego państwa zachodnie, które odrzuciły propozycję ZSRR zbudowania koalicji antynazistowskiej oraz zgodziły się na kolaborację z Adolfem Hitlerem w latach 1938-1939.

Putin zaprezentował też Polsce jako modelową współpracę rosyjsko-niemiecką, w której odrzucono historyczne rozrachunki na rzecz partnerstwa. Warszawa miała się stać trzecim elementem tego układu. Oznaczało to pośrednią ofertę reanimacji Trójkąta Królewieckiego, którego formułę politycy PiS zdecydowanie odrzucali, gdyż Polska byłaby w niej tylko odbiorcą decyzji uzgadnianych przez Moskwę i Berlin oraz potwierdziłaby odwrócenie się od Europy Środkowej, przede wszystkim od państw bałtyckich i Ukrainy. Trójkąt był typową pułapką strategiczną, prowadzącą do izolacji Polski w jej otoczeniu międzynarodowym. Nie bez powodu więc premier Rosji, opisując II wojnę światową, określił jej sprawców jako nazistów, unikając ich identyfikacji narodowej (Niemcy) i państwowej (III Rzesza Niemiecka). Zupełnie świadomie premier Rosji nie utożsamiał wybuchu wojny z Niemcami i germanizmem. Słowem kluczem w jego analizie byli naziści.

W Liście do Polaków Putin zaprezentował także ważne tezy o znaczeniu niemal historiozoficznym. Pierwszą był relatywizm historyczny w kontekście wskazania katów i ofiar, ponieważ - jak pisał ówczesny premier Rosji - 1) "nie ma takiego sędziego, który mógłby wystawić przeszłości absolutnie bezstronny werdykt”, ale także 2) "nie ma kraju, który by nie 
zaznał [...] ostrych zakrętów, decyzji państwowych dalekich od wszelkich zasad moralnych". Z tego powodu należy zrezygnować $\mathrm{z}$ formułowania "wzajemnych roszczeń i krzywd", gdyż jest to "nadzwyczaj szkodliwe i nieodpowiedzialne"161.

Rozmywanie kategorii historycznych w kontekście sprawstwa wojennego i bycia ofiarą było nie do przyjęcia dla polityków PiS, na czele z prezydentem Kaczyńskim. Dlatego też zarówno list Putina, jak i jego przemówienie na Westerplatte wymusiły reakcję prezydenta Kaczyńskiego, która dokonała się w dwóch przemówieniach wygłoszonych 1 września 2009 roku $^{162}$. Odpowiedź wynikała co najmniej z dwóch powodów.

Po pierwsze, prezydent nie mógł milczeć, jeśli wychodził z założenia, że trzeba "swojej wizji oczywistych faktów historii bronić". Jak mówił, Polskę predestynują do zajmowania takiego stanowiska: potencjał terytorialny, zasługi historyczne, przemiany po upadku komunizmu, powiązania sojusznicze. Taka postawa miała uzasadnienie w jego wizji stosunków międzynarodowych oraz paradygmatu polityki zagranicznej, któremu hołdował ${ }^{163}$. Lech Kaczyński nagannie natomiast ocenił rok później reakcję Tuska na Westerplatte. Wypomniał mu milczenie w sprawie Katynia oraz „akceptujące wysłuchanie wystąpień Putina”. Uznał taką postawę

161 W. W. Putin, List do Polaków, „Gazeta Wyborcza”, 31 VIII 2009, nr 203, s. 1; Przemówienie premiera Putina na obchodach 70. rocznicy wybuchu II wojny światowej, 13 VII 2016, http://www.dzieje.pl, dostęp 10 III 2020.

162 Pierwsze z przywoływanych przemówień zostało wygłoszone na obchodach tzw. krajowych w nocy o godzinie 4.45, co determinowało zakres jego bezpośredniego oddziatywania. Drugie zaś było skierowane do polityków reprezentujących około 20 państw, którzy zgromadzili się na Westerplatte na obchodach międzynarodowych rocznicy. Prezydent rozpoczął to przemówienie o godz. 15.43. Vide Przemówienie Prezydenta na obchodach 70. rocznicy wybuchu II wojny światowej, 1 IX 2009, http://www.prezydent. pl/archiwum, dostęp 7 XI 2013; Przemówienie prezydenta na Westerplatte, 1 IX 2009, http://www.prezydent.pl/archiwum, dostęp 7 XI 2013. Upowszechniane wersje wystąpień w: Prezydent Lech Kaczyński na Westerplatte, http://www.youtube.com, dostęp 9X2013; Lech Kaczyńskiprzemawia na Westerplatte 1.09.2009, http://www.youtube.com, dostęp 9X 2013; Dwa przemówienia prezydenta L. Kaczyńskiego na Westerplatte, 1 IX 2009, http://hej-kto-polak.pl/wp, dostęp 18X2013; Przemówienia na Westerplatte, http://www. tvn24.pl, dostęp $19 \times 2013$.

163 L. Kaczyński, Prezydent w "Sygnatach dnia" o obchodach 70. rocznicy wybuchu II wojny światowej i podwyższaniu podatków [Rozmowa Henryka Szrubarza z prezydentem Lechem Kaczyńskim], 5 IX 2009, http://www.prezydent.pl/archiwum, dostęp 25X 2013. 
za przejaw kapitulacji. Niemal identycznie rzecz ocenił brat prezydenta - Jarosław. Dla niego milczenie Tuska było przyzwoleniem na podważenie przez Rosję ładu światowego i dominacji państw demokratycznych oraz zgodą na projekt osi niemiecko-rosyjskiej jako modelu współpracy w kontekście likwidacji następstw traktatu wersalskiego. Tusk pozwolił, by w rocznicę wybuchu II wojny światowej wielkim zwycięzcą została Angela Merkel, o której względy zabiegał rosyjski premier ${ }^{164}$. Na milczenie premiera nałożyło się inne wrażenie medialne - zauważone przez historyka Andrzeja Nowaka - Tusk potraktował Putina jako reprezentanta Europy Wschodniej, niemal ignorując Ukrainę i jej premier Julię Tymoszenko, teoretycznie strategicznego partnera Polski na Wschodzie ${ }^{165}$.

Po drugie, dwie strony konfliktu politycznego w Polsce: PO oraz PiS miały odmienne oczekiwania rocznicowe w 2009 roku. Ówczesny obóz rządzący chciał zdjąć piętno polityczne z debaty historycznej na temat II wojny światowej, ponieważ pojmował politykę jako działalność wolną od balastu przeszłości. Wobec Rosji postulowano zaś specyficznie pojmowany realizm - milczącą akceptację jej polityki historycznej oraz skoncentrowanie się na problemach teraźniejszych i przyszłych. Uważano też, że debatować o przeszłości powinni w imieniu strony polskiej historycy, usuwający uprzedzenia i nieufność. W wersji skrajnej tygodnik „Polityka” proponował nawet narodową terapię w postaci leczenia Polaków z "nerwicy natręctw", „neurotycznego stosunku do sąsiadów", „starannie konserwowanej pamiętliwości”, przy kształtowaniu zdolności wczuwania się w sytuację drugiej strony ${ }^{166}$. Taka postawa strony polskiej miała zapewnić realizację polityki resetu. Natomiast opozycja prawicowa spod znaku PiS nie miała wątpliwości, że zgodnie z regułami polityczności historia zostanie potraktowana instrumentalnie i podporządkowana polityce; oczekiwano więc mocnej reakcji władz RP na ewentualne konfrontacyjne wystąpienie Putina. Niewątpliwie dla polityków PiS

164 Ł. Warzecha, Lech Kaczyński. Ostatni wywiad..., s. 252; J. Kaczyński, Piłsudskim nie jestem..., s. 136-137.

165 A. Nowak, Europa Wschodnia - polskie pytania o Europę i jej Wschód (po 10 kwietnia 2010 roku), [w:] Polska w grze międzynarodowej..., s. 15.

166 A. Krzemiński, Pamięć i pamiętliwość, „Polityka”, 29 VIII 2009, nr 35(2720), s. 12-14. 
niewytłumaczalna była pozytywna ocena dokonana przez rząd D. Tuska treści opublikowanych i wygłoszonych przez Putina na przełomie sierpnia i września 2009 roku. To był element interpretowania racji stanu.

Zapoznawszy się z tezami głoszonymi przez Putina, prezydent Kaczyński zaproponował na Westerplatte (w przemówieniu „międzynarodowym") odmienną od rosyjskiej narrację, przede wszystkim odrzucił relatywizm w odniesieniu do prawdy. Powiedział: „Prawda jest jedna, prawda [...] wyzwala, a nie niewoli, wyzwala, a nie upokarza". Wielce wymowny był także tytuł artykułu Kaczyńskiego opublikowanego w „Rzeczpospolitej" - Pojednanie możliwe tylko dzięki prawdzie ${ }^{167}$. Wypowiedź Kaczyńskiego o prawdzie kontrastowała z wystąpieniem Putina, co wyraziście podkreślało sprzeczności historyczne między Polską a Rosją o charakterze ideologicznym, aksjologicznym i cywilizacyjnym. Wybuch wojny prezydent Polski związał zaś ściśle z rozwojem totalitaryzmu i powstaniem III Rzeszy Niemieckiej oraz podpisaniem paktu o nieagresji między ZSRR i III Rzeszą w 1939 roku, który nie był zawierany „w dobrej wierze". Na ten pakt jako przyczynę wybuchu wojny wskazał wprost w tekście Pojednanie możliwe tylko dzięki prawdzie, opublikowanym na łamach „Rzeczpospolitej” właśnie 1 września 2009 roku: „Do tej totalnej wojny doprowadził pakt Stalina z Hitlerem z 23 sierpnia 1939 r. [...]". Odsłonił także w swoim wystąpieniu motywacje stojące u podstaw decyzji Hitlera i Stalina, w tym antypolonizm jako przejaw szowinizmu. Już w mowie porannej (nazwijmy ją „krajową") prezydent uznał wojnę za walkę "przeciwko niemieckiemu nazizmowi, ale także przeciwko bolszewickiemu totalitaryzmowi". Wygłosił wtedy dość nośne "godnościowe" słowa, pośrednio nawiązując do listu Putina z 31 sierpnia: „[...] to nie Polska powinna odrabiać lekcje pokory. Nie mamy do tego żadnego powodu. Powód mają inni. Powód mają ci, którzy do tej wojny doprowadzili, którzy tę wojnę ułatwili". W roli sprawców obsadził przywódców niemieckiego - Hitlera, i radzieckiego - Stalina, którzy chcieli zastąpić "naszą" cywilizację "totalitarnymi wizjami świata bez wolności, bez ludzkich praw”.

167 Przemówienie Prezydenta na obchodach 70. rocznicy wybuchu Il wojny światowej...; List Putina do Polaków - petna wersja, http://wyborcza.pl, dostęp 19 X 2013. 
Nosicielami tych wizji były państwa niemieckie i radzieckie, których prawnymi spadkobiercami są RFN i Federacja Rosyjska. Kaczyński nie zamierzał w tej kwestii milczeć. Opisywał też dynamikę sytuacji międzynarodowej w latach 1939-1945. W pierwszym etapie wojny Moskwa i Berlin ustanowiły sojusz w celu podzielenia się Europą, zaplanowały też w ostatniej fazie rozegranie wojny między sobą o pełne zwycięstwo.

Niezależnie od ustaleń historycznych, kamieniami milowymi w polskiej interpretacji przyczyn wybuchu wojny prezydent uczynił: 1) wystąpienie Piłsudskiego z inicjatywą wojny prewencyjnej przeciwko Niemcom pod władzą Hitlera; 2) odrzucenie przez Polskę niemieckiej propozycji przystąpienia do paktu antykominternowskiego i udziału w wojnie przeciwko ZSRR; 3) dochowanie wierności sojuszniczej przez II Rzeczpospolitą; 4) bohaterską polską obronę na obu frontach we wrześniu 1939 roku; 5) polski heroizm w walce o ocalenie człowieczeństwa cywilizacji przed barbarzyństwem.

W czasie obchodów 70. rocznicy wybuchu II wojny światowej przedmiotem sporu między L. Kaczyńskim a W. Putinem stał się ład wersalski. Kaczyński wystąpił jako jego zdecydowany obrońca wobec sugestii premiera Rosji, że traktat wersalski był błędnym rozwiązaniem i zdetonował wybuch II wojny światowej z dwóch powodów: ogólnego i szczegółowego. Po pierwsze, „niemożliwe jest stworzenie skutecznego systemu bezpieczeństwa zbiorowego bez udziału wszystkich krajów kontynentu, w tym Rosji". Po drugie, w traktacie zostały upokorzone Niemcy, między innymi kosztem powstania niepodległej Polski. Były to wnioski wielce sugestywne w odniesieniu do teraźniejszości. Jednoznacznie Putin przypominał, że bez Rosji nie można budować, przynajmniej w Europie, ładu politycznego oraz nie można także lekceważyć interesów Niemiec. Natomiast zgodnie z polskimi ocenami Kaczyński uznał traktat wersalski za czynnik przebudowy Europy Środkowej, ukonstytuowania się państw narodowych w tej części kontynentu, uzyskania przez Polskę niepodległości, a przez Gdańsk statusu wolnego miasta oraz ustanowienia pokoju w skali europejskiej i uniwersalnej. Rolę destrukcyjną wobec systemu wersalskiego przypisał zaś totalitaryzmowi, w wariancie III Rzeszy; równie wiodąca rola ZSRR nie została wskazana przez 
prezydenta ${ }^{168}$. Lech Kaczyński wyrażał imperatyw właściwy dla myśli politycznej PiS - w systemie wersalskim dokonało się zrekonstruowanie Europy Środkowo-Wschodniej jako realnej przestrzeni politycznej, ponieważ - według M. Cichockiego - „[...] my nie możemy istnieć bez tej części kontynentu. Dlatego albo ją odbudujemy, powołamy do życia, albo nas nie będzie" ${ }^{169}$.

Prezydent podjął się także w obu przemówieniach oraz w artykule w „Rzeczpospolitej” obrony polityki zagranicznej II Rzeczypospolitej, zwłaszcza decyzji podjętych w latach 1933-1939 przez Józefa Piłsudskiego, Józefa Becka i Edwarda Śmigłego-Rydza, którzy musieli rozwiązywać dramatyczny dylemat wszystkich państw środkowoeuropejskich - „albo wasalizacja, albo obrona własnej podmiotowości i tożsamości". Odrzucił także jako bezzasadne zestawianie porozumienia o nieagresji między Polską a Niemcami w 1934 roku oraz decyzję Polski o zajęciu Zaolzia z 1938 roku z paktem Ribbentrop-Mołotow. Zaprezentował również odmienną od Putinowskiej interpretację konferencji monachijskiej, którą uznał za przejaw kapitulacji wobec imperializmu. Pod tym względem zestawił konferencję w Monachium z inwazją rosyjską na Gruzję w 2008 roku, ogłaszając przy tej okazji: „Nie wolno ustępować imperializmowi, ani nawet skłonnościom neoimperialnym". Według prezydenta polityka „równego dystansu wobec obu totalitaryzmów" była słuszna, gdyż wybór przez Polskę współpracy albo z III Rzeszą (propozycje Joachima von Ribbentropa), albo z ZSRR (oferta Władimira Potiomkina) oznaczał „[...] nie tylko utratę części terytorium, ale także udział w wojnie w roli wasala jednego z totalitaryzmów. Miałby też daleko idące konsekwencje dla naszego kontynentu. Nasiliłby proces infekowania totalitaryzmami słabnącej, wolnej części Europy". W przemówieniu porannym wyraźnie dokonał identyfikacji z postawą Becka i Śmigłego-Rydza, przywołując ich dwie najważniejsze wypowiedzi: Becka z 5 maja o pierw-

168 Przemówienie Prezydenta na obchodach 70. rocznicy wybuchu II wojny światowej...; List Putina do Polaków - petna wersja...

169 M. Cichocki, Szkice z polskiej podmiotowości, [w:] Rzeczpospolita na arenie międzynarodowej..., s. 83-84. 
szeństwie honoru przed pokojem w życiu państw i narodów oraz Śmigłego-Rydza z 19 lipca o woli obrony państwa nawet w osamotnieniu ${ }^{170}$.

Prezydent Kaczyński dokonał jeszcze jednej historycznej konfrontacji w zestawieniu z narracją Putina. Premier Rosji zaproponował w swoim liście podstawę aksjologiczną wspólnej pamięci o przeszłości w postaci uznania ofiar Katynia i Miednoje oraz zmarłych żołnierzy rosyjskich z wojny 1920 roku jako symboli „wspólnego żalu i wzajemnego przebaczenia". Reakcja Kaczyńskiego w tej kwestii była zdecydowanie negatywna. Mówił: „Trzeba też potrafić przyznać się do grzechów i nie stawiać w jednej płaszczyźnie decyzji o zamordowaniu 30 tys. ludzi i epidemii tyfusu lub innych chorób. To nie jest droga do pojednania". Prezydent nie tylko odrzucił podejście Putina do kwestii katyńskiej, ale też w przemówieniu porannym zestawił ją z Holokaustem i uznał za skutek rosyjskiej zemsty za wynik wojny 1920 roku. Sformułował klarowną konkluzję: „Żydzi ginęli dlatego, że byli Żydami, polscy oficerowie ginęli dlatego, że byli polskimi oficerami - taki był wyrok i w pierwszym, i w drugim przypadku"171. W artykule w „Rzeczpospolitej" prezydent wprost uznał Auschwitz i Katyń za zbrodnie ludobójstwa, o których „nigdy nie można zapomnieć". W jego opinii oba totalitaryzmy dopuściły się zbrodni wojennych i przeciw ludzkości, co powinno stać się częścią pamięci zbiorowej wolnej i demokratycznej Europy ${ }^{172}$.

Dla Kaczyńskiego układ Ribbentrop-Mołotow nie był porozumieniem o nieagresji, ale "o podziale wpływów w dużej części Europy" oraz podstawą sojuszniczego współdziałania w wojnie z Polską. Kiedy Wojsko Polskie walczyło, Rosja bolszewicka wypełniła swoje zobowiązania wobec Niemiec i zadała Polsce „cios nożem w plecy”. O ile międzynarodowa zgoda na wcielenie Austrii do III Rzeszy oraz układ monachijski zostały uznane przez Putina za przyczyny wybuchu wojny, o tyle dla Kaczyńskiego

170 Przemówienie Prezydenta na obchodach 70. rocznicy wybuchu ll wojny światowej...; Przemówienie prezydenta na Westerplatte...; L. Kaczyński, Pojednanie możliwe tylko dzięki prawdzie..., s. 1.

171 List Putina do Polaków - petna wersja...; Przemówienie Prezydenta na obchodach 70. rocznicy wybuchu II wojny światowej...; Przemówienie prezydenta na Westerplatte...

172 L. Kaczyński, Pojednanie możliwe tylko dzięki prawdzie..., s. 1. 
konferencja w Monachium jedynie poprzedzała wybuch wojny, chociaż była wyborem hańby oraz kupowaniem „pokoju w zamian za rezygnację z wartości". Jednak w odniesieniu do Polski prezydent zdecydowanie podkreślił: „Nie byliśmy w Monachium”, mimo iż uznał uczestnictwo w okrojeniu Czechosłowacji w 1938 roku za błąd i grzech, nawet gdyby dało się znaleźć usprawiedliwienie dla tej decyzji ${ }^{173}$. Takie podejście do sprawy wcielenia Zaolzia do Polski było ważnym ustępstwem ze strony Kaczyńskiego w jego polityce środkowoeuropejskiej, gdyż w kategoriach historycznych ta decyzja podjęta przez ówczesne władze II Rzeczypospolitej nie tylko była wytłumaczalna, ale też stały u jej podstaw bardzo istotne argumenty natury wojskowej i gospodarczej, a także psychospołecznej i demograficznej.

Natomiast odnosząc się do współczesności, jako czynniki stabilizujące ład europejski prezydent wymienił Sojusz Północnoatlantycki i Unię Europejską, a nie relacje niemiecko-rosyjskie. W jego opinii sukces osiągnięty przez te organizacje był możliwy, bo podstawą współpracy europejskiej i transatlantyckiej stała się wspólnota wartości, takich jak wolność, demokracja i pluralizm, przeciwstawione imperializmowi i strefom wpływów. Prezydent jednoznacznie odrzucił propozycję Putina oparcia współpracy europejskiej na „rusztowaniu” niemiecko-rosyjskim ${ }^{174}$. Po uroczystościach rocznicowych ta sugestia została nazwana przez L. Kaczyńskiego powrotem do osi, typem rusztowania, „na którym dla Polski to co najwyżej stryczek może być" oraz koncepcją dla Polski niemożliwą do przyjęcia ${ }^{175}$. Taka optyka była nie do zaakceptowania ani w Pałacu Prezydenckim w Warszawie, ani na ul. Nowogrodzkiej (siedziba władz centralnych PiS). W konkluzji mowy popołudniowej na Westerplatte prezydent zaproponował alternatywne rozwiązanie: „[...] współpracu-

173 Przemówienie Prezydenta na obchodach 70. rocznicy wybuchu ll wojny światowej...; Przemówienie prezydenta na Westerplatte...; L. Kaczyński, Pojednanie możliwe tylko dzięki prawdzie..., s. 2.

174 Przypominamy! Lech Kaczyński w 2009 r. na Westerplatte: „Nie wolno ustępować imperializmowi!", 1 IX 2019, http://www.wpolityce.pl, dostęp 10 III 2020.

175 Prezydent: Polityka historyczna jednym z obowiązków państwa, 4 IX 2009, http://www. prezydent.pl/archiwum, dostęp 29 X 2013; Prezydent w "Sygnatach dnia" o obchodach 70. rocznicy wybuchu Il wojny światowej i podwyższaniu podatków... 
jąca ze sobą Europa nie wymaga rusztowania opartego o dwa państwa, wymaga szerokiej, wielostronnej współpracy. I wymaga demokracji [...] w relacji między państwami"176.

Prezydent wykonał jeszcze jeden ważny manewr argumentacyjny w kontekście wychwalania przez Putina, w obecności kanclerz Merkel, owego "rusztowania niemiecko-rosyjskiego" - po prostu przypomniał, że to właśnie Polska i Niemcy (w domyśle nie Rosja) należą do Unii Europejskiej i Sojuszu Północnoatlantyckiego. Ta pierwsza (unijna) wspólna polsko-niemiecka przynależność zobowiązuje wszystkich członków do „respektowania swoich elementarnych interesów”, a druga więź jest oparta na wartościach takich jak: 1) ograniczenie równowagi sił, odrzucenie polityki imperialnej w kategoriach stref wpływów na rzecz reguły współpracy; 2) akceptacja systemu wartości - demokracja, pluralizm, wolnośćc ${ }^{177}$. Wydarzenia sierpniowo-wrześniowe w 2009 roku dobitnie pokazały dwie wersje polityki zagranicznej Polski - jedną reprezentowaną przez koalicję PO-PSL i drugą, alternatywnie inną, wyrażaną przez prezydenta wspieranego przez opozycyjne stronnictwo PiS.

Po upływie pięciu lat od obchodów rocznicowych, w 2014 roku PO znalazła się w swoistej pułapce rosyjskiej - nie można było mieć żadnych wątpliwości, że założenia przyjęte przez partię w odniesieniu do polityki zagranicznej wobec Rosji były fałszywe. Rzeczywistość polityczna bardzo mocno potwierdzała klęskę resetu w stosunkach polsko-rosyjskich, ogłoszonego przez PO w 2008 roku. Pierwszym dowodem była katastrofa smoleńska, a w konsekwencji to, w jaki sposób władze Rosji potraktowały państwo polskie, prawdę o tym wydarzeniu, prawo międzynarodowe oraz godność ofiar tej tragedii. Z oczywistych względów politycznych PO nie była w stanie wyciągnąć adekwatnych wniosków, wiernie stała bowiem po stronie rosyjskiej w zderzeniu z opozycją w Polsce co do przyczyn i okoliczności katastrofy. Kolejnymi dowodami na klęskę polityki zagranicznej koalicji PO-PSL w postaci resetu były: wydarzenia na Krymie, zakrojone na szeroką skalę zbrojenia rosyjskie oraz reakcja

176 Przemówienie Prezydenta na obchodach 70. rocznicy wybuchu ll wojny światowej...

177 Ibidem. 
znacznej części opinii międzynarodowej na politykę imperialistyczną Rosji. Chodziło jednak nie tylko o ocenę Rosji, ale także o strategię Tuska-Sikorskiego "płynięcia w głównym nurcie europejskim”, polegającą na wykonywaniu ugodowej polityki wobec Moskwy. Im bardziej PiS eksponowało zagrożenie rosyjskie dla Europy, które stawało się zjawiskiem bezdyskusyjnym, tym bardziej PO trwała na stanowisku, że Rosja ulega europeizacji i należy z nią budować pragmatyczne stosunki ${ }^{178}$. Na te klisze nakładało się także bardzo negatywne ocenienie przez PiS postawy rządu D. Tuska w odniesieniu do katastrofy smoleńskiej oraz niezdolność, wręcz manifestowana publicznie, do wyciągnięcia z niej wniosków na temat polityki zagranicznej Rosji.

Wprost kuriozalne wydawały się stwierdzenia zawarte w Priorytetach Polskiej Polityki Zagranicznej 2012-2016, przygotowanych w kilka miesięcy po katastrofie smoleńskiej i skandalu z jej wyjaśnianiem. Stwierdzenia te dowodziły co najmniej niezrozumienia środowiska międzynarodowego oraz dynamiki stosunków międzynarodowych. Pierwsze - w najbliższych latach „ryzyko konfliktu zbrojnego w bezpośrednim sąsiedztwie lub na terytorium Polski będzie niewielkie"; opisując uwarunkowania polskiej polityki zagranicznej, nie wskazano rosyjskiego imperializmu. Drugie - „Polsce zależy na utrzymaniu dobrych, pragmatycznych stosunków z Rosją na zasadach wzajemności”, a dzięki „pozytywnej dynamice” we wzajemnych relacjach możliwa jest „intensyfikacja dialogu politycznego

178 Trudno koncepcję rządu PO-PSL resetu w stosunkach z Rosją nazwać „pragmatyzacją" polityki Polski przynajmniej z dwóch powodów. Po pierwsze, nie przysporzyło to Polsce żadnych korzyści, a wręcz ułatwiło Moskwie przedmiotowe traktowanie Polski, co udowodnity wydarzenia po katastrofie smoleńskiej, budowa Nord Stream, warunki kontraktu gazowego. Po drugie, nie można odnaleźć racjonalnych przestanek stojących u podstaw przekonania, że można tą drogą uporządkować relacje z Moskwą. Skutek byt jeden - brak możliwości dokonania efektywnego resetu w stosunkach polsko-rosyjskich nie mógt przynieść, jak mniemano w rządzie PO-PSL, wzmocnienia pozycji Polski w Unii i Sojuszu. Ponieważ nie osiągnięto tego celu, ranga Polski w Europie Środkowej i Wschodniej uległa obniżeniu, co było widoczne zwtaszcza w odniesieniu do sprawy ukraińskiej oraz w stosunkach polsko-litewskich. Na pewno zaś stworzyło politykom PO możliwości objęcia wysokich stanowisk w UE, ale już nie w Sojuszu. Pozycja Polski w regionie uległa niemal destrukcji. Odmienne zdanie w: M. Stolarczyk, Rosja w polityce zagranicznej Polski..., s. 206. 
i kontaktów gospodarczych" oraz rozwiązywanie konkretnych problemów (np. mały ruch graniczny). Trzecie - Rosja ulega modernizacji i zabiega o zbliżenie z Europą, dlatego Polska będzie popierała wysiłki Rosji w tych kierunkach oraz udzielała poparcia dla reform na rzecz „budowy państwa prawa i pluralizmu politycznego”, oczywiście w Rosji. Czwarte - Polska opowiada się za całościowym i szybkim uregulowaniem współpracy między Unią Europejską a Rosją ${ }^{179}$. Przy takim nastawieniu politycy PO sprawujący najważniejsze urzędy w Rzeczypospolitej zostali zaskoczeni w 2014 roku kolejną odsłoną polityki imperialnej Rosji. Nie byli przygotowani na taki rozwój wydarzeń, zignorowali całkowicie ostrzeżenia formułowane niejednokrotnie przez PiS. Jeśli okres resetu w stosunkach polsko-rosyjskich potraktować w kategoriach gry, to politycy PO zostali ograni przez Putina i to w sposób widowiskowy, bez żadnego kamuflażu. „Płynięcie w głównym europejskim nurcie” spowodowało marginalizację Polski w kontekście poszukiwania rozwiązań w konflikcie rosyjsko-ukraińskim, gdyż Warszawa nie znalazła się w 2014 roku wśród uczestników formuły normandzkiej (Niemcy, Francja, Rosja, Ukraina), tracąc jakikolwiek wpływ na wydarzenia w sąsiedztwie.

W 2014 roku PO podjęła próbę zrewidowania stosunku do Rosji, kierując się nie tyle własnymi refleksjami i przyznaniem się do błędu politycznego, ile kolejnym dostosowaniem się do nowego trendu, który pojawił się na Zachodzie pod wpływem zmian w stosunkach amerykańsko-rosyjskich w ostatnich miesiącach prezydentury Obamy. Reset amerykańsko-rosyjski uległ zakończeniu, co potwierdziły decyzje Sojuszu Północnoatlantyckiego podjęte w Newport. PiS uznało, że nowa sytuacja zaskoczyła polityków PO, a zmiana kursu dokonana przez tę partię była koniunkturalna i nie oznaczała dogłębnej rewizji polityki zagranicznej rządu PO-PSL. Polityki, dla której oparciem było "proste, bezmyślne, bezrefleksyjne i naiwnie optymistyczne myślenie o Polsce i świecie". Zdaniem autora tych określeń - Waszczykowskiego - minister Sikorski był niezdolny do wykonania racjonalnego zwrotu, jego myślenie polityczne opierało się bowiem na fałszywej ocenie rosyjskiej

179 Priorytety Polskiej Polityki Zagranicznej 2012-2016..., s. 14. 
agresji na Gruzję w 2008 roku oraz na niezrozumieniu istoty kryzysu na Ukrainie w 2014 roku. Z tego powodu polityka zagraniczna Sikorskiego zakończyła się spektakularną klęską co najmniej w dwóch wymiarach.

Pierwszy - nie udała się „piastowska modernizacja kraju”, która w ujęciu międzynarodowym miała oznaczać w drugiej dekadzie XXI wieku powstanie trójkąta Niemcy-Francja-Polska, nie bacząc na zasadnicze różnice między Polską a osią Paryż-Berlin w kwestii oceny Rosji. W obliczu kolejnej rosyjskiej agresji te plany okazały się kompletną fikcją. Obie stolice zachodnioeuropejskie nie uzgadniały swoich najważniejszych decyzji z Warszawą, traktując ją instrumentalnie. Takie ignorowanie, przy jednoczesnej izolacji w Europie Środkowej, w warunkach nowej dynamiki stosunków międzynarodowych jawiło się jako bardzo groźne. Natomiast rząd PO-PSL poprzez zbliżenie się do wspomnianej osi nie był w stanie osiągnąć jakiejkolwiek zmiany w swojej polityce zagranicznej na odcinku rosyjskim. Drugi wymiar polegał na przekreśleniu wszelkich iluzji co do pojednania z Rosją, które zamierzano osiągnąć przez rezygnację z aktywności w Europie Środkowej i wobec Europy Wschodniej, co miało Polsce zagwarantować miejsce w „elitarnym klubie uprzywilejowanych przyjaciół Rosji". Do tego klubu Polska nie weszła, a jej polityka regionalna uległa degradacji ${ }^{180}$.

PiS odrzuciło w 2014 roku pogląd lansowany przez polityków PO, że Putin, atakując Ukrainę, dokonał zaskakującego zwrotu w polityce zagranicznej Rosji i nikt tego nie przewidział. Szczerski przypomniał z trybuny sejmowej, że sześć lat wcześniej w Tbilisi prezydent Kaczyński nie tylko postawił właściwą diagnozę sytuacji, ale również zarysował realny plan działań. Jednak rząd PO-PSL wybrał wariant wojny z prezydentem, zamiast rozpocząć przygotowania całego regionu na wyzwania wynikające z rosyjskiego imperializmu. Podjęcie wówczas takich zabiegów mogłoby zablokować scenariusz wojenny, gdyż pokazałoby Rosji mocną wolę oporu i solidarność regionalną, na podobieństwo tej zaprezentowanej

180 W. Waszczykowski, Wystąpienie w czasie dyskusji na temat informacji ministra spraw zagranicznych o zatożeniach polskiej polityki zagranicznej w 2014 roku..., s. 193-194. 
w Tbilisi ${ }^{181}$. Natomiast rządowi, walczącemu z prezydentem, towarzyszyło oczekiwanie w kwestii ukraińskiej na dyrektywy płynące z Brukseli, żeby móc - jak to ujął P. Żurawski vel Grajewski - „popłynąć w głównym

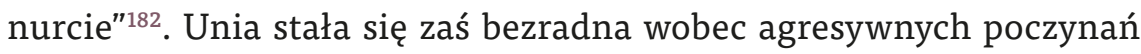
Moskwy. Z tego powodu polityka tandemu Tusk-Sikorski była pasywna, co doprowadziło do tego, że poziom stosunków polsko-ukraińskich był wówczas najniższy w XXI wieku. W zderzeniu z Rosją w Kijowie nie postrzegano Warszawy jako pewnego partnera, dlatego szukano poparcia wśród mocarstw zachodnioeuropejskich, w tym w Niemczech.

Po przejęciu władzy w Polsce w 2015 roku PiS oficjalnie i publicznie kreśliło czarny obraz Rosji z punktu widzenia nie tylko polskiego, ale również powszechnego. We wspomnianym dokumencie strategicznym Koncepcja obronna Rzeczypospolitej Polskiej przypisano Rosji: dążenie do zaprowadzenia nowego ładu międzynarodowego w postaci koncertu mocarstw; utrzymywanie agresywnej linii w polityce zagranicznej i bezpieczeństwa; prowadzenie w tym czasie działań zamaskowanych, "poniżej progu wojny" (tzw. wojna hybrydowa i asymetryczna); wspieranie konfliktów o skali regionalnej z udziałem członków Paktu Północnoatlantyckiego; prowokowanie konfliktów zastępczych w różnych częściach świata jako formy nacisku na Zachód ${ }^{183}$. W innym ważnym rządowym dokumencie pojawiła się kolejna doniosła konstatacja: „Tendencje te utrzymają się zapewne w najbliższym czasie, narażając bezpośrednie sąsiedztwo Rzeczypospolitej na wstrząsy polityczne i społeczne, także w przypadku agresji poniżej progu otwartej wojny"184. W debacie sejmowej w 2016 roku w imieniu KP PiS poseł Gosiewska mówiła, że Rosja: 1) porzuciła prawo i zasady w stosunkach międzynarodowych na rzecz stosowania siły; 2) powróciła do polityki stref wpływów i wasalizacji obszaru postradzieckiego. Z tej diagnozy wywiodła wniosek najważniejszy

\footnotetext{
181 K. Szczerski, Wystąpienie wczasie dyskusji na temat informacji ministra spraw zagranicznych o założeniach polskiej polityki zagranicznej w latach 2014-2015, [w:] SS Sejm, 7 kadencja, 79 pos., 6 XI 2014, s. 177, http://orka2.sejm.gov.pl, dostęp 15 III 2020.

182 P. Żurawski vel Grajewski, Specyfika relacji polsko-ukraińskich..., s. 51.

183 Koncepcja obronna Rzeczypospolitej Polskiej..., s. 21-22.

184 Strategia Polskiej Polityki Zagranicznej 2017-2021..., s. 9.
} 
dla myśli politycznej PiS w kontekście rosyjskim, że marzenia o włączeniu Rosji do struktur europejskich i transatlantyckich są nierealistyczne. Marzenia, które PiS dostrzegało zarówno u swoich przeciwników liberalnych w Polsce, jak i w stolicach zachodnioeuropejskich ${ }^{185}$. O konkretnych rosyjskich działaniach militarnych mówił w Sejmie minister Waszczykowski; bynajmniej nie można ich lokować w obszarze "poniżej progu wojny". Wymienił: prowadzenie działań wojskowych przeciwko Ukrainie na jej terytorium, postępującą militaryzację obwodu królewieckiego i rozbudowę Zachodniego Okręgu Wojskowego o trzy nowe dywizje $^{186}$. Z tych wypowiedzi wyłaniał się inny obraz Rosji, niż to sugerowały dokumenty przygotowywane w czasach rządów koalicji PO-PSL i ówczesne wypowiedzi jej liderów.

W sytuacji zaistniałej w Europie Wschodniej w pierwszej dekadzie XXI wieku obaj liderzy PiS - Jarosław Kaczyński i Lech Kaczyński - postanowili już w latach 2005-2007 "przenieść" stosunki polsko-rosyjskie na forum Unii i Sojuszu, widząc w nich „lewary" potencjału politycznego Polski, znacznie słabszego od Rosji. Diagnoza dokonana przez prezesa PiS była bardzo realistyczna i w znacznym stopniu wiarygodna. Cele rosyjskiej polityki zagranicznej, mimo chwilowych zawirowań i zmian taktycznych w latach dziewięćdziesiątych XX wieku, pozostawały niezmienne: strategiczna kontrola nad obszarem postsowieckim, istnienie strefy buforowej w Europie Środkowej, wrogość wobec Sojuszu Północnoatlantyckiego, wyparcie Stanów Zjednoczonych z Europy. W Moskwie postrzegano te cele w kategoriach koniecznych warunków utrzymania statusu mocarstwa ${ }^{187}$.

Po sukcesie wyprawy Lecha Kaczyńskiego do Tbilisi w 2008 roku jego brat doszedł do dwóch ważnych wniosków: 1) tylko zdecydowana reakcja międzynarodowa państw środkowoeuropejskich przy jednoznacznym wsparciu Stanów Zjednoczonych zniweczyła plany strategiczne Rosji

185 M. Gosiewska, Wypowiedź, [w:] WNPSejm, 8 kadencja, 78 pos., 14 III 2019, http://www. sejm.pl, dostęp 14 II 2020.

186 Informacja Ministra Spraw Zagranicznych o zadaniach polskiej polityki w 2017 roku...

187 M. Menkiszak, Strategiczna kontynuacja, taktyczna zmiana. Polityka bezpieczeństwa europejskiego Rosji, OSW, Warszawa 2019, s. 6-10. 
w odniesieniu do Kaukazu; 2) państwa zachodnioeuropejskie (Niemcy i Francja), działające bez współpracy z Waszyngtonem, są bezsilne wobec Rosji ${ }^{188}$. Kiedy więc PiS przejęło w całości władzę centralną w Polsce w 2015 roku, rozpoczęło realizację tej alternatywnej polityki - komunikowania Rosji, że „[...] jej strefa wpływów kończy się na jej granicach. I ani metra dalej"189. Tym samym partia J. Kaczyńskiego rzuciła Rosji strategiczne wyzwanie w Europie Środkowej. Natomiast w relacjach dwustronnych nową politykę wobec Rosji w 2017 roku M. Gosiewska nazwała "polityką powściągliwości", co oznaczało „utrzymywanie kontaktów [...] w tych obszarach, gdzie istnieje szansa na wzajemne zrozumienie", ale bez nadmiernych nadziei na osiągnięcie jakichkolwiek sukcesów ${ }^{190}$. Takie podejście zasadniczo utrudniało władzom w Warszawie prowadzenie gry w innych obszarach, faktycznie bowiem „zamrażało” jeden kierunek - rosyjski.

W konkluzji należy stwierdzić, że obie partie polityczne - PiS oraz PO - wychodziły ze skrajnie odmiennych założeń w polityce zagranicznej. W sposób niemal pełny tę rozbieżność ilustruje notatka sekretarza stanu w Kancelarii Prezesa Rady Ministrów i szefa gabinetu Tuska, Sławomira Nowaka, który w kilka tygodni po przejęciu władzy przez PO sformuło-

188 J. Kaczyński, Za Leszka z Polską się liczono [Wywiad Piotra Gursztyna z Jarostawem Kaczyńskim], „Do Rzeczy”, 7-13 X 2013, nr 37(37), s. 20.

189 W. Waszczykowski, Wystaliśmy Rosji jasny sygnat [Wywiad Marcina Makowskiego z Witoldem Waszczykowskim], „Do Rzeczy”, 18-24 VII 2016, nr 29(180), s. 26.

190 M. Gosiewska, Wypowiedź, [w:] WNP Sejm, 8 kadencja, 35 pos., 9 II 2017, http://www. sejm.pl, dostęp 24 II 2020. Negatywną ocenę koncepcji PiS polityki rosyjskiej zaprezentowała Katarzyna Petczyńska. Uznała ją za prowokowanie Rosji w warunkach, kiedy Polska rządzona przez PiS ma słabą pozycję w Unii, a region środkowoeuropejski jest dla Stanów Zjednoczonych marginalny. Realizacja „twardej” koncepcji wobec Rosji doprowadziła - jej zdaniem - do utraty przez Polskę wpływu na terenie rosyjskiej „bliskiej zagranicy" oraz na kształtowanie się unijnej polityki wobec Federacji, a w konsekwencji Moskwa przestała traktować Warszawę jako istotnego gracza. To wyjaśnienie wydaje się pozornie logiczne, gdyby nie klęska polityki rosyjskiej koalicji PO-PSL, kierującej się stylem myślenia Pełczyńskiej. Absolutnie nie można też zaakceptować ocen typowo politycznych, niepopartych żadnym materiałem źródłowym, że Polska pod rządami PiS „zdystansowała się wobec Zachodu“, utracita „w relacjach z Rosją wyrazistą tożsamość”, „wypisała się z wielkiej polityki wobec Rosji”. K. Pełczyńska, Polska wobec Rosji. Radykalizm bez polityki, „Sprawy Międzynarodowe” 2018, nr 3, s. 31-42. 
wał w Założeniach polskiej polityki zagranicznej w $2008 \mathrm{r}$. dwa wnioski. Po pierwsze - „W stosunkach z zagranicą zmieniamy podejście do partnerów", co było zanegowaniem polityki realizowanej przez poprzedników i oznaczało strategiczną rewolucję, która faktycznie się dokonała w latach 2007-2015. Po drugie - pomyślność i bezpieczeństwo Polski zależą „od losu wspólnoty państw zachodnich". W ten sposób negliżowano znaczenie dla Polski i Europy Środkowej, i Europy Wschodniej. Pierwszy pogląd zaowocował zmianami w relacjach z Berlinem, Moskwą i Waszyngtonem, co lapidarnie już w 2005 roku ujął Lech Kaczyński, porównując obie partie polityczne: „Istotna różnica między nami polega na tym, że ja chcę w ramach pierwszej wizyty udać się do Waszyngtonu, a Donald Tusk do Berlina"191. Jednoznacznie ten stan skomentował też J. Kaczyński: „[...] chodziło o strategiczną reorientację Polski z USA na Niemcy. To było główne założenie polityczne ekipy Tuska"192. Drugi pogląd sprowadzał się do odrzucenia polityki zagranicznej rządów PiS na rzecz podnoszenia podmiotowości i samodzielności Polski w środowisku międzynarodowym, przede wszystkim w Unii Europejskiej i w Europie Środkowej oraz wobec Europy Wschodniej ${ }^{193}$. Wybrano wariant podporządkowania się strategiom i decyzjom podejmowanym przez ową „wspólnotę państw zachodnich", a faktycznie przez mocarstwa europejskie. Polska miała zajmować postawę albo pasywną, albo adaptacyjną.

PiS konsekwentnie krytykowało politykę zagraniczną D. Tuska, nazywaną "płynięciem z głównym nurtem". Wraz z jej realizacją owa krytyka się zaostrzała, aż przeszła w stan negacji. W 2007 roku poseł PiS Paweł Kowal dokonał interpretacji takiej polityki u progu rządów D. Tuska jako przeciwstawiania polityce amerykańskiej relacji Polski z naszymi partnerami z UE. Takie podejście - według niego - było całkowicie błędne i w długim dystansie groźne dla polskiej polityki zagranicznej, jako że

\footnotetext{
191 Wywiad Lecha Kaczyńskiego dla "Naszego Dziennika", 7 X 2005, http://pis.org.pl, dostęp 10 II 2011.

192 J. Kaczyński, Polska naszych marzeń..., s. 121.

193 Archiwum Rady Ministrów, Sekretariat Prezesa Rady Ministrów, „Założenia polskiej polityki zagranicznej w 2008 r. Notatka Stawomira Nowaka ze stycznia 2008 roku", Warszawa 2008, s. 9.
} 
mogło doprowadzić do osłabienia pozycji Polski w Sojuszu, a następnie w Unii. Dwa lata później ten sam polityk przestrzegał w imieniu Klubu Parlamentarnego PiS, żeby rząd nie podejmował ważnych decyzji "tylko po to, abyśmy byli w głównym nurcie, bo większość nie zawsze ma rację", lecz zachęcał do powrotu do wartości z czasów „pierwszej Solidarności", kiedy uchwalono na jej I Zjeździe w 1981 roku posłanie do ludzi pracy Europy Wschodniej, oraz do samodzielnej racjonalnej oceny środowiska międzynarodowego. Małgorzata Gosiewska przypomniała w Sejmie kolejnej kadencji: „[...] Polska nie jest w stanie zapomnieć i nigdy nie zapomni dziedzictwa "Solidarności « i dziedzictwa słynnego posłania do narodów Europy Wschodniej uchwalonego podczas pierwszego zjazdu "Solidarności» w hali Olivia w Gdańsku we wrześniu 1981 r."194. Natomiast u progu następnej dekady dokonano pełnego odrzucenia linii strategicznej w polityce zagranicznej koalicji PO-PSL, nazywając ją w Raporcie o stanie Rzeczypospolitej z 2011 roku „bezrozumną polityką zagraniczną". Mówiono także w PiS o „samodegradacji statusu Polski” na arenie międzynarodowej (M. Błaszczak) ${ }^{195}$. Alternatywnym rozwiązaniem dla "płynięcia z głównym nurtem" był inny model polityki przy-

194 W. Wybranowski, Powrót do konwenansów [Rozmowa Wojciecha Wybranowskiego z Pawłem Kowalem], „Nasz Dziennik", 24 XI 2007, http://www.naszdziennik.pl, dostęp 11 VI 2012; P. Kowal, Wystąpienie w czasie dyskusji na temat informacji ministra spraw zagranicznych o zatożeniach polskiej politykizagranicznejw 2009 roku, [w:] SSSejm, 6 kadencja, 35 pos., 13 II 2009, s. 260, http://orka2.sejm.gov.pl, dostęp 15 III 2020; M. Gosiewska, Wypowiedź, [w:] WNPSejm, 8 kadencja, 10 pos., 29 I 2016, http://www.sejm.pl, dostęp $20 \mathrm{~V} 2020$.

195 Określenia „płynięcie z głównym nurtem polityki unijnej” użyła w sensie pejoratywnym w 2010 roku Anna Fotyga. M. Bober, Rząd przeksztatca Polskę w kolonię..., s. 3. Ten problem podnieśli także posłowie PiS w trakcie dyskusji sejmowej na temat informacji ministra Sikorskiego o założeniach polityki zagranicznej Polski na rok 2011. Vide także M. Błaszczak, Wystąpienie w czasie dyskusji na temat informacji ministra spraw zagranicznych o zatożeniach polskiej polityki zagranicznej w 2011 roku, [w:] SS Sejm, 6 kadencja, 87 pos., 16 III 2011, s. 16, http://orka2.sejm.gov.pl, dostęp 4 V 2019; J. Sellin, Wystąpienie w czasie dyskusji na temat informacji ministra spraw zagranicznych o zatożeniach polskiej polityki zagranicznej w 2011 roku, [w:] SS Sejm, 6 kadencja, 87 pos., 16 III 2011, s. 30, http://orka2.sejm.gov.pl, dostęp 4 V 2019. Wedtug Orzelskiej-Stączek pojęcie „ptynięcie w głównym nurcie" zostało po raz pierwszy użyte w lutym 2008 roku w czasie dyskusji między rządem a prezydentem nad uznaniem niepodlegtości Kosowa. A. Orzelska-Stączek, Ministrowie spraw zagranicznych..., s. 87. 
gotowywany przez PiS - "powrót do gry na międzynarodowej arenie" (W. Waszczykowski) oraz „najwyższy czas odrzucić kompleksy niższości, służalczości i murzyńskości" (M. Gosiewska) ${ }^{196}$.

Najbardziej obrazowo politykę zagraniczną inspirowaną myślą PO opisali w Sejmie w latach 2012-2013 posłowie Szczerski i Waszczykowski. Ten pierwszy konkludował w sposób literacki: „Wraz z ministrem Sikorskim do gmachu MSZ wkroczyły trzy siostry: fikcja, niekompetencja i arogancja. A zaraz za nimi przyszli ich bracia: chaos, kompleks i bezsens. Pan minister spędza czas z siostrami, a nas gnębią ich bracia. Najwyższy czas ich stamtąd wyprowadzić, wszystkich". Natomiast ten drugi przypisywał polityce Sikorskiego: „Brak realnej oceny sytuacji międzynarodowej, brak jasno sprecyzowanej racji stanu, interesu narodowego, klarownych zobowiązań i często eufemistyczne wskazywanie instrumentów [...]". Takie pojmowanie polityki wynikającej z nieprawdziwej diagnozy miało prowadzić do zepchnięcia Polski na pozycje peryferyjne i marginalne. Zarzucał ówczesnemu ministrowi spraw zagranicznych prowadzenie polityki nieodpowiadającej ani ambicjom Polski, ani interesom narodowym. Styl tej polityki został określony jako publicystyczno-propagandowy i megalomański ${ }^{197}$.

W PiS wskazano konkretne błędy popełnione przez koalicję PO-PSL, między innymi w odniesieniu do kwestii bezpieczeństwa i członkostwa w Sojuszu Północnoatlantyckim. Oceniano, że polityka realizowana w tej organizacji przez Polskę pod rządami koalicyjnymi jest błędna, nie gwarantuje bowiem bezpieczeństwa, w tym energetycznego. Jej negatywne konsekwencje są dodatkowo wzmocnione przez klientystyczną posta-

\footnotetext{
196 Informacja Ministra Spraw Zagranicznych o zadaniach polskiejpolityki w2017 roku...; M. Gosiewska, Wypowiedź, [w:] WNPSejm, 8 kadencja, 78 pos., 14 III 2019, http://www.sejm.pl, dostęp 14 II 2020.

197 K. Szczerski, Wystapienie w czasie dyskusji na temat informacji ministra spraw zagranicznych o zatożeniach polskiej polityki zagranicznej w 2012 roku..., S. 180; W. Waszczykowski, Wystąienie w czasie dyskusji na temat informacji ministra spraw zagranicznych o zatożeniach polskiej polityki zagranicznej w 2012 roku, [w:] SS Sejm, 7 kadencja, 11 pos., 29 III 2012, s. 194, http://orka2.sejm.gov.pl, dostęp 15 III 2020; idem, Wystąpienie w czasie dyskusji na temat informacji ministra spraw zagranicznych o zatożeniach polskiej polityki zagranicznej $w 2013$ roku..., s. 17.
} 
wę wobec Rosji i Niemiec, zgodę na hegemonię w Unii najsilniejszych państw członkowskich oraz porzucenie polityki „jagiellońskiej” wobec Europy Wschodniej. Podsumowaniem mogłyby być dwa wnioski sformułowane przez PiS w 2011 roku. Pierwszy: „Polska płynie z głównym nurtem [...]. Ale nie jest to statek czy choćby łódź mająca napęd i ster, lecz dryfująca tratwa”. Drugi: „[...] od rządu Rzeczypospolitej wymagamy skutecznego reprezentowania naszych interesów narodowych, a nie płynięcia z głównym nurtem"198.

Prawo i Sprawiedliwość konsekwentnie w okresie swojego politycznego bytu było formacją „euroatlantycką". Kurs transatlantycki i zarazem eurorealizm oraz postulowana wysoka, a także podmiotowa aktywność w Europie Środkowej i wobec Europy Wschodniej były najważniejszymi wyróżnikami myśli politycznej tego stronnictwa w zakresie polityki zagranicznej. Stronnictwo opracowało własną koncepcję roli Sojuszu Północnoatlantyckiego w polityce bezpieczeństwa Polski, czekając na zaistnienie korzystnych warunków do jej realizacji. Oczekiwanie to nosiło znamiona niemal pewności co do zaistnienia takich okoliczności, nie było bowiem wątpliwości, że Rosja jest zagrożeniem dla hemisfery zachodniej. Taka ocena została wzmocniona w latach 2008-2010, co było następstwem agresji Rosji na Gruzję oraz katastrofy katyńskiej. Czekano więc na: 1) wygraną w wyborach; 2) koniec resetu w stosunkach amerykańsko-radzieckich.

Wskazane przesłanki teoretyczne i ideowe oraz typ rywalizacji politycznej w Polsce uzasadniały negatywną ocenę polityki zagranicznej Polski wobec Sojuszu i Unii w okresie rządów koalicji lewicowo-ludowcowej oraz liberalno-ludowcowej. Bardzo zdecydowanej krytyce poddano styl myślenia Platformy Obywatelskiej o polityce zagranicznej Polski na wszystkich jego poziomach: teoretycznym, koncepcyjnym i decyzyjnym.

198 Raport o stanie Rzeczypospolitej..., s. 106, 112; M. Błaszczak, Wystąpienie w czasie dyskusji na temat informacji ministra spraw zagranicznych o zatożeniach polskiej polityki zagranicznej w 2011 roku..., s. 18; vide K. Szczerski, Analiza neogeopolityczna..., s. 57. 


\subsection{Zasady polityki transatlantyckiej}

Po wygranych wyborach prezydenckich i parlamentarnych w 2015 roku obóz Zjednoczonej Prawicy, zdominowany programowo przez PiS, a reprezentowany przez prezydenta Andrzeja Dudę i rząd Beaty Szydło, mógł zrealizować własną koncepcję polityki transatlantyckiej Polski. Jej założenia zostały określone w latach 2005-2014 w partyjnych dokumentach programowych oraz dokumentach rządowych. Przejawiały się również w decyzjach politycznych dwóch gabinetów PiS rządzących w okresie 2005-2007 oraz prezydenta L. Kaczyńskiego. Po 2015 roku pojawiło się kolejne źródło programowe - dorobek ideowy tragicznie zmarłego prezydenta, zmaterializowany w jego licznych wystąpieniach publicznych i wywiadach medialnych.

Nie bez powodu na "testament" L. Kaczyńskiego powoływali się A. Duda i M. Morawiecki. W 20. rocznicę wejścia Polski do Sojuszu prezydent objaśniał nową jakość obecności tej organizacji w Polsce, przytaczając wtedy rozmowę z L. Kaczyńskim. Nieżyjący prezydent miał mu powiedzieć przed laty, że kiedy w Polsce znajdą się wojska amerykańskie i amerykańskie instalacje militarne, wtedy „[...] cały świat naprawdę zobaczy, że tu nie ma już rosyjskiej strefy wpływów, że to nie jest nawet jakaś strefa buforowa, gdzie właściwie nie wiadomo, co to jest, coś pomiędzy Zachodem a Rosją. Bo jak znajdą się tutaj wojska amerykańskie, to rzeczywiście będziemy częścią Zachodu". Premier Morawiecki mówił wprost o realizacji "testamentu" Lecha Kaczyńskiego, który marzył o stałej obecności wojsk Sojuszu na terytorium Polski ${ }^{199}$. Do dorobku zmarłego prezydenta nawiązywał także minister spraw zagranicznych W. Waszczykowski: „Nam stale chodzi o jedno, już od czasów prezydentury Lecha Kaczyńskiego: o podmiotowość" ${ }^{200}$. W PiS powszechne było mniemanie,

199 Archiwum Prezydenta RP, https://www.prezydent.pl, dostęp 12 XI 2019: „Wywiad Prezydenta Andrzeja Dudy dla Radia Szczecin”, 12 III 2019; „Wywiad Prezydenta RP Andrzeja Dudy dla RDC", 10 IV 2018; M. Morawiecki na spotkaniu z żotnierzami wielonarodowego batalionu NATO w Bemowie Piskim, 29 III 2018, http://www.radiomaryja.pl, dostęp 9 V 2019. Wypowiedź premiera: „Stała obecność wojsk NATO na terytorium Polski byta zawsze marzeniem prezydenta Lecha Kaczyńskiego i realizacją jego testamentu".

200 W. Waszczykowski, Odnosimy sukces i świat to widzi [Rozmowa Jacka i Michała Karnowskich z Witoldem Waszczykowskim], „Sieci”, 3-9 VII 2017, nr 27(240), s. 29. 
że w polityce zagranicznej Polski jej linię strategiczną wyznaczył prezydent Kaczyński i należy kontynuować oraz rozwijać jego aktywności.

Gdyby poszukiwać uzasadnienia teoretycznego dla polityki transatlantyckiej PiS, to należałoby sięgnąć do rozważań na temat państwa średniego pivotalnego. Na uzasadnienie teoretyczne nakładają się polskie doświadczenia historyczne związane z okresem mocarstwowości I Rzeczypospolitej oraz z dziejami II Rzeczypospolitej, będącej historycznie pierwszym polskim wariantem państwa średniego pivotalnego. Dla tego typu państw właściwa jest alternatywa co do modelu polityki zagranicznej - albo balansowanie, albo bandwagoning. W latach 19911992, w czasie istnienia rządu J. Olszewskiego, J. Kaczyński jako polityk odrzucił politykę balansowania. Wyciągnął więc odmienne wnioski niż w latach 1932-1934 Piłsudski, który opowiedział się za taką polityką. To przewartościowanie strategiczne na skalę historyczną wynikało z pozytywnej oceny: integracji europejskiej, zmian w polityce wewnętrznej i zewnętrznej Niemiec, obecności amerykańskiej w Europie. Kaczyńskiego i Piłsudskiego różnił przede wszystkim stosunek do Niemiec. W opinii tego pierwszego ocena RFN powinna zasadniczo różnić się od oceny Federacji Rosyjskiej. Tę różnicę przywołał w wywiadzie dla gazety „Bild”: „W Berlinie zasiada demokratycznie wybrany rząd i obowiązują prawo oraz moralność. O Rosji natomiast nie da się tego powiedzieć" ${ }^{201}$. Jednak Kaczyński odrzucał klientelizm zarówno wobec Berlina, jak i wobec Moskwy, wybierając bandwagoning wobec Waszyngtonu, zwany strategicznym partnerstwem ${ }^{202}$. Piłsudski natomiast udzielał swoim współpracownikom rady, żeby bacznie obserwowali Stany Zjednoczone, zmiany w polityce amerykańskiej mogą mieć bowiem znaczący wpływ na procesy międzynarodowe, co będzie oddziaływało na sytuację w Europie, polity-

201 Cyt. za: Kaczyński odpowiedziat na pytanie, czy Putin stat za zamachem na jego brata, http://www.fakt.pl, 25 | 2020, dostęp 26 I 2020.

202 Vide M. Habowski, Prawo i Sprawiedliwość wobec zagadnień polityki zagranicznej, [w:] Polityka zagraniczna Polski w latach 2004-2011..., s. 127. Negatywna ocena polityki bandwagoningu vide R. Zięba, Gtówne kierunki polityki zagranicznej..., s. 161-162; idem, Implikacje stosunków polsko-amerykańskich dla polityki zagranicznej Polski, „Przegląd Politologiczny" 2015, nr 2, s. 7-20. 
kę innych państw (zwłaszcza Wielkiej Brytanii), a w przypadku Polski na perspektywy efektywnego kształtowania własnego bezpieczeństwa ${ }^{203}$.

Reasekuracją instytucjonalną dla bandwagoningu była przynależność zarówno do Sojuszu, jak i do Unii, a funkcjonalną zdefiniowanie w środowisku międzynarodowym własnych interesów, składających się na rację stanu. O nieudolność w tej drugiej sprawie PiS oskarżało większość gabinetów III Rzeczypospolitej, a nawet w całości ten podmiot polityczny, dlatego też wylansowano hasło „IV Rzeczpospolita”. Opisała ten stan Anna Fotyga: „[...] nie potrafimy zdefiniować nawet naszych oczywistych interesów i tak strasznie zależy nam, aby inne kraje nas chwaliły, abyśmy mieli z nimi "dobre relacje», dlatego boimy się nawet dyskusji na temat naszych interesów" ${ }^{204}$. Natomiast bez zdefiniowania własnych interesów bandwagoning mógł oznaczać tylko uzależnienie, bez osiągania realnych korzyści w odniesieniu przede wszystkim do statusu międzynarodowego Polski, jej pozycji międzynarodowej oraz bezpieczeństwa.

Nie można rozpatrywać polityki transatlantyckiej w oderwaniu od podstaw ideowych i programowych polityki zagranicznej realizowanej przez wszystkie gabinety rządowe tworzone przez PiS w III Rzeczypospolitej. Na te podstawy składało się pięć elementów: 1) traktowanie Polski jako państwa średniego, czyli zdolnego do prowadzenia podmiotowej i suwerennej polityki zagranicznej; 2) przypisywanie Europie Środkowej roli czynnika wzmacniającego istotnie potencjał polityczny i bezpieczeństwo Polski; 3) uznanie integralności roli mocarstwowej Stanów Zjednoczonych w świecie i bezpieczeństwa Europy; 4) niemożność uregulowania w czasie bieżącym stosunków polsko-rosyjskich zgodnie z interesami Rzeczypospolitej; 5) strategiczne znaczenie i autonomia sojuszu Polski ze Stanami Zjednoczonymi wobec procesów integracyjnych w Europie i rywalizacji wewnątrz Unii Europejskiej.

203 Analiza ewolucji polityki polskiej wobec Stanów Zjednoczonych w okresie 19261939 (z przywołaniem danych źródłowych) vide W. Paruch, Myśl polityczna obozu pitsudczykowskiego (1926-1939)..., s. 669-671.

204 M. Bober, Rząd przeksztatca Polskę w kolonię..., s. 3. 
Z wymienionych pięciu elementów polityki zagranicznej wypracowanej przez PiS kluczowe było traktowanie regionu Europy Środkowej jako priorytetowego dla Rzeczypospolitej. To właśnie na tym obszarze znajdowały się zasoby, które Polska mogła zdyskontować, budując swój potencjał polityczny państwa średniego na pięciu kierunkach: a) unijnym, b) północnoatlantyckim, c) amerykańskim, d) niemieckim, e) rosyjskim. Bez zbudowania nowej architektury stosunków regionalnych szansa na podmiotowość Polski zasadniczo uległaby redukcji, w osamotnieniu przestawała być bowiem atrakcyjna dla Waszyngtonu oraz jawiła się jako zbyt słaba wobec Brukseli, Moskwy i Berlina, aby mogła być traktowana w sposób partnerski. Czerpiąc z doświadczeń historycznych II połowy XVIII wieku oraz lat międzywojennych XX stulecia, można było mieć pewność, że zagłada Europy Środkowej będzie jednocześnie oznaczała upadek odrodzonej po raz kolejny polskiej suwerennej państwowości. Jak to ustaliła Joanna Sanecka-Tyczyńska, koncepcja polityki regionalnej PiS wynikała z pięciu przesłanek.

1. Region jest całością, na którą składają się państwa o silnej, bo odzyskanej tożsamości politycznej, zakotwiczonej w narodowym charakterze państwowości. Czynnikami dodatkowymi były: pluralizm kulturowy nacechowany tolerancją wobec różnorodności religijno-wyznaniowej i narodowo-etnicznej, wspólnota interesów i wartości w Unii i Sojuszu, podobna najnowsza historia w postaci podboju przez państwa totalitarne, przekonanie o destrukcyjnym znaczeniu historycznym konfliktów międzypaństwowych wobec zagrożenia uprzedmiotowieniem przez mocarstwa.

2. Konieczność przezwyciężenia statusu peryferyjnego wobec hemisfery zachodniej, ponieważ region może być nowym centrum pobudzającym rozwój kontynentu w warunkach kryzysu Zachodu (moralnego i demograficznego) oraz barierą, która skutecznie powstrzyma odradzanie się rosyjskiego imperializmu oraz hegemonię Niemiec w Unii.

3. Prawo do sprawiedliwości dziejowej, wynikające chociażby ze „zdrady" Zachodu w ostatniej fazie II wojny światowej oraz z zysków osiągniętych przez tenże Zachód po akcesji państw środkowoeuropejskich do Sojuszu i do Unii, co znacznie wzmocniło potencjał tych organizacji 
międzynarodowych. Zachód zrobił bardzo dobry interes, przyjmując państwa Europy Środkowej do Unii.

4. Aktywna polityka regionalna jest nakazem polskiej racji stanu, niewynikającym bynajmniej z kolejnego przeżywania snu o jagiellońskiej potędze czy też z restauracji koncepcji antemurale chrześcijaństwa, ale $\mathrm{z}$ realizmu politycznego, pragmatyzmu oraz faktycznego braku alternatywnego projektu korzystnego dla państw środkowoeuropejskich.

5. Budowa powiązań sieciowych w Europie Środkowej, których zwornikiem powinna być Polska, musi odbywać się w Unii Europejskiej i w Sojuszu Północnoatlantyckim, a nie przeciwko nim czy też zamiast współpracy unijnej i północnoatlantyckiej. Powiązania sieciowe miały stanowić mechanizm współpracy państw położonych w regionie, co J. Kaczyński uważał za wykonalne, „póki jest NATO bez Rosji i Unia bez Rosji, i Polska w obydwu organizacjach"205. Projektowane (i realizowane z całym rozmachem po 2015 roku) powiązania sieciowe miały być środkiem do zapowiadanej przez PiS rekonstrukcji Europy Środkowej, ale także sposobem na przezwyciężenie rozbieżności między państwami regionu niechętnymi do rozumowania w kategoriach geopolitycznej jedności. Scenariusze alternatywne, takie jak bycie peryferiami wschodnimi Unii i zachodnimi hemisfery rosyjskiej lub rola bufora między Zachodem i Wschodem, musiały doprowadzić do utraty przez te państwa podmiotowości na rzecz czynników zewnętrznych wobec regionu, co mogło doprowadzić po raz trzeci w ostatnich dekadach do przekształcenia obszaru w pole walki mocarstw, w przypadku rozpadu koncertu mocarstw (współdecydujących o losach państw średnich i małych) na system blokowy (dwie koalicje dążące do wojny) ${ }^{206}$.

Z tych podstaw polityki zagranicznej PiS wywiodło koncepcję polityki transatlantyckiej, która wynikała z przesłanki zdefiniowanej przez J. Cza-

205 J. Kaczyński, Piłsudskim niejestem..., s. 135. Problematyka środkowoeuropejska w myśli politycznej PiS oczekuje na swojego badacza. Na tym etapie refleksji naukowej wyniki analiz Saneckiej-Tyczyńskiej wydają się najbardziej pogłębione i oparte na podstawowym materiale źródtowym. J. Sanecka-Tyczyńska, Racja stanu we wspótczesnej polskiej myśli politycznej..., s. 319-324.

206 Vide M. J. Chodakiewicz, op. cit., s. 414. 
putowicza w 2018 roku w wystąpieniu sejmowym: „[...] wojskowa obecność Stanów Zjednoczonych w Europie i ich silna pozycja w NATO mają fundamentalne znaczenie dla bezpieczeństwa militarnego Polski i całego regionu. W interesie Polski i Europy Środkowo-Wschodniej jest trwałe zaangażowanie Stanów Zjednoczonych i Sojuszu Północnoatlantyckiego w tej części świata. Polska jest jak najżywotniej zainteresowana utrzymaniem silnych więzi transatlantyckich"207. W PiS dość racjonalnie uważano, że w polityce amerykańskiej ważny może być jedynie region, a nie sama Polska ze swoim potencjałem. Region, który powiązany silnymi więzami ze Stanami Zjednoczonymi dawał im możliwość blokowania Rosji oraz oddziaływania na sytuację w Europie w warunkach rosnących w siłę Niemiec, ukierunkowanych na politykę interesów z Rosją.

Polityka transatlantycka, według PiS, miała się opierać na trzech zasadach: 1) likwidacji „szarej strefy” w Europie Środkowej; 2) jedności i całościowości bezpieczeństwa Sojuszu Północnoatlantyckiego; 3) współpracy Organizacji Paktu i Unii Europejskiej. Te zasady wywodziły się z przeświadczenia, że sama przynależność Polski do Sojuszu Północnoatlantyckiego nie rozwiązuje problemu jej bezpieczeństwa, lecz tworzy nowe warunki dla polityki zagranicznej. Napisano to wprost w programie z 2009 roku, dezawuując tezę, że po wstąpieniu Polski do obu organizacji polityka uległa „spełnieniu" i weszła w „fazę poststrategiczną, w której nie stoimy już przed koniecznością dokonywania zasadniczych wyborów"208. Ten sposób myślenia uległ wzmocnieniu po 2014 roku, kiedy zmaterializowały się prognozy prezydenta Kaczyńskiego wypowiedziane w Tbilisi w 2008 roku o agresywnej polityce Rosji - po Gruzji Kreml „zainteresował się" Ukrainą ${ }^{209}$. W tym kontekście należy rozpatrywać

207 Cytowaną przestankę minister nazwat „tezą trzecią", po środkowoeuropejskiej i unijnej, w odniesieniu do polityki zagranicznej Polski. J. Czaputowicz, Informacja ministra spraw zagranicznych o zadaniach polskiej polityki zagranicznej w 2018 roku..., s. 82.

208 Program Prawa i Sprawiedliwości 2009..., s. 172, 216-218.

209 Trudno przyznać rację Mieczysławowi Stolarczykowi, że w postawie prezydenta Kaczyńskiego wobec wojny 2008 roku wzięty górę „emocje nad chłodną, wymaganą od głowy państwa, oceną tego rodzaju sytuacji i reakcji na nią". Wręcz przeciwnie - L. Kaczyński kierował się racjonalnością i realizmem, co przyczyniło się do odniesienia przez niego sukcesu. Niestety to Unia Europejska okazała się wtedy „miękka” wobec Rosji, 
wypowiedź J. Kaczyńskiego z 2014 roku, jakże charakterystyczną dla myśli politycznej PiS: „Granica NATO nie jest wcale pewną linią, której nie przekroczy prezydent Putin w swoich zakusach [...]. W obecnej sytuacji militarnej obawiam się nie tylko o Kijów, ale też o Warszawę, a nawet o Berlin. Biorąc pod uwagę stan armii niemieckiej, to Putin też nie miałby kłopotów"210. Te obawy prezesa PiS niewątpliwie dodatkowo wzmacniała negatywna ocena polityki zagranicznej koalicji PO-PSL, postrzeganej przez lidera opozycyjnego stronnictwa jako niezdolnej do właściwej reakcji na rosyjskie zagrożenia i uzależnionej w strategicznych wyborach od Niemiec.

Likwidacja „szarej strefy” w Europie Środkowej miała dla PiS dwa wymiary: 1) równouprawnienia regionu wobec Europy Zachodniej co do obecności wojsk i instalacji militarnych Sojuszu, adekwatnych do "flankowego" położenia tej części kontynentu; 2) prowadzenia polityki "otwartych drzwi" wobec państw usytuowanych w Europie Środkowej i Wschodniej wyrażających polityczną wolę akcesji do Sojuszu. Minister spraw zagranicznych W. Waszczykowski w latach 2015-2016 deklarował publicznie (z trybuny sejmowej i w wywiadzie prasowym): 1) „My uważamy, że w NATO nie może być dwóch pułapów bezpieczeństwa: inny dla Europy Zachodniej, gdzie stacjonują wojska amerykańskie, są bazy wojskowe, instalacje obronne, a w Polsce nic nie ma”; 2) „Nie ma i nie może być mowy o powrocie do szarych stref czy próżni bezpieczeństwa w naszej części kontynentu" ${ }^{\text {211 }}$. Dlatego też, z tego drugiego powodu, PiS konsekwentnie opowiadało się „za utrzymaniem przez Sojusz polityki otwartych drzwi", pod jednym warunkiem, że "proces rozszerzania będzie służył wzmacnianiu funkcji obronnych NATO".

co prawdopodobnie utwierdziło ją w przekonaniu, że może kontynuować politykę imperialną bez realnych konsekwencji. M. Stolarczyk, Rosja w polityce zagranicznej Polski..., s. 211.

210 J. Kaczyński, Wypowiedź dla „Dziś wieczorem” w TVPInfo, 3 IX 2014, http://www.tvp.info, dostęp 29 | 2020.

211 W. Waszczykowski, Uchodźcynie przyjdą do Polski [Wywiad Marka Czarneckiego i Agaty Kondzińskiej z Witoldem Waszczykowskim], „Gazeta Wyborcza”, 25XI 2015, nr 275, s. 11; idem, Informacja ministra spraw zagranicznych o zadaniach polskiej politykizagranicznej w 2016 roku..., s. 73. 
Zasadnicze powody wspierania przez Polskę aktywności Sojuszu wobec otoczenia międzynarodowego przedstawił prezydent Duda na otwarciu szczytu Organizacji w Warszawie w 2016 roku: „Stabilność regionu euroatlantyckiego jest zależna od bezpieczeństwa poza jego granicami. Dotrzymując swoich zobowiązań na rzecz obronności, musimy jednocześnie pogłębiać współpracę z wszystkimi naszymi partnerami, zarówno w naszym wschodnim, jak i południowym sąsiedztwie, poprzez wspieranie ich zdolności obronnych" ${ }^{212}$. Postulat polityki „otwartych drzwi" był także niemal tradycyjny dla myśli politycznej PiS. Potwierdzały go zapisy w programach PiS z lat 2007, 2009 i 2014. Poparto w nich jednoznacznie politykę „otwartych drzwi” dla państw środkowoeuropejskich i dotychczas neutralnych. Pisano, że zamknięcie się Paktu na te państwa wystawiałoby Europę Środkową, w tym Polskę, na podporządkowanie interesom rosyjskim i niemieckim oraz czyniło z Polski państwo peryferyjne w hemisferze euroatlantyckiej. W programie z 2014 roku stwierdzano zaś w sposób uogólniający: „Uważamy jednocześnie, że należy nieustająco podkreślać, iż koncepcja rozszerzenia NATO na kraje Europy Wschodniej i południowego Kaukazu jest nadal aktualna i powinna być opracowywana w ramach tworzenia scenariuszy przyszłości". Pięć lat wcześniej w innym programie sformułowano bardzo ważną zasadę odnoszącą się do stosunków międzynarodowych: wybór danego państwa na rzecz członkostwa w Pakcie musi się opierać "[...] wyłącznie na woli państw członkowskich i państwa kandydującego. Wykluczone musi być faktyczne dopuszczanie do udziału w tym procesie jakiegokolwiek państwa trzeciego, przyznawanie mu swoistego nieformalnego weta"213. Minister Waszczykowski politykę rozszerzania nazwał "polityką podmiotową"214.

212 Duda: NATO powinno pozostać przy polityce otwartych drzwi, 8 VII 2016, http://www.gazetaprawna.pl, dostęp 14 II 2020.

213 Taka jednoznacznie ujęta zasada powtarzała się w kolejnych programach PiS. Program Prawa i Sprawiedliwości 2014..., s. 153; Program Prawa i Sprawiedliwości 2009..., s. 172; Dbamyo Polskę. Dbamyo Polaków..., s. 50.

214 W. Waszczykowski, Chcemy Unii Europejskiej, ale innej [Wywiad Jacka i Michała Karnowskich z Witoldem Waszczykowskim], „Sieci”, 11-17 | 2016, nr 2(163), s. 31. 
Według PiS jedynie rozszerzenie gwarantowałoby realizację stabilizującej roli Sojuszu. Zastrzeżenie co do prawa weta oczywiście odnosiło się do Rosji. We wspomnianym dokumencie partyjnym z 2007 roku znalazła się szczegółowa lista potencjalnych nowych członków: „Jesteśmy zwolennikami budowania szybkich i pewnych perspektyw członkostwa w strukturach euroatlantyckich, w szczególności dla Ukrainy, Mołdawii, Gruzji, ale również innych partnerów w regionie - Azerbejdżanu, Armenii, a w przyszłości Białorusi"215. Była to polityka „otwartych drzwi", która wynikała z przekonania, że jest to efektywna droga podnoszenia bezpieczeństwa Polski, zgodna z interesami Europy i Stanów Zjednoczonych. Taką diagnozę wskazali Aleksander Szczygło i Witold Waszczykowski na łamach "Gazety Wyborczej”: „Im więcej w NATO państw demokratycznych, z cywilnym nadzorem nad siłami zbrojnymi, przejrzystą polityką obronną, a więc przewidywalnych, tym lepiej dla bezpieczeństwa Sojuszu i jego sąsiadów"216. Sojusz był więc postrzegany jako kotwica wewnętrzna dla państw postradzieckich (postkomunistycznych), z których wiele miało niestabilny zarówno system polityczny, jak i ład społeczny oraz nie wypracowało własnej linii strategicznej w polityce zagranicznej i wahało się między skrajnościami - kursem euroatlantyckim a filorosyjskim. Odwracano myślenie, które zdawało się dominować, że do Sojuszu można przyjmować jedynie państwa z uporządkowaną sytuacją wewnętrzną uważano, że to właśnie jasne stanowisko w sprawie akcesji do Organizacji Paktu najlepiej pomoże w stabilizacji wewnętrznej.

Polityka rozszerzenia Sojuszu, według PiS, powinna odbywać się na dwóch azymutach geograficznych: bałkańskim i postradzieckim. W 2006 roku prezydent Kaczyński sformułował postulat likwidacji tej „szarej strefy" i zaproponował rozszerzenie Sojuszu o państwa Europy Środkowej, wymieniając trochę odmienny zestaw państw niż rok później w programie partyjnym. Prezydent wyszczególnił wówczas: Ukrainę,

215 Dbamyo Polskę. Dbamyo Polaków..., s. 53.

216 A. Szczygło, W. Waszczykowski, Jakiego NATO chcemy, "Gazeta Wyborcza”, 15 III 2009, nr 62, s. 21. 
Gruzję, Chorwację, Macedonię i Albanięe217. Niezależnie od pojemności owej listy oraz realnego terminarza, zarówno prezydent, jak i stronnictwo go popierające byli zwolennikami zaprezentowania wiążącej perspektywy, nawet wieloletniej i ewolucyjnej, opartej na konieczności spełnienia konkretnych warunków przez pewną grupę państw środkowoeuropejskich. Lech Kaczyński opowiedział się też za nawiązaniem współpracy z: Serbią, Bośnią i Hercegowiną oraz Czarnogórą. W jego opinii akcesja tych wszystkich państw byłaby zrealizowaniem obowiązku przez Sojusz, poszerzeniem obszaru wolności, zniesieniem reliktów pojałtańskiego podziału Europy, wypełnieniem powinności moralnych Zachodu wobec Europy Środkowej, stwarzaniem systemu stabilności, pokoju i bezpieczeństwa.

W kwestii rozszerzenia Sojuszu prezydent A. Duda oraz oba gabinety Zjednoczonej Prawicy, działające w latach 2015-2019, kontynuowali kurs wyznaczony przez prezydenta Kaczyńskiego w odniesieniu do dwóch azymutów geograficznych. Dawali temu wyraz w swoich wystąpieniach najważniejsi politycy PiS. Dla Dudy współpraca ze Szwecją i z Finlandią, otwarcie drzwi dla Ukrainy, Gruzji i Mołdawii oraz przyjęcie państw zachodniobałkańskich stanowiły strategiczną konieczność. W Sejmie minister J. Czaputowicz (w latach 2018-2019) opowiedział się także za: współpracą Sojuszu z państwami z otoczenia Polski - Finlandią, Szwecją, Ukrainą, Mołdawią i Gruzją; przyjęciem do Paktu Republiki Macedonii Północnej; umacnianiem oddziaływania Sojuszu na Ukrainę $e^{218}$. W odniesieniu do państw demokratycznych tzw. zachodnich, które nie

217 Na liście kandydatów do członkostwa w Sojuszu prezydent Kaczyński niekiedy umieszczał również Mołdawię. Vide Archiwum Prezydenta RP, https://www.prezydent.pl, dostęp 10 X 2019: „Wystąpienie Prezydenta na Szczycie Prezydentów Europy Środkowej”, 19 V 2006; „Wykład Prezydenta w The Chicago Council on Global Affairs”, 25 IX 2007.

218 Archiwum Prezydenta RP, https://www.prezydent.pl, „Wywiad dla PAP przed szczytem NATO", 7 VII 2016, dostęp 12 VI 2010; J. Czaputowicz, Informacja ministra spraw zagranicznych o zadaniach polskiej polityki zagranicznej w 2019 roku, 13 III 2019, http:// www.gov.pl, dostęp 12 V 2019; idem, Informacja ministra spraw zagranicznych o zadaniach polskiej polityki zagranicznej w 2018 roku..., s. 82; vide W. Waszczykowski, Teraz to NATO wchodzi do Polski [Wywiad Grzegorza Osieckiego z Witoldem Waszczykowskim], „Dziennik Gazeta Prawna”, 7 VII 2016, nr 130, s. 3. 
aspirowały do członkostwa w Sojuszu, np. Finlandia i Szwecja, minister Waszczykowski zaczął używać formuły „rozszerzenie współpracy poza obszar traktatowy"219. Podobnie sprawę postrzegał prezydent Duda, który uznał, że i Szwecja, i Finlandia mają specjalne znaczenie dla Polski oraz „stanowią integralną i niezbędną część Obrony Europejskiej w ramach Unii Europejskiej", dlatego też Sojusz powinien wypracować szczególne relacje z tymi państwami ${ }^{220}$. Niewątpliwie kandydatów do realizacji tej formuły poszukiwano w sferze oddziaływania Rosji. Wymienione państwa skandynawskie takie kryterium spełniały.

Politycy PiS odpowiedzialni za politykę zagraniczną w latach 20152019 najwięcej uwagi poświęcali ewentualnej akcesji Ukrainy i Gruzji do Sojuszu Północnoatlantyckiego, doceniając geopolityczne znaczenie tych państw dla Polski. Określił je w latach 2008-2010 L. Kaczyński, kiedy decydowało się przyznanie Kijowowi i Tbilisi tzw. MAP (Membership Action Plan). Ewentualne przyjęcie tych państw oznaczało „rozbicie postsowieckiego układu geopolitycznego" z korzyścią dla Polski. Pociągnęłoby za sobą także stabilizację w tej części Europy, chociaż wiązało się z wieloma niebezpieczeństwami i nie było całkowicie jednoznaczne ${ }^{221}$. Można nawet powiedzieć, że ta sprawa stała się niezależna od zawirowań w stosunkach dwustronnych, zwłaszcza między Warszawą a Kijowem, oraz od obsady personalnej stanowisk władzy na Ukrainie i w Gruzji ${ }^{222}$. W utrzymaniu niepodległej i suwerennej Ukrainy PiS widziało niemal gwaranta bezpieczeństwa geopolitycznego Polski, zwłaszcza w kontekście postępującego zbliżenia rosyjsko-białoruskiego i militaryzacji obwodu królewieckiego,

219 Ibidem.

220 Archiwum Prezydenta RP, https://www.prezydent.pl, „Prezydent Andrzej Duda w NATO Defense College, Włochy", 17 V 2016, dostęp 12 VI 2020.

221 Ł. Warzecha, Lech Kaczyński. Ostatni wywiad..., s. 257.

222 Liczne wypowiedzi ministrów Waszczykowskiego i Czaputowicza w kontekście ukraińskim vide: W. Waszczykowski, Otwarte drzwi dla Ukrainy, „Rzeczpospolita”, 13 IX 2016, nr 214, s. A10-A11; idem, Nie ujawniamy nazwisk z listy osób objętych zakazem wjazdu do Polski [Wywiad Grzegorza Osieckiego z Witoldem Waszczykowskim], „Dziennik Gazeta Prawna", 13 IX 2017, nr 177, s. 6; J. Czaputowicz, Dialog to nie ustępstwo[Wywiad Macieja Pieczyńskiego z Jackiem Czaputowiczem], „Do Rzeczy”, 29 I-4 II 2018, nr 5(258), s. 35. 
co miałoby brzemienne skutki dla strategii i doktryny obronnej Rzeczypospolitej. Oczywiście Gruzja takiej roli nie spełniała.

Kurs w sprawie Ukrainy określił jednoznacznie minister Meller w swoim exposé w 2006 roku: „Włączenie Ukrainy do NATO wzmocni ten sojusz, ale będzie też bardzo korzystne dla Polski, dlatego będziemy o to zabiegać" ${ }^{\prime 23}$. Destabilizacja Ukrainy, poprzedzająca jej pełne uzależnienie od Rosji, była bowiem najczarniejszym scenariuszem dla Polski w środowisku międzynarodowym, ponieważ oznaczałaby powrót do sytuacji z okresu 1921-1991. W tym kontekście w odniesieniu do popierania euroatlantyckich aspiracji Kijowa przeważały kalkulacje geopolityczne i pragmatyczne. Na zupełnie inne elementy zwracano uwagę w przypadku Gruzji.

Stosunek PiS do aspiracji euroatlantyckich Gruzji wynikał niejako naturalnie z prowadzonej przez Lecha Kaczyńskiego polityki, dla której kulminacją były wydarzenia w Tbilisi (inwazja rosyjska) i w Bukareszcie (szczyt Sojuszu) w 2008 roku. Był to jakby „testament" polityczny prezydenta w sprawach międzynarodowych zostawiony następcom. Ujął to lapidarnie minister Czaputowicz: „z perspektywy Polski i państw bałtyckich drzwi do świata zachodniego są dla Gruzji otwarte". Wprawdzie w latach 2015-2019 niewiele zostało z planów energetycznych L. Kaczyńskiego, w których tranzyt ropy naftowej przez Gruzję był kluczowy, ale jednak reminiscencje gruzińskie w myśli politycznej PiS przetrwały nawet wielokrotne zmiany polityczne w Tbilisi. W 2018 roku minister Czaputowicz sformułował w radio następującą ocenę: „Gruzja jest jednym z najbardziej wiarygodnych, a także zaangażowanych w działania Sojuszu partnerów; uważamy, że Gruzja zasługuje na członkostwo w NATO jako najlepiej przygotowany kandydat". Rolę Polski na drodze akcesyjnej Gruzji widział jako wypracowanie „odpowiedniego klimatu międzynarodowego" 224 . Liczono także na to, że sukcesy Gruzji w polityce

\footnotetext{
${ }^{223}$ S. Meller, Informacja ministra spraw zagranicznych o zadaniach polskiej polityki zagranicznej w 2006 r...., s. 12.

224 J. Czaputowicz, Rosja wyczuwa stabość [Wywiad Jacka Karnowskiego z Jackiem Czaputowiczem], „Sieci”, 13-19 VIII 2018, nr 33(298), s. 41; idem, Gruzja zasługuje na cztonkostwo
} 
euroatlantyckiej będą miały siłę oddziaływania na cały region Kaukazu jako pozytywny przykład kursu odmiennego od filorosyjskiego.

Jednak oprócz kalkulacji typowo politycznych związanych z gruzińskimi aspiracjami euroatlantyckimi pojawiały się jeszcze inne argumenty - emocjonalne i afektywne. Podniosła je w Sejmie poseł Gosiewska: "[...] z Gruzją i Gruzinami wiążą nas, Polaków, wielowiekowe związki serdeczności, sojuszów i przyjaźni oraz że Gruzini z sercem przyjmowali zesłańców polskich, którzy za caratu trafili tam na zesłanie". Chodziło także o współpracę w okresie międzywojennym oraz za prezydentury L. Kaczyńskiego ${ }^{225}$.

W latach 2015-2019, w porównaniu z okresem 2005-2007, politycy PiS odpowiedzialni za sprawowanie władzy mocno zaangażowali się w rozszerzenie Sojuszu na kierunku bałkańskim. Dostrzegali tam pole gry politycznej ważne dla bezpieczeństwa na kontynencie, w którą zaangażowani byli aktorzy zewnętrzni. Oczywiste było, że Rosja dąży do destabilizacji tego regionu. Motywację wskazał w wywiadzie w „Radio Maryja" minister Czaputowicz: „Jeśli my nie zapewnimy tam stabilności teraz, to później sytuacja może rozwinąć się w niekorzystnym kierunku. [...] Chodzi o to, żeby Bałkany Zachodnie utrzymać - mówiąc kolokwialnie-blisko UE i Sojuszu Północnoatlantyckiego" ${ }^{226}$.Z tego powodu Polska włączyła się w 2018 roku w proces berliński, którego celem było przyjęcie państw zachodniobałkańskich do struktur europejskich, i w dniach 3-5 lipca 2019 roku zorganizowała w Poznaniu konferencję w ramach tego procesu. Udzieliła także mocnego wsparcia dla akcesji Macedonii Północnej i Albanii do Sojuszu oraz oceniła pozytywne efekty wejścia w 2017 roku Czarnogóry do Paktu. Przyjęcie tej ostatniej do Sojuszu było postrzegane jako historyczne wydarzenie, Organizacja uzyskała bowiem w tej części Bałkanów przyczółek, który nadał mu „nową geopolityczną

w NATO jako najlepiej przygotowany kandydat, 24X 2018, http://www.polskieradio24.pl, dostęp 15 II 2020.

225 M. Gosiewska, Wypowiedź, [w:] WNPSejm, 8 kadencja, 78 pos., 14 III 2019, http://www. sejm.pl, dostęp 14 II 2020.

226 J. Czaputowicz, Opowiadamy się za szybkim rozpoczęciem negocjacji akcesyjnych z Albanią i Macedonią Ptn., 8 IX 2019, http://www.radiomaryja.pl, dostęp 5 II 2020. 
dynamikę"227. Niewątpliwie punktem odniesienia było tradycyjne rozdarcie widoczne na Bałkanach między okcydentalizacją a orientacją filorosyjską, przyczyniające się między innymi do przekształcenia tego obszaru w kocioł, w którym tliło się zarzewie wojny.

Owszem, proces berliński odnosił się do integracji europejskiej państw zachodniobałkańskich, ale według PiS tylko Sojusz mógł zapewnić osiągnięcie tego celu poprzez skuteczne ustabilizowanie obszaru. Zdaniem Czaputowicza: „NATO chciałaby [tak w oryginale - W.P.] i będzie stabilizować ten region, bo on ma znaczenie dla bezpieczeństwa całej UE" (5 grudnia 2018 roku)"228. W opinii PiS czas naglił, dlatego należało szybko podejmować strategiczne decyzje, uprzedzając rywali politycznych. Nie ukrywano, że chodzi o Rosję, której Sojusz miał zablokować „drogę na Bałkany". Natomiast uważano, że Macedonia Północna nie tylko będzie wiarygodnym członkiem Paktu, ale również wniesie "prawdziwą wartość dodaną dla bezpieczeństwa Sojuszu". Z całym przekonaniem więc minister Błaszczak deklarował: „Cieszymy się, że już wkrótce do Sojuszu Północnoatlantyckiego dołączy 30. państwo, czyli Macedonia Północna. Jesteśmy gotowi na tego typu inicjatywy"229. Sprawy Albanii oraz Bośni i Hercegowiny były bardziej skomplikowane, chociażby z racji niewydolności systemu politycznego w tych państwach, stosunków z Serbią, a także tendencji separatystycznych w Bośni i Hercegowinie oraz w Kosowie.

W kontekście Bałkanów między okresem „pierwszych rządów" a latami 2015-2019 jest zasadnicza różnica. W latach 2005-2007 władze RP posiadające rekomendacje PiS nie opracowały strategii wobec regionu bałkańskiego - nie interesowano się nim ani jako częścią Europy Środkowej, ani jako odrębnym subregionem. Wprawdzie prezydent Kaczyński uczestniczył w 2009 roku w spotkaniu prezydentów Europy Środkowej

227 Polska za utrzymaniem polityki otwartych drzwi NATO, 27 V 2016, http://www.biznesalert.pl, dostęp 15 II 2020.

228 NATO uchyla drzwi krajom Batkanów Zachodnich, by osłabić wpływy Rosji, 5 XII 2018, http://www.pap.pl, dostęp 15 II 2020.

229 M. Błaszczak, Jesteśmy jednym z liderów NATO i ksztattujemy jego oblicze, 12 III 2019, http://www.polskieradio24.pl, dostęp 15 II 2020. 
w Nowym Sadzie, ale trudno mówić o wymiernych efektach strategicznych, o które już wtedy nie było łatwo, zważywszy na stosunek rządu D. Tuska do prezydenta i jego aktywności międzynarodowej ${ }^{230}$. Należy więc się zgodzić z opinią wyrażoną w 2008 roku, stanowiącą podsumowanie poprzednich lat, że Polska zajęła pozycję „odległego obserwatora", zamykając swoją politykę bałkańską w myśleniu życzeniowym i ogólnikowym ${ }^{231}$. Po utracie władzy przez PiS w stronnictwie zaczął dojrzewać pomysł na politykę wobec Bałkanów. Ryszard Czarnecki przypisał jej trzy zadania i postrzegał ją jako: 1) sposób realizacji strategii śródziemnomorskiej Polski; 2) przeciwwagę dla polityki RFN; 3) inwestycję w przyszłość, kiedy państwa bałkańskie znajdą się w Unii i staną się partnerami w budowaniu koalicji zadaniowych we Wspólnocie. Ostatnie zadanie determinowało pozytywny stosunek Polski do aspiracji unijnych i północnoatlantyckich wszystkich państw bałkańskich. Polityk ten wskazał wówczas fundament takiej polityki - zasadę postrzegania regionu jako „Bałkanów różnych prędkości" ${ }^{232}$. Uzupełnieniem tej zasady było przekonanie o „równym dystansie wobec państw bałkańskich"233, zważywszy na skalę konfliktów w tym subregionie. Nie może więc dziwić sytuacja, że po przejęciu w 2015 roku władzy w Polsce politycy PiS - począwszy od prezydenta, a skończywszy na parlamentarzystach - zaczęli zwracać uwagę na Bałkany, intensyfikując stosunki dwustronne ze wszystkimi państwami, ale przede wszystkim wciągając te państwa do budowanej współpracy sieciowej. W konsekwencji mamy państwa bałkańskie w tzw. Formacie Bukareszteńskim i w Trójmorzu oraz na szczytach parlamentarnych państw środkowoeuropejskich, organizowanych przez Sejm VIII

\footnotetext{
230 S. Cenckiewicz, A. Chmielecki, op. cit., s. 214.

231 W. Stanistawski, Polska na Bałkanach Zachodnich - życzliwy, roztargniony kibic, „Polski Przegląd Dyplomatyczny", marzec-kwiecień 2008, nr 2(42), s. 18.0 przyczynach braku polskiej polityki bałkańskiej videP. Świeboda, Polski powrót na Batkany-za iprzeciw, „Polski Przegląd Dyplomatyczny”, marzec-kwiecień 2008, nr 2(42), s. 20.

232 R. Czarnecki, Batkański kociot - polska szansa, „Polski Przegląd Dyplomatyczny”, marzec-kwiecień 2008, nr 2(42), s. 7-8; vide M. Gniazdowski, Batkany Zachodnie: sprawa środkowoeuropejskiej solidarności, „Polski Przegląd Dyplomatyczny”, marzec-kwiecień 2008, nr 2(42), s. 10, 14.

233 P. Świeboda, op. cit., s. 21.
} 
kadencji. W PiS zwyciężył pogląd, że Bałkany - i wschodnie, i zachodnie - są integralną częścią Europy Środkowej w sensie naturalnym i historycznym oraz stanowią pośrednie sąsiedztwo Polski.

W odniesieniu do poszczególnych państw zachodniobałkańskich i całego regionu Polska podjęła w latach 2015-2019 kilka kompleksowych działań, o których 17 kwietnia 2019 roku mówił w Sejmie wiceminister spraw zagranicznych Konrad Szymański. W podsumowaniu zawarł dwa kluczowe wnioski oddające istotę stanowiska rządu. Pierwszy - „Polska była w gronie państw wspierających kolejne rundy rozszerzenia NATO. W ostatnich latach, w 2017, przy aktywnym wsparciu Polski, członkiem NATO została Czarnogóra, a w 2018 zaproszona Republika Macedonii Północnej. Polska jest też w gronie sojuszników zabiegających o utrzymanie na ścieżce euroatlantyckiej Bośni i Hercegowiny”. Drugi - „Zarówno na forum Sojuszu, jak i w rozmowach z poszczególnymi sojusznikami prezentujemy stanowisko stwierdzające, że rozszerzenie Sojuszu o kolejne państwa to fundament polityki NATO realizowany z korzyścią także dla nowo przyjmowanych państw, zaś państwa trzecie nie powinny mieć prawa weta w tej sprawie". Zgodnie z tą deklaracją Warszawa uruchomiła (lub kontynuowała) dwustronny format nazwany konferencjami: skopijską, belgradzką i tirańską, mającymi na celu przekazywanie poszczególnym państwom bałkańskim polskich doświadczeń w zakresie procesu akcesyjnego ze strukturami europejskimi ${ }^{234}$.

Natomiast wobec kryzysu uchodźczego w Europie, PiS przykładało wielką wagę do Turcji jako bardzo ważnego członka Paktu. Takie podejście było charakterystyczne dla lat 2015-2017. To o Turcji minister Waszczykowski mówił w 2015 roku: „nasz najbliższy sojusznik w tamtym regionie" oraz formułował wniosek, że Turcja „musi być traktowana jako państwo bezpieczne". Przychylała się do tej oceny także poseł M. Gosiew-

234 K. Szymański, Odpowiedź na interpelację nr 30610 w sprawie wyhamowania dziatań polskiego rządu na rzecz rozszerzenia Unii Europejskiej i NATO, 17 IV 2019, http://orka2.sejm. gov.pl, dostęp 5 II 2020; Wizyta w Warszawie wicepremiera do spraw europejskich Macedonii Pótnocnej, 20 IX 2019, http://www.gov.pl, dostęp 5 II 2020; Konferencje bilateralne, http://www.gov.pl, dostęp 5 II 2020. Z trzech konferencji tylko skopijską uruchomiono za rządów koalicji PO-PSL (2010 rok), a dwie pozostate w latach 2017-2018. 
ska, reprezentująca oficjalnie KP PiS, podzielając to stanowisko na dwa sposoby: „Turcja szczególnie powinna być dla naszej polityki ważnym punktem odniesienia. [...] kraj ten - [1] tradycyjnie, historycznie Polsce przecież bliski - [2] nabiera coraz większego znaczenia"235. W 2016 roku relacje polsko-tureckie zostały przeniesione na poziom dyplomacji parlamentarnej, w ramach której w dniach 27-28 października marszałek Kuchciński złożył wizytę w Turcji, gdzie został przyjęty przez prezydenta Erdoğana. Marszałek podjął między innymi temat współpracy środkowoeuropejskiej oraz odwołał się do tradycji dyplomatycznych w relacjach dwustronnych (od 1533 roku) ${ }^{236}$. Następnie w 2017 roku (październik) prezydent Erdoğan przyjechał do Warszawy, a wcześniej (maj) premier Szydło rozmawiała z nim w Chinach. Polscy politycy zapewniali - na wyraźne żądanie tureckie - że popierają starania Turcji o wstąpienie do UE, a prezydent Turcji przywoływał wielowiekową tradycję stosunków polsko-tureckich, które przez ponad 600 lat „odbywały się w atmosferze przyjaznej i pokojowej"237.

Jednak po okresie 2016-2017 intensywność relacji polsko-tureckich wyraźnie się zmniejszyła, co oznaczało, że nadzieja na strategiczną kooperację z tym państwem również zmalała. Wpływ miała na to niewątpliwie polityka zagraniczna i wewnętrzna prezydenta Recepa Tayyipa Erdoğana, między innymi zwrot w kierunku Rosji oraz budowa państwa autorytarnego. W Warszawie zareagowano na postępujące zbliżenie turecko-rosyjskie, ostro krytykowane przez Stany Zjednoczone, oraz islamizację systemu politycznego Turcji, a także coraz bardziej intensywne konflikty na linii Ankara-Bruksela. Turcja, podobnie jak Rosja i Biało-

235 Wypowiedź W. Waszczykowskiego dla PAP, 29 XI 2015, http://www.pap.pl, dostęp 5 XII 2019; M. Gosiewska, Wypowiedź, [w:] WNP Sejm, 8 kadencja, 78 pos., 14 III 2019, http:// www.sejm.pl, dostęp 14 II 2020.

236 M. Kuchciński w Turcji m.in. o bezpieczeństwie, kryzysie migracyjnym i gospodarce, $28 \mathrm{X}$ 2016, http://www.radiomaryja.pl, dostęp 20 V 2020; Marek Kuchciński spotkat sięz prezydentem Turcji, 27 X 2016, http://www.wprost.pl, dostęp 20 V 2020.

237 Prezydent Duda: Polska popiera starania Turcji o wstąpienie do UE, 17 X 2017, http://www. tvp.info, dostęp 14 VI 2020; Erdogan do Dudy: Jeżeli nie chcecie nas wUE, powiedzcie nam o tym, 17 X 2017, http://www.gazetaprawna.pl, dostęp 14 VI 2020. 
ruś, stała się dla PiS symbolem zaprowadzania porządku autorytarnego zamiast demokracji.

Podsumowując, poglądem niemal tradycyjnym dla myśli politycznej PiS było wspieranie aspiracji euroatlantyckich Ukrainy i Gruzji (od okresu zmian w tych państwach za sprawą przejęcia władzy przez polityków zorientowanych na Zachód). Po 2015 roku oba gabinety Zjednoczonej Prawicy opowiadały się także za akcesją państw zachodniobałkańskich do Sojuszu: „Chcemy, żeby okręg Bałkanów Zachodnich był rejonem stabilności. Inaczej różne mocarstwa będą tutaj starały się zagrozić bezpieczeństwu UE"238.

Popierając politykę rozszerzenia Sojuszu (a także Unii), rządy PiS pozytywnie odnosiły się do różnych pośrednich form aktywności Sojuszu w regionie środkowoeuropejskim, które wskazywały na wzrost jego zaangażowania w sytuację w tej części kontynentu. W 2007 roku minister Fotyga podkreśliła w Sejmie, że Polska wspiera takie formy aktywności Sojuszu wobec świata zewnętrznego, jak: współpraca NATO-Rosja, Partnerstwo dla Pokoju, Rada Partnerstwa Euroatlantyckiego i Stambulska Inicjatywa Współpracy ${ }^{239}$.

Polityka "otwartych drzwi" wobec Wschodu wynikała z czystych kalkulacji politycznych prezydenta Kaczyńskiego, w której przeważały dwa elementy. Pierwszy - w skali globalnej jest bardzo istotne, gdzie państwa postsowieckie (oprócz Ukrainy i Gruzji także Azerbejdżan, Kazachstan, Turkmenistan) będą poszukiwały swojego bezpieczeństwa: „we współpracy z Zachodem, w członkostwie w NATO [...] czy gdzie indziej". Drugi - bezpieczeństwo energetyczne stanowiło nowy wymiar w myśleniu o bezpieczeństwie państwa i kontynentu, a w tej materii prezydent w latach 2006-2007 przy poparciu rządu budował konstelacje polityczne i gospodarcze łączące Polskę z państwami Kaukazu i Azji Środkowej, bo to one miały dostarczać Polsce znaczne ilości surowców energetycz-

238 Wypowiedź J. Czaputowicza w: M. Cedro, Batkany nie znoszą próżni. Albo Unia, albo marsz na Wschód, „Dziennik Gazeta Prawna”, 17 V 2018, nr 95, s. 19.

239 A. Fotyga, Informacja ministra spraw zagranicznych o zadaniach polskiej polityki zagranicznej w 2007 r...., s. 363. 
nych ${ }^{240}$. W tym układzie kluczową rolę przypisywał Azerbejdżanowi. Prezydent starał się też tymi projektami zainteresować inne państwa członkowskie Unii oraz Komisję Europejską (a nawet ONZ). Najważniejszymi osiągnięciami politycznymi Kaczyńskiego w tej materii były trzy szczyty prezydentów w latach 2007-2008 w: Krakowie, Wilnie i Kijowie oraz Wspólna deklaracja Prezydentów Azerbejdżanu, Gruzji, Kazachstanu, Litwy, Polski i Ukrainy z 12 maja 2007 roku, która miała zainicjować pracę nad rurociągiem łączącym trzy morza: Kaspijskie, Czarne i Bałtyckie, a także następstwa tej deklaracji w postaci późniejszych bardziej szczegółowych porozumień z 2008 roku. Dla tych projektów Sojusz jawił się jako gwarant bezpieczeństwa ${ }^{241}$. Jednak był z nimi jeden zasadniczy problem "polski" - rząd koalicji PO-PSL dystansował się od nich, wybierając inną opcję w polityce energetycznej w postaci porozumienia wieloletniego z Rosją.

W opinii polityków PiS pozytywne rozwiązanie wspomnianych dylematów stanowiło „klucz do siły” Sojuszu w skali powszechnej, tym bardziej że prezydent Kaczyński uważał Organizację Paktu za „eksportera względnej stabilizacji i względnego pokoju". Ten czynnik bardzo mocno rzutował na popieranie przez prezydenta euroatlantyckich planów

240 Dwie koncepcje były najważniejsze: 1) GUAM, czyli Organizacja na rzecz Demokracji i Rozwoju, powstata w 2006 roku oraz 2) Euroazjatycki Korytarz Transportu Ropy Naftowej (EAKTR), zaproponowany Unii w 2009 roku; to jego częścią miał być rurociąg Odessa-Brody-Płock-Gdańsk. Trzecia propozycja miała charakter rządowy - powstały w 2006 roku projekt „energetycznego NATO”, ale także przy zdecydowanym wsparciu prezydenta Kaczyńskiego. Archiwum Prezydenta RP, https://www.prezydent.pl, dostęp 10 X 2019: „Spotkanie Prezydenta z Ministrem Przemysłu i Energii Azerbejdżanu", 13 V 2009; „Wystąpienie Prezydenta na szczycie GUAM w Baku”, 19 VI 2007; Dwa lata solidarnego państwa. Rządy premierów Kazimierza Marcinkiewicza, Jarostawa Kaczyńskiego październik 2005-październik 2007, Centrum Informacyjne Rządu, Warszawa 2007, s. 9-10, 54; Rząd premiera Jarosława Kaczyńskiego. 365 dni..., s. 12-14. Vide A. Niedźwiecki, Polska polityka europejska w latach 2005-2007. Zarys problemu, "Athenaeum" 2008, vol. 19, s. 39-53.

241 Archiwum Prezydenta RP, https://www.prezydent.pl, dostęp 10 X 2019: „Wystąpienie Prezydenta w nowojorskim Metropolitan Club”, 25 IX 2009; „Wywiad Prezydenta dla "New York Times"”, 12 III 2009; „Wypowiedź Prezydenta na konferencji prasowej po spotkaniu prezydentów w Wilnie”, 6 XI 2006; „Wspólna deklaracja Prezydentów Azerbejdżanu, Gruzji, Kazachstanu, Litwy, Polski i Ukrainy”, 12 V 2007; „Wspólna deklaracja i koncepcja", 22 V 2008. 
państw bałkańskich. Na Szczycie Prezydentów Europy Środkowej 19 maja 2006 roku L. Kaczyński mówił: „Pakt Północnoatlantycki [...] powinien zagościć też na Bałkanach, w tej części naszego kontynentu, który ma szczególnie złe doświadczenia z ostatnich kilkunastu lat. Sądzę, że dopiero wtedy, gdy przynależność do Paktu będzie tam przynależnością powszechną, będziemy mogli mówić o wykluczeniu sytuacji, w której dojdzie do konfliktów zbrojnych"242.

W konsekwencji więc, niezależnie od negatywnego stosunku mocarstw europejskich, w 2008 roku na szczycie Organizacji Paktu w Bukareszcie (2-4 kwietnia) L. Kaczyński opowiedział się za przyjęciem Ukrainy i Gruzji do Planu Działań na rzecz Członkostwa w NATO, chociaż nie miał żadnych złudzeń, że ani Kijów, ani Tbilisi nie są gotowe do członkostwa w Pakcie. Chodziło jednak przede wszystkim o efekt polityczny w postaci wsparcia w tych państwach tendencji euroatlantyckich i zarazem antyrosyjskich oraz uwikłanie Sojuszu w stabilizację niepodległości tych państw. Przyjęty plan działań nie oznaczał bynajmniej zobowiązania się do osiągnięcia w zdefiniowanej perspektywie zakładanego w nim celu, lecz jawił się jako deklaracja woli. Był to niewątpliwy sukces L. Kaczyńskiego, osiągnięty wbrew zwolennikom bliskiej współpracy z Rosją (za kilka miesięcy miała się narodzić polityka resetu wobec Moskwy). Prezydent złożył też w Bukareszcie inną propozycję - budowy regionalnego systemu bezpieczeństwa opartego na Pakcie Północnoatlantyckim ${ }^{243}$. Ta druga propozycja była mocno zakorzeniona w mniemaniu, że istnieje "daleko posunięta zbieżność oceny natury zagrożenia bezpieczeństwa międzynarodowego" w państwach znajdujących się w środkowoeuro-

242 Archiwum Prezydenta RP, https://www.prezydent.pl, „Wystąpienie Prezydenta na Szczycie Prezydentów Europy Środkowej", 19 V 2006, dostęp 10 X 2019.

243 Archiwum KPRM, t. 1140/2/5, „Udział prezydenta Rzeczypospolitej Polskiej Pana Lecha Kaczyńskiego w szczycie państw Trójkąta Weimarskiego", Warszawa, 3 VII 2006, SKM 450-35/06; Wypowiedź prezydenta L. Kaczyńskiego na szczycie NATO w Bukareszcie, 2-4 IV 2008, http://www.lechkaczynski.org, dostęp 1 VI 2019. Vide też Archiwum Prezydenta RP, https://www.prezydent.pl, „Wystąpienie Prezydenta na konferencji Foreign Policy Association", 24 IX 2008, dostęp 10 X 2019. 
pejskim otoczeniu Rzeczypospolitejej4 ${ }^{24}$ Ten projekt w zmodyfikowanej wersji podniósł w kilka lat później ówczesny współpracownik prezydenta - Andrzej Duda.

Do pierwszej kwestii L. Kaczyński wrócił w 2010 roku na spotkaniu z korpusem dyplomatycznym, kiedy nawiązał do decyzji bukareszteńskich i powtórzył: „Polska jest, była i będzie zwolennikiem poszerzenia Paktu Północnoatlantyckiego". Jednocześnie wskazał, że chodzi o Gruzję i Ukrainę oraz państwa bałkańskie i w tym kontekście „Jest bardzo istotne, aby owe postanowienia [bukareszteńskie - W.P.] pozostały w mocy" ${ }^{245}$. Jednak rok wcześniej wyraził także swoje niezadowolenie z decyzji bukareszteńskich, ponieważ przyjęto wtedy jedynie postulat przystąpienia Gruzji i Ukrainy do Sojuszu, a powinien zostać przyjęty plan wejścia - "wtedy może nie mielibyśmy sprawy Osetii i Abchazji". Prezydent Kaczyński uważał, że Pakt Północnoatlantycki zareagował zbyt powściągliwie na agresję rosyjską wobec Gruzji, co z jednej strony ośmieliło Rosję do kontynuacji tego typu polityki, a z drugiej zachwiało wiarygodnością Sojuszu w środowisku międzynarodowym ${ }^{246}$.

Po katastrofie smoleńskiej, będąc już w pełnej opozycji, PiS przypominało rządzącej koalicji liberalno-ludowcowej, że w interesie Polski jest podnoszenie na forum międzynarodowym euroatlantyckich aspiracji Ukrainy i Gruzji. Kiedy sytuacja międzynarodowa tej pierwszej uległa zasadniczej komplikacji w 2014 roku, Krzysztof Szczerski, przepraszając za wolny świat, zaproponował przygotowanie Kijowa do sprostania wymogom obu wspólnot euroatlantyckich. Wystąpił z propozycją utworzenia funduszu stabilizacyjnego na rzecz Ukrainy, na podobieństwo akcji uruchomionej w kontekście greckim. Fundusz miał być najistotniejszym elementem specjalnego pakietu dla Kijowa (inne to: inwestycje handlo-

\footnotetext{
244 J. Czaputowicz, Wystąpienie, [w:] SS Sejm, 8 kadencja, 78 pos., 14 III 2019, S. 149, http:// orka2.sejm.gov.pl, dostęp 4 VII 2019.

245 Archiwum Prezydenta RP, https://www.prezydent.pl, „Wypowiedź Prezydenta na spotkaniu z korpusem dyplomatycznym”, 2 II 2010, dostęp 10 X 2019; Vide „Wypowiedź Prezydenta dla "Faktu«", 12 III 2009, dostęp 10 X 2019.

246 Archiwum Prezydenta RP, https://www.prezydent.pl, „Wywiad z prezydentem Lechem Kaczyńskim w TVP Info", 12 III 2009, dostęp 15 X 2019.
} 
we i infrastrukturalne, ratyfikacja umowy stowarzyszeniowej, zniesienie wiz, doraźna pomoc stabilizacyjna $)^{247}$.

Drugą zasadę, na której opierała się koncepcja PiS polityki transatlantyckiej Polski, mocno wyeksponowali w latach 2015-2016 prezydent A. Duda i minister obrony narodowej A. Macierewicz. Chodziło o zasadę: „Jedność NATO i bezpieczeństwo NATO jest całościowe”. Ta zasada nie wymagała rozbudowanych wyjaśnień. Należy ją odczytywać w kategoriach utrzymania tak spójności Organizacji Paktu wobec wyzwań współczesności, jak i solidarności wszystkich państw członkowskich. Można powiedzieć, że PiS było formacją wyczuloną na te cechy Sojuszu. Jest wielce prawdopodobne, że na ten stan rzutowały dwie oceny: pragmatyczna i historyczna. $Z$ analizy środowiska międzynarodowego, chociażby Unii Europejskiej, wynikało, że tzw. mocarstwa europejskie starają się odmiennie traktować państwa zachodnioeuropejskie i środkowoeuropejskie. O ile nie wyobrażano sobie niedotrzymania zobowiązań Sojuszu wobec pierwszego z regionów, o tyle nie sprzeciwiano się specjalnym uprawnieniom Rosji wobec drugiego z nich. Zasada jedności i całościowości miała co najmniej cztery aspekty.

Po pierwsze, nie można koncentrować się na wybranych obszarach potencjalnych działań ani różnicować członków Sojuszu ze względu na poziom wsparcia z jego strony. Nie wolno odgraniczać bezpieczeństwa na rubieżach południowych od zagrożeń nadchodzących ze Wschodu, ponieważ "zagrożenie płynie z tego samego miejsca” (według Macierewicza). O ile zagrożenia na Południu mają charakter cywilizacyjny, o tyle na kresach wschodnich Sojuszu są militarne, ale w obu przypadkach niezbędna jest zdecydowana reakcja Organizacji Paktu248. W zgodzie z tą logiką pozostawało Ministerstwo Spraw Zagranicznych, przygotowując Strategię Polskiej Polityki Zagranicznej 2017-2021. Nie ograniczono się w niej do zadań na kierunku wschodnim, ale wskazywano, że

247 K. Szczerski, Przepraszam za wolnyświat [Wywiad Mariusza Staniszewskiego z Krzysztofem Szczerskim], „Do Rzeczy”, 17-23 III 2014, nr 12(60), s. 26.

248 Konferencja prasowa MON A. Macierewicza, 20 VI 2016, http://www.pap.pl, dostęp 5 XII 2019. 
istnieje konieczność ustabilizowania sąsiedztwa śródziemnomorskiego i bliskowschodniego, „skąd docierają do Europy takie wyzwania jak terroryzm czy wielkie migracje"249. Chociażby te dwa zjawiska były najlepszymi argumentami przemawiającymi za jednością i całościowością bezpieczeństwa Paktu Północnoatlantyckiego.

Po drugie, identyczna interpretacja traktatu waszyngtońskiego w odniesieniu do wszystkich państw członkowskich Sojuszu, czyli podmiotowe traktowanie każdego z członków. Taki pogląd oznaczał brak zgody na tzw. ograniczone członkostwo w Sojuszu, będące pochodną okoliczności upadku komunizmu w Europie Środkowej i zobowiązań podjętych wówczas przez Waszyngton wobec Moskwy.

Po trzecie, odejście od traktowania Europy Środkowej w kategoriach "buforu NATO" na rzecz jego "flanki wschodniej", co oznacza dostosowanie potencjału obronnego tego regionu do skali zagrożeń ${ }^{250}$. Najpełniej tę rolę zdefiniował Mariusz Błaszczak już w 2014 roku, mówiąc: "Jesteśmy zaporą przed Rosją dla całej Europy", dlatego Zachód solidarnie powinien wzmocnić jej potencjał wojskowy ${ }^{251}$. Jedność bezpieczeństwa w myśli strategicznej i w doktrynie obronnej Sojuszu była w PiS wyraźnie postrzegana przez pryzmat Europy Środkowej, gdyż - jak argumentował Szczerski - „Siła Polski jest pochodną siły regionu jako całości"252. Z innej (osobistej) strony sprawę ujął poseł PiS Michał Jach (przewodniczący Komisji Obrony Narodowej w Sejmie VIII kadencji): „Dopóki Sojusz drobiazgowo przestrzegał umowy z Rosją z 1997 roku, zgodnie z którą na terenie nowych państw członkowskich nie mogą powstawać stałe bazy wojsk NATO, czułem się jak sojusznik drugiej kategorii"253.

249 Strategia Polskiej Polityki Zagranicznej 2017-2021..., s. 11.

250 Archiwum Prezydenta RP, https://www.prezydent.pl, „Wywiad prezydenta dla "Nowoczesnej Armii «", 1 IX 2015, dostęp 12 XI 2019; Konferencja prasowa MON, 20 VI 2016, http://www.pap.pl, dostęp 10 V 2019.

251 M. Btaszczak, Jesteśmy zaporą przed Rosją...

252 Cyt. za: G. Osiecki, M. Potocki, Duda aktywny w regionie, „Dziennik Gazeta Prawna”, 18 VIII 2015, nr 159, s. 8.

253 M. Jach, Nie ma bezpiecznego świata bez NATO, 7 VII 2016, http://www.polska-zbrojna.pl, dostęp 5 II 2020. 
Po czwarte, PiS podnosiło bardzo mocno aspekt aksjologiczny jedności i całościowości bezpieczeństwa Sojuszu. Te cechy bezpieczeństwa, żeby odnosić się do niego w sposób trwały, musiały opierać się - w opinii Waszczykowskiego - na „wierności wartościom spajającym naszą cywilizację"254. Przypominano tę zasadę szczególnie wtedy, kiedy do Paktu przyjmowano kolejnych członków albo podnoszono problem przyjęcia do organizacji państw zachodniobałkańskich oraz Ukrainy i Gruzji. Kolektywna obrona nie tylko miała być realizowana dla całości terytorium Sojuszu tworzonego przez państwa członkowskie, ale również miała gwarantować ochronę ładu aksjologicznego przed jego burzycielami. Ten ład odróżniał hemisferę euroatlantycką od innych obszarów świata.

Biorąc pod uwagę relacje między Sojuszem a Unią, PiS było konsekwentne w trzech kwestiach:1) z punktu widzenia Polski (jej interesów) pierwszeństwo w zakresie bezpieczeństwa i obronności przynależy do Sojuszu, a nie do Unii; 2) konieczna jest współpraca obu organizacji, przy założeniu, że rolę wiodącą w kwestiach militarnych o znaczeniu strategicznym będzie spełniał Sojusz; 3) członkostwo Polski w obu organizacjach należy rozgraniczać, ponieważ w odniesieniu do Sojuszu nie ma kolektywnego członkostwa państw unijnych, nosi ono bowiem charakter indywidualny. Można znaleźć kilka wyjaśnień takiego stanowiska politycznego przyjętego przez PiS.

Pierwsze sformułowali zarówno minister stanu Szczerski, jak i minister spraw zagranicznych Waszczykowski. Minister w Pałacu Prezydenckim podzielił bezpieczeństwo na dwa rodzaje - militarne (hard power) i "miękkie" (soft power) oraz przyporządkował do nich obie organizacje międzynarodowe: „NATO jest sojuszem wojskowym, nastawionym na bezpieczeństwo militarne oparte na więzi transatlantyckej, podczas gdy UE jest wspólnotą bezpieczeństwa miękkiego". Nazwał ten podział „złotą formułą". Za naturalne zadania Unii uznał działalność w zakresie bezpieczeństwa w odniesieniu do zagrożeń energetycznych, hybrydowych i cybernetycznych, a jednocześnie zauważał: „Te dwie organizacje siebie

254 Informacja Ministra Spraw Zagranicznych o zadaniach polskiej polityki w 2017 roku... 
nie zastąpią ani nie mogą siebie wykluczać" 255 . Podobny pogląd wyrażali w następnych latach kolejni ministrowie spraw zagranicznych - Waszczykowski i Czaputowicz, podkreślając, że jedynie Sojusz jest zdolny do skutecznej obrony swoich członków, zwłaszcza wtedy, kiedy powstaje realne, militarne, „twarde" zagrożenie bezpieczeństwa pochodzące z otoczenia międzynarodowego.

Drugie wyjaśnienie zaprezentowała kilka lat wcześniej minister Fotyga. W informacji o zadaniach polskiej polityki zagranicznej wygłoszonej w 2007 roku w Sejmie mówiła: „Chcemy [...], żeby głos Polski w ramach Sojuszu Północnoatlantyckiego był głosem suwerennym, a nie głosem rozmytym przez układ sił i pozycję wewnątrz Unii Europejskiej". Obawiano się sytuacji, kiedy na forum Sojuszu partnerem dla Stanów Zjednoczonych byłaby Unia Europejska jako wspólnota, wówczas polskie racje stałyby się drugorzędne, a nawet nieistotne, gdyż dominowałoby stanowisko mocarstw europejskich i perspektywa zachodnioeuropejska kosztem Europy Środkowej. Miarodajna w tej sprawie była opinia P. Żurawskiego vel Grajewskiego: „Z punktu widzenia interesów Rzeczypospolitej, powstanie wspólnej i spójnej polityki Unii Europejskiej wobec Stanów Zjednoczonych byłoby najprawdopodobniej zjawiskiem niepożądanym. Jej zasady ustalano by w Paryżu i w Berlinie, w mniej lub bardziej otwartej współpracy z Moskwą"256. Uzasadnienie dla takiej polityki było dość proste - dla Paryża i Berlina zasadność sojuszu z Amerykanami w starym stylu się wyczerpała.

Kolejne wyjaśnienie w odniesieniu do relacji Sojusz-Unia zostało zawarte w Strategii Polskiej Polityki Zagranicznej 2017-2021. Zaprezentowano w niej skrajnie odmienne opisy kondycji Sojuszu i Unii. O pierwszej organizacji pisano, że w latach 2014-2016 „udało się zahamować negatywne tendencje". Natomiast niepokojem napawała sytuacja w Unii podzielonej

255 K. Szczerski, Nie będziemy walczyli samotnie [Rozmowa Grzegorza Osieckiego i Michała Potockiego z Krzysztofem Szczerskim], „Dziennik Gazeta Prawna”, 12 VII 2016, $\mathrm{nr} 133$, s. 5 . O tych samym zadaniach w zakresie obronności dla UE mówit także minister Waszczykowski. Vide W. Waszczykowski, Teraz to NATO wchodzi do Polski..., s. 3.

256 P. Żurawski vel Grajewski, Czy Unia Europejska może/powinna mieć spójną politykę wobec USA?, [w:] Polska w grze międzynarodowej..., s. 92, 132. 
wewnętrznie, będącej w kryzysie, niezdolnej do szybkiej i skutecznej odpowiedzi na wyzwania współczesności. Wskazywano też przyczyny tej różnej sytuacji obu organizacji:1) wadliwy w Unii mechanizm decyzyjny, który „podminował równowagę między państwami dużymi i małymi”; 2) nieuzasadnione poszerzanie kompetencji organów unijnych kosztem prerogatyw państw członkowskich i procedur demokratycznych. Prognozowano również dalszy paraliż Unii wynikający z rywalizacji euroentuzjastów z eurosceptykami. Za podsumowanie tej diagnozy może posłużyć wniosek zawarty w Strategii: „Głównym filarem bezpieczeństwa militarnego i stabilności w Europie jest, i w przewidywalnej przyszłości pozostanie, NATO oraz Stany Zjednoczone, odgrywające kluczową rolę w Sojuszu. Należy jednocześnie mieć na uwadze, że Europa nie jest i nie będzie jedynym miejscem militarnego i politycznego zaangażowania amerykańskiego na świecie" 257 .

W odniesieniu do trzeciej kwestii, czyli zależności między członkostwem w Sojuszu i w Unii, wypowiedział się prezydent Kaczyński w 2007 roku. Odrzucił wtedy członkostwo zbiorowe państw unijnych w Sojuszu: „[...] jeżeli byśmy tu przyjęli zasadę członkostwa kolektywnego [...], to powiedzmy nasza swoboda działania by niezwykle uległa ograniczeniu, ponieważ my jesteśmy w UE państwem dużym, ale zgoła nie największym, więc są tacy, którzy by chętnie przejęli za nas nasze interesy". Nie wykluczał współdziałania członków Unii na forum północnoatlantyckim, ale stawiał warunek: „Jeżeli UE ma tu jakiś wspólny interes, który wszyscy akceptujemy, to wtedy oczywiście występujemy wspólnie i będziemy tak czynić" 258 . Jak najbardziej taki pogląd wynikał ze sposobu postrzegania Unii jako wspólnoty suwerennych państw, a nie pierwowzoru federacji paneuropejskiej.

Mimo tych zasadniczych ograniczeń w relacji Sojusz-Unia, PiS widziało konieczną przestrzeń współpracy (uzupełniania się) dla obu wspólnot w ujęciu zarówno rzeczowym, jak i geograficznym. Oba te ujęcia się 
krzyżowały. W ujęciu rzeczowym, jak już zostało wspomniane, dla Sojuszu było zarezerwowane bezpieczeństwo „twarde”, a dla Unii „miękkie". W 2011 roku uznano w programie europejskim PiS, że Unia może być dopiero w przyszłości, a nie aktualnie, drugim filarem bezpieczeństwa w Europie (pierwszym był oczywiście Sojusz), ale pod czterema warunkami: 1) europejska polityka bezpieczeństwa i obrony nie może być konstruowana w opozycji do Stanów Zjednoczonych i więzi transatlantyckich; 2) cele i formy tej polityki szczegółowej Unii nie mogą być wyznaczane przez grupę najsilniejszych państw Unii; 3) podstawą polityki bezpieczeństwa i obrony powinno być utrzymywanie jedności kontynentu w tej kwestii, bez jego różnicowania na strefy bardziej bezpieczne od innych; 4) unijnej polityki bezpieczeństwa i obrony nie wolno tworzyć we współpracy z państwami pozaunijnymi (w domyśle we współpracy z Rosją) ${ }^{259}$.

Natomiast w ujęciu geograficznym Sojusz powinien zajmować się flanką wschodnią, gdzie uwidoczniło się z całą mocą zagrożenie militarne, a Unia kierunkiem południowym, na którym mamy do czynienia $\mathrm{z}$ innymi wyzwaniami (migracje, terroryzm, ekstremizm). Tych zagrożeń nie można zwalczyć „środkami czysto militarnymi”, lecz z udziałem straży granicznych i policji państwowej oraz realizując wieloletni program pomocy rozwojowej. Sojusz nie może zaś podejmować się tego typu zadań ${ }^{260}$. Jednak wobec unijnej polityki bezpieczeństwa i obrony PiS sformułowało w 2011 roku więcej uwag z kontekstem geograficznym: 1) "animowanie" współpracy w ramach wymiaru wschodniego (Ukraina, Białoruś, Mołdawia); 2) "animowanie" współpracy w ramach wymiaru północnego; 3) uporządkowane wspólne stosunki z Rosją; 4) stabilizacja i rozwój Bałkanów; 5) rozwój współpracy z państwami śródziemnomorskimi ${ }^{261}$. Z perspektywy okresu rządów 2015-2019 PiS oceniało efekty działań Unii na tych kierunkach geograficznych jako mizerne. Przede

\footnotetext{
259 Europa solidarnych narodów. Program polityki europejskiej Prawa i Sprawiedliwości, PiS, Warszawa 2004, s. 22.

260 W. Waszczykowski, Dtuga droga do pokoju, „Rzeczpospolita”, 12 XII 2017, nr 268, s. A10.

261 Europa solidarnych narodów..., s. 22.
} 
wszystkim Unia nie dopracowała się konsekwentnej polityki ani na odcinku rosyjskim, ani wschodnioeuropejskim i bałkańskim, ani nawet północnoeuropejskim. Trudno dostrzec spektakularne sukcesy oraz dążenie Brukseli na tych odcinkach geograficznych do uwzględniania interesów środkowoeuropejskich, w tym polskich. To budziło jeszcze poważniejsze zastrzeżenia co do sensu polityki bezpieczeństwa i obrony UE w wariancie realizowanym przez Brukselę w drugiej dekadzie XXI wieku.

W latach 2015-2019 w relacjach Unia-Sojusz pojawił się jeszcze jeden problem, wynikający z wyjścia Zjednoczonego Królestwa ze Wspólnoty Europejskiej. Jedna z najsilniejszych armii europejskich dysponująca potencjałem atomowym opuszczała Unię, ale pozostawała w Sojuszu, co niewątpliwie znacznie komplikowało sytuację, biorąc pod uwagę dążenie Brukseli do intensyfikacji działań na rzecz Wspólnej Polityki Bezpieczeństwa i Obrony (WPBiO). Andrzej Duda na 53. Monachijskiej Konferencji Bezpieczeństwa 17 lutego 2017 roku wyraził nadzieję, że Wielka Brytania: 1) nie opuści europejskiej struktury bezpieczeństwa i 2) będzie uczestniczyć w $\mathrm{WPBiO}^{262}$.

We wspomnianym już wystąpieniu sejmowym A. Fotyga deklarowała: "Chcemy wzmocnienia NATO, przy jednoczesnej budowie wspólnej europejskiej polityki obronnej". Identyczne zdanie znalazło się w programie partyjnym $\mathrm{z}$ tego samego roku ${ }^{263}$. Bardziej konkretnej wypowiedzi odnoszącej się do tej kwestii udzielił kilka miesięcy wcześniej prezydent Kaczyński. Podkreślił, że Polska należy do państw, które relacje SojuszUnia widzą w sposób „jednoznacznie bezkonfliktowy”: „Sojusz Północnoatlantycki po dwóch stronach Atlantyku, Stany Zjednoczone z jednej strony, a poszerzająca się grupa państw europejskich z drugiej, jest trzonem tego systemu bezpieczeństwa"264. Jednak żeby takie współdziałanie

\footnotetext{
262 Archiwum Prezydenta RP, https://www.prezydent.pl, „Wystąpienie Prezydenta na 53. Monachijskiej Konferencji Bezpieczeństwa", 17 II 2017, dostęp 12 VI 2020.

263 A. Fotyga, Informacja ministra spraw zagranicznych o zadaniach polskiej polityki zagranicznej w 2007 r..., s. 363; Dbamy o Polskę. Dbamy o Polaków..., s. 4.

264 Archiwum Prezydenta RP, https://www.prezydent.pl, „Wypowiedź Prezydenta na konferencji prasowej po zakończeniu szczytu NATO", 29 IX 2006, dostęp 10 X 2019. W Sejmie w podobnym tonie mówit poset PiS Paweł Zalewski: „europejski wysitek obronny powinien być komplementarny do zasobów Sojuszu". P. Zalewski, Wystąpienie w imie-
} 
było możliwe, to powinny być spełnione dwa warunki natury strategicznej: 1) silne amerykańskie przywództwo w hemisferze euroatlantyckiej; 2) trwała amerykańska obecność polityczna i wojskowa w Europie ${ }^{265}$. Tym samym politycy PiS odrzucali takie kierunki strategiczne, jak amerykański izolacjonizm oraz europejski antyamerykanizm, widząc w tym tworzenie warunków do upadku świata demokratycznego w zderzeniu z międzynarodową konkurencją i rywalizacją (Federacja Rosyjska, Chiny).

W programie IV Rzeczpospolita - Sprawiedliwość dla Wszystkich z 2005 roku przestrzegano: „Europa nie może konkurować z Ameryką w kwestii światowego bezpieczeństwa. Prowadzenie takiej polityki miałoby negatywne konsekwencje dla bezpieczeństwa światowego i dla bezpieczeństwa samej Europy". Zamiast konkurencji proponowano "utrzymywanie i stałe wzmacnianie więzi transatlantyckich". Uważano bowiem, że: „Sojusz Europy ze Stanami Zjednoczonymi ma podstawowe znaczenie dla bezpieczeństwa naszego kontynentu" i jest korzystny dla Polski. Dlatego też sformułowano obietnicę: „[...] będziemy popierać wszelkie działania służące wzmacnianiu więzi z Waszyngtonem zarówno w ramach Sojuszu Atlantyckiego, jak i Unii Europejskiej" ${ }^{266}$. Takie zasadnicze stanowisko przesądzało o stosunku stronnictwa J. Kaczyńskiego do różnych projektów budowy nowej europejskiej architektury bezpieczeństwa. Europa XXI wieku miała być przyjazna wobec Stanów Zjednoczonych, a w tym kontekście Pakt był forum realizacji tego posłannictwa.

Imperatyw jedności europejsko-amerykańskiej wyraźnie wskazywali w Sejmie kolejni ministrowie spraw zagranicznych z nominacji PiS w różnych okresach, kiedy to stronnictwo sprawowało rządy w Rzeczypospolitej - zarówno w latach 2005-2007, jak i w okresie 2015-2019. Stefan Meller deklarował w 2006 roku, że Polska będzie wspierać EPBiO, „by cechowała ją komplementarność w odniesieniu do możliwości i zasobów NATO". Tę komplementarność odnosił do współdziałania bojowe-

niu KP PiS w dyskusji nad informacją Ministra Spraw Zagranicznych o zadaniach polskiej polityki zagranicznej w 2006 r., [w:] SS Sejm, 5 kadencja, 10 pos., 15 II 2006, s. 15, http:// orka2.www.sejm.gov.pl, dostęp 7 V 2019.

265 Vide A. Fotyga, Polska-USA. Sympatia i mtodość..., s. 9.

266 IV Rzeczpospolita - Sprawiedliwość dla Wszystkich..., s. 40. 
go, zbrojeniowego i przemysłowo-technologicznego. Dziesięć lat później w podobnym duchu wypowiadał się W. Waszczykowski: „Uznając pierwszoplanową rolę Sojuszu w utrzymaniu bezpieczeństwa transatlantyckiego, opowiadamy się za bliższą i bardziej efektywną współpracą NATO i Unii Europejskiej w rozwiązywaniu złożonych problemów międzynarodowych”. Podobnego zdania był także K. Szczerski: „Stany Zjednoczone nie mogą być postrzegane jako czynnik zewnętrzny wobec UE, bo Europa wtedy jest bezpieczna i silna, kiedy jest Europą transatlantycką, ściśle współpracującą z USA. Mówienie, że jest inaczej, podważa fundament bezpieczeństwa europejskiego"267.

Dość jednoznacznie sprawę relacji między Stanami Zjednoczonymi a Unią Europejską opisał A. Macierewicz. Odrzucił pomysł budowy armii europejskiej skierowanej przeciwko Waszyngtonowi i jednocześnie konkludował, że „oderwanie Europy od USA i zdanie Europy na łaskę i niełaskę sił zbrojnych Rosji jest katastrofą wolnego świata"268. Dlatego Polska opowiedziała się w 2017 roku za mechanizmem stałej współpracy strukturalnej w dziedzinie obronności i bezpieczeństwa Unii Europejskiej, jednak podkreślała jednocześnie konieczność pełnej zbieżności z Sojuszem Północnoatlantyckim ${ }^{269}$. To był warunek niezbędny polskiej akceptacji dla polityki obronnej i zagranicznej Unii. Polska pod rządami PiS była gotowa angażować się w europejskie projekty obronne, w tym wojskowe, o ile były one zbieżne z priorytetami Sojuszu ${ }^{270}$. Nie zamie-

267 S. Meller, Informacja ministra spraw zagranicznych o zadaniach polskiej polityki zagranicznejw 2006 r...., s. 11-12; W. Waszczykowski, Informacja ministra spraw zagranicznych o zadaniach polskiej polityki zagranicznej w 2016 roku..., s. 74; K. Szczerski, Zarządzanie kryzysowe [Wywiad Jakuba Mielnika z Krzysztofem Szczerskim], „Wprost”, 20-26 II 2017, $\mathrm{nr}$ 8, s. 68.

268 Wywiad A. Macierewicza dla TVP, http://www.pap.pl, dostęp 7 V 2019. Konieczność wspótpracy Unia-Sojusz została wskazana także w exposé M. Morawieckiego. M. Morawiecki, Przedstawienie przez prezesa Rady Ministrów programu dziatania Rady Ministrów z wnioskiem o udzielenie jej wotum zaufania, [w:] SS Sejm, 8 kadencja, 54 pos., 12 XII 2017, s. 12, http://orka2.www.sejm.gov.pl, dostęp 7 V 2019.

269 Konferencja premiera M. Morawieckiego, 14 VII 2017, http://www.premier.gov.pl, dostęp 20 V 2019.

270 K. Szymański, Długa droga do odrodzenia Unii [Rozmowa Jędrzeja Bieleckiego z Konradem Szymańskim], „Rzeczpospolita”, 14 III 2019, nr 62, s. A9. 
rzano sprzyjać ani jakimkolwiek emancypacyjnym działaniom Paryża i Berlina, ani pacyfistycznym projektom opartym na redukcji amerykańskiej obecności w Europie. PiS obawiało się, że u podstaw europejskiej polityki obronnej leży mocno obecne w Brukseli, Paryżu i Berlinie przeświadczenie, że Unia powinna kroczyć w kierunku zbudowania własnego systemu wspólnego bezpieczeństwa raczej autonomicznego niż alternatywnego wobec struktur Sojuszu Północnoatlantyckiego. Taki scenariusz był oceniany jako nierealny i zarazem niebezpieczny dla euroatlantyckiej hemisfery.

Na stosunek PiS do współpracy Sojusz-Unia wpływ miał pogląd, że istnieją trwałe rozbieżności między Stanami Zjednoczonymi, Europą Zachodnią i Europą Środkową. Te rozbieżności widziano na dwóch płaszczyznach. Pierwsza - mocarstwa zachodnioeuropejskie dominujące w Unii, przede wszystkim Francja i Niemcy, chciały wzmacniać swój status międzynarodowy, osłabiając więzi transatlantyckie. W tym kontekście unijna polityka w kwestii obronności i bezpieczeństwa miała być środkiem do realizacji wskazanego celu, dlatego ewoluowała w kierunku coraz bardziej autonomicznym wobec Stanów Zjednoczonych - od Europejskiej Tożsamości Bezpieczeństwa i Obrony z 1994 roku (ESDI) do Europejskiej Polityki Bezpieczeństwa i Obrony z 1999 roku (ESDP) ${ }^{271}$. Druga - dla państw zachodnioeuropejskich zagrożenie rosyjskie stało się tylko czynnikiem historycznym lub było wyzwaniem raczej strategicznym niż realnym z zakresu polityki bieżącej. Rosja została uznana za jednego z najważniejszych partnerów w interesach. W tych warunkach Sojusz stracił bardzo wiele na atrakcyjności dla Paryża i Berlina. Natomiast odmienne oceny dominowały w większości stolic środkowoeuropejskich (z wyjątkiem Budapesztu). Silny Sojusz miał być zabezpieczeniem przed Moskwą.

Biorąc pod uwagę relacje Sojusz-Unia, J. Kaczyński wskazał trzy scenariusze niekorzystne dla Polski: 1) dominacja w Pakcie mocarstw, bez podmiotowości innych państw członkowskich; 2) rozluźnienie związ-

271 Szerzej vide P. Żurawski vel Grajewski, Bezpieczeństwo międzynarodowe. Wymiar militarny, Wydawnictwo Naukowe PWN, Warszawa 2012, s. 231, 259-264. 
ków między instytucjami unijnymi a północnoatlantyckimi, zwłaszcza w sferze militarno-wojskowej; 3) projekt współpracy strategicznej Francja-Niemcy-Polska-Rosja przeciwko Stanom Zjednoczonym ${ }^{272}$. Z tego powodu w latach 2001-2015 PiS było raczej przeciwne wspólnej polityce zagranicznej i obronnej Unii Europejskiej, ale faktycznie gotowe było ją poprzeć, jednakże pod jednym warunkiem - efektem tej polityki będzie powstanie europejskiej armii, którą postrzegano jako warunek mocarstwowości Unii w stosunkach międzynarodowych. Ten postulat na poziomie ogólnym rozważał wielokrotnie J. Kaczyński, począwszy od 2004 roku, widząc w tym jeden z projektów przebudowy Unii Europejskiej. Wprowadził go do debaty publicznej w Polsce na posiedzeniu Sejmu 21 stycznia, snując rozważania o budowie europejskich sił zbrojnych, które „[...] byłyby, przynajmniej do pewnego stopnia, równoważne wobec sił Stanów Zjednoczonych. Biorąc pod uwagę potencjał Europy, zbliżony do potencjału amerykańskiego, to jest możliwe, ale to by wymagało zasadniczej weryfikacji europejskiej polityki w różnych dziedzinach, z ostatecznym skupieniem się na polityce ekonomicznej i budżetowej". Jednocześnie realistycznie oceniał: „Nie ma najmniejszych zapowiedzi tego rodzaju zmiany. Jeśli tak, to wchodzenie w owe wspólnoty jest wchodzeniem w sferę fikcji i podważaniem NATO, czyli jedynej w istocie gwarancji bezpieczeństwa, i podważaniem naszych stosunków ze Stanami Zjednoczonymi"273. Tej opinii pozostał wierny, kiedy został premierem. W 2006 roku sformułował dwa warunki poparcia takiego projektu: 1) regulacje na temat armii europejskiej powinny być określone w czasie dyskusji o konstytucji Unii; 2) euroarmia nie może być traktowana jako kontrpropozycja dla Paktu Północnoatlantyckiego. W sprawie armii europejskiej wypowiedział się także 6 listopada 2006 roku na łamach „Financial Times" prezydent L. Kaczyński (nawiązując do propozycji upublicznionej przez brata): „Polska proponuje utworzenie przez Unię Europejską powiązanej z NATO stutysięcznej armii, którą można by było

272 Vide J. Kaczyński, Tuska zupa z buta, „Gazeta Wyborcza”, 22 II 2011, nr 43, s. 20.

273 Idem, Wystapienie w debacie nad informacją ministra spraw zagranicznych o podstawowych kierunkach polityki zagranicznej Polski w 2004 roku... 
wykorzystać dla obrony Europy, a także wysyłać w regiony zapalne". Miała ona istnieć niezależnie od sił narodowych i być wykorzystywana w reagowaniu kryzysowym ${ }^{274}$.

Jednak nigdy politycy PiS nie skonkretyzowali pomysłu powołania armii europejskiej w okresie swoich rządów w Polsce. Ostatnia wzmianka na jej temat pojawiła się jeszcze w programie z 2011 roku, w którym zapisano możliwość utworzenia „z czasem" wspólnej armii państw UE ${ }^{275}$. Na jej temat wypowiedział się także prezydent Duda w 2016 roku: „Jeżeli mielibyśmy budować europejską armię, to ona musi być elementem Sojuszu Północnoatlantyckiego. To nie może być [...] jakieś NATO-bis [...]"276. Taki scenariusz zacieśnienia polityki obronnej Unii z zasadniczych powodów był uznany przez J. Kaczyńskiego za nierealny, dlatego też politycy PiS odpowiedzialni za politykę zagraniczną w latach 20152019 mogli swobodnie dezawuować projekt armii europejskiej ${ }^{277}$. Tym bardziej że w czasie dyskusji konstytucyjnej w Unii Europejskiej kwestie militarne nie były traktowane jako pierwszoplanowe. Skupiono się na projektach wzmocnienia wspólnotowych organów pozapaństwowych, które miały zasadniczo wzmocnić kierunek budowy europejskiej federacji, co PiS odrzucało.

Wyjaśnienia braku szans na taki kierunek zmian w Unii udzielił K. Szczerski w wywiadzie: „Budowa europejskiej armii wymagałaby całkowitej zmiany charakteru UE, a to wymagałoby silnej woli politycznej państw członkowskich". Takiej woli nie dostrzegał u większości państw członkowskich Unii Europejskiej z powodu braku społecznego przyzwo-

274 Cyt. za: L. Kaczyński, UE potrzebuje własnej armii, 6 XI 2006, http://www.wiadomosci. wp.pl, dostęp 1 II 2020.

275 Polska nowoczesna, Polska solidarna, Polska bezpieczna..., s. 223.

276 Archiwum Prezydenta RP, https://www.prezydent.pl, „Wywiad dla PAP przed szczytem NATO", 7 VII 2016, dostęp 12 VI 2020.

277 Vide Wypowiedź J. Kaczyńskiego na Śląsku, 6 XI 2006, http://www.bankier.pl, dostęp 27 XII 2019; J. Kaczyński, UE powinna stać się supermocarstwem z prawdziwą armią, dużo silniejszą od rosyjskiej[Rozmowa Tomasza Grodeckiego i Agaty Jabłońskiej-Andrzejczuk z Jarostawem Kaczyńskim], 31 III 2017, http://www.forsal.pl, dostęp 9 XII 2019; idem, Musimy wrócić do dużej armii w Polsce, bo bez tego nie będziemy bezpieczni, 15 III 2015, http://www.wpolityce.pl, dostęp 9 XII 2019. 
lenia na podniesienie wydatków na zbrojenia. Podobne uwagi publicznie kierowała do Kaczyńskiego również kanclerz Niemiec Angela Merkel, ale trudno byłoby sobie wyobrazić zgodę Francji na rozwiązanie wojskowe tego typu. Krzysztof Szczerski ujął sprawę jednoznacznie: „Nie wierzę w budowę europejskiej alternatywy dla Sojuszu Północnoatlantyckiego. Mówienie o armii europejskiej tylko osłabi Europę [... ${ }^{2278}$. Dość wymownie o tej sprawie wypowiedział się także minister Waszczykowski: „Nie ma potrzeby tworzyć wspólnej armii, bo jest NATO i mamy wspólną armię"279. Jeszcze bardziej zdecydowany głos w tej sprawie zabrał minister Macierewicz. Jego stosunek był zdecydowanie negatywny z trzech istotnych powodów. Primo - uznał projekt utworzenia armii europejskiej za sprzeczny z ideą Unii Europejskiej niepodległych narodów, a za przejaw dążenia do jej federacyjnej przebudowy. Secundo - negliżował znaczenie militarne takiej armii, która nie będzie w stanie sprostać potędze atomowej, czyli będzie bezsilna w konfrontacji z Rosją. Tertio - odczytywał projekt w kategoriach antyamerykańskich, jako „oderwanie Europy od USA", a przyjęcie takiej intencji oznaczałoby realizację marzeń Rosji o skonfliktowaniu państw europejskich ze Stanami Zjednoczonymi. Za podsumowanie mogłyby służyć słowa ministra: „To katastrofa wolnego świata. Mam nadzieję, że nigdy do tego nie dojdzie"280.

W latach 2015-2019 politycy PiS odpowiedzialni za politykę zagraniczną wielokrotnie wyjaśniali sens swojego politycznego credo w sprawie relacji Sojusz-Unia. Już w innych okolicznościach międzynarodowych, zwłaszcza w latach 2018-2019, czynili to z trybuny sejmowej szefowie MSZ: Konrad Szymański i Jacek Czaputowicz. W 2017 roku ówczesny wicepremier M. Morawiecki także w Sejmie podkreślił, że Polska dąży do "[...] jak najdalej idącej harmonizacji działań NATO i Unii Europejskiej. [...] Z tym zamiarem przystąpiliśmy również do stałej współpracy struk-

278 K. Szczerski, Nie będziemy walczyli samotnie..., s. 5; idem, Cztery warunki Dudy dla Niemiec [Wywiad Jędrzeja Bieleckiego z Krzysztofem Szczerskim], „Rzeczpospolita”, 15 VI 2015, nr 137, s. A6.

279 W. Waszczykowski, Dość zacieśniania Unii [Wywiad Renaty Grochal z Witoldem Waszczykowskim], „,Gazeta Wyborcza”, 25 VI 2016, nr 147, s. 9.

280 A. Macierewicz, Wywiad dla TVP, 16 XI 2018, http://www.pap.pl, dostęp 30 XII 2019. 
turalnej w dziedzinie obronności. NATO jest i pozostanie fundamentem naszego bezpieczeństwa, zaś Stany Zjednoczone - naszym głównym sojusznikiem"281.

Wiceminister spraw zagranicznych K. Szymański złożył w Sejmie deklarację podobną do tej z 2007 roku: „[...] chcemy, aby rosnąca rola Unii Europejskiej w obszarze bezpieczeństwa i obronności [...] była budowana w pełnej synergii z planami NATO"282. Kilka miesięcy później w tym samym roku szczegółowo wyjaśniał: „Z politycznego punktu widzenia najważniejszym elementem polskiego przesłania [...] było oczywiście szukanie takich scenariuszy rozwoju polityki bezpieczeństwa, które byłyby komplementarne w stosunku do NATO". Dla uzasadnienia tego kierunku postępowania wymienił dwie przyczyny: 1) „znakomita większość państw aktywnych w zakresie polityki obronnej Unii Europejskiej jest również członkiem NATO"; 2) zasoby przeznaczane na obronność w Europie są „wciąż zbyt małe", żeby można było w oparciu o nie zbudować europejską alternatywną wobec Sojuszu konstrukcję w zakresie bezpieczeństwa. Dlatego też Pakt "pozostaje kluczowym wymiarem bezpieczeństwa europejskiego", a wszelkie rozwiązania alternatywne Polska uważa za szkodliwe i kontrproduktywne ${ }^{283}$. Jednoznacznie kwestię tę ujął Waszczykowski: „dla NATO nie ma alternatywy”, przesądza o tym jego „skala możliwości obronnych", w tym potencjał nuklearny, którym Unia nie dysponuje ${ }^{284}$.

W 2019 roku myśli swojego poprzednika na urzędzie potwierdził i rozwinął minister spraw zagranicznych Jacek Czaputowicz: „Jesteśmy zwolennikami stworzenia w ramach NATO, mówiąc obrazowo, wojskowego Schengen. Popieramy współpracę NATO-Unia Europejska w tej

\footnotetext{
281 M. Morawiecki, Wystąpienie, [w:] SS Sejm, 8 kadencja, 54 pos., 12 XII 2017, s. 12, http:// orka2.sejm.gov.pl, dostęp 12 V 2019.

282 K. Szymański, Wystąpienie, [w:] SS Sejm, 8 kadencja, 61 pos., 13 IV 2018, s. 149-150, http://orka2.sejm.gov.pl, dostęp 12 V 2019; Vide też S. Szynkowski vel Sęk, Wystąpienie, [w:] SS Sejm, 8 kadencja, 61 pos., 13 IV 2018, s. 231, http://orka2.sejm.gov.pl, dostęp $12 \mathrm{~V} 2019$.

283 K. Szymański, Wystapienie, [w:] SS Sejm, 8 kadencja, 81 pos., 13 IX 2018, s. 175, http:// orka2.sejm.gov.pl, dostęp 12 V 2019.

284 W. Waszczykowski, Dtuga droga do pokoju..., s. A10.
} 
kwestii". W następnych słowach minister wyjaśniał, że Polska jest zainteresowana rozwojem współpracy obronnej w Unii Europejskiej polegającej na: 1) podnoszeniu interoperacyjności i kompatybilności sił zbrojnych państw europejskich oraz mobilności armii i sprzętu wojskowego; 2) utworzeniu Europejskiego Funduszu Obronnego; 3) ponoszeniu odpowiedzialności za pokój i bezpieczeństwo „w duchu podejścia 360 stopni". Jednak Czaputowicz zastrzegał: „[...] budowa tzw. autonomii strategicznej Unii Europejskiej nie może [...] odbywać się kosztem NATO i osłabiania więzi transatlantyckich"285. PiS uważało, że Polska powinna angażować się we wspólną Europejską (Wspólną) Politykę Bezpieczeństwa i Obrony, widząc w niej jedynie europejski filar Sojuszu, a nie czynnik emancypacji Europy spod kurateli Stanów Zjednoczonych. Bardzo pozytywnie podchodzono do wszelkich projektów finansowego zaangażowania Unii w podnoszenie obronności na jej obszarze. Już w 2014 roku politycy PiS proponowali utworzenie specjalnego funduszu. Prezes J. Kaczyński nazwał go Funduszem Bezpieczeństwa Europejskiego, a M. Błaszczak Europejskim Funduszem Pożyczkowym. W obu przypadkach pieniądze miały być przeznaczane na dozbrojenie armii, zwłaszcza państw zagrożonych rosyjską agresją. Kaczyński mówił nawet o 100 mld euro na dozbrojenie polskiej armii ${ }^{286}$.

Wcześniej, trzy lata przed wystąpieniem Czaputowicza, poprzedni minister spraw zagranicznych w rządzie PiS, Waszczykowski, obiecywał w Sejmie: „Polska będzie się angażować w działania na rzecz wzmocnienia wspólnej polityki bezpieczeństwa i obrony Unii Europejskiej”, ponieważ: „Im więcej elementów obronnych, tym lepiej". Minister sprecyzował, co to za elementy. Wskazał trzy: 1) "wspólny mechanizm szybkiej reakcji"; 2) prowadzenie misji pokojowych i stabilizacyjnych; 3) stworzenie cywilnego i wojskowego zabezpieczenia dla tych misji ${ }^{287}$.

285 J. Czaputowicz, Wystąienie, [w:] SS Sejm, 8 kadencja, 78 pos., 14 III 2019, s. 149-150, http://orka2.sejm.gov.pl, dostęp 12 V 2019.

286 Zachód nas nie obroni, 18 IX 2014, http://www.nowakonfederacja.pl, dostęp 5 II 2020; M. Błaszczak, Jesteśmy zaporą przed Rosją...

287 W. Waszczykowski, Informacja ministra spraw zagranicznych o zadaniach polskiej polityki zagranicznej w 2016 roku..., s. 74. 
O ile J. Kaczyński sformułował postulat utworzenia armii europejskiej, o tyle w stronnictwie było zbyt wiele wątpliwości co do realnego znaczenia EPBiO, aby postrzegać ją jako narzędzie zapewnienia bezpieczeństwa Polsce. W 2010 roku na specjalnej konferencji zgłoszono dwa zastrzeżenia: 1) brak mechanizmów prawnych w EPBiO; 2) dominacja interesów państw członkowskich UE opartych na innej od polskiej ocenie zagrożeń ${ }^{288}$. Przed EPBiO stawiano dwa warunki. Pierwszy - uznanie trwałej obecności Stanów Zjednoczonych w systemie bezpieczeństwa na kontynencie europejskim. Mówił o tym w Sejmie poseł PiS Paweł Zalewski: „Zależy nam także na budowaniu takiej formuły stosunków transatlantyckich, które traktować będą Stany Zjednoczone jako uczestnika bezpieczeństwa europejskiego" ${ }^{289}$. Drugi - odrzucenie myślenia w UE w kategoriach konkurencji między EPBiO a Sojuszem lub powielania zadań na rzecz komplementarności. Politycy PiS opowiadali się przeciwko dublowaniu zadań przez Unię i Sojusz. W programie PiS już w 2005 roku zapisano: „Uważamy jednak za zbędne działania, które dublowałyby zdolności i cele z powodzeniem realizowane w ramach NATO"290. Ten pogląd uzasadnił dwa lata później premier J. Kaczyński: „skala współczesnych zagrożeń i wyzwań dla bezpieczeństwa międzynarodowego implikują potrzebę bliskiej współpracy obu organizacji [Sojuszu i Unii - W.P.], jeżeli chcemy uniknąć porażki w przeciwstawieniu się im"291. Jednoznacznie relacje wojskowe Unia-Sojusz ujął w 2017 roku minister Waszczykowski: „Współpraca strukturalna Unii powinna stanowić wzmocnienie dla kooperacji NATO-UE"292.

288 Nowoczesna Polska 2020..., s. 116-117.

289 P. Zalewski, Wystąpienie w imieniu KP PiS w dyskusji nad informacją Ministra Spraw Zagranicznych o zadaniach polskiej polityki zagranicznej w 2006 r., [w:] SS Sejm, 5 kadencja, 10 pos., 15 II 2006, s. 15, http://orka2.www.sejm.gov.pl, dostęp 7 V 2019.

290 IV Rzeczpospolita - Sprawiedliwość dla Wszystkich..., s. 51. Zgodnie z tą wytyczną programową wypowiadali się politycy PiS „oddelegowani” w partii na odcinek polityki zagranicznej i obronnej. Vide A. Szczygło, W. Waszczykowski, op. cit., s. 21.

291 Archiwum KPRM, t. 1199/3/III, „List premiera J. Kaczyńskiego do premiera Turcji Recepa Tayyipa Erdoğana", 25 VII 2007, SJK 450-37(1)/07, s. 1.

292 Sesja Rady Pótnocnoatlantyckiej z Wysoką Przedstawiciel UE ds. Zagranicznych F. Mogherini, 5 XII 2017, http://msz.gov.pl, dostęp 1 VI 2019. 
Tym samym należy stwierdzić, że poglądy PiS na relacje między Sojuszem a Unią były w znacznym stopniu zdeterminowane przez wątpliwości co do realnych możliwości szybkiego zbudowania efektywnej unijnej architektury bezpieczeństwa, która byłaby korzystna dla Polski i Europy Środkowej. W 2010 roku jeden z ekspertów PiS pisał: „Czas złudzeń i oczekiwań na zbudowanie siły UE powinniśmy już uznać za wyczerpany" ${ }^{293}$. Ta konstatacja obowiązywała także w następnych latach, a dodatkowo uległa „wzmocnieniu” w warunkach wojny rosyjsko-ukraińskiej rozpoczętej w 2014 roku i bezradności Unii Europejskiej w tym konflikcie oraz co najmniej niejasnej i niekonsekwentnej postawy mocarstw europejskich (Francja, RFN, Włochy) w sprawie tego konfliktu. Mając wątpliwości co do zdolności Unii do zbudowania europejskiej architektury efektywnego bezpieczeństwa oraz odrzucając wszelkie projekty autonomizacji tej architektury wobec Sojuszu Północnoatlantyckiego, prezydent Duda i oba gabinety PiS poparli dwie deklaracje o współpracy Sojusz-Unia z 2016 (8 lipca, warszawska) i z 2018 roku (10 lipca, brukselska). Tę pierwszą uznano nawet za wielki sukces szczytu warszawskiego. Były one zgodne z linią strategiczną PiS w tej materii, ustalały bowiem obszary współpracy między obiema organizacjami. Pisano o przeciwdziałaniu zagrożeniom, koordynacji działań i ćwiczeń, współpracy operacyjnej, tworzeniu spójnych zdolności obronnych, podejmowaniu badań nad obronnością, a przede wszystkim o budowaniu potencjału obronnego na dwóch flankach - wschodniej i południowej. W deklaracji brukselskiej ustalono skoncentrowanie współpracy w obszarze obronności „miękkiej” typu: cyberbezpieczeństwo, zagrożenia hybrydowe, mobilność wojskowa, walka z terroryzmem, bezpieczeństwo kobiet. Zgodnie z tymi ustaleniami miała się rozwijać unijna współpraca strukturalna oraz Europejski Fundusz Obronny (European Defence Fund, EDF) ${ }^{294}$.

\footnotetext{
293 P. Żurawski vel Grajewski, Geopolityka - siła - wola..., s. 169.

294 Szczyt NATO w Warszawie, 8-9 lipca 2016, 8 VII 2016, http://www.consilium.europa.eu, dostęp 5 II 2020; Szczyt NATO w Brukseli (11-12 lipca 2018), 11-12 VII 2018, http://www. consilium.europa.eu, dostęp 5 II 2020.
} 
Podobne sugestie odnośnie do zadań Unii znajdziemy w Strategii Polskiej Polityki Zagranicznej 2017-2021, jak i w Informacji Ministra Spraw Zagranicznych o zadaniach polskiej polityki zagranicznej w 2017 roku. Wspólną Politykę Bezpieczeństwa i Obrony UE interpretowano w tych materiałach jako tworzenie autonomicznej przestrzeni do działań, ale komplementarnych w stosunku do Sojuszu. Wskazywano następujące zadania: przeciwdziałanie zagrożeniom hybrydowym, informatycznym i infiltracyjnym (oddziaływanie czynników zewnętrznych w sąsiedztwie południowym i wschodnim), a także wspieranie rozwoju europejskiego przemysłu obronnego. Przywoływano pozytywne przykłady Europejskich Grup Bojowych oraz agencji Frontex. Taki kierunek budowania WPBiO minister Waszczykowski nazwał dość kuriozalnie - „rozwój zdolności cywilno-wojskowych"295.

W latach 2016-2017 politycy PiS dostrzegli nowe komplikacje w relacjach Sojusz-Unia. Pierwsze stały się pochodną zmian w amerykańskiej polityce zagranicznej wraz z objęciem urzędu prezydenta przez Donalda Trumpa oraz reakcją państw zachodnioeuropejskich na nowy kurs strategiczny Waszyngtonu ${ }^{296}$. Kiedy zaczęły eskalować napięcia między Stanami Zjednoczonymi a osią francusko-niemiecką dominującą w Unii Europejskiej, premier M. Morawiecki 28 czerwca 2018 roku opowiedział się w Radzie Europejskiej za stabilizacją dotychczasowego układu transatlantyckiego ${ }^{297}$. Polska pod rządami PiS jednoznacznie odrzuciła mnożenie rozbieżności między Waszyngtonem a Brukselą. W kilkanaście dni po zmianie w Białym Domu poseł PiS Izabela Kloc zaapelowała w Sejmie: „[...] Unia Europejska winna wysłać czytelny sygnał, że współpraca transatlantycka pozostanie jednym z filarów jej po-

295 Strategia Polskiej Polityki Zagranicznej 2017-2021..., s. 8; Informacja Ministra Spraw Zagranicznych o zadaniach polskiej polityki zagranicznej w 2017 roku...

296 Vide M. A. Piotrowski, B. Wiśniewski, Strategia bezpieczeństwa narodowego USA. Podejście administracji Trumpa, „Biuletyn PISM”, 21 XII 2017, http://www.pism.pl, dostęp 30 I 2020; M. A. Piotrowski, Zmiany w gtównych zatożeniach Strategii obrony narodowej USA, „Biuletyn PISM", 26 I 2018, http://www.pism.pl, dostęp 30 I 2020.

297 Konferencja premiera M. Morawieckiego, 28 VI 2018, http://www.premier.gov.pl, dostęp 29 V 2019. 
lityki zagranicznej"298. Następnie, kiedy rozbieżności między Stanami Zjednoczonymi a państwami zachodnioeuropejskimi stawały się coraz bardziej widoczne, zdecydowanie wypowiedział się w 2019 roku w Sejmie minister Czaputowicz: „Jesteśmy przekonani, że utrzymanie silnych więzi transatlantyckich leży w interesie wszystkich, po obu stronach Atlantyku. Polska jest zdecydowanym orędownikiem dialogu w sytuacji zróżnicowanych stanowisk partnerów wspólnoty transatlantyckiej wynikających z odmiennych uwarunkowań, ocen czy doświadczeń"299.

Drugi typ komplikacji, które zaczęły narastać od 2016 roku w sposób dla PiS raczej niespodziewany, wynikał z rozpoczęcia procesu wyjścia Zjednoczonego Królestwa z Unii. Wielka Brytania była postrzegana jako ważny partner w Sojuszu, który zaczął jednak pozostawać poza inicjatywami wojskowymi Unii. Politycy PiS dostrzegali negatywne skutki decyzji podjętej przez Brytyjczyków dla Polski, Europy i Unii Europejskiej, ale wykazywali wiele zrozumienia dla niej, ponieważ: „decyzja należała do społeczeństwa brytyjskiego, wypowiedzieli się w referendum". Nie oceniano jej w kategoriach błędu, lecz racji stojących u jej podstaw, licząc w sposób niemal pewny (według A. Dudy), że: „Relacji transatlantyckich wyjście Londynu z UE nie osłabi" ${ }^{300}$. Można by przywołać w tym kontekście wyjaśnienia Andrzeja Nowaka, który sięgnął do dorobku historyka idei Johna Greville'a Agarda Pococka (myśli opublikowane już w 2005 roku): Anglia, będąc w Unii, utraciła swoją wyjątkową rolę zdolność budowy własnej hemisfery cywilizacyjno-kulturowej w postaci Zjednoczonego Królestwa o charakterze globalnym. Swoista zamiana Wspólnoty Brytyjskiej na Unię Europejską była historycznym błędem, z którego się wycofano ${ }^{301}$.

\footnotetext{
298 I. Kloc, Wystąpienie, [w:] SS Sejm, 8 kadencja, 35 pos., 9 II 2017, S. 138, http://orka2.sejm. gov.pl, dostęp 4 VI 2019.

299 J. Czaputowicz, Wystąpienie, [w:] SS Sejm, 8 kadencja, 78 pos., 14 III 2019, s. 151, http:// orka2.sejm.gov.pl, dostęp 6 VI 2019.

300 Archiwum Prezydenta RP, https://www.prezydent.pl, dostęp 12 VI 2020: „Wywiad dla PAP przed szczytem NATO”, 7 VII 2016; „Wywiad Prezydenta RP dla RMF FM”, 18 I 2017.

301 A. Nowak, Europa Wschodnia-polskie pytania..., s. 21.
} 
Politycy PiS zamierzali zabiegać o poparcie Londynu dla polityki wzmacniania wschodniej flanki Sojuszu. Podkreślali to zarówno B. Szydło, jak i M. Morawiecki po rozmowach z premier Theresą May. Ten drugi 20 grudnia 2018 roku deklarował: „Kluczowa pozostaje współpraca transatlantycka-podkreśliliśmy parę razy, jak ważne jest cementowanie tych relacji transatlantyckich i utrzymanie spójności, siły NATO". U progu wyjścia Zjednoczonego Królestwa z Unii A. Macierewicz zapewniał: 1) „Wielka Brytania będzie uczestniczyła w obronie wschodniej flanki. Nic w tej sprawie się nie zmieniło"; 2) „Jesteśmy absolutnie pewni, że Brexit nie będzie miał negatywnego wpływu na poziom zaangażowania Wielkiej Brytanii w NATO". Wyjście Zjednoczonego Królestwa jeszcze bardziej wzmocniło wątpliwości co do budowy architektury bezpieczeństwa europejskiego w oparciu o kooperację wojskową wewnątrz Unii, którą opuszczało przecież państwo dysponujące znacznym potencjałem militarnym. Należy się zgodzić z opiniami takich badaczy jak Józef Fiszer i Marcin Sienkiewicz. Ten pierwszy uznał, że: „Brexit, osłabiając UE, osłabi zarazem jej rolę w budowie nowego ładu globalnego, będącego wciąż in statu nascendi. To zaś wzmocni w świecie pozycję państw należących do tak zwanej grupy BRIC, a zwłaszcza Chin i Rosji". Natomiast według drugiego wyjście Wielkiej Brytanii z Unii stworzy niebezpieczeństwo, że we Wspólnocie dojdzie do „zachwiania wewnętrznej równowagi”, „pojawienia się niekorzystnych zmian w sposobie jej funkcjonowania" oraz „Wzrostu politycznej pozycji Niemiec" ${ }^{302}$. W PiS nie było żadnych wątpliwości, że bez Wielkiej Brytanii Unia będzie na pewno słabsza, a jednocześnie będzie musiała skonfrontować się z obawami przed efektem domina, czyli będzie musiała się zmierzyć z obawami, że inne państwa mogą naśladować Londyn, zwłaszcza jeśli ten odniesie sukces poza Wspólnotą.

Antidotum na proces wychodzenia Zjednoczonego Królestwa było podjęcie bezpośrednich uzgodnień na linii Warszawa-Londyn w duchu budowania dwustronnych powiązań sojuszniczych, między innymi w oparciu o Organizację Paktu. W 2016 roku uruchomiono polsko-brytyjskie konsultacje rządowe. Ten nowy kurs minister Waszczykowski na-

302 J. M. Fiszer, Polityka zagraniczna Polski w XXI wieku..., s. 147; M. Sienkiewicz, op. cit., s. 144. 
zwał w Sejmie w 2017 roku „utrzymywaniem wzmocnionej współpracy”. Natomiast na pytanie, czy warto utrzymywać bliskie relacje z państwem opuszczającym Unię, odpowiadał: „Warto współpracować z państwem nuklearnym, stałym członkiem Rady Bezpieczeństwa ONZ oraz nadal aktywnym partnerem w europejskiej polityce bezpieczeństwa. [...] taka współpraca leży w strategicznym interesie Rzeczypospolitej". Wyjście Wielkiej Brytanii z Unii nie było traktowane przez PiS jako dekompozycja europejskiego modelu bezpieczeństwa. Jego głównym filarem nie były bowiem instytucje unijne, lecz północnoatlantyckie oraz partnerstwo Londynu z Waszyngtonem, a tu nie tylko nie dokonywały się żadne zmiany, ale też $\mathrm{D}$. Trump poparł decyzję Brytyjczyków o opuszczeniu Wspólnoty. Według polityków PiS należało w brexicie, nie mogąc mu przeciwdziałać, szukać szansy, bo - jak to ujął Waszczykowski - „Brexit to oczywiście cios dla Unii Europejskiej, ale też i szansa dla nas na nawiązanie wielosektorowej współpracy z drugą gospodarką europejską i światowym mocarstwem". Natomiast premier Morawiecki dokonał jego wykładni w kontekście północnoatlantyckim: „dążymy do tego, żeby zabezpieczyć jak najbliższą obecność Wielkiej Brytanii przy naszym sojuszu NATO". Minister Błaszczak uzasadniał to dużym potencjałem militarnym Wielkiej Brytanii oraz jej ważną rolą w północnoatlantyckim systemie obrony ${ }^{303}$.

Był jeszcze jeden czynnik uznawany przez PiS za oddziałujący pozytywnie na charakter stosunków polsko-brytyjskich. Chodziło o podobne postrzeganie polityki zagranicznej prowadzonej przez Rosję oraz wybór

\footnotetext{
303 VideWypowiedź B. Szydło w: Konferencja prasowa z premierem Wielkiej Brytanii, 5 II 2016, http://www.pap.pl, dostęp 22 XII 2019; wypowiedź M. Morawieckiego w: Konferencja premiera z premier Wielkiej Brytanii T. May w Londynie, 20 XII 2018, http://www.gazetaprawna.pl, dostęp 29 I 2020; wypowiedź A. Macierewicza w: Konferencja prasowa, 24 VI 2016, http://www.pap.pl, dostęp 30 I 2020; Wypowiedź ministra Błaszczaka w Polskim Radiu 24, 22 XII 2017, http://www.pap.pl, dostęp 1 II 2020; Konferencja z okazji szczytu NATO, 9 VII 2016, http://www.pap.pl, dostęp 2 II 2020; Konferencja premiera po szczycie RadyEuropejskiejw Brukseli, 23 III 2018, http://www.pap.pl, dostęp 2 II 2020; Informacja Ministra Spraw Zagranicznych o zadaniach polskiej polityki w 2017 roku...; W. Waszczykowski, Wypowiedź, [w:] WNPSejm, 8 kadencja, 78 pos., 14 III 2019, http://www.sejm.pl, dostęp 14 II 2020.
} 
opcji na rzecz twardej polityki wobec Kremla, uznawanej za skuteczną. Pod tym względem, w opinii PiS, Zjednoczone Królestwo odróżniało się korzystnie od innych mocarstw europejskich ${ }^{304}$.

Problem relacji Sojusz-Unia za czasów administracji Trumpa zmaterializował się w konkretnej sprawie - stosunku Polski do realizacji zapisów traktatu z Lizbony w zakresie bezpieczeństwa. Po wielu latach od ogłoszenia powstania Wspólnej Europejskiej Polityki Bezpieczeństwa i Obrony i po kilku od podpisania traktatu lizbońskiego, w latach 2016-2017 Unia zdecydowała się zaprezentować całościową koncepcję kształtu tej polityki oraz podjąć działania wykonawcze - powiadomiła o zamiarze utworzenia Europejskiego Funduszu Obronnego (European Defence Fund, EDF) oraz mechanizmu Stałej Współpracy Strukturalnej (Permanent Structured Cooperation, PESCO) ${ }^{305}$. Ofensywa podjęta przez administrację unijną była szeroka i zmieniała poprzednie założenia odnoszące się do polityki zagranicznej Unii. Polska rządzona przez PiS przystąpiła więc do zaproponowanych działań, gdyż - jak mówił Waszczykowski - „Kwestia marzenia Unii, aby mieć swoją tożsamość obronną sama w sobie nie jest zła [...]", zwłaszcza kiedy siły europejskie stałyby się wsparciem dla Sojuszu ${ }^{306}$.

W PiS pojawiły się jednak wątpliwości - czy wbrew licznym deklaracjom Brukseli budowana europejska wspólnota obronna nie będzie ewoluowała w kierunku bycia konkurencją dla Sojuszu. Taki kierunek w sensie strategicznym wydawał się mało prawdopodobny, ale część członków Unii Europejskiej widziałaby w niej od samych narodzin Wspólnej Europejskiej Polityki Bezpieczeństwa i Obrony czynnik emancypacji Europy spod protektoratu Stanów Zjednoczonych, a na pewno nie chciałaby z niej uczynić kolejnego narzędzia wykorzystywanego przez Waszyngton do wzmacniania swojej globalnej supremacji, nakręcania

304 VideK. Głębocki, Wypowiedź, [w:] WNPSejm, 8 kadencja, 35 pos., 9 II 2017, http://www. sejm.pl, dostęp 24 II 2020.

305 J. J. Węc, Reforma wspólnej polityki bezpieczeństwa i obrony Unii Europejskiej w latach 2016-2017, „Politeja” 2018, nr 54(3), s. 47 i n.

306 W. Waszczykowski, Wystaliśmy Rosji jasny sygnat..., s. 26. 
wyścigu zbrojeń oraz militaryzacji polityki ${ }^{307}$. Zasadnicze wątpliwości co do WEPBiO zostały zaprezentowane na III Kongresie PiS w 2010 roku. W jednym z wniosków zapisano, że właśnie ta polityka wspólnotowa „W obecnym kształcie nie wydaje się właściwym narzędziem do zapewniania bezpieczeństwa Polsce", jest bowiem zdominowana przez interesy tych państw członkowskich UE, które mają inną od polskiej „optykę zagrożeń" ${ }^{308}$. Te same wątpliwości pojawiły się także wiele lat później, kiedy WEPBiO zaczęła się materializować w konkretnych programach. Wyraził je prezydent Duda 11 października 2019 roku, mówiąc swoim europejskim partnerom, że doprecyzowania wymaga "strategiczna autonomia" tej polityki. Konkludował: „Polska chciałaby raczej strategicznej skuteczności" i odrzuca podejście do tej kwestii w kategoriach „sprzeciwu wobec zaangażowania USA w Europie”, bo to "realnie osłabia bezpieczeństwo całej Zjednoczonej Europy". Polska propozycja była wyrazista - WPBiO musi być komplementarna i synergiczna wobec Sojuszu, wtedy będzie miała poparcie Warszawy ${ }^{309}$.

Kiedy sytuacja międzynarodowa uległa zaostrzeniu po 2014 roku, ambicje wojskowe Unii wygenerowały także problem finansowy, opisany przez Kamila Mazurka: „który podmiot i w jakim stopniu powinien realizować zadanie wzmocnienia wspólnych zdolności obronnych państw członkowskich". Powstawało więc pole do naturalnej rywalizacji. Jak zauważył ten analityk, premier Morawiecki nie miał innego wyjścia i chcąc uniknąć kolejnego starcia z Komisją Europejską, zgłosił akces Polski do tej inicjatywy, mimo że Warszawa postanowiła partycypować w niej w małym stopniu. Oczekiwano na wyklarowanie się kierunku, w jakim inicjatywa PESCO miałaby być rozwijana, i wielokrotnie zaklinano, że taka współpraca musi być powiązana z Sojuszem i realizowana w jego

307 Szerzej na ten temat vide M. Stolarczyk, Wzrost kontrowersji w stosunkach transatlantyckich i ich implikacje dla bezpieczeństwa europejskiego, [w:] Bezpieczeństwo Polski i bezpieczeństwo europejskie na początku XXI wieku. Wybrane aspekty, red. M. Stolarczyk, Wydawnictwo Uniwersytetu Śląskiego, Katowice 2004, s. 23 i n.

308 Nowoczesna Polska 2020..., s. 116.

309 Wystąpienie Prezydenta podczas 2. sesji plenarnej na szczycie Grupy Arraiolos, 11 X 2019, http://www.prezydent.pl, dostęp 2 V 2020. 
ramach $^{310}$. W tej materii stanowisko Polski było analogiczne do postawy państw wschodniej flanki Sojuszu, bo - jak napisała analityk Justyna Gostkowska - „Dla większości państw wschodniej flanki zachodnioeuropejskie koncepcje "europejskiej autonomii strategicznej" wydają się generować więcej problemów niż (choćby zalążków) alternatywnych rozwiązań dla zapewnienia europejskiego i regionalnego bezpieczeństwa". Wskazała dwa powody, a faktycznie trzy: 1) preferencje dla reagowania kryzysowego na flance południowej; 2) nieuwzględnianie wyzwań i zagrożeń na Wschodzie; 3) rozumowanie alternatywne w stosunku do sojuszu europejsko-amerykańskiego ${ }^{311}$.

Chodziło zwłaszcza o kontekst amerykański i północnoatlantycki. Polska precyzyjnie nakreśliła swój stosunek do PESCO. Uczynił to minister Waszczykowski po sesji Rady Północnoatlantyckiej z Wysoką Przedstawiciel UE ds. Wspólnej Polityki Zagranicznej i Bezpieczeństwa Federicą Mogherini 5 grudnia 2017 roku: „Współpraca strukturalna Unii powinna stanowić wzmocnienie dla kooperacji NATO-UE". Wskazał też dwa konkretne cele tej współpracy: 1) wzrost liczby obszarów kooperacji, zwłaszcza w odniesieniu do zagrożeń hybrydowych i walki z terroryzmem; 2) ścisła koordynacja, aby zapobiec ewentualnemu powielaniu podejmowanych działań. Rzecz charakterystyczna, nie przewidywał realnych zadań wojskowych dla PESCO ani nie podejmował w tym kontekście kwestii jakiejkolwiek roli tej inicjatywy w odniesieniu do flanki wschodniej Sojuszu ${ }^{312}$. W tej materii nie było żadnych wątpliwości, że Unia może realizować zadania korzystne i ważne dla Polski. Granice poparcia dla

310 PESCO: rusza wspótpraca obronna 25 państw, 11 XII 2017, http://consilium.europa.eu, dostęp 7 XII 2019; M. Terlikowski, PESCO: Unia Europejska zacieśnia wspótpracę obronna, 28 VI 2017, http://polska-zbrojna.pl, dostęp 7 XII 2019; Archiwum Prezydenta RP, https://www.prezydent.pl, „Wystąpienie Prezydenta na spotkaniu noworocznym z Korpusem Dyplomatycznym", 11 I 2018, dostęp 12 VI 2020; K. Mazurek, Europejska ofensywa w obszarze obronności - EDF, PESCO i CARD, Fundacja im. Kazimierza Putawskiego, Warszawa 2018, s. 18-19. Vide T. Zieliński, Europejska Unia Obrony wyzwaniem dla wschodniej flanki NATO, „Zeszyty Naukowe ASzWoj” 2017, nr 4(109), s. 46-62.

311 J. Gostkowska, Brukselski szczyt NATO: wschodnia flanka między USA a Europa " Analizy OSW", 9 VII 2018, http://www.osw.waw.pl, dostęp 30 I 2020.

312 Wypowiedź ministra W. Waszczykowskiego, 5 XII 2017, http://www.msz.gov.pl, dostęp $29 \mid 2020$. 
projektu PESCO zakreśliła w wystąpieniu sejmowym M. Gosiewska, mówiąc: „[...] będziemy popierać współpracę europejskich przemysłów obronnych PESCO tak długo, jak długo będzie to przynosić korzyści polskiemu przemysłowi, polskim robotnikom i polskiej armii". Jednocześnie ostrzegała w sposób reprezentatywny dla PiS: „Realia są jednak takie, że europejska samodzielność obronna to wizja odległej przyszłości. Europa bez Stanów Zjednoczonych jest dziś bezbronna"313.

PESCO było zaś postrzegane przez PiS jako możliwość stałej współpracy strukturalnej. Politycy PiS nie komentowali publicznie zbyt często tego niedookreślonego projektu Unii Europejskiej. Więcej miejsca poświęcił jej minister Czaputowicz w swoim exposé sejmowym 21 marca 2018 roku. Zakreślił dla niej trzy obszary działań: 1) rozwój krajowego przemysłu zbrojeniowego; 2) zmiana struktury narodowego budżetu obronnego;3) zwiększenie szybkości transgranicznego przerzutu wojsk sojuszniczych. Trudno uznać te zadania za kluczowe dla zapewnienia bezpieczeństwa Europie Środkowej ${ }^{314}$.

Inicjatywa stworzenia Europejskiej Unii Obrony wydawała się też kolejnym mgławicowym projektem Wspólnoty Europejskiej, których w jej dziejach jest wiele ${ }^{315}$. Natomiast więcej konkretnych efektów spodziewano się po Europejskim Funduszu Obronnym. Zajął się nim minister Czaputowicz we wspomnianej informacji o zadaniach polskiej polityki zagranicznej na 2018 rok. Widział w nim czynnik wsparcia dla badań nad nowymi technologiami obronnymi, dla rozwoju przemysłu zbrojeniowego oraz zdolności bojowych wojsk państw członkowskich UE, a także dla struktury ich budżetów wojskowych. Jednak wyrażał również swoje obawy, że beneficjentami Funduszu będą najsilniejsze państwa człon-

313 M. Gosiewska, Wypowiedź, [w:] WNPSejm, 8 kadencja, 78 pos., 14 III 2019, http://www. sejm.pl, dostęp 14 II 2020.

314 J. Czaputowicz, Informacja ministra spraw zagranicznych o zadaniach polskiej polityki zagranicznej $w 2018$ roku..., s. 86.

315 Problem kontrowersji w unijnej polityce obrony i bezpieczeństwa w: J. Gostkowska, W stronę sojuszu wojskowego? Perspektywy Europejskiej Unii Bezpieczeństwa i Obrony, OSW, Warszawa 2019, passim. 
kowskie Unii ${ }^{316}$. Z powodów zasadniczych więc dla polityków PiS budowa Europejskiej Unii Obrony nie mogła odbywać się kosztem wzmocnienia wschodniej flanki NATO. Wypowiedzi polityków PiS odpowiedzialnych za politykę zagraniczną na temat PESCO zawsze zawierały jeden wątek - PESCO nie może być w kolizji z Sojuszem, lecz musi działać z nim spójnie, nie może też powielać działań i wydatków Paktu. Według A. Dudy: „Nie możemy dopuścić, by były to jakieś dwie odrębne polityki, które będą się rozchodziły - i nie daj, Panie Boże - będą sobie przeciwstawne, a zatem będą nas osłabiały"317. Za podsumowanie stosunku PiS do europejskich inicjatyw obronnych może posłużyć wypowiedź posła Michała Jacha, przewodniczącego - ze wskazania PiS - Komisji Obrony Narodowej w Sejmie VIII kadencji. Odniósł się w 2019 roku do obu kluczowych projektów unijnych - zarówno do PESCO, jak i do EDF. W pierwszej inicjatywie za cenne dla Polski uznał zadania z zakresu przegrupowywania wojsk między państwami oraz usprawnienie ich mobilności. Co do drugiej, wskazał możliwość podniesienia poziomu technologii i wyposażenia Sił Zbrojnych RP ${ }^{318}$.

316 J. Czaputowicz, Informacja ministra spraw zagranicznych o zadaniach polskiej polityki zagranicznej $w 2018$ roku..., s. 86.

317 Vide K. Szymański, Premier niezmiennie inwestuje w region [Wywiad Grzegorza Osieckiego z Konradem Szymańskim], „Dziennik Gazeta Prawna”, 3 I 2018, nr 2, s. 7; W. Waszczykowski, Wystaliśmy Rosjijasnysygnat..., s. 26; R. Legutko, Tuskniejestjakżona Cezara [Wywiad Jacka Nizinkiewicza z Ryszardem Legutko], „Rzeczpospolita”, 13 III 2017, nr 60, s. A5; R. Czarnecki, Podwójna gra Berlina [Wywiad Marcina Makowskiego z Ryszardem Czarneckim], „Do Rzeczy”, 4-10 VII 2016, nr 27(178), s. 19; J. Czaputowicz, Informacja ministra spraw zagranicznych o zadaniach polskiej polityki zagranicznej w 2018 roku..., s. 86; Archiwum Prezydenta RP, https://www.prezydent.pl, „Wystąpienie Prezydenta po przedstawieniu przez Szefa MSZ informacji o zadaniach polskiej polityki zagranicznej", 21 III 2018, dostęp 12 VI 2020.

318 M. Jach, Wypowiedź, [w:] WNPSejm, 8 kadencja, 78 pos., 14 III 2019, http://www.sejm.pl, dostęp 14 II 2020. 



\subsection{I faza polityki transatlantyckiej}

\section{Prawa i Sprawiedliwości (2015-2016)}

Krzysztof Szczerski, minister stanu w Kancelarii Prezydenta Andrzeja Dudy, ogłosił w kwietniu 2016 roku cel strategiczny dla prezydenta, rządów oraz większości parlamentarnej Zjednoczonej Prawicy w kontekście bezpieczeństwa Rzeczypospolitej Polskiej. Mimo koalicyjnych rządów, to w obozie Zjednoczonej Prawicy polityka zagraniczna była domeną najsilniejszego ugrupowania - Prawa i Sprawiedliwości. Dwaj mniejsi koalicjanci: Solidarna Polska i Porozumienie Jarosława Gowina oraz liderzy obu tych ugrupowań nie mieli niemal żadnego wpływu na politykę zagraniczną obu gabinetów - Beaty Szydło i Mateusza Morawieckiego. Dlatego też to w myśli politycznej PiS należy szukać wyjaśnienia polityki transatlantyckiej większości parlamentarnej będącej zapleczem tych gabinetów. W tym aspekcie także prezydent A. Duda był wyrazicielem tych samych poglądów co większość parlamentarna. W obozie Zjednoczonej Prawicy polityka zagraniczna realizowana przez urzędy Prezydenta RP, Prezesa Rady Ministrów i Marszałka Sejmu oraz trzy odpowiednie kancelarie była spójna. W jej kontekście MSZ spełniało rolę raczej pomocniczą i wykonawczą niż ideotwórczą, gdyż główne linie strategiczne były formułowane przez prezesa J. Kaczyńskiego i przekazywane bezpośrednio prezydentowi, dwom kolejnym premierom oraz marszałkowi Markowi Kuchcińskiemu. 
W wywiadzie dla gazety „Rzeczpospolita” K. Szczerski sformułował wytyczną dla polityki transatlantyckiej: Polska powinna przejść „ze stanu politycznego członkostwa w NATO do pełnowymiarowego członkostwa militarnego" ${ }^{11}$. Dla polityków PiS (w tym dla parlamentarzystów) była to kardynalna kwestia z zakresu polityki zagranicznej, mająca mocne uzasadnienie w myśli politycznej tego ugrupowania. PiS od początku swojego istnienia we wszystkich programach postrzegało zagrożenie rosyjskie w kategoriach realnych, a nie abstrakcyjnych ${ }^{2}$. Prezes partii J. Kaczyński mówił: „[...] dziś na świecie nie ma ważniejszej sprawy niż ograniczenie rosyjskiego ekspansjonizmu"3. Uważano w stronnictwie, że Rosja ma potencjał i wolę niszczenia państw położonych na pewno w obszarze "bliskiej zagranicy", ale również prawdopodobnie w całym regionie środkowoeuropejskim. Zdawano sobie sprawę z niebezpieczeństw wynikających ze zdolności militarnych Rosji, z jej przygotowania wojskowego, ze stanu uzbrojenia, z zabezpieczenia finansowego (zyski ze sprzedaży surowców), doktryny wojennej, rosyjskiej kultury strategicznej oraz ze spójności ośrodka decyzyjnego w okresie rządów W. Putina.

Głównym elementem linii strategicznej w koncepcji PiS polityki zagranicznej było przekonanie o konieczności powstrzymywania imperialnej polityki Moskwy już na obszarze „bliskiej zagranicy”, zanim dojdzie do rozszerzenia agresji w postaci np. wojny hybrydowej (asymetrycznej) na region Europy Środkowej, w tym na państwa członkowskie Sojuszu Północnoatlantyckiego i Unii Europejskiej. Nie uważano, że członkostwo państw środkowoeuropejskich w Unii i Sojuszu zaimpregnowało je na zagrożenia ze strony Kremla. To niebezpieczeństwo było nie tylko wyjątkowo groźne, ale dla Rosji również wykonalne, zważywszy na słabość wewnętrzną, gospodarczą i militarną państw leżących na tym obszarze,

K. Szczerski, Stawka większa niż Trybunat [Rozmowa Andrzeja Gajcy z Krzysztofem Szczerskim], „Rzeczpospolita”, 18 IV 2016, nr 90, s. A4.

2 O genezie polityki transatlantyckiej vide J. Sanecka-Tyczyńska, Państwo obywatelskie i wspólnota polityczna..., passim; eadem, Racja stanu we wspótczesnej polskiej myśli politycznej..., passim; eadem, Model bezpieczeństwa zewnętrznego państwa..., s. 218-231.

3 J. Kaczyński, Odtączyć Rosję od kroplówki [Wywiad Pawta Majewskiego i Michała Sutdrzyńskiego z Jarosławem Kaczyńskim], „Rzeczpospolita”, 14 III 2014, nr 61, s. A6-A7. 
ich penetrację dokonywaną przez Rosję, uzależnienie energetyczne, dobre relacje Rosja-Niemcy oraz brak instalacji północnoatlantyckich na wschód od granic RFN.

W realiach lat 2015-2019 chodziło o podejmowanie przez władze RP działań we wschodniej części Europy Środkowej: bezpośrednich wobec niepodległej i integralnej Ukrainy, pośrednich na rzecz istnienia Białorusi oraz ze względu na strategiczne partnerstwo z trzema państwami bałtyckimi. Trudno było realizować politykę bezpieczeństwa Polski przy destabilizacji wymienionych państw i ich spenetrowaniu przez Rosję. PiS odrzucało (z powodów historycznych, emocjonalnych, pragmatycznych) zarówno politykę izolowania się od wschodniej, będącej poza Unią i Sojuszem, Europy Środkowej, jak również politykę oderwania się od problemów tej części kontynentu, preferowaną przez Platformę Obywatelską w czasie rządów tej formacji oraz przez środowiska narodowe powiązane przejściowo z ruchem Kukiz'154 . Były to zasadnicze przesłanki, którymi się kierowano przy tworzeniu programów, odnoszące się do stosunków dwustronnych z państwami postradzieckimi położonymi między Rzeczpospolitą a Federacją Rosyjską.

Prawo i Sprawiedliwość przewartościowało politykę realizowaną wobec Białorusi w latach 2005-2007, kiedy dwa problemy: sytuacja mniejszości polskiej w Republice oraz zaprowadzanie autorytaryzmu przez prezydenta Białorusi zdeterminowały politykę Warszawy wobec Mińska, nasycając ją całkowitą nieskutecznością. Po przejęciu władzy w 2015 roku w kierunku prezydenta Białorusi Alaksandra Łukaszenki wysyłano wyraźne sygnały, mimo oczywistych zastrzeżeń wobec kształtu systemu politycznego w Republice. Niemniej w latach 2015-2019 znacznie obniżono poziom oddziaływania na stosunki polsko-białoruskie dwóch wspomnianych czynników: postulatu demokratyzacji Białorusi oraz żądań w sprawie mniejszości polskiej w tym państwie. Zwyciężył realizm,

\footnotetext{
$4 \quad$ Najpetniej środkowoeuropejskie uzależnienie bezpieczeństwa Polski ujmował Szczerski: 1) „Bezpieczeństwo Ukrainy jest także naszym bezpieczeństwem”; 2) „Pokój na Ukrainie jest warunkiem polskiego bezpieczeństwa". K. Szczerski, Polska jest silna [Rozmowa Aleksandry Rybińskiej z Krzysztofem Szczerskim], „Sieci”, 27 XI-3 XII 2017، nr 48, s. 76; idem, Cztery warunki Dudydla Niemiec..., s. A6.
} 
gdyż dawanie preferencji tym czynnikom zamrażało jakiekolwiek szanse wywierania dyskretnego (pośredniego) wpływu na politykę zagraniczną Mińska oraz działało na rzecz zbliżenia białorusko-rosyjskiego. W 2016 roku minister spraw zagranicznych Witold Waszczykowski złożył wizytę (pierwszą od 8 lat) w Mińsku, a w 2017 roku udzielił opiniotwórczemu tygodnikowi "Wprost” wywiadu o znamiennym tytule Chcę się ułożyć z Białorusią, w którym pokazał intencje Warszawy otwarcia nowego rozdziału w relacjach z Mińskiem ${ }^{5}$. Już po rozmowach z Łukaszenką w 2016 roku, Waszczykowski zapowiadał: „Jesteśmy gotowi rozpocząć rozwiązywanie problemów w naszych dwustronnych relacjach. Dlatego postanowiliśmy bez żadnych wstępnych warunków rozpocząć dialog"6.

Wizyty na Białorusi składali w latach 2016-2019: ówczesny wicepremier i minister finansów Mateusz Morawiecki, wicemarszałek Sejmu Ryszard Terlecki, minister Witold Waszczykowski i najwyższy rangą przedstawiciel Rzeczypospolitej - marszałek Senatu Stanisław Karczewski. Zaproszono także Białoruś na cztery szczyty parlamentarne organizowane przez Sejm. Uruchomiono więc na tym odcinku dyplomację parlamentarną. Marszałek Karczewski mówił w czasie jednej z wizyt w Mińsku (2019): „Polskę i Białoruś dzieli granica, ale ta granica powinna nas łączyć we wzajemnej współpracy". W czasie poprzedniej wizyty (2018) złożył jeszcze bardziej zobowiązującą deklarację: „Polska może być oknem dla Białorusi do współpracy z Europą". Szerokim echem odbiło się spotkanie Karczewskiego z Łukaszenką 4 grudnia 2016 roku, komentowane w polskich środkach przekazu społecznego ${ }^{7}$.

5 W. Waszczykowski, Chcę się utożyć z Biatorusią..., s. 35. Vide U. E. Snapkouski, BiałoruśPolska: jak wyjść z btędnego koła w rozwoju wzajemnych stosunków, [w:] Stosunki Polski z Litwa, Białorusią i Ukraina. 450 lat po unii lubelskiej, red. T. Stępniewski, B. Surmacz, Instytut Europy Środkowej, Lublin 2019, s. 146-154.

$6 \quad$ A. Poczobut, Białoruś. Minister Waszczykowski spotkat się z Łukaszenką. Ten się skarżyt: "Droga ministra z Warszawy do Mińska byta dtuga", 23 III 2016, http://www.wyborcza.pl, dostęp 10 VI 2020.

7 Marszałek Karczewski w Mińsku: Polskęi Białoruś dzieli granica, ale ta granica powinna nas tączyć, 7 VI 2019, http://www.kresy24.pl, dostęp 28 XII 2019; MarszatekSenatu Karczewski na Białorusi, 29 VII 2018, http://www.narodowcy.pl, dostęp 27 XII 2019; Karczewski: Łukaszenka to takicieptycztowiek, 7 XII 2016, http://www.tvn24.pl, dostęp 27XII 2019; Białoruś: 
Te dość obszerne, jak na uwarunkowania po stronie białoruskiej, inicjatywy i wypowiedzi polityków PiS należy odczytywać według oceny sformułowanej w 2006 roku przez MSZ dla premiera J. Kaczyńskiego: „Utrzymanie faktycznej niepodległości Białorusi jest kwestią kluczową dla stabilności całego regionu Europy Środkowo-Wschodniej i przyszłości procesów demokratycznych na obszarze b. ZSRR" ${ }^{8}$. Niemniej jednak w tej ocenie tkwił ważny dla polityków PiS dylemat - czy wspierać istnienie niepodległej Białorusi, kierując się realizmem, czy raczej działać na rzecz jej demokratyzacji, będąc wiernym wartościom. Te cele były sprzeczne w warunkach rządów Łukaszenki w Mińsku, wyjątkowo czułego na wszelkie formy polskiego wsparcia dla inicjatyw demokratycznych w tym państwie, zarówno polonijnych, jak i rodzimych, opozycyjnych wobec autorytarnego systemu. Kompletnie nierealistycznie brzmiały sugestie MSZ z 2006 roku, że jest możliwa polityka 1) jednoczesnego wspierania społeczeństwa na Białorusi i utrwalania nieugiętej postawy Łukaszenki wobec Moskwy, dążącej do wchłonięcia Republiki oraz 2) przekonywania Rosji, że demokratyzacja Białorusi jest dla niej korzystna i nie przyniesie strat imperium ${ }^{9}$. W latach 2015-2019 zrezygnowano $\mathrm{z}$ tych sugestii.

Jednak inicjatywy parlamentarne i rządowe wobec Białorusi ani nie przyniosły strategicznego przełamania w stosunkach dwustronnych, ani nie spowodowały korekty kursu Mińska na pogłębianie powiązań z Moskwą. Trudno też dostrzec znaczące zyski dla ówczesnej polityki Polski. Okazało się bowiem, że polityka zagraniczna Łukaszenki w kontekście utrzymywania niezależności Białorusi od Rosji była odwrotnie proporcjonalna od siły nacisku Kremla na zjednoczenie. Im bardziej Moskwa

Spotkanie marszałka Karczewskiego z prezydentem Łukaszenką, 5 XII 2016, http://www. kresy24.pl, dostęp 27 XII 2019.

8 Archiwum MSZ, sygn. 140.09, w. 2, "Materiał tezowo-informacyjny do wykorzystania podczas wizyty oficjalnej Premiera RP Pana Jarosława Kaczyńskiego z Premierami Państw Bałtyckich. Wizyta oficjalna Premiera RP na Litwie, Wilno, 7-8 grudnia 2006 r.", 4 XII 2006, s. 12.

9 Archiwum MSZ, sygn. 140/09, w. 2, „Sugestie do rozmowy Premiera RP Pana Kazimierza Marcinkiewicza z Premierem KH J.L.R. Zapatero podczas III międzyrządowych konsultacji, Grenada, 9 marca 2006 r.", 6 III 2006, s. 29. 
naciskała na Mińsk, tym bardziej Łukaszenka instrumentalnie pokazywał, że ma alternatywne rozwiązanie - zbliżenie się do tzw. Zachodu. Jednak Polska osiągnęła rezultaty z polityki wysyłania sygnałów do Mińska i były one wyjątkowo ważne. Pośrednie wzmacnianie A. Łukaszenki w relacjach białorusko-rosyjskich doprowadziło do sytuacji, że do przeniesienia znacznej liczby wojsk rosyjskich na terytorium Białorusi nie doszło przed rozbudową flanki wschodniej Sojuszu. Prezydent Białorusi nie uznał także polityki faktów dokonanych realizowanych przez Rosję w odniesieniu do Abchazji, Osetii, Krymu i Donbasu, czyli przynależności do Rosji tych terytoriów formalnie ukraińskich i gruzińskich.

Zasadniczo odmiennie kształtowały się stosunki polsko-litewskie w latach 2015-2019. Rządom PiS udało się przełamać impas w relacjach bilateralnych odziedziczony po rządach koalicji PO-PSL, kiedy minister Sikorski faktycznie doprowadził do zamrożenia stosunków między Warszawą a Wilnem. Natomiast politykom $\mathrm{PiS}$ w dwa lata po przejęciu władzy w Polsce, w 2017 roku udało się dokonać zasadniczych zmian w stosunkach polsko-litewskich w kierunku strategicznego partnerstwa, budowanego - co jest znamienne - „w cieniu tradycji państwa polsko-litewskiego". Kluczową rolę odegrała wizyta marszałka Sejmu Marka Kuchcińskiego na Litwie i jego wystąpienie w Seimasie 27 września 2017 roku z okazji 630. rocznicy chrztu Litwy ${ }^{10}$. Wizyta nastąpiła po spotkaniach premiera Litwy Sauliusa Skvernelisa z prezesem Kaczyńskim w Warszawie: pierwsze miało miejsce w październiku (lub w listopadzie) 2016 roku, a drugie we wrześniu 2017 roku. Po drugim premier Litwy miał powiedzieć: „Jarosław Kaczyński patrzy na Litwę jak na państwo strategicznie przyjazne"11. $\mathrm{O}$ ile rozmowy $\mathrm{z}$ inspiracji centrali partyjnej PiS na Nowogrodzkiej były raczej dyskrecjonalne, o tyle nowy impuls

10 Przed wizytą Kuchcińskiego na Litwie, Warszawa, Wilno i Kijów sfinalizowały sformowanie wspólnej jednostki wojskowej - Wielonarodowej Brygady LitPolUkrBrig imienia księcia i hetmana wielkiego litewskiego Konstantego Ostrogskiego. A. Kuczyńska-Zonik, D. Wilczewski, „Polska i Litwa podają sobie dtonie”. Polska perspektywa wspótpracy bilateralnej, [w:] Stosunki Polski z Litwą, Biatorusią i Ukrainą..., s. 72.

11 Spotkat się z Kaczyńskim przy kuflu piwa. I jest efekt!, 2 VIII 2017, http://www.fakt.pl, dostęp 27 XII 2019; Spotkanie premiera Litwy i prezesa PiS w Warszawie, 5 IX 2017, http:// www.telewizjarepublika.pl, dostęp 27 XII 2019. Dziennik „Fakt” jako termin pierwsze- 
został upubliczniony w 2017 roku, kiedy to Kuchciński, powołując się na spuściznę Lecha Kaczyńskiego (16 wizyt na Litwie w okresie prezydentury), stwierdził w Seimasie, że „w imię przeszłości i przyszłości" potrzebna jest odwaga na skalę polityków sprzed 630 lat i podjęcie bardzo bliskiej współpracy. Ponad rok później (19 grudnia 2018) w kolejnym wystąpieniu Kuchciński sformułował już daleko idącą konkluzję: „Sprawa jest zasadnicza, chodzi o bezpieczeństwo Polski i Litwy. W obliczu różnych zagrożeń zewnętrznych jest to pierwszoplanowa i strategiczna sprawa"12.

Zestawienie tych dwóch wizyt wyraźnie wskazuje na bardzo szybkie zacieśnianie współpracy Warszawy z Wilnem. Potwierdzały je w latach 2018-2019 liczne wydarzenia o charakterze symbolicznym: wzajemne uczestnictwo w obchodach odzyskania niepodległości po Wielkiej Wojnie, wspólne uroczystości 550-lecia parlamentaryzmu Rzeczypospolitej Obojga Narodów obchodzone w Warszawie i w Wilnie oraz 450. rocznicy ustanowienia Unii Lubelskiej zorganizowane w Lublinie. W Wilnie i Warszawie zaczęto odczytywać historię jako czynnik łączący, a nie dzielący oba państwa i narody, co było wręcz rewolucyjnym podejściem w skali historycznej, biorąc pod uwagę stosunek odrodzonego państwa litewskiego do historii w XX wieku. Polska sięgnęła po nowe symbole zaczerpnięte z dziejów wspólnego państwa. Warto wymienić patrona polsko-litewsko-ukraińskiej brygady - księcia Konstantego Ostrogskiego, hetmana wielkiego litewskiego, który rozbił wojska moskiewskie, oraz projekt postawienia na dziedzińcu sejmowym pomników najwybitniejszych marszałków Izby Poselskiej Sejmu Rzeczypospolitej Obojga Narodów, w tym litewskich, chociażby Lwa Sapiehy. W 2019 roku reaktywowano po 10 latach Zgromadzenie Parlamentarne Sejmu i Senatu RP oraz Seimasu Republiki Litewskiej ${ }^{13}$. Generalny kierunek w tym segmencie

go spotkania podał listopad 2016, a TV Republika za „mediami litewskimi” wymienita październik.

12 Marszatek Sejmu z pierwszą oficjalną wizytą w Wilnie z okazji 630-lecia chrztu Litwy, 27 IX 2017, http://www.marekkuchcinski.pl, dostęp 27 XII 2019; Kuchciński w Wilnie: Są sprawy Polaków na Litwie, ale sprawa zasadnicza to bezpieczeństwo Polski i Litwy, 20 XII 2018, http://www.kresy24.pl, dostęp 27 XII 2019.

13 A. Kuczyńska-Zonik, D. Wilczewski, op. cit., s. 83-84. 
polityki historycznej nakreślił w Sejmie minister Czaputowicz, mówiąc, że Polska przy okazji tych rocznic historycznych powinna „wykazywać swą solidarność i świadomość wspólnoty losów historycznych z innymi narodami w naszym regionie, które 100 lat temu wraz z nami wybiły się na niepodległość" ${ }^{\prime 14}$. Do zaistnienia takiej sytuacji nie doszło ani w latach międzywojennych, ani w okresie 1991-2015. Wiązało się to z przekonaniem, że w Europie Środkowej i Wschodniej historię należy odczytywać w kategoriach zbieżności, a nie postrzegać jako przedmiot konfliktu. Najpełniej to przewartościowanie historii jest widoczne w inicjatywach parlamentarnych, rozwijanych pod patronatem i z inicjatywy marszałka Sejmu M. Kuchcińskiego. Chodzi o inicjatywy Europa Karpat i szczyty parlamentarne szefów parlamentów państw Europy Środkowej i Wschodniej. W obu tych projektach odczytano lokalizację geograficzną jako spoiwo dla państw leżących na tym obszarze i w nich uczestniczących.

W opisanych poglądach i działaniach właściwych dla okresu 20152019 należy widzieć następstwa „twardej” reakcji polityków PiS na kolejne rosyjskie agresje w latach 2008-2014 na Gruzję i Ukrainę (najpierw Krym, a następnie wschodnie rejony Ukrainy). Polityka faktów dokonanych ze strony Moskwy w postaci aneksji Krymu oraz powołania federacji noworosyjskiej zostały bezwzględnie odrzucone, adekwatnie do wydarzeń, przez prezydenta Lecha Kaczyńskiego oraz będące w opozycji PiS. Prezydent Kaczyński prognozował w czasie najazdu rosyjskiego na Gruzję w 2008 roku, że "dziś Gruzja, jutro Ukraina, pojutrze państwa bałtyckie, a później może i czas na mój kraj, na Polskę", oraz wzywał wtedy, żeby „ten świat reagował jeszcze mocniej, w szczególności Unia Europejska i NATO"15. Natomiast kilka lat później, po inwazji rosyjskiej na Krym, a przed wojną o wschodnie ziemie Ukrainy, prezes J. Kaczyński pokusił się o inną, równie trafną prognozę: „jeśli im się uda, to pewnie spróbują i na wschodniej Ukrainie". Obaj politycy proponowali reakcję zdecydo-

\footnotetext{
14 J. Czaputowicz, Informacja ministra spraw zagranicznych o zadaniach polskiej polityki zagranicznej w 2018 roku..., s. 90.

15 Stowa, które powstrzymaty Rosję. 10. rocznica wystąpienia Lecha Kaczyńskiego w Tbilisi, 12 VIII 2018, http://www.tvp.info, dostęp 28 XII 2019.
} 
waną, którą były premier, jeszcze przed zajęciem przez Rosję wschodniej Ukrainy (marzec 2014 roku), zestawił z polityką Ronalda Reagana zniszczenia ZSRR i nazwał ją „odłączeniem Rosji od kroplówki”, którą są pieniądze za ropę naftową i gaz ziemny ${ }^{16}$. W opinii zarówno prezydenta L. Kaczyńskiego w 2008 roku, jak i byłego premiera J. Kaczyńskiego w 2014 roku, ówczesne wydarzenia ostatecznie sfalsyfikowały poglądy (od początku uznawane przez nich za fałszywe) z lat dziewięćdziesiątych XX wieku, że Rosja zmieniła swoją naturę polityczną, stając się członkiem demokratycznej wspólnoty. Według L. Kaczyńskiego: „Rosja po raz kolejny pokazała swoją twarz. Prawdziwą twarz"17. Można przyjąć, za Ryszardem Ziębą, że po 2014 roku paradygmat analityczny odzyskał swoją moc eksplanacyjną w odniesieniu do stosunków międzynarodowych, a przede wszystkim zachowań Rosji ${ }^{18}$. PiS konsekwentnie kierowało się wiedzą utrwaloną na temat Rosji, a nie ideologicznymi wyobrażeniami właściwymi dla liberałów i lewicy o zmianie jej natury oraz odrzuceniu imperatywów wynikających z historii Rosji carskiej i bolszewickiej.

Kiedy PiS przejęło władzę w Rzeczypospolitej w 2015 roku, zdecydowana postawa wobec Rosji nie uległa zmianie. Prezydent Duda oraz szefowie kolejnych gabinetów Zjednoczonej Prawicy zajęli wobec Rosji postawę jednoznacznie „twardą": obrona niepodległości i niepodzielności Ukrainy, żądanie wycofania wojsk rosyjskich z okupowanych terytoriów, wsparcie dla polityki jak najszerszych sankcji międzynarodowych nałożonych na Kreml, respektowanie prawa międzynarodowego przez Rosję ${ }^{19}$. Tym środkom miał towarzyszyć międzynarodowy dialog z Rosją na wielu płaszczyznach, ale tu wskazywano ważne trzy zasady: „Nor-

16 J. Kaczyński, Tusk powinien przyznać się do btędu..., s. 27; idem, Odtączyć Rosję od kroplówki..., s. A6-A7.

17 L. Kaczyński, Koniec dziwnej przyjaźni [Wywiad Józefa Tresnaka z Lechem Kaczyńskim], "Wprost", 31 III 2008, nr 35, s. 79.

18 R. Zięba, Teoria bezpieczeństwa państwa w ujęciu neorealistycznym..., s. 27.

19 Vide J. Czaputowicz, Dialog to nie ustępstwo..., s. 34-35; idem, Bazy USA z Niemiec do Polski - Zapraszamy [Wywiad Katarzyny Gójskiej z Jackiem Czaputowiczem], „Gazeta Polska", 14-20 II 2018, nr 8, s. 32; idem, Rosja wyczuwa stabość..., s. 42; K. Szczerski, Polska droga na szczyt [Wywiad Piotra Goćka z Krzysztofem Szczerskim], „,Do Rzeczy”, 7-13 IX 2015, nr 37(136), s. 24; idem, Polska jest silna..., s. 76. 
malizacja relacji UE-Rosja nie może się jednak dokonywać w oparciu o przesłanki wyrastające z [1] logiki systemu jałtańskiego zakładającego istnienie stref wpływów. Dialog z Rosją winien służyć komunikowaniu spójnego i jednoznacznego przesłania [2] nie pozostawiającego wątpliwości ani co do priorytetów Zachodu, ani co do [3] oceny polityki samej Federacji Rosyjskiej”. Ten dialog miał być oparty na zasadzie „3xD” (defence, deterrence, dialogue), która jawiła się jako zaprzeczenie polityki business as usual połączonej z „marginalizacją kwestii spornych" ${ }^{20}$. Taka polityka została uznana przez polityków PiS za taktykę, która może przynieść korzyści w postaci zatrzymania imperializmu rosyjskiego. Prezydent Duda mówił o takiej pryncypialnej postawie: „Trzeba pewne sprawy nazywać po imieniu i my tak robimy [...]"21.

Odrzucono model polityki "miękkiej” wobec Rosji, ponieważ - jak głosił tytuł opublikowanego w tygodniku "Sieci" wywiadu z ministrem spraw zagranicznych Jackiem Czaputowiczem - Rosja wyczuwa słabośćc2. W PiS obawiano się także innego scenariusza, że w państwach zachodnioeuropejskich za sprawą sił politycznych albo lewicowych, albo prawicowo-narodowych zwycięży wola "porozumienia z Rosją za wszelką cenę i pozostawienia jej wolnej ręki w stosunku do państw byłego ZSRR oraz Europy Środkowo-Wschodniej". W ten sposób ten scenariusz opisała M. Gosiewska, występująca w imieniu KP PiS w czasie dyskusji sejmowej nad exposé ministra Waszczykowskiego 9 lutego 2017 roku. Według niej nastąpiłby wtedy powrót do polityki stref wpływów w Europie i reaktywowanie "ducha Jałty"23.

Dla realizacji własnej koncepcji polityki zagranicznej, zwłaszcza kiedy poprzednia koalicja PO-PSL realizowała politykę resetu w stosunkach polsko-rosyjskich, niezbędna była intensyfikacja działań Polski w Sojuszu Północnoatlantyckim oraz w stosunkach dwustronnych ze Stanami

\footnotetext{
20 Strategia Polskiej Polityki Zagranicznej 2017-2021..., s. 9, 11.

21 A. Duda, Widzę próbę zablokowania dobrych zmian [Wywiad Tomasza Wróblewskiego i Mariusza Staniszewskiego z Andrzejem Dudą], „Wprost”, 15-21 II 2016, nr 7, s. 13.

22 J. Czaputowicz, Rosja wyczuwa stabość..., s. 42.

23 M. Gosiewska, Wypowiedź, [w:] WNP Sejm, 8 kadencja, 35 pos., 9 II 2017, http://www. sejm.pl, dostęp 24 II 2020.
} 
Zjednoczonymi Ameryki na rzecz obecności wojsk północnoatlantyckich i amerykańskich w Polsce, szerzej w Europie Środkowej. Bez szybkiego i wyraźnego wzmacniania wschodniej flanki Sojuszu, połączonego z modernizacją i rozbudową Sił Zbrojnych Rzeczypospolitej, „twarda” polityka wobec Rosji byłaby z jednej strony nieodpowiedzialna, gdyż narażałaby Polskę na rosyjskie skuteczne retorsje (jak w okresie "pierwszego PiS", 2005-2007), a z drugiej kompletnie nieefektywna, osłabiająca pozycję Polski w Unii Europejskiej, Europie Środkowej i Sojuszu Północnoatlantyckim jako państwa jedynie rusofobicznego, prowadzącego megalomańską politykę zagraniczną. Głównym argumentem dla „twardej” polityki Polski wobec Rosji stało się przekonanie J. Kaczyńskiego, że Moskwa: „[...] atakuje tam, gdzie widzi słabość i szanse na zwycięstwo, jak choćby na Krymie czy też we wschodniej Ukrainie. Ma jednak problem tam, gdzie napotyka na zdecydowany opór, nawet dyplomatyczny" ${ }^{24}$.

Opisane rozumowanie było charakterystyczne dla myślenia politycznego właściwego dla PiS, tym bardziej że dostrzegano w tej formacji dysproporcje między Polską a Rosją w głównych dziedzinach decydujących o statusie międzynarodowym i polityce zagranicznej. $Z$ tego to powodu już w okresie 2005-2007 J. Kaczyński wypracował koncepcję przenoszenia trudnych tematów polsko-rosyjskich na forum Unii Europejskiej i Sojuszu Północnoatlantyckiego. Konsekwentnie w tej partii stano na stanowisku, że stosunki Polska-Rosja są częścią relacji hemisfery euroatlantyckiej i Federacji Rosyjskiej. Prezes Kaczyński przestrzegał: „Musimy jednak pamiętać o stawce, o jaką toczy się gra”, a jednocześnie dodawał: „Zachód odpowiada dziś na pytanie, czy w Europie można siłą przesuwać granice, dokonywać aneksji terytorium innego państwa. Jeśli odpowiedź nie będzie twarda, negatywna, nasz los będzie trudny [...]". Prezes partii przygotowującej się do przejęcia odpowiedzialności za Rzeczpospolitą nie przeceniał jej możliwości w kontekście rosyjskim, ponieważ „Teraz wszystko zależy od Zachodu", w którym jest bardzo silne stronnictwo filorosyjskie, wspierane przez służby specjalne i agenturę wpływu Kremla oraz ośrodki gospodarcze

24 Kaczyński odpowiedział na pytanie, czy Putin stat za zamachem... 
robiące interesy z Rosją ${ }^{25}$. Nie może więc zaskakiwać późniejsza konstatacja Szczerskiego: „Bez solidarności europejskiej w tym zakresie terytoria [ukraińskie - W.P.], o których mówimy, podzielą los Abchazji czy Osetii. Świat o nich z czasem zapomni. Siła weźmie górę nad prawem"26. Przenoszenie problemów w relacjach polsko-rosyjskich na forum dwóch wymienionych organizacji miało co najmniej dwa ograniczenia o znaczeniu strategicznym. Pierwszym było wyraźne uzależnienie Komisji Europejskiej od woli RFN, co mogło oznaczać, że organy wspólnotowe o tyle będą gotowe brać pod uwagę interesy Polski, o ile te nie będą rażąco sprzeczne z niemiecką racją stanu oraz linią strategiczną Berlina wobec Moskwy. Drugim ograniczeniem była zmienna strategia Stanów Zjednoczonych wobec Federacji Rosyjskiej, zależna od odczytywania globalnych interesów Waszyngtonu co najmniej w dwóch regionach świata: na Bliskim Wschodzie oraz na Dalekim Wschodzie. Niejednokrotnie była też pochodną trzech spraw szczegółowych: walki z terroryzmem, kwestii chińskiej i bezpieczeństwa Izraela.

W modelu PiS polityki wobec Rosji w latach 2015-2019 nastąpiła istotna komplikacja związana ze stanem spraw między obozem rządzącym Polską a organami wspólnotowymi (Komisja Europejska, Parlament Europejski), kiedy właśnie te organy zaczęły głęboko ingerować w wewnętrzne sprawy w Polsce, przyjmując perspektywę stronnictw opozycyjnych liberalnych i lewicowych. Można było dojść do wniosku, że "twarda" polityka Polski wobec Rosji, nieuzgadniana ani z Brukselą, ani z Berlinem, drażniła administrację unijną. W rzeczywistości więc skutecznie można było przenosić problemy polsko-rosyjskie jedynie na forum Sojuszu Północnoatlantyckiego, zwłaszcza za prezydentury Donalda Trumpa w Waszyngtonie. Z tych powodów już u progu prezydentury Dudy, minister Szczerski zastrzegał, że „Polska nie wykonuje żadnych ruchów, które w jakikolwiek sposób antagonizowałyby nas

25 J. Kaczyński, Tusk powinien przyznać się do błędu..., s. 27.

26 K. Szczerski, Skuteczna odpowiedź na prowokacje Rosji [Wywiad Marcina Makowskiego z Krzysztofem Szczerskim], „Do Rzeczy”, 23-29 V 2016, nr 21(172), s. 36. 
i Rosję. Odwrotnie. Zależy nam na dobrych relacjach polsko-rosyjskich i podchodzimy do nich bez żadnych uprzedzeń"27.

Był jeszcze jeden dodatkowy czynnik związany z polityką rosyjską - w obozie rządzącym w całym okresie 2015-2019 panowało przekonanie, że Rosja celowo rozbija jedność regionu oraz Unii i Sojuszu ${ }^{28}$. Ten czynnik był traktowany jak perspektywa, z której można oceniać zachowania członków obu organizacji. Dlatego też negatywnie odniesiono się do reakcji Berlina i Paryża, które podjęły dialog z Rosją na temat Ukrainy w formule normandzkiej i mińskiej. Ten dialog odbywał się jedynie w gronie mocarstw europejskich, z pominięciem Unii i Sojuszu, co było zgodne z rosyjskimi planami. Polska pod rządami PiS była bardzo sceptyczna wobec ewentualnych efektów polityki realizowanej we wskazanej formule, twierdząc, że jest to tylko etap pierwszy, polegający na ustanowieniu rozejmu. Wobec tego etapu Polska - jak to ujął K. Szczerski miała być "krytycznym recenzentem”. Formułowano też opinie bardziej negatywne: 1) format normandzki „już się przeżył" (K. Szczerski) oraz 2) nie będzie zrealizowany (W. Waszczykowski). Dlatego pojawiła się sugestia, że należy go poszerzyć, bo „same potęgi europejskie, jak Francja czy Niemcy, nie są w stanie doprowadzić do zmian w konfrontacji z Rosją". Kiedy się okazało, że poszerzenie jest "poza możliwościami" Polski, zaczęto mówić o następnej fazie rozwiązywania konfliktu rosyjsko-ukraińskiego - negocjacjach pokojowych, a "na tym etapie powinny zostać uwzględnione opinie wszystkich państw zainteresowanych zakończeniem konfliktu, a jest ich znacznie więcej niż tych, które biorą udział w formacie normandzkim"29.

Politykę transatlantycką większości parlamentarnej Zjednoczonej Prawicy i jej rządów w latach 2015-2019 można podzielić na dwie fazy. Ce-

27 Idem, Polska droga na szczyt..., s. 24.

28 Wypowiedź W. Waszczykowskiego, 18 IV 2019, www.defence24.pl, dostęp 1 VI 2019.

29 K. Szczerski, Nie przejmujmy się pieniaczami [Wywiad Grzegorza Osieckiego i Zbigniewa Parafianowicza z Krzysztofem Szczerskim], „Dziennik Gazeta Prawna”, 13 I 2016, nr 7, s. 4; idem, Polska droga na szczyt..., s. 24; idem, Wschodni protokół rozbieżności [Wywiad Michała Potockiego z Krzysztofem Szczerskim], „Dziennik Gazeta Prawna”, 24 VIII 2015, nr 163, s. 14; W. Waszczykowski, Chcę się ułożyć z Białorusią..., s. 35. 
zurą graniczną między nimi był szczyt w Warszawie 8-9 lipca 2016 roku. Spotkanie było następstwem zwrotu strategicznego w Waszyngtonie. W latach 2001-2014 wszelkie projekty autorstwa partii czy też gabinetów tworzonych wówczas przez PiS (2005-2007) oraz prezydenta Kaczyńskiego (2005-2010), mające na celu uzyskanie przez Polskę pełnoprawnego członkostwa w Sojuszu (zniesienie wszelkich ograniczeń wynikających ze strategicznego porozumienia Waszyngton-Moskwa w sprawie nieobecności północnoatlantyckich instalacji wojskowych na polskich ziemiach), były niewykonalne jako niekompatybilne z obowiązującą wówczas strategiczną koncepcją Sojuszu. W 1999 roku Organizacja Paktu uznała, że obrona zbiorowa jest drugorzędna wobec konieczności stabilizacji euroatlantyckiego środowiska bezpieczeństwa oraz jego wymiaru politycznego. W kolejnej strategii Sojuszu z 2010 roku pojawiły się już nowe akcenty w odniesieniu do obrony zbiorowej. Jednak nadal pisano, że obszar euroatlantycki cechuje spokój i brak zagrożeń konwencjonalnych. Podniesieniu znaczenia obrony zbiorowej nie towarzyszyły wówczas żadne decyzje o konsekwencjach wojskowych i zbrojeniowych, wręcz odwrotnie, w Waszyngtonie podjęto w 2012 roku decyzję o uznaniu za priorytetowe zaangażowanie polityczno-wojskowe w regionie Azji i Pacyfiku, przy jednoczesnym nadaniu Europie rangi trzeciej (wyprzedzał ją jeszcze Bliski Wschód). Towarzyszyło tej decyzji ogłoszenie cesji wojsk amerykańskich w Europie ${ }^{30}$.

W latach 1999-2014 Rosja była definiowana w Stanach Zjednoczonych jako strategiczny partner w stabilizowaniu sytuacji na świecie, co uległo zmianie w 2014 roku. W Waszyngtonie zwyciężyło wówczas przekonanie, że należy porzucić politykę resetu z Rosją. Dialog z Moskwą w oparciu o Akt założycielski NATO-Rosja z 1997 roku, w ramach formuły Rady NATO-Rosja, stał się bowiem nieefektywny, gdyż Rosja zaczęła traktować to jako sposób na wzmocnienie swojej pozycji, której nadano cechy antyamerykańskie. Przesłanki takiej decyzji pojawiły się w 2014 roku,

30 Vide The Alliance's Strategic Concept, http://www.nato.int, dostęp 15 V 2019; NATO's Strategic Concept 2010, Active Engagement, Modern Defence, http://www.nato.int, dostęp 15 V 2019. 
w ostatnich miesiącach rządów administracji B. Obamy, a nowa strategia wobec Rosji zaczęła obowiązywać za prezydentury D. Trumpa. Owszem, Europa Środkowa, w tym Polska, nadal była postrzegana w Waszyngtonie w kategoriach funkcjonalności w polityce rosyjskiej, ale dokonało się w tej materii odmienne odczytanie zachowań międzynarodowych Rosji. W Narodowej Strategii Bezpieczeństwa Rosję uznano za wroga Stanów Zjednoczonych oraz wskazano kurs na odbudowę amerykańskiej potęgi militarnej i rozszerzenie obecności globalnej Stanów Zjednoczonych ${ }^{31}$.

Niewątpliwie takie zmiany w polityce zagranicznej Stanów Zjednoczonych odpowiadały PiS. Od samego początku (2008 rok) politycy tej partii negatywnie oceniali politykę resetu w stosunkach amerykańsko-rosyjskich. Uważali ją nie tylko za niekorzystną, ale także za niebezpieczną dla Polski, zagrażającą bezpieczeństwu i podmiotowości Europy Środkowej. Postrzegano tę politykę jako opartą na fałszywych założeniach o możliwości ustanowienia nowego ładu strategicznego, w którym Rosja porzuciłaby swoją imperialistyczną politykę. Jarosław Kaczyński w 2008 roku powiedział w Sejmie o takim działaniu: „To jest polityka prowadząca donikąd"32. Była to perspektywa przyjęta przez PiS dla oceny rozmów Tusk-Putin w latach 2008-2009 (Moskwa, Sopot). Miarodajnym potwierdzeniem tych negatywnych opinii była podjęta w lutym 2009 roku decyzja administracji Obamy, przy akceptacji rządu D. Tuska, o wycofaniu się z budowy tarczy antyrakietowej na rzecz strategicznej współpracy z Rosją. Ukoronowaniem tej polityki była umowa Barack Obama-Dmitrij Miedwiediew, podpisana w Pradze 8 kwietnia 2010 roku (dzień po spotkaniu Tusk-Putin w Katyniu i dwa dni przed katastrofą smoleńską) o kontroli zbrojeń strategicznych. O ile treść układu realnie była drugorzędna, o tyle uznanie Rosji za "drugie mocarstwo" po

31 President Donald J. Trump Announces a National Security Strategy to Advance America's Interests, http://www.whitehouse.gov, dostęp 12 V 2019.

32 J. Kaczyński, Przemówienie po informacji prezesa Rady Ministrów na temat stanu realizacji programu działania rządu w rok po jego powotaniu, [w:] SS Sejm, 6 kadencja, 29 pos., 20 XI 2008, http://orka2.www.sejm.gov.pl, dostęp 16 III 2011; vide G. Gęsicka, Wystapienie w czasie dyskusji na temat informacji ministra spraw zagranicznych o zatożeniach polskiej polityki zagranicznej w 2010 roku..., s. 147. 
Stanach Zjednoczonych było faktycznym przyzwoleniem na politykę realizowaną przez Putina. Zestawienie obu decyzji: o tarczy antyrakietowej i w sprawie układu strategicznego pokazywało skalę niebezpieczeństwa dla Polski wynikającego z polityki resetu ${ }^{33}$.

Przejęcie władzy w Polsce przez PiS niemal zbiegło się z utrwaleniem w Waszyngtonie nowej strategii wobec Rosji. Już 6 listopada 2014 roku, w czasie dyskusji nad informacją ministra spraw zagranicznych Grzegorza Schetyny o zadaniach polskiej polityki zagranicznej w latach 20142015, Szczerski w imieniu KP PiS radził „wykorzystać zwrot w polityce światowej na rzecz powrotu do strategicznego sojuszu bezpieczeństwa ze Stanami Zjednoczonymi", z jednej strony, w kontekście zwiększenia bezpieczeństwa całego regionu, a z drugiej - w ujęciu militarnym ${ }^{34}$.

Jeszcze zanim PiS przejęło odpowiedzialność za Polskę w 2015 roku, zostały podjęte pierwsze decyzje o znacznym, rozszerzonym zaangażowaniu amerykańskim w Europie Środkowej - zarówno bezpośrednim, jak i poprzez Sojusz Północnoatlantycki. Chodzi o dwie decyzje, które powzięto na szczycie Sojuszu w Newport: 1) o znaczącym wzmocnieniu zdolności obronnych Sojuszu, aby mógł szybciej reagować na potencjalne wyzwania i zagrożenia, w tym na peryferiach Sojuszu; 2) o tworzeniu flanki wschodniej Organizacji, czyli ciągłej rotacyjnej obecności wojsk Sojuszu, aby podnieść poziom bezpieczeństwa w Europie Środkowej w kontekście polityki rosyjskiej. W Newport dokonano analizy sytuacji w Europie, co stało u podstaw podjęcia stosownych decyzji wojskowych o istotnych skutkach politycznych. Zostały one zawarte w Deklaracji szczytu walijskiego z 5 września. Wyjaśniano w niej, że przyjęto „[...] spójny i wszechstronny pakiet niezbędnych środków reagowania na zmiany w środowisku bezpieczeństwa na granicach NATO i na innych obszarach ważnych dla NATO. Stanowi on odpowiedź na wyzwania rzucone przez

33 A. Nowak, Europa Wschodnia-polskie pytania..., s. 10.

34 K. Szczerski, Wystąpienie w czasie dyskusji na temat informacji ministra spraw zagranicznych o założeniach polskiej polityki zagranicznej w latach 2014-2015..., s. 178. 
Rosję oraz ich strategiczne konsekwencje". Jednocześnie Sojusz zawieszał współpracę cywilną i wojskową z Rosją ${ }^{35}$.

Prawo i Sprawiedliwość zareagowało na decyzję tego szczytu pozytywnie, zgodnie z dyrektywą: „Decyzje z Newport [są] dobre, ale niewystarczające". Jak to określił Duda, wzmocniły one poczucie stabilności w regionie, ale ustanowiły jedynie środki tymczasowe w postaci rotacyjnej stałej obecności sił północnoatlantyckich w regionie. Natomiast dalekosiężnym celem powinno być przyjęcie trwałej i wysuniętej obecności Sojuszu na tym obszarze, rozumianej jako koncentracja sprzętu, sił, struktur, planów. Decyzje te były niewystarczające, ponieważ Polska wciąż pozostawała członkiem Sojuszu „klasy drugiej”, a od tego należało odejść. Ustalenia te tak wyjaśniał W. Waszczykowski: „Decyzje NATO są odpowiedzią na eskalowanie problemów przez Rosję. [...] Więc my odpowiadamy na zachowanie Rosji, które do tej pory było konfrontacyjne czy wręcz agresywne". Jednak domagał się równocześnie decyzji bardziej odważnych, ponieważ nadszedł czas, by odejść od zobowiązań politycznych podjętych wobec Rosji w 1997 roku, kiedy to uzgodniono, że na terenie ówcześnie nowych środkowoeuropejskich państw członkowskich Paktu nie będą stacjonowały znaczące oddziały wojskowe, gdyż to zobowiązanie: „Zostało podjęte w innych warunkach, wobec innej Rosji, która złamała to zobowiązanie i prowadzi agresywną politykę" ${ }^{36}$. Kilka miesięcy po tej wypowiedzi Waszczykowskiego, w 2017 roku Macierewicz dwukrotnie, na spotkaniach z żołnierzami, doprecyzował uzasadnienie decyzji Sojuszu: 1) najpierw w Piotrkowie Trybunalskim - „[...] jest odpowiedzią na zagrożenie agresją, jaka wisi nad Polską i innymi krajami Europy Środkowej i Wschodniej ze względu na zagrożenie ze wschodu"; 2) następnie na Łotwie - „Polska nie ma cienia wątpliwości, że wspólna

35 Deklaracja szczytu walijskiego złożona przez Szefów Państw i Rządów uczestniczących w posiedzeniu Rady Pótnocnoatlantyckiej w Walii 5 września 2014 r., http://www.bbn.gov.pl, dostęp 4 V 2019.

36 Na czym ma polegać korekta Dudy...; Wypowiedź W. Waszczykowskiego, 7 VII 2016, http://wiadomosci.dziennik.pl, dostęp 30 IV 2019; Archiwum Prezydenta RP, https://www.prezydent.pl, „List prezydenta na uroczystości z okazji 17. rocznicy wstąpienia Polski do NATO", 11 III 2016, dostęp 12 VI 2020. 
obrona wschodniej flanki przez NATO jest jedynym sposobem skutecznego odstraszenia i powstrzymania rosyjskiego imperializmu"37.

Szczyt walijski dokonywał zwrotu w polityce Sojuszu zarówno wobec Rosji, jak i wobec Europy Środkowej o konsekwencjach kontynentalnych i globalnych. Tym samym powstały korzystne warunki, żeby prezydent Duda i premier Szydło mogli realizować myśl polityczną PiS. Jednak zwrot strategiczny dokonany przez Sojusz w Newport nie zadowalał polityków PiS, ponieważ „Po Newport zmieniła się sytuacja"38. Zmiany dokonane w Newport opisał w wystąpieniu sejmowym Waszczykowski dopiero w 2018 roku. Chodziło o jeden, ale za to kluczowy aspekt decyzji z Newport - o ustanowienie szpicy wojskowej, którą miano przerzucić do Europy Środkowej w razie zagrożenia. Okazało się jednak, że owa „szpica nie doleci, ponieważ Rosjanie uzyskali tzw. zdolności antydostępowe" ${ }^{\prime 3}$. Z tego powodu w PiS powstał projekt „Newport plus”, którego istota polegała na zainstalowaniu wojsk Sojuszu w regionie środkowoeuropejskim. O tym projekcie mówił już w Sejmie Szczerski w listopadzie 2014 roku, przedkładając go jako propozycję dla rządu PO-PSL. Dokonał też jego wykładni, tłumacząc, że oznacza on wyjście poza porozumienie RosjaNATO w kwestii lokalizacji wojsk północnoatlantyckich i infrastruktury krytycznej na terytorium nowych państw członkowskich Sojuszu ${ }^{40}$. Niemal nazajutrz po objęciu urzędu prezydenta przez A. Dudę, projekt "Newport plus" stał się oficjalną inicjatywą Polski zgłoszoną wobec partnerów północnoatlantyckich - najpierw przez prezydenta (o czym powiedział w orędziu do Zgromadzenia Narodowego 6 sierpnia 2015 roku), a następnie po wyborach parlamentarnych także przez rząd B. Szydło.

37 Piknikżotnierzy NATO w Piotrkowie Trybunalskim, 28 III 2017, http://www.pap.pl, dostęp 29 | 2020; Konferencja prasowa MON, 28 IX 2017, http://www.pap.pl, dostęp 29 | 2020.

38 K. Szczerski, Po Newport zmienita się sytuacja [Wywiad Andrzeja Gajcy z Krzysztofem Szczerskim], „Rzeczpospolita”, 11 II 2016, nr 34, s. A5.

39 W. Waszczykowski, Wypowiedź, [w:] WNP Sejm, 8 kadencja, 60 pos., 21 III 2018, http:// www.sejm.pl, dostęp 14 II 2020.

40 K. Szczerski, Wystąpienie w czasie dyskusji na temat informacji ministra spraw zagranicznych o zatożeniach polskiej polityki zagranicznej w latach 2014-2015..., s. 177. 
Od samego początku chodziło o zainstalowanie baz amerykańskich w regionie Europy Środkowej ${ }^{41}$.

Formułując publicznie takie opinie, politycy PiS oczekiwali od przywódców świata zachodniego większego wsparcia. Zanim Duda objął oficjalnie urząd prezydenta RP, jego doradca K. Szczerski mówił w wywiadzie, że potrzebna jest „[...] kolejna faza reorganizacji strategicznej Sojuszu: abyśmy nie tylko ucieszyli się szpicą NATO, ale poszli krok dalej. Realną potrzebą są bazy i infrastruktura NATO w Polsce". Nadmieniał, że nie chodzi już o poszukiwanie "formuł zastępczych", typu „stała baza rotacyjna", lecz o kierunek strategiczny na rzecz realnej stałej obecności Sojuszu w Polsce, nie tylko personalnej, ale także infrastrukturalnej ${ }^{42}$.

Pracę w tym kierunku zapowiadał już w 2015 roku (nawet przed powstaniem pierwszego gabinetu Zjednoczonej Prawicy) nieformalny kandydat tego stronnictwa na ministra spraw zagranicznych - Waszczykowski, mówiąc o działaniach na rzecz "wyrównania statusu bezpieczeństwa" między Europą Zachodnią a Środkową. Jednak ostrożnie zastrzegał, że chodzi jedynie o "pewną liczbę wojsk i instalacji sojuszniczych", które będą miały charakter tylko defensywny i będą się mieściły w obowiązujących porozumieniach międzynarodowych ${ }^{43}$. Zabieganie o bazy wojskowe Sojuszu oraz Stanów Zjednoczonych wynikało z generalnego przekonania właściwego dla PiS. Politycy tego stronnictwa uważali, że artykuł 5 traktatu waszyngtońskiego nie działa automatycznie, co oznacza, że pomoc będzie udzielona tylko takiemu państwu członkowskiemu, które wykaże zdolność do efektywnej obrony swojej niepodległości. W zaistniałych warunkach, kiedy Rosja była gotowa do

41 Vide Archiwum Prezydenta RP, https://www.prezydent.pl, dostęp 12 VI 2020: „Wywiad prezydenta dla Telewizji Republika”, 7 VIII 2015; „Orędzie Prezydenta RP Andrzeja Dudy przed Zgromadzeniem Narodowym", 6 VIII 2015.

42 K. Szczerski, Zapalimy polską latarnię[Wywiad Pawła Wrońskiego z Krzysztofem Szczerskim], „Gazeta Wyborcza”, 10 VI 2015, nr 133, s. 6-7.

43 W. Waszczykowski, Geopolityczne dylematy, czyli układanie się między Moskwą a Brukselą [Wywiad Grzegorza Osieckiego, Zbigniewa Parafianowicza i Michała Potockiego z Witoldem Waszczykowskim], „Dziennik Gazeta Prawna”, 26 X 2015, nr 15, s. 7; idem, Nie atakujemy już Tuska [Wywiad Jacka Przybylskiego z Witoldem Waszczykowskim], „Do Rzeczy”, 14-20 XII 2015, nr 51(150), s. 28. 
ofensywnych działań militarnych, Polska potrzebowała reasekuracji wojskowej swojej suwerenności i niepodległości, zważywszy na stan Wojska Polskiego odziedziczony po poprzednikach, którzy przyjęli założenie o trwałym i zagwarantowanym bezpieczeństwie Rzeczypospolitej. Przyjęta wówczas doktryna obronna realnie uniemożliwiała kilkudniową obronę terytorium Rzeczypospolitej, włączając w to stolicę.

Jednak po wygranych przez PiS wyborach prezydenckich i parlamentarnych w pierwszej kolejności należało jak najszybciej wcielić w życie postanowienia z Newport. Dla polityków tej formacji czas zawsze był dość istotny z racji przekonania, że zagrożenie rosyjskie jest realne i stale narasta, a tak zagrożone państwo, tracąc swoje szanse rozwojowe, obniżało też swoją atrakcyjność inwestycyjną. Tym bardziej że odpowiedź rosyjska na szczyt w Newport pojawiła się bardzo szybko. W grudniu 2014 roku dokonano zmian w rosyjskiej doktrynie wojennej. Wprowadzono nową formułę interpretacji obowiązku zapewnienia bezpieczeństwa i obrony, rozszerzając ją na „bliską zagranicę", położoną między innymi w Europie Wschodniej, oraz wobec zagrożonych obywateli rosyjskich pozostających poza granicami Rosji. Tym zmianom doktrynalnym towarzyszyła „skokowa rozbudowa rosyjskiego potencjału militarnego na zachodnim kierunku strategicznym" ${ }^{44}$.

W zaistniałych warunkach, w PiS decyzje z Newport oceniano jako korzystne, ale jednocześnie niewystarczające, miały bowiem charakter rozwiązań doraźnych i tymczasowych, a nie długoterminowych i systemowych, które pozwalałyby brać je w rachubę przy konstruowaniu nowej polskiej doktryny obronnej. Największe zaniepokojenie wywołał fakt, że na szczycie oficjalnie nie anulowano (nie zawieszono) paktu z Rosją z 1997 roku, mimo iż Moskwa od 2008 roku łamała jego postanowienia, wywołując wojny w Europie. Politycy PiS oczekiwali takiego unieważnienia oraz innych decyzji, np. utworzenia stałych baz amerykańskich

\footnotetext{
44 P. Soloch, P. Pietrzak, Szczyt NATO w Warszawie: uwarunkowania, rezultaty, wnioski dla Polski, http://bbn.gov.pl, dostęp 4 V 2019; A. Madej, P. Świeżak, Informacja na temat doktrynywojennej Federacji Rosyjskiej, „Bezpieczeństwo Narodowe” 2015, nr 36, s. 177178; A. M. Dyner, Rosja wzmacnia potencjat wojskowy na zachodzie państwa, "Biuletyn PISM" 2018, nr 173, s. 1-3, http://pism.pl, dostęp 4 V 2019.
} 
w Polsce i w państwach bałtyckich - kilku oficerów Sojuszu nie mogło być bowiem efektywnym zabezpieczeniem. Winą obarczono polską delegację w Newport na czele z prezydentem Bronisławem Komorowskim $^{45}$. Z jednej strony widziano w decyzjach walijskich powrót Sojuszu do jego misji, którą jest „[...] gwarantowanie bezpieczeństwa wszystkim państwom członkowskim. Bez wyjątku i w równym stopniu". Z drugiej jednak, kiedy PiS przejęło rządy w Polsce, to jej nowe władze zaczynały coraz głośniej mówić o rozwiązaniu optymalnym, a za takie uważano rozmieszczenie w Polsce stałych baz Sojuszu. Mówił o tym w orędziu inauguracyjnym A. Duda: „[...] trzeba sprawę postawić jednoznacznie. Potrzebujemy większych gwarancji ze strony NATO. Nie tylko my jako Polska, ale cała Europa Środkowo-Wschodnia w obecnej sytuacji geopolitycznej [...]. Potrzebujemy większej obecności NATO w tej części Europy, a także w naszym kraju"46.

Pod tym względem porozumienie z Newport wymagało znacznego rozszerzenia. Odczytywano je bowiem jako podnoszenie zdolności Sojuszu do szybkiego reagowania oraz przemieszczania sił, a oczekiwano kolejnego kroku - równomiernego zwiększania obecności sił zbrojnych Organizacji na całym jej terytorium. Musiało to oznaczać rozmieszczenie wojsk Sojuszu w Europie Środkowej ${ }^{47}$. Porównując w 2018 roku dwa kolejne szczyty Sojuszu - walijski i warszawski, wiceminister obrony narodowej Tomasz Szatkowski podkreślał z perspektywy czasu różnice między podjętymi wówczas decyzjami. Mówił w wywiadzie: „[...] szczyt w Newport był próbą dostosowania istniejącego systemu z poprzedniej epoki do zmiany środowiska bezpieczeństwa po aneksji Krymu i rosyjskiej agresji w Donbasie. Ta stara epoka w historii NATO, rozpoczęta w latach 90., w której nie dostrzegano większych, »klasycznych « zagrożeń dla NATO ze strony aktorów państwowych, kończy się na naszych oczach". Rząd PiS nie chciał uchodzić za kontynuatora polityki koalicji PO-PSL

Szczyt NATO - sukces czy porażka?, 7 IX 2014, http://www.tvp.info, dostęp 4 II 2020.

Orędzie nowego prezydenta...

47 Vide K. Szczerski, Nie jesteśmy niemieckim zasobem..., s. 14; idem, Po Newport zmienita się sytuacja..., s. A5. 
w kwestiach transatlantyckich i dlatego postawił na wzmacnianie różnic między decyzjami podjętymi w 2014 i w 2016 roku. W Newport powzięto decyzje o wzmocnieniu Sił Odpowiedzi Sojuszu, co oznaczało kontynuację myślenia w kategoriach operacji reagowania kryzysowego, podczas gdy celem powinno być wzmacnianie obrony kolektywnej. W domniemaniu Szatkowskiego takie decyzje zapadły dopiero w Warszawie ${ }^{48}$.

W zaistniałych nowych warunkach prezydent Duda zdecydował się na skupienie wokół Polski środkowoeuropejskich członków Sojuszu, aby wzmocnić siłę oddziaływania na szybką realizację decyzji, a przede wszystkim dążyć do ich rozszerzenia zgodnie z polskimi oczekiwaniami. Miały temu służyć dwa międzynarodowe projekty zaproponowane przez prezydenta Dudę: Inicjatywa Bukareszteńska i Trójmorze. Obie formalnie były niezależne od siebie, ale faktycznie wyrastały z podobnej przesłanki o konieczności sektorowej i sieciowej integracji państw środkowoeuropejskich przynależnych do organizacji hemisfery zachodniej (Sojusz i Unia), mającej na celu osiągnięcie synergii potencjału w odniesieniu do regionu. Obie też były zorientowane na Stany Zjednoczone.

4 listopada 2015 roku Polska i Rumunia wspólnie zorganizowały w Bukareszcie spotkanie dziewięciu państw wschodniej flanki Sojuszu. Przesłanie tego szczytu sprecyzował na dwa miesiące przed jego rozpoczęciem K. Szczerski. W ogólnopolitycznym kontekście chodziło o pokazanie światu, że Sojusz potrafi się adaptować do nowych sytuacji i zagrożeń, a odpowiedzią organizacji jest przyjęcie strategicznego kursu na osiągnięcie spójności infrastruktury obronnej na całym jej terytorium. Natomiast do konkretnych działań odnosiły się trzy oczekiwania: 1) znalezienie "podstawowego pola zgody" w regionie w kwestii bezpieczeństwa wschodniej flanki Sojuszu; 2) zbudowanie regionalnej grupy nacisku w odniesieniu do zapowiadanego już wtedy szczytu Sojuszu w Warszawie w sprawie doprecyzowania decyzji z Newport; 3) rozpoczęcie przekonywania partnerów zachodnioeuropejskich do zaakcepto-

48 T. Szatkowski, Postanowienia szczytu NATO w Brukseli kluczowe dla strategii wzmocnienia, 17 VII 2018, http://www.defence24.pl, dostęp 30 I 2020. 
wania zmian strategicznych w Sojuszu, polegających na wzmocnieniu jego wschodniej flanki ${ }^{49}$. Polska podjęła więc grę o skutkach globalnych.

Na szczycie przyjęto deklarację Sojusznicza jedność, wspólna odpowiedzialność, w której wzywano do trwałej obecności sojuszniczej na tejże flance ${ }^{50}$. „Dziewiątkę Bukareszteńską" (zwaną Inicjatywą Bukareszteńską) stanowiły środkowoeuropejskie państwa członkowskie Paktu: Polska, Bułgaria, Republika Czeska, Estonia, Litwa, Łotwa, Rumunia, Słowacja, Węgry. Te państwa należy podzielić na dwie grupy: państwa frontowe (Polska, Rumunia, państwa bałtyckie) i neutralne w kontekście rosyjskiego zagrożenia (Republika Czeska, Słowacja, Bułgaria, Węgry). Zgromadzenie tak zróżnicowanych państw było niewątpliwym sukcesem polsko-rumuńskim, ale także "nagrodą" za przywrócenie w polskiej polityce zagranicznej strategii L. Kaczyńskiego, dobrze zapamiętanej w regionie. Minister Szczerski jednoznacznie wiązał wtedy (dzień po szczycie) Inicjatywę Bukareszteńską z przygotowywanym „konsensusem warszawskim" w tej sprawie. Natomiast w następnych latach, 2016-2018 minister rozszerzył interpretację tego wydarzenia i znaczenie forum. Uznał, że Polska i Rumunia stały się „krajami filarowymi” dla bezpieczeństwa regionu $\mathrm{z}$ racji uczestnictwa $\mathrm{w}$ amerykańskim programie antyrakietowym oraz dokonały konsolidacji regionu na dwóch płaszczyznach: 1) wszystkich państw członkowskich Sojuszu leżących na jego wschodniej flance; 2) państw położonych w obszarze Morza Czarnego na rzecz budowy systemu bezpieczeństwa wokół Polski, Rumunii i Turcji151.

Swoistym dopełnieniem tego formatu były określone zadania do realizacji o charakterze militarnym adresowane do państw środkowoeuropejskich, zapisane w Strategii Polskiej Polityki Zagranicznej 2017-2021: 1) współpraca Polska-Rumunia-państwa bałtyckie w odniesieniu do

49 K. Szczerski, Polska droga na szczyt..., s. 23.

50 P. Soloch, P. Pietrzak, op. cit., s. 23.

51 Wypowiedź Szczerskiego w: Z. Parafianowicz, Polsko-rumuńska reanimacja Sojuszu, „Dziennik Gazeta Prawna”, 5 XI 2015, nr 216, s. 5; K. Szczerski, Nie będziemy walczyli samotnie..., s. 5; idem, Moskwa nie ma powodu, by budować Fort Putin [Rozmowa Grzegorza Osieckiego i Zbigniewa Parafianowicza z Krzysztofem Szczerskim], „Dziennik Gazeta Prawna", 15 X 2018, nr 200, s. 6. 
Misji Patrolowania Przestrzeni Powietrznej i Wzmocnionej Wysuniętej Obecności; 2) współpraca polsko-litewsko-ukraińska w postaci wspólnej brygady; 3) budowa więzi infrastrukturalnych w regionie trzech mórz: Bałtyckiego, Adriatyckiego i Czarnego; 4) zacieśnianie współpracy przemysłów obronnych państw wyszehradzkich i w kooperacji z państwami skandynawskimi oraz na linii Polska-Ukraina ${ }^{52}$.Zadania były wyjątkowo ambitne, a całe przedsięwzięcie szeroko zakrojone. Jako podsumowanie można przytoczyć słowa ministra Witolda Waszczykowskiego i posła PiS Krzysztofa Ostrowskiego, wygłoszone z trybuny sejmowej. Ten pierwszy stwierdził: „Nasi sojusznicy postrzegają nas jako uczestnika gry zespołowej, którą jest zapewnienie bezpieczeństwa całemu regionowi". Podczas gdy według drugiego: „Współpraca bukareszteńska ma uzupełnić działania Sojuszu, ma też umożliwić wypracowanie wspólnych stanowisk w sprawach rozstrzyganych na forum Sojuszu. Chodzi o dotarcie do NATO-wskich sojuszników ze wspólnym punktem widzenia na zagrożenie dla wschodniej flanki NATO i działania na rzecz wzmocnienia naszych wschodnich rubieży" 53 .

Projekt Trójmorza miał inny sens w odniesieniu do kwestii transatlantyckich ${ }^{54}$. Wyjaśnił go w przemówieniu sejmowym minister Waszczykowski 9 lutego 2017 roku. Sprecyzował, że chodzi o dwa zadania ze sobą połączone: budowę infrastruktury Północ-Południe oraz podniesienie poziomu bezpieczeństwa energetycznego w kontekście zagwarantowania regionowi zaopatrzenia w gaz ziemny z innych kierunków niż rosyjski (głównie amerykański). Trójmorze jak najbardziej wynikało z dorobku ideowego prezydenta L. Kaczyńskiego, na kontynuatora którego kreował się A. Duda. To L. Kaczyński konsekwentnie postrzegał współpracę Północ-Południe w kategoriach infrastrukturalnych i energetycznych. Był

52 Strategia Polskiej Polityki Zagranicznej 2017-2021..., s. 11.

53 Informacja Ministra Spraw Zagranicznych o zadaniach polskiej polityki w 2017 roku...; K. Ostrowski, Wypowiedź, [w:] WNP Sejm, 8 kadencja, 78 pos., 14 III 2019, http://www.sejm.pl, dostęp 14 II 2020.

54 Opis projektu Trójmorze w wersji początkowej vide P. Żurawski vel Grajewski, A. B. Motusic, Adriatic-Baltic-Black Sea. Visions of Cooperation, ed. K. Redtowska, Institue of Eastern Studies, Warszawa 2017, passim. 
projektodawcą zarówno Via Carpatii (patronat nad Deklaracją łańcucką z 27 października 2006 roku o budowie karpackiego korytarza transportowego ${ }^{55}$ ), jak i szczytów energetycznych (projekt Euroazjatyckiego Korytarza Transportu Ropy Naftowej).

Strategiczny kierunek postawiony przed Trójmorzem potwierdzały kolejne doroczne szczyty prezydenckie, zwoływane w Dubrowniku, Warszawie, Bukareszcie i Lublanie, a także przyjmowane na nich deklaracje $^{56}$. Istotę Trójmorza opisywał prezydent Duda w swoich publicznych wystąpieniach w 2017 roku, definiując projekt w kategoriach przede wszystkim infrastrukturalnych, rozumianych na różne sposoby: 1) jako wyrównywanie dysproporcji w tej dziedzinie istniejących między Europą Zachodnią a Środkową; 2) jako tworzenie koniecznego fundamentu „W przestrzeni Północ-Południe" dla osiągnięcia synergii gospodarczej w regionie, budowania więzi gospodarczych między różnymi podmiotami (państwa, miasta, porty, społeczności lokalne) oraz relacji międzyludzkich; 3) jako budowanie osi Północ-Południe uzupełniającej kierunek Wschód-Zachód, ponieważ „trzy morza Europy Środkowej to trzy bramy do globalnego handlu" i należy je połączyć wspólną infrastrukturą; 4) jako tworzenie koniecznej infrastruktury komunikacyjnej dla realizacji wspólnych celów w zakresie bezpieczeństwa i obronności całego regionu ${ }^{57}$. Do tych dwóch sensów wskazanych przez Dudę należałoby dodać jeszcze jeden - włączenie Stanów Zjednoczonych Ameryki oraz amerykańskiego kapitału w rozwój Europy Środkowej. Tym samym, mimo preferowanego charakteru infrastrukturalnego, przed projektem pojawiły się bardzo szerokie, strategiczne horyzonty.

55 DeklaracjaŁańcucka, 27X2006, http://www.prezydent.pl/archiwum-lecha-kaczynskiego, dostęp 14 II 2020.

56 Zob. Informacja Ministra Spraw Zagranicznych o zadaniach polskiej polityki w 2017 roku...; Wspólna deklaracja wsprawie Inicjatywy Trójmorza, Dubrownik, 25 VIII 2016, http://www. prezydent.pl, dostęp 14 II 2020.

57 Archiwum Prezydenta RP, https://www.prezydent.pl, dostęp 12 VI 2020: „Wystąpienie prezydenta w trakcie dorocznej narady MSZ”, 4 IX 2017; „Wywiad z Prezydentem dla "Sieci«", 25 V 2017; „Konferencja prasowa Prezydenta po spotkaniu szefów państw i rządów NATO w Brukseli", 25 V 2017. 
Obie inicjatywy: bukareszteńska i adriatycko-bałtycko-czarnomorska miały służyć budowaniu sieci powiązań środkowoeuropejskich na rzecz bezpieczeństwa regionu. Związane były też z aktywnością amerykańską w Europie Środkowej. Istotą Inicjatywy Bukareszteńskiej było grupowanie państw członkowskich Sojuszu Północnoatlantyckiego na rzecz podniesienia obronności jego wschodniej flanki, natomiast projekt Trójmorza nie tylko narodził się w Nowym Jorku (29 września 2015 roku), ale też patronat amerykański był dla tego przedsięwzięcia oczywisty, co wymownie potwierdził udział D. Trumpa w II Szczycie Trójmorza w Warszawie (6-7 lipca 2017 roku). Nietrudno było przypisać tym inicjatywom charakter antyrosyjski i zauważyć kontekst chiński, zwłaszcza kiedy Trump zdecydował się na twardy kurs wobec Moskwy (sankcje) oraz na ograniczenie ekspansji gospodarczej ChRL, ale też - co było wielce charakterystyczne - w obu tych projektach w wersji pierwotnej nie było Niemiec. Dopiero na III Szczyt Trójmorza został zaproszony minister spraw zagranicznych RFN Heiko Maas oraz wysokiej rangi urzędnicy unijni (Jean-Claude Juncker i Corina Creţu) ${ }^{58}$. Pozyskanie dla tej inicjatywy Niemiec PiS wykorzystało w walce wewnętrznej z PO, zarzucając partii, że po zaproszeniu Berlina do projektu przestała ona krytykować tę inicjatywę. Jak to ujęła M. Gosiewska: „Stanowisko rządu niemieckiego ma w oczach opozycji większe znaczenie w postrzeganiu tej inicjatywy niż polskie narodowe interesy"59. W tym aspekcie posunięcie polityków PiS było gambitem wobec przeciwników politycznych na arenie wewnętrznej. Natomiast w odniesieniu do Trójmorza można sformułować ważną prawidłowość - im bardziej wzrastało zaangażowanie strony amerykańskiej w Europie Środkowej (między innymi gospodarcze), tym wyraźniej słabło, pierwotnie bardzo silne, zainteresowanie Polski wizjami aktywności chińskiej w tym regionie. O ile w 2015 roku prezydent Duda z entuzjazmem mówił o projekcie Nowego Jedwabnego Szlaku („Jeden Pas i Jeden Szlak"), widząc w nim wielki potencjał, szansę 
na rozwój gospodarczy regionu i wielkie inwestycje chińskie o charakterze infrastrukturalnym, o tyle w latach następnych trudno dostrzec przeniesienie tych wizji na konkretne koncepcje i programy ${ }^{60}$. Nie powstało żadne chińskie centrum logistyczne w Polsce, a kapitał chiński nie został zaangażowany w poważne polskie projekty infrastrukturalne. "Zwrot chiński" przeprowadzony przez PiS okazał się dobrą formą nacisku na Stany Zjednoczone, żeby zachęcić je do podejmowania decyzji zwiększających ich zaangażowanie w Europie Środkowej.

Należy przyznać rację badaczowi koncepcji Trójmorza Marcinowi Sienkiewiczowi, że była ona efektem pogłębionej refleksji PiS nad położeniem geopolitycznym Polski i jego przewartościowaniem dokonanym w ostatnim półwieczu. Dla PiS obszar położony między trzema morzami to jeden z najważniejszych geopolitycznie regionów świata, nazywanych przez politologów - osiowymi. Ich status polityczny ma istotny wpływ na system międzynarodowy. Jerzy Soroka i Tomasz Stępniewski wprowadzili określenie oddające znaczenie Trójmorza - „bezpieczeństwo geopolityczne" jako jego "brakujący aspekt” (a faktycznie ukryte oddziaływanie) oraz "simulacrum idei Piłsudskiego" w nowych czasach ${ }^{61}$. Widać w tej inicjatywie silne rezydua rządów „pierwszego PiS” (2005-2007) i dorobku prezydenta Kaczyńskiego, ale równie ważne stawały się inne okoliczności, które uwidoczniły się z całą ostrością po 2015 roku: 1) agresywna polityka Rosji wobec regionu; 2) marginalizacja państw środkowoeuropejskich w procesie decyzyjnym Unii, połączona z krytyką władz państwowych na Węgrzech, w Polsce i w Republice Czeskiej, między innymi z powodu braku zgody na relokację migrantów.

Z tych powodów autorzy projektu (A. Duda, K. Szczerski) podkreślali, że ani nie jest to kontynuacja międzywojennej idei Międzymorza, która miała charakter głównie polityczny, ani nie ma charakteru antyunijnego. Wskazywali natomiast na powiązania tej inicjatywy z integracją europej-

\footnotetext{
60 Archiwum Prezydenta RP, https://www.prezydent.pl, „Wywiad dla CCTV (chińskiej telewizji)", 26 XI 2015, dostęp 12 VI 2020.

61 G. Soroka, T. Stępniewski, The Three Seas Initiative. Geopolitical Determinants and Polish Interests, „Rocznik Instytutu Europy Środkowo-Wschodniej” 2019, nr 3, s. 24, 26.
} 
ską, jako formę regionalnej wewnętrznej współpracy (na podobieństwo Beneluksu), motywowanej poszukiwaniem kapitałów zewnętrznych (amerykańskich) na rzecz modernizacji Europy Środkowej. Z tego powodu propozycji uczestnictwa w projekcie nie złożono ani Ukrainie, ani Białorusi i Mołdawii. Tym samym politycy PiS naruszyli ważną zasadę charakteryzującą myśl formacji, że należy budować współpracę regionalną ponad granicami unijnymi i północnoatlantyckimi przebiegającymi w poprzek regionu. Zwyciężył jednak realizm - gdyby Polska próbowała wciągnąć do projektu trzy wymienione państwa, wówczas najprawdopodobniej inicjatywa nie doszłaby do skutku wobec oporu niektórych państw środkowoeuropejskich (np. Węgier) oraz braku zgody strony amerykańskiej ${ }^{62}$.

Najpełniej znaczenie współpracy polsko-rumuńskiej omówił minister Błaszczak w 2018 roku, a więc już po decyzjach warszawskich o wzmocnieniu wojskowym flanki wschodniej Sojuszu. Uznał, że kooperacja Warszawa-Bukareszt jest kluczowa na tej flance, integruje bowiem dwa obszary (ewentualne teatry działań wojennych): środkowoeuropejski (Polska, państwa bałtyckie) i południowy (Rumunia, Bułgaria, Grecja). Wskazał też jej praktyczne uwarunkowanie w postaci realizacji flagowego projektu infrastrukturalnego PiS - arterii komunikacyjnej Via Carpatia, która zapewni mobilność sił na flance wschodniej „w sytuacji zagrożenia" ${ }^{63}$. Jednak o znacznym zróżnicowaniu politycznym państw tworzących format bukareszteński oraz inicjatywę Trójmorza politycy PiS milczeli, chociaż właśnie to zjawisko wydawało się głównym wyzwaniem dla dyplomacji rządów tej partii. Uczestników tych dwóch formatów dzielił od Polski nie tylko stosunek do Niemiec, ale także odniesienie się do polityki imperialnej Rosji.

Rząd Zjednoczonej Prawicy przystąpił w 2016 roku także do budowania relacji trójstronnych Polska-Rumunia-Turcja. Ten model współpracy

\footnotetext{
62 M. Sienkiewicz, op. cit., s. 143. Prezentacja różnych perspektyw w odniesieniu do Trójmorza vide G. Soroka, T. Stępniewski, op. cit., s. 15-29. Także: M. J. Chodakiewicz, op. cit., passim.

63 Konferencja w Bukareszcie, 13 III 2018, http://www.pap.pl, dostęp 1 II 2020.
} 
nazwano formatem „trilog" („trójkąt flanki wschodniej”), wyraźnie wiążąc go z Paktem Północnoatlantyckim. Faktycznie został on rozpoczęty już w 2012 roku, ale bez specjalnego oddźwięku medialnego. Rozwojowi formatu miały służyć regularne, konsultacyjne spotkania ministrów spraw zagranicznych tych trzech państw. Budowa trilogu wynikała z trzech głównych przesłanek. Primo - chodziło o budowanie pomostu między wzmacnianą flanką wschodnią a południowym teatrem działań Sojuszu, którego centrum była Turcja, gdzie Amerykanie rozlokowali broń atomową oraz strategiczne lotnictwo; taki pomost był warunkiem koniecznym podejmowania idei stworzenia architektury bezpieczeństwa regionalnego. Secundo - chciano uzyskać poparcie Turcji dla integralności Ukrainy i Gruzji, naruszonej przez rosyjską agresję; dla zadań skomplikowanych, zważywszy na wzmacnianą systematycznie kooperację turecko-rosyjską, kontrastującą z polityką zagraniczną Warszawy i Bukaresztu. Tertio - zamierzano wzmacniać orientację euroatlantycką Turcji, mimo zmian wewnętrznych w tym państwie, zbliżenia Ankary do Moskwy i faktycznego zablokowania akcesji Turcji do Unii; rozluźnianie związków Turcji z Sojuszem było wyjątkowo niebezpieczne dla sytuacji zarówno na Bliskim Wschodzie, jak również w Europie Środkowej (basen Morza Czarnego i region Bałkanów) ${ }^{64}$. Znaczącym sukcesem Polski była wspólna deklaracja z 2019 roku podjęta w tym trójkącie w sprawie poparcia aspiracji północnoatlantyckich Ukrainy i Gruzji ${ }^{65}$.

Jednak sugerowanie, że trilog będzie nowym strategicznym sojuszem, byłoby zdecydowaną przesadą; takiej roli w latach 2016-2019 nie odegrał. Nie doszło chociażby do spotkania na najwyższym szczeblu - premierów

64 Minister Waszczykowski leci do Turcji z szefem rumuńskiego MSZ. Czy chodzi o broń atomową?, 23 VIII 2016, http://www.pch24.pl, dostęp 2 II 2020; Spotkanie szefów dyplomacji Polski, Rumunii i Turcji w Bukareszcie, 10 IX 2018, http://www.msz.gov.pl, dostęp 2 II 2020; Polska, Rumunia i Turcja - nowy sojusz strategiczny w regionie?, 13 IV 2016, http://www.forsal.pl, dostęp 2 II 2020; Minister Czaputowicz na spotkaniu z szefami dyplomacji Rumunii i Turcji w Bukareszcie, 11 IX 2018, http://www.gazetaprawna.pl, dostęp 2 II 2020; Spotkanie szefów dyplomacji Polski, Rumunii i Turcji w Ankarze, 19 IV 2019, http://www.gov.pl, dostęp 2 II 2020.

65 Ukraina i Gruzja muszą stać się cztonkami NATO - szefowie MSZ Polski, Rumunii i Turcji, 19 IV 2019, http://www.jagiellonia.org, dostęp 5 II 2020. 
lub prezydentów (w odróżnieniu od innych formatów środkowoeuropejskich), ani do pojawienia się wzmianek na ten temat w programach PiS czy w publicznych wystąpieniach czołowych liderów, np. J. Kaczyńskiego, oraz w exposé kolejnych premierów Zjednoczonej Prawicy. Minister Szczerski pytany wprost o ten format nawet nie sugerował spotkania trzech prezydentów, lecz ograniczył się do podkreślenia wyjątkowości współpracy polsko-rumuńskiej66.

Relacje polsko-rumuńskie rzeczywiście kształtowały się odmiennie. Za czasów prezydentów Andrzeja Dudy i Klausa Iohannisa tempo rozwoju stosunków Warszawa-Bukareszt uległo przyspieszeniu. Politycy PiS odczytali potencjalną zbieżność interesów między dwoma państwami, wynikającą z położenia geopolitycznego, uświadamiania sobie niebezpieczeństwa rosyjskiego, tradycji sojuszu, pragmatyki politycznej oraz definiowania zagrożeń, a także statusu w Unii Europejskiej i w Sojuszu Północnoatlantyckim. W warunkach zaangażowania amerykańskiego w obu państwach niejako "przypomniano sobie”, że w 2009 roku ówcześni prezydenci obu państw: Lech Kaczyński i Traian Băsescu podpisali porozumienie strategiczne (7 października). Już wtedy Polska i Rumunia próbowały koordynować wspólną politykę wobec obszaru postradzieckiego i bałkańskiego, szukając między sobą strategicznych zbieżności. Tę koordynację widać było już na szczycie Sojuszu rok wcześniej w Bukareszcie, kiedy oba państwa przyczyniły się do deklaratywnego otwarcia Ukrainie i Gruzji drogi do Paktu. Koalicja PO-PSL zamroziła postęp w umacnianiu więzi polsko-rumuńskich. Dopiero po powtórnym dojściu PiS do władzy w Polsce ministrowie spraw zagranicznych - Witold Waszczykowski i Lazăr Comănescu - podpisali 23 grudnia 2015 roku dołączony do wspomnianej strategicznej deklaracji Plan działania na lata 2016-2020, nadający partnerstwu charakter wykonawczy ${ }^{67}$.

66 K. Szczerski, Pierwszy raz od końca zimnej wojny zwiększamy obecność wojskowa USA i NATO równocześnie, 12 VII 2016, http://www.prezydent.pl, dostęp 2 II 2020.

67 Prezydenci podpisali porozumienie o partnerstwie strategicznym Polski i Rumunii, 7 X 2009, http://www.bankier.pl, dostęp 18 || 2020; SzefMSZ w Rumunii o bezpieczeństwie i wspótpracy dwustronnej, 23 XII 2015, http://www.defence24.pl, dostęp 18 II 2020. Vide Kontynuacja w polskiej polityce zagranicznej, „Rocznik Strategiczny” 2009/2010, s. 302. 
Rząd powołany przez PiS dał wyraźny sygnał, że będzie korygował politykę transatlantycką swoich poprzedników, opierając ją na własnym dorobku ideowym, koncepcyjnym i politycznym z minionych lat. Uczyniła tak premier B. Szydło w exposé 18 listopada 2015 roku, zapowiadając, że jej gabinet będzie równolegle podejmował łączne działania w dwóch kierunkach: rozbudowy Sił Zbrojnych RP i umacniania wschodniej flanki Sojuszu ${ }^{68}$. Celem zapowiadanych przez Polskę działań było takie kształtowanie polityki Sojuszu, żeby przeszedł od reasekuracji na poziomie politycznych deklaracji środkowoeuropejskich członków Paktu do budowy realnych mechanizmów militarnych odstraszania Rosji.

Oprócz zainspirowania forum bukareszteńskiego, Polska wniosła jeszcze inny wkład do polityki Sojuszu - podjęła decyzję budżetową o przeznaczaniu 2 proc. PKB na obronę oraz obiecała w latach 20182019 , że te wydatki mogą być podniesione do 2,5 proc. w roku 2030. Taki zapis znalazł się w programie z 2019 roku. Opozycji liberalnej trudno było zdezawuować politykę gabinetów PiS na tym odcinku, ponieważ to jednoznacznie nadałoby stanowisku PO kontekst antyamerykański i skierowany przeciwko Sojuszowi Północnoatlantyckiemu ${ }^{69}$. Wzrost finansowania miał umożliwić podniesienie stanu Sił Zbrojnych RP do 200 tys. żołnierzy. Pośrednie zapowiedzi tego typu decyzji można odnaleźćjuż w exposéJ. Kaczyńskiego jako premiera w 2006 roku oraz w wystąpieniu L. Kaczyńskiego na szczycie Sojuszu w Bukareszcie w 2008 roku. Prezydent mówił wtedy: „Każde państwo powinno dawać odpowiedni wkład do wspólnej obrony. Nie jestem zwolennikiem takiego sojuszu, w którym wszystkie obowiązki obrony spoczywają na Stanach Zjednoczonych [... $]^{\prime 70}$. Te wypowiedzi dowodziły, że dla PiS problematyka wojskowa była jedną z zasadniczych kwestii, do której odnoszono się

68 B. Szydto, Przedstawienie przez prezesa Rady Ministrów programu działania Rady Ministrów z wnioskiem o udzielenie jej wotum zaufania, [w:] SS Sejm, 8 kadencja, 1 pos., 18 XI 2015, s. 57, http://orka2.www.sejm.gov.pl, dostęp 7 V 2019.

69 Dobry czas dla Polski..., s. 187.

70 J. Kaczyński, Przedstawienie przez prezesa Rady Ministrów programu działania Rady Ministrów z wnioskiem o udzielenie jej wotum zaufania..., s. 174; Szczyt NATO w Bukareszcie, 2-4 IV 2008, http://www.lechkaczynski.org, dostęp 1 II 2020. 
w najważniejszych dokumentach partyjnych. Interesowano się przede wszystkim trzema segmentami: stanem armii, przemysłem zbrojeniowym i służbami specjalnymi ${ }^{71}$.

W PiS prezentowano różne uzasadnienia inwestowania we własne siły zbrojne. Najwcześniejsze z nich odnajdziemy w programie z 2003 roku, gdzie zostało ono powiązane z obecnością Polski w Pakcie Północnoatlantyckim: bez energicznych działań „zmierzających do modernizacji i rewitalizacji naszych sił zbrojnych" Polska nie będzie w stanie wykorzystać w Sojuszu dywidendy wynikającej z potencjału politycznego, demograficznego i geograficznego. Ówczesne rządy lewicowo-ludowcowe uznano za niezdolne do przyjęcia i wykonania tego priorytetu ${ }^{72}$. Następne, bardziej konkretne informacje pojawiły się w kolejnym programie z 2005 roku. Pisano w nim: „Polska, będąc frontowym krajem NATO, a także z uwagi na swe szczególne, naznaczone historią położenie strategiczne, nie może rezygnować także z tradycyjnego podejścia do obrony terytorium kraju". Zapowiadano więc „rekonstrukcję sił na wypadek klasycznej agresji zbrojnej", przeznaczenie odpowiednich środków na armię, zakupy uzbrojenia, odnowę moralną i kadrową Wojska Polskiego, reformę kontroli nad wojskiem i dowodzenia w wojsku ${ }^{73}$.

Inne uzasadnienie wskazał K. Szczerski na początku prezydentury A. Dudy. Mówił w wywiadzie, że chodzi o takie zwiększenie potencjału obronnego wszystkich członków Sojuszu, żeby „przeciwnikom nie opłacało się nawet planowanie wymierzonych w nas działań"74. Trzecie sformułowali minister obrony narodowej M. Błaszczak i wiceminister spraw zagranicznych K. Szymański. Pierwszy mówił, że dzięki temu Polska pokazuje, że: „Nie jesteśmy tylko biorcą bezpieczeństwa”, lecz „Dajemy przykład innym krajom Sojuszu, stając się siłą napędową całego Paktu”. Natomiast według drugiego polityka Polska stara się pokazywać, że nie chodzi o relacje jednostronne i nie jest jedynie biorcą bezpieczeństwa,

\footnotetext{
71 Vide J. Sanecka-Tyczyńska, Racja stanu we wspótczesnej polskiej myśli politycznej..., s. 409-411.

72 Program Prawa i Sprawiedliwości [2003]..., s. 27.

73 IV Rzeczpospolita - Sprawiedliwość dla Wszystkich..., s. 51.

74 K. Szczerski, Polska droga na szczyt..., s. 24.
} 
lecz „istotnym elementem architektury bezpieczeństwa całości Zacho$\mathrm{du}^{\text {"75 }}$. Czwarte uzasadnienie zaprezentował A. Macierewicz: „Był to jeden z kluczowych argumentów na rzecz zgody na takie usytuowanie wojsk NATO na terenie Polski" ${ }^{\prime 76}$. Dlatego też strona polska wyrażała publicznie wsparcie dla żądań prezydenta Trumpa, który domagał się, żeby członkowie Sojuszu solidarnie partycypowali w wydatkach na obronność na poziomie co najmniej 2 proc. Według Macierewicza skończył się czas, kiedy państwa bogate nie wywiązywały się ze zobowiązań finansowych i po prostu korzystały z parasola ochronnego Stanów Zjednoczonych. Natomiast po konferencji bezpieczeństwa w Monachium w 2018 roku premier Morawiecki apelował do członków Sojuszu, żeby „nie było państw, które nie wydają tej kwoty, a jednocześnie żyją pod parasolem NATO". Proponował też stworzenie „drogi dotarcia do progu 2 punktów procentowych" dla wszystkich państw sojuszniczych ${ }^{77}$.

Tak wysoki, jak na Europę, poziom wydatków militarnych w budżecie państwa był traktowany przez PiS jako istotny argument. Beata Szydło podkreślała, że dzięki tej decyzji Polskę „można traktować poważnie” oraz uznać ją za partnera, „któremu można zaufać”. Według ministra Błaszczaka: „Dajemy przykład innym krajom Sojuszu, stając się siłą napędową całego Paktu. Nie jesteśmy tylko biorcą bezpieczeństwa". Natomiast minister Waszczykowski mówił: „Jest to wielka kontrybucja, wielki wysiłek na rzecz obrony NATO". Dla kolejnego premiera, M. Morawieckiego, takie nakłady na obronę mogą być powodem do dumy, gdyż Polska po Wielkiej Brytanii podejmuje drugi największy wysiłek w odniesieniu do

75 Konferencja prasowa M. Błaszczaka, 15 III 2018, http://www.pap.pl, dostęp 22 XII 2019; Wiceminister Konrad Szymański w programie "Horyzont” TVN24, 7 I 2017, http://www. msz.gov.pl, dostęp 5 II 2020.

76 Konferencja prasowa po posiedzeniu sejmowej komisji obrony, 21 IX 2016, http://www. pap.pl, dostęp 2 II 2020.

77 Konferencja po spotkaniu szefów państw NATO, 26 V 2017, http://www.pap.pl, dostęp 27 XII 2019; Wypowiedź premiera po konferencji bezpieczeństwa w Monachium, 17 || 2018, http://www.premier.gov.pl, dostęp 29 I 2020. 
wydatków na zbrojenia. Takie wyliczenia zaprezentował premier na Zgromadzeniu Parlamentarnym Sojuszu w Warszawie 25 maja 2018 roku $^{78}$.

Według PiS rozbudowa Sił Zbrojnych powinna polegać na dostosowaniu ich "do istniejących zagrożeń, a nie do abstrakcyjnych norm nowoczesności" ${ }^{\text {"9 }}$. Linię strategiczną w dziedzinie wojskowości, wyznaczoną przez gabinet Szydło, kontynuował następny rząd pod przewodnictwem Morawieckiego, mający poparcie tej samej większości parlamentarnej w Sejmie VIII kadencji. Nowy premier w swoim exposé 12 grudnia 2017 roku niejako „konsumował” efekty dwuletnich już rządów Zjednoczonej Prawicy. Mówił więc o dokonującej się rozbudowie infrastruktury wojskowej i stałej współpracy strukturalnej w dziedzinie obronności ${ }^{80}$. Istniała też spójność w polityce obronnej realizowanej przez dwóch kolejnych ministrów w tym resorcie - Macierewicza i Błaszczaka. Obaj uważali, że Polska z racji położenia strategicznego (państwo frontowe) nie może rezygnować z tradycyjnego podejścia do obrony terytorium kraju, dlatego też pod osłoną wojsk Sojuszu należy „stworzyć naprawdę silną armię"81. Ten wniosek dodatkowo uzasadniały okoliczności agresji rosyjskiej na Ukrainę.

Polskiej interpretacji formuły „wzmocnienie wojskowe wschodniej flanki Sojuszu" dokonał prezydent Duda w lutym 2016 roku w wywiadzie dla tygodnika „Wprost", mówiąc, że chodzi o obecność żołnierzy i bazy z uzbrojeniem. Wtórny jest natomiast charakter tej obecności - baza stała czy rotacyjna, kluczowe bowiem są dwie inne kwestie: „[1] możliwość szybkiego przerzucenia oddziałów państw NATO do Polski w przypadku zagrożenia i [2] obecność na naszym terenie takich sił, abyśmy byli

\footnotetext{
78 Wywiad B. Szydto w programie I PR, 7 VII 2017, http://www.pap.pl, dostęp 10 V 2019; Konferencja prasowa M. Btaszczaka, 15 III 2018, http://www.pap.pl, dostęp 10 V 2019; Przemówienie premiera M. Morawieckiego podczas posiedzenia ZP NATO w Warszawie, $25 \mathrm{~V}$ 2018, http://premier.gov.pl, dostęp 10 V 2019; Wypowiedź ministra Waszczykowskiego na konferencji w Waszyngtonie po obradach koalicji walczącej z IS, 22 VII 2016, http:// www.pap.pl, dostęp 30 I 2020.

79 D. Gawin, Przekleństwo 1709 roku..., s. 59.

80 M. Morawiecki, Przedstawienie przez prezesa Rady Ministrów programu działania Rady Ministrów z wnioskiem o udzielenie jej wotum zaufania..., s. 12.

81 Spotkanie zinternautami A. Macierewicza, 6XI 2017, http://www.pap.pl, dostęp 1 VI 2019.
} 
w stanie odeprzeć każde potencjalne niebezpieczeństwo, jak również wspomóc kraje sojusznicze - przede wszystkim państwa bałtyckie" ${ }^{82}$.

Minister Waszczykowski wyjaśniał w 2016 roku wzmocnienie wojskowe wschodniej flanki Sojuszu, przedstawiając mocne argumenty, które można podzielić na dwie grupy. Po pierwsze, mówił o: usunięciu z rachub politycznych "burzycieli pokoju europejskiego" poczucia niewiary w spoistość Sojuszu; wyeliminowaniu pokusy testowania jego spoistości; obniżeniu ryzyka konfliktu. Po drugie, widział w zapowiadanych decyzjach strategiczno-wojskowych przezwyciężenie nierównoprawnego statusu bezpieczeństwa "starych" i "nowych" państw członkowskich Sojuszu ${ }^{83}$.

\subsection{II faza polityki transatlantyckiej Prawa i Sprawiedliwości (2017-2019)}

Strategiczne i zarazem odnoszące się do szczegółowych kwestii decyzje w sprawie realizacji postanowień ze szczytu w Newport zapadły w lutym i czerwcu 2016 roku w czasie rozmów na poziomie ministrów spraw zagranicznych i obrony państw członkowskich Sojuszu. To po nich minister Macierewicz powiedział 14 czerwca na konferencji prasowej, że nastąpił przełom w Sojuszu i wojska rozlokowane na wschodniej flance nie będą miały charakteru ćwiczebnego, lecz bojowy ${ }^{84}$. Natomiast minister Szczerski uważał, że przygotowując nowy szczyt w Warszawie, należy wyjść poza decyzje podjęte w Newport i nie przywiązywać większej wagi do "formuł językowych" definiujących obecność sił Sojuszu w regionie, ale skoncentrować się na podniesieniu jego zdolności do obrony i od-

82 A. Duda, Widzę próbę zablokowania dobrych zmian..., s. 13. W tym wywiadzie prezydent sformutował ważne zastrzeżenie w sprawie baz Sojuszu w Polsce: „Jeśli kiedyś flanka wschodnia NATO znajdowała się w Niemczech Zachodnich i tam powstały bazy, to ta flanka powinna teraz zostać przesunięta na wschód. Nie twierdzę, że trzeba likwidować bazy w Niemczech, bo one mają znaczenie strategiczne, ale obecność NATO w naszej części Europy powinna zostać wzmocniona".

83 W. Waszczykowski, Informacja ministra sprawzagranicznych o zadaniach polskiejpolityki zagranicznej w2016 roku..., s. 73-74; wypowiedź Waszczykowskiego za: M. Miłosz, Będzie więcej sit NATO na wschodniej flance, „Dziennik Gazeta Prawna”, 15 VI 2016, nr 114, s. 5.

84 Konferencja prasowa MON, 14 VI 2016, http://www.pap.pl, dostęp $30 \mathrm{I} 2020$. 
straszania w oparciu o siły państw środkowoeuropejskich i obecność sił Sojuszu. Tę polską propozycję nazwał „Newport plus”, a faktycznie był to plan prezydenta Dudy. Postanowienia wojskowe, które mają być wykonywane, muszą być „adekwatne” do warunków, które w ciągu dwóch lat uległy zmianie: kiedy podejmowano decyzje w Newport, sądzono, że "[...] destabilizacja na wschodzie będzie przejściowa, a okazała się trwała. Dlatego również odpowiedź NATO musi mieć symetryczny charakter". Chodziło o rozlokowanie kolejnych wojsk, wraz z dowództwem, infrastrukturą i systemami rozpoznania, będących realną siłą obronną, zdolną do działania w chwili zagrożenia, a nie siłą ćwiczebną ${ }^{85}$.

Dla polityków PiS przełomem nie były decyzje z Newport, ale te podjęte w Warszawie. Nie chciano eksponować kontynuacji, ale zmianę, jaka dokonała się między szczytami w Newport i w Warszawie. Dał temu wyraz minister Szczerski w wywiadzie dla „Dziennika Gazety Prawnej”, przyznając, że pomysł szczytu warszawskiego był autorstwa prezydenta Bronisława Komorowskiego i Tomasza Siemoniaka, ministra obrony narodowej w rządzie koalicji PO-PSL, ale: „[...] stan decyzji, które miały zapaść na szczycie, był dalece różny od tego, co udało się osiągnąć dzięki pracy prezydenta [A. Dudy - W.P.] i rządu [B. Szydło - W.P.]. Doszło do zasadniczej zmiany ich treści. I to już jest pełny sukces obecnie sprawujących władzę" ${ }^{16}$. Na szczycie walijskim nie zdecydowano się ani na ustanowienie wysuniętej obecności jednostek bojowych na wschodniej flance, ani na utworzenie stosownej struktury dowodzenia dla tego teatru działań wojennych.

Na całkiem inny kontekst decyzji podjętych w Newport zwrócił uwagę W. Waszczykowski na konferencji w Waszyngtonie 22 lipca 2016 roku. Polityk akcentował istotną różnicę między Newport a planem „Newport plus". Minister przyznał, że "mechanizm obrony krajów członkowskich NATO w razie inwazji "nie jest automatyczny “" (chodziło o artykuł 5 traktatu z Waszyngtonu). Kontynuował: „Dlatego Polska zabiega o obecność

85 K. Szczerski, Skuteczna odpowiedź na prowokacje Rosji..., s. 35; idem, Nie przejmujmysię pieniaczami..., s. 4.

86 Idem, Pierwszy raz od końca zimnej wojny... 
na swoim terytorium zarówno oddziałów NATO, jak i wojsk USA". Ustanowiona w Newport tzw. szpica interwencyjna Sojuszu, "dolatująca na wypadek problemów", nie jest natomiast wystarczająca. Minister Waszczykowski wyeksponował przede wszystkim dwie kwestie problematyczne i zarazem niebezpieczne dla Polski (powołując się na wypowiedź prezydenta Trumpa): 1) brak automatyzmu w udzielaniu pomocy wzajemnej między członkami Sojuszu; 2) wolną wolę państw członkowskich w określaniu skali, zakresu i zasięgu pomocy w przypadku agresji ${ }^{87}$.

Oczekiwania strony polskiej uogólnił tuż przed szczytem warszawskim Sojuszu minister Macierewicz: 1) określenie skali zaangażowania Stanów Zjednoczonych w misjach obronnych w Europie Środkowej; 2) podjęcie rozstrzygnięć systemowych o trwałej obecności wojskowej Paktu na jego wschodniej flance; 3) zabezpieczenie wojskowe flanki południowej Sojuszu (Rumunia i Bułgaria); 4) podniesienie znaczenia współdziałania państw położonych na flankach wschodniej i południowej Sojuszu, czyli państw wyszehradzkich i bałtyckich oraz Rumunii i Bułgarii. Polska była bardzo zainteresowana decyzjami o wymiarze strategicznym („Newport plus") i nie ukrywała tego ani przed własną, ani przed międzynarodową opinią publiczną. Intencje polskie precyzyjnie sformułowała 18 kwietnia 2016 roku premier Szydło: „Nic się nie zmieniło [...]. Cały czas była mowa o stałej obecności sił NATO w Polsce, to jest ten cel, który myśmy zakładali, i który będzie w tej chwili [...] spełniony". Jednocześnie bagatelizowała problem „retorycznych" $i$ „werbalnych" sformułowań na temat określenia owej obecności w Polsce. Niezależnie od nazewnictwa Polska dążyła do stałej obecności sił Sojuszu na swoim terytorium ${ }^{88}$.

Politycy PiS spodziewali się po kolejnym szczycie Organizacji Paktu przełomu na dwóch płaszczyznach, w odniesieniu do: 1) przywódców państw członkowskich Sojuszu w aspekcie roli flanki wschodniej, w tym

\footnotetext{
87 Wypowiedź ministra Waszczykowskiego na konferencji w Waszyngtonie po obradach koalicji walczącej z IS...

88 Konferencja prasowa B. Szydło z premierem Danii, 18 IV 2016, http://www.defence24.pl, dostęp 10 V 2019.
} 
Polski, dla bezpieczeństwa w obszarze euroatlantyckim oraz 2) Rosji, która dotychczas uzurpowała sobie prawo weta przeciw decyzjom wojskowym Paktu w Europie Środkowej, a teraz będzie bardziej skłonna do wyraźnej korekty swojej aktywności międzynarodowej, zwłaszcza wobec Ukrainy $^{89}$. To drugie oczekiwanie szybko okazało się co najmniej naiwne, ale nie można też wykluczyć, że Rosja zrezygnowała z eskalacji konfliktu na Ukrainie i jego przeniesienia na inne terytoria Europy Środkowej. Natomiast na pewno nie przeszła na pozycje koncyliacyjne. Niemniej w Moskwie zauważono, że decyzje warszawskie utrudniły jej militarny dostęp do Niemiec i Bałkanów Zachodnich, Sojusz bowiem zaczął tworzyć zręby bariery wojskowej w postaci sił ostrzegawczego i specjalnego reagowania w Europie Środkowej. Dodatkowo sukces Polski poważnie komplikował sprawę wywierania nacisku na Warszawę, żeby ta wróciła do polityki realizowanej przez koalicję PO-PSL.

W czasie negocjacji wewnątrzsojuszniczych w 2016 roku uzgodniono ustanowienie wzmocnionej obecności militarnej na wschodniej flance w postaci czterech wielonarodowych wzmocnionych batalionów rozmieszczonych w Polsce i w trzech republikach bałtyckich, opartych na wyznaczeniu tzw. państw ramowych (Stany Zjednoczone Ameryki, Wielka Brytania, Niemcy, Francja) ${ }^{90}$. Następnie szczyt w Warszawie w lipcu 2016 roku przyjął te ustalenia i oficjalnie przekazał je opinii międzynarodowej ${ }^{11}$. Tym samym przez rząd B. Szydło został osiągnięty podstawowy cel artykułowany od lat przez PiS - stała obecność sił Sojuszu w Polsce, co interpretowano jako odwrócenie sytuacji, kiedy Polska była członkiem Sojuszu kategorii B. Nowy stan skomentował minister Wasz-

89 A. Macierewicz, Konferencja prasowa przed szczytem NATO, 8 VII 2016, http://wiadomoscidziennik.pl, dostęp 28 XII 2019; Pożegnanie Polskiego Kontyngentu Wojskowego, 12 II 2018, http://www.pap.pl, dostęp 28 XII 2019.

90 Wedtug Macierewicza decydujące byty ustalenia dokonane w lutym 2016 roku, kiedy zdecydowano o ksztatcie politycznym „wysuniętej trwałej obecności sit NATO na wschodniej flance". Briefing w Bąkowej Górze, 7 V 2016, http://www.pap.pl, dostęp 29 XII 2019.

91 Deklaracja końcowa szczytu NATO w Warszawie. Wydana przez Szefów Państw i Rządów uczestniczących w posiedzeniu Rady Pótnocnoatlantyckiej w Warszawie w dniach 8 i 9 lipca 2016 r., s. 205 i n., http://www.bbn.gov.pl, dostęp 12 V 2019. 
czykowski: „Tak jak w 1999 r. weszliśmy do NATO, tak po warszawskim szczycie sojuszu NATO wejdzie do Polski". Konsekwencje decyzji szczytu warszawskiego uznał za czynnik zmieniający geopolitykę. Podobnie tę sprawę widział minister Macierewicz, który w Brukseli mówił, że dokonała się w Warszawie "niezwykła, historyczna i głęboka zmiana w NATO", przede wszystkim w zakresie zrozumienia negatywnych konsekwencji polityki rosyjskiej, która wymusza zasadnicze zmiany w Sojuszu, aby przezwyciężyć trend rozmontowywania tej organizacji właściwy dla lat dziewięćdziesiątych ${ }^{92}$.

Decyzje warszawskie w sprawie konkretyzacji Planu Gotowości Sojuszniczej polegały na „wzmocnieniu wysuniętej obecności” w odniesieniu do flanki wschodniej Paktu, ponieważ: „U granic NATO i w innych rejonach rozciąga się łuk niebezpieczeństwa i niestabilności". Wynikały z trzech tradycyjnych zadań Sojuszu: obrony zbiorowej, zarządzania kryzysowego, bezpieczeństwa kooperatywnego. Za czynnik sprawczy niestabilności uznano w deklaracji warszawskiej Rosję, wskazując na fiasko polityki budowania partnerstwa NATO-Rosja. Stwierdzano: „Rosja naruszyła zaufanie leżące u samych podstaw naszej współpracy i podważyła podstawowe zasady architektury bezpieczeństwa globalnego i euroatlantyckiego". W tej sytuacji ogłoszono politykę odejścia od ustępstw wobec Moskwy oraz brak dogodnych warunków do realizacji partnerstwa strategicznego NATO-Rosja ${ }^{93}$. PiS byłoby skłonne zaakceptować dialog Sojuszu z Rosją w formule komisji, ale dopiero po wykonaniu wszystkich decyzji ostatnich szczytów Paktu, które „podniosą status bezpieczeństwa Polski i Europy Środkowej poprzez zwiększoną obecność zarówno wojsk sojuszniczych, jak i sojuszniczego uzbrojenia"94. Stronnictwo J. Kaczyńskiego konsekwentnie stało na stanowisku, że są to warunki konieczne w negocjacjach z Moskwą; wszelkie rozmowy oparte na formule resetu

\footnotetext{
92 W. Waszczykowski, Teraz to NATO wchodzi do Polski..., s. 3; Macierewicz na konferencji prasowej w Brukseli, 9 XI 2017, http://www.pap.pl, dostęp 5 XII 2019.

93 Deklaracja końcowa szczytu NATO w Warszawie..., s. 206.

94 W. Waszczykowski, Nie atakujemy już Tuska..., s. 28.
} 
uważano za nieefektywne, a nawet ośmielające Rosję do prowadzenia polityki imperialnej.

Następowało oczekiwane przez PiS przejście Organizacji Paktu od polityki reasekuracji jego członków środkowoeuropejskich do rozpoczęcia prac nad polityką ich obrony. Wojskowy sens tej zmiany opisywał dość optymistycznie minister Waszczykowski, mówiąc, że chodzi o "stworzenie tzw. follow-on-forces, czyli sił, które byłyby w stanie nie tylko odstraszać, lecz i szybko odwojować tereny zajęte przez nieprzyjaciela". W innej, wcześniejszej wypowiedzi wskazywał, że „w szczytowych momentach eskalacji napięcia" w Polsce może stacjonować ok. 10 tys. żołnierzy sojuszniczych ze sprzętem (grupa batalionowa, brygada, personel bazy w Redzikowie), a to już jest "poważna siła, która zmienia geopolitykę". Został również wyraźnie wskazany nieprzyjaciel dla tych wojsk - była nim Federacja Rosyjska. Kwestię zadań wojskowych tych sił Sojuszu ujął czytelnie minister Macierewicz: „chodzi o siły niezbędne, żeby skutecznie powstrzymać Rosję. [...] na tak długo, zanim nie dotrą pozostałe siły"95. Wyraźnie z tej wypowiedzi wynika, że polityk odpowiedzialny w PiS za sprawy wojskowe nie przeceniał możliwości Sił Zbrojnych RP w samodzielnym i długotrwałym powstrzymywaniu potencjalnego agresora. Niemniej minister Waszczykowski zinterpretował decyzje szczytu warszawskiego w lapidarnym komentarzu: „Ustawiliśmy jednak tablice ostrzegawcze z napisem "Baczność! Teren Polskiej Rzeczpospolitej«"96.

Politycy PiS uznali decyzje warszawskie nie tylko za wielki sukces, ale też za strategiczny przełom o znaczeniu historycznym. Tak go ocenili na konferencjach 9-10 lipca 2016 roku (zaraz po szczycie) zarówno prezes Kaczyński, jak i minister Macierewicz. Kaczyński powiedział: „Sukces jest wielki. Mamy zmianę zasadniczą [...]", oraz chwalił jego sprawców, w tym A. Macierewicza, który po raz kolejny „wpisał się pięknie w polską historię". Natomiast w opinii Macierewicza: „W dwa lata po Walii NATO

\footnotetext{
95 Idem, Zamelduję pani premier wykonanie zadania [Wywiad Jacka i Michała Karnowskich z Witoldem Waszczykowskim], „Sieci”, 6-12 XI 2017, nr 45(258), s. 35-36; idem, Teraz to NATO wchodzi do Polski..., s. 3; Konferencja prasowa MON, 14 VI 2016, http://www.pap.pl, dostęp 30 I 2020.

96 Informacja Ministra Spraw Zagranicznych o zadaniach polskiej polityki w 2017 roku...
} 
stanęło na wysokości zadania. Pokazało, gdzie jest granica agresji, której nie można w żaden sposób przekroczyć. To stwarza nadzieję, że będziemy żyli w bardziej bezpiecznym świecie". Ponad rok później (9 listopada 2017 roku) Macierewicz, nawiązując do tego wydarzenia, uznał, że wtedy dokonała się „niezwykła, historyczna i głęboka zmiana w NATO”, polegająca na przełamaniu procesu rozmontowywania Sojuszu, prowadzonego od lat dziewięćdziesiątych poprzedniego stulecia. Minister obrony narodowej widział ten przełom w kontekście całego regionu, a nie tylko Polski. Z jednej strony decyzje te korygowały sytuację geopolityczną państw wyszehradzkich, bałtyckich i wschodniobałkańskich w wyniku wprowadzenia wojsk amerykańskich do regionu, a z drugiej stawały się imperatywem koniecznej intensyfikacji bliskiej współpracy polityczno-wojskowej państw środkowoeuropejskich. Tego bowiem wymagała doktryna działania wojsk Sojuszu, którym trudno byłoby operować w granicach jednego państwa w warunkach zagrożenia, skoro były rozlokowane w kilku i podległe jednemu dowództwu taktycznemu ${ }^{97}$.

Przełomowy charakter decyzji warszawskich podjętych podczas szczytu Sojuszu - według PiS - należy dostrzegać też w innym wymiarze. Był to sukces „twardej" polityki wobec Rosji. U podstaw modelu polityki zagranicznej przyjętej przez Polskę pod rządami PiS stanęło przekonanie, że tylko jednoznaczne i odważne decyzje wobec Moskwy skłonią ją do wycofania się z zajętych terenów, podjęcia rozmów normalizacyjnych, a w długoterminowej perspektywie do rezygnacji z imperializmu i nacisku na Europę Środkową. Andrzej Duda określił rosyjski kontekst decyzji warszawskich Sojuszu jako realizację „dwutorowej polityki" wobec Moskwy, czyli „wzmocnienie odstraszania i obrony oraz utrzymanie uwarunkowanego dialogu". Wskazywane "uwarunkowanie" dialogu NATO-Rosja wynikało z przekonania prezydenta, że „Moskwa nie jest zainteresowana uczciwym, konstruktywnym dialogiem”. Miesiąc później

97 Konferencja prasowa prezesa J. Kaczyńskiego, 10 VII 2016, http://www.pap.pl, dostęp 1 VI 2019; Konferencja prasowa MON, 9 VII 2016, http://www.pap.pl, dostęp 29 XII 2019; Konferencja prasowa w Brukseli, 9 XI 2017, http://www.pap.pl, dostęp 27 XII 2019; Konferencja prasowa z okazji szczytu NATO, 8 VII 2016, http://www.pap.pl, dostęp 2 II 2020. 
Duda uznał, że z powodu agresywnej polityki Rosji (kwestie krymska, ukraińska, gruzińska) nie można „podwyższać poziomu dialogu z Rosją". Rozumiał to jako utrzymywanie sankcji oraz porzucenie rozumowania w kategoriach resetu wynikającego z zasady business as usual, ponieważ: „Najpierw Rosja musi wykazać dobrą wolę, pokazać, że chce przystąpić do poważnej rozmowy na temat wprowadzenia pokoju i uspokojenia sytuacji $[\ldots]^{n 98}$, a przede wszystkim powinna respektować prawo międzynarodowe.

Politycy PiS podawali różne wyjaśnienia dla tego wydarzenia - szczytu warszawskiego. Według premier Szydło szczyt doprowadził do przygotowania nowej mapy bezpieczeństwa światowego i wzmocnienia bezpieczeństwa Polski, a także wykazał zwartość Sojuszu w kontekście rosyjskiego zagrożenia ${ }^{99}$. Zdaniem prezesa Kaczyńskiego szczyt spowodował ożywienie Sojuszu, dokonał jego reanimacji, a przede wszystkim dał Polsce wzrost bezpieczeństwa oraz poczucie pewności ${ }^{100}$. Najbliższy współpracownik prezydenta Dudy w zakresie polityki zagranicznej, minister Szczerski, eksponował kontekst szerszy niż tylko krajowy, bo regionalny, a nawet globalny, ponieważ z jednej strony „Teraz odbędzie się wojskowe konstruowanie naszej poszerzonej obecności", a z drugiej nastąpi zainstalowanie wojsk Sojuszu w Polsce, co umożliwi „utrzymywanie poprawnych stosunków z Rosją"101. Dla ministra Waszczykowskiego decyzje warszawskie miały wielopłaszczyznowe znaczenie. Po pierwsze - zmieniały status bezpieczeństwa w całym regionie. Po drugie - były odpowiedzią na politykę zagraniczną Rosji wywoływania konfliktów zbrojnych. Po trzecie - przez militarne wzmocnienie wschodniej flanki Sojuszu organizacja powróciła do swojej podstawowej misji w postaci

98 Archiwum Prezydenta RP, https://www.prezydent.pl, dostęp 12 VI 2020: „Wystąpienie Prezydenta RP na posiedzeniu Zgromadzenia Parlamentarnego NATO", 28 V 2018; „Wypowiedź Prezydenta na konferencji w Rydze”, 27 VI 2018; „Wywiad dla tygodnika "Der Spiegel“", 24 XII 2015.

99 Konferencja premier B. Szydto, 11 VII 2016, http://www.premier.gov.pl, dostęp 1 VI 2019.

100 Konferencja prasowa prezesa J. Kaczyńskiego, 10 VII 2016, http://www.pap.pl, dostęp 1 VI 2019.

101 K. Szczerski, Nie będziemy walczyli samotnie..., s. 5; idem, Skuteczna odpowiedź na prowokację Rosji..., s. 36. 
kolektywnej obrony wszystkich państw członkowskich, także położonych w Europie Środkowej ${ }^{102}$.

Najpełniejsze i najbardziej zróżnicowane wyjaśnienia formułowali kolejni ministrowie obrony narodowej. Macierewicz mówił wprost, że jest to odpowiedź na „zagrożenie agresją, jaka wisi nad Polską i innymi krajami Europy Środkowej i Wschodniej ze względu na zagrożenie ze Wschodu". Jest to jedyny sposób "skutecznego odstraszania i powstrzymania rosyjskiego imperializmu”, a „Polska, kraje bałtyckie, Rumunia - wschodnia flanka NATO - ma prawo do obrony i działań, które będą odstraszały i broniły przed agresywną aktywnością Federacji Rosyjskiej [...]". Według niego nastąpiła adaptacja struktur Sojuszu do wyzwań współczesności, w tym zagrożenia na flankach wschodniej i południowej, a Polska wyszła z tego szczytu wzmocniona, z rzeczywistymi możliwościami obrony i odstraszania ${ }^{103}$. Kolejny minister obrony narodowej M. Błaszczak po upływie kilku miesięcy od szczytu warszawskiego kładł nacisk na kontekst amerykański podjętych wówczas decyzji: „Obecność wojsk NATO, a szczególnie amerykańskich, jest kluczowa dla naszego bezpieczeństwa, wszyscy zdajemy sobie sprawę, że tylko armia Stanów Zjednoczonych daje gwarancję odparcia wroga, gwarancję bezpieczeństwa"104.

Na nieco inne znaczenie szczytu warszawskiego zwrócili uwagę minister w Kancelarii Prezydenta Marek Magierowski i poseł PiS Michał Jach. Minister odniósł się do dwóch aspektów decyzji szczytu: politycznego i militarnego. Ten pierwszy uznał za ważniejszy z trzech powodów: 1) Rosja dostała jednoznaczny sygnał o budowie flanki wschodniej Sojuszu;

102 Wywiad z W. Waszczykowskim, 18 IV 2018, http://www.defence24.pl, dostęp 4 V 2019; Wywiad z W. Waszczykowskim, 7 VII 2016, http://www.wiadomosci.dziennik.pl, dostęp 1 VI 2019; Informacja Ministra Spraw Zagranicznych o zadaniach polskiej polityki w 2017 roku...

103 Konferencja prasowa Antoniego Macierewicza w Brukseli, 9 XI 2017, http://www.pap.pl, dostęp 15 V 2019; Piknik żotnierzy NATO w Piotrkowie Trybunalskim, 28 III 2017, http:// www.pap.pl, dostęp 9 V 2019; Konferencja prasowa MON, 28 IX 2017, http://www.pap.pl, dostęp 9 V 2019; Konferencja prasowa MON, 14 VI 2016, http://www.pap.pl, dostęp 9 V 2019; Konferencja prasowa MON, 9 VII 2016, http://www.pap.pl, dostęp 29 XII 2019; Konferencja prasowa w Londynie, 12 X 2017, http://www.pap.pl, dostęp 29 I 2020.

104 Rozmowa M. Błaszczaka w TVP Info, 12 III 2018, http://www.pap.pl, dostęp 9 V 2019. 
2) Pakt odzyskuje "prawdziwą jedność", mimo kontrowersji wśród jego członków; 3) Sojusz wraca do swoich korzeni, czyli „obrony terytorium państw sojuszniczych". W tym kontekście aspekt militarny nie wyglądał imponująco. Minister stwierdzał: „Pod względem militarnym możemy się zżymać, że to tak mało [...]. Przecież czterema batalionami nie jesteśmy w stanie się obronić przed potencjalnym atakiem"105.

Natomiast poseł Jach, wskazując rozmieszczenie w Polsce batalionowej grupy bojowej Sojuszu, amerykańskiej brygady pancernej i rozpoczęcie budowy tarczy antyrakietowej, przypisywał tym czynnikom rolę polityczną oraz podkreślał, że uderzenie Rosji na żołnierzy państw Zachodu: „[...] wywoła natychmiastową reakcję tych państw. To ma dla Polski kapitalne znaczenie". Jeszcze mocniej aspekty polityczne wyeksponował ów poseł dwa lata później w dyskusji sejmowej nad informacją ministra spraw zagranicznych o zadaniach polskiej polityki zagranicznej na 2018 rok. W jego opinii szczyt Sojuszu w Warszawie zmienił postrzeganie Polski i Europy Środkowej, a zachodni partnerzy uznali, że „Rosja jest zagrożeniem dla bezpieczeństwa nie tylko tego regionu, ale i całej Europy". Jednocześnie odczytywał decyzje warszawskie, zwłaszcza wojskowe, jako przyjęcie przez Polskę roli „głównego ogniwa stabilizującego bezpieczeństwo na wschodniej flance NATO"106.

Podsumowując, dla polityków PiS decyzje warszawskie były kamieniem milowym w budowaniu bezpieczeństwa Polski i Europy Środkowej. Zmianie uległy dzięki temu dwa negatywne zjawiska. Po pierwsze, udało się zahamować proces właściwy dla lat dziewięćdziesiątych, polegający na rozmontowywaniu Organizacji Paktu. Po drugie, zmienił się charakter członkostwa Polski w Sojuszu, stał się realny, bo wcześniej miał "charakter jednak trochę papierowy". Żadna z głównych formacji politycznych w Polsce nie pokazywała tak jednoznacznie decydującej roli Sojuszu Północnoatlantyckiego i Stanów Zjednoczonych dla bezpieczeństwa Polski

105 M. Magierowski, Decyzje podjęte na szczycie to sygnat, jakiego Rosja nie dostawała od lat, 9 VII 2016, http://www.telewizjarepublika.pl, dostęp 5 II 2020.

106 M. Jach, Nie ma bezpiecznego świata bez NATO...; idem, Wypowiedź, [w:] WNP Sejm, 8 kadencja, 60 pos., 21 III 2018, http://www.sejm.pl, dostęp 14 II 2020. 
jak PiS. Stronnictwo to próbowało przekonywać polską (w mniejszym stopniu międzynarodową) opinię publiczną do swoich racji w dwóch kwestiach: po pierwsze - między Warszawą a Waszyngtonem istnieją wspólne interesy, a nie tylko intencje i wola polityczna; po drugie - dokonał się niemal skokowy wzrost poziomu bezpieczeństwa Polski, któremu władze państwowe wyłonione przez PiS potrafią sprostać ${ }^{107}$.Zgodnie z tym kierunkiem myślenia zorganizowano na szeroką skalę (transmisje w mediach i liczne podniosłe wypowiedzi ${ }^{108}$ ) uroczystość powitania żołnierzy amerykańskich przybywających w styczniu 2017 roku do Żagania. Uczestniczyli w niej najważniejsi politycy PiS, a premier Szydło skomentowała sytuację: „Dzisiaj to wielki dzień, [...] mogę powiedzieć, że obecność wojsk amerykańskich tutaj w Polsce to jest właśnie kolejny krok w realizacji strategii przez rząd PiS wzmacniania bezpieczeństwa Polski, wzmacniania bezpieczeństwa naszego regionu. [...] Czynimy pierwszy krok. Pierwszy z wielu, które jeszcze przed nami"109.

Tak jak powiedziała B. Szydło, decyzje warszawskie Sojuszu, wynikające z planu "Newport plus", nie były spełnieniem strategicznym w zakresie bezpieczeństwa Rzeczypospolitej, lecz jedynie kolejnym krokiem we właściwym kierunku. Następnym miało być doprowadzenie do sytuacji, w której Stany Zjednoczone zaangażują się militarnie w sposób stały w regionie. Zamiar taki upublicznił A. Duda w odniesieniu do planowanych rozmów z D. Trumpem w 2017 roku $^{110}$.

Tak ukształtowana komunikacja polityczna wynikała przede wszystkim z typu rywalizacji politycznej w Polsce, noszącej charakter konfliktu unicestwiającego, nazywanego przez polityków liberalnych (PO) formułą opozycji totalnej, także w sprawach międzynarodowych. Sukcesy PiS

107 Vide K. Szczerski, Prezydent nie jest zależny od PiS [Wywiad Grzegorza Osieckiego z Krzysztofem Szczerskim], „Dziennik Gazeta Prawna”, 21 VI 2017, nr 118, s. 8; A. Macierewicz, Konferencja prasowa w Żaganiu, 14 XII 2016, http://www.pap.pl, dostęp 29 XII 2019.

108 Vide Żagań. Amerykańskie wojsko przyjechato na dtuższą wizytę, 13 | 2017, http://www. regionfan.pl, dostęp $20 \mathrm{I} 2020$.

109 Powitanie żotnierzy USA w Polsce, 14 I 2017, http://www.pap.pl, dostęp 20 I 2020.

110 Archiwum Prezydenta RP, https://www.prezydent.pl, „Wywiad prezydenta Andrzeja Dudy dla PR", 6 VII 2017, dostęp 12 VI 2020. 
w "polityce amerykańskiej" miały wyraźnie kontrastować z polityką realizowaną przez rządy koalicji PO-PSL. Im bardziej prezydent Duda i oba gabinety Zjednoczonej Prawicy odnosili konkretne zyski ze współpracy ze Stanami Zjednoczonymi, tym bardziej PO stawała się partią niemal amerykofobiczną. Takie oceny wzmacniało częste przywoływanie opinii R. Sikorskiego, ministra spraw zagranicznych w gabinecie D. Tuska, na temat stosunków polsko-amerykańskich, które zostały nagrane na nielegalnych, ale upublicznionych w 2014 roku taśmach z podsłuchu w restauracji Sowa \& Przyjaciele. Minister określał wówczas stosunki polsko-amerykańskie jako przejawy „murzyńskości”, ,frajerstwa”, ,płytkiej dumy i niskiej samooceny", które powodują konflikty z Niemcami i z Rosją. Komentarz do tej sytuacji wygłosił minister Waszczykowski w marcu 2016 roku: „My od tej murzyńskości, którą określał poprzedni minister Sikorski, odeszliśmy poprzez intensyfikację dialogu polsko-amerykańskiego"111. PiS zależało, żeby stosunki z Waszyngtonem nie były postrzegane jako przejaw owej „murzyńskości”, tylko jako działanie zgodnie z interesem Rzeczypospolitej. Niemniej faktycznie rządy Zjednoczonej Prawicy wybrały opcję bandwagoningu wobec Stanów Zjednoczonych. W tym kontekście należy przypomnieć, że już w 2003 roku prezes Kaczyński przestrzegał w Sejmie przed "wasalstwem" wobec tego uniwersalnego mocarstwa, ponieważ "to zawsze szkodzi" $i$ "to trzeba odrzucać"112. Taką linię przyjęło PiS jeszcze w okresie bycia w opozycji, kiedy poparło zaangażowanie Polski po stronie Stanów Zjednoczonych w Afganistanie i w Iraku oraz ówczesne decyzje rządu lewicowo-ludowcowego. To wówczas - jak to ocenił Ryszard Zięba - „Stopniowo, ale coraz wyraźniej, Polska zaczęła reprezentować oparte na realistycznym paradygmacie rozumienie bezpieczeństwa i preferowania zasobów i instrumentów wojskowych, własnych, koalicyjnych (natowskich) i amerykańskich"113.

111 Hipokryzja Sikorskiego! Zrobiliśmy laskę Amerykanom, 23 VI 2014, http://www.fakt.pl, dostęp 20 I 2020; Amerykanie w szoku. Nie wierza, że Waszczykowski to powiedziat, 31 III 2016, http://www.fakt.pl, dostęp 20 I 2020.

112 J. Kaczyński, Wystąpienie w czasie dyskusji na temat informacji rządu na temat polskiej polityki zagranicznej $w 2003$ roku...

113 R. Zięba, Implikacje stosunków polsko-amerykańskich..., s. 14. 
O ile trudno się zgodzić z przypisywaniem rządom L. Millera i M. Belki myślenia w kategoriach paradygmatu realistycznego, o tyle wniosek jest poprawny - Polska wybrała opcję polityki wiązania swojego bezpieczeństwa ze Stanami Zjednoczonymi.

Rządy koalicji PO-PSL podjęły działania na rzecz osłabienia tego kursu, natomiast opozycyjna wobec PiS w latach 2015-2019 Platforma Obywatelska była gotowa poszukiwać gwarancji bezpieczeństwa Polski w systemie budowanym przez Unię Europejską, a opartym na odpowiedzialności RFN za kontynent europejski oraz w normalizacji stosunków z Rosją. PiS po wygranych wyborach zmieniło ten kierunek w polityce zagranicznej Polski. W konsekwencji decyzji podjętych w Newport i w Warszawie Polska stała się miejscem rozlokowania dowództwa dywizji wielonarodowej, koordynującego działania batalionowych grup bojowych ${ }^{114}$. W świadomości powszechnej Polaków to Sojusz, a nie Unia, stawał sięjednoznacznie podmiotem zapewniającym Polsce bezpieczeństwo.

Na początku 2017 roku (9 lutego) minister Waszczykowski w informacji o polityce zagranicznej zaprezentowanej posłom nakreślił plan: "Oczywistym zadaniem polskiej polityki zagranicznej w tych warunkach jest pełna realizacja decyzji warszawskiego szczytu NATO, a także wcześniejszych uzgodnień z Newport" ${ }^{\prime 115}$. Jednak w następnych miesiącach okazało się to planem minimum, który zaczęto rozbudowywać. We wspomnianym już wywiadzie dla gazety „Rzeczpospolita” K. Szczerski nie tylko sformułował dyrektywę „wprowadzenia NATO do Polski", ale również wyłożył cel strategiczny takiej decyzji militarnej. Jej znaczenie strategiczne było znacznie głębsze niż jedynie dyslokacja wojsk, wręcz fundamentalne w sensie politycznym. Wykraczano poza doktrynę wojskową, a nawet poza planowanie strategiczne. Minister mówił dziennikarzowi: „My chcemy, żeby ewentualna agresja na Polskę oznaczała automatyczną konfrontację z całym sojuszem i jego siłą wojskową znaj-

114 Zadanie, http://mndne.wp.mil.pl, dostęp 12 V 2019.

115 Informacja Ministra Spraw Zagranicznych o zadaniach polskiej polityki w 2017 roku... 
dującą się na terytorium naszego kraju w celu wspólnej obrony"116. Ten styl myślenia strategicznego przypominał kalkulacje prowadzone przez obóz piłsudczykowski w latach 1926-1939. Celem realizowanej wówczas polityki zagranicznej było dokonanie przewartościowania strategicznego, tak żeby każdy zamach na terytorium i suwerenność Polski musiał oznaczać jednocześnie wybuch wojny światowej. Dla gabinetów tworzonych przez PiS bezpieczeństwo Polski zostało mocno osadzone w sytuacji w regionie środkowoeuropejskim, co miało służyć uniknięciu stanu wyizolowania w przypadku ewentualnego zagrożenia dla Rzeczypospolitej. Dlatego też premier Szydło po spotkaniu z kanclerz Merkel mówiła 7 lutego 2017 roku: „Wzmocnienie wschodniej flanki NATO jest niezwykle istotne z punktu widzenia bezpieczeństwa naszego regionu"117.

Wychodząc z takich strategicznych założeń, decyzje Sojuszu podjęte w Newport i w Warszawie PiS oceniało dopiero jako początek procesu podnoszenia poziomu bezpieczeństwa Polski przez tworzenie podstaw do wzmocnionej obecności Sojuszu w Europie Środkowej. Miały to być pierwsze realne kroki prowadzące do zniwelowania różnic między Europą Zachodnią a wschodnią flanką Sojuszu. Oczekiwano wprowadzenia stałych sił Sojuszu i budowy rozwiniętych militarnych instalacji obronnych. Minister J. Czaputowicz w informacji przedstawionej Sejmowi w 2019 roku opisał cele stojące przed polską polityką północnoatlantycką. Mówił: „Umocnienie wojskowej obecności NATO na wschodniej flance Sojuszu Północnoatlantyckiego, w tym szczególnie zacieśnienie współpracy wojskowej Polski i Stanów Zjednoczonych, pozostaje naszym priorytetem". W tych słowach zawarte było przekonanie, że rozbudowa wschodniej flanki Sojuszu będzie środkiem do zwiększenia zaangażowania wojskowego, o politycznych konsekwencjach, Stanów Zjednoczonych w regionie środkowoeuropejskim. Tym samym oczekiwano przewartościowania strategicznego przede wszystkim w Stanach Zjednoczonych, a w konsekwencji również w Sojuszu Północnoatlantyckim.

116 K. Szczerski, Stawka większa niż Trybunat..., s. A4.

117 Konferencja premier Beaty Szydło po spotkaniu z kanclerz Angelą Merkel, 7 II 2017, http:// www.pap.pl, dostęp 29 XII 2019. 
Minister Czaputowicz zaprezentował posłom trzy wyjaśnienia. Po pierwsze - „Zależy nam szczególnie na wzmocnieniu potencjału odstraszania i obrony Sojuszu”. Po drugie - Polska zabiega, aby "stać się rdzeniem obecności wojskowej NATO i USA w naszym regionie". Po trzecie - „Masowe rosyjskie manewry u granic wschodniej flanki NATO wymagają szybkiego tworzenia zgrupowań wojsk sojuszniczych mogących zapewnić równowagę sił w regionie". O ile dwa pierwsze wyjaśnienia miały charakter ogólny i perspektywiczny, o tyle trzecie przynależało do polityki bieżącej i wynikało z kalkulacji, że Rosja będzie wywierała coraz większą presję na kontynent europejski; wliczając w to także możliwość rozszerzenia agresji poza Ukrainę i Gruzję. Trzecie wyjaśnienie wzmocnił kilka dni później poprzedni minister spraw zagranicznych W. Waszczykowski. Według niego brak obecności wojsk Sojuszu w Europie Środkowej byłby "sytuacją prowokacyjną" wobec Rosji, prowadzącą do eskalacji jej polityki imperialnej ${ }^{118}$. To właśnie polityka rosyjska była podstawowym, prezentowanym powszechnie przez polityków $\mathrm{PiS}$, uzasadnieniem dla projektów wzmocnienia obecności Sojuszu w Polsce. Anna Fotyga przypomniała, że jest to kontynuacja uprzednich starań prezydenta Lecha Kaczyńskiego i ministra Aleksandra Szczygły, "o czym zbyt mało się pamięta, także w naszym obozie politycznym"119. Bardzo prawdopodobne, że miała na myśli zaangażowanie prezydenta w projekt tarczy antyrakietowej, ostatecznie zniweczony przez prezydenta B. Obamę i rząd D. Tuska.

Jacek Czaputowicz w swoim sejmowym wystąpieniu wskazał także środki, które zostały uruchomione, aby opisywany stan osiągnąć: stacjonowanie wojsk Sojuszu w Polsce (amerykańskich, brytyjskich, rumuńskich, chorwackich); powstanie w Elblągu wielonarodowego dowództwa; obecność w sposób rotacyjny i ciągły amerykańskiej brygady pancernej; kontynuacja prac nad powstaniem bazy antyrakietowej w Redzikowie ${ }^{120}$. Ta ostatnia kwestia mogła stać się dla polityków PiS powodem do dumy,

118 Wypowiedź W. Waszczykowskiego, 18 IV 2019, www.defence24.pl, dostęp 1 VI 2019.

119 A. Fotyga, Polska nie wpisuje się w nastrój antyamerykanizmu [Wywiad Wojciecha Muchy z Anną Fotygą], "Gazeta Polska”, 18 VII 2018, nr 138, s. 28.

120 J. Czaputowicz, Informacja ministra spraw zagranicznych o zadaniach polskiej polityki zagranicznej w 2019 roku... 
bardzo mocno kontrastowała bowiem tę partię z jej rywalką - Platformą Obywatelską, jeśli chodzi o podejście do Sojuszu Północnoatlantyckiego. Mówił o tym na konferencji prasowej zaraz po szczycie warszawskim J. Kaczyński, który przypomniał, że w przeszłości to właśnie rząd Tuska "się gwałtowanie wycofał z chęci budowy tarczy" na rzecz resetu z Rosją ${ }^{121}$.

Wprowadzenie wojsk północnoatlantyckich i amerykańskich do kilku państw środkowoeuropejskich PiS odczytało jako otwarcie nowych możliwości dla międzynarodowej aktywności Polski w regionie. W Strategii Polskiej Polityki Zagranicznej 2017-2021 ogłoszono, że wschodnia flanka Sojuszu ma dwa wymiary: południowy i północny, a Polska będzie wspierać projekty służące wzmocnieniu obu "poprzez współpracę z krajami skandynawskimi, a także aktywność w basenie Morza Czarnego"122. Według prezydenta Dudy dokonywała się realizacja zasady "360 stopni", czyli zapewniania przez Sojusz równego bezpieczeństwa na różnych azymutach. Chodziło mu przede wszystkim o zintegrowanie w ramach wschodniej flanki Paktu dwóch inicjatyw militarnych: enhanced forward presence - rozmieszczenia grup batalionowych państw członkowskich na obszarze nadbałtyckim, oraz tailored forward presence - zwiększenia obecności wojsk północnoatlantyckich w regionie nadczarnomorskim ${ }^{123}$. Dla polityki zagranicznej Polski oznaczało to istotne rozszerzenie zainteresowań przestrzennych w kontekście tych obszarów. Pewnym novum w polityce zagranicznej Polski był wzrost zainteresowania regionem Morza Czarnego na taką skalę. Wyjaśnił ten trend minister Czaputowicz: „Rosja jest zagrożeniem dla bezpieczeństwa europejskiego, zwłaszcza ze względu na swoje działania w regionie Morza Czarnego, dlatego popieramy obecność wojskową NATO w tym regionie"124. O ile w latach 2005-2007 Polska rządzona przez PiS wykazywała zainteresowanie

121 J. Kaczyński, Wystąpienie na konferencji prasowej PiS, 11 VII 2016, http://www.tvn24.pl, dostęp 29 XII 2016.

122 Strategia Polskiej Polityki Zagranicznej 2017-2021..., s. 8.

123 Archiwum Prezydenta RP, https://www.prezydent.pl, „Wystąpienie Prezydenta na Forum GLOBSEC 2017", 26 V 2017, dostęp 12 VI 2020.

124 Ukraina i Gruzja muszą stać się cztonkami NATO - szefowie MSZ Polski, Rumunii i Turcji, 19 IV 2019, http://www.jagiellonia.org, dostęp 14 II 2020. 
Morzem Czarnym głównie z perspektywy gruzińskiej i energetycznej, o tyle w okresie 2015-2019 zakres i zasięg odniesienia zdecydowanie się rozszerzyły - na Rumunię, Turcję i Bułgarię oraz na sprawy jednoznacznie militarne.

Rozwój wydarzeń w latach 2015-2019 w skali kontynentalnej i globalnej prowadził w PiS do wzmocnienia przekonania, że tylko Pakt Północnoatlantycki jest podmiotem mogącym realnie zapewnić bezpieczeństwo. Równocześnie coraz wyraźniej ugruntowywał się pogląd o słabości w tej materii Unii Europejskiej, o jej iluzorycznej roli w systemie bezpieczeństwa. Niewątpliwie sprzyjały takim ocennym krystalizacjom procesy, które nasiliły się w tym czasie w Unii: 1) kolizyjny kurs przyjęty przez Komisję Europejską wobec rządów Zjednoczonej Prawicy w Polsce, utrwalony w wyniku powiązań liderów unijnych z opozycją liberalno-lewicową w Polsce; 2) wzrastające nastroje antyamerykańskie w Europie Zachodniej w warunkach sprawowania urzędu prezydenta Stanów Zjednoczonych przez D. Trumpa; 3) postępująca dominacja osi niemiecko-francuskiej, narzucającej Unii sposób postrzegania zagrożeń w Europie oraz roli Rosji w środowisku międzynarodowym; 4) tendencje do marginalizacji we Wspólnocie znaczenia państw środkowoeuropejskich w kontekście określenia celów strategicznych Unii. Niemal negatywny stosunek rządów Zjednoczonej Prawicy do uzależnienia bezpieczeństwa Polski od relacji między Stanami Zjednoczonymi a Unią Europejską miał mocne osadzenie w procesach zachodzących we współpracy transatlantyckiej. Między Berlinem, Paryżem a Waszyngtonem coraz wyraźniej widoczne były rozbieżności dotyczące postulowanego systemu bezpieczeństwa. Za administracji Trumpa nastąpił powrót do koncepcji globalnego przywództwa Stanów Zjednoczonych, na pewno w hemisferze euroatlantyckiej, co kolidowało z niemieckim podejściem multilateralnym i francuskim projektem autonomii strategicznej Unii. Waszyngton postanowił narzucać swoją wolę najważniejszym europejskim sojusznikom w kwestiach strategicznych. Oznaczało to, że Unia, zdominowana 
przez oś francusko-niemiecką, nie będzie w stanie wypracować wiarygodnej polityki wobec Rosji, korzystnej dla Europy Środkowej ${ }^{125}$.

Nie może więc dziwić ocena dokonana przez premiera Morawieckiego w 2019 roku: „Nie ma drugiej takiej siły w globalnej architekturze bezpieczeństwa jak Sojusz Północnoatlantycki, a wszyscy członkowie NATO mają poczucie współodpowiedzialności za bezpieczeństwo całej euroatlantyckiej Wspólnoty". W tym wystąpieniu, skierowanym bezpośrednio do premierów Grupy Wyszehradzkiej, Morawiecki (podobne oceny przekazał też premierom państw bałtyckich rok wcześniej) wyjaśnił polskie postrzeganie aktualnych zagrożeń. Wymienił cztery: wojna na wschodzie Ukrainy, niestabilność południowej flanki Sojuszu, międzynarodowy terroryzm i cyberbezpieczeństwo ${ }^{126}$. Właśnie przez pryzmat tych czterech zagrożeń należy patrzeć na politykę północnoatlantycką obozu Zjednoczonej Prawicy w latach 2017-2019.

W styczniu 2018 roku minister obrony narodowej M. Błaszczak ujawnił w Waszyngtonie, że na posiedzeniu rządu RP sformułowano oczekiwania wobec Stanów Zjednoczonych dotyczące wzmocnienia ich wojsk w Polsce. Z inicjatywy polityków PiS odpowiedzialnych za obronność powstała koncepcja utworzenia w Polsce stałej bazy amerykańskiej, nazwanej roboczo przez prezydenta Dudę „Fort Trump”. Początków konkretnego myślenia w PiS o utworzeniu takiej bazy należy dopatrywać się w I połowie 2016 roku, czyli jeszcze przed szczytem Sojuszu w Warszawie. W czasie debaty sejmowej nad exposé ministra Waszczykowskiego 29 stycznia poseł PiS Piotr Pyzik wyjaśnił, że celem Polski jest dążenie do utworzenia stałych baz „w przestrzeni tzw. flanki północno-wschodniej" Sojuszu, które będą zdolne do szybkiego reagowania „w razie zagrożenia któregokolwiek z członków Sojuszu czy Sojuszu jako całości"127.

125 Szerzej vide J. Gostkowska, Niemiecko-amerykańskie spory o bezpieczeństwo. Konsekwencje dla wschodniej flanki, „Analizy OSW”, 22 II 2019, http://www.osw.waw.pl, dostęp $30 \mathrm{I} 2020$.

126 Spotkanie premierów V4 w Wesotej, 10 III 2019, http://premier.gov.pl, dostęp 28 | 2020; Konferencja po spotkaniu premiera z premierami państw battyckich w Wilnie, 9 III 2018, http://www.premier.gov.pl, dostęp 2912020.

127 P. Pyzik, Wypowiedź, [w:] WNPSejm, 8 kadencja, 78 pos., 14 III 2019, http://www.sejm.pl, dostęp 14 II 2020. 
Na wysoki poziom polityczny oczekiwania te zostały podniesione niemal nazajutrz po szczycie. Szczerski, oceniając go, powiedział już 12 lipca 2016 roku: „To krok do strategicznego zrównoważenia, ale jeszcze nie równowaga"128. Brak tej równowagi wynikał z jednej strony z potencjału ofensywnego Rosji, a z drugiej strony z defensywnego charakteru wojsk Sojuszu w Europie Środkowej. Na projekt „Fort Trump" należy także patrzeć z perspektywy wskazanej przez Szczerskiego w wywiadzie telewizyjnym w 2019 roku. Mówił w nim: „Źródłem bezpieczeństwa i ochrony wschodniej flanki NATO będzie Polska, bo tutaj będzie centrum stacjonowania wojsk amerykańskich, które potem będą mogły operować na całym obszarze"129. Andrzej Duda nazwał tę nową rolę międzynarodową Polski "hubem sojuszniczej obecności" na wschodniej flance Sojuszu ${ }^{130}$. Plany były więc bardzo szerokie, miały strategiczny charakter.

Różnice między obecnością rotacyjną wojsk północnoatlantyckich i amerykańskich a lokalizacją stałej bazy wyjaśniał minister M. Błaszczak. Przekonywał, że dzięki niej „agresor nie napadnie na Polskę, bo wojska Stanów Zjednoczonych są realną przeciwwagą dla wojsk innych państw". Byłby to także sygnał, że „w tym rejonie świata zagrożeń agresją nie ma", oraz impuls do rozwoju gospodarczego w sferze nie tylko wojskowej, ale również cywilnej. Minister przywołał jeszcze jeden powód uzasadniający starania o stałą bazę, w zasadzie najważniejszy: „Jeżeli patrzymy na potencjał armii poszczególnych państw, to potencjał armii Stanów Zjednoczonych jest realny, a potencjał armii innych państw europejskich wchodzących w skład NATO jest różny"131. Trudno tę argumentację uznać za afirmację unijnych starań o autonomię strategiczną wobec Stanów Zjednoczonych. Natomiast W. Waszczykowski inaczej

128 K. Szczerski, Pierwszy raz od końca zimnej wojny...

129 Idem, Wszystkie instalacje w ramach Fort Trump będą otwarte dla naszych partnerów, 10 VI 2019, http://www.tvp.info, dostęp 15 II 2020.

130 Archiwum Prezydenta RP, https://www.prezydent.pl, „Wypowiedź Prezydenta dla mediów w związku z odprawą kierowniczej kadry MON i Sit Zbrojnych RP", 7 III 2019, dostęp 12 VI 2020.

131 Konferencja prasowa w Waszyngtonie, 18 | 2018, http://www.pap.pl, dostęp 30 I 2020; Wywiad min. M. Btaszczaka dla PAP, 28 IX 2018, http://www.pap.pl, dostęp 29 V 2019; Wywiad dla programu I PR, 13 VI 2018, http://www.pap.pl, dostęp 1 II 2020. 
rozkładał akcenty, wyjaśniając w radio, że: „Chodzi o obecność, która odstraszy jakikolwiek konflikt czy prowokacje”. Twierdził, iż projekt jest uzasadniony, bo traktat waszyngtoński nie przewiduje mechanicznej odpowiedzi na zagrożenie, a „USA to jedyne państwo w NATO, które ma historię wiarygodnych odpowiedzi i współpracy sojuszniczej". Z tego powodu są bardziej godne zaufania niż "niektórzy sojusznicy w Europie"132.

Nazwa „Fort Trump" miała skutecznie wypromować pomysł w Stanach Zjednoczonych, uczynić go „hasłem czytelnym zawsze i wszędzie”, była figurą mającą na celu nadanie impetu rozmowom w tej sprawie - jak to ujmowali Mariusz Błaszczak i Paweł Soloch (szef Biura Bezpieczeństwa Narodowego). Była to metafora, figura retoryczna, służąca zdynamizowaniu rozmów polsko-amerykańskich ${ }^{133}$. Jednak kluczowe uzasadnienie wyeksponował prezydent Duda na wspólnej konferencji z D. Trumpem 18 września 2018 roku, kiedy powiedział: „Jestem przekonany, że dla interesów Stanów Zjednoczonych - także związanych z bezpieczeństwem samych Stanów - obecność armii USA u nas jest istotna, również po to, by chronić amerykańskie interesy"134. Zupełnie świadomie dążono do zaprezentowania Polski rządzonej przez PiS jako ostoi pozycji mocarstwowej Stanów Zjednoczonych w skali co najmniej kontynentalnej, a nawet globalnej. Było wiadomo, że istnieje ścisły związek między amerykańskim zaangażowaniem kapitałowym a obecnością wojskową tego uniwersalistycznego mocarstwa, zwłaszcza w regionie, w otoczeniu którego Rosja realizowała swoją ekspansywną politykę oraz wobec którego stosowała politykę penetracji i uzależnienia. Trudno było sobie wyobrazić przepływ amerykańskich technologii i inwestycji bez ich zabezpieczenia wojskowego.

132 Wywiad W. Waszczykowskiego w polskim Radio, 2 XI 2018, http://www.polskieradio24.pl, dostęp 4 V 2019.

133 Wywiad min. M. Btaszczaka dla PAP, 28 IX 2018, http://www.pap.pl, dostęp 23 V 2019; P. Soloch, Wokót przysztej bazy USA w Polsce pojawia się wiele manipulacji, 16 III 2019, http://www.demaskator24.pl, dostęp 4 II 2020.

134 Archiwum Prezydenta RP, https://www.prezydent.pl, „Wspólna konferencja prasowa Prezydentów Polski i USA", 18 IX 2018, dostęp 12 VI 2020. 
Politycy PiS mocno zaangażowali się w ten projekt wojskowy, dostrzegając przede wszystkim jego nośność w Stanach Zjednoczonych, ale zarazem trudności w pozyskaniu dla tej koncepcji zarówno prezydenta Trumpa, jak również Pentagonu, a także Kongresu. Argumentami na rzecz tego projektu miały być: wydatki na zbrojenia Polski, zaangażowanie w działania sojusznicze Paktu, modernizowanie wojska, rozwijanie Wojsk Obrony Terytorialnej ${ }^{135}$. Jednak trudności się mnożyły wraz ze wzrostem dezaprobaty Partii Demokratycznej dla polityki zagranicznej administracji Trumpa. Chcąc urealnić ten projekt na amerykańskiej arenie politycznej, Polska wyraziła nawet gotowość sfinansowania budowy infrastruktury (ok. 2 mld USD) oraz ponoszenia części kosztów związanych ze stacjonowaniem wojsk Stanów Zjednoczonych w stałej bazie ${ }^{136}$. W sposób zdecydowany ostrzegano stronnictwa opozycyjne: „Jeśli Fort Trump zostanie zaprzepaszczony przez czyjeś partyjniactwo, nie będzie mu to wybaczone. Decyzja o stałych bazach jest tak ważna, że żadne podziały wewnętrzne nie powinny mieć tu znaczenia"137.

Kiedy okazało się, że Stany Zjednoczone nie są gotowe do znacznego zwiększenia swojej militarnej obecności w Europie z powodów finansowych i społecznych, w kilka tygodni po wprowadzeniu w publiczny obieg projektu „Fort Trump” zaczęto upowszechniać jego wersje zmodyfikowane, w postaci planu albo przeniesienia do Polski baz amerykańskich z Niemiec, albo uczynienia z Polski amerykańskiego hubu wojskowego. Czaputowicz wysuwał w tej kwestii argumenty ekonomiczne, przekonując, że dyslokacja takich baz z Niemiec do Polski skutkowałaby „obniżeniem kosztów dla budżetu USA", a ponieważ jest zbieżna z polskimi interesami, Polska jest gotowa dołożyć wszelkich starań, żeby do takich działań doprowadzićc ${ }^{138}$. Te wypowiedzi można uznać także za sondo-

135 Vide Rozmowa ministra Btaszczaka w programie "Sygnaty dnia", 7 V 2018, http://www. pap.pl, dostęp 30 I 2020.

136 Vide M. Błaszczak, Konferencja prasowa MON, 21 VI 2018, http://www.pap.pl, dostęp $30 \mid 2020$.

137 K. Szczerski, Moskwa nie ma powodu, by budować Fort Putin..., s. 6; Archiwum Prezydenta RP, https://www.prezydent.pl, „Konferencja prasowa Prezydenta w Nowym Jorku”, 26 IX 2018, dostęp 12 VI 2020.

138 J. Czaputowicz, Bazy USA z Niemiec do Polski..., s. 32. 
wanie stanu stosunków amerykańsko-niemieckich po tym, jak Trump zrezygnował z polityki swoich poprzedników stawiania w Europie na Niemcy (Germany first). Natomiast szef BBN P. Soloch tłumaczył, że hub "oznacza rolę państwa centralnego dla obecności sojuszniczej na wschodniej flance", nowoczesny typ bazy typu hybrydowego, której rola będzie polegała na zbudowaniu w Polsce instalacji wojskowych pozwalających zarówno na dokonywanie ćwiczeń, jak i na szybkie przebazowanie wojsk w przypadku zagrożenia wojennego ${ }^{139}$.

Faktycznie „Fort Trump", w wersji podstawowej i zmodyfikowanej, okazał się jedynie maksymalistyczną polską ofertą negocjacyjną wobec Waszyngtonu. Tak ją nazwał prezydent $\mathrm{Duda}^{140}$. Miała ona ułatwić podjęcie w czerwcu i we wrześniu 2019 roku, na dwóch spotkaniach DudaTrump, decyzji o wzmocnieniu obecności sojuszniczej w Polsce w postaci deklaracji z 12 czerwca i z 23 września o współpracy wojskowej, czyli o trwałej obecności wojsk Stanów Zjednoczonych w Rzeczypospolitej. O ile w pierwszej z nich zapowiedziano utworzenie/ustanowienie w Polsce: dowództwa dywizyjnego wojsk amerykańskich o zdolnościach dowodzenia siedmioma brygadami, bazy rozpoznawczych bezzałogowców, centrum szkolenia bojowego, bazy przerzutowej, większych zdolności do działania sił specjalnych na rzecz wsparcia potencjalnej operacji wojskowej, o tyle w drugiej ogłoszono konkretne lokalizacje dla dodatkowych żołnierzy amerykańskich w Polsce i nowej infrastruktury, zobowiązując się ogólnie do „zwiększonej współpracy w zakresie infrastruktury oraz współpracy obronnej". Łącznie w Polsce miało stacjonować 4,5 tysiąca żołnierzy amerykańskich, z obietnicą zwiększenia o dodatkowy tysią ${ }^{141}$.

139 P. Soloch, Wokót przysztej bazy USA...; SzefBBN o „Fort Trump": Poczekajmyna ostateczne rezultaty rozmów, na stole leżą różne kwestie, 13 III 2019, http://www.polskieradio24.pl, dostęp 4 II 2020.

140 M. Świerczyński, Co zostało z amerykańskiego Fort Trump w Polsce?, 13 VI 2019, http:// www.polityka.pl, dostęp 4 II 2020.

141 Ibidem; M. Partyka, Duda i Trump podpisali deklarację ws. zwiększenia obecności wojsk USA w Polsce, 23 IX 2019, http://www.rmf24.pl, dostęp 11 XII 2019; Wspólna Deklaracja Prezydentów o Wspótpracy Obronnej w zakresie obecności sit zbrojnych USA na terytorium RP, 12 VI 2019, http://n-16.dcs.redcdn.pl, dostęp 2 II 2020; Wspólna deklaracja Prezydentów PL i USA na temat pogtębienia wspótpracy obronnej, 23 IX 2019, http://www.prezy- 
Strona polska wyraźnie jednak widziała wówczas potrzebę utworzenia stałej wielkiej amerykańskiej bazy wojskowej na swoim terytorium ${ }^{142}$.

Do fiaska medialnego w sprawie budowy bazy „Fort Trump” odniósł się minister Czaputowicz, mówiąc, że współcześnie jedna wielka baza wojskowa nie jest potrzebna, istotne jest natomiast wzmocnienie wszechstronnej obecności amerykańskiej w Polsce (faktycznie było to wycofywanie się z projektu „Fort Trump"). Taka obecność służy realizacji dwóch konkretnych zadań. Po pierwsze, zwiększa potencjał odstraszania, dlatego też „Rosja zastanowi się dwa razy, zanim zdecyduje się na uderzenie na Polskę". Po drugie, stwarza dogodne warunki do skutecznej obrony przed ewentualnym atakiem ${ }^{143}$. W mniemaniu ministra decyzje obu prezydentów były w tej materii wystarczające. Inni politycy PiS jeszcze bardziej podnosili znaczenie deklaracji Duda-Trump. Dla Jacka Sasina było to porozumienie „absolutnie bez precedensu", a według Jana Parysa: „[...] polisa ubezpieczeniowa dla nas. Ewentualny przeciwnik będzie się długo zastanawiał, czy podjąć ekspansję w tym kierunku. Bo liczba Amerykanów w Polsce jest na tyle duża, że nie da jej się po prostu wyminąć"144.

W warunkach nabrzmiałych i rosnących kontrowersji między Stanami Zjednoczonymi a głównymi państwami zachodnioeuropejskimi zrzeszonymi w Unii Europejskiej oraz wobec ograniczonych możliwości poszerzania i pogłębiania obecności amerykańskiej w Polsce, premier M. Morawiecki w latach 2018-2019 zadeklarował nową rolę dla Polski. Mówił w wywiadzie prasowym: „Polska chce być integratorem, zwornikiem jedności transatlantyckiej. Chcemy przybliżać do siebie Stany Zjednoczone i Europę, ponieważ od tego zależy przyszłość Polski i wolnego świata". Natomiast na dwóch konferencjach w Brukseli

dent.pl, dostęp 2 II 2020; Prezydenci Duda i Trump rozmawiali w Nowym Jorku. Podpisano szczegółową deklarację, 23 IX 2019, http://www.pch24.pl, dostęp 2 II 2020.

142 VideArchiwum Prezydenta RP, https://www.prezydent.pl, „Wywiad Prezydenta w programie "Wydarzenia i Opinie» w Polsat News", 3 X 2018, dostęp 12 VI 2020.

143 J. Czaputowicz, Polska wie, jak ratować brexit [Wywiad Jędrzeja Bieleckiego z Jackiem Czaputowiczem], „Rzeczpospolita”, 21 I 2019, nr 20, s. A9.

144 Miller zazdrości Dudzie? Zdumiewająca teza Jacka Sasina ws. spotkania z Trumpem, 24 IX 2019, http://wideo.wp.pl, dostęp 5 II 2020; J. Parys, Spotkanie Duda-Trump to nasza polisa ubezpieczeniowa, 24 IX 2019, http://www.dorzeczy.pl, dostęp 5 II 2020. 
w czerwcu 2018 roku stwierdzał wprost, że Polska będzie działała na rzecz redukcji napięć w relacjach Unia Europejska-Stany Zjednoczone oraz będzie tworzyć fundamenty współpracy między Brukselą a Waszyngtonem na polu obronności i geopolityki ${ }^{145}$. Szczerski na określenie tej roli użył innego terminu - pomost. Najbardziej szczegółowo tę deklarowaną rolę opisywała w Sejmie M. Gosiewska: „Im więcej jest nieporozumień w tych relacjach, a ostatnio ich nie brakuje, tym ważniejsze zadanie stoi przed Polską. To polska dyplomacja powinna aktywnie zabiegać o to, aby nieporozumienia nie doprowadziły do zerwania fundamentalnej dla naszego bezpieczeństwa nici porozumienia i transatlantyckiej współpracy"146. Premier tę rolę objaśniał jako zaprzeczenie polityki manewrowania między Stanami Zjednoczonymi a Unią Europejską, bo jest to sytuacja "niekomfortowa". Natomiast bycie integratorem będzie oznaczało z jednej strony utrzymanie sojuszu ze Stanami Zjednoczonymi, co oznacza między innymi wspieranie międzynarodowej aktywności Waszyngtonu, a z drugiej strony uwzględnianie interesów Unii Europejskiej w relacjach polsko-amerykańskich.

Niewątpliwie wniosek jest bezdyskusyjny - współpraca, a nie rywalizacja między Stanami Zjednoczonymi i państwami członkowskimi Unii Europejskiej jest niezbędna Polsce w kontekście koncepcji polityki zagranicznej realizowanej przez Zjednoczoną Prawicę. Jak to ujął wiceminister spraw zagranicznych Konrad Szymański: „Obawy o więzi transatlantyckie są dzisiaj uzasadnione i Polska jest jednym z krajów, które ten stan

145 M. Morawiecki, Chcemy dać Polakom święty spokój i dostatnie życie [Wywiad Michała Szułdrzyńskiego i Andrzeja Steca z Mateuszem Morawieckim], „Rzeczpospolita”, 6 III 2019, nr 55, s. A7; vide idem, Pokazujemy naszą wiarygodność [Wywiad Katarzyny Gójskiej i Tomasza Sakiewicza z Mateuszem Morawieckim], „Gazeta Polska”, 13 VI 2018, nr 24, s. 28; idem, Pokazujmy naszą wiarygodność [Wywiad Tomasza Sakiewicza z Mateuszem Morawieckim], „Gazeta Polska”, 12 IX 2018, nr 37, s. 18; Wypowiedź premiera po spotkaniu z kanclerz Niemiec A. Merkel w Brukseli, 19 VI 2018, http://www.premier. gov.pl, dostęp 2 II 2020; Premier po Radzie Europejskiej w Brukseli, 28 VI 2018, http:// www.premier.gov.pl, dostęp 2 II 2020.

146 K. Szczerski, Izrael powinien sobie cenić przychylność Polski [Wywiad Magdaleny Cedro i Grzegorza Osieckiego z Krzysztofem Szczerskim], „Dziennik Gazeta Prawna”, 18 II 2019, nr 34, s. 4; W. Waszczykowski, Wypowiedź, [w:] WNP Sejm, 8 kadencja, 78 pos., 14 III 2019, http://www.sejm.pl, dostęp 14 II 2020. 
rzeczy przyjmują z zaniepokojeniem i bez satysfakcji, ponieważ skutki polityczne będą, a może już są bardzo negatywne dla jedności Zachodu". Premier Morawiecki też zauważał ten negatywny scenariusz, bo: „Każdy zapewne dostrzega, że drogi Unii i Ameryki zaczęły się dość mocno rozchodzić [...]"147. Scenariusz konfliktowy między Stanami Zjednoczonymi a całościowo ujmowaną Europą był przez PiS odrzucany, więc przyjęto za fałszywe założenie, że: „dobre relacje z Ameryką wiążą się ze złymi relacjami z Europą i odwrotnie" ${ }^{148}$.

Wyjątkowe zaniepokojenie Polski wywoływały napięcia w relacjach między Stanami Zjednoczonymi a Unią Europejską, których przyczyną był stosunek do Chin i Rosji. Dla Warszawy nie do przyjęcia był trend widoczny w Europie Zachodniej traktowania i Rosji, i Chin jako przeciwwagi strategicznej dla Stanów Zjednoczonych. Dlatego też Szymański przestrzegał: „Nie można budować tego, na czym Unii zależy, czyli specjalnej roli protagonisty wartości na świecie, będąc strategicznym partnerem Rosji czy Chin”. Podobnie oceniał Czaputowicz: „Dla Polski najgorzej jest wówczas, gdy polityki zagraniczne Stanów Zjednoczonych i Unii się rozchodzą"149. O ile w aktualnym systemie politycznym Unii Europejskiej wskazane kontrowersje są jedynie rozbieżnościami, o tyle w przypadku przebudowy Unii w kierunku federacyjnym mogą się znacznie pogłębić w wyniku dominacji w Brukseli zachodnioeuropejskiej perspektywy postrzegania środowiska międzynarodowego. Dostrzegł to już w 2003 roku Lech Kaczyński: „W naszym interesie jest utrzymywanie ścisłego sojuszu z USA, choćby ze względu na Rosję, ale nie będzie to możliwe, bo zacznie obowiązywać wspólna polityka zagraniczna i obronna. Koncepcja federacyjnej Unii jest dobra dla tych, którzy będą tam dominować"150.

\footnotetext{
147 M. Morawiecki, Pokazujemy naszą wiarygodność..., s. 28.

148 K. Szczerski, Izrael powinien sobie cenić..., s. 4.

149 K. Szymański, Rosja i Chiny nie są alternatywą dla wspótpracy z USA [Wywiad Magdaleny Cedro z Konradem Szymańskim], „Dziennik Gazeta Prawna”, 6 VI 2018, nr 108, s. 2-3; J. Czaputowicz, Rosja wyczuwa słabość..., s. 43.

150 L. Kaczyński, Jeśli Wrzodak, daję dyla [Wywiad Jarosława Kurskiego z Lechem Kaczyńskim], „Gazeta Wyborcza”, 3 VI 2003, nr 128, s. 6-7.
} 
Jednak obiektywnie widoczny jest w Europie Zachodniej brak zarówno zapotrzebowania na rolę Polski jako zwornika w relacjach amerykańsko-europejskich, jak i akceptacji dla takiej roli i w Paryżu, i w Berlinie z dwóch zasadniczych powodów. Po pierwsze - licznych rozbieżności w najistotniejszych sprawach między Waszyngtonem a kluczowymi stolicami europejskimi, chociażby w odniesieniu do: polityki wobec Rosji, statusu Niemiec w Europie, zaangażowania amerykańskiego na Bliskim Wschodzie, aspiracji mocarstwowych Chińskiej Republiki Ludowej, stosunku do wyjścia Wielkiej Brytanii z Unii Europejskiej. Po drugie - aktualnego stanu w stosunkach polsko-francuskich i polsko-niemieckich, ponieważ i w Berlinie, i w Paryżu nie dokonała się akceptacja nowej polityki zagranicznej Polski ukierunkowanej na podnoszenie własnej podmiotowości, między innymi w Unii Europejskiej i Europie Środkowej. 


\section{Eurorealizm}

\subsection{Podstawy eurorealizmu}

Podstawową cechą myśli politycznej PiS w odniesieniu do polityki zagranicznej Polski jest eurorealizm, przeciwstawiany eurosceptycyzmowi i euroentuzjazmowi. Takiej jednoznacznej samoidentyfikacji dokonano w programie z 2019 roku. Za credo tej identyfikacji można uznać słowa Andrzeja Dudy: „Bycie w Unii Europejskiej ma swoje plusy i ma swoje minusy [...]"1. Eurorealizm wynikał z dwóch zasadniczych przesłanek: po pierwsze - z realizmu politycznego i poznawczego, determinującego myślenie o organizacjach międzynarodowych, integracji i globalizacji; po drugie - z systemu wartości, w którym wartością prymarną jest państwo polskie, jego niepodległość, suwerenność i integralność. Ważną rolę w ocenie Unii Europejskiej oraz projektowaniu polityki zagranicznej Polski w tej organizacji odgrywała perspektywa geopolityczna i historyczna. Z tych powodów PiS jako spadkobierca ideowy PC przyjęło kurs europejski, opowiadając się najpierw za akcesją Polski do Unii Europejskiej, a następnie za wzmacnianiem podmiotowości Rzeczypospolitej w tej organizacji międzynarodowej.

1 Dobry czas dla Polski..., s. 177. Andrzej Duda 20 grudnia 2019 roku ztożyt deklarację w duchu eurorealistycznym: „Jestem eurorealistą, zawsze tak o sobie mówię". Archiwum Prezydenta RP, https://www.prezydent.pl, „Wywiad Prezydenta dla 300 Polityka iWP", 20 XII 2018, dostęp 12 VI 2020. 
Wszelkie wątpliwości formułowane w tej kwestii wobec PiS miała rozstrzygnąć przyjęta 28 czerwca 2003 roku przez Radę Polityczną uchwała stronnictwa pod tytułem Silna Polska w Europie. Metodycznie wyjaśniono w tym dokumencie stanowisko władz partii. Ogłaszając poparcie dla obecności Polski w Unii, odrzucono błędy entuzjazmu oraz kierunek paneuropejski. Opisywano tę Wspólnotę jako narzędzie promocji interesów suwerennego państwa polskiego ${ }^{2}$. Jednak w sensie ogólnym Unia Europejska zawsze była postrzegana przez PiS jako organizacja międzynarodowa suwerennych państw narodowych, a nie jako etap wstępny, w postaci suprapaństwa, do zbudowania europejskiej federacji lub konfederacji - projektów o charakterze paneuropejskim.

Dla polityków tego stronnictwa takie wizje, kreślone przede wszystkim przez lewicę, liberałów i chadeków, były przejawem z jednej strony konstruktywizmu sprzecznego ze stanem stosunków społecznych i rzeczywistości politycznej w Europie, a z drugiej strony pozornego myślenia utopijnego, które było bardzo niebezpieczne, ponieważ maskowało interesy mocarstw zachodnioeuropejskich, traktujących Unię Europejską jako środek polityczny wykorzystywany do realizacji własnych interesów narodowych i racji stanu swoich państw. W skrajnym wariancie chodziło o uprzedmiotowienie Europy Środkowej, będącej łatwym do wykorzystania rezerwuarem taniej i wykwalifikowanej siły roboczej oraz przestrzenią bogatą w znaczne zasoby gospodarcze, które można było przejąć $\mathrm{z}$ racji braku kapitału w regionie. Taką politykę przypisywano przede wszystkim Niemcom i Francji. O ile w latach 2001-2005 PiS prowadziło polemikę na dwóch kierunkach - z entuzjastami i sceptykami, o tyle w następnym okresie (po 2005 roku) za głównego przeciwnika stronnictwo uznało pierwszą grupę. $Z$ badań socjologicznych wynikało bowiem, że eurosceptycy w Polsce systematycznie tracili wyborców (kryzys LPR i Samoobrony był tego dowodem), podczas gdy i lewica, i liberałowie w Polsce jednoznacznie wybrali orientację euroentuzjastyczną. To o euroentuzjastach mówił europoseł PiS Z. Krasnodębski: „Smutno myśleć,

2 Vide Silna Polska w Europie. Uchwata nr 1/06/03 Rady Politycznej Prawa i Sprawiedliwości, „Międzynarodowy Przegląd Polityczny” 2003, nr 3, s. 122-125. 
że są w Polsce ludzie uważający się za patriotów UE, będący fanatykami unijnymi. Ma to dla naszego życia publicznego dewastujący skutek"3. W podobnym duchu pisał o euroentuzjastach Jacek Kloczkowski: „Ich utopijne, często po prostu niemądre dywagacje o rozstrzygniętym pomyślnie raz na zawsze geopolitycznym położeniu Polski działają rozkładowo na same fundamenty myślenia politycznego Polaków"4.

Wizji paneuropejskich nie postrzegano w kategoriach wielkiego romantycznego celu o znaczeniu historycznym, wręcz nawet historiozoficznym, lecz widziano w nich czynnik zagrażający istnieniu Unii Europejskiej. Według PiS bowiem obie alternatywne postawy: eurosceptyczna i euroentuzjastyczna były ze sobą ściśle powiązane zgodnie z regułą - im silniejszy euroentuzjazm, tym bardziej wzrasta poparcie społeczne dla eurosceptycyzmu, którego zwolennicy nie tylko byli odpowiedzialni za niski poziom zaufania do instytucji unijnych, ale również nie odczytywali potrzeb społecznych narodów europejskich ${ }^{5}$. Koncepcje rozwoju Unii wynikające z euroentuzjazmu uznano za niebezpieczne zarówno dla Polski, jak i dla Unii Europejskiej.

W opinii PiS integracja europejska ani nie zmieniła istoty stosunków międzynarodowych (poliarchia), ani nie zniosła rywalizacji właściwej dla środowiska międzynarodowego (wróg-sojusznik). Stronnictwo J. Kaczyńskiego w odniesieniu do problematyki unijnej odrzucało przekonanie, że we współczesnej myśli politycznej uległa niemal likwidacji jej warstwa ideologiczna. Uznano, iż w III Rzeczypospolitej doszło do błędnego odczytania wniosku Daniela Bella o kryzysie ideologii. Ten wybitny politolog sformułował ów pogląd w latach pięćdziesiątych XX wieku, opisując kondycję intelektualną ówczesnej elity politycznej. Natomiast w środowiskach lewicowych i liberalnych uznano tę ocenę za

Z. Krasnodębski, Te wydarzenia zapamiętają pokolenia [Wywiad Michała Karnowskiego ze Zdzisławem Krasnodębskim], „Sieci”, 27 IV-3 V 2020, nr 18, s. 31.

4 J. Kloczkowski, Gra bez wyjścia, czyli nic pewnego w geopolityce poza problemami, [w:] Polska w grze międzynarodowej..., s. 249.

5 VideW. Paruch, Romantyzm celówi pozytywizm środków. Piłsudczycy o warunkach potęgi Rzeczypospolitej w środowisku międzynarodowym, [w:] Sen o potędze. Bezpieczeństwo suwerenność - mocarstwowość. Rzeczpospolita Polska 1918-1939, red. E. Maj i inni, Wydawnictwo UMCS, Lublin 2014, s. 591-604. 
ponadczasową, podczas gdy w następnych dekadach faktycznie dokonywała się transformacja funkcji ideologii. W coraz większym stopniu jej funkcją stawało się nie tyle wyjaśnianie i ocenianie rzeczywistości, ile systematyzowanie wiedzy oraz racjonalizowanie i uzasadnianie decyzji politycznych, podejmowanych zwłaszcza w warunkach niepewności i kryzysu ${ }^{6}$. Zanegowanie w Polsce w ostatniej dekadzie XX wieku ważnej roli ideologii w życiu politycznym pociągnęło za sobą utrwalanie się mitów politycznych oraz negowanie wiedzy politologicznej o świecie, między innymi w odniesieniu do środowiska międzynarodowego, np. o ponadczasowym i niehistorycznym charakterze integracji europejskiej, o zastąpieniu rywalizacji między państwami trwałą kooperacją, o zredukowaniu polityki do zarządzania państwem zgodnie z zasadami good governance. W tym fałszywym podejściu do ideologii i polityki widziano źródło pasywności i bierności na arenie europejskiej, preferowanych przez polskie ugrupowania lewicowe i liberalne. Dla PiS integracja europejska była procesem historycznym, to znaczy zachodzącym w określonym czasie, w zastanych warunkach społecznych i świadomościowych. Jak to ujął prezydent Duda: „Europa nie jest dziełem dzisiejszych polityków, jest nam powierzona przez pokolenia narodów europejskich, które tworzyły jej [...] historię"7. Takie poglądy miały zakotwiczenie w odrzuceniu teleologicznego charakteru historii (nie ma żadnego „końca historii"), dlatego też - jak konkludował A. Nowak - „Unia w obecnym swym kształcie nie stanowi jej ostatecznego horyzontu. Trzeba mieć odwagę spojrzeć dalej. Z tego punktu widzenia, który przekazała nam historia". To credo wyjaśnia stosunek polityków PiS do zaklinań o historycznych i niepodważalnych decyzjach podejmowanych w Brukseli i ich wielkiej doniosłości ${ }^{8}$.

Dla myśli politycznej PiS ważne było postrzeganie przezJ. Kaczyńskiego polityki zagranicznej w dwóch ujęciach typowo międzynarodowych:

\footnotetext{
6 Vide K. Zuba, Polska scena polityczna. Ciągtość i zmiana, Wydawnictwo Sejmowe, Warszawa 2012, s. 202-203.

7 Wystąienie Prezydenta RP na spotkaniu noworocznym z Korpusem Dyplomatycznym, 11 | 2018, http://www.prezydent.pl, dostęp 2 V 2020.

8 A. Nowak, Europa Wschodnia-polskie pytania..., s. 24.
} 
1) jako aktywności w postaci gry prowadzonej przez państwo, wykorzystujące swoje zasoby i umiejętności, aby je pomnożyć oraz zwiększyć swój wpływ polityczny na innych uczestników stosunków międzynarodowych; 2) jako stałego dążenia państwa do utrzymywania zmiennej równowagi między rywalizacją a współpracą w danym czasie, przestrzeni i sytuacji. Dochodziła jeszcze trzecia perspektywa - przekonanie, że polityka zagraniczna zależy od czynników wewnętrznych każdego państwa. Dla Kaczyńskiego najważniejsze były takie cechy odnoszące się do państwa, jak: 1) system polityczny przygotowany na sytuacje kryzysowe; 2) spójny model decydowania politycznego w polityce zagranicznej, pozwalający przyjąć i realizować określoną koncepcję polityki zagranicznej; 3) charakter środowiska politycznego sprawującego rządy w wyniku wyborów. W Polsce, według niego, tylko szeroko rozumiany ruch niepodległościowy mógł zapewnić optymalne podejście do kwestii stosunków międzynarodowych, które spełniałoby trzy kryteria: ocena zagrożeń międzynarodowych, opracowanie skutecznej strategii politycznej i mobilizacja zasobów na rzecz realizacji racji stanu i interesów narodowych. Drugie kryterium było mocno uwarunkowane zdolnością odczytywania przeszłości i kodu geopolitycznego. Prezes PiS nie przypisywał tych umiejętności (ani woli) przeciwnikom politycznym - począwszy od postkomunistów, a skończywszy na liberałach i narodowcach ${ }^{9}$.

Stawką w grze w stosunkach międzynarodowych jest najpierw zakres i zasięg podmiotowości, a następnie suwerenność państwa. Jedną z aren międzynarodowych, na których prowadzona jest owa gra, są organizacje międzynarodowe. Takie myślenie polityczne jest mocno osadzone w paradygmacie doktryny realizmu zarówno klasycznego (Hans Morgenthau, Max Weber), jak i strukturalnego (Kenneth Waltz, John Mearsheimer) ${ }^{10}$, ale również w filozofii politycznej egzystencjonalistycznej. Wybór paradygmatu analitycznego przez PiS w kontekście Unii Europejskiej był jak najbardziej trafny, bo - jak zauważył Jacek Więcławski w artykule

10 Changing World Order. The Republic of Turkey's Rise as a Middle Power, ed. N. Grimsel, Stellenbosch University, [b.m.w.] 2014, s. 18-20. 
o realizmie H. Morgenthaua - dopóki Unia nie stanie się federacją (lub konfederacją), dopóty podejście realistyczne ma sens, gdyż wyjaśnia mechanizm rywalizacji we Wspólnocie ${ }^{11}$. Wyraziste reminiscencje takiego sposobu myślenia odnajdujemy w programie PiS z 2019 roku, w części Diagnoza ${ }^{12}$.

Obowiązkiem polityka jest myślenie w kategoriach bytu państwowego, przygotowanie państwa na sytuacje kryzysowe, których źródłem mogą być poliarchiczne środowisko międzynarodowe, nierówny rozkład sił czy typ systemu bezpieczeństwa. Tym samym Unia Europejska jawiła się nie tylko jako arena międzynarodowej rozgrywki, ale także jako zasób, którym Polska - będąc jej członkiem - mogłaby dysponować w przypadku różnego rodzaju kryzysów. Przynależność doUnii była także odczytywana przez PiS jako wyraz suwerenności Rzeczypospolitej oraz wybór cywilizacyjno-kulturowy, który przekreślał następstwa II wojny światowej. W sposób jednoznaczny odrzucono więc mniemania, że współczesność zmieniła naturę nie tylko stosunków międzynarodowych, ale w ogóle rzeczywistości politycznej; rywalizacja i polaryzacja zostały bowiem zastąpione przez kompromis i dialog.

Prawo i Sprawiedliwość, opisując w ten sposób stosunki międzynarodowe w Europie, sformułowało w 2004 roku postulat polityki czynnej-jej celem miało być uzyskanie wpływu na procesy integracyjne na kontynencie oraz na ewolucję Unii. Polityka czynna była niezbędnym składnikiem eurorealizmu ${ }^{13}$. Wyodrębnienie się orientacji eurorealistycznej w analizie współczesnej polskiej myśli politycznej było w ostatniej dekadzie XX stulecia stosunkowo trudne, ponieważ dyskusji publicznej został narzucony, głównie przez środki komunikacji społecznej, podział dychotomiczny (biegunowy) - na entuzjastów i sceptyków. W roli podmiotu kreującego taki podział wystąpili zwolennicy Unii, gdyż zasadniczo upraszczał im propagandę unijną oraz nie zmuszał do polemiki wokół charakteru

\footnotetext{
11 J. Więctawski, Hans Morgentau, realizm klasyczny ijego rekomendacje dla polskiej polityki zagranicznej, "Myśl Ekonomiczna i Polityczna” 2011, nr 3, s. 121.

12 Dobry czas dla Polski..., s. 171.

13 Europa solidarnych narodów..., s. 5.
} 
Wspólnoty. Spory dotyczyły odpowiedzi na pytanie o zasadność wejścia Polski do wspólnot europejskich, natomiast nie sprzyjało to wykreowaniu polskiej koncepcji zarówno pożądanego kształtu Wspólnoty, jak również polityki europejskiej po spodziewanej akcesji do tej organizacji. O ile postawa przeciwników Wspólnoty była w tej materii jasna (krytykowali potrzebę obecności Polski w tej organizacji), o tyle stanowisko entuzjastów europejskich w Polsce było niejednoznaczne. Starali się być pasywni wobec toczonej wówczas w Europie dyskusji o kierunku rozwoju integracji, a jednocześnie nie formułowali polskiego oryginalnego stanowiska na temat wizji wspólnoty europejskiej. Racjonalność nie była mocną stroną tej debaty, zdominowanej przez emocje i dogmaty.

Rację miał Łukasz Machaj, który uznał, że taki kształt debaty był przyczyną słabości Polski w pierwszych latach obecności w Unii, tym bardziej że zasadniczo politykę europejską Rzeczypospolitej realizowali politycy rządzący już w latach dziewięćdziesiątych w rządach SLD-PSL i AWS-UW. Na tym tle stanowisko środowiska politycznego skupionego wokół J. Kaczyńskiego (głównie w Porozumieniu Centrum) zdecydowanie się wyróżniało, wskazywało bowiem perspektywę oceny sytuacji w Europie. Tą perspektywą miała być racja stanu Rzeczypospolitej i polski interes narodowy oraz odniesienie się do fundamentów rozwoju wspólnoty europejskiej ${ }^{14}$. W uchwale Kongresu PC w 1992 roku zaprezentowano uzasadnienie kursu europejskiego: „Polska ma za małe własne zasoby, by tylko wewnętrznymi siłami dokonać koniecznej przebudowy". W latach 1993-1994 w kolejnych dokumentach partyjnych PC sformułowano zadania dla Polski w postaci szybkiego wejścia do "struktur świata zachodniego" (Sojusz i Unia), ale "w całości, a nie de facto fragmentarycznie", ponieważ przeciwieństwem dla tego scenariusza mogła być „zależność od Rosji"15. Jednak w Polsce w latach dziewięćdziesiątych XX wieku

14 Zdominowanie debaty publicznej o integracji europejskiej w Polsce w latach dziewięćdziesiątych XX wieku przez entuzjastów i sceptyków zostało opisane w: Ł. Machaj, Za i przeciw Europie. Integracja europejska w polskiej myśli politycznej w latach 1989-2001, Wydawnictwo Uniwersytetu Wroctawskiego, Wroctaw 2006, passim.

15 Uchwata nr 4 II Kongresu Porozumienia Centrum „Porozumienie Centrum w obronie polskiej racji stanu", czerwiec 1992, Warszawa, [w:] Nowe państwo. Porozumienie Centrum 
i w pierwszej dekadzie XXI stulecia trudno było zostać zwolennikiem integracji europejskiej, który odrzucał europejską utopię o budowie federacji europejskiej lansowaną przez liberałów i lewicę, a jednocześnie kierował się racjonalnością.

Nie można mieć wątpliwości, że opisany dychotomiczny podział w oparciu o kryterium stosunku do integracji europejskiej był uproszczony, ale wyraźnie pokazywał zróżnicowanie poglądów na Unię Europejską. Entuzjaści byli gorącymi zwolennikami nie tylko kontynuacji tego projektu, ale również pogłębiania (zakres) i poszerzania (zasięg) Wspólnoty w kierunku federalizacji. Natomiast ich adwersarze, nawet jeśli nie negowali racji stojących u podstaw istnienia Wspólnoty, odrzucali zasadność akcesji Polski do niej. W obu przypadkach źródeł takich poglądów należy szukać raczej w założeniach ideologicznych (ideologiczne źródła myśli politycznej) niż w diagnozie, analizie i ocenie rzeczywistości politycznej, w tym stosunków międzynarodowych (pragmatyczne źródła myśli politycznej).

Z tych powodów euroentuzjazm i eurosceptycyzm stały się postawami dogmatycznymi, a nosiciele takich poglądów nie byli skłonni do zawarcia jakiegokolwiek kompromisu czy też dokonania zmian w swoich opiniach pod wpływem oceny trendów międzynarodowych, a zwłaszcza sytuacji w Europie, podczas gdy: „Integracja europejska to nie jakaś czekająca na realizację wizja polityczna, lecz stan faktyczny" ${ }^{16}$. Natomiast rację miał Krzysztof Zuba, który już w 2006 roku odnotował, że eurorealizm jest kategorią kluczową w analizowaniu postaw wobec integracji europejskiej. Proponował, żeby debaty na ten temat nie spłycać do podziału na sceptyków i entuzjastów ${ }^{17}$. Mimo takich ustaleń jeszcze w 2012 roku Danuta Karnowska pisała w opracowaniu naukowym, a nie w artykule

w dokumentach..., s. 130; Program Porozumienia Centrum dotyczący polityki zagranicznej, 1993, Warszawa, [w:] Nowe państwo. Porozumienie Centrum w dokumentach..., s. 172; Uchwata nr 7 III Kongresu Porozumienia Centrum w sprawie przystapienia Polski do NATO i Unii Europejskiej, [w:] Nowe państwo. Porozumienie Centrum w dokumentach..., s. 192.

16 Polska katolicka w chrześcijańskiej Europie, PiS, Warszawa 2005, s. 46.

17 K. Zuba, Polski eurosceptycyzm i eurorealizm, Wydawnictwo Uniwersytetu Opolskiego, Opole 2006, s. 55. 
publicystycznym: „Prawo i Sprawiedliwość wpisywało się swoją polityką wobec Unii Europejskiej w trend określany popularnie eurosceptycznym lub eurorealistycznym"18.

Cechą eurorealizmu jest generalna akceptacja integracji, ale z istotnymi zastrzeżeniami: 1) wobec niektórych jej form i przejawów tworzących pozapaństwową przestrzeń publiczną; 2) wobec kierunku, nadanego jej w ostatnich dwóch dekadach, faktycznego przejmowania ważnych kompetencji państw członkowskich przez instytucje wspólnotowe; 3) wobec celu w postaci najpierw suprapaństwa, a następnie federacji europejskiej oraz ludu europejskiego jako podstawy społecznej; 4) wobec procedur i negocjacji właściwych dla systemu politycznego Unii Europejskiej wypierających wartości, na których powinna opierać się Wspólnota.

Po osiągnięciu przez Polskę w latach 1999-2004 głównych założeń z zakresu polityki zagranicznej, co do których istniała polityczna zgoda niemal wszystkich głównych partii parlamentarnych - przyjęcia do Sojuszu Północnoatlantyckiego i akcesji do Unii Europejskiej - doszło między nimi do polaryzacji stanowisk na płaszczyźnie międzynarodowej i podziału na dwa bieguny: liberalno-lewicowy i konserwatywny (dopełnieniem był nurt narodowy). W sferze werbalnej znacznie ostrzejszy był spór o Unię Europejską niż o Sojusz Północnoatlantycki. Polaryzacja nie tylko uniemożliwiła wypracowanie polskiej doktryny integracyjnej, ale też pogłębiała się wraz z zacieśnianiem się związków między Polską a Unią Europejską ${ }^{19}$. Jednak głównymi stronami sporu w Polsce stali się realiści i entuzjaści, przy bardzo słabej pozycji sceptyków, zwłaszcza wtedy gdy wybory w 2007 roku zakończyły się wygraną PO oraz zdominowaniem prawicy przez PiS. Sceptycy stracili dostęp do trybuny sejmowej i do głównych mediów. Wówczas zaostrzył się także

18 D. Karnowska, Polityka zagraniczna Prawa i Sprawiedliwości w latach 2005-2011. Próba bilansu, „Nowa Polityka Wschodnia” 2012, nr 2(3), s. 48.

19 K. Zuba, Polska, [w:] Doktryny integracyjne państw europejskich, red. K. Zuba, Wydawnictwo Sejmowe, Warszawa 2017, s. 196-197; A. Podolski, Czy Polska ma doktrynę integracyjną?, [w:] Czy Polska ma doktrynęintegracyjną?, Ośrodek Myśli Politycznej, Kraków 1998, s. 107. 
spór o UE toczony w Polsce między realistami a entuzjastami. Wzmacniały go dwa istotne zjawiska.

Po pierwsze, w wyniku alternacji władzy stronnictwo eurorealistyczne w postaci PiS sprawowało rządy naprzemiennie z euroentuzjastami lewicowymi i liberalnymi, co dawało realistom możliwość kształtowania modelu polityki zagranicznej wynikającego z własnej myśli politycznej. Taki stan był możliwy w niewielu państwach członkowskich Unii, a faktycznie miał miejsce w XXI wieku w Zjednoczonym Królestwie, na Węgrzech i we Włoszech. Po drugie, stronnictwa lewicowe i liberalne w Polsce zostały zepchnięte w kierunku entuzjastycznego interpretowania teorii integracji europejskich. Po 2007 roku w PO zanikły relikty recypowania do myślenia politycznego o Unii Europejskiej paradygmatu realistycznego. Europejskie nastawienie PO miało ją odróżniać od PiS, które zostało okrzyknięte przez polskich liberałów i lewicę jako ugrupowanie sceptyczne. Tak więc im bardziej PiS prezentowało swój realizm wobec Unii i wolę przeciwstawiania się niektórym projektom i decyzjom organów wspólnotowych, tym bardziej PO stawała się bezkrytyczna wobec Unii i przechodziła na pozycje ortodoksyjnie entuzjastyczne.

W debatach publicznych na temat integracji europejskiej toczonych w III Rzeczypospolitej rzadko posługiwano się takimi kategoriami, jak racja stanu i interes narodowy, podmiot polityczny i środek polityczny. Czynnikiem łączącym euroentuzjastów i eurosceptyków było traktowanie wspólnoty europejskiej jako podmiotu politycznego, który jest uprawniony do posiadania swoich interesów i może je realizować suwerennie w środowisku międzynarodowym. Dla entuzjastów wspólnota europejska - oceniana zdecydowanie pozytywnie jako nieuchronność historyczna, niemal spełnienie historii i osiągnięcie przez Europejczyków najważniejszego dla nich celu - stawała się stopniowo nadrzędna wobec państwa, uprawniona do ograniczania jego suwerenności, a nawet do ingerencji w jego sytuację wewnętrzną; odpowiednikiem społecznym i mentalnym miały być lud europejski i tożsamość europejska. To one w perspektywie najbliższych lat miały zdominować świadomość społeczną, wypierając z niej identyfikację narodową i państwową. Bez żadnych wątpliwości, Unię Europejską traktowano nie jako organizację 
międzynarodową, ale jako podmiot specjalnego typu już w formie uzyskanej w ostatniej dekadzie XX wieku, stąd też pojęcie „suprapaństwo". Euroentuzjaści uznali na tym etapie integracji Wspólnotę za suprapaństwo (quasi-państwo) - transnarodowy byt polityczny roszczący sobie prawo do suwerenności zastrzeżonej tylko dla państw, jednak zawieszony w próżni społecznej, w tym tożsamościowej oraz ekonomicznej (minimalny budżet będący w dyspozycji instytucji unijnych w porównaniu z produktem krajowym brutto wypracowanym w Europie), co w zasadniczy sposób odróżnia go od superpaństwa. Mieszkańcy tego suprapaństwa mają stanowić społeczność ponadnarodową lub bardziej postnarodową, która powstaje dzięki wysiłkom instytucji unijnych, ustanawiających niemal suwerennie abstrakcyjne wartości traktowane jako uniwersalne, na które składają się procedury i mechanizmy. Zwolennicy tego trendu z nadzieją oczekują, że gdy powiedzie się ten konstruktywistyczny eksperyment, wówczas narodzi się federacja europejska - superpaństwo powstałe "na gruzach" narodów zamienionych w Europejczyków ${ }^{20}$. Dla PiS jest to nie tylko nieakceptowalny kierunek zmian politycznych, ale również fałszowanie i zniekształcanie rzeczywistości europejskiej, zdominowanej przez narody i reprezentujące je państwa o własnej tożsamości politycznej, ukształtowanej w wyniku procesu historycznego.

Takie podejście w sferze politycznej mogło rozwijać się stosunkowo łatwo, ponieważ - jak napisała Magdalena Zając-Frąs - większość teorii integracji powstałych w ostatnich dekadach, zarówno tych klasycznych, jak i nowoczesnych, czerpała z paradygmatu liberalnego. W liberalizmie zakorzenione były: federalizm, (neo)funkcjonalizm, teoria komunikacyjna, podejście międzyrządowe, instytucjonalizm i wielopoziomowy system zarządzania ${ }^{21}$. To właśnie dla liberałów Unia stała się wyjątkowo ważnym przedmiotem analiz naukowych i projekcji rozwojowych, a jednocześnie argumentem za tym, że stosunki międzynarodowe ule-

\footnotetext{
20 Vide Z. Krasnodębski, Większego cudu nie będzie. Zebrane eseje i szkice IV, Ośrodek Myśli Politycznej, Kraków 2011, s. 13-15.

${ }_{21}$ M. Zając-Frąs, Teorie i modele integracji europejskiej, „Zeszyty Naukowe Uniwersytetu Ekonomicznego w Krakowie" 2011, nr 852, s. 6.
} 
gły zasadniczym zmianom o charakterze historycznym; podczas gdy dla realistów Unia była tylko jedną z organizacji międzynarodowych, którą należy analizować z wykorzystaniem utrwalonej wiedzy o stosunkach międzynarodowych, polityce zagranicznej i państwie. Mieli rację Jeffrey W. Legro i Andrew Moravcsik, pisząc w 1999 roku, że realizm jako paradygmat teoretyczny jest w kłopocie odnośnie do Unii Europejskiej ${ }^{22}$. W odniesieniu do PiS za miarodajne możemy uznać poglądy Szczerskiego na temat dominujących teorii integracyjnych. Za ewidentną słabość uznał on niedostrzeganie złożoności relacji między wspólnotą europejską a państwami narodowymi. Te relacje zostały oparte na błędnym założeniu, że integracja osłabia państwa narodowe w kontekście przesunięcia ich suwerenności na Wspólnotę, podczas gdy faktycznie prowadzi do powstania między nimi zróżnicowania, nierówności i zhierarchizowania. W wyniku tych procesów jedne państwa znacznie zwiększyły swój potencjał polityczny oraz wpływ na środowisko międzynarodowe (mocarstwa europejskie), a suwerenność innych została zredukowana (państwa średnie i małe) ${ }^{23}$.

Sceptycy europejscy także dokonywali nadinterpretacji roli politycznej Unii, widząc w niej zagrożenie dla państwa i narodu polskiego w sensie tożsamościowym, mentalnym, cywilizacyjnym, kulturowym, społecznym i ekonomicznym. W ich mniemaniu Polska mogła sięlepiej rozwijać, pozostając poza Wspólnotą, postrzeganą także jako podmiot polityczny, ale w sposób jednoznacznie negatywny ${ }^{24}$.

22 J. W. Legro, A. Moravcsik, Is Anybody still Realist?, "International Security" 1999, $\mathrm{nr} 24(2)$, s. 4.

23 K. Szczerski, Utopia europejska..., s. 8-9.

24 Rozważania na temat eurosceptycyzmu oraz jego typów w zasadzie spłaszczają różnicę między tym nurtem myśli politycznej a eurorealizmem, zacierają między nimi różnice i wyodrębniają eurosceptycyzm twardy i miękki. Confer K. Zuba, Polski eurosceptycyzm w kontekście dylematów teoretycznych i porównawczych, "Politeja” 2015, nr 33(1), s. 155176; A. Pacześniak, Eurosceptycyzm polskich partii politycznych - ile w tym przekonania, a ile pragmatyzmu?, „Politeja” 2015, nr 33(1), s. 177-200; A. Pleśniarska, Integracja europejska w obliczu eurosceptycyzmu, "Zeszyty Naukowe Uniwersytetu Ekonomicznego w Krakowie" 2017, nr 966(6), s. 29-43. 
Dychotomiczny podział areny politycznej w Polsce ulegał stopniowej dekompozycji w XXI wieku wraz z umacnianiem się, mierzonego wpływami wyborczymi, potencjału politycznego stronnictwa PiS, które zaproponowało ocenę integracji europejskiej diametralnie inną od oceny zarówno sceptyków, jak i entuzjastów ${ }^{25}$. Jednak owa odmienność bardzo długo "gubiła się" w ostrym sporze ideologiczno-politycznym między dwoma skrajnymi biegunami areny politycznej w III Rzeczypospolitej. Środowisko polityczne skupione wokół J. Kaczyńskiego w II połowie lat dziewięćdziesiątych XX stulecia nie dysponowało stosowną siłą ani w parlamencie, ani w środkach komunikacji społecznej, żeby dokonać dekompozycji w odniesieniu do tej sytuacji. Natomiast stanowisko europejskie zarówno PC, jak i PiS wynikało w sensie poznawczym z realizmu. Koncentrowano uwagę na mechanizmie rządzącym środowiskiem międzynarodowym oraz warunkującym politykę zagraniczną, a także na związkach przyczynowo-skutkowych. Kierowano się również realistyczną doktryną stosunków międzynarodowych, czyli rozpatrywano politykę zagraniczną Polski na poziomie państwa i systemu międzynarodowego ${ }^{26}$. Zdekonstruowanie wspomnianego dychotomicznego charakteru sporu o Unię Europejską było dla PiS zadaniem stosunkowo trudnym z powodu jaźni odzwierciedlonej, jaką uzyskało stronnictwo. Warto odwołać się do ocen badaczy problematyki europejskiej, które są w kontrze do najważniejszych źródeł z zakresu myśli politycznej PiS.

Beata Master w odniesieniu do PiS trafnie zauważyła, że jest to „Partia postrzegana w Polsce i za granicą jako eurosceptyczna” (pozostawiając to stwierdzenie bez komentarza). Natomiast Anetta Grzesik-Robak sformułowała kuriozalną ocenę, nie potrafiąc przezwyciężyć politycznej dychotomii utrwalonej na przełomie XX i XXI wieku. Według niej PiS „w kwestii wejścia Polski do UE reprezentuje umiarkowany euroentuzjazm, momentami graniczący z eurosceptycyzmem". Jarosław Och zaliczył PiS do tej samej grupy partii co Samoobronę i LPR, a jednocze-

25 Vide W. Paruch, Przeszłość w myśli politycznej Prawa i Sprawiedliwości..., s. 483-498.

26 J. Czaputowicz, System międzynarodowy jako poziom analizy w nauce o stosunkach międzynarodowych, s. 4-10, http://ptsm.edu.pl, dostęp 1 XI 2017. 
śnie zaznaczył: „PiS w sprawach przyszłości Unii reprezentowało stanowisko Unii przychylne". Taki sposób wnioskowania odzwierciedlał nie tyle efekt krytyki i interpretacji źródeł wytworzonych przez PiS, ile atmosferę tworzoną przez media w Polsce, zwłaszcza w okresie rządów koalicji PO-PSL ${ }^{27}$. Nie przyjmowano też do wiadomości, że analizowanie Unii odmienne od liberalno-lewicowego, poprzez wskazywanie na stosowane w niej mechanizmy decyzyjne, nie jest równoznaczne z postawą eurosceptyczną czy też antyunijną, lecz wynika przede wszystkim z realizmu poznawczego i politycznego. W ramach rywalizacji politycznej stronnictwa lewicowe i liberalne, a przede wszystkim środki komunikacji społecznej zaliczane do tych nurtów ideowych, nakreśliły obraz PiS jako formacji antyeuropejskiej, a w okresie 2015-2019, kiedy PiS sprawowało rządy, a opozycja przyjęła charakter totalny, przypisano obozowi rządzącemu działania na rzecz wyjścia Polski ze Wspólnoty, zwłaszcza po opuszczeniu jej przez Wielką Brytanię.

W polskiej politologii dopiero Joanna Sanecka-Tyczyńska, analizując rację stanu we współczesnej myśli politycznej, wskazała najważniejsze cechy eurosceptycyzmu na przykładzie LPR, co jednoznacznie pokazało odmienność eurosceptycyzmu i eurorealizmu. Dla sceptyków Unia Europejska jest zaprzeczeniem integracji europejskiej, dlatego - ich zdaniem - Polska powinna funkcjonować poza Wspólnotą, która jest szkodliwa dla interesów narodowych, godzi w wartości chrześcijańskie, jest niebezpieczna dla demokracji, przypomina wspólnotę komunistyczną ${ }^{28}$.

27 B. Master, Unia Europejska w programach głównych polskich ugrupowań politycznych po 2004 roku, "Studia Politicae Universitatis Silesiensis” 2014, t. 12, s. 57; A. Grzesik-Robak, Wzmocnienie czy ostabienie suwerenności państwowej w kontekście integracji europejskiej w opinii wybranych polskich partii politycznych, "Studia Europejskie” 2007, nr 1, s. 40; M. Bonikowska, Przysztość Unii Europejskiej w kontekście prowadzonej obecnie debaty, [w:] Ksztattowanie się nowego tadu międzynarodowego, red. A. Chodubski i inni, Fundacja Rozwoju Uniwersytetu Gdańskiego, Gdańsk 2007, s. 261-264; J. Och, Polskie elity partyjne wobec przysztości Unii Europejskiej - perspektywa 1989-2008, czasopisma. bg.ug.edu.pl, DOI: 10.5604/01.3001.0013.1592, s. 292-293, 300.

28 J. Sanecka-Tyczyńska, Racja stanu we wspótczesnej polskiej myśli politycznej..., s. 344-349. 
Biorąc pod uwagę wyniki badań Ewy Nalewajko i Krzysztofa Zuby nad źródłami postaw w Polsce wobec integracji, należy stwierdzić istnienie w odniesieniu do PiS trzech źródeł myśli politycznej stronnictwa w kontekście europejskim: 1) ideologiczno-programowego; 2) politycznego; 3) poznawczego ${ }^{29}$. Politycy PiS wypracowali własną perspektywę aksjologiczną oraz metodę analizowania Unii Europejskiej z wykorzystaniem kategorii politycznych obecnych w doktrynie (neo)realistycznej, a także rozpoznawania zachodzących w niej procesów i zjawisk. Samodzielna diagnoza i ocena pozwalały opracować własną koncepcję integracji europejskiej oraz wynikające z niej konkretne programy. Należy podkreślić, że Unii nie traktowano jako hemisfery odrębnej od stosunków transatlantyckich czy też sytuacji na kontynencie i w regionie. Polityka wobec instytucji unijnych oraz wewnątrz tej organizacji międzynarodowej niejednokrotnie była pochodną innych ważnych kwestii międzynarodowych: rosyjskiej, niemieckiej, amerykańskiej, środkowoeuropejskiej i wschodnioeuropejskiej.

Wybór orientacji eurorealistycznej przez PiS miał, podobnie jak stosunek do Sojuszu Północnoatlantyckiego, głęboko ideologiczny charakter. Wynikał z debaty toczonej jeszcze w Porozumieniu Centrum, w czasie której poddano krytyce i w konsekwencji odrzucono zarówno integracyjne projekty entuzjastyczne, jak i alternatywne wobec wspólnot idee organizacji stosunków międzynarodowych w Europie. To w programie PC z 1991 roku zapisano wyjątkowo ważne wtedy zdanie: „[...] szukanie trzeciej drogi między Zachodem i Wschodem jest niebezpiecznym błędem narażającym nasz kraj na osamotnienie i podporządkowanie cudzym interesom"30. PiS po kryzysie formacji eurosceptycznych (LPR i Samoobrona RP), dążąc w latach 2008-2015 do odzyskania władzy, zagospodarowało wyborców niechętnych Unii Europejskiej i ambiwa-

29 E. Nalewajko, Eurosceptyczne partie $i$ ich liderzy w publicznej debacie o integracji wprowadzonej w latach 2000-2003, [w:] Przed referendum europejskim - absencja, sprzeciw, poparcie, red. L. Kolarska-Bobińska, Instytut Spraw Publicznych, Warszawa 2003, s. 117123; K. Zuba, Polski eurosceptycyzm i eurorealizm..., s. 137-166.

30 Deklaracja programowa Porozumienia Obywatelskiego Centrum wrzesień 1991, Warszawa, [w:] Nowe państwo. Porozumienie Centrum w dokumentach..., s. 69. 
lentnych wobec niej, „oswajając” ich z akceptacją integracji europejskiej jako korzystnej dla nich i dla Polski oraz pokazując, że konsekwencje akcesji są zależne od postawy władz RP na forum tej organizacji międzynarodowej. Te zabiegi zyskiwały na znaczeniu w warunkach najpierw (2001-2005) rywalizacji z PO o podobny elektorat, a następnie sprawowania rządów w Polsce przez euroentuzjastyczną PO i ewoluujące w tym kierunku PSL (2007-2015).

Najlepszym dowodem na kierowanie się przez liderów PiS realizmem poznawczym oraz doktryną (neo)realistyczną stosunków międzynarodowych jest zapis w Manifeście politycznym PiS z 2001 roku, czyli przed podjęciem przez Polaków ostatecznej decyzji w referendum akcesyjnym: „musi [je] poprzedzić rzetelna analiza doraźnych i możliwych do przewidzenia długofalowych skutków integracji oraz kosztów rezygnacji z członkostwa w Unii Europejskiej" ${ }^{31}$. Powtórzył te racje L. Kaczyński dwa lata później, mówiąc, iż w debacie akcesyjnej należy rozważyć zalety i wady kontraktu europejskiego, „polityków bowiem nie stać na entuzjazm ani na pesymizm, muszą walczyć o interes swojego narodu i państwa"32.

Prawo i Sprawiedliwość uważało, że dyskusja przed referendum była absurdalna, ponieważ polegała na starciu dwóch postaw dogmatycznych, a powinna koncentrować się na rzeczowym podejściu do problemu pod kątem zysków i strat, jakie są związane z wejściem Polski do UE. W tej sprawie wypowiedział się już Kongres Założycielski PiS w 2001 roku, kiedy zaprezentowano stanowisko, że podjęcie decyzji o akcesji do Unii powinno być poprzedzone rzetelną analizą doraźnych i długofalowych skutków integracji, zysków członkostwa, gdyż: „Naród musi zdecydować świadomie". Wtedy nie tylko nawoływano do przeprowadzenia kalkulacji politycznej w sprawie wejścia do Unii, ale również przestrzegano, że Wspólnota, do której Polska aspiruje, nie przypomina już EWG, przyjęto bowiem kurs na unię polityczną, zdominowaną coraz bardziej przez po-

31 Prawo i Sprawiedliwość - Manifest polityczny, „Polska Scena Polityczna. Vademecum partii i ugrupowań politycznych" 2001, nr 11, s. 10.

32 L. Kaczyński, Jeśli Wrzodak, daję dyla..., s. 13. 
prawność polityczną. Natomiast wprowadzenie euro postrzegano jako czynnik, który postawił Unię na rozdrożu: albo budowa suprapaństwa prowadząca do powstania federacji jako superpaństwa, albo nieuchronny kryzys strefy euro jako konstrukcji ekonomicznej i politycznej Europy. Konkludowano: „Wejście do Unii ma sens, jeżeli będzie w istotny sposób sprzyjać szybkiemu rozwojowi gospodarczemu i jednocześnie zapewni nam realny wpływ na całość biegu spraw europejskich".

Taki pogląd w tamtych latach wyróżniał PiS na arenie politycznej w Polsce, zdominowanej przez stronnictwa rozumujące o integracji w kategoriach jedynie ideologicznych i emocjonalnych, a nie pragmatycznych i racjonalnych. Ton debacie nadawała lewica i liberałowie oraz narodowcy. PiS udzieliło poparcia akcesji Polski do Unii, ale jednocześnie opisano domniemane konsekwencje. Z jednej strony Polska mogła zostać uzależniona jako peryferie od obcego centrum politycznego zainteresowanego utrzymywaniem nad Wisłą status quo społecznego oraz stworzeniem korzystnych warunków do przejęcia licznych polskich zasobów, ale z drugiej strony Polska mogła mieć szansę na przyspieszony rozwój połączony z wpływem na kształt Europy. Rozstrzygnięcie między tymi scenariuszami miało zależeć od polityki, dlatego PiS podkreślało, że najważniejsza jest jakość polskiej obecności w tej organizacji (a nie termin wstąpienia do niej). W celu zapewnienia owej jakości sformułowano warunek brzegowy obecności w Unii - zachowanie suwerennego i unitarnego państwa narodowego, co zagwarantuje urzeczywistnianie interesów narodowych oraz utrzymanie ładu demokratycznego. Powtórzono te opinie w programie z 2003 roku $^{33}$.

Dla PiS akcesja Polski do Unii Europejskiej była zarówno koniecznością historyczną, a nawet fatalizmem dziejowym, jak również wyborem pragmatycznym i wyrazem sprawiedliwości dziejowej za „zdradę” Zachodu po II wojnie światowej. Dlatego też PiS opowiedziało się jednoznacznie za wejściem Polski do wspólnot z powodów aksjologicznych i zarazem pragmatycznych, opartych z jednej strony na wiedzy historycz-

33 Vide i confer Dokumenty programowe i ideowe. Kongres zatożycielski Prawo i Sprawiedliwość..., s. 8, 29, 74; Program Prawa i Sprawiedliwości [2003]..., s. 27. 
nej, a z drugiej strony na ewaluacji środowiska międzynarodowego w ujęciu długookresowym. Alternatywnym rozwiązaniem było pozostanie poza Unią, co dla PiS oznaczało podporządkowanie Rosji. Decyzję w tej sprawie podjął Kongres partii 18 stycznia 2003 roku. W jej uzasadnieniu napisano, że takiego wyboru partia dokonuje warunkowo, „w imię racji bezpieczeństwa kraju i umocnienia naszej pozycji na arenie międzynarodowej”. To właśnie podstawowe racje państwa „przemawiają za podjęciem ryzyka zmierzenia się z niesatysfakcjonującymi warunkami akcesji w dziedzinie ekonomicznej i społecznej" ${ }^{34}$.

Pozostawanie Polski poza Unią Europejską oznaczałoby jednocześnie trwanie w "szarej strefie", nieustannie poddawanej penetracji przez Rosję, prowadzącej do uzależnienia zgodnie z mechanizmem dziejowym utrwalanym od XVIII wieku. Ten europejski wybór jasno określił J. Kaczyński w 2002 roku: „Polska w obecnym układzie sił w Europie po prostu nie ma innego wyjścia" ${ }^{35}$. Przemawiały za taką decyzją: ewaluacja stanu państwa polskiego, racje geopolityczne, przede wszystkim obawa przed Rosją, oraz czynniki ekonomiczne ${ }^{36}$. Jednak te same kryteria, które przemawiały za wejściem Polski do Unii Europejskiej, były przez władze PiS wykorzystywane w latach 2002-2004 do krytykowania traktatu akcesyjnego wynegocjowanego przez rząd SLD-PSL. Politycy PiS byli przekonani, że istniała możliwość takiego poprowadzenia gry politycznej, aby możliwe było wynegocjowanie dla Polski lepszych warunków akcesyjnych do $\mathrm{UE}^{37}$.

34 Polska polityka europejska. Uchwata nr 52003 Kongresu Założycielskiego "Prawa iSprawiedliwość”, Falenty 18 / 2003, „Międzynarodowy Przegląd Polityczny” 2003, nr 1, s. 109-114.

35 J. Kaczyński, Nie boję się o wartości [Rozmowa Jarostawa Kurskiego z Jarostawem Kaczyńskim], „Gazeta Wyborcza”, 12 IV 2002, nr 86, s. 18.

36 Idem, Wywiad z prezesem Prawa i Sprawiedliwości [Rozmawiał Maciej Małecki] „ Przegląd Europejski" 2003, nr 1, s. 112; vide L. Kaczyński, Wspinaczka wśród spadających kamieni [Rozmowa Rafała Pazio z Lechem Kaczyńskim], „Najwyższy Czas” 2003, nr 11, s. 9.

37 Uchwała Zarządu Gtównego Prawo i Sprawiedliwość z dnia 16 listopada 2002 w sprawie działań mających na celu poprawę warunków członkostwa Polski w Unii Europejskiej, „Polska Scena Polityczna. Vademecum partii i ugrupowań politycznych" 2002, nr 21, s. 6. 
Partia kierowana przez J. Kaczyńskiego uznała wspólnoty europejskie za środek polityczny, którym Polska powinna się posługiwać w realizacji swoich interesów. Oznaczało to odrzucenie poglądów, że Wspólnota jest podmiotem politycznym. Krzysztof Szczerski proponował, żeby traktować system europejski w sposób realistyczny, czyli za pomocą takich kategorii, jak: stratyfikacja, przewaga, sojusz, relacje centrum-peryferie, klientelizm, czyli pojęć, których polityka europejska nie toleruje, gdyż nie są właściwe dla postpolityki. Polska, chcąc korzystać z tego ważnego środka politycznego, powinna zostać członkiem tej Wspólnoty, gdyż wtedy uzyskałaby wpływ na jej funkcjonowanie i mogłaby wykorzystywać ją jako instrument w polityce wewnętrznej (modernizacja) i zagranicznej (lewarowanie). O ile ocena Sojuszu Północnoatlantyckiego była oczywista - uznano go za klasyczną koalicję zawartą między państwami w celu obrony przed wrogiem, o tyle ewaluacja Unii Europejskiej była bardziej skomplikowana z racji popularności i dominacji w przekazach medialnych haseł głoszonych przez euroentuzjastów o wyjątkowym suprapaństwowym charakterze tej Wspólnoty.

Czynnikiem rozstrzygającym o odrzuceniu tego twierdzenia było przekonanie, że nie istnieje lud europejski, na kontynencie zamieszkują narody, a wspólne cechy kulturowe wynikające z chrześcijaństwa nie wystarczą, żeby ukształtował się demos europejski. Dla Lecha Kaczyńskiego brak takiego demosu oznaczał jednocześnie nieistnienie ani tożsamości europejskiej, ani europejskiej opinii publicznej. Prezydent mówił 24 stycznia 2006 roku w wywiadzie dla PAP: „Dzisiaj Europejczycy definiują się jednak raczej jako Polacy, Niemcy, Francuzi, Duńczycy itd. [...] Tożsamość europejska, o której się wspomina, jeżeli występuje, to najwyżej w opozycji do czegoś - na przykład w opozycji do Stanów Zjednoczonych. A budowa wspólnej tożsamości na bazie antagonizmów to najgorsza droga dla jednoczącej się Europy"38. Sen Immanuela Kanta o zwycięstwie idei Weltbürgertum nie spełnił się - nie można zbudować państwa wbrew faktycznym warunkom, w zgodzie z wymyślonymi

38 Wywiad prezydenta Lecha Kaczyńskiego dla PAP na tematy międzynarodowe, 24 I 2006, http://www.pap.pl, dostęp 24 VIII 2014. 
teoretycznymi zasadami. Nie spełnił się w całej rozciągłości, lecz fragmentarycznie - tak, w odniesieniu do części elit społecznych. Prezydent wspomniał o tym na spotkaniu z kanclerz Merkel w 2006 roku, formułując wniosek, że w takiej sytuacji socjopolitycznej czynnikiem spajającym Unię może być solidarność państw członkowskich budowana wokół wspólnoty interesów ${ }^{39}$.

Jeśli Unia Europejska nie ma odpowiednika w strukturze społecznej, to oznacza, że jest jedynie systemem instytucji typu władczego, które są poddawane penetracji przez poszczególne państwa członkowskie. $\mathrm{Z}$ tego powodu teza o nieuchronnej potrzebie dążenia do zbudowania państwa europejskiego, wbrew stosunkom społecznym, jest niebezpieczną utopią, która w ujęciu średniookresowym doprowadzi do: 1) zawłaszczenia coraz silniejszych instytucji wspólnotowych przez mocarstwa europejskie; 2) ukształtowania się centrum europejskiego w postaci koncertu mocarstw zachodnioeuropejskich (Europa karolińska) oraz peryferii środkowoeuropejskich i południowoeuropejskich;3) podjęcia dialogu przez mocarstwa europejskie, a zwłaszcza Niemcy, z Rosją w sprawie rozgraniczenia stref wpływów; 4) trwałego przekształcenia Europy Środkowej w peryferie Unii Europejskiej z zagwarantowanymi interesami Rosji. Natomiast w ujęciu długookresowym państwo europejskie ukształtowane wbrew stosunkom społecznym byłoby efemerydą skazaną na klęskę w globalnej rywalizacji oraz na kryzys prowadzący do upadku Unii i dominacji Rosji w Europie. Mimo tych rozlicznych zastrzeżeń najważniejsi politycy PiS wielokrotnie składali europejskie deklaracje, dlatego też za miarodajne możemy uznać w tym przypadku słowa L. Kaczyńskiego z 2006 roku: „[...] jestem za Unią Europejską.

39 P. Semka, op. cit., s. 248; K. Szczerski, Dynamika systemu europejskiego. Rozważania o nowym ksztatcie polityki w Unii Europejskiej, Wydawnictwo Uniwersytetu Jagiellońskiego, Kraków 2008, s. 157; Archiwum MSZ, sygn. 140/o9, w. 1, „Notatka informacyjna z wizyty Prezydenta Rzeczypospolitej Polskiej, Pana Lecha Kaczyńskiego w Berlinie, 8-9 marca 2006 r.", 21 III 2006, s. 3-4. 
Twierdzenia, że należę do przeciwników Unii, są najgłębszym nieporozumieniem. Uważam wejście Polski do UE za wielki sukces" ${ }^{40}$.

Prawo i Sprawiedliwość zracjonalizowało stosunek do integracji europejskiej w rozumieniu instytucjonalnym i procesualnym. Instytucje europejskie traktowano jako płaszczyznę, na której państwa prowadzą grę polityczną, rywalizując o zaspokojenie swoich egoistycznych roszczeń. W tym kontekście politycy PiS przywracali polityce jej właściwy wymiar związany z politycznością i myśleniem w kategoriach wrógsojusznik. Natomiast w sensie procesualnym znacznie większy nacisk położono na dynamikę procesów niż na konkretne stany. Z tego powodu wyjątkowo ważne było mnożenie zasobów będących w dyspozycji Polski oraz podnoszenie jej potencjału politycznego, żeby rozszerzać i pogłębiać podmiotowość. Najważniejszymi czynnikami decydującymi o statusie Polski w grze europejskiej były: zachowanie suwerenności, szeroka podmiotowość oraz kondycja państwa - tylko sprawne państwo mogło bowiem wykorzystywać swoje zasoby na forum Unii, uczestnicząc w przetargach o pozyskanie kolejnych ${ }^{41}$. Dlatego też w 2002 roku PiS sformułowało postulat nowelizacji konstytucji, aby zagwarantować wyższość polskiego prawa konstytucyjnego nad traktatami unijnymi. Widziano w tym rozwiązaniu zabezpieczenie przez możliwymi eksperymentami prawnymi w $\mathrm{UE}^{42}$. W tej kwestii wzorowano się na rozwiązaniach przyjętych w RFN. W programie z 2011 roku zapisano więc: „Polska Konstytucja mówi o wyższości norm konstytucyjnych w stosunku do umów międzynarodowych i przepisów wydawanych przez Unię Europejską", tym samym Polska nie może zgodzić się na przyjęcie rozwiązania traktatowego przyznającego prawu europejskiemu pozycję nadrzędną wobec konstytucji RP. Konkretnie domagano się respektowania dwóch zasad: 1) wszelkie rozstrzygnięcia traktatowe przenoszące kompetencje państwowe na rzecz Unii powinny być zatwierdzane w drodze referen-

\footnotetext{
40 Wywiad prezydenta Lecha Kaczyńskiego dla PAP na tematy międzynarodowe, 24 I 2006, http://www.pap.pl, dostęp 24 VIII 2014.

${ }_{41}$ K. M. Ujazdowski, Wystąpienie, [w:] SS Sejm, 4 kadencja, 16 pos., 14 III 2002, http:// orka2.sejm.gov.pl, dostęp 15 IX 2009.

42 Uchwała Zarządu Gtównego Prawo i Sprawiedliwość..., s. 327.
} 
dum; 2) Trybunał Konstytucyjny dysponuje prawem oceny zgodności traktatów unijnych z konstytucją $\mathrm{RP}^{43}$.

Ten wątek był rozwijany w następnych programach upublicznianych przez PiS. Odwołajmy się do dwóch z nich, powstałych w latach 2010-2011, czyli w okresie bycia przez PiS w opozycji. W projekcie nowej konstytucji z 2010 roku zamieszczono normę: „Wszystkie przepisy prawne wydawane lub stosowane przez władze Rzeczypospolitej Polskiej muszą być zgodne z Konstytucją". Rok później stwierdzono jednoznacznie: "Członkostwo Polski w Unii Europejskiej nie może [...] naruszać nadrzędności Konstytucji RP w porządku prawnym obowiązującym w Rzeczypospolitej". Dla PiS było to najbardziej praktyczne kryterium "posiadania" przez państwo suwerenności. Ważne stwierdzenie zawarto też w programie z 2009 roku: „Rzeczą ustawodawstwa każdego państwa członkowskiego jest [...] określenie, w jaki sposób stanowisko rządu prezentowane na forum Rady w najistotniejszych sprawach powinno mieć demokratyczne oparcie w kraju"44.

Według PiS, Trybunał Konstytucyjny w Polsce należy wyposażyć w dwa uprawnienia - orzekania obligatoryjnego o zgodności z konstytucją 1) umów międzynarodowych podpisanych w imieniu Rzeczypospolitej oraz 2) aktów stanowienia prawa pochodzących od organizacji międzynarodowych, którym Polska przekazała niektóre kompetencje organów władzy państwowej. Sugerowano takie rozwiązanie w 2003 roku, zanim Polska stała się członkiem Unii, w uchwale Silna Polska w Europie. Zobowiązano wówczas Klub Parlamentarny partii do wniesienia w Sejmie projektu nowelizacji konstytucji ${ }^{45}$. Chciano tak zrobić także w związku z ratyfikacją traktatu z Lizbony, ale ówczesna większość parlamentarno-rządowa odrzucała taką regulację konstytucyjną. Znaczenie zagwarantowania pierwszeństwa prawa polskiego nad europejskim po przyjęciu traktatu z Lizbony zdecydowanie wzrosło z jednego zasadniczego powo-

Europa solidarnych narodów..., s. 11, 15, 29.

Nowoczesna, solidarna, bezpieczna Polska..., s. 176.

Konstytucja Rzeczypospolitej Polskiej. Projekt Prawa i Sprawiedliwości, PiS, [b.m.w.] 2005, s. 21 (art. 60), 41 (art. 129); Nowoczesna, solidarna, bezpieczna Polska..., s. 172; Silna Polska w Europie..., s. 124. 
du - pozycja Polski w Unii w systemie lizbońskim w porównaniu z nicejskim uległa osłabieniu w kontekście możliwości uzyskania wpływu na regulacje unijne ustanawiane przez Radę Unii. PiS starało się więc poszukiwać różnych zabezpieczeń polskich interesów przed ewentualnymi niekorzystnymi decyzjami Brukseli ${ }^{46}$.

Prawo i Sprawiedliwość, a przede wszystkim prezydent L. Kaczyński uważali traktat lizboński za sukces Polski, osiągnięty w wyniku trudnych negocjacji, mimo iż po fiasku Konstytucji dla Europy w stronnictwie dominował pogląd, że praca nad nowymi regulacjami traktatowymi w kilka lat po traktacie z Nicei jest niepotrzebna, gdyż - jak to ujął L. Kaczyński „Powinniśmy obecne ramy prawne przyjąć po to, aby usprawnić działanie Unii i na nowo przekonać jej mieszkańców do projektu europejskiego" ${ }^{47}$. Kiedy jednak przystąpiono do negocjowania nowego traktatu, i prezydent, i rząd odrzucili postawę radykalną, czyli blokowanie prac, gdyż doprowadziłoby to Polskę do zupełnej izolacji. Podjęto grę negocjacyjną. Po wynegocjowaniu nowego układu położono nacisk w komunikowaniu politycznym na różnice między tym traktatem a poprzednim projektem Konstytucji dla Europy. Prezydent Kaczyński przedstawił nawet katalog zysków osiągniętych przez Polskę w czasie wielomiesięcznych dyskusji. Były to: prolongowanie nicejskiego systemu głosowania do $2017 \mathrm{roku}$, reaktywacja mechanizmu z Joaniny, nieuznanie prymatu prawa unijnego nad krajowym, domniemanie kompetencji państw narodowych, a nie instytucji wspólnotowych, zapowiedź solidarności energetycznej, przystąpienie przez Polskę do protokołu brytyjskiego, co oznaczało nieprzyjmowanie obligatoryjnych rozwiązań unijnych sprzecznych z tradycją i obyczajowością ${ }^{48}$. W tym kontekście L. Kaczyński przyznał po kilku miesiącach, że postulat wprowadzenia pierwiastkowego systemu liczenia głosów w Radzie Europejskiej miał charakter jedynie taktyczny,

\footnotetext{
46 Bardzo ciekawa analiza zmiany pozycji Polski w Unii po przyjęciu traktatu z Lizbony w: M. Kleinowski, Wptyw traktatu lizbońskiego na sitę Polski w Radzie Unii Europejskiej، „Myśl Ekonomiczna i Polityczna” 2015, nr 1, s. 184-207.

47 Archiwum Rady Ministrów, Sekretariat Prezesa Rady Ministrów, „Pismo prezydenta Lecha Kaczyńskiego do premiera Kazimierza Marcinkiewicza", 15 VI 2006, s. 2.

48 Polityka zagraniczna. Bezpieczeństwo..., s. 141.
} 
nie spodziewano się bowiem, że zostanie przeforsowany. Był zagrywką służącą osiągnięciu ważniejszych celów na innych polach. Natomiast zawetowanie traktatu strona polska odrzucała z powodów zasadniczych, ponieważ inni członkowie Unii zgodzili się na wzmocnienie Niemiec w procedurach unijnych ${ }^{49}$.

W trakcie negocjacji nad nowym traktatem w Brukseli i w Lizbonie przeważała jeszcze jedna kalkulacja, wynikająca z generalnych poglądów obu braci Kaczyńskich na politykę. Ustalano we Wspólnocie reguły, które miały wejść w życie w całości za siedem lat, a „w Unii Europejskiej to bardzo długo", tym bardziej jak wówczas zaznaczano: „Unia trzeszczy już teraz w związku z kryzysem i sytuacją w strefie euro". Z tego powodu wszelkie planowanie w długoterminowej perspektywie było naiwnością ${ }^{50}$. PiS, analizując kilka projektowanych rozstrzygnięć uznawanych przez stronnictwo za niekorzystne dla Polski, zdecydowało się skoncentrować uwagę na zmianie systemu ważenia głosów w Radzie UE, uznając niejako tym samym za drugorzędne takie kwestie, jak wprowadzenie do traktatów Invocatio Dei czy też utworzenie Europejskiej Unii Obronnej51. Warunki wynegocjowane przez prezydenta okazały sięjednak wyjątkowo ważne w kontekście stanowiska zajętego przez Polskę w sporze z Unią Europejską toczącego się w latach 2015-2019 wokół tzw. naruszeń praworządności, a faktycznie wokół reformy wymiaru sprawiedliwości. Strona polska mogła ogłosić, że to Unia narusza przepisy traktatowe, ingerując w kwestie konstytucyjne państwa członkowskiego oraz zawłaszczając nowe uprawnienia dla instytucji wspólnotowych.

Inaczej ten problem został przedstawiony w programie z 2011 roku. Stwierdzono w nim, że stronnictwo będzie dążyć do zmian w konstytucji RP, które „[...] jednoznacznie określą jej nadrzędny charakter wobec

49 Ł. Warzecha, Lech Kaczyński. Ostatni wywiad..., s. 264-265. O pierwiastkowym systemie gtosowania oraz o roli tej propozycji w negocjacjach unijnych w: Polska polityka zagraniczna: jeden krok - dwie odstony, "Rocznik Strategiczny” 2007/2008, s. 308310; W. Słomczyński, K. Zajączkowski, Kompromis Jagielloński - system głosowania dla Rady UE, „Międzynarodowy Przegląd Polityczny” 2007, nr 2(18), s. 14-32.

50 Ibidem, s. 265; vide P. Żurawski vel Grajewski, Prawda o traktacie lizbońskim, „Gazeta Polska Codziennie", 4-6 I 2014, nr 3, s. 12.

51 Idem, Nicejska równowaga, „Polska w Europie” 2004, nr 1, s. 23-41. 
wszystkich regulacji obowiązujących w naszym państwie, a więc wobec pierwotnego i pochodnego prawa europejskiego, oraz umożliwią efektywną kontrolę zgodności stosowanego w Polsce prawa unijnego z naszą ustawą zasadniczą"52. W programie z 2014 roku zaproponowano rozwiązanie najbardziej dojrzałe - przyjęcie ustawy o wykonywaniu suwerenności państwa, która ustanowiłaby prymat kompetencji narodowych w stosunkach z organizacjami międzynarodowymi wedle formuły "kompetencja do określania kompetencji pozostaje zawsze

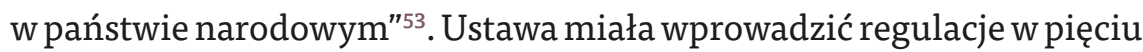
obszarach: 1) potwierdzić nadrzędność konstytucji RP nad prawem UE i orzeczeniami TSUE; 2) określić zasady i warunki przekazywania kompetencji organom unijnym; 3) gwarantować podmiotowość organów państwa polskiego w zakresie finansów i podatków; 4) ustalić zasady ograniczenia pola kompetencji organom unijnym; 5) określić zasady równowagi między przekazanymi kompetencjami a kontrolą instytucji państwa polskiego nad ich wykonaniem. Jeśli natomiast integracja ulegałaby zasadniczemu pogłębianiu i rozszerzaniu, to wówczas konieczne byłoby jednoczesne zwiększenie nadzoru nad tym procesem ze strony rządu i parlamentu Rzeczypospolitej. Tym samym praktyka stosowana w latach 2015-2019 przez władze RP pochodzące z nominacji PiS miała mocne osadzenie w myśli politycznej tej partii, a nie wynikała tylko z bieżących sporów politycznych z organami unijnymi. Jednak zapowiadanej w 2014 roku ustawy nie przyjęto ani nawet nie podniesiono tego tematu w Sejmie VIII kadencji.

Przesunąwszy Wspólnotę Europejską do kategorii środków politycznych, a nie podmiotów, PiS skoncentrowało swoją uwagę na analizowaniu stosunków międzynarodowych pod kątem identyfikacji interesów najważniejszych państw unijnych, a nie na obawach o upadek polskości w przypadku, gdyby powstało europejskie superpaństwo. PiS uważało taki scenariusz za projekt polityczny niemożliwy do zrealizowania, gdyż był niedostosowany do rzeczywistości. Nie widziano żadnych szans na

52 Polska nowoczesna, Polska solidarna, Polska bezpieczna..., s. 219.

53 Zdrowie, praca, rodzina..., s. 151. 
jego urzeczywistnienie w następnych dekadach. Znacznie bardziej obawiano się, że unijnym instytucjom europejskie mocarstwa będą narzucały swoją wolę, a w rzeczywistości euroentuzjazm to zarówno polityczna przykrywka stosowana dla ukrycia egoizmów narodowych przez państwa zachodnioeuropejskie, jak i zasłona dla działań z zakresu inżynierii społecznej, stosowanych w celu zamaskowania wielkiego eksperymentu przebudowy świadomości Europejczyków.

Eurorealizm sformułowany przez PiS wyrastał w Polsce z negatywnej oceny polityki zagranicznej prowadzonej w pierwszych dwóch dekadach przywróconej suwerenności. Niezależnie od osiągniętych sukcesów jak przyjęcie do Sojuszu Północnoatlantyckiego i Unii Europejskiej, zasadnicze wątpliwości budziła warstwa poznawcza i aksjologiczna. Dwie główne wady polityki zagranicznej Polski trafnie zdiagnozował politolog Ryszard Skarzyński, pisząc, że: po pierwsze - nie sformułowano podstaw do oceny stosunków i środowiska międzynarodowego przez pryzmat własnych interesów; po drugie - nie wypracowano żadnej spójnej polskiej wizji organizacji środowiska międzynarodowego tworzącej fundament pod koncepcje i programy w polityce zagranicznej ${ }^{54}$. Taka sytuacja negatywnie kontrastowała z myśleniem politycznym obowiązującym w II Rzeczypospolitej, w której i piłsudczycy, i narodowcy sformułowali własne alternatywne projekty pożądanego ładu międzynarodowego.

Znaczenie wskazanych wad uległo wzmocnieniu, kiedy w latach 1999-2004 Polska zrealizowała swoje dwa główne cele akcesyjne. Łatwo można było zauważyć pustkę aksjologiczną i błądzenie poznawcze wynikające z niemal bezkrytycznego kultu liberalnej doktryny stosunków międzynarodowych, czego dowodem była dominacja euroentuzjastów w parlamencie oraz w środowiskach opiniotwórczych, a także brak rzeczowej dyskusji w czasie europejskiego referendum akcesyjnego w Polsce. Atmosferę intelektualną opisał Bronisław Wildstein: „Przystąpienie do NATO i UE, skądinąd korzystne dla naszego kraju, miało być aktem

54 Uniwersytety są podstawą suwerenności dzisiejszego państwa. Rozmowa z prof. dr. hab. Ryszardem Skarzyńskim, „Geopolityka” 2012, nr 5(14), s. 6. 
finalnym naszej historii" ${ }^{55}$. Natomiast dla PiS przystąpienie do obu tych organizacji tworzyło nowe pole do prowadzenia gry międzynarodowej, stało się wyzwaniem i zarazem szansą na zasadnicze wzmocnienie statusu i pozycji międzynarodowej Rzeczypospolitej. Jednak wymagało przemyślenia polityki zagranicznej.

Tak jak już zostało wspomniane, z dokumentów programowych PiS można wywnioskować, że to ugrupowanie negatywnie oceniało założenia poznawcze i aksjologiczne przyjęte przez elitę rządzącą III Rzeczpospolitą, z wyjątkiem dwóch okresów: 1991/1992 i 2005-2007 (gabinety J. Olszewskiego, K. Marcinkiewicza, J. Kaczyńskiego). Dla polityków PiS rozwój nie był tożsamy ani z zerwaniem z przeszłością, ani z przynależnością do organizacji międzynarodowych, czy też z realizacją ideologicznego projektu będącego efektem intelektualnych spekulacji ${ }^{56}$. Rzeczywistość polityczna dla polityków PiS jawiła się jako przestrzeń przenikania się ciągłości i zmienności, w której - jak zapisano w 2007 roku - „Podstawowe interesy narodowe są niezmienne, [...] wynikają z fundamentalnych i niezmiennych wartości Polski, a ich realizacja stanowi dla państwa i jego mieszkańców potrzebę nadrzędną"57.

Zdiagnozowany przez PiS kryzys w myśleniu politycznym o stosunkach międzynarodowych niewątpliwie osłabiał potencjał polityczny Polski oraz jej podmiotowość w Unii Europejskiej, skuteczność polityki zagranicznej oraz zdolność do efektywnego gospodarowania własnymi zasobami. Ten ostatni skutek najpełniej ujawnił się w postaci kryzysu demograficznego wywołanego migracją i niżem oraz imitacyjnym charakterem gospodarki, mimo stałego rozwoju ekonomicznego i konsumpcji dużych środków unijnych, które wydatkowano bezplanowo w skali państwa. PiS, przejmując władzę dwukrotnie, w 2005 i w 2015 roku, lub dążąc do zwycięstwa wyborczego w latach 2001-2005 i 2007-2015, oficjalnie zaproponowało wyborcom uznanie państwa za wartość podsta-

55 B. Wildstein, Czy Polaków stać na niepodlegtość?, [w:] Rzeczpospolita na arenie międzynarodowej..., s. 27.

56 Deklaracja ideowa Ruchu Spotecznego imienia Prezydenta RP Lecha Kaczyńskiego, 10.04.2011 roku, http://lechkaczynski.pl, dostęp 1 X 2015.

57 Strategia bezpieczeństwa narodowego Rzeczypospolitej Polskiej..., s. 4-5. 
wową, co musiało mieć swoje konsekwencje dla polityki Polski wobec UE. Nie ukrywano, że na tym odcinku zostanie dokonana rewizja polityki zagranicznej Polski, jej warstwy poznawczej i aksjologicznej.

Kierując się własnymi kryteriami oceny środowiska i stosunków międzynarodowych, politycy PiS uznali, że ani ład globalny, ani porządek kontynentalny nie są konstytuowane w oparciu o normy prawa międzynarodowego, lecz są pochodną układu sił między poszczególnymi państwami, które w sensie historycznym są skazane na rywalizację. Chcąc w niej wygrać, należy zwiększać potencjał polityczny, zwłaszcza w ujęciu komparatystycznym wobec sąsiadów. Jarosław Kaczyński mówił o tym wielokrotnie ${ }^{58}$. PiS przywiązywało więc wyjątkowe znaczenie do czynników decydujących o potencjale państwa, takich jak demografia, wojskowość, gospodarka, system polityczny, edukacja, kultura, tożsamość, czemu dawało wyraz w swoich dokumentach programowych. Bez uporządkowania tych dziedzin państwo nie byłoby zdolne do odgrywania ważnej roli w rywalizacji międzynarodowej w Unii Europejskiej. To był wniosek sformułowany na podstawie analizy dziejów poprzednich form polskich państwowości: Rzeczypospolitej Obojga Narodów i II Rzeczypospolitej. W obu tych okresach Polska utrzymywała swoją podmiotowość, a w konsekwencji byt polityczny, w warunkach albo przewagi nad potęgą sąsiadów, albo równowagi sił, zwłaszcza w odniesieniu do Rosji i Niemiec. Stosunek PiS do prawa międzynarodowego był jednak oparty na swoistej sprzeczności, widocznej w kontekście unijnym. Wyraził ją J. Kaczyński we wspomnieniach o bracie, którego poglądom przypisał ową sprzeczność - nieżyjący prezydent z jednej strony miał krytyczny stosunek do dokonywanych przez biurokrację unijną nadregulacji prawnych, krępujących życie społeczne i gospodarcze oraz wolności w Europie, ale z drugiej strony zdawał sobie sprawę, że dla takiego państwa jak Polska - „niedysponującego atutem jakiejś wielkiej siły w sferze

58 Chociażby jednoznaczne tezy: J. Kaczyński, Przemówienie w dyskusji nad informacją rzadu na temat polskiej polityki zagranicznej w 2003 roku, [w:] SS Sejm, 4 kadencja, 40 pos., 22 | 2003, http://orka2.www.sejm.gov.pl, dostęp 17 IV 2014; idem, Polityka zagraniczna jest twardą grą... 
materialnej, gospodarczej, czy w jakiejkolwiek innej dziedzinie", funkcjonowanie w oparciu o prawo międzynarodowe jest niezbędne. Stanie na jego straży mogłoby być "miękkim” środkiem zabezpieczającym przed agresją ${ }^{59}$. Takie podejście do roli prawa międzynarodowego przejął po swoim wielkim poprzedniku na urzędzie prezydenta RP Andrzej Duda. Jak mówił, naruszanie prawa międzynarodowego, określającego relacje między państwami, doprowadzi do destabilizacji i zniszczy stan pokoju, przed czym powinna się bronić hemisfera zachodnia ${ }^{60}$.

W polityce europejskiej PiS kierowało się czterema głównymi wyznacznikami, które nadawały jej sens oraz wynikały z ogólnych i uniwersalnych rozważań na temat polityki i polityczności. Polityka europejska RP nie była spod ich wpływu wyłączona.

Polska jest potencjalnym kandydatem na państwo średnie w sensie funkcjonalnym, hierarchicznym i behawioralnym, co oznacza określony model przywództwa na arenie międzynarodowej, realizowany w określonym w sensie geopolitycznym regionie (middlepowermanship, pivotal middle power $)^{61}$. Jest to wniosek wynikający z postrzegania środowiska międzynarodowego w kategoriach hierarchizacji państw opartej na uwzględnianiu ich potencjału, który implikuje status w środowisku, role i zachowania w stosunkach międzynarodowych. Taka hierarchizacja realnie istniała w Unii Europejskiej, co potwierdziły przepisy traktatu z Lizbony oraz praktyka stosowana przez instytucje wspólnotowe ${ }^{62}$. Porównywanie potencjałów państw powinno uwzględniać trzy aspek-

59 Idem, Mój brat chciat zbudować Polskę solidarna, [w:] Lech Kaczyński. Pamięć i zobowiazanie..., s. 46.

60 Vide Archiwum Prezydenta RP, https://www.prezydent.pl, „Rozmowa z prezydentem W "Sygnałach Dnia»", 11 XI 2015, dostęp 12 VI 2020.

61 Definicja i parametry państwa średniego w: M. Klatt, op. cit., s. 128; M. Özkan, Pivotal Middle Powers and World Order. Toward a New Understanding of International Politics?, s. 2, http://www.eisa-net.org, dostęp 15 VII 2015; idem, A New Approach to Global Security. Pivotal Middle Powers and Global Politics, „Perception. Journal of International Affairs”, Spring 2006, s. 80-84; Changing World Order..., s. 6-7; R. Chase, E. Hill, P. Kennedy, Pivotal States and US Strategy , "Foreign Affairs”, January-February 1996, vol. 75, no. 1, s. 37.

62 Analiza traktatu lizbońskiego vide T. Kubin, Głosowanie większością kwalifıkowana w Radzie Unii Europejskiej w Traktacie z Lizbony, „Polski Przegląd Dyplomatyczny”, lipiec-sierpień 2008, nr 4(44), s. 77-82; P. Semka, op. cit., s. 269. 
ty: komparatystyczny, regionalny i kontynentalny. Jeśli weźmiemy pod uwagę te kryteria, to dla Polski jako państwa średniego pivotalnego naturalnym obszarem aktywności jest Europa Środkowa i Wschodnia. To w tym regionie rozstrzyga się status Polski jako państwa średniego w skali kontynentalnej i globalnej, w tym także na forum Unii Europejskiej. PiS postrzegało obecność i możliwości Polski w tej organizacji jednoznacznie w kontekścieśrodkowoeuropejskim i wschodnioeuropejskim. Odrzucało zaś projekt polskich liberałów identyfikowania się jedynie z hemisferą zachodnioeuropejską, gdyż to niemal automatycznie oznaczałoby ograniczenia dla polityki zagranicznej Polski oraz skazanie Warszawy na bycie jedynie odbiorcą decyzji podejmowanych w Brukseli.

Polska z racji statusu państwa średniego pivotalnego powinna wybrać politykę typu bandwagoning, odrzucić zaś alternatywną typu balancing ${ }^{63}$. Podmiotem do realizacji tego modelu polityki były Stany Zjednoczone Ameryki, a nie żadne mocarstwo europejskie. Odrzucenie polityki balansowania, typowej dla Polski międzywojennej, wynikało z przekonania, że wejście Rzeczypospolitej do Sojuszu Północnoatlantyckiego i Unii Europejskiej, których członkiem były Niemcy, pozwoli przezwyciężyć historyczne przekleństwo położenia między Niemcami a Rosją. Obaj wielcy sąsiedzi nie byli traktowani - jak uprzednio - jednakowo. Klientelizm w UE także został wykluczony. Takie nastawienie determinowało stosunek do Rosji, Niemiec i aspiracji militarnych Unii Europejskiej. Odrzucono bowiem wariant balansowania między Berlinem a Moskwą, ale także między Waszyngtonem a Brukselą, na rzecz bezpośredniego militarnego zaangażowania Stanów Zjednoczonych w bezpieczeństwo Europy Środkowej. W odniesieniu do Rosji i Niemiec poszukiwano czynników reasekuracji bezpieczeństwa Polski, co determinowało postrzeganie zarówno Stanów Zjednoczonych i Sojuszu Północnoatlantyckiego, jak również Unii Europejskiej. Mocarstwo globalne oraz obie organizacje międzynarodowe miały nie tylko zabezpieczać przed nieuchronnymi

63 K. N. Waltz, op. cit., s. 38. 
tendencjami militarnymi Rosji, ale też krępować RFN różnymi zależnościami, chroniąc Europę przed hegemonią Republiki ${ }^{64}$.

Środowisko międzynarodowe ma charakter poliarchiczny, co oznacza, że jest przestrzenią, w której dominują rywalizacja i konflikt. Źródłem tego stanu jest istota poliarchii, czyli spór między państwami o dystrybucję potęgi. Taki spór rozgrywa się także na forum UE. To państwa są nosicielami i dysponentami własnych ocen przeszłości, wartości wywiedzionych z tradycji, ładu politycznego w odniesieniu do organizacji środowiska międzynarodowego i przestrzeni wewnętrznej, sił o znaczeniu strategicznym. Wymienione cechy gwarantują tożsamość polityczną w Unii. Jarosław Kaczyński konsekwentnie powtarzał: „w Europie i świecie mamy do czynienia z konkurencją" ${ }^{\prime 65}$. Miało to swoje konsekwencje w odniesieniu do Unii. Dla prezesa PiS była ona forum rywalizacji i rozwiązywania naturalnych konfliktów między państwami członkowskimi, natomiast dialog i kompromis jawiły się jako stany tymczasowe. Kaczyński nie przeceniał znaczenia instytucjonalizacji stosunków międzynarodowych dokonanej po II wojnie światowej w Europie. Owszem, uważał ją za ważną, ale nie zmieniała ona istoty relacji międzypaństwowych w Europie. Mocarstwa europejskie dążyły i nadal dążą do maksymalizacji własnej potęgi przez wzmacnianie siły, wyznaczanie stref wpływów, uprzedmiatawianie państw średnich i małych, wyznaczanie kierunków ekspansji. To były również zadania dla Polski, bycie państwem średnim zobowiązywało do obrony własnego statusu.

Polityka zagraniczna Polski jest w dużym stopniu zależna od sytuacji wewnętrznej. Rzeczpospolita, będąc w kryzysie wewnętrznym, nie jest zdolna do prowadzenia racjonalnej i konsekwentnej aktywności w środowisku międzynarodowym, a nawet przeciwnie, kieruje się fałszywymi ocenami. Teza o słabości państwa pod rządami „obozu III Rzeczypospolitej" stała się mocno obecna na początku drugiej dekady XXI wieku w debacie publicznej. Przykładem może być ważna książka Artura Wołka pod tym tytułem i podane w niej miażdżące argumenty na

\footnotetext{
64 M. Kaczmarski, op. cit., s. 19.

65 J. Kaczyński, Polityka zagraniczna jest twardą grą...
} 
rzecz prawdziwości tego twierdzenia ${ }^{66}$. Akceptując w pełni tezę o słabym państwie, PiS dokonywało też diagnozy tego stanu. Wskazywano cztery cechy: 1) fragmentację władzy politycznej, prowadzącą do przekształcenia państwa w pole rywalizacji różnych grup interesu; 2) transakcyjność dominującą w polityce, polegającą na zawieraniu przez państwo umów z najsilniejszymi grupami kosztem wykluczenia słabszych; 3) kryzys moralny ogarniający przestrzeń publiczną, przejawiający się w korupcji, prywacie polityków oraz różnych patologiach; 4) kryzys instytucjonalny państwa paraliżujący decydowanie polityczne ${ }^{67}$. Uznając państwo za najważniejszy podmiot polityczny, PiS jednocześnie wskazywało na jego powinności wobec własnego społeczeństwa. Ich znaczenie wzrosło wraz z akcesją do Unii. Obowiązkiem władzy w Polsce było zdefiniowanie interesów państwowych, nadawanie społeczeństwu tożsamości politycznej, kształtowanie wspólnoty w postaci narodu ${ }^{68}$. Jarosław Kaczyński przedstawił te powinności klarownie w 2006 roku w dwóch zdaniach (które już były przywoływane w tej monografii):1) „Jak chce się mieć państwo, to po prostu kosztuje"; 2) „Swoje państwo trzeba szanować" ${ }^{69}$. One wykluczały wszelki serwilizm na arenie międzynarodowej, determinowały politykę wewnętrzną, jej powiązania z polityką zagraniczną oraz konsekwentną obronę własnych interesów narodowych, przedkładanych nad interesy Wspólnoty. To Polska była suwerenna, a nie Unia Europejska.

Według J. Saneckiej-Tyczyńskiej realistyczna postawa PiS opierała się na trzech założeniach. Pierwszym był prymat racji stanu nad integracją europejską, wynikający z przeświadczenia, że pojęcie racji stanu jest zarezerwowane dla państwa, podobnie jak suwerenność. W odniesieniu do Polski zdefiniowanie racji stanu oraz odzyskanie niepodległości i suwerenności lokowały się „poza Unią”, były bowiem wobec niej i pierwotne, i prymarne. Drugim było uznanie podmiotowości państw członkowskich za pierwotne i ważniejsze od Unii, gdyż to one utworzyły Wspólnotę w wy-

\footnotetext{
66 Vide A. Wołek, Stabe państwo, Ośrodek Myśli Politycznej - Instytut Studiów Politycznych PAN, Kraków-Warszawa 2012, passim.

67 VideJ.Sanecka-Tyczyńska, Racjastanu we wspótczesnejpolskiejmyślipolitycznej..., s.96-99.

68 IV Rzeczpospolita-Sprawiedliwość dla Wszystkich..., s. 38.

69 J. Kaczyński, Bezpieczeństwo kosztuje...
} 
niku dobrowolnej umowy międzynarodowej. Unia nie powołała państw narodowych do życia. Za trzecie założenie autorka uznała przekonanie o konfliktowym charakterze Unii, wynikającym zarówno z natury stosunków międzynarodowych, jak również z istoty polityki zagranicznej. Główne osie konfliktów w Unii przebiegały między państwami członkowskimi oraz między nurtami myśli politycznej ${ }^{70}$.

Cechą myśli politycznej PiS nie jest teleologizm, lecz myślenie scenariuszowe (wariantowe), dlatego też każda sytuacja międzynarodowa jest traktowana w sposób historyczny, a nie jako akt finalny dziejów, do którego należy dążyć, a następnie go konserwować. Dzieje są przez PiS opisywane w sposób procesualny; bardzo mocno eksponuje się ich dynamikę i zmienność, traktując struktury międzynarodowe jak zjawiska historyczne. Tym samym dla polityków PiS znacznie ważniejsze były tendencje panujące w Unii oraz interesy państw członkowskich niż instytucje wspólnotowe i ład prawny jako „formy zastygłe”. Prawo europejskie było postrzegane jako instrument, za pomocą którego państwa zaspokajają swoje potrzeby - od aksjologicznych do ekonomicznych. Według Saneckiej-Tyczyńskiej myślenie scenariuszowe właściwe dla myśli politycznej PiS o integracji europejskiej jest ilustrowane przez sześć wariantów rozpatrywanych przez J. Kaczyńskiego: 1) powrót do integracji gospodarczej; 2) powstanie federacji paneuropejskiej; 3) Unia „dwóch prędkości"; 4) podporząadkowanie Unii współpracy niemiecko-rosyjskiej; 5) fragmentacja regionalna wspólnoty; 6) rozpad Unii ${ }^{71}$. Wszystkie te warianty niosły odmienne wyzwania dla Rzeczypospolitej, a na pewno wymagały strategii politycznej i aktywności międzynarodowej, a nie "płynięcia z głównym nurtem". Dwa z tych scenariuszy - piąty i szósty - zostały ocenione przez K. Szczerskiego, który rozpad Unii nazwał scenariuszem bardzo złym, a fragmentację regionalną - "dramatycznym", bo zaowocowałaby ona powstaniem w Europie Środkowej „szarej strefy”. Natomiast o Unii „dwóch prędkości” prezydent Duda mówił: „To jest właśnie rozwalanie europejskiej wspólnoty". Polska rządzona przez PiS

70 J.Sanecka-Tyczyńska, Racja stanu we wspótczesnej polskiej myśli politycznej.., s. 351-353.

71 Ibidem, s. 353. 
miała tym scenariuszom przeciwdziałać, natomiast za jeden z czynników, który mógłby je uruchomić, uważano euroentuzjazm, z jednej strony prowadzący do zakwestionowania Unii w jej dotychczasowym kształcie, a z drugiej strony blokujący reformy konieczne do przywrócenia jej pierwotnego sensu organizacji międzynarodowej ${ }^{72}$.

Prawo i Sprawiedliwość nie postrzegało też integracji europejskiej zero-jedynkowo, czyli opracowując własną koncepcję Unii, nie zakładało, że nie można pogodzić postępu integracji z umacnianiem suwerenności Polski. Wręcz odwrotnie, dla tej partii przynależność Polski do Unii miała być ważnym czynnikiem wzmacniającym suwerenność i podmiotowość Polski w środowisku międzynarodowym. Odrzucano dogmat euroentuzjastów, że "więcej Europy” (przyspieszenie integracji rozumiane w kategoriach jej pogłębienia w wymiarze politycznym) będzie prowadzić do zaniku narodów i reprezentujących ich interesy państw. Tym samym "więcej Europy" nie oznaczało "mniej Polski". W tezach sformułowanych w 2006 roku, przed pierwszą wizytą w Brukseli premiera J. Kaczyńskiego, odniesiono się do tego sprzężenia: „Unia Europejska nie może się rozwijać w opozycji do państw narodowych. Siła Unii Europejskiej tkwi właśnie w państwach narodowych i w ich zdolności do wypracowywania kompromisów, w różnorodności rozwiązań prawno-ustrojowych, w bogactwie strategii, modeli, pomysłów i recept na funkcjonowanie państwa i całej Wspólnoty"73.

Taki sposób myślenia znalazł odzwierciedlenie w programie partii z 2014 roku $^{74}$. Hasło „więcej Europy” zostało w myśli politycznej PiS zastąpione nieco innym wyzwaniem - „inna Europa”. Uznano bez żadnych wątpliwości, że wszelkie pomysły przezwyciężenia kryzysu Unii poprzez realizację strategii "więcej Europy" faktycznie doprowadzą najpierw do jego pogłębienia oraz polaryzacji międzypaństwowej i wewnątrzpań-

\footnotetext{
72 K. Szczerski, Utopia europejska..., s. 22; Archiwum Prezydenta RP, https://www.prezydent.pl, „Wywiad z Prezydentem w tygodniku "Sieci«", 1 X 2018, dostęp 12 VI 2020.

73 Archiwum Rady Ministrów, Sekretariat Prezesa Rady Ministrów, „Tezy do wystąpienia Prezesa Rady Ministrów RP, Pana Jarosława Kaczyńskiego w Brukseli 30 sierpnia 2006 r.", 11 VIII 2006, [b.p.].

74 Zdrowie, praca, rodzina..., s. 148.
} 
stwowej (ta ostania płaszczyzna będzie zdominowana przez populistów i eurosceptyków), a następnie do rozpadu Wspólnoty. Przyczyną słabości Unii nie są bowiem państwa narodowe i nieuchronna rywalizacja między nimi, ale strategia obrana przez mocarstwa europejskie i realizowana przez instytucje unijne. Ciekawe stanowisko zaprezentował K. Szymański, który na konwencji PiS w 2019 roku wyróżnił dwa typy populizmu: antyeuropejski i euroentuzjastyczny. Ten pierwszy szerzy się pod hasłami nacjonalistycznymi, a ten drugi pod przykrywką UE i sprowadza się do żądań ograniczenia budżetu unijnego, zablokowania rozszerzenia Unii, limitowania korzystania z unijnych czterech wolności. Ten drugi typ populizmu Szymański uznał za "o wiele groźniejszy” dla UE75.

\subsection{Przestanki polityki europejskiej}

Dla PiS przynależność Polski do Unii Europejskiej na przełomie XX i XXI wieku była bezdyskusyjna. Takie nastawienie wynikało z różnych przyczyn: geopolitycznych, historycznych, cywilizacyjnych, kulturowych oraz rozwojowych. Nie było w tej kwestii żadnych istotnych wątpliwości co do strategicznego kursu, który Polska powinna realizować. Równocześnie PiS postrzegało Unię Europejską jako międzynarodową organizację suwerennych państw członkowskich, które zawarły ze sobą kontrakt w postaci umów międzypaństwowych (traktatów), określających zarówno jej system polityczny (instytucje, zasady, wartości, prawo), jak i kompetencje poszczególnych organów unijnych, ale jednocześnie państwa te gwarantowały sobie poszanowanie suwerenności. Konsekwentnie odrzucano wszelkie projekty paneuropejskiego typu federacji i konfederacji, uważając je za szkodliwe dla Rzeczypospolitej, godzące w jej rację stanu, ład aksjologiczny i porządek społeczny. W PiS, po wejściu do Unii, umocniło się przekonanie o historycznym znaczeniu tego faktu, ale w ujęciu prospektywnym, a nie ocennym. W programie z 2005 roku pisano: „Polska

75 K. Szymański, Unia polskich oczekiwań, [w:] Myśląc Polska. 5-7 lipca 2019 r., Katowice. Konwencja Programowa Prawa i Sprawiedliwości oraz Zjednoczonej Prawicy, PiS, [b.m.w.] 2019, s. 173-174. 
stoi [...] przed wielkim wyzwaniem określenia własnej roli i miejsca w rozszerzonej Unii Europejskiej"76. Postrzegano więc Wspólnotę Europejską jako dynamiczne środowisko międzynarodowe, w którym możliwe są do zrealizowania różne scenariusze i warianty. Wiele zależało od polityki zagranicznej prowadzonej przez Warszawę.

Jeśli chodzi o kierunek ewolucji Unii Europejskiej w XXI wieku, to PiS go nie akceptowało, zwłaszcza zarysowującej się alternatywy - albo Unia Europejska przyjmie nowe wartości, niestojące u podstaw powstania wspólnot w latach pięćdziesiątych XX wieku, a będące konglomeratem ideologii lewicowej i liberalnej, albo zamieni się w suprapaństwo kierujące się w polityce wewnętrznej i zagranicznej interesami zinterpretowanymi i narzuconymi przez oś Berlin-Paryż, co oznaczałoby zepchnięcie Europy Środkowej na margines procesów decyzyjnych i rozwojowych w Europie. Stan, w którym znalazła się Unia, już w 2004 roku PiS określiło jako kryzys, jeszcze zanim zaczęły się przejawiać jego oznaki w drugiej dekadzie XXI wieku w postaci wyjścia Zjednoczonego Królestwa z Unii, braku solidarności wobec otoczenia zewnętrznego, kontrowersji wokół stosunków transatlantyckich i polityki rosyjskiej oraz kryzysu migracyjnego. W 2011 roku pisano, że polska polityka „musi się zmierzyć z kryzysem zasad, jakie legły u podstaw Wspólnoty". Jako przyczyny systemowego kryzysu w Unii wymieniano: dążenie mocarstw zachodnioeuropejskich do ustanowienia hegemonii w organizacji, egoizm i krótkowzroczność wypierające solidarność, dominację kalkulacji ekonomicznej nad wspólnymi wartościami pierwotnymi ${ }^{77}$. W 2016 roku Jacek Czaputowicz pytał w jednym ze swoich tekstów naukowych, czy dokonuje się koniec Unii Europejskiej jako potęgi normatywnej ${ }^{78}$.

Myślenie PiS o konstrukcji i funkcjonowaniu Unii Europejskiej było zdeterminowane przez dwa założenia, w zasadzie właściwe dla doktryny realistycznej.

\footnotetext{
76 IV Rzeczpospolita - Sprawiedliwość dla Wszystkich..., s. 39.

77 Europa solidarnych narodów..., s. 7.

78 J.Czaputowicz, Globalna strategia UE - koniec Unii Europejskiejjako potęginormatywnej?, „Przegląd Europejski” 2016, nr 4(42), s. 24.
} 
Pierwsze - w polityce należy odróżniać podmioty i środki polityczne. Do tej pierwszej kategorii zaliczano państwa kreujące rzeczywistość polityczną w ujęciu międzynarodowym, a w drugim zbiorze umieszczono między innymi organizacje międzynarodowe, które uzyskują cechę polityczności z powodu ich wykorzystywania przez państwa do realizacji własnych interesów. W tym duchu minister spraw zagranicznych W. Waszczykowski deklarował w Sejmie 29 stycznia 2016 roku: „[...] będziemy dążyć do zakorzenienia polityki zagranicznej w woli politycznej suwerennych państw, które - jeśli łączy je głęboka wspólnota wartości i interesów - gotowe są solidarnie współpracować ze sobą w celu realizacji wspólnych celów. Z tych źródeł wyrastają NATO i Unia Europejska"79. Nie można więc było rozpatrywać Unii w oderwaniu od suwerenności państw członkowskich.

Drugie - nie ma we współczesnym świecie żadnych oznak upadku narodu jako podstawowej, wielkiej grupy społecznej oraz odejścia od państw narodowych i egoizmu państwowego, sterującego poczynaniami rządów. Narody i państwa w perspektywie najbliższych dekad nie zostaną zastąpione przez lud europejski i suprapolityczną wspólnotę transnarodową ${ }^{80}$. Wręcz odwrotnie, w warunkach globalizacji i integracji wzrosło znaczenie obrony tożsamości i interesów narodowych oraz zabezpieczania racji stanu, dość łatwo jest bowiem przekroczyć granicę między podmiotowością polityczną a uprzedmiotowieniem, między państwem średnim a klientem w stosunkach międzynarodowych. Owszem, na konwencji programowej PiS w 2019 roku Radosław Zenderowski przekonywał, że w Europie powstała dychotomia socjopolityczna. Z jednej strony metropolie mają charakter kosmopolityczny, a ich mieszkańcy ulegają deetnicyzacji, ale z drugiej strony na znacznych obszarach narasta kolejna fala etnicyzacji o charakterze autochtonicznym i separaty-

\footnotetext{
79 W. Waszczykowski, Informacja ministra spraw zagranicznych o zadaniach polskiej polityki zagranicznej w 2016 roku..., s. 73.

80 Vide J. S. Nye jr, Konflikty międzynarodowe. Wprowadzenie do teorii i historii, Wydawnictwa Akademickie i Profesjonalne, Warszawa 2009, s. 22.
} 
stycznym (chociażby Katalonia, Szkocja, Baskonia, Włochy, Belgia) oraz imigracyjnym (np. muzułmanie w Szwecji, Niemczech i we Francji) ${ }^{81}$.

W opinii PiS każde silne państwo, w tym najważniejsze europejskie, prowadziło politykę historyczną mającą na celu wzmacnianie tożsamości narodowej, co faktycznie dezawuowało projekt budowy jednolitego ludu europejskiego. W tym kontekście III Rzeczpospolita wyróżniała się negatywnie, narzuciła bowiem swoim obywatelom świadomość hybrydalną, właściwą dla postkomunizmu. Taki stan w warunkach integracji europejskiej mógł Polsce zagrażać, więc żeby tego uniknąć - wszak PiS było zwolennikiem obecności Polski w Unii Europejskiej - należało zdekonstruować wspomniany typ świadomości i przywrócić Polakom pamięć historyczną. Warto po raz wtóry przytoczyć wypowiedź L. Kaczyńskiego: „Potwierdzanie własnej pamięci to ciągle zadanie stojące przed narodami Europy" 82 .

Do tych dwóch założeń, z których wywiedziona została koncepcja PiS Unii Europejskiej, należy dodać jeszcze trzecie. PiS od samego początku istnienia formacji konsekwentnie stało na stanowisku, że Wspólnotę ogarnął kryzys, któremu należy przeciwdziałać, ponieważ Unia jest Polsce potrzebna w realizacji jej interesów. Kolejne wydarzenia i procesy zachodzące we Wspólnocie były intepretowane w kategoriach generowania i pogłębiania połączonego kryzysu instytucjonalnego i funkcjonalnego o charakterze egzystencjalnym, albo jako efekt jego zaistnienia. Tak odczytywano chociażby fiasko prac nad konstytucją unijną, kłopoty z ratyfikacją traktatu z Lizbony, kryzys migracyjny, wyjście Zjednoczonego Królestwa ze Wspólnoty, kryzys grecki i strefy euro, bezradność wobec agresywnej polityki Rosji, słabość w zakresie bezpieczeństwa i obrony. Kompleksowo o kryzysie Unii powiedział 11 stycznia 2018 roku prezydent Duda: „W moim przekonaniu nasza wspólnota stoi bowiem przed trzema zasadniczymi zagrożeniami: po pierwsze krótkookresowej dekompozycji, po drugie średniookresowej politycznej dezintegracji, a po trzecie

81 R. Zenderowski, Polityka zagraniczna państwa wobec megatrendów cywilizacyjno-kulturowych w polityce światowej, [w:] Myśląc Polska..., s. 186.

82 L. Kaczyński, Pojednanie możliwe tylko dzięki prawdzie... 
długookresowej strategicznej degradacji globalnej pozycji UE"83. Kryzys Unii oraz jego najważniejsze przejawy PiS interpretowało w dwóch kategoriach - zarówno interesów państw członkowskich, jak i ich tożsamości politycznej. Ta druga perspektywa była wyjątkowo istotna, bo opierała się na przekonaniu, że Unia nie potrafi sobie poradzić z kształtowaniem się tożsamości politycznej jej „nowych” członków, którzy podążają bardzo szybko drogą wyznaczoną w poprzednich dekadach przez "starych", zachodnioeuropejskich uczestników integracji. Chcą traktować Unię jako narzędzie realizacji własnej polityki zagranicznej, czego im się odmawia pod pretekstem nierespektowania przez nich zasad i wartości unijnych.

Wychodząc z takich założeń, PiS zaakceptowało model integracji nazywany „Europą Ojczyzn”, chociażby w programie z 2009 roku, odczytując go jako negację europejskiego federalizmu. Wcześniej, w 2004 roku PiS wprowadziło do polskiej debaty politycznej określenie „Europa solidarnych narodów", nazywając je programem polityki europejskiej partii. Natomiast w jednym ze swoich zagranicznych wywiadów premier Morawiecki użył w 2019 roku określenia „Unia Narodów 2.o.”, która miała powstać w wyniku modernizacji idei ojców założycieli i miała polegać - według Szczerskiego - na postawieniu Unii „z głowy na nogi"84. Ten projekt polityczny PiS zamierzało realizować na trzech poziomach: prawno-politycznym, socjologiczno-kulturowym i propagandowo-interpretacyjnym.

83 Wystąpienie Prezydenta RP na spotkaniu noworocznym z Korpusem Dyplomatycznym, 11 | 2018, http://www.prezydent.pl, dostęp 2 V 2020. W odniesieniu do dokonanej przez PiS oceny sytuacji, w jakiej znalazła się Unia na początku XXI wieku, pojawia się pytanie, czy nie jest to podręcznikowy przykład mispercepcji. Niewątpliwie dla entuzjastów integracji, których jest wielu nie tylko wśród polityków, ale również wśród naukowców, polityka europejska PiS jest przejawem adaptacji nadrealistycznej. Zapewne można by byto takie opinie przyjąć, gdyby nie uwikłanie ich autorów w bieżące spory polityczne wokół Unii. Niekiedy bowiem granice między polityką a politologią są płynne.

84 Program „Europa solidarnych narodów” został oficjalnie przyjęty przez Radę Polityczną PiS 28 maja 2004 roku - Europa solidarnych narodów...; Nowoczesna, solidarna, bezpieczna Polska..., s. 176; Poland's vision for Europe, 30 IV 2019, http://www.politico.eu, dostęp 2 V 2020; K. Szczerski, Wypowiedź, [w:] WNP Sejm, 7 kadencja, 3 pos., 15 XII 2011, http://www.sejm.pl, dostęp 20 V 2020. 
Należy zauważyć, że w kwestiach europejskich PiS było stronnictwem wyjątkowo konsekwentnym w sensie ideowym i politycznym. Podstawy koncepcji polityki europejskiej PiS nie uległy zmianom ani pod wpływem wejścia Polski do Unii, ani w wyniku przyjęcia traktatu z Lizbony, czy też kryzysu, przed jakim stanęła Unia w drugiej dekadzie XXI wieku. Już w 2002 roku, w rocznicę Konstytucji 3 maja PiS przyjęło Deklarację konstytucyjną o nadrzędności polskiej konstytucji nad wszystkimi aktami prawa unijnego, realizowaną przez Trybunał Konstytucyjny - od traktatów międzypaństwowych do aktów normatywnych wydawanych przez instytucje wspólnotowe ${ }^{85}$. Dla PiS pierwszeństwo polskiej konstytucji nad prawem wtórnym stanowionym przez Unię było niemal oczywiste. Natomiast co do prawa pierwotnego Unii to była zasadnicza różnica Polska je przyjmowała w procesie legislacyjnym (np. traktat z Lizbony).

Na drugim poziomie, socjologiczno-kulturowym, odrzucano wszelkie działania na rzecz budowy wielokulturowego ludu europejskiego, występowano w obronie chrześcijańskiego charakteru i dziedzictwa kontynentu, pierwotnych aksjologicznych fundamentów integracji oraz zachowania tożsamości narodów europejskich zamieszkujących suwerenne państwa członkowskie. Unia miała być wspólnotą opartą na wspólnych wartościach o rodowodzie historycznym, a nie na konstruktywistycznej wizji idealnego suprapaństwa. Winę za destrukcję aksjologiczną Unii przypisywano „europejskiemu socjalizmowi” i "moralnemu liberalizmowi"86.

Poziom propagandowo-interpretacyjny polegał na odczytywaniu przez PiS traktatów wspólnotowych (z Maastricht, Nicei, Lizbony) w kategoriach umów międzypaństwowych, które kreowały organizację międzynarodową, a następnie się do niej odnosiły; nie definiowano zaś Unii Europejskiej w kategoriach ani transnarodowych, ani suprapaństwowych. Suwerenność i narodowy charakter państw członkowskich były prezentowane przez PiS jako warunki brzegowe integracji europejskiej.

85 Deklaracja konstytucyjna Prawa i Sprawiedliwości w święto Konstytucji 3 maja, "Polska Scena Polityczna. Vademecum partii i ugrupowań politycznych" 2002, nr 9, s. 9.

86 Europa solidarnych narodów..., s. 7. 
Dlatego też w programie z 2011 roku zapisano, że Unia Europejska jako organizacja międzynarodowa „z oczywistych powodów" nie jest zdolna „stać się demokratycznymi strukturami zastępującymi narodowe państwa członkowskie”, które „muszą pozostać silną kotwicą zabezpieczającą przed nadużywaniem instytucji europejskich do biurokratycznych manipulacji, forsowania ideologicznych utopii lub osłaniania nacjonalizmu silnych"87.

Unia Europejska postrzegana przez PiS w kategoriach „Europy solidarnych narodów" była środowiskiem międzynarodowym w oczywisty sposób zdominowanym przez rywalizację państw dbających o swoje interesy. Natomiast system polityczny Unii, realizacja tak zasad unijnych, jak i wspólnotowych polityk publicznych powinny: 1) zabezpieczać interesy słabszych i biedniejszych członków przed zdominowaniem przez innych i podporządkowaniem mocarstwom europejskim;2) wyrównywać poziom zamożności państw i regionów; 3) chronić wszystkich członków przed kryzysami i zagrożeniami zewnętrznymi ${ }^{88}$. PiS, forsując koncepcję „Europy solidarnych narodów”, uznawało ją za sposób na przezwyciężenie kryzysu europejskiego na trzech płaszczyznach: bezpieczeństwa, sąsiedztwa i projektu integracyjnego. Z powodu tak poważnego kryzysu Unia Europejska wymagała generalnej odnowy, zerwania z trendami integracyjnymi ostatnich dekad oraz powrotu do źródeł. W opinii ministra W. Waszczykowskiego Unia Europejska przy jej dzisiejszej kondycji nie będzie w stanie zatrzymać pogarszania się sytuacji w swoim wschodnim i południowym sąsiedztwie oraz przeciwdziałać polityce imperialnej Rosji ${ }^{89}$.

Przekonaniu, właściwemu myśli politycznej PiS, o niezmienności interesów narodowych towarzyszyło posługiwanie się kategorią „kod geopolityczny" w myśleniu o środowisku międzynarodowym, w tym

Nowoczesna, solidarna, bezpieczna Polska..., s. 216-222.

88 K. Zuba, Europejska polityka Polski, „ETE Working Paper” 2015, t. 1, nr 1, s. 19-21.

89 Minister Witold Waszczykowski o priorytetach polskiej dyplomacji, http://www.msz.gov.pl, dostęp 10 III 2018. 
o Europie (i Unii Europejskiej) $)^{90}$. Jak to ujął K. Szczerski: „Każdy kraj ma inny obszar geograficzny, o którym powinien wiedzieć wszystko i na którym powinny się skupiać jego uwaga i kompetencja instytucji państwa"91. Kategoria "kod geopolityczny” spełniała dwie funkcje, a na pewno odróżniała myśl polityczną PiS od przekonań polskiej lewicy i liberałów. Pierwsza - to właśnie kod stał się narzędziem stosowanym bezpośrednio w identyfikowaniu wrogów i sojuszników, a pośrednio w kreowaniu emocji wykorzystywanych w polityce zagranicznej i historycznej ${ }^{92}$. Najbardziej wyraziście można zauważyć „obowiązywanie” wspomnianej kategorii analitycznej w formułowaniu opinii o Rosji, Niemczech i Europie Środkowej. Niejako ożywiono wartościowanie z okresu rozbiorów, powstań narodowych, II Rzeczypospolitej oraz obu wojen światowych. W tej kwestii, jak już zostało wspomniane, PiS świadomie wpisywało się w dzieje etosu konfederackiego, powstańczego, irredentystycznego, piłsudczykowskiego, antykomunistycznego. Odrzucono podejście do historii oparte na założeniu, że "różne sposoby działania w takim samym stopniu prowadziły do niepodległości Polski" ${ }^{\text {93 }}$. Był do powrót do wartościowań piłsudczykowskich, a odrzucenie poglądów właściwych dla PRL w latach 1956-1989 (oraz dla postkomunizmu), że walka o niepodległość przybierała szeroki wachlarz postaw, co pozwalało z kolei uznać za postawy niepodległościowe podejście trójlojalistów z okresu zaborów, a nawet komunistów z lat 1918-1956.

Druga funkcja "kodu geopolitycznego" odnosiła się do polskich dziejów. Dość jasno opisał ją w 2011 roku Jarosław Kaczyński: Polska jest $\mathrm{w}$ „geopolitycznym zawieszeniu [...] między byciem wielkim państwem

90 Pojęcie "kod geopolityczny" w rozumieniu: C. Flint, Wstęp do geopolityki, Wydawnictwo Naukowe PWN, Warszawa 2008, passim.

91 Szczerski wymienit kierunek wschodni i relacje między Niemcami a Rosją. K. Szczerski, Wypowiedź, [w:] WNP Sejm, 7 kadencja, 91 pos., 23 IV 2015, http://www.sejm.gov.pl, dostęp 21 V 2020.

92 B. Sajduk, op. cit., s. 80. Na temat postugiwania się „kodem geopolitycznym” we wspótczesnej myśli politycznej w: J. Macała, Polish Geopolitical Codes Illustriated with the Example of the Electoral Programs of the Major Political Parties in 1991-2011, „Athenaeum. Polskie Studia Politologiczne" 2017, vol. 56, s. 7-20.

93 Ł. Warzecha, Lech Kaczyński. Ostatni wywiad..., s. 117-118. 
europejskim a niebyciem wielkim państwem europejskim"94. Próby rozwiązania tego dziejowego dramatu historycznego trwały niemal przez całe dzieje polskiej państwowości, począwszy od chrztu w X wieku, kiedy z racji położenia geograficznego Polski na nizinie otwartej na wschód i zachód kolejne pokolenia zmagały się z wyzwaniami napływającymi z tych dwóch kierunków geograficznych. Osłabienie tej determinanty politycznej nastąpiło wtedy, kiedy państwo polskie uzyskało potencjał europejskiego mocarstwa (XV-XVII wiek) i podjęło wyzwania na wszystkich azymutach geograficznych.

Posługiwanie się „kodem geopolitycznym” w myśleniu politycznym przyczyniło się do trzech istotnych konsekwencji widocznych w dorobku ideowym formacji J. Kaczyńskiego. Te konsekwencje określały koncepcję polityki unijnej tej partii politycznej. PiS postrzegało problematykę unijną jako bardzo ważny, ale jednak tylko fragment generalnej kwestii europejskiej. Akcesja Polski do Unii była zmianą o wielkiej doniosłości historycznej, ale nie oznaczała "końca historii" na kontynencie oraz zakwestionowania „kodów geopolitycznych" i zaszłości historycznych. Nie można było dzielić dziejów Polski według cezury roku 2004.

Po pierwsze, na podstawie analizy historycznej i geopolitycznej, PiS sformułowało wniosek, że normalizacja stosunków polsko-rosyjskich jest w perspektywie krótkookresowej niemożliwa do osiągnięcia, a tzw. reset w relacjach z Moskwą był strategicznym błędem rządu koalicji PO-PSL, wynikającym z co najmniej naiwnej oceny środowiska międzynarodowego, a przede wszystkim intencji Rosji. Uważano, że władze RP nie musiały dostosowywać się do ówczesnego charakteru stosunków między Stanami Zjednoczonymi i Rosją oraz między Niemcami i Rosją, kiedy oba państwa uznały, że z Kremlem można ustalać funkcjonowanie ładu międzynarodowego oraz dokonywanie w nim ewentualnych zmian. W tym aspekcie widoczna była kontynuacja między dwoma okresami rządów PiS - w latach 2005-2007 i po roku 2015. Zasadę tę sprecyzował minister K. Szczerski, doradca prezydenta Andrzeja Dudy ds. polityki zagranicznej: „Klucz do zmiany relacji z Rosją leży w Moskwie. Przeka-

94 J. Kaczyński, Polska naszych marzeń..., s. 122. 
zujemy ten komunikat otwarcie. Polska nie wykonuje żadnych ruchów, które w jakikolwiek sposób antagonizowałyby nas i Rosję. Odwrotnie. Zależy nam na dobrych relacjach polsko-rosyjskich i podchodzimy do nich bez żadnych uprzedzeń. Drugą sprawą jest to, że nasze relacje z Rosją są także częścią systemu relacji euroatlantyckich z tym krajem. Tutaj reguła jest prosta - jest nią bezwzględny prymat przestrzegania prawa międzynarodowego" ${ }^{\prime 95}$. Tę zasadę można odnieść zarówno do prezydentury L. Kaczyńskiego i A. Dudy, jak również do gabinetów tworzonych przez PiS w XXI wieku.

Jednak pożądanych gestów ze strony Rosji bynajmniej się nie spodziewano. Według PiS mnogość sprzeczności między Polską a Rosją była nieprzezwyciężalna w ujęciu polityki bieżącej i średniookresowej; ten stan wynikał z przeszłości, geopolityki i ideologii oraz przyjęcia w Moskwie założenia, że orientacja antypolska może być czynnikiem budowania nowej rosyjskiej tożsamości narodowej po upadku komunizmu. Diagnoza sytuacji strategicznej w relacjach polsko-rosyjskich nadawała polskiej obecności w UE istotny wymiar. PiS uważało, że będzie można wykorzystywać Unię Europejską we wzmacnianiu pozycji Warszawy wobec Moskwy, o ile rządy RP będą umiały kreować politykę wschodnią Brukseli. Unię Europejską należało uczynić lewarem w polityce polskiej wobec Kremla.

Po drugie, dla polityków PiS Unia Europejska stanowiła forum, na którym można było układać polsko-niemieckie relacje, a jednocześnie krępować nadmierny potencjał polityczny Berlina oraz przypisywane mu dążenie do zdominowania stosunków międzynarodowych w Europie. PiS podchodziło do RFN pragmatycznie, czyli starało się opierać politykę wobec Berlina na ocenie zarówno stosunków polsko-niemieckich w przeszłości, jak i konkretnych decyzji politycznych. Zanegowało tym samym założenie właściwe dla wszystkich rządów lewicowo-ludowcowych i liberalno-ludowcowych o polsko-niemieckiej „wspólnocie interesów” oraz

95 K. Szczerski, Sukces szczytu NATO będzie sukcesem Polski [Wywiad z ministrem Krzysztofem Szczerskim dla „Do Rzeczy” przeprowadzony przez Piotra Goćka], 7 IX 2015, http://www.prezydent.pl, dostęp 7 XI 2017. 
o „strategicznym partnerstwie”. Takie podejście miało poważne konsekwencje dla polityki unijnej prowadzonej przez gabinety rządowe PiS, które miały i wolę, i odwagę, żeby niejednokrotnie nie zgadzać się z decyzjami forsowanymi w Brukseli przez Berlin. Najlepszym przykładem może być kryzys migracyjny, przed którym Unia stanęła w 2015 roku. Na pewno też nie oczekiwano, że RFN przejmie odpowiedzialność za kondycję Unii. Kryzys migracyjny był bezspornym dowodem konsekwencji PiS w blokowaniu decyzji unijnych narzuconych przez Berlin, ale w Warszawie nieakceptowanych. Czaputowicz wskazał dwie przyczyny zdecydowanego odrzucenia polityki Brukseli w kwestii polityki migracyjnej: „1) nieefektywna, bowiem uchodźcy przybywają do zamożnych państw Europy Zachodniej; 2) niezgodna z zasadami UE"96.

Po trzecie, Europa Środkowa była postrzegana przez PiS jako przestrzeń, w której Polska powinna kształtować swój potencjał polityczny, niezależnie od przynależności do Unii państw leżących w regionie. W tym sensie Europa Środkowa była postrzegana przez PiS jako trwały byt geopolityczny, istniejący niezależnie od jej statusu międzynarodowego, podczas gdy Unia Europejska jako byt historyczny, czyli osadzony w danym czasie. Europę Środkową traktowano z jednej strony jako zasób niezbędny w polityce sięgania po status państwa średniego, z drugiej zaś jako czynnik lewarowania pozycji Polski w organizacjach międzynarodowych, w tym w Unii Europejskiej. Nie można było być podmiotowym członkiem Unii bez aktywnej polityki środkowoeuropejskiej, gdyż wyizolowany potencjał polityczny Polski nie był wystarczający, żeby była ona jednym z decydujących graczy na forum tej organizacji.

Zarówno prezydenci L. Kaczyński i A. Duda, jak również gabinety rządowe kierowane przez polityków PiS prowadzili politykę rekonstrukcji regionu, która miała być wstępem do podnoszenia podmiotowości tej części Europy w Unii Europejskiej i w Sojuszu Północnoatlantyckim, ale też w odniesieniu do Rosji i Niemiec. Niska podmiotowość Europy

96 J. Czaputowicz, Informacja ministra spraw zagranicznych o zadaniach polskiej polityki zagranicznej w 2018 roku..., s. 87. 
Środkowej sprzyjała uprzedmiotawianiu i naruszaniu suwerenności poszczególnych państw leżących na tym obszarze.

W podsumowaniu należy przyjąć, że nie można analizować polityki unijnej projektowanej przez PiS w oderwaniu od trzech kontekstów: rosyjskiego, niemieckiego i środkowoeuropejskiego. W 2011 roku PiS jednoznacznie odrzuciło podstawę polityki europejskiej rządu Donalda Tuska, określoną jako „płynięcie z głównym nurtem”, czyli świadomą rezygnację z eksponowania podmiotowości Polski i regionu Europy Środkowej w Unii Europejskiej na rzecz powiązania interesów Polski z głównymi mocarstwami zachodnioeuropejskimi, przede wszystkim z Niemcami ${ }^{97}$. Jak napisał Klaus Bachmann, PiS przywróciło w analizowaniu Unii Europejskiej znaczenie czynnika geopolitycznego, „zapomnianego" przez stronnictwa lewicowe i liberalne, które uległy manierze negliżowania geopolityki zgodnie z duchem rozumowania w instytucjach europejskich ${ }^{98}$. Dlatego też ważnym elementem eurorealistycznej koncepcji Europy, formułowanej przez PiS, było jasne wskazywanie czynnika asekuracji dla Polski w Unii Europejskiej. Tym czynnikiem miało być partnerstwo strategiczne ze Stanami Zjednoczonymi Ameryki. Można je odczytywać w kategoriach polityki typu bandwagoning (a na pewno partnerstwa asymetrycznego ${ }^{99}$ ) wobec tego mocarstwa uniwersalistycznego, co oznaczało, że Warszawa pod rządami PiS odnosiła się z rezerwą do Europejskiej Polityki Bezpieczeństwa i Obrony, wspierała Waszyngton w ekspedycjach na Bliskim Wschodzie, popierała kolorowe rewolucje i orientację euroatlantycką w państwach postradzieckich, wyrażała gotowość do uczestnictwa w systemie obrony antyrakietowej. Na tych polach PiS było zdecydowane nawet przeciwstawić się ewentualnym antyamerykańskim decyzjom Unii.

W myśli politycznej PiS w odniesieniu do polityki europejskiej wyjątkową rolę przypisano Europie Środkowej i Wschodniej, przynajmniej

\footnotetext{
97 Vide Raport o stanie Rzeczypospolitej..., s. 111.

98 K. Bachmann, Z perspektywy Brukseli: czy UE ma świadomość geopolityczna??, „Rocznik Strategiczny" 2004/2005, s. 33.

99 L. Czechowska, op. cit., s. 57.
} 
z czterech powodów. Po pierwsze, konsolidacja wokół Polski państw tego regionu, niezależnie od przynależności organizacyjnej do Unii i Sojuszu, wzmacniałaby jej pozycję w Unii Europejskiej, w procesach decyzyjnych, co znacznie zwiększyłoby wpływ Polski na politykę Unii wobec Rosji. Po drugie, maksymalna redukcja penetracji rosyjskiej w Europie Wschodniej (Ukraina, Gruzja, Białoruś, Mołdawia) sprzyjałaby bezpieczeństwu Europy Środkowej oraz osłabiałaby mocarstwowość Moskwy. Po trzecie, państwa środkowoeuropejskie wsparte przez ich efektywne oddziaływanie na Europę Wschodnią mogłyby stanowić czynnik równowagi wewnętrznej w Unii Europejskiej wobec Europy Zachodniej, a przede wszystkim wobec koalicji Berlin-Paryż, a także w wyniku synergii mogłyby być atrakcyjnym partnerem dla Stanów Zjednoczonych i dla Chin. Po czwarte, z powodu ekonomicznej konieczności zbudowania osi rozwoju Północ-Południe łączącej trzy morza: Bałtyckie, Adriatyckie i Czarne, która zbalansowałaby pod względem ekonomicznym współpracę Wschód-Zachód i dokonałaby zasadniczego przełomu geostrategicznego w regionie ${ }^{100}$.

Wyrazem priorytetowego znaczenia Europy Środkowej w koncepcji PiS polityki europejskiej były sprzęgające się inicjatywy polityczne realizowane z całym rozmachem w latach sprawowania władzy w Polsce przez tę partię: Szczyt Energetyczny w Krakowie ${ }^{101}$, inicjatywa Trójmorza $^{102}$, Format Bukareszteński, Szczyt Przewodniczących Parlamentów Państw Europy Środkowej i Wschodniej ${ }^{103}$, Europa Karpat ${ }^{104}$. Ciekawym

100 A. Duda, Wystąpienie Prezydenta RPAndrzeja Dudypodczas Dubrovnik Forum 2016, 25 VIII 2016, http://www.prezydent.pl, dostęp 3 XI 2017.

101 Prezydencki Szczyt Energetyczny w Krakowie, 11 V 2007, http://www.prezydent.pl, dostęp 2 XI 2017.

102 Szczyt Trójmorza zudziatem prezydenta USA, 6 VII 2017, http://www.prezydent.pl, dostęp 3 XI 2017; M. Michałek, Wielki plan małych państw. Jak Trójmorze wzmocni lub podzieli Unię, http://www.tvn24.pl, dostęp 2 XI 2017; M. Kobosko, Koncepcja Trójmorza ma sens, 15 XII 2016, http://www.rp.pl, dostęp 6 XI 2017.

103 W Sejmie szczyt szefów parlamentów państw Europy Środkowej i Wschodniej, 18 V 2017, http://www.pap.pl, dostęp 2 XI 2017; Szczyt szefów Parlamentów Państw Europy Środkowej i Wschodniej, 16 V 2017, http://www.parlamentarny.pl, dostęp 2 XI 2017.

104 Vide Europa Karpat. Rzecz o wspótpracy, red. W. Paruch, Wydawnictwo Sejmowe, Warszawa 2017. 
pomysłem była propozycja zmiany formuły Rady Państw Morza Bałtyckiego. W 2007 roku premier Kaczyński w rozmowie z premierem Szwecji Fredrikiem Reinfeldtem zaproponował wpisanie tej inicjatywy we współpracę Północ-Południe w postaci formuły NB8 (państwa nordyckie, państwa bałtyckie, Polska i Niemcy). Chciano w ten sposób nadać temu przedsięwzięciu wymiar regionalny ${ }^{105}$.

Liczne inicjatywy środkowoeuropejskie wraz z zaangażowaniem w niektórych przypadkach Europy Wschodniej miały dwa szerokie konteksty. Pierwszy opisał prezydent Kaczyński na przykładzie szczytu energetycznego. Mówił: „[...] taka polityka mogłaby przekonać Rosję, że z Polską trzeba się dogadywać jak z partnerem, choć, rzecz jasna, to by musiało potrwać sporo lat"106. Miał to być klasyczny sposób „lewarowania" pozycji Polski. Faktycznie Rosja podjęła to wyzwanie, o czym świadczyła reakcja Putina na szczyt krakowski, kiedy premier Rosji postanowił zneutralizować poczynania prezydenta Kaczyńskiego ${ }^{107}$. Drugi kontekst - unijny - podejmowanych w regionie działań scharakteryzował prezydent Duda: „[...] zjednoczona, niepodzielna Unia, a w niej dynamicznie rozwijająca się Europa Środkowa są nieodzowne i współzależne. Zaburzenie efektywnego funkcjonowania jednego z nich z pewnością utrudni działanie drugiego" ${ }^{108}$. Wspomniane rozwiązania miały służyć budowie powiązań sieciowych w regionie, opartych nie tylko na racjach geopolitycznych, wykorzystywanych w latach międzywojennych w piłsudczykowskiej koncepcji Międzymorza i Trzeciej Europy, ale również na więziach ekonomicznych, a przede wszystkim infrastrukturalnych (koleje, drogi, interkonektory gazowe i kolejowe, huby, logistyka, telekomunikacja). W regionalnych koncepcjach PiS było zdecydowanie mniej rozumowania w kategoriach dawnej, utraconej przeszłości (jak w pro-

105 Archiwum MSZ, sygn. 143/o9, w. 2, „Notatka ze spotkania Prezesa Rady Ministrów, Pana Jarosława Kaczyńskiego z Premierem Królestwa Szwecji, Panem Fredrikiem Reinfeldtem", 11 VI 2007, s. 2-3.

106 Ł. Warzecha, Lech Kaczyński. Ostatni wywiad..., s. 248.

107 P. Kowal, Wielki powrót geopolityki..., s. 57.

108 Wystapienie Prezydenta RP na spotkaniu noworocznym z Korpusem Dyplomatycznym, 11 | 2018, http://www.prezydent.pl, dostęp 2 V 2020. 
jektach piłsudczyków), więcej zaś merytorycznego zróżnicowania oraz pragmatyzmu, a także dążenia do zdynamizowania aktywności regionu i zerwania z poszukiwaniem przez państwa tej części Europy orientacji klientystycznej skierowanej albo na Zachód, albo na Wschód w celu uzyskania poparcia mocarstw zewnętrznych wobec regionu. W PiS panowało przekonanie, że zbudowanie jednej organizacji środkowoeuropejskiej jest zarazem niewykonalne i bezcelowe. Decydowała ocena regionalnego środowiska międzynarodowego - leżące w nim państwa miały zróżnicowane interesy narodowe, przeszłość niekiedy zdominowaną przez wzajemne konflikty międzypaństwowe, silną tendencję do wzmacniania własnej suwerenności, niewielką wiedzę o czynnikach łączących ten obszar geopolityczny, różną świadomość społeczną, gospodarkę zależną albo od potencjału gospodarczego państw zachodnioeuropejskich, albo od dostaw surowców z Rosji, co w obu przypadkach pociągało spenetrowanie systemu politycznego.

Ten stan dość precyzyjnie określił prezydent Duda: „Dotychczas rozwój [...] dokonywał się przede wszystkim na osi Wschód-Zachód. Pomimo niewątpliwego dorobku, który wypracowany został w rezultacie realizacji tego modelu działań, nie wykorzystuje on w pełni potencjału drzemiącego w krajach leżących nad Bałtykiem, Adriatykiem i Morzem Czarnym. Dlatego właśnie tak istotne znaczenie ma dziś wzbogacenie procesu europejskiej integracji poprzez budowę więzów i połączeń na osi Północ-Południe"109. Celem postawionym przed projektami regionalnymi było przezwyciężenie w Europie układu relacji centrum-peryferie, którego wyrazem był jednokierunkowy transfer z Zachodu na Wschód oraz zjawiska znane jako postkolonializm lub gospodarka imitacyjna. Konkretnymi efektami miały być budowa Via Carpatii, korytarza transportowego i gazowego Bałtyk-Adriatyk oraz przyjęcie przez Unię Europejską subregionalnej Strategii Karpackiej. Długotrwałe utrzymywanie się statusu Europy Środkowej jako peryferii może doprowadzić w kon-

109 Rację miał Maciej Kobosko, oceniając projekt Trójmorza: „Ten projekt jest do bólu pragmatyczny, i właśnie przez to ma zdecydowanie większe szanse na realizację". M. Kobosko, op. cit. 
sekwencji do pogłębienia zapóźnienia gospodarczego regionu oraz powstania "próżni geopolitycznej", którą będzie bardzo łatwo zawłaszczyć. Natomiast myśl polityczną PiS w kontekście środkowoeuropejskim cechował wyjątkowy optymizm. Wyraził go Szczerski, przypisując regionowi ogromny potencjał modernizacyjny, oparty na wypracowanym przez wieki własnym wzorcu rozwojowym ${ }^{110}$.

Drugą mocno akcentowaną płaszczyzną w zakresie polityki zagranicznej jest wzmocnienie bezpieczeństwa regionu w odniesieniu do sąsiedztwa, zwłaszcza wschodniego (Rosja) i południowego (imigranci). O ile inicjatywa Trójmorza stanowi ofertę rozwojową dla 12 państw członkowskich Unii Europejskiej, o tyle Format Bukareszteński jest projektem polityczno-militarnym dla 9 państw wschodniej flanki Sojuszu Północnoatlantyckiego. Duda scharakteryzował cel Formatu, mówiąc, że jest to: „określenie podstawowego pola zgody w ramach tej części Europy. [...] co do potrzeby prymarnej - wzmocnienia bezpieczeństwa wschodniej flanki Sojuszu"111.

Natomiast po kilku latach bycia w opozycji PiS zaproponowało odrzucenie polityki obecności Polski w Unii Europejskiej prowadzonej przez rządy zarówno lewicowo-ludowcowe L. Millera i M. Belki, jak również liberalno-ludowcowe D. Tuska i E. Kopacz. Politykę tę uznano za błędną, lekceważącą polskie interesy oraz wspierającą działania na rzecz centralizacji Unii Europejskiej. Negowano "politykę białej flagi” oraz postawy euroentuzjastyczną i eurosceptyczną. Obie traktowano niemal identycznie, jako przejaw doktrynerstwa, ulegania złudzeniom i nieliczenia się z racją stanu Rzeczypospolitej ${ }^{112}$. Polityka Polski powinna mieć charakter czynny i powinna opierać się na eurorealizmie. Credo w tej kwestii przedstawił w Sejmie w 2002 roku Kazimierz Michał Ujazdowski: „Ideologiczne okowy nie wyjaśniają istoty polskiej polityki wobec Unii Europejskiej, istoty problemów, przed którymi stoi polska polityka. [...] Najważniejsze jest jednak to, że w polskiej polityce wobec Unii Europej-

10 K. Szczerski, Utopia europejska..., s. 203.

111 Idem, Sukces szczytu NATO...

112 Europa solidarnych narodów..., s. 6. 
skiej powinniśmy się kierować realizmem, a nie doktrynerstwem"113. Realizm miał się przejawiać w forsowaniu wartości chrześcijańskich stojących u podstaw utworzenia Unii Europejskiej, wbrew współczesnej myśli socjalistycznej i liberalnej, oraz w budowaniu otwartej wspólnoty wolnych narodów i demokratycznych państw narodowych, ponieważ to one właśnie są nosicielami idei europejskich konstytuujących pluralizm na kontynencie. PiS podkreślało, że siła i legitymacja Unii Europejskiej wywodzą się z mandatu i woli współpracy suwerennych państw. Natomiast aby ta współpraca mogła osiągać kolejne etapy, najsilniejsze państwa europejskie powinny zerwać z egoizmem narodowym, ponieważ to w nim zawsze tkwiły źródła łamania praw i zasad w stosunkach międzynarodowych ${ }^{114}$.

Biorąc pod uwagę myśl polityczną PiS przejawiającą się w jej świadectwach i śladach (te ostatnie właściwe były dla rządów PiS w latach 2005-2007 i po 2015 roku oraz w czasie prezydentury L. Kaczyńskiego i A. Dudy), można ustalić kanon eurorealistycznej koncepcji polityki zagranicznej Polski w i wobec Unii Europejskiej, złożony z trzech czynników.

1. Wzmacnianie potencjału politycznego Polski w Europie Środkowej i wobec Europy Wschodniej, które powinno zaowocować przywództwem Polski w regionie oraz budową powiązań sieciowych między państwami położonymi na tym obszarze, niezależnie od ich przynależności organizacyjnej (Unia Europejska, Sojusz Północnoatlantycki). Opisując ową regionalną rolę Polski, prezes Kaczyński posłużył się analogiami geograficzno-historycznymi: „Każde państwo, a ściślej: każde duże państwo członkowskie Unii Europejskiej - a Polska takim państwem jest - ma czy stara się mieć swoją strefę szczególnie zaawansowanej współpracy. Przykładowo, dla Francji są to byłe kolonie francuskie w Afryce i Azji, dla Wielkiej Brytanii - Commonwealth, czyli kraje niegdyś formalnie zwią-

113 K. M. Ujazdowski, Informacja ministra spraw zagranicznych o podstawowych kierunkach polityki zagranicznej Polski, [w:] SS Sejm, 4 kadencja, 16 pos., 14 III 2002, http://orka2. sejm.gov.pl, dostęp 14 IX 2008.

114 Program Prawa i Sprawiedliwości 2014..., s. 158; Europa solidarnych narodów..., s. 8. 
zane ze Zjednoczonym Królestwem, dla Hiszpanii - Ameryka Łacińska. Rzeczpospolita również powinna mieć taką strefę - w sposób naturalny powinien nią być obszar krajów położonych na wschód i północny wschód od Polski, w tym także państwa powstałe na gruzach ZSRS. Polska musi być swoistym "podwójnym ambasadorem ": reprezentować te kraje, ich aspiracje i dążenia europejskie i transatlantyckie wobec Unii Europejskiej z jednej strony, a Unię Europejską - wobec nich z drugiej strony"115. Wiele w tym myśleniu odniesień historycznych i rozumowania w kategoriach ciągłości historycznej.

2. Konsekwentna budowa sojuszu ze Stanami Zjednoczonymi Ameryki w postaci zarówno partnerstwa strategicznego, jak i współpracy euroatlantyckiej, mająca na celu zainstalowanie amerykańskich sił zbrojnych w Europie Środkowej. W tej kwestii przyjęto dwa założenia: ewentualne zastrzeżenia zgłaszane na forum unijnym będą lekceważone, a Polska będzie respektowała strategiczne oczekiwania Waszyngtonu.

3. Polska wzmocniona przez regionalne przywództwo i sojusz ze Stanami Zjednoczonymi jest w stanie osiągnąć status państwa średniego, co pozwoli jej efektywnie kształtować Unię Europejską oraz jej politykę zagraniczną, zwłaszcza wobec Rosji, a także osłabiać hegemonię niemiecką w tej organizacji europejskiej.

4. Polska jako państwo średnie, posiadające wysoką podmiotowość w obu organizacjach działających w hemisferze euroatlantyckiej oraz mocno w nich osadzone, będzie gotowa do podjęcia procesu normalizacji stosunków z Rosją bez groźby popadnięcia w zależność typu klientelistycznego.

Na tym kanonie została oparta koncepcja PiS dotycząca budowy i funkcjonowania Unii Europejskiej. Partia J. Kaczyńskiego chciała uczestniczyć w sposób podmiotowy w dyskusji na ten temat. W opinii PiS efektem tej ogólnoeuropejskiej dyskusji miała być odnowa Unii Europejskiej, gdyż uważano, że organizacja jest w stanie kryzysu i dryfuje w błędnym kierunku, co finalnie doprowadzi albo do zakwestionowania

115 J. Kaczyński, Silna Polska w świecie, „Nasz Dziennik”, 31 XII 2010-2 I 2011, http://www. naszdziennik.pl, dostęp 12 V 2013. 
zasadności jej istnienia, albo do budowy suprapaństwa europejskiego. Te dwa rozwiązania uznano za wyjątkowo szkodliwe dla Rzeczypospolitej. W okresie 2004-2019 dyskusja dwukrotnie przybrała na sile - w czasie przygotowywania i przyjmowania traktatu z Lizbony oraz po opublikowaniu przez Komisję Europejską kierowaną przez Jeana-Claude'a Junckera w 2017 roku Białej księgi w sprawie przyszłości Europy.

Na przełomie pierwszej i drugiej dekady XXI wieku w stronnictwie utrwaliło się przekonanie, że kryzys Unii jest wielopłaszczyznowy: aksjologiczny, legitymizacyjny, decyzyjny, instytucjonalny i funkcjonalny. Pisał o tym w swojej monografii Utopia europejska Szczerski oraz mówił o tym minister Czaputowicz w Sejmie 21 marca 2018 roku. Używano na jego opisanie różnych określeń: rozłam, polaryzacja, dekompozycja, zerwanie z ciągłością, fragmentacja, separacja. Tak opisany stan miał swoje konsekwencje: narastanie eurosceptycyzmu i renacjonalizacja polityki w państwach członkowskich ${ }^{116}$. Można przyjąć za Zbigniewem Czachórem, że w myśli politycznej PiS dokonała się mentalna instytucjonalizacja kryzysu Unii ${ }^{117}$, wynikająca z uznania za fałszywe założenia, że istnienie demosu europejskiego jest faktem. To właśnie on może zastąpić narody, a przyszłość należeć będzie do podmiotów suprapaństwowych w warunkach zamierania funkcji państwa. PiS zdecydowanie odrzucało takie podejście do integracji europejskiej, traktując je jako przejaw konstruktywizmu, wynikający z postmarksizmu. Dobitnie to ujął Szczerski: „nie twórzmy Europejczyków, bo oni istnieją, a cywilizacja europejska ma wspaniałe korzenie - grecko-rzymsko-chrześcijańskie"118.

116 . Czaputowicz, Informacja ministra spraw zagranicznych o zadaniach polskiej polityki zagranicznej w 2018 roku..., s. 82. O kryzysie strukturalnym i funkcjonalnym w Unii vide K. Szczerski, Utopia europejska..., s. 71-76; idem, O nieistnieniu i warunkach zaistnienia. Unia Europejska a problem demokracji, [w:] Politikon III: kto jest suwerenem? Kontrowersje wokót Traktatu Lizbońskiego, red. M. Burzyk, M. Podniesiński, M. Rysiewicz, Koło Nauk Politycznych UJ, Kraków 2012, s. 199-212; Z. Czachór, 2019. Powrót do przysztości, „Instytut Idei” 2019, nr 6, s. 92-98; idem, Kryzys i zaburzona dynamika Unii Europejskiej, Dom Wydawniczy Elipsa, Warszawa 2013, passim.

117 Idem, Unia Europejska w stanie krytycznym. Nowe sytuacje - nowe konstelacje - nowe orientacje, „Przegląd Europejski” 2018, nr 1, s. 21.

118 K. Szczerski, Wypowiedź, [w:] WNP Sejm, 7 kadencja, 3 pos., 15 XII 2011, http://www. sejm.pl, dostęp $21 \mathrm{~V} 2020$. 
Z tych powodów zarówno partia w swych podstawowych dokumentach programowych, jak i poszczególni jej politycy odpowiedzialni za prace w zakresie polityki zagranicznej proponowali różne rozwiązania, które miały doprowadzić do przezwyciężenia kryzysu. Ich cechą wspólną był brak zgodności z nurtami myślenia o pożądanych kierunkach rozwoju wspólnoty dominującymi w najważniejszych organach unijnych (Komisja Europejska, Parlament Europejski, Trybunał Sprawiedliwości Unii Europejskiej, a nawet Rada Europejska). Uważano odnowę Unii za niezbędną, ponieważ brak zmian oznaczałby: 1) stagnację; 2) niezdolność do rozwiązywania najważniejszych problemów na kontynencie; 3) wzrost nastrojów antyunijnych ${ }^{119}$.

Propozycje PiS dotyczące odnowy Unii były oparte na trzech założeniach, o których marszałek Sejmu M. Kuchciński mówił 23 maja 2016 roku w Luksemburgu na Konferencji Przewodniczących Parlamentów Unii Europejskiej. Zaprezentował tam tezy dokumentu powstałego w Kancelarii Sejmu „Europa solidarnych państw" - bezpieczeństwo, granice, odnowione instytucje, mającego akceptację prezesa Kaczyńskiego ${ }^{120}$. Pierwsze założenie - potrzebne są rozwiązania systemowe, $w$ tym także zmiana traktatów podpisanych w Lizbonie, czyli w wyniku porozumienia wszystkich państw członkowskich. Drugie założenie - decyzje o odnowie Unii mogą być podjęte jedynie na zasadzie porozumienia suwerennych państw członkowskich oraz zgodnie z wolą społeczną wyrażoną albo przez parlamenty narodowe, albo w drodze referendum. Tym samym instytucjom wspólnotowym nie przypisywano w tej kwestii roli ani decydującej, ani nawet inicjującej. Nie bez powodu to właśnie marszałek Kuchciński przedstawił projekt PiS na posiedzeniu przewodniczących parlamentów państw unijnych, a nie europosłowie PiS w Parlamencie Europejskim należeli oni do formacji Europejscy Konserwatyści i Reformatorzy, której

\footnotetext{
119 Archiwum autora, „Wystąpienie marszałka Sejmu Marka Kuchcińskiego na spotkaniu powitalnym z uczestnikami konferencji "Solidarność i suwerenność»", 30 VIII 2016, s. 2.

120 Archiwum autora, „Deklaracja zaproponowana przez marszałka Sejmu »Europa solidarnych państw - bezpieczeństwo, granice, odnowione instytucje»", s. 1-2.
} 
realna rola w Parlamencie była niewielka ${ }^{121}$. Natomiast zaprezentowane stanowisko przez przewodniczącego jednej z izb polskiego parlamentu w oficjalnej dyskusji miało swoją wymowę i wywołało rezonans wśród uczestników tego szczytu. Trzecie założenie - „Unia potrzebuje realizmu w ustanawianiu nowych rozwiązań", osadzonych we wspólnej europejskiej tradycji oraz w świadomości społecznej. Dla PiS przeciwieństwem owego realizmu były wszelkie projekty paneuropejskie, lansowane przez europejskich radykałów, liberałów i socjalistów. Według Kuchcińskiego: „Ponadpaństwowy federacyjny model integracji europejskiej pogłębi kryzys i problemy w Europie, a jego usilne forsowanie może prowadzić do dezintegracji UE". Wskazywano także konkretne szkody: blokowanie przedsiębiorczości i wolności gospodarczej, wzrost biurokracji, nadmiar regulacji prawnych, wzmacnianie eurosceptycyzmu ${ }^{122}$.

\subsection{Koncepcja Unii Europejskiej}

Analizy koncepcji Unii Europejskiej, wypracowanej przez PiS, należy dokonać na kilku płaszczyznach merytorycznych. Co ciekawe, najważniejsze elementy tej koncepcji zostały uszczegółowione w dwóch okresach: 2001-2003 i 2015-2019, wtedy podjęto bowiem najważniejsze decyzje programowe.

1. W 2006 roku prezydent Kaczyński udzielił instrukcji ówczesnemu premierowi Marcinkiewiczowi: „[...] partie tworzące większość parlamentarną, kreujące kierowany przez Pana Premiera Gabinet, akceptują w swoich programach UE jako instytucjonalny związek blisko ze sobą współpracujących niepodległych państw i odnoszą się z dystansem do rozwiązań federacyjnych lub quasi-federacyjnych. [...] proszę Pana Pre-

121 Nie można zaakceptować opinii Beaty Master, że EKiR jest frakcją eurosceptyczną, gdyż zasadnicza większość jej członków stoi na gruncie realizmu w odniesieniu do Unii. B. Master, op. cit., s. 63.

122 Archiwum autora, „Wystąpienie marszałka Sejmu Marka Kuchcińskiego na Konferencji Przewodniczących Parlamentów Unii Europejskiej w Luksemburgu", 23 V 2016, s. 1. 
miera o reprezentowanie powyżej wyrażonego stanowiska"123. PiS konsekwentnie stało na stanowisku, że Unia Europejska powinna pozostać organizacją międzynarodową powstałą w wyniku decyzji suwerennych państw działających według historycznej reguły „wolni z wolnymi, równi z równymi". Ta reguła została wpisana do programu z 2019 roku, a jej zwolennikiem był prezydent Duda. W 2017 roku mówił na Forum Ekonomicznym w Krynicy, że Wspólnota „powinna być unią wolnych państw i wolnych narodów, powinna być unią państw narodowych [...] wolnych narodów i równych państw" ${ }^{\prime 24}$. Niezwykle trafnego określenia dla myśli politycznej PiS użył Krasnodębski: „polityczna forma organizująca relacje polityczne państw europejskich". W odniesieniu do Unii niechętnie sięgano po sformułowanie "ponadnarodowa”, czy też do rozważań o jej wyjątkowym statusie systemowym w dziejach ludzkości ${ }^{125}$. Przytoczona dewiza staropolska była upowszechniana przez polityków PiS po 2015 roku. Takie podejście oznaczało, że Unia powstała w wyniku umowy międzynarodowej, a jej filarem są państwa członkowskie, dlatego też konieczne jest utrzymanie funkcji pomocniczej Unii wobec tychże państw, bez ograniczania ich podmiotowości oraz suwerenności. Wszelkie kompetencje Unii są bowiem wtórne - wynikają z decyzji państw członkowskich. Wyraźne naruszanie suwerenności państw doprowadzi najpierw do zakwestionowania Wspólnoty przez narody, a następnie do jej upadku.

Jacek Czaputowicz przypomniał w Sejmie VIII kadencji przepisy traktatu lizbońskiego (art. 5, ust. 2): „Unia działa wyłącznie w granicach kompetencji przyznanych jej przez państwa członkowskie, a wszelkie kompetencje nieprzyznane Unii w traktatach należą do państw człon-

123 Archiwum Rady Ministrów, Sekretariat Prezesa Rady Ministrów, „Pismo prezydenta Lecha Kaczyńskiego do premiera Kazimierza Marcinkiewicza", 15 VI 2006, s. 3.

124 Dobry czas dla Polski..., s. 183; Archiwum Prezydenta RP, https://www.prezydent.pl, „Wystąpienie Prezydenta w panelu XXVII Forum Ekonomicznego w Krynicy", 5 IX 2017, dostęp 12 VI 2020.

125 Z. Krasnodębski, Te wydarzenia zapamiętają pokolenia..., s. 31. 
kowskich"126. Tym samym mocno artykułowano w PiS, że "celem Unii nie może być zastępowanie państw narodowych” oraz przejmowanie ich kompetencji, lecz jedynie "pomaganie państwom narodowym w realizowaniu ich zadań" w warunkach globalizacji i nowoczesności. Wnioskowano więc konsekwentnie: „Przekazywanie kompetencji na rzecz Unii jest uzasadnione o tyle i tylko o tyle, o ile wspólne realizowanie pewnych zadań daje wszystkim większe korzyści"127. Miernikiem owych korzyści miały być oczywiście racje państwowe, w które zbyt często godziły decyzje Komisji Europejskiej, generujące konflikty. Kuchciński sformułował dwie przestrogi: 1) narzucanie woli politycznej przez Komisję Europejską może prowokować nowe konflikty; 2) stosowanie przez Komisję Europejską środków przymusowych wzmacnia postawy radykalne ${ }^{128}$.

Postrzegano Unię jako podmiot sprzyjający integracji całego kontynentu, dlatego też PiS opowiadało się za polityką rozszerzania rozumianą na trzy sposoby. Po pierwsze, miała być to "polityka otwartych drzwi" wobec kolejnych państw aspirujących do członkostwa, przede wszystkim wschodnioeuropejskich i zachodniobałkańskich oraz Turcji ${ }^{129}$. W tym kontekście ciekawa była reakcja PiS na wyjście Zjednoczonego Królestwa z Unii. Podkreślano, że ten fakt powinien skłaniać Wspólnotę do jeszcze większej otwartości na państwa kandydujące, gdyż tylko w ten sposób Unia może zachować swoją dynamikę i międzynarodową rolę orędownika pokoju, rozwoju i stabilizacji, a także pomnażać swój potencjał. W rozszerzeniu widziano także „lekarstwo" na groźbę rozpadu Wspólnoty. Takie credo wyraził prezydent Duda w 2017 roku: „[...] dla mnie Unia Europejska jest tworem żywym, nie jest skostniałym zamkiem objętym ochroną konserwatorską, którego nie można rozbudować. Można go roz-

126 J. Czaputowicz, Informacja ministra spraw zagranicznych o zadaniach polskiej polityki zagranicznej w 2018 roku..., s. 83-84.

127 Europa solidarnych narodów..., s. 9; Nowoczesna, solidarna, bezpieczna Polska..., s. 176.

128 Archiwum autora, „Wystąpienie marszatka Sejmu Marka Kuchcińskiego na Konferencji Przewodniczących Parlamentów Unii Europejskiej w Luksemburgu", 23 V 2016, s. 2.

129 Za "testament" dla PiS w okresie 2015-2019 w kwestii rozszerzenia Unii Europejskiej można uznać zapis z opracowania z 2007 roku będącego podsumowaniem, a jak się okazało - zamknięciem rządu J. Kaczyńskiego. Pisano w nim: „Dalsze rozszerzenie UE uznajemy za strategiczny cel". Rząd Premiera Jarosława Kaczyńskiego. 365 dni..., s. 55. 
budować!"130. Po drugie, funkcjonowanie Unii miało obejmować nowe obszary - głównie wskazywano bezpieczeństwo wewnętrzne i zewnętrzne, zaopatrzenie w surowce, gospodarkę wodną oraz energetykę. Z tym postulatem korespondowało oczekiwanie zwiększenia budżetu unijnego, adekwatnie do skali nowych wyzwań. Po trzecie, zasadniczym zadaniem Unii wobec Europy było prowadzenie polityki na rzecz równomiernego rozwoju kontynentu, co w praktyce miało oznaczać osłabienie dominacji regionu zachodnioeuropejskiego, jako najbogatszego, który wyjątkowo dużo skorzystał na poprzednich rozszerzeniach, pozyskując nowe rynki zbytu oraz przejmując liczne przedsiębiorstwa.

Za istotę Wspólnoty uznano równość jej członków oraz regionów. Odrzucano tym samym wszelkie projekty wewnętrznego podziału Unii w oparciu o koncepcję „Unii wielu prędkości”, tworzenie wewnętrznego kręgu państw należących do strefy euro czy też podział na państwa stare i nowe ze względu na czas akcesji do Wspólnoty. Uzasadnienie takiej postawy przedstawił w Sejmie minister Czaputowicz: „Jesteśmy zdecydowanymi przeciwnikami Unii Europejskiej dwóch prędkości. Oczywistym rezultatem utworzenia jądra Europy czy Europy pierwszej prędkości byłoby przeniesienie każdego rzeczywistego procesu decyzyjnego z traktatowych instytucji Unii Europejskiej, w których reprezentowane są wszystkie państwa członkowskie, do nowo utworzonych instytucji strefy euro i gremiów nieformalnych. Doprowadziłoby to do marginalizacji Europy Środkowej i innych regionów: Skandynawii, państw południa strefy euro, które walczą ze skutkami kryzysu finansowego"131. W tej wypowiedzi znalazły się główne argumenty, którymi posługiwało się PiS na forum europejskim, dezawuując dominujące w Brukseli pomysły reformowania Unii.

2. Ogólną ocenę wyjątkowego historycznego statusu Unii Europejskiej można znaleźć w programie z 2007 roku: „Postrzegamy UE jako

130 Archiwum Prezydenta RP, https://www.prezydent.pl, dostęp 12 VI 2020: „Wystąpienie Prezydenta na konferencji prasowej prezydentów państw Grupy Wyszehradzkiej", 14 X 2017; „Wystąpienie Prezydenta na forum Arraiolos”, 14 IX 2017.

131 J. Czaputowicz, Informacja ministra spraw zagranicznych o zadaniach polskiej polityki zagranicznej w 2018 roku..., s. 84. 
wspólnotę działającą w oparciu o czytelne i sprawiedliwe zasady oraz wartości"132. Pozostaje wątpliwość, czy ta życzeniowa ocena była wyrazem idealizmu politycznego, czy raczej niemożliwych do spełnienia oczekiwań. W PiS doskonale rozumiano, że Unia powstała w wyniku racjonalnej umowy między państwami europejskimi, zachęcanymi przez Stany Zjednoczone, w celu zaspokojenia interesów poszczególnych państw członkowskich, najpierw przede wszystkim gospodarczych, ale również politycznych. Niemniej jednak jeśli Unia Europejska miała być trwałym związkiem suwerennych państw, to powinna mieć jasno określoną sferę aksjologiczną, złożoną z wartości i zasad zapisanych w traktatach, oraz sprecyzowany rodowód, nawiązujący do idei ojców założycieli wspólnot europejskich w latach pięćdziesiątych XX wieku. Wartości nie mogą być jednak „ideologicznymi i politycznymi zaklęciami”, lecz powinny wynikać z wielowiekowej tożsamości europejskiej, przekazanej współczesnym przez poprzednie pokolenia, które - według Dudy - „tworzyły jej trudną, ale fascynującą historię". PiS łączyło wartości z zasadami z jednego, ale bardzo ważnego powodu - Unia nie mogła być zideologizowana, lecz - jak to ujął A. Duda - powinna być oparta na wewnętrznym kompromisie na rzecz podejmowania pragmatycznych działań. Owe działania musiały zaś mieć swoje rusztowanie w postaci zasad regulujących funkcjonowanie Wspólnoty. To właśnie zasady miały gwarantować, że żadne z państw członkowskich nie będzie wykorzystywało Unii przeciwko innym członkom Wspólnoty na ich niekorzyść'133. Odwrót od pierwotnych idei europejskich, sprecyzowanych jeszcze przez Winstona Churchilla - prekursora powojennej integracji - dokonujący się systematycznie od lat siedemdziesiątych, uznano za błąd. Należało więc je przywrócić, co oznaczało dokonanie reintegracji w oparciu o utracone idee, ale też budowę Unii „zdrowego rozsądku"134. Chodziło o trzy obszary.

\footnotetext{
132 Dbamyo Polskę. Dbamy o Polaków..., s. 50.

133 Wystąpienie Prezydenta RP na spotkaniu noworocznym z Korpusem Dyplomatycznym, 11 | 2018, http://www.prezydent.pl, dostęp 2 V 2020.

134 Zdrowie, praca, rodzina..., s. 158. Vide M. Sienkiewicz, op. cit., s. 144.
} 
Pierwszy miał charakter systemowy. Współpraca europejska powinna być praktykowana w oparciu o zasady demokracji, bo tylko one zagwarantują Unii siłę i sprawczość. Kwestią fundamentalną - jak to określił minister Czaputowicz - jest „zdolność do uzyskania rzeczywistego mandatu demokratycznego do działania". To właśnie mandat demokratyczny pozwoli organizacji wykorzystywać „zasoby wytwarzane przez obywateli państw członkowskich w celu realizacji demokratycznie określonych celów". Z tej wypowiedzi wynikało, że demokracja odnosiła się do legitymizacji, mechanizmu decyzyjnego oraz wyznaczania celów. Jako jedyną drogę minister wskazywał wolę wyrażoną na poziomie parlamentów narodowych. To one reprezentują obywateli państw członkowskich. Takiej woli nie wyrażała ani Komisja Europejska, ani Parlament Europejski ${ }^{135}$. Już w 2011 roku PiS zaliczyło do zasad określających działalność Unii dwie inne: policentryczność, czyli przyzwolenie w ramach systemu politycznego Unii na różne powiązania sieciowe między państwami członkowskimi, oraz równość państw członkowskich, przeciwstawianą hierarchizacji korzystnej dla mocarstw europejskich i państw zachodnioeuropejskich ${ }^{136}$.

Drugi miał charakter uniwersalny i zarazem kulturowy. Polegał na wskazaniu trzech źródeł konstytuujących cywilizację europejską: chrześcijaństwa, filozofii greckiej i prawa rzymskiego. PiS odrzucało tym samym odwoływanie się do idei oświeceniowych, z których czerpała lewica i liberałowie, ponieważ stronnictwo uważało, że to właśnie z chrześcijaństwa wynikają optymalne rozwiązania właściwe dla kultury politycznej, takie jak tolerancja i szacunek do człowieka. Liberalizm i lewicowość w tym sensie traktowano jako wywracanie porządku społecznego, które polega na odrzuceniu chrześcijaństwa bez żadnej własnej konstruktywnej propozycji moralnej. Stwierdzano, że w istocie chodzi o „budowę społeczeństwa bez religii, bez tradycji, bez wspólnej etyki i kultury"137.

\footnotetext{
135 J. Czaputowicz, Informacja ministra spraw zagranicznych o zadaniach polskiej polityki zagranicznej w 2018 roku..., s. 84.

136 J. Sanecka-Tyczyńska, Racja stanu we wspótczesnej polskiej myśli politycznej..., s. 354.

137 Polska katolicka w chrześcijańskiej Europie..., s. 42.
} 
W tej materii wiarygodnie brzmiały słowa prezydenta Dudy: „Fundamentem Unii Europejskiej nie są liberté, égalité i fraternité, tylko jest [...] niewiasta, a na jej skroniach wieniec z 12 gwiazd, które są na fladze Unii Europejskiej. I ci, którzy Unię Europejską zakładali, dokładnie tak właśnie myśleli i dokładnie na tych właśnie wartościach - wynikających z kultury judeochrześcijańskiej, z tego korzenia rozwoju cywilizacyjnego - oparli ten wielki projekt" ${ }^{\prime 138}$.

Oświecenie wzbudzało w PiS co najmniej ambiwalentne uczucia, a na pewno nie wywoływało zachwytu. Jak pisał Krasnodębski: „[...] projekt Oświecenia nie powiódł się", ponieważ "Człowiek i jego rozum okazał się dość nędznym substytutem Boga"139. Właśnie oświeceniu przypisywano antyrealizm, polegający na odrzuceniu zastanej rzeczywistości, i opcję na rzecz zbudowania drogą rewolucyjną "alternatywnego świata" w oparciu o "konieczne prawa rozumu" oraz narzucenia tej jedynej wizji - jak się okazało, utopijnej i opartej na przymusie - wszystkim państwom. W rezultacie przyniosło to absolutyzm oświecony oraz zniszczenie pluralizmu i parlamentaryzmu, jakże charakterystycznych dla czasów monarchii stanowej. Warto przywołać za Dariuszem Gawinem sposób myślenia konserwatysty Edmunda Burke'a: „Porządek społeczny, ufundowany na ciągłości, tradycji, obyczajach, był organiczny - zatem rozum, który przywoływali rewolucjoniści, był sztuczny, mechaniczny, nieludzki. Warunkiem konstruowania jakichś abstrakcyjnych budowli musiało zatem być rozcinanie tego, co żywe i organiczne"140.

Kult oświecenia w Polsce był nieuzasadniony z dwóch powodów historycznych. Pierwszy - triumf oświecenia oznaczał upadek I Rzeczypospolitej - pluralistycznej i parlamentarnej, a zlikwidowanej przez trzy monarchie absolutystyczne, odwołujące się do myśli oświeceniowej. Drugi - odzyskanie przez Polskę po raz drugi niepodległości w wyni-

138 Archiwum Prezydenta RP, https://www.prezydent.pl, „Wystąpienie Prezydenta podczas uroczystego otwarcia II Ogólnopolskiego Kongresu Europeistyki w Szczecinie", 26 IX 2017, dostęp 12 VI 2020.

139 Z. Krasnodębski, Drzemka rozsądnych..., s. 89.

140 D. Gawin, Rewolucja czy konstytucjonalizm? Dwuznaczne dziedzictwo polityczne oświecenia, http://omp.org.pl, dostęp 10 VI 2020. 
ku Jesieni Ludów z jednej strony nie miało znamion rewolucji na rzecz nowej utopii, lecz było powrotem do utrwalonych historycznie archetypów niepodległości i republikanizmu, z drugiej strony oznaczało koniec władzy komunistów, czerpiących obficie z oświeceniowych idei: rewolucjonizmu, inżynierii społecznej, względnej nietranscendentnej moralności, antyreligijności i monizmu ideologicznego. Po oświeceniu we współczesności pozostały rezydua, które są widoczne w myśli nowej lewicy i liberałów w postaci postmodernizmu i nowego rewolucjonizmu, osadzone mocno w doświadczeniach rewolucji kulturowej 1968 roku, od której PiS się zdecydowanie odżegnywało. Unia Europejska nie mogła być modelowana w oparciu o restytucję oświecenia.

W 2004 roku w swoim dokumencie programowym PiS stwierdzało: „Upominamy się o respektowanie podstaw chrześcijańskiej cywilizacji Zachodu i o duchowo-moralną jedność Europy". Natomiast rok później partia, odnosząc się do kwestii konstytucji dla Europy, przyjęła dokument przed wyborami, czyli nie zważając na konsekwencje wyborcze, o wielce wymownym tytule Polska katolicka w chrześcijańskiej Europie. Pisano w nim, że w konstytucji europejskiej „musi się znaleźć odniesienie do Boga i chrześcijańskiego dziedzictwa Europy”. Miał to być „znak cywilizacyjnej orientacji". W tej kwestii często sięgano do nauczania Jana Pawła II, który łączył demokrację z wartościami. Domagano się więc wpisania stosownych regulacji w tym duchu do dyskutowanego na początku XXI wieku traktatu konstytucyjnego, twierdząc, że z chrześcijaństwa wywodzi się ład społeczny i moralny obowiązujący na kontynencie, zwłaszcza w kontekście osoby, rodziny i narodów, ale przywoływano także przykład polski - chrześcijańskie wartości wynikają z polskich dziejów, począwszy od I Rzeczypospolitej, a skończywszy na wydarzeniach z sierpnia 1980 roku. Wszelkie osadzanie integracji europejskiej w ideologii (neo)liberalnej czy też lewicowej (postmarksistowskiej) było traktowane przez PiS jako kompromitowanie tej wielkiej idei. Tuż przed wygranymi wyborami w 2005 roku sformułowano bardzo ostrą ocenę, stwierdzając, że Unia w skrajnych przypadkach „wspiera wynaturzenia, patologie moralne czy wręcz zbrodnie traktowane jako wyraz ludzkiej wolności i znamię "społeczeństwa otwartego«". W kolejnych progra- 
mach, zwłaszcza z okresu 2014-2019, takich mocnych stwierdzeń nie znajdziemy ${ }^{141}$.

Trzeci obszar odnosił się do sfery międzypaństwowej i był typowo polityczny. Został określony przez marszałka Kuchcińskiego jako „solidarność równych, wolnych i suwerennych narodów, pokój i współpraca między sąsiadami, demokratyczne rządy" ${ }^{142}$. Natomiast prezydent Duda sporządził trochę odmienną listę wartości. Wymienił trzy: jedność, równość i solidarnośćc ${ }^{143}$. W tym katalogu wartości dwie wyjątkowo często były przywoływane przez stronnictwo: suwerenność i solidarność.

W strategii polityki zagranicznej Polski na lata 2017-2021 zapisano zasadnicze spostrzeżenie: „Suwerenność pozostaje w XXI wieku najpowszechniejszym punktem odniesienia dla wszystkich istniejących współcześnie państw, niezależnie od rosnącej liczby różnych projektów integracyjnych"144. Dla PiS suwerenność państw członkowskich była wartością prymarną Unii Europejskiej, której instytucje wspólnotowe nie mogły naruszać, ponieważ państwa członkowskie "muszą zachować możliwość podejmowania własnych decyzji, w sprawach dla nich strategicznych, wynikających ze specyficznej sytuacji historycznej i geopolitycznej"145. Roszczenia w tej materii instytucji wspólnotowych były traktowane jako łamanie pierwotnego prawa europejskiego zapisanego w traktatach. Określono więc zasadę, że jakiekolwiek zmiany w traktatach unijnych mogą być dokonywane jedynie w wyniku powszechnej zgody wszystkich członków, a nie głosowania większościowego w Radzie Europejskiej w oparciu o przepisy traktatu czy to z Nicei, czy z Lizbony. Powszechna zgoda jako zasada „wyklucza wszelkie formy narzucania woli

${ }_{141}$ Polska katolicka w chrześcijańskiej Europie..., s. 40, 42; Europa solidarnych narodów..., s. 6; IV Rzeczpospolita - Sprawiedliwość dla Wszystkich..., s. 42.

142 Archiwum autora, „Deklaracja zaproponowana przez marszałka Sejmu »Europa solidarnych państw - bezpieczeństwo, granice, odnowione instytucje»", s. 1.

143 Archiwum Prezydenta RP, https://www.prezydent.pl, „Wystąpienie Prezydenta RP podczas wspólnej konferencji z Prezydentem Butgarii", 5 X 2017, dostęp 12 VI 2020.

144 Strategia Polskiej Polityki Zagranicznej 2017-2021..., S. 22.

145 Archiwum Prezesa Rady Ministrów, Sekretariat Prezesa Rady Ministrów, „Tezy do wystąpienia Prezesa Rady Ministrów RP, Pana Jarosława Kaczyńskiego w Brukseli 30 sierpnia 2006 r.", 11 VIII 2006. 
jakiemukolwiek narodowi w Europie przez państwa lub grupy państw odwołujące się do liczby swoich obywateli"146.

Za test na suwerenność Polski w Unii Europejskiej PiS uznało zachowanie: zdolności do kształtowania własnego ładu społecznego i aksjologicznego, w tym kultury, tożsamości i tradycji; uprawnień organów władzy RP do kreowania prawa w państwie zgodnie z konstytucją; możliwości formułowania koncepcji własnej polityki zagranicznej i jej realizacji; własności ziemi w polskiej dyspozycji. Jednocześnie, stojąc na gruncie ochrony suwerenności, władze RP z rekomendacji PiS miały nie tylko odrzucać wszelkie projekty budowy w Europie suprapaństwa, ale również unikać drugiej skrajności - cofnięcia integracji lub jej przekształcenia w „Unię wielu prędkości”, co mogło grozić zatriumfowaniem egoizmów narodowych. Chciano poszukiwać równowagi między zasadą suwerenności państwowej a prerogatywami instytucji powstałych w wyniku integracji1 ${ }^{147}$. Podejście było dość oryginalne, rozpatrywano bowiem projekt „Unii wielu prędkości” w kategoriach realizacji partykularnych interesów niektórych państw zachodnioeuropejskich, a nie jako wynik dbałości o efektywność integracji. Precyzyjnie sytuację zinterpretował prezydent Duda, który kategorycznie odrzucił „Unię różnych prędkości", polegającą na utworzeniu różnych porządków instytucjonalnych wewnątrz Wspólnoty i wykluczeniu niektórych państw członkowskich z pierwszego kręgu decyzyjnego. Odróżnił ten kierunek rozwoju Wspólnoty od budowania więzi regionalnych i funkcjonalnych, które były faktem (strefa Schengen, strefa euro, Beneluks, wspólnota nordycka) i wobec których PiS nie formułowało istotnych zastrzeżeń.

Prezydent mówił w 2017 roku: „Współpracujemy z sobą i zakładamy, że jesteśmy równymi członkami Unii Europejskiej. Jeżeli one zostaną złamane [...] będzie to oznaczało koniec Unii jako takiej, czyli absolutny jej schyłek, który w efekcie doprowadzi do rozpadu"148. Między dwoma

\footnotetext{
146 Strategia Polskiej Polityki Zagranicznej 2017-2021..., s. 22.

147 Ibidem, s. 22-23.

148 Archiwum Prezydenta RP, https://www.prezydent.pl, „Wystąpienie Prezydenta RP podczas wspólnej konferencji z Prezydentem Butgarii", 5 X 2017, http://www.prezydent.pl, dostęp 12 VI 2020.
} 
przytoczonymi argumentami nie było sprzeczności, ponieważ w interesie niektórych państw członkowskich Unii było zmarginalizowanie roli regionu środkowoeuropejskiego, żeby spełniał rolę jedynie dostarczyciela zasobów niezbędnych dla Europy Zachodniej. Miesiąc wcześniej Duda opisał mechanizm rozpadu Wspólnoty jako następstwo realizacji „Unii wielu prędkości": najpierw zostanie zakwestionowana przez państwa kategorii B i C jako organizacja nieatrakcyjna, bez znaczenia dla ich rozwoju, co pociągnie za sobą dezaprobatę społeczną, a następnie państwa zaliczane do grupy A uświadomią sobie, że poniosły straty, eliminując z Unii biedniejszych sąsiadów. Jednak utraconej Wspólnoty nie da sięjuż ani odzyskać, ani skleić na nowo, co będzie oznaczało porzucanie Unii przez poszczególne państwa oraz klęskę Europy w rywalizacji gospodarczej z innymi kontynentami ${ }^{149}$.

Fundamenty, na których PiS chciało oprzeć relacje między państwami członkowskimi Unii, zostały wyszczególnione w programie z 2014 roku. Było ich siedem: 1) wielość centrów regionalnych, przeciwstawionych centralizacji brukselskiej; 2) równość państw zamiast ich hierarchizacji; 3) deregulacja przeprowadzona przez instytucje unijne w miejsce kolejnych sankcji, zakazów i nakazów; 4) solidarność między państwami, uwzględniająca możliwości najsłabszego z nich; 5) otwartość na przyjęcie nowych członków; 6) demokracja zorganizowana i praktykowana efektywnie w państwach członkowskich przy rezygnacji z budowy suprapaństwa demokratycznego; 7) powrót we współpracy między państwami do tożsamości cywilizacyjnej grecko-rzymsko-chrześcijańskiej zamiast konstruktywizmu społecznego ${ }^{150}$. Za właściwe można przyjąć określenie „suwerenizm”, jako termin oddający istotę polityki europejskiej Polski prowadzonej przez gabinety utworzone przez PiS w dwóch

\footnotetext{
149 Archiwum Prezydenta RP, https://www.prezydent.pl, dostęp 12 VI 2020: „Wystąpienie prezydenta w trakcie dorocznej narady MSZ”, 4 IX 2017; „Wystąpienie Prezydenta w panelu XXVII Forum Ekonomicznego w Krynicy", 5 IX 2017.

150 Zdrowie, praca, rodzina..., s. 158-159.
} 
okresach rządów tej formacji w Polsce. Linię strategiczną tych rządów określała bowiem partia, a nie Rada Ministrów czy MSZ ${ }^{151}$.

Prawo i Sprawiedliwość odrzucało wszelkie projekty realnej hierarchizacji państw członkowskich Unii, czyli wydzielenia ze zbioru tzw. mocarstw europejskich, nawet jeśliby przyznano Polsce miejsce w tym gronie. Do sprawy odniósł się L. Kaczyński, wyjaśniając, że gdyby taka grupa państw powstała, wówczas Polska byłaby w niej najsłabsza, natomiast: „Pozycja najsłabszego wśród silnych nie jest atrakcyjna, choć oczywiście stwarza bardzo miłe pozory [...]". Korzystniejsza dla Polski byłaby "demokratyzacja” Unii, czyli „wyrównanie pozycji krajów słabszych i mocniejszych". Jednak prezydent miał wiele wątpliwości, czy taki scenariusz jest możliwy do zrealizowania z powodu oportunizmu państw małych ${ }^{152}$. W miejsce hierarchizacji państw unijnych prezydent Duda zaproponował dalszy rozwój Unii w oparciu o: 1) cztery swobody jednolitego rynku - przepływu osób, towarów, usług i kapitału; 2) jedność instytucji, prawa, rynku i budżetu; 3) przywrócenie szacunku instytucji unijnych dla demokratycznych wyborów narodów europejskich dokonywanych w państwach członkowskich - podmiotach suwerennych w Unii i wobec Unii ${ }^{153}$.

Natomiast solidarność „najlepiej wyraża sens i rolę Unii”, leży także u podstaw wielkich osiągnięć Wspólnoty, za które uważano stworzenie wspólnego obszaru gospodarczego. Jego konkretnymi efektami były wspólna polityka rolna oraz polityka spójności. Solidarność europejską wywiedziono z chrześcijaństwa i zdefiniowano jako wspólnotę interesów oraz odpowiedzialność za całość. Była też postrzegana jako przeciwieństwo egoizmu mocarstw europejskich, dążących do przeforsowania swoich partykularnych interesów oraz zdominowania organów

151 I. P. Karolewski, T. Mehlhausen, Między polityką kreowania a asertywnością. Polskie debatyo Europie na przykładzie europejskiego traktatu konstytucyjnego i wojny na Ukrainie, „Przegląd Politologiczny" 2017, nr 2, s. 56.

152 Ł. Warzecha, Lech Kaczyński. Ostatni wywiad..., s. 256.

153 Archiwum Prezydenta RP, https://www.prezydent.pl, „Wystąpienie prezydenta podczas inauguracji roku akademickiego w Kolegium Europejskim w Natolinie", 29 IX 2017، dostęp 12 VI 2020. 
wspólnotowych. Ostrzegano więc: „Będziemy się temu zdecydowanie przeciwstawiać"154. Solidarność traktowano także jako podstawę jedności, niezbędnej dla obrony interesów Unii w środowisku międzynarodowym ${ }^{155}$. Niemniej PiS tę wartość wywiodło z dwóch źródeł typowo polskich: dorobku ruchu solidarnościowego i nauczania Jana Pawła II. Traktowano ją jako podstawę uniwersalną dla najważniejszych obszarów życia społecznego i stosunków międzynarodowych ${ }^{156}$.

Nierespektowanie wartości europejskich było powodem odrzucenia w 2004 roku przez PiS Konstytucji dla Europy, którą uznano za szkodliwą dla Polski i dla integracji. W zasadzie uważano ją za przedsięwzięcie, do którego narody europejskie nie były przygotowane. Ujął ten aspekt dość plastycznie prezydent Kaczyński: „Używając kulinarnego porównania, sól jest potrzebna do prawie każdej zupy, ale zupa przesolona ma fatalny smak. I owa Konstytucja była bardzo silnym przesoleniem unijnej zupy"157. Szczegółowe wyjaśnienia odrzucenia były dwa - ta konstytucja z jednej strony była oderwana od tradycji i kultury europejskiej, a z drugiej ustanawiała dominację najsilniejszych państw, aprobując ich egoizm, kosztem unijnej solidarności. W tym drugim obszarze wskazywano: 1) zagrożenie dla suwerenności państw poprzez wprowadzenie głosowania większościowego w zakresie polityki zagranicznej, którą miały zawłaszczyć instytucje unijne; 2) nadanie Unii uprawnień w dziedzinie kultury i edukacji, co oznaczało naruszenie w tych obszarach monopolu państw członkowskich; 3) wprowadzenie wyższości prawa europejskiego nad konstytucjami, tworzące warunki do przebudowy ładu prawnego

154 Europa solidarnych narodów..., s. 8-9; IV Rzeczpospolita - Sprawiedliwość dla Wszystkich..., s. 43; Dbamy o Polskę. Dbamyo Polaków..., s. 51; Nowoczesna, solidarna, bezpieczna Polska..., s. 176; Zdrowie, praca, rodzina..., s. 157-158.

155 Archiwum MSZ, sygn. 140/o9, w. 2, „Materiat tezowo-informacyjny do wykorzystania podczas wizyty Premiera RP Pana Jarosława Kaczyńskiego z Premierami Państw Bałtyckich. Wizyta oficjalna Premiera RP na Litwie, Wilno, 7-8 grudnia 2006 r.", 4 XII 2006, s. 12.

156 Archiwum Rady Ministrów, Sekretariat Prezesa Rady Ministrów, „Tezy do wystąpienia Prezesa Rady Ministrów RP, Pana Jarosława Kaczyńskiego w Brukseli 30 sierpnia 2006 r.", 11 VIII 2006, [b.p.].

157 Wywiad prezydenta Lecha Kaczyńskiego dla PAP na tematy międzynarodowe, 24 I 2006, http://www.pap.pl, dostęp 14 VIII 2014. 
i społecznego w poszczególnych państwach, co w rzeczywistości oznaczałoby rezygnację z suwerenności; 4) przyznanie sobie przez instytucje unijne nowych uprawnień, w tym do koordynacji polityki gospodarczej i polityki zatrudnienia, prowadzących do ograniczenia konkurencji wewnątrzunijnej oraz możliwości rozwojowych państw środkowoeuropejskich. Konkluzja była wielce wymowna: „Nie możemy zgodzić się na traktat zmieniający charakter Unii i pozbawiający państwa europejskie kompetencji, bez których trudno wyobrazić sobie ich suwerenność"158.

Najpełniejsze wyjaśnienia stanowiska PiS w tej kwestii zaprezentował w Sejmie Jarosław Kaczyński 21 stycznia 2004 roku. Negatywne stanowisko partii zostało opisane przez odwołanie się do argumentów ze sfery decyzyjnej, duchowej, gospodarczej, zagranicznej i obronnej. Pierwsza była stosunkowo prosta - Polska nie mogła zaakceptować nowego sposobu głosowania. Co do drugiej Kaczyński uznał, że konstytucja Unii zapowiada realizację wielkiego antychrześcijańskiego eksperymentu konstruktywistycznego, negującego rolę konstytucji narodowych oraz instytucji demokratycznych ukształtowanych w państwach członkowskich. W odniesieniu do gospodarki prezes PiS oskarżył twórców konstytucji o przekazywanie instytucjom unijnym narzędzi sterujących rozwojem, co grozi zablokowaniem szybkiego tempa rozwoju gospodarczego w Polsce. Najostrzejsza ocena dotyczyła postulowanej organizacji polityki zagranicznej i obronnej, opartej na dominacji interesów najważniejszych państw unijnych. Reakcja była jasna: „To nie ma żadnego sensu z punktu widzenia naszych najbardziej elementarnych interesów i dlatego nie możemy się na to zgodzić"159.

3. Unia musi być zakorzeniona w stosunkach społecznych istniejących w Europie oraz musi rozwiązywać najważniejsze problemy społeczne widoczne na kontynencie. System polityczny Unii wszedł w spiralę kryzysu, nie miał bowiem nie tylko realnych podstaw społecznych, ale

158 Europa solidarnych narodów..., s. 14-15; IV Rzeczpospolita - Sprawiedliwość dla Wszystkich..., s. 41-42.

159 J. Kaczyński, Wystąpienie w debacie nad informacją ministra spraw zagranicznych o podstawowych kierunkach polityki zagranicznej Polski w 2004 roku... 
również zorientowania społecznego - był oderwany od rzeczywistości społecznej. Prezydent Kaczyński już w 2006 roku określał sytuację dość jasno: „[...] dzisiaj zasadniczym problemem, przed którym stoi UE i elity polityczne, jest odzyskanie zaufania społecznego do działań Wspólnoty. Aby stało się to możliwe, musimy dowieść, że potrafimy skutecznie zająć się sprawami najważniejszymi dla obywateli Europy" ${ }^{160}$. W opinii PiS ta organizacja międzynarodowa coraz bardziej oddala się od społeczeństw europejskich w kierunku utopii, a obywatele państw członkowskich według Dudy - nie mają „poczucia sprawczości w polityce”, a głos wielu z nich jest dezawuowany ze względów ideologicznych i wykluczany z debaty publicznej w wyniku uznania go za przejaw populizmu ${ }^{161}$. Ostrzegano więc: „Ponieważ nie istnieje i nie będzie istnieć naród europejski, do którego woli można by się odwołać poprzez wybory lub referendum, potrzebne jest wypracowanie takich mechanizmów podejmowania na szczeblu Unii decyzji w istotnych kwestiach, które zapewnią większy wpływ wszystkich obywateli państw członkowskich za pośrednictwem mechanizmów funkcjonujących na szczeblu państw narodowych"162. Kuchciński mówił na szczycie przewodniczących parlamentów o koniecznym zakorzenieniu Unii w rzeczywistości politycznej państw członkowskich oraz w demokracjach narodowych, przeciwstawiając tym cechom ideologizację dyskusji europejskiej, która ignoruje fakty społeczne ${ }^{163}$. Prezydent Duda domagał się zaś „upodmiotowienia głosu obywateli w debacie o przyszłości Unii Europejskiej"164.

160 Archiwum Rady Ministrów, Sekretariat Prezesa Rady Ministrów, „Pismo prezydenta Lecha Kaczyńskiego do premiera Kazimierza Marcinkiewicza", 15 VI 2006, s. 1.

161 Archiwum Prezydenta RP, https://www.prezydent.pl, „Wystąpienie Prezydenta podczas inauguracji wystawy poświęconej Jerzemu Iwanowiczowi Szajnowiczowi", 20 XI 2017, dostęp 12 VI 2020.

162 Nowoczesna, solidarna, bezpieczna Polska..., s. 176.

163 Archiwum autora, „Wystąpienie marszałka Sejmu Marka Kuchcińskiego podczas Konferencji Przewodniczących Parlamentów UE”, Tallin, 23-24 IV 2018, s. 1; ibidem, „Wystąpienie marszałka Sejmu Marka Kuchcińskiego na Konferencji Przewodniczących Parlamentów UE", 8-9 IV 2019, Wiedeń, s. 2.

164 Archiwum Prezydenta RP, https://www.prezydent.pl, „Wystąpienie Prezydenta podczas inauguracji wystawy poświęconej Jerzemu Iwanowiczowi Szajnowiczowi", 20 XI 2017, dostęp 12 VI 2020. 
Z opisanych przesłanek wynikały wnioski dla Unii. Po pierwsze, uruchomienie nowych impulsów na rzecz pobudzania gospodarki jest możliwe jedynie w przypadku poszerzania przestrzeni wolności gospodarczych wbrew trendowi biurokratyzowania życia gospodarczego przez administrację unijną. Po drugie, konieczność utrzymania dwóch polityk szczegółowych: wspólnej polityki rolnej i polityki spójności, będących podstawą polityki regionalnej. PiS uznawało je za fundamenty istnienia i akceptacji Unii jako wspólnoty działającej w kierunku zaspokajania oczekiwań społecznych i wyrównywania poziomów życia na kontynencie. Po trzecie, poszerzanie i pogłębianie wolnego rynku w Europie w odniesieniu do przepływu osób, towarów, kapitału i usług. Te tradycyjne cztery wolności unijne, mocno eksponowane w licznych enuncjacjach programowych, należało oprzeć na dwóch zasadach: wolnej konkurencji i solidarności społecznej, czyli odrzucić w tej kwestii rodzącą się w Europie Zachodniej politykę protekcjonizmu narzucaną instytucjom unijnym. Po czwarte, zasadnicza zmiana roli instytucji wspólnotowych, które wydają zakazy, nakazy i sankcje, a powinny skoncentrować się na: byciu strażnikiem realizacji czterech wolności, przeprowadzaniu deregulacji, znoszeniu barier krępujących inicjatywy różnego typu, wyrównywaniu szans i egzekwowaniu równych zasad w Unii.

Według PiS wolna konkurencja wewnątrz Unii jest nienaruszalna, zwłaszcza między starymi członkami i nowymi, i stanowi szansę dla gospodarki europejskiej oraz szybkiego wyrównania dysproporcji między regionami. Cztery wolności, traktowane w sposób szeroki, pozwoliłyby Europie Środkowej wykorzystać jej przewagi konkurencyjne, ponieważ działałby mechanizm wyrównywania poziomu rozwoju, a także doprowadziłyby do tego, że rynek europejski przestałby być „jednolity”, a stałby się „wspólny"165. Dlatego też partia Kaczyńskiego odrzucała harmonizację prawa podatkowego i ubezpieczeń społecznych w Unii, optując za ochroną konkurencji systemowej we Wspólnocie, chociażby w tych dwóch dziedzinach życia ekonomicznego. Stwierdzano kategorycznie, że polski budżet nie może być kontrolowany przez unijnych urzędników,

165 Vide K. Szczerski, Utopia europejska..., s. 39. 
gdyż to godziłoby w kanony demokracji, o podatkach i wydatkach może bowiem decydować tylko organ państwa pochodzący z demokratycznych wyborów i reprezentujący suwerena (naród). W strategii polityki zagranicznej Polski na lata 2017-2021 przywołano nawet historyczną dewizę rewolucji antyabsolutystycznych - No taxation without representation ${ }^{166}$. Patrząc na historię Europy, a przede wszystkim na dzieje monarchii stanowych i cztery klasyczne rewolucje zrodzone z idei powstałych na kontynencie (niderlandzka, angielska, francuska, amerykańska), można by takie uprawnienia budżetowe uznać za istotę nowożytnej europejskiej kultury politycznej zrodzonej z oporu przeciwko despotyzmowi i absolutyzmowi. Instytucje unijne zaczęły uzurpować sobie prawo decydowania o podatkach, co było niemożliwe do zaakceptowania, gdyż oznaczałoby, że Unia dąży do bycia już nie tylko suprapaństwem z hybrydowym ustrojem, ale superpaństwem o charakterze federalnym.

Prawo i Sprawiedliwość uważało, że Unia może sprostać wyzwaniom globalnym przy jednoczesnym zastosowaniu dwóch rozwiązań: poszerzaniu budżetu unijnego przez wprowadzanie dodatkowych dochodów i uszczelnianie dotychczasowych podatków oraz utrzymaniu tradycyjnych programów unijnych uzupełnianych o nowe, realizowane w kolejnych obszarach zainteresowania, takich jak nauka, technologia, cyfryzacja, rozwój, klimat oraz środowisko. Takie podejście oznaczało brak zgody na rewizję wydatków unijnych na rzecz chociażby rolnictwa, spójności, infrastruktury, telekomunikacji. Dlatego też PiS zdecydowanie broniło utrzymania funduszy strukturalnych. Politycy PiS odpowiedzialni za politykę europejską obalali mit, że te wydatki unijne są formą "dotacji” za pośrednictwem Unii wypłacanych przez państwa bogate biednym, głównie położonym w Europie Środkowej. Do tej kwestii odnieśli się publicznie J. Czaputowicz i K. Szymański. Ten pierwszy opisał je w Sejmie: „Stanowią one rekompensatę dla słabszych partnerów wypłacaną przez bardziej rozwinięte pod względem gospodarczym

166 Europa solidarnych narodów..., s. 18; IV Rzeczpospolita - Sprawiedliwość dla Wszystkich..., s. 45; Zdrowie, praca, rodzina..., s. 157; Strategia Polskiej Polityki Zagranicznej 2017-2021..., s. 15-16; Dobry czas dla Polski..., s. 185. 
państwa w zamian za zniesienie ceł i kwot protekcjonistycznych oraz za otwarcie mniej konkurencyjnych gospodarek na swobodną konkurencję ze strony silniejszych. Fundusze nie są zatem jakąś charytatywną darowizną bogatszych dla biedniejszych. Większość z tych środków wraca do płatników netto". Drugi odniósł się do sprawy na konwencji programowej PiS 5-7 lipca 2019 roku w Katowicach. Szymański określił składkę unijną jako „dobrą inwestycję publiczną, z której płynie przyzwoity zysk", osiągany przez „stare" państwa członkowskie, widoczny we wzroście ich PKB oraz w bilansach firm. Podkreślił, że znaczna część pieniędzy zainwestowanych w nowych państwach członkowskich wraca do płatników netto. Oszacował ją na kwotę około 200 mld euro zwrotu z inwestycji oraz realizacji kontraktów ${ }^{167}$. Takie podejście do sprawy funduszy europejskich było cechą odróżniającą myśl polityczną PiS od konkurentów lewicowych i liberalnych.

Zdaniem polityków PiS misją Unii po jej rozszerzeniu powinno być dążenie do rzeczywistego zjednoczenia Europy, co można było osiągnąć przez stworzenie korzystnych warunków systemowych dla nowych państw członkowskich, faktycznie zaś dla Europy Środkowej. Zachód powinien wziąć odpowiedzialność za przyszłość tej części kontynentu. W 2011 roku zaproponowano powołanie specjalnego funduszu solidarności dla nowych członków, a w latach 2014-2015 wprowadzono pojęcie zrównoważonego rozwoju w skali zarówno Polski, jak i Europy ${ }^{168}$. Ten pomysł został przeciwstawiony koncepcji rozwoju polaryzacyjno-dyfuzyjnego, opartego na planie inwestowania w wybrane centra gospodarcze, które w następnej fazie miały spowodować rozwój peryferii. Polscy konserwatyści uznali ten projekt za przejaw liberalizmu, a faktycznie

167 J. Czaputowicz, Informacja ministra spraw zagranicznych o zadaniach polskiej polityki zagranicznej w 2018 roku..., s. 86; K. Szymański, Unia polskich oczekiwań..., s. 173.

168 Trudno się zgodzić z oceną sformułowaną przez Piotra Tośka, że model rozwoju gospodarczego zaproponowany przez PiS oznacza autarkię. Taka opinia zaprezentowana przez tego politologa nie została opatrzona żadnymi danymi ekonomicznymi i wydaje się wynikać z przeceniania efektów pozytywnych koncepcji neoliberalnych dominujących w ostatniej dekadzie XX wieku w Europie Środkowej. P. Tosiek, Polska wizja "rekonstytucji” Unii Europejskiej: nowy model integracji zróżnicowanej?, „Przegląd Europejski" 2017, nr 3, s. 51. 
ekonomicznej utopii, prowadzący do niesprawiedliwości społecznej, a w konsekwencji do kryzysu, który zakwestionuje istnienie Unii i ładu europejskiego. Innym wyraźnie już widocznym skutkiem przyjętego błędnego modelu rozwoju w skali kontynentu było uczynienie Niemiec jedynym faktycznym beneficjentem procesu integracji opartego na euro. KrzysztofSzczerski model polaryzacyjno-dyfuzyjny połączył z projektami federalizacji Unii, dostrzegając ich wzajemne sprzężenie prowadzące do powstania lokomotyw rozwoju i obszarów biedy, co miałoby się pokrywać z podziałem centrum-peryferie ${ }^{169}$.

Wszelkie formy zaangażowania Unii w sprawy społeczne nie mogły jednak przekraczać zasady pomocniczości (subsydiarności) wywiedzionej z nauki społecznej Kościoła katolickiego. To znaczy, że jeśli Unia jest wspólnotą międzypaństwową, to pierwszeństwo w rozwiązywaniu problemów społecznych mają wspólnoty bardziej podstawowe, jak rodzina, samorząd, państwo. Dopiero gdy te wspólnoty okażą się bezradne, powinna się zaangażować wspólnota z wyższego poziomu stosunków społecznych - organizacja międzynarodowa. Jednak takie zaangażowanie nie może być ingerencją w przyrodzone uprawnienia innych wspólnot.

4. PiS wypracowało własny projekt zmian instytucjonalnych w systemie politycznym Unii, który wynikał z mocnych oskarżeń kierowanych pod adresem instytucji unijnych, że łamią prawo pierwotne UE, nadużywają swojej pozycji, uzurpują sobie kompetencje przynależne państwom członkowskim, łamią zasady subsydiarności, co prowadzi do działań na szkodę integracji. Szczerski nazwał nową wizję Unii „demokracją międzyrządową", a proces do tego prowadzący - rekonstytucją Unii, co miało oznaczać z jednej strony odżegnywanie się od rewolucji w systemie politycznym Unii, a z drugiej strony przeprowadzenie zmian normatywnych (zmiana wartości) i instytucjonalnych (przemodelowanie struktury). Duda mówił zaś - jak klasyczny konserwatysta - o powrocie do rozwiązań (źródeł), które zostały już w przeszłości integracji sprawdzone i wywodzą się z jej początków, a polegały na realizacji „koncepcji pozytywnego multilateralizmu". Według PiS system polityczny Unii nie

169 K. Szczerski, Dynamika systemu europejskiego..., s. 40. 
powinien być budowany na podobieństwo państwa demokratycznego, czyli opartego na trójpodziale władzy. Argumentacja była dość prostaUnia nie jest superpaństwem, lecz organizacją międzynarodową, która powinna przybrać postać demokracji międzyrządowej. Organy unijne tworzące arenę wspólnotową mają charakter tylko pomocniczy wobec areny międzyrządowej i muszą być podporządkowane wartościom wspólnotowym, więc nie należy na nie patrzeć z perspektywy mechanizmu równowagi władz: prawodawczej, wykonawczej i sądowniczej ${ }^{170}$, gdyż tych kompetencji nie można przypisać jednoznacznie poszczególnym instytucjom. Odrzucano więc kliszę państwową analizowania systemu politycznego Unii, której efektem było nadawanie Wspólnocie charakteru suprapaństwa.

Proponowane zmiany w systemie politycznym Unii wynikały z czterech konkretnych przesłanek. Pierwsza - tak jak politycy PiS nie fetyszyzowali traktatów unijnych, tak również nie uważali, że system polityczny Unii jest niezmienną i wieczną strukturą. I prawo unijne, i system polityczny były postrzegane jako efekt kontraktu politycznego, ze swej natury podlegającego rewizji. Druga - stronnictwo J. Kaczyńskiego nie oceniało dobrze ładu instytucjonalnego Unii, bynajmniej nie bezpośrednio z powodu przepisów traktatowych, lecz praktyki politycznej. Traktaty tworzyły rusztowania prawne korzystne dla Polski - dodawały jej wagi przekraczającej potencjał gospodarczy, ale jednocześnie były też "winne" pośrednio, ponieważ nie zablokowały skutecznie uzurpacji kompetencji dokonywanej przez organy wspólnotowe. Trzecia - organy wspólnotowe nie reprezentowały suwerena europejskiego, nie ma bowiem ani ludu, ani narodu europejskiego, istnieje tylko wspólnota narodów. Nie ma więc bazy społecznej dla uzurpacji politycznej dokonywanej przez instytucje

170 Wedtug Szczerskiego: „Pojęcie rekonstytucji w naukach politycznych oznacza dokonywanie zmiany nie po to, by zakwestionować (zniszczyć) to, co było poprzednio - to nazywamy rewolucją - lecz chodzi o taką zmianę, która pozwoli na zachowanie ciągłości instytucji politycznych, przy równoczesnej zmianie parametrów ich działania". Idem, Utopia europejska..., s. 10, 73, 93; Archiwum Prezydenta RP, https://www.prezydent.pl, dostęp 12 VI 2020: „Wystąpienie Prezydenta na otwarciu Forum Regionów Trójmorza”, 3 VII 2018; „Wystąpienie Prezydenta podczas 73. sesji Zgromadzenia Ogólnego ONZ”, 26 IX 2018. 
wspólnotowe, tym samym nie mają one legitymacji demokratycznej. Ludzie stają się Europejczykami, bo każdy człowiek i rodzina przynależą do jednego z narodów europejskich. Czwarta - właśnie instytucje unijne oskarżono o kryzys integracji, podsycanie nastrojów wrogich wobec Wspólnoty, dzielenie państw członkowskich, rozczarowanie narodów europejskich Unią. Za oś sprawnego funkcjonowania systemu politycznego Unii Europejskiej PiS uznało harmonijną współpracę między suwerennymi państwami członkowskimi, połączoną z uniemożliwieniem instytucjom wspólnotowym działań typu "piętnowanie, dzielenie i antagonizowanie narodów europejskich" (A. Duda) ${ }^{171}$. Była to jedyna droga do rewizji podstaw prawnych Unii.

Projektowany przez PiS ład instytucjonalny Unii miał być zaprzeczeniem powstałych w Polsce projektów liberalnych firmowanych przez PO. Ich istotę wypunktował K. Szczerski jeszcze w Sejmie VII kadencji. Zarzucił PO, że przyjęła błędne założenia projektu wyprowadzenia Unii z kryzysu: 1) scentralizowanie procesu decyzyjnego w Unii; 2) zhierarchizowanie centrum decyzyjnego; 3) ustalanie wagi państw członkowskich w oparciu o kryterium gospodarcze; 4) wyposażenie centrum we władzę dyscyplinowania słabszych i biedniejszych państw członkowskich; 5) nadanie centrum uprawnień nakładania sankcji, regulacji, nakazów i zakazów; 6) zanegowanie woli narodów wyrażonych w wyborach tzw. krajowych; 7) narzucenie Europie przez centrum jednego modelu społeczno-gospodarczego ${ }^{172}$. Dla polskiej racji stanu takie zmiany były nieakceptowalne, ale również to właśnie o nakazach i zakazach unijnych prezydent Duda mówił, że Europejczycy ich nie rozumieją i one zniechęcają najbardziej do Unii ${ }^{173}$.

171 IV Rzeczpospolita-Sprawiedliwość dla Wszystkich..., s. 43; Zdrowie, praca, rodzina..., s. 159; Wystąpienie Prezydenta RP na spotkaniu noworocznym z Korpusem Dyplomatycznym, 11 | 2018, http://www.prezydent.pl, dostęp 2 V 2020.

172 K. Szczerski, Wypowiedź, [w:] WNP Sejm, 7 kadencja, 3 pos., 15 XII 2011, http://www. sejm.pl, dostęp $21 \mathrm{~V} 2020$.

173 Archiwum Prezydenta RP, https://www.prezydent.pl, „Wystąpienie Prezydenta w panelu XXVII Forum Ekonomicznego w Krynicy", 5 IX 2017, dostęp 12 VI 2020. 
W programie partii z 2007 roku zapisano zaś, że wszelka rewizja systemu politycznego Unii powinna prowadzić do zwiększenia przejrzystości wewnętrznych mechanizmów decyzyjnych oraz podniesienia transparentności funkcjonowania instytucji unijnych ${ }^{174}$. Można sformułować wniosek, że PiS chciało nowej konfiguracji integracji europejskiej w sensie instytucjonalnym i funkcjonalnym, ale z wykorzystaniem rozwiązań sprawdzonych w pierwszych dekadach budowania Wspólnoty. Niemal automatycznie oznaczało to konfrontację z euroentuzjastami, gdyż opierało się na założeniu, że nie będzie efektywnej odnowy Unii bez porzucenia przez nią misji ideologicznej i celów konstruktywistycznych ${ }^{175}$.

Trudno zgodzić się ze stwierdzeniem politologa Piotra Tośka, że w początkowej fazie "drugich rządów" PiS trudno dostrzec na poziomie debaty naukowej klarowną i jednoznaczną koncepcję integracji europejskiej autorstwa tego stronnictwa ${ }^{176}$. Takowa została przedstawiona dopiero w książce K. Szczerskiego z 2017 roku Utopia europejska ${ }^{177}$. Tosiek nie zauważył, że już w 2011 roku Z. Krasnodębski pisał o europejskiej utopii ${ }^{178}$. W jednym aspekcie Tosiek miał rację - naukowcy nie podjęli trudu przeanalizowania myśli politycznej PiS w odniesieniu do polityki zagranicznej, ale koncepcja PiS Unii Europejskiej kształtowała się przez wiele lat. Politycy PiS mówili i pisali o tym dość często. Przełomowy wydaje się program z 2014 roku, w którym opisano fundamenty koncepcji organizacji Wspólnoty. Krzysztof Szczerski dokonywał w swojej monografii pewnego podsumowania. Nie ma także racji Beata Master, pisząc, że PiS jest rzecznikiem "podejścia konfederalnego w ramach Unii Europejskiej"179.

174 Dbamyo Polskę. Dbamyo Polaków..., s. 50.

175 Nową konfigurację integracji europejskiej jako antidotum na rozpad Unii zaproponowat Jan Zielonka. Taka koncepcja nieśmiało przebijała się w środowisku naukowców. J. Zielonka, Koniec Unii Europejskiej?, PISM, Warszawa 2014. Piotr Tosiek tad instytucjonalny i funkcjonalny Unii zawarty w koncepcji PiS nazwał "rekonstytucją", zgodnie z nazewnictwem wprowadzonym przez Szczerskiego. P. Tosiek, op. cit., s. 50.

176 Ibidem, s. 48.

177 K. Szczerski, Utopia europejska...

178 Z. Krasnodębski, Większego cudu nie będzie..., s. 13 i n.

179 B. Master, op. cit., s. 62. Jeśli poszukiwać teorii europejskich najlepiej oddających myśl polityczną PiS, to temu stronnictwu zdecydowanie najbliżej jest do teorii międzyrządowości, przy odrzuceniu federalizmu i (neo)funkcjonalizmu. Vide M. A. Cichocki, 
W żadnym z dokumentów PiS nie określiło swojego stanowiska w ten sposób. Raczej odcinało się od postrzegania Wspólnoty jako federacji i konfederacji z powodów zasadniczych, gdyż oba te określenia wynikają z rozumowania o Unii w kategoriach paneuropejskich, czyli suprapaństwowych i superpaństwowych.

Za instytucje reprezentujące państwa członkowskie Unii, a w konsekwencji także narody europejskie, PiS uznawało Radę Europejską, Radę Unii Europejskiej oraz parlamenty narodowe, ponieważ za tymi instytucjami stoi legitymacja demokratyczna, to one reprezentują narody i państwa oraz są predystynowane do urzeczywistniania demokracji międzyrządowej. Jak to ujęła w Sejmie Izabela Kloc: „Prawo i Sprawiedliwość jest orędownikiem reformy Unii, w wymiarze polityczno-instytucjonalnym opowiada się za centralną rolą rządów państw członkowskich, w tym wiodącą rolą Rady Europejskiej, oraz za dowartościowaniem parlamentów narodowych" ${ }^{180}$. Wymienione instytucje określono jako "główne instytucje decyzyjne UE rozstrzygające wszystkie zasadnicze i strategiczne zagadnienia" oraz „wytyczające kierunki polityki”. Postulowano więc potwierdzenie w traktatach roli rządów i parlamentów narodowych oraz polityczne wzmocnienie Rady Europejskiej chociażby w odniesieniu do polityki zagranicznej, natomiast prawodawcze wzmocnienie Rady Unii Europejskiej, na której powinna spoczywać największa odpowiedzialność w dziedzinie projektowania unijnego prawa, najpierw zgodnie z regułami nicejskimi, a następnie lizbońskimi, jeśli chodzi o ważenie i liczenie głosów. Obie instytucje - Rada Europejska i Rada Unii - były postrzegane jako ucieleśnienie „demokracji międzyrządowej” lub wizji Unii Europejskiej typu „model współpracy”. Pierwszego określenia użył K. Szczerski. Owa "demokracja międzyrządowa” miała być ufundowana na czterech filarach:1) powszechna zgoda państw członkowskich;

„Więcej Europy" jako przykład strategii antykryzysowej - próba oceny efektywności, „Studia Europejskie" 2017, nr 2, s. 12; K. Zuba, The role of ideology and political partie in the proces of formulating Polish foreign policy, [w:] Poland's foreign policy in the $21^{\text {st }}$ century, ed. S. Bieleń, Wydawnictwo Difin, Warszawa 2011, s. 214.

180 I. Kloc, Wypowiedź, [w:] WNPSejm, 8 kadencja, 60 pos., 21 III 2018, http://www.sejm.pl, dostęp 14 II 2020. 
2) parlamenty narodowe kontrolerami instytucji unijnych; 3) wyliczenie kompetencji wyłączonych Unii realizowanych przez organy wspólnotowe; 4) egzekwowanie zasady pomocniczości ${ }^{181}$. Tak o Radzie Unii Europejskiej pisano w jednym z dokumentów PiS: „Będziemy działać na rzecz zachowania kluczowej roli i utrzymania decyzyjnej samodzielności [...], organu złożonego z przedstawicieli rządów państw narodowych, w stosunku do innych instytucji Unii"182. Natomiast na "model współpracy" miało składać się pięć elementów: 1) Unia nie jest tożsama z Europą, lecz kompatybilna, ale to Wspólnota dźwiga odpowiedzialność za sytuację na kontynencie; 2) integracja uzupełnia państwa narodowe w ich funkcjach; 3) Unia nie jest ojczyzną, tylko zbiorem ojczyzn; 4) zarówno UE, jak i państwa członkowskie są zorientowane na osiąganie korzyści; 5) demokracja może być praktykowana jedynie w państwach narodowych, bo Unia nie tworzy stosownej przestrzeni, a dla demokracji może być nawet zagrożeniem ${ }^{183}$. Oba modele teoretyczne są oparte na jednym założeniu - ich nosiciel (czyli PiS) akceptuje członkostwo w Unii połączone z częściowym oddelegowaniem suwerenności, ale pod stałą kontrolą krajowych organów władzy (prezydent, parlament, sąd konstytucyjny). Tym samym naturalne jest wskazywanie Rady Europejskiej i Rady Unii jako głównych instytucji unijnych, wich pracach podmiotami są bowiem państwa członkowskie.

Roli wiodącej w Unii nie przypisywano ani Komisji Europejskiej, ani Parlamentowi Europejskiemu. Ten pogląd wynikał z postrzegania Unii, i jasno wyartykułowali go minister spraw zagranicznych Czaputo-

181 K. Szczerski, Utopia europejska..., s. 155-156, 235-236.

182 Europa solidarnych narodów..., s. 12; IV Rzeczpospolita - Sprawiedliwość dla Wszystkich..., s. 44; Nowoczesna, solidarna, bezpieczna Polska..., s. 176. Znaczenie Rady Unii Europejskiej dla obrony racji stanu i interesów narodowych państw członkowskich wynika z analizy wyników głosowań w tej instytucji, przeprowadzonej przez Adriana Gorgosza. Z tej analizy wynika, że poszczególne państwa były w stanie konsekwentnie bronić w Radzie swoich interesów w pojedynkę; budowanie koalicji sprzeciwu było znacznie rzadsze. A. Gorgosz, Kto i z kim? Analiza rozbieżności stanowisk w gtosowaniu w Radzie Unii Europejskiej w latach 2009-2014, „Przegląd Europejski” 2018, nr 2, s. 175-198.

183 I. P. Karolewski, T. Mehlhausen, op. cit., s. 58-59. Autorzy wymienili w stosownej tabeli jedynie cztery elementy „modelu wspótpracy”, ale w jej interpretacji został wskazany jeszcze piąty element. 
wicz i minister w Kancelarii Prezydenta Szczerski. Według pierwszego: „Komisja Europejska nie jest superrządem, a Parlament Europejski nie jest superparlamentem uprawnionym do instruowania rządów i parlamentów narodowych”. Natomiast zdaniem drugiego: „Instytucje unijne, takie jak Komisja Europejska czy Parlament Europejski, nie mogą same być źródłem swojej władzy i uprawnień decyzyjnych. Nie mogą kreować nowej władzy [...] samymi własnymi decyzjami czy własnymi roszczeniami kompetencyjnymi". Tylko i wyłącznie państwa członkowskie w drodze negocjacji międzyrządowych w oparciu o traktaty mogą przyznawać kompetencje, ponieważ to do nich należy „kompetencja do kompetencji"184. W tej kwestii PiS nie pozostawiało żadnych wątpliwości. Instytucje europejskie były postrzegane jako powołane po to, aby „pomagać państwom europejskim oraz działać na rzecz dobra wspólnego". Dość precyzyjnie opisano ich zadania: 1) sprzyjanie wolności na rzecz rozwoju; 2) umacnianie pluralizmu i różnorodności utrwalonej historycznie w Europie; 3) dbałość o bezpieczeństwo mieszkańców państw europejskich ${ }^{185}$. Jednocześnie padło zastrzeżenie, że: „Komisja nie może jednak być politycznym centrum Unii. Nie należy więc zrównywać jej z Radą ${ }^{186}$. Z tego powodu kompetencje Komisji nie powinny być rozbudowywane. Reasumując, PiS odrzucało kierunek pozatraktatowego rozszerzania w praktyce roli Komisji w systemie politycznym. Tu proponowano nie tylko zahamowanie tego trendu, ale również inne jej usytuowanie w systemie politycznym UE, zgodne z filozofią zapisaną w unijnym prawie pierwotnym.

Partia Kaczyńskiego uważała, że działalność głównych instytucji wspólnotowych była zaprzeczeniem ich posłannictwa. Przyjmowały rolę strony w sporach z państwami członkowskimi, broniąc rzekomych wartości europejskich i próbując narzucać państwom swoją wolę. PiS odrzucało też, zwłaszcza po 2015 roku, wszelką stronniczość i model ich

184 J. Czaputowicz, Informacja ministra spraw zagranicznych o zadaniach polskiej polityki zagranicznej w 2018 roku..., s. 83; K. Szczerski, Utopia europejska..., s. 20.

185 Archiwum autora, „Deklaracja zaproponowana przez marszałka Sejmu »Europa solidarnych państw - bezpieczeństwo, granice, odnowione instytucje»", s. 2.

186 Europa solidarnych narodów..., s. 12-13. 
upolitycznienia. Dlatego też przestrzegano, że instytucje wspólnotowe „nie mogą być wykorzystywane do kampanii ideologicznych, ingerencji w sprawach moralnych i obyczajowych oraz ograniczania wolności głoszenia poglądów zgodnych z chrześcijańskim systemem wartości"187. W latach 2015-2019 doszedł kolejny zarzut - ingerencji motywowanej politycznie i ideologicznie w ład wewnętrzny, w tym w porządek ustrojowy państw członkowskich. Ingerencji dokonywanej wbrew przepisom traktatów unijnych. W konsekwencji domagano się jednoznacznego określenia kompetencji organów wspólnotowych oraz zatrzymania praktyki łamania traktatu z Lizbony, w którym zapisano domniemanie kompetencji państw członkowskich. Żądano, żeby instytucje europejskie były praworządne, czyli przestrzegały prawa europejskiego zapisanego w traktatach, podczas gdy w rzeczywistości dokonywały one jego interpretacji rozszerzającej, w wyniku której powstała przestrzeń do ingerencji w sprawy wewnętrzne państw. Z naruszeniami traktatów korespondowało nieszanowanie konstytucji narodowych ${ }^{188}$. Ten proces dokonywał się nie tylko wbrew traktatowi z Lizbony, ale także bez zgody Rady Europejskiej. Naruszanie traktatów europejskich doprowadziło do nierównego traktowania państw członkowskich. Koronnym dowodem było postępowanie Komisji Europejskiej wobec Polski w sprawie reformy sądownictwa, w której Warszawa recypowała rozwiązania stosowane w zachodnioeuropejskich państwach członkowskich Unii, wywołując w tej kwestii spór polityczny i sądowy z instytucjami wspólnotowymi.

Mocne zarzuty były formułowane także wobec Parlamentu Europejskiego i Trybunału Sprawiedliwości Unii Europejskiej. W uchwale Rady Politycznej PiS Silna Polska w Europie przypisano Parlamentowi rolę kontrolno-informacyjną, odrzucając wszelkie pomysły rozszerzenia jego kompetencji oraz uznania go za reprezentanta suwerena, który może podejmować decyzje w jego imieniu ${ }^{189}$. O Parlamencie Europejskim

\footnotetext{
187 Archiwum autora, „Wystąpienie marszałka Sejmu Marka Kuchcińskiego na Konferencji Przewodniczących Parlamentów Unii Europejskiej w Luksemburgu", 23 V 2016, s. 2; Polska nowoczesna, Polska solidarna, Polska bezpieczna..., s. 172.

188 Dobry czas dla Polski..., s. 185.

189 Silna Polska w Europie..., s. 124.
} 
Kuchciński mówił: „Model parlamentaryzmu europejskiego ma wady konstrukcyjne i działa źle"190. Ten pogląd nie uległ weryfikacji nawet po wygranych wyborach europejskich w 2019 roku. Dla PiS najważniejszą rolą Parlamentu Europejskiego było kontrolowanie Komisji Europejskiej, podczas gdy Parlament coraz wyraźniej chciał zastępować parlamenty narodowe, co przyczyniło się do deficytu demokracji w Unii.

Jako remedium na obowiązujący model parlamentaryzmu europejskiego proponowano wzmocnienie znaczenia parlamentów narodowych przez włączenie ich w unijny proces decyzyjny, czyli rozszerzenie, a co najmniej wykonywanie, przepisów traktatu z Lizbony, w którym z parlamentów narodowych uczyniono strażników prawidłowego funkcjonowania Unii w kontekście respektowania zasady pomocniczości. Zostały one wmontowane w proces legitymizacji Unii. Wyposażono je w "mechanizm wczesnego ostrzegania" (system kolorowych kartek) możliwy do zastosowania w przypadku, gdyby organy unijne łamały zasadę pomocniczości ${ }^{191}$.

Według PiS ten mechanizm nie został faktycznie uruchomiony (pozostał martwy poza bardzo nielicznymi i nieistotnymi wyjątkami), co zaowocowało nagminnym przekraczaniem przez instytucje unijne zasady pomocniczości. Dlatego też PiS opowiedziało się za wyposażeniem parlamentów narodowych w rozszerzony system kartek, ale działających realnie: „zieloną", „pomarańczową", „żółtą" i „czerwoną”. W praktyce oznaczało to przyznanie grupie parlamentów narodowych (1/4 lub 1/3 bądź $1 / 2$ tychże parlamentów) zarówno prawa do inicjatywy europejskiej, jak i uprawnienia do wstrzymywania lub wetowania wobec decyzji Komisji Europejskiej. „Czerwona" kartka wydawała się w tej kwestii klu-

190 Archiwum autora , „Wystąpienie marszałka Sejmu Marka Kuchcińskiego na Konferencji Przewodniczących Parlamentów Unii Europejskiej w Luksemburgu", 23 V 2016, s. 3. O iluzji demokracji w odniesieniu do Parlamentu Europejskiego vide T. G. Grosse, Kryzys demokracji w Europie, „Przegląd Europejski” 2014, nr 3, s. 32-33.

191 Analiza formalnej roli parlamentów narodowych w systemie politycznym UE dokonana przez Martę Zalewską i Oskara Josefa Gstreina potwierdzita właściwą ocenę polityczną formułowaną przez PiS. Vide M. Zalewska, O. J. Gstrein, Parlamenty narodowe i ich rola w procesie integracji europejskiej. Deficyt demokracji wUE w czasach kryzysu ekonomicznego i niepewności politycznej, „Studia Europejskie” 2013, nr 1, s. 51-73. 
czowa, oznaczała bowiem bezwarunkowe odrzucenie inicjatywy ustawodawczej Komisji. Chodziło już nie tylko o łamanie zasady pomocniczości, ale też o rozwiązanie uniwersalne ${ }^{192}$. Jak podkreśliła poseł (a następnie europoseł) Izabela Kloc, dotychczasowe stosowanie „żółtej” kartki było nieskuteczne; ten mechanizm „stał się drwiną z demokracji", ponieważ Komisja Europejska notorycznie lekceważyła takie uprawnienia parlamentów narodowych. Dlatego należało ten system kartek zasadniczo zmienić ${ }^{193}$. Kuchciński nazwał ten proces przywracaniem równowagi między parlamentami narodowymi a instytucjami europejskimi. Wskazywał też na parlamenty narodowe z dwóch powodów: 1) posiadania silnej legitymacji demokratycznej; 2) bycia przestrzenią komunikowania między Unią a społeczeństwami ${ }^{194}$. W odniesieniu do polskich posłów do Parlamentu Europejskiego formułowano jeszcze jedno ważne oczekiwanie, że będą lojalni wobec racji stanu Rzeczypospolitej i interesów narodowych, a nie wobec frakcji partyjnych czy też partii europejskich ${ }^{195}$. Żądaniu wzmocnienia parlamentów narodowych w systemie politycznym Unii towarzyszyło przekonanie, że w Polsce Sejm powinien mieć realny wpływ na politykę europejską Rzeczypospolitej, co najmniej za pośrednictwem dwóch instrumentów: 1) zobowiązania rządu do współdziałania z Sejmem w sprawach europejskich; 2) poddania wprowadzania w Polsce prawa europejskiego kontroli Sejmu ${ }^{196}$. Niedoścignionym wzorcem był model obowiązujący w RFN.

Prawo i Sprawiedliwość konsekwentnie odrzucało roszczenia Komisji Europejskiej i Trybunału Europejskiego do zawłaszczania kolejnych pozatraktatowych kompetencji. Przeciwstawiano się aspiracjom obu tych instytucji wspólnotowych. Komisja Europejska nie była postrzegana przez PiS jako strażnik traktatów, ale jako zakamuflowany reprezentant

192 Archiwum autora, „Wystąpienie marszałka Sejmu Marka Kuchcińskiego podczas szczytu przewodniczących parlamentów UE", Bratysława, 7 X 2016, s. 2.

193 I. Kloc, Wystąpienie, [w:] SS Sejm, 8 kadencja, 78 pos., 14 III 2019, http://orka2.sejm.gov.pl, dostęp 14 II 2020.

194 Archiwum autora, „Wystąpienie marszałka Sejmu Marka Kuchcińskiego na Konferencji Przewodniczących Parlamentów UE", Wiedeń, 8-9 IV 2019, s. 2.

195 Europa solidarnych narodów..., s. 6.

196 IV Rzeczpospolita-Sprawiedliwość dla Wszystkich..., s. 46. 
interesów najsilniejszych państw członkowskich. Chociaż w tej kwestii była widoczna wyraźna ewolucja stosunku PiS do Komisji Europejskiej. W latach 2005-2011 uważano, że relacje na linii rząd RP-Komisja są dość ważne, a w interesie Polski leży wzmacnianie jej pozycji w systemie politycznym Unii jako samodzielnego ośrodka decyzyjnego, zdolnego do przeciwstawienia się mocarstwom europejskim. Jeszcze w 2011 roku pisano: „Ważne jest także dobre współdziałanie z Komisją Europejską, pogłębianie jej zrozumienia dla polskich spraw w Unii"197. Takie oczekiwania przestały się pojawiać w programach powstałych w latach późniejszych (2014-2019). Uznano je za złudzenia, zwłaszcza w czasach Komisji kierowanej przez J.-C. Junckera, w sensie ideologicznym jednoznacznie zorientowanej na paradygmat lewicowo-liberalny oraz wspierającej w Polsce "opozycję totalną" w walce z obozem rządzącym po 2015 roku. Potwierdził taką ocenę w Sejmie minister Czaputowicz: „Nic zaś tak nie szkodzi idei integracji europejskiej jak faktyczna nierówność jej państw członkowskich wobec prawa, stosowanie podwójnych standardów i odchodzenie Komisji Europejskiej od roli obiektywnej strażniczki traktatów ku funkcji instrumentów w rękach niektórych państw"198.

Natomiast już w 2011 roku w działaniach TSUE dostrzeżono zagrożenie dla porządku prawnego w Polsce, niepokój budziła tendencja do narzucania przez ten organ norm niemożliwych do przyjęcia z powodów moralnych, kulturowych i prawnych. Prognozowano, że polskie wartości konstytucyjne "prędzej czy później zderzą się z prawem" stanowionym przez TSUE ${ }^{199}$. Przyjęto więc już w 2011 roku postulat, żeby kwestie obyczajowe i moralne nie były regulowane prawem europejskim, lecz pozostały w domenie państw członkowskich. Diagnozy te okazały się w pewnym sensie prorocze w kontekście ingerencji Trybunału Europejskiego w sprawy wewnętrzne w Polsce po 2015 roku, ale zapewne

197 Vide Nowoczesna, solidarna, bezpieczna Polska..., s. 223; Polska nowoczesna, Polska solidarna, Polska bezpieczna..., s. 173.

198 J. Czaputowicz, Informacja ministra spraw zagranicznych o zadaniach polskiej polityki zagranicznej w 2018 roku..., s. 84.

199 Europa solidarnych narodów..., s. 11. 
nie spodziewano się ingerencji w odniesieniu do porządku prawnego w Polsce opartego na przepisach konstytucyjnych.

5. PiS chciało innego od realizowanego rozłożenia zainteresowań rzeczowych instytucji unijnych. W 2009 roku stwierdzono, że stan integracji europejskiej „cechuje przerost unijnych regulacji w dziedzinach, które bez uszczerbku dla nowoczesności i rozwoju można w większym stopniu pozostawić państwom narodowym". Unia jawiła się politykom PiS jako wspólnota, w której przekroczono granice biurokratyzacji i regulacji, zwłaszcza w gospodarce. Wiele kwestii powinno być regulowanych albo przez państwa członkowskie, albo przez mechanizm rynkowy. Jednocześnie zauważano „zbyt niski poziom elementów wspólnotowych w sprawach, w których wspólna polityka z pewnością przyniosłaby wszystkim członkom wartość dodaną". W 2009 roku wymieniono trzy takie kwestie szczegółowe: bezpieczeństwo, obronność i energetykę. Dziesięć lat później nieśmiało dodano kolejne: demografię, uszczelnienie podatków, wspieranie rodzin ${ }^{200}$. Syntetycznie sprawę ujął prezydent Duda, wypowiadając się w kontekście oskarżeń formułowanych przez opozycję, że PiS przygotowuje wyjście Polski z Unii wzorem Zjednoczonego Królestwa: „My natomiast chcemy w niektórych obszarach ściślejszej współpracy [...]", a na pewno utrzymania podstawowych zasad funkcjonowania Wspólnoty ${ }^{201}$.

Inną kwestią szczegółową, ale w komunikowaniu politycznym PiS wyjątkowo ważną, było nieprzystępowanie Polski do strefy euro w określonym czasie historycznym. Dla stronnictwa wprowadzenie euro i utworzenie strefy euro "podmyły" fundamenty integracji europejskiej w odniesieniu do wspólnoty: prawa, instytucji, rynku, budżetu. Wspólna waluta nie spełniła swojej funkcji, ponieważ nie przyczyniła się do równomiernego rozwoju całej Unii, gdyż nie została oparta na trwałych podstawach. Zamiast rozwoju wygenerowała negatywne skutki: 1) niestabilność; 2) podział Unii na dwa kręgi; 3) nieproporcjonalność

200 Nowoczesna, solidarna, bezpieczna Polska..., s. 176; Dobry czas dla Polski..., s. 177.

201 Archiwum Prezydenta RP, https://www.prezydent.pl, „Wywiad dla tygodnika "Der Spiegelı", 24 XII 2015, dostęp 12 VI 2020. 
gospodarczą - zyski dla państw najsilniejszych ekonomicznie, przede wszystkim Niemiec, a kłopoty dla państw słabych, jak Grecja, Włochy, Hiszpania, Słowacja; 4) ukierunkowanie energii Wspólnoty na ratowanie strefy euro ${ }^{202}$. Należało więc ratować Unię przed konsekwencjami tej decyzji walutowo-finansowej, stojąc na straży jedności w zakresie prawa, instytucji, rynku i budżetu - jak to wskazał A. Duda ${ }^{203}$. Badania Marcina Galenta dowiodły, że PiS w tej kwestii miało rację, przyczyny kryzysu strefy euro tkwiły bowiem w skonstruowaniu tej budowli na wadliwych założeniach ordoliberalnych, a nie na nieodpowiedzialności niektórych państw członkowskich w prowadzonej przez nie polityce gospodarczej, społecznej i rozwojowej. To władze Wspólnoty nie zdały egzaminu i nie potrafiły zablokować w odpowiednim czasie pogłębiania się i rozszerzenia kryzysu, nie chciały bowiem rozwiązywać realnych problemów społecznych i gospodarczych istniejących w poszczególnych państwach. Zawiodło wykonywanie zasady pomocniczości, strefa euro wymaga zaś dwóch działań naprawczych:1) systemowej zmiany konstrukcji; 2) przemyślenia roli wzorca niemieckiego jako modelowego dla wszystkich państw niezależnie od ich sytuacji ${ }^{204}$.

Uważano, że na danym etapie rozwoju gospodarczego Polski podjęcie decyzji o wprowadzeniu euro byłoby błędem z trzech najistotniejszych powodów. Po pierwsze, system euro funkcjonował źle, generował niestabilność oraz posługiwał się nieprawidłowym mechanizmem adaptacji do procesów gospodarczych zachodzących w świecie, co tym samym pogłębiło kryzys strefy euro i wywołało załamanie gospodarcze w przynależnych do niego państwach (Grecja, Hiszpania, Włochy). Po drugie, niezależna polityka monetarna, wzorem Zjednoczonego Królestwa, Danii i Szwecji, dawała Polsce możliwości realizacji własnej koncepcji rozwojowej oraz prowadzenia skutecznej polityki społecznej. Po trzecie, Polacy,

\footnotetext{
202 K. Szczerski, Utopia europejska..., s. 41, 169-170.

203 Archiwum Prezydenta RP, https://www.prezydent.pl, „Wystąpienie Prezydenta na spotkaniu z Ambasadorami RP", 2 VII 2018, dostęp 12 VI 2020.

204 Kompetentna analiza przyczyn kryzysu strefy euro - ideologiczno-doktrynalnych, prawnych i ekonomicznych w: M. Galent, Kryzys systemowy strefy euro w cieniu traktatu z Maastricht i traktatu z Lizbony, „Politeja” 2018, nr 3(54), s. 199-210.
} 
a na pewno wyborcy PiS, w zdecydowanej większości nie byli zainteresowani rezygnacją z własnej waluty. Ponadto wprowadzenie euro byłoby zabójcze dla polskiej prowincji w warunkach istniejących znacznych dysproporcji rozwojowych. Podjęto działania zapowiadane po wygranych wyborach w 2015 roku, ale znacznie wcześniej wielokrotnie pisano, że przyjęcie euro przyniosłoby: przejęcie polskich przedsiębiorstw przez silne korporacje zachodnioeuropejskie oraz zmniejszenie atrakcyjności polskiego eksportu. Sprecyzowano też wtedy warunek konieczny do przyjęcia euro. Tym warunkiem było upodobnienie się polskiej gospodarki w zakresie struktury, potencjału i dochodowości do zachodnioeuropejskiej, czyli doprowadzenie do ostatecznego zlikwidowania skutków II wojny światowej, komunizmu i okupacji sowieckiej. Dopiero wtedy koszty integracji monetarnej mogłyby być zdecydowanie niższe niż ewentualne korzyści ${ }^{205}$. Z tych powodów PiS kategorycznie opowiedziało się za utrzymaniem złotego i - jak pisano w 2014 roku - „jego podmiotowości jako polskiej waluty narodowej"206. Za podsumowanie może służyć cytat z programu przyjętego w 2019 roku: „Sprawie euro nadaliśmy sens ekonomiczny, a nie ideologiczny"207.

W okresie rządów sprawowanych przez PiS w latach 2015-2019 wskazano jeszcze jeden warunek konieczny do spełnienia, żeby Polska mogła podjąć decyzję w sprawie przyjęcia euro. Opisano go w strategii polityki zagranicznej Polski na lata 2017-2021. Powinna dokonać się stabilizacja strefy euro w postaci przezwyciężenia jej kryzysu, aby „wiadomo było, do jakiego obszaru wspólnej waluty przystępuje Polska"208. Natomiast w realnym horyzoncie czasowym nie dostrzegano możliwości przełamania kryzysu strefy euro, więc sprawa akcesji do niej stawała się niejako bezprzedmiotowa.

205 Europa solidarnych narodów..., s. 20; IV Rzeczpospolita - Sprawiedliwość da Wszystkich..., s. 62-63; Archiwum Prezydenta RP, https://www.prezydent.pl, „Wywiad dla PAP przed szczytem NATO", 7 VII 2016, dostęp 12 VI 2020.

206 Zdrowie, praca, rodzina..., s. 157-158.

207 Dobry czas dla Polski..., s. 178.

208 Strategia Polskiej Polityki Zagranicznej 2017-2021..., s. 15. 
6. PiS zaproponowało instytucjom unijnym odmienny od utrzymującego się od co najmniej dekady wymiar geopolityczny. Jego istotą miała stać się policentryczność, którą odczytywano jako położenie nacisku na odmienności różnych regionów istniejących na kontynencie. Jego konstytutywnymi cechami są: kulturowa różnorodność, mnogość narodów, wielość państw. Cechami, których nie da się znieść, bo wynikają z dziejów Europy. Takie podejście oznaczało kurs na odbudowę tożsamości Europy Środkowej i przywrócenie jej roli geopolitycznej utraconej po II wojnie światowej, kiedy uznano ją za podzieloną na część zachodnią i wschodnią, zgodnie z trzywiekową propagandą rosyjską. Przesłanki, z których wywiedziono te poglądy, ujął prezydent Kaczyński w 2006 roku w odniesieniu do Grupy Wyszehradzkiej, mówiąc, że w Unii Europejskiej - jako wspólnocie współpracy wielostronnej i ścierania się interesów - „łatwiej jest występować w grupie krajów, które są sobie bliskie geograficznie, ale także łączy je pewne smutne, ale wielkie historyczne doświadczenie, którym jest doświadczenie realnego socjalizmu"209.

Wola przeorientowania geopolitycznego Unii, przynajmniej częściowego, prowadziła do konsekwentnego wspierania polityki rozszerzenia Wspólnoty. W tej kwestii podnoszono przede wszystkim racje geopolityczne. Warto odwołać się do dwóch wystąpień Dudy z okresu 2016-2017. Według prezydenta: „[1] Polska jest dziś tym krajem, który konsekwentnie przypomina, że europejska wspólnota musi nieustannie poszerzać swe granice. Izolacja prowadzi do partykularyzmu i wzmacnia szkodliwe podziały. Budowie pokoju i porozumieniu pomiędzy narodami sprzyja natomiast postawa inkluzywna, otwarta na współpracę i integrację"; [2] „bardzo ważne zadanie Europy Środkowej - być adwokatem polityki "otwartych drzwi « zarówno UE i NATO. Interesem naszej części Europy jest to, aby nie stać się na trwałe regionem granicznym, ale by rozszerzać więzi euroatlantyckie na Wschód i na Południe. Dlatego jesteśmy

209 Archiwum Prezydenta RP, https://www.prezydent.pl, „Wypowiedź Prezydenta na spotkaniu z Ambasadorami", 31 III 2006, dostęp 10 VI 2020. 
rzecznikami poszerzania stabilności"210. Duda z zahamowaniem polityki rozszerzenia UE wiązał niebezpieczne konsekwencje: 1) podział Europy przy zdominowaniu Wspólnoty przez państwa zachodnioeuropejskie; 2) przekształcenie Europy Środkowej w pole rywalizacji między Zachodem i Wschodem. Nałożenie tych zjawisk prowadziłoby do zagłady regionu środkowoeuropejskiego w ujęciu historycznym.

W PiS uważano, że Wspólnota Europejska powinna przywiązywać taką samą wagę do wszystkich kierunków działania w odniesieniu do swojego środowiska międzynarodowego. Obawiano się dominacji kwestii zachodnioeuropejskich i śródziemnomorskich kosztem zagadnień wschodnioeuropejskich i bałtyckich. W 2007 roku oceniano, że proporcja między zainteresowaniem jednym i drugim blokiem tematów wynosi 30 proc. do 70 proc. Unia Europejska miała być organizacją międzynarodową, opartą na wartościach i zasadach, wspomagającą państwa członkowskie powiązane różnymi zależnościami sieciowymi z najbliższym otoczeniem. Głównym zadaniem Europejskiej Polityki Sąsiedztwa powinno zaś być rozwiązywanie zamrożonych konfliktów w sąsiedztwie oraz wspieranie reform i modernizacji państw znajdujących się w tej sferze. Niestety, nie dostrzegano skutecznej realizacji tego posłannictwa chociażby w odniesieniu do Mołdawii, Gruzji, Turcji, Kosowa, Bośni i Hercegowiny, Białorusi, Ukrainy. W wymienionych państwach prowadzono rachityczne działania, brak było woli osiągnięcia pożądanych zmian w kierunku transatlantyckim ${ }^{211}$.

Prawo i Sprawiedliwość już w okresie „pierwszych rządów” sformułowało zarzuty wobec Europejskiej Polityki Sąsiedztwa. W jednej z notatek przygotowanych w MSZ w 2006 roku konstatowano: „Zasadniczym problemem wschodniej EPS UE jest brak równowagi między skalą zadań, wynikających z Planów Działania, a środkami finansowymi [...]". Ten brak równowagi czynił działania Unii ruchami pozorowanymi, dlatego też nie

\footnotetext{
210 Archiwum Prezydenta RP, https://www.prezydent.pl, dostęp 12 VI 2020: „Wystąpienie Prezydenta RP na dorocznej naradzie ambasadorów Ukrainy", 24 VIII 2016; „Wystąpienie Prezydenta na Forum GLOBSEC 2017", 26 V 2017.

211 K. Szczerski, Utopia europejska..., s. 235-239.
} 
mogły one przesądzić o sukcesie orientacji euroatlantyckiej w państwach regionu. Ogólnie polityka unijna realizowana przez rządy PiS wynikała z polskich roszczeń do pełnienia przez Polskę szczególnej roli w Europie Środkowej i Wschodniej, na podobieństwo dominacji Francji w polityce unijnej wobec Maghrebu, a Hiszpanii wobec Ameryki Południowej. Te roszczenia uzasadniano położeniem geograficznym i istniejącą w tej części Europy wspólnotą historii, kultury i tradycji ${ }^{212}$. Dlatego też polityka unijna PiS została podporządkowana dwom kluczowym wyzwaniom o charakterze geopolitycznym. Chodziło o: 1) „budowanie odporności regionalnej [Europa Środkowa - W.P.] na zagrożenia zewnętrzne oraz działania skierowane na obniżenie statusu regionu i jego spójności"; 2) wypracowanie i prowadzenie spójnej polityki całej Unii wobec Rosji w duchu solidarności wszystkich państw członkowskich i obrony interesów Wspólnoty ${ }^{213}$.

W PiS uważano, że aktywność regionalna Rzeczypospolitej zasadniczo wzmocni jej możliwości gry na forum Unii, ale także zablokuje niemieckie (i francuskie) projekty postrzegania tej części kontynentu jedynie przez pryzmat relacji z Moskwą i interesów z nią prowadzonych. Według PiS mylne było mniemanie, prezentowane przede wszystkim w Berlinie i Paryżu, że Rosja gwarantuje stabilizację na obszarze postradzieckim. Uważano, że Moskwa destabilizuje cały region, podsycając różnego rodzaju konflikty, między innymi etniczne, co jest metodą penetracji i uzależnienia całego regionu. Ewentualne pasywne zachowanie Polski spowodowałoby, że perspektywa niemiecko-francuska zaczęłaby bezalternatywnie dominować w Brukseli i stałaby się dogmatem polityki unijnej wobec Rosji. Preferowaną przez Niemcy i Francję politykę

212 Archiwum MSZ, sygn. 58/07, w. 1, „Rola Polski w Europejskiej Polityce Sąsiedztwa Unii Europejskiej wobec Rosji, Ukrainy i Białorusi", 14 III 2006, s. 1-2.

213 Dobry czas dla Polski..., s. 171; Archiwum MSZ, sygn. 143/9, w. 1, „Wizyta prezydenta Republiki Francuskiej Pana Nicolasa Sarkozy w Polsce. Sugestie do rozmów do wykorzystania podczas wizyty Prezydenta RF Pana Nicolasa Sarkozy", 14 VI 2007, s. 8-10, 22; sygn. 143/09, w. 2, „Materiał informacyjno-tezowy dla Prezesa Rady Ministrów RP Jarosława Kaczyńskiego w związku ze spotkaniem z Premierem Republiki Finlandii Panem Matii Vanhanenem (Helsinki, 12 września 2007 r.)", 4 IX 2007, s. 11-14. 
wobec Rosji nazwano "strategią Talleyranda"214. Według PiS ta strategia jako podstawa stosunku Unii do Rosji była bezradna wobec celu Moskwy, jakim było zniszczenie istniejącego systemu międzynarodowego, w tym zachodniej aksjologii. Środkiem do tego celu było dokonanie podziału w Unii na stare i nowe państwa członkowskie, przy jednoczesnym kreśleniu obrazu tych ostatnich jako „uwikłanych w historyczne kompleksy i niepełnowartościowych partnerów, niemających nic do zaoferowania "starej " Europie i stanowiących dla niej brzemię gospodarcze". W domniemaniu, Bruksela powinna uznać specjalne wpływy Rosji na tym obszarze. Racją stanu Polski było zaś zablokowanie takiej polityki. W działaniach na tym kierunku było dużo realizmu. Po pierwsze, uważano, że Polska samodzielnie nie jest w stanie wykonać tego zadania, potrzebny jest potencjał całego regionu i wsparcie Brukseli. Po drugie, zdawano sobie sprawę z tego, że im bardziej Polska będzie wpływała na politykę wschodnią Brukseli, tym bardziej Rosja będzie atakowała Polskę, głównie przez podejmowanie działań na rzecz jej izolacji na arenie międzynarodowej oraz destabilizacji od wewnątrz z wykorzystaniem pól konfliktów pomiędzy polskimi siłami politycznymi. Opisane już w 2005 roku w MSZ sprzężenie nabrało bardzo niebezpiecznego wymiaru w kontekście następstw katastrofy smoleńskiej i działań podjętych w tej kwestii przez koalicję PO-PSL wspieranej przez media liberalno-lewicowe ${ }^{215}$.

"Strategia Talleyranda" zachęcałaby Rosję do intensyfikowania swojej imperialnej polityki oraz - jak to powiedział prezydent Kaczyński prezydentowi Niemiec Horstowi Koehlerowi - prowadziłaby do asymetrii w postaci znacznie większego uzależnienia Unii od Rosji niż Rosji od Unii $^{216}$. Z tych powodów PiS miało ambiwalentny stosunek do formuły

214 Przegląd sytuacji strategicznej - aspekty globalne i regionalne, „Rocznik Strategiczny” 2006/2007, S. 59. „Strategię Talleyranda” można określić jako dostosowywanie się do zachodzących zmian, nawet radykalnych, w celu ochrony własnych interesów i pozycji.

215 Archiwum MSZ, sygn. 177/09, w. 4, „Polska polityka wschodnia: uwarunkowania międzynarodowe, zagrożenia i wyzwania (pełna wersja materiatów na naradę Ambasadorów RP, Warszawa 27.06-01.07 br.)", 2 VI 2005, s. 155-157.

216 Archiwum MSZ, sygn. 143/9, w. 1, „Notatka z rozmowy Prezydenta RP Pana Lecha Kaczyńskiego z Prezydentem RFN Panem Horstem Koehlerem w dniu 11 kwietnia br. w Rydze", 27 IV 2007, s. 1. 
Trójkąta Weimarskiego. Uważano ją za nieefektywną, bez szczególnego znaczenia dla polskiej polityki, a tworzącą złudzenie, że Polska może oddziaływać na Berlin i Paryż w kwestii ich wyborów strategicznych, podczas gdy w rzeczywistości Warszawa zderzała się w tej formule z osią francusko-niemiecką dążącą do supremacji w Unii i uprzedmiotowienia Europy Środkowej ${ }^{217}$.

Szkodliwy idealizm stojący u podstaw formuły weimarskiej dobrze określił publicysta Ł. Warzecha: „Prosta geopolityczna analiza interesów pokazuje, że nie może on być dla Polski korzystny, jako że dwaj pozostali członkowie Trójkąta - Francja i Niemcy - mają więcej wspólnych interesów (choćby na osi z Moskwą czy w energetyce) niż każde z tych państw ma z Polską. Daje to czytelny układ "dwa kontra jeden "218. Do takich wniosków PiS doszło po okresie sprawowania władzy w latach 20052007, kiedy podejmowano próby uczynienia z Trójkąta forum dyskusji o najważniejszych sprawach, ale trafiano na niechęć partnerów. W PiS nie oczekiwano też, że te mocarstwa europejskie będą się kierowały dobrymi intencjami i że nie podejmą w stosunkach z Rosją żadnych decyzji niekorzystnych dla Polski. W tej kwestii nie było jednak po stronie PiS konsekwencji. W 2017 roku minister Czaputowicz wyraził w Sejmie płonne nadzieje, że uda się „lepiej wykorzystać Trójkąt Weimarski na rzecz zgodnej współpracy między naszymi trzema krajami. [...] Bez tej współpracy bowiem trudno wyobrazić sobie przyszłość projektu europejskiego, skoro Polska, Niemcy i Francja stanowią jedną trzecią terytorium Unii Europejskiej i ponad jedną trzecią jej ludności". Minister proponował sprzężenie Trójkąta Weimarskiego i Grupy Wyszehradzkiej, miała to być „klamra polityczna dwóch części Europy”219. Jeśli potraktować słowa Czaputowicza jako ofertę adresowaną do Paryża i Berlina, to jej efekty były znikome. Partnerzy zachodnioeuropejscy nie skorzystali z niej. Można wobec niej sformułować również istotne zastrzeżenie

\footnotetext{
217 Vide W. Waszczykowski, Tylko Jarostaw może zastąpić Lecha Kaczyńskiego, [w:] Dwa ognie..., s. 360.

218 Ł. Warzecha, O wypetnianiu przez Polskę..

219 Informacja Ministra Spraw Zagranicznych o zadaniach polskiej polityki w 2017 roku...
} 
merytoryczne, zawarte w pytaniu - czy w interesie Polski było rozmywanie Grupy Wyszehradzkiej przez „łączenie” jej z Trójkątem Weimarskim? Takie podejście do tej sprawy najprawdopodobniej wzmocniłoby orientację filoniemiecką w Pradze, Budapeszcie i Bratysławie, podczas gdy sprzeczności polsko-francuskie, mimo formalnego strategicznego partnerstwa, nie dawały szans na stworzenie adekwatnej przeciwwagi.

Był jeszcze inny powód odrzucenia „strategii Talleyranda". Skoro ta strategia musiała doprowadzić do znacznego wzmocnienia Rosji, to jedynym sposobem na uniknięcie takiego zagrożenia było przyjęcie przez państwa środkowoeuropejskie orientacji albo germanofilskiej, albo filofrancuskiej, co w praktyce oznaczało utrwalenie na dekady peryferyjnego i przedmiotowego statusu regionu. W Warszawie chciano uniknąć takiego wyboru ${ }^{220}$.

W ramach policentryczności PiS oczekiwało od Unii zasadniczego wsparcia w odniesieniu do położenia frontowego na wschodnim pograniczu Wspólnoty w warunkach zamrożenia dalszego rozszerzania na tym kierunku. Sąsiedztwo wschodnie Polski było postrzegane nie tylko jako zagrożenie militarne, ale także jako czynnik generujący zjawiska: zorganizowanej przestępczości, niekontrolowanej migracji oraz inwigilacji ukierunkowanej na spenetrowanie systemu politycznego w Polsce. Polska pod rządami PiS domagała się uwzględniania jej stanowiska w polityce wschodniej Unii w kontekście stwarzania realnych szans i perspektyw na przyjęcie do Wspólnoty państw wschodnioeuropejskich. Odrzucano pomysły trwałego odwrócenia się od tej części Europy ${ }^{221}$.

Wyjątkowe znaczenie polityki środkowoeuropejskiej i wschodniej Polski dla Prawa i Sprawiedliwości prowadziło stronnictwo do wspierania budowy Wspólnej Polityki Zagranicznej i Bezpieczeństwa oraz Europejskiej Polityki Bezpieczeństwa, pod warunkiem że polski głos będzie brany pod uwagę w Brukseli. W strategii bezpieczeństwa narodowego przygotowanej przez rząd J. Kaczyńskiego w 2007 roku sformułowano konstatację: „W interesie bezpieczeństwa Polski jest umacnianie pozy-

220 M. A. Cichocki, Polska polityka musi być świadoma własnej podmiotowości...

221 Vide Europa solidarnych narodów..., s. 24. 
cji Unii w świecie i zwiększanie jej międzynarodowego zaangażowania zarówno w skali regionalnej, jak i globalnej". Jako wyjątkowe dziedziny aktywności instytucji unijnych wskazywano: stabilizację sąsiedztwa na Wschodzie i na Południu oraz rozbudowę wspólnej reakcji wojskowej i cywilnej w warunkach kryzysów ${ }^{222}$.

Koncepcji Unii Europejskiej upowszechnianej przez PiS nie można rozpatrywać bez modelu polityki europejskiej tego stronnictwa. Po 2015 roku miał być on skrajnie odmienny od "systemu PO-PSL", przemyślany w kontrze do polityki europejskiej tandemu Tusk-Sikorski. Wyjaśnienie było dość oczywiste: „W latach 2007-2015 kurczyły się możliwości oddziaływania Polski na procesy międzynarodowe w sąsiedztwie, regionie, Europie i na świecie w warunkach rozwoju imperializmu rosyjskiego i kryzysu Unii Europejskiej”. Cechą charakterystyczną „systemu PO-PSL" była przede wszystkim wadliwa polityka wewnątrz Unii. Z perspektywy czterech lat od przejęcia władzy w 2015 roku oskarżano poprzedników o: klientelizm wobec mocarstw europejskich znany z dokumentów; naiwność w postrzeganiu Wspólnoty; pasywną politykę regionalną obniżającą potencjał Polski w Unii; rozluźnianie związków ze Stanami Zjednoczonymi za miraże wzięcia przez Unię odpowiedzialności za bezpieczeństwo Polski; rezygnację z prowadzenia własnej polityki historycznej. Najgorsze dla PiS było przeświadczenie, że te elementy występowały łącznie i dodatkowo były „w kolizji z polskością i prawdą". Przytaczano przykłady różnych następstw wywołanych przez tak umocowaną politykę europejską. W zamian zaproponowano nową politykę europejską, która miałaby trzy azymuty: racja stanu, polskie interesy narodowe i podmiotowość Polski ${ }^{223}$. 



\section{Zakończenie}

Koncepcja PiS polityki zagranicznej Polski realizowana w latach 20152019 została uwarunkowana przez najważniejsze cechy właściwe dla działalności ideotwórczej tego stronnictwa.

Po pierwsze, w myśli politycznej PiS jest dostrzegalna akceptacja klasycznego myślenia o polityce z wykorzystaniem kategorii polityczności, odnoszącej się do stosunków społecznych. To ona przesądzała o postrzeganiu środowiska międzynarodowego przez pryzmat podziału podmiotów politycznych na sojuszników i wrogów, oczywiście w realiach XXI wieku, kiedy Polska funkcjonowała jako członek hemisfery euroatlantyckiej na skutek przynależności do Sojuszu Północnoatlantyckiego i Unii Europejskiej. Narzucała również konieczność wzmacniania potencjału politycznego Rzeczypospolitej poprzez, z jednej strony, sanację państwa, jego zmodernizowanie i uporządkowanie, z drugiej, aktywną politykę zagraniczną, której pierwszą sferą działalności była Europa Środkowa i Wschodnia. Zbudowanie powiązań sieciowych w tej części kontynentu miało uczynić z Polski ważnego partnera dla Stanów Zjednoczonych i w Sojuszu Północnoatlantyckim (druga sfera działalności). Polska spełniająca rolę przywódczą w regionie oraz będąca wiarogodnym partnerem dla Waszyngtonu w jego polityce globalnej mogła uzyskać właściwą 
pozycję w Unii Europejskiej. Tak postrzegany status Polski w hemisferze euroatlantyckiej stwarzał w dłuższej perspektywie szansę normalizacji stosunków z Rosją oraz uniknięcia podporządkowania Niemcom.

Po drugie, PiS kierowało się w działalności ideotwórczej zarówno realizmem jako doktryną narzucającą sposób poznawania stosunków międzynarodowych, jak i wartościami wywiedzionymi z polskich dziejów, zmagając się niejednokrotnie z dylematem sprzeczności między przesłankami pragmatycznymi i aksjologicznymi. Obie sfery miały bardzo ważny łącznik w postaci państwa. Z doktryny realistycznej wynikało, że to właśnie państwo jest głównym podmiotem politycznym, posługującym się w polityce różnymi środkami, natomiast z polskich dziejów wywnioskowano uznanie Rzeczypospolitej za wartość prymarną, którą należało chronić. Myślenie polityczne PiS było jednoznacznie państwowocentryczne. W tej materii wnioski wyciągnięto z pierwszego okresu sprawowania rządów w Rzeczypospolitej (2005-2007) oraz z oceny polityki zagranicznej realizowanej przez rządy liberalno-ludowcowe, wobec których PiS znajdowało się w opozycji. Polityka północnoatlantycka i europejska (unijna) w latach 2015-2019 została podporządkowana dwom koncepcjom: roli Paktu Północnoatlantyckiego w środowisku międzynarodowym jako gwaranta bezpieczeństwa w Europie Środkowej oraz zmian w Unii Europejskiej w celu złamania roszczeń tej organizacji do bycia suprapaństwem, prowadzących do osiągnięcia statusu superpaństwa w postaci federacji lub konfederacji.

Po trzecie, PiS jest najważniejszym w Polsce reprezentantem eurorealizmu w odniesieniu do Unii Europejskiej. Stronnictwo stanęło na stanowisku historycznej konieczności akcesji Polski do Unii, przy jednoczesnym wpływaniu przez Rzeczpospolitą na rozwój tej organizacji międzynarodowej, dlatego odrzucono projekty alternatywne - „płynięcia w głównym nurcie", bo w praktyce oznaczały postawę klientystyczną wobec Niemiec (euroentuzjazm) oraz separowania się od wspólnoty (eurosceptycyzm). Nie ma żadnego poświadczenia źródłowego, że w stronnictwie J. Kaczyńskiego rozważano kiedykolwiek wariant wyjścia Polski zUnii Europejskiej. Dlatego wszelkie oskarżenia ze strony polityków opozycyjnych o wyprowadzanie Polski ze Wspólnoty należy traktować tylko 
w kategoriach poszukiwania przez te stronnictwa "czynnika gry", który odwróciłby niekorzystne dla nich trendy sondażowe i przyniósł sukces w wyborach, przede wszystkim europejskich w 2019 roku. Takie podejście okazało się nieużyteczne w sensie wyborczym, ale miało wpływ na aktywność PiS, zwłaszcza brak odwagi w zaprezentowaniu pełnej koncepcji sanacji Unii Europejskiej, np. na forum rządowym lub partyjnym. Prezydent Duda zapewniał 21 stycznia 2019 roku: „Dzisiaj nie ma w Polsce nikogo rozsądnie myślącego, w żadnym poważnym istniejącym w Polsce ugrupowaniu politycznym, które w ogóle rozważałoby kwestię wyjścia Polski z Unii Europejskiej"1. Uważano w PiS, że wejście do Unii jako organizacji międzynarodowej stworzyło Polsce nowe możliwości rozwojowe oraz w zakresie podnoszenia jej podmiotowości. Tylko podążając w tym kierunku, Polska mogła neutralizować negatywne skutki swojego położenia geopolitycznego na osi Wschód-Zachód, utrwalone przez ostatnie 300 lat. Zamierzano wykorzystywać dotychczasowy potencjał Polski do ożywienia osi Północ-Południe, przebiegającej przez Europę Środkową i łączącej wszystkie państwa położone w tym regionie. Jednak z postawy realistycznej wynikało, że nie ma obiektywnych szans na zbudowanie jednego formatu współpracy środkowoeuropejskiej, dlatego też budowano powiązania sieciowe na poziomie zarówno prezydenckim i rządowym, jak i parlamentarnym.

Po czwarte, trwały kurs transatlantycki był wyróżnikiem myśli politycznej środowiska politycznego skupionego wokół Jarosława Kaczyńskiego przez niemal 30 lat istnienia III Rzeczypospolitej. To był wybór o charakterze nie tylko strategicznym, ale również historycznym. Jego najważniejszym skutkiem było przezwyciężenie następstw rozbiorów i zaborów oraz II wojny światowej. Wyraźnie dostrzegalny był jeden warunek - obecność Stanów Zjednoczonych w Europie, co oznaczało odrzucenie projektów ukierunkowanych na zbudowanie europejskiego systemu bezpieczeństwa, opartego na aktywności w tej dziedzinie Unii Europejskiej, co w praktyce przyniosłoby powstanie koncertu mocarstw, 
z udziałem Rosji i Niemiec na poziomie uzgodnień strategicznych. Taki scenariusz oznaczałby marginalizację polskich interesów narodowych oraz zepchnięcie Polski do roli peryferii europejskiej, narażonej na imperializm rosyjski. PiS wypracowało rozwiązanie alternatywne, urzeczywistniane w latach 2015-2019 - „wprowadzenie Sojuszu do Polski”.

We wstępie do monografii została wskazana potrzeba sfalsyfikowania odnoszących się do myśli politycznej PiS hipotez, obecnych w debacie publicznej. Myśl polityczna tej formacji jest dość odległa od nacjonalizmu, zwłaszcza w kontekście definiowania narodu jako wspólnoty oraz postrzegania relacji państwo-naród. Wyraźnym piętnem na działalności ideotwórczej odcisnął się polski republikanizm oraz myśl piłsudczykowska. Uznaniu państwa za wartość prymarną towarzyszyło przekonanie, że jedynie niepodległe państwo gwarantuje każdej jednostce korzystanie z wolności nie tylko w sensie liberalnym (negatywnym, wolność od), ale również w ujęciu pozytywnym (konserwatywnym, wolność do). W myśli politycznej PiS można dostrzec recepcję wiedzy z zakresu nauk społecznych, chociażby w odniesieniu do polityczności, konfliktów, konsolidacji i polaryzacji politycznej, historii, co nadaje jej strukturę jednej z najbardziej spójnych i uporządkowanych myśli w nowoczesnych dziejach Polski.

Prawo i Sprawiedliwość jako formacja polityczna wypracowało zarówno model polityki zagranicznej suwerennej Rzeczypospolitej, jak również koncepcję jej obecności podmiotowej w hemisferze euroatlantyckiej. Podjęto trud refleksji na temat kwestii „więcej niż suwerenność", w warunkach swoistej pustki intelektualnej po realizacji w latach 19992004 celów strategicznych w postaci wejścia do Sojuszu Północnoatlantyckiego i Unii Europejskiej. Było to tym trudniejsze, że przeciwnicy polityczni w tym czasie zostali niemal sparaliżowani rozumowaniem w kategoriach „końca historii", czyli teleologicznego postrzegania stosunków międzynarodowych. W tym aspekcie istnieje ciągłość w okresie 2005-2019, kiedy PiS stało się partią: po pierwsze - najpierw relewantną na arenie politycznej w Polsce, a po drugie - następnie „skazaną" na sprawowanie samodzielnych rządów w warunkach bardzo ostrego konfliktu o charakterze unicestwiającym. 
Udział w rządzeniu (2005-2007 i 2015-2019) lub bycie w opozycji (2007-2015) nie miały znaczenia dla rozwoju myśli politycznej PiS w odniesieniu do polityki zagranicznej Polski. O ile w latach 2012-2014 partia zasadniczo zmieniła treści i model komunikowania politycznego w sprawach wewnętrznych, o tyle w odniesieniu do polityki zagranicznej takich zmian nie sposób zauważyć, co nie oznacza, że nie dokonywano rewizji niektórych poglądów lub ich uszczegółowienia. Dwa przykłady są w tej kwestii wyjątkowo istotne. Pierwszy - w latach 2005-2006 przetestowano możliwość normalizacji stosunków polsko-rosyjskich, co doprowadziło do wniosku, że jest ona niewykonalna w perspektywie realnej w sensie historycznym. Dlatego też należy wybrać model polityki "twardej” wobec Kremla. W tym celu poszukiwano silnych czynników reasekuracji bezpieczeństwa Rzeczypospolitej, zwłaszcza kiedy Rosja uruchomiła w 2008 roku politykę imperialistyczną w Europie. Drugi - w okresie 2015-2019 dokonano zmian, w porównaniu do lat 2005-2010 (dwa pierwsze gabinety PiS i prezydentura L. Kaczyńskiego), w definiowaniu Europy Środkowej, polegających na rozszerzeniu zainteresowania na jej obszar południowy oraz na coraz wyraźniejszym oddzielaniu tego regionu od Europy Wschodniej. Takie podejście może w przyszłości doprowadzić do trójczęściowego zorganizowania polityki zagranicznej Polski na: zachodnią, środkowoeuropejską i wschodnią. Zadania w tych trzech ujęciach geograficznych są zasadniczo odmienne. Efektem zmian było podjęcie nowych sieciowych inicjatyw w odniesieniu do Europy Środkowej, których następstwem miało być łączenie różnych subregionów leżących na tym obszarze - od bałtycko-skandynawskiego do bałkańsko-czarnomorskiego.

W latach 2015-2019 stały się widoczne ważkie problemy międzynarodowe o znaczeniu strategicznym dla polityki zagranicznej Polski zaprojektowanej przez konserwatywne stronnictwo PiS; problemy, które rzutowały lub mogą rzutować nie tylko na jej efektywność, ale wręcz nawet na możliwości realizacyjne. Kurs na budowanie tożsamości środkowoeuropejskiej warunkującej wzrost podmiotowości regionu natrafił na bariery. Przede wszystkim na brak akceptacji w Berlinie, przyzwyczajonego przez poprzednie dekady do polskiej polityki polegającej na 
bandwagoningu wobec RFN, którego najpełniejszym przejawem była aktywność międzynarodowa tandemu Tusk-Sikorski. Powtórne rządy PiS, podobnie jak w pierwszym okresie, były mocno atakowane przez ośrodki władzy i propagandy w Niemczech, jawnie sprzyjające opozycji totalnej w Polsce, co w Warszawie było postrzegane co najmniej jako naruszanie zasad w relacjach dwustronnych. Polityka dwóch gabinetów PiS: B. Szydło i M. Morawieckiego nie korespondowała z głównymi nurtami: lewicowo-liberalnym i lewicowo-radykalnym, dominującymi w instytucjach unijnych (Parlament Europejski, TSUE, Komisja Europejska), co musiało prowadzić do sporów na linii Warszawa-Bruksela. Nieporozumień tych nie można było uniknąć $\mathrm{z}$ dwóch powodów: instytucje unijne, łamiąc traktaty z Lizbony, godziły w suwerenność Rzeczypospolitej, natomiast PiS odrzucało strategiczny kierunek traktowania Unii jako suprapaństwa, prowadzący do budowy europejskiej federacji. W tej sytuacji rządy PiS koncentrowały się na blokowaniu niekorzystnych decyzji, a jedynie nieśmiało prezentowały własną koncepcję sanacji wspólnoty europejskiej, mimo iż ten projekt miał dość wyraziste cechy.

Trudno jest określić w 2020 roku, na ile zwrot środkowoeuropejski w polityce zagranicznej Stanów Zjednoczonych pod rządami D. Trumpa jest trwały, a na ile w przypadku zwycięstwa demokratów nastąpi powrót do polityki porozumiewania się z Rosją oraz traktowania Niemiec jako wyraziciela interesów europejskich. Bez strategicznego partnerstwa między Polską a Stanami Zjednoczonymi dzieło budowy powiązań sieciowych w Europie Środkowej może znaleźć się w regresie, zwłaszcza Inicjatywa Bukareszteńska i Trójmorze. Ewentualny kolejny reset w stosunkach amerykańsko-rosyjskich może przynieść co najmniej zatrzymanie rozbudowy flanki wschodniej Sojuszu Północnoatlantyckiego, a bez tego przedsięwzięcia polityka „twarda” Warszawy wobec Kremla nie będzie miała ważnego rusztowania, może okazać się więc nieskuteczna w sensie strategicznym.

Za główne wyzwanie PiS uznało dokonanie zasadniczych zmian w Europie Środkowej, warunkujących jej znaczenie w Unii Europejskiej i Sojuszu Północnoatlantyckim oraz wobec mocarstw: Stanów Zjednoczonych, Niemiec, Rosji, ChRL. Jednak hemisfera środkowoeuropejska jest bardzo 
trudną przestrzenią do podejmowania inicjatyw międzynarodowych, chociażby z racji mnogości partnerów, stojących w obliczu dylematu - czy silniejszy jest wspólny regionalny kod kulturowy i położenie geopolityczne, czy też egoizm państwowy mający silne umocowanie w nacjonalizmie i skłaniający do polityki klientystycznej wobec mocarstw europejskich (przede wszystkim Niemiec i Rosji). Doświadczenia historyczne w tej kwestii nie są jednoznaczne, lecz wielce dyskusyjne. Niemniej w tej materii dorobek rządów PiS w latach 2015-2019 jest wyjątkowy, zwłaszcza w zestawieniu z koalicją PO-PSL, która doprowadziła do degradacji pozycji Polski w regionie w wyniku wyboru koncepcji orientacji na mocarstwa zachodnioeuropejskie i ułożenia relacji polsko-rosyjskich kosztem interesów środkowoeuropejskich. Polska stała się zwornikiem w Europie Środkowej, państwem osiowym w regionie, co pozwoliło jej uzyskać status państwa średniego pivotalnego. Pojawia się pytanie o trwałość tej konstelacji, wydaje się, że zasadniczo akceptowanej przez partnerów środkowoeuropejskich. Zwrot środkowoeuropejski rządów PiS doprowadził do: bardzo korzystnych zmian w stosunkach bilateralnych z Litwą, Rumunią, Chorwacją, Łotwą, Węgrami, Gruzją, Republiką Czeską i ze Słowacją; niewielkiego ocieplenia w relacjach z Ukrainą i Białorusią; nadania znacznej dynamiki stosunkom z państwami zachodniobałkańskimi.

Na zakończenie warto wyeksponować ważną cechę myśli politycznej PiS. Na poziomie ideologicznym, aksjologicznym, poznawczym i metapolitycznym obserwujemy jej ciągłość i niezmienność. Najważniejsze cechy zostały ukształtowane przed powrotem do władzy w 2015 roku, a często genetycznie były osadzone w dorobku ideowym Porozumienia Centrum. 



\section{Bibliografia}

\section{1. ŹRÓDEA}

\subsection{Materiały archiwalne}

Archiwum autora

„Deklaracja zaproponowana przez marszałka Sejmu »Europa solidarnych państw - bezpieczeństwo, granice, odnowione instytucje«".

„Wystąpienie marszałka Sejmu Marka Kuchcińskiego na Konferencji Przewodniczących Parlamentów UE", Wiedeń, 8-9 IV 2019.

„Wystąpienie marszałka Sejmu Marka Kuchcińskiego na Konferencji Przewodniczących Parlamentów Unii Europejskiej w Luksemburgu", 23 V 2016.

„Wystąpienie marszałka Sejmu Marka Kuchcińskiego na spotkaniu powitalnym z uczestnikami konferencji "Solidarność i suwerenność»", 30 VIII 2016. „Wystąpienie marszałka Sejmu Marka Kuchcińskiego podczas Konferencji Przewodniczących Parlamentów UE", Tallin, 23-24 IV 2018.

„Wystąpienie marszałka Sejmu Marka Kuchcińskiego podczas szczytu przewodniczących parlamentów UE", Bratysława, 7 X 2016.

Archiwum Kancelarii Prezesa Rady Ministrów "List premiera J. Kaczyńskiego do premiera Turcji Recepa Tayyipa Erdoğana", 25 VII 2007. 
„Notatka informacyjna nt. działań Federacji Rosyjskiej w kwestii pozyskiwania zaawansowanych technologicznie systemów uzbrojenia w kontekście doświadczeń z operacji gruzińskiej", 23 XII 2009.

„Notatka informacyjna z rozmowy telefonicznej Prezydenta RP Pana Lecha Kaczyńskiego z Prezydentem Gruzji Panem Micheilem Saakaszwili", 17 XII 2009. „Pismo minister Anny Fotygi do min. Radosława Sikorskiego", 16 I 2007. "Udział prezydenta Rzeczypospolitej Polskiej Pana Lecha Kaczyńskiego w szczycie państw Trójkąta Weimarskiego", Warszawa, 3 VII 2006.

„Założenia polskiej polityki zagranicznej w 2006 r.", luty 2006.

\section{Archiwum Ministerstwa Spraw Zagranicznych}

„Materiał informacyjno-tezowy dla Prezesa Rady Ministrów RP Jarosława Kaczyńskiego w związku ze spotkaniem z Premierem Republiki Finlandii Panem Matii Vanhanenem (Helsinki, 12 września 2007 r.)", 4 IX 2007.

„Materiał tezowo-informacyjny do wykorzystania podczas wizyty oficjalnej Premiera RP Pana Jarosława Kaczyńskiego z Premierami Państw Bałtyckich. Wizyta oficjalna Premiera RP na Litwie, Wilno, 7-8 grudnia 2006 r.", 4 XII 2006. „Notatka informacyjna nt. polityki zagranicznej Federacji Rosyjskiej w okresie prezydentury Władimira Putina", luty 2006.

„Notatka informacyjna z wizyty Prezydenta Rzeczypospolitej Polskiej, Pana Lecha Kaczyńskiego w Berlinie, 8-9 marca 2006 r.", 21 III 2006.

„Notatka z rozmowy Prezydenta RP Pana Lecha Kaczyńskiego z Prezydentem RFN Panem Horstem Koehlerem w dniu 11 kwietnia br. w Rydze", 27 IV 2007.

„Notatka ze spotkania Prezesa Rady Ministrów, Pana Jarosława Kaczyńskiego z Premierem Królestwa Szwecji, Panem Fredrikiem Reinfeldtem", 11 VI 2007. „Polska polityka wschodnia: uwarunkowania międzynarodowe, zagrożenia i wyzwania (pełna wersja materiałów na naradę Ambasadorów RP, Warszawa 27.06-01.07 br.)", 2 VI 2005.

„Rola Polski w Europejskiej Polityce Sąsiedztwa Unii Europejskiej wobec Rosji, Ukrainy i Białorusi", 14 III 2006.

„Sugestie do rozmowy Premiera RP Pana Kazimierza Marcinkiewicza z Premierem KH J.L.R. Zapatero podczas III międzyrządowych konsultacji, Grenada, 9 marca 2006 r.", 6 III 2006.

„Wizyta prezydenta Republiki Francuskiej Pana Nicolasa Sarkozy w Polsce. Sugestie do rozmów do wykorzystania podczas wizyty Prezydenta RF Pana Nicolasa Sarkozy", 14 VI 2007.

\section{Archiwum Prezydenta RP, https://www.prezydent.pl}

„Decyzję Waszyngtonu przyjąłem z niepokojem” [Wywiad prezydenta Kaczyńskiego dla gazety „Fakt”], 18 IX 2009.

„Konferencja prasowa Prezydenta po spotkaniu szefów państw i rządów NATO w Brukseli", 25 V 2017. 
„Konferencja prasowa Prezydenta w Nowym Jorku”, 26 IX 2018.

"List prezydenta na uroczystości z okazji 17. rocznicy wstąpienia Polski do NATO", 11 III 2016.

"Odprawa rozliczeniowo-koordynacyjna kierowniczej kadry MON i SZ RP”, 8 III 2010.

"Orędzie Prezydenta RP Andrzeja Dudy przed Zgromadzeniem Narodowym", 6 VIII 2015.

„Prezydent Andrzej Duda w NATO Defense College, Włochy”, 17 V 2016.

„Przemówienie prezydenta na Westerplatte”, 1 IX 2009.

„Rozmowa prezydenta Lecha Kaczyńskiego z Andersem Fogh Rasmussenem”, 12 III 2010.

„Rozmowa z prezydentem w "Sygnałach Dnia», 11 XI 2015.

"Spotkanie Prezydenta z Ministrem Przemysłu i Energii Azerbejdżanu”, 13 V 2009.

„Wspólna deklaracja i koncepcja”, 22 V 2008.

„Wspólna deklaracja Prezydentów Azerbejdżanu, Gruzji, Kazachstanu, Litwy,

Polski i Ukrainy", 12 V 2007.

„Wspólna konferencja prasowa Prezydentów Polski i USA”, 18 IX 2018.

"Wykład Prezydenta w The Chicago Council on Global Affairs", 25 IX 2007.

„Wypowiedź Prezydenta dla "Faktu»", 12 III 2009.

„Wypowiedź Prezydenta dla mediów w bazie Bagram”, 26 III 2018.

„Wypowiedź Prezydenta dla mediów, w ostatnim dniu wizyty w Davos”, 24 I 2019. „Wypowiedź Prezydenta dla mediów w związku z odprawą kierowniczej kadry MON i Sił Zbrojnych RP", 7 III 2019.

„Wypowiedź Prezydenta na konferencji prasowej po spotkaniu prezydentów w Wilnie", 6 XI 2006.

"Wypowiedź Prezydenta na konferencji prasowej po zakończeniu szczytu NATO", 29 IX 2006.

„Wypowiedź Prezydenta na konferencji w Rydze”, 27 VI 2018.

„Wypowiedź Prezydenta na spotkaniu z Ambasadorami”, 31 III 2006.

„Wypowiedź Prezydenta na spotkaniu z korpusem dyplomatycznym”, 2 II 2010. "Wystąpienie Prezydenta na 53. Monachijskiej Konferencji Bezpieczeństwa", 17 II 2017.

„Wystąpienie Prezydenta na briefingu prasowym po spotkaniu z Sekretarzem Stanu USA", 20 VIII 2008.

„Wystąpienie Prezydenta na forum Arraiolos”, 14 IX 2017.

„Wystąpienie Prezydenta na Forum GLOBSEC 2017”, 26 V 2017.

„Wystąpienie Prezydenta na konferencji Foreign Policy Association”, 24 IX 2008. „Wystąpienie Prezydenta na konferencji prasowej prezydentów państw Grupy Wyszehradzkiej", 14 X 2017.

„Wystąpienie Prezydenta na otwarciu Forum Regionów Trójmorza”, 3 VII 2018. 
„Wystąpienie Prezydenta na spotkaniu noworocznym z Korpusem Dyplomatycznym", 11 I 2018.

„Wystąpienie Prezydenta na spotkaniu z Ambasadorami RP”, 2 VII 2018.

„Wystąpienie Prezydenta na szczycie GUAM w Baku”, 19 VI 2007.

"Wystąpienie Prezydenta na Szczycie Prezydentów Europy Środkowej”, 19 V 2006.

„Wystąpienie Prezydenta po przedstawieniu przez Szefa MSZ informacji o zadaniach polskiej polityki zagranicznej", 21 III 2018.

"Wystąpienie Prezydenta podczas 73. sesji Zgromadzenia Ogólnego ONZ", 26 IX 2018.

„Wystąpienie prezydenta podczas inauguracji roku akademickiego w Kolegium Europejskim w Natolinie", 29 IX 2017.

„Wystąpienie Prezydenta podczas inauguracji wystawy poświęconej Jerzemu Iwanowiczowi Szajnowiczowi", 20 XI 2017.

„Wystąpienie Prezydenta podczas uroczystego otwarcia II Ogólnopolskiego Kongresu Europeistyki w Szczecinie", 26 IX 2017.

"Wystąpienie Prezydenta RP na dorocznej naradzie ambasadorów Ukrainy", 24 VIII 2016.

„Wystąpienie Prezydenta RP na posiedzeniu Zgromadzenia Parlamentarnego NATO", 28 V 2018.

„Wystąpienie Prezydenta RP podczas wspólnej konferencji z Prezydentem Bułgarii", 5 X 2017.

„Wystąpienie Prezydenta w nowojorskim Metropolitan Club”, 25 IX 2009.

"Wystąpienie Prezydenta w panelu XXVII Forum Ekonomicznego w Krynicy”, 5 IX 2017.

"Wystąpienie prezydenta w trakcie dorocznej narady MSZ", 4 IX 2017.

„Wywiad dla CCTV (chińskiej telewizji)”, 26 XI 2015.

„Wywiad dla PAP przed szczytem NATO”, 7 VII 2016.

„Wywiad dla tygodnika "Der Spiegel»", 24 XII 2015.

„Wywiad prezydenta Andrzeja Dudy dla PR”, 6 VII 2017.

„Wywiad Prezydenta Andrzeja Dudy dla Radia Szczecin”, 12 III 2019.

"Wywiad Prezydenta dla 30oPolityka i WP", 20 XII 2018.

"Wywiad Prezydenta dla "New York Times", 12 III 2009.

„Wywiad Prezydenta dla "Nowoczesnej Armii“", 1 IX 2015.

„Wywiad prezydenta dla Telewizji Republika”, 7 VIII 2015.

"Wywiad Prezydenta RP Andrzeja Dudy dla RDC”, 10 IV 2018.

„Wywiad Prezydenta RP dla RMF FM", 18 I 2017.

„Wywiad Prezydenta RP dla Wirtualnej Polski”, 21 I 2019.

„Wywiad Prezydenta w programie "Wydarzenia i Opinie» w Polsat News", 3 X 2018.

„Wywiad w »Polskim Przeglądzie Dyplomatycznym»”, 23 X 2016.

„Wywiad z Prezydentem dla "Sieci«", 25 V 2017. 
„Wywiad z prezydentem Lechem Kaczyńskim w TVP Info", 12 III 2009. „Wywiad z Prezydentem w tygodniku "Sieci«”, 1 X 2018.

Archiwum Rady Ministrów, Sekretariat Prezesa Rady Ministrów "List Donalda Tuska do Władimira Putina”, czerwiec 2008. „List Przemysława Gosiewskiego do Donalda Tuska”, 10 VI 2008.

„List Władimira Putina do Donalda Tuska”, 8 VII 2008.

„Pismo ministra obrony narodowej Radosława Sikorskiego do prezesa Rady Ministrów Jarosława Kaczyńskiego", 7 XII 2006.

„Pismo prezydenta Lecha Kaczyńskiego do premiera Kazimierza Marcinkiewicza", 15 VI 2006.

„Tezy do wystąpienia Prezesa Rady Ministrów RP, Pana Jarosława Kaczyńskiego w Brukseli 30 sierpnia 2006 r.", 11 VIII 2006.

"Założenia polskiej polityki zagranicznej w 2008 r.", Warszawa 2008.

„Założenia polskiej polityki zagranicznej w 2008 r. Notatka Sławomira Nowaka ze stycznia 2008 roku", Warszawa 2008.

\subsection{Dokumenty i programy}

IV Rzeczpospolita - dwanaście tez konstytucyjnych. Program Prawa i Sprawiedliwości, PiS, [b.m.w., b.r.w.].

IV Rzeczpospolita - Sprawiedliwość dla Wszystkich. Program 2005, PiS, [b.m.w.] 2005.

Dbamy o Polskę. Dbamy o Polaków, PiS, [Warszawa] 2007.

Deklaracja ideowa Ruchu Społecznego imienia Prezydenta RP Lecha Kaczyńskiego, 10.04.2011 roku, http://lechkaczynski.pl.

Deklaracja konstytucyjna Prawa i Sprawiedliwości w święto Konstytucji 3 maja, Warszawa 2002, „Polska Scena Polityczna. Vademecum partii i ugrupowań politycznych" 2002, nr 9.

Deklaracja końcowa szczytu NATO w Warszawie. Wydana przez Szefów Państw i Rządów uczestniczących w posiedzeniu Rady Północnoatlantyckiej w Warszawie w dniach 8 i 9 lipca 2016 r., http://www.bbn.gov.pl.

Deklaracja Łańcucka, 27 X 2006, http://www.prezydent.pl/archiwum-lecha-kaczynskiego.

Deklaracja polityczna Prawo i Sprawiedliwość, PiS, Warszawa 2001.

Deklaracja programowa Porozumienia Obywatelskiego Centrum wrzesień 1991, Warszawa, [w:] Nowe państwo. Porozumienie Centrum w dokumentach (1990-2001), wstęp, wybór i oprac. A. Chmielecki, Patria Media, Gdańsk 2020.

Deklaracja szczytu walijskiego złożona przez Szefów Państw i Rządów uczestniczących w posiedzeniu Rady Północnoatlantyckiej w Walii 5 września 2014 r., http:// www.bbn.gov.pl.

Dobry czas dla Polski. Program 2019 Prawa i Sprawiedliwości, PiS, [b.m.w.] 2019. 
Dokumenty programowe i ideowe. Kongres założycielski Prawo i Sprawiedliwość, Falęty 1-2 grudnia 2001 r., PiS, [b.m.w.] 2001.

Dwa lata solidarnego państwa. Rządy premierów Kazimierza Marcinkiewicza, Jarosława Kaczyńskiego październik 2005 - październik 2007, Centrum Informacyjne Rządu, Warszawa 2007.

Europa Karpat. Rzecz o współpracy, red. W. Paruch, Wydawnictwo Sejmowe, Warszawa 2017.

Europa solidarnych narodów. Program polityki europejskiej Prawa i Sprawiedliwości, PiS, Warszawa 2004.

Exposé premiera Jana Olszewskiego - fragment dotyczący polityki zagranicznej 21 grudnia 1991 r., http://stosunki-miedzynarodowe.pl.

Głosuj na Prawo i Sprawiedliwość. Program, PiS, Warszawa 2001.

Informacja Ministra Spraw Zagranicznych o zadaniach polskiej polityki w 2017 roku, 9 II 2017, http://www.msz.gov.pl.

Kaczyński: musimy mieć silniejszą armię, 14 X 2015, http://www.pap.pl.

Koncepcja Obronna Rzeczypospolitej Polskiej, MON, Warszawa 2017.

Konferencja prasowa dotycząca umowy o zakupie rakiet Patriot, 28 III 2018, http:// www.pap.pl.

Konstytucja Rzeczypospolitej Polskiej. Projekt Prawa i Sprawiedliwości, PiS, Warszawa 2005.

Konwencja konstytucyjna Prawa i Sprawiedliwości, PiS, Warszawa 2003.

Nowe państwo. Porozumienie Centrum w dokumentach (1990-2001), wstęp, wybór i oprac. A. Chmielecki, Patria Media, Gdańsk 2020.

Nowoczesna Polska 2020. Materiały i dokumenty [III Kongres Prawa i Sprawiedliwości. Zespół Pracy Państwowej], PiS, Poznań 2010.

Nowoczesna, solidarna, bezpieczna Polska. Program Prawa i Sprawiedliwości, PiS, Kraków 2009.

Obrona terytorialna, MON, Warszawa 2017, http://www.mon.gov.pl.

Oto deklaracja ideowa Ruchu im. Lecha Kaczyńskiego, 10 IV 2011, http://www.wiadomosci.dziennik.pl.

Polska katolicka w chrześcijańskiej Europie, PiS, Warszawa 2005.

Polska nowoczesna, Polska solidarna, Polska bezpieczna. Program Prawa i Sprawiedliwości 2009, 2011, PiS, Warszawa 2011.

Polska obywatelska. Podstawy programu politycznego Platformy Obywatelskiej RP, PO, Warszawa 2007.

Polska polityka europejska. Uchwała nr 52003 Kongresu Założycielskiego „Prawa i Sprawiedliwość", Falenty 18 I 2003, "Międzynarodowy Przegląd Polityczny" 2003, nr 1.

Prawo i Sprawiedliwość - Manifest polityczny, „Polska Scena Polityczna. Vademecum partii i ugrupowań politycznych" 2001, nr 11.

Priorytety Polskiej Polityki Zagranicznej 2012-2016, MSZ, Warszawa 2012. 
Program Porozumienia Centrum dotyczacy polityki zagranicznej, 1993, Warszawa,

[w:] Nowe państwo. Porozumienie Centrum w dokumentach (1990-2001), wstęp, wybór i oprac. A. Chmielecki, Patria Media, Gdańsk 2020.

Program Prawa i Sprawiedliwości 2014, PiS, [b.m.w.] 2014.

Program Prawa i Sprawiedliwości, PiS, Warszawa 2003.

Raport o stanie Rzeczypospolitej, PiS, Warszawa 2011.

Rząd Premiera Jarosława Kaczyńskiego. 365 dni lipiec 2006 - lipiec 2007, CIR, Warszawa 2007.

Silna Polska w Europie. Uchwała nr 1/06/03 Rady Politycznej Prawa i Sprawiedliwości, „Międzynarodowy Przegląd Polityczny” 2003, nr 3.

Spotkanie z internautami, 16 IX 2017, http://www.pap.pl.

Strategia bezpieczeństwa narodowego Rzeczypospolitej Polskiej, [b.o.w.], Warszawa 2007.

Strategia Polskiej Polityki Zagranicznej 2017-2021, MSZ, [b.m.w., b.r.w.].

Tezy o polityce RP wobec Rosji i Ukrainy, 4 III 2008, n-22-2.dcs.redcdn.pl.

Uchwała nr 4 II Kongresu Porozumienia Centrum „Porozumienie Centrum w obronie polskiej racji stanu", czerwiec 1992, Warszawa, [w:] Nowe państwo. Porozumienie Centrum w dokumentach (1990-2001), wstęp, wybór i oprac. A. Chmielecki, Patria Media, Gdańsk 2020.

Uchwała nr 7 III Kongresu Porozumienia Centrum w sprawie przystąpienia Polski do NATO i Unii Europejskiej, 15 V 1994, Warszawa, [w:] Nowe państwo. Porozumienie Centrum w dokumentach (1990-2001), wstęp, wybór i oprac. A. Chmielecki, Patria Media, Gdańsk 2020.

Uchwała Zarządu Głównego Prawo i Sprawiedliwość z dnia 16 listopada 2002 w sprawie działań mających na celu poprawę warunków członkostwa Polski w Unii Europejskiej, „Polska Scena Polityczna. Vademecum partii i ugrupowań politycznych" 2002, nr 21.

Wspólna Deklaracja Prezydentów o Wspótpracy Obronnej w zakresie obecności sił zbrojnych USA na terytorium RP, 12 VI 2019, http://n-16.dcs.redcdn.pl.

Wspólna deklaracja Prezydentów PL i USA na temat pogłębienia wspótpracy obronnej, 23 IX 2019, http://www.prezydent.pl.

Wspólna deklaracja w sprawie Inicjatywy Trójmorza, Dubrownik, 25 VIII 2016, http://www.prezydent.pl.

Wypowiedź dla "Financial Times", 26 II 2016, http://www.rfm24.pl.

Zasadnicze cele naprawy Państwa [III Krajowa Konwencja Platformy Obywatelskiej RP, 21 V 2006], PO, Warszawa 2006.

Zdrowie, praca, rodzina. Program Prawa i Sprawiedliwości 2014, PiS, Warszawa 2014.

\subsection{Wspomnienia, pamiętniki, wywiady}

Bober M., Nie czekamy na nagrodę pocieszenia [Wywiad Mariusza Bobera z Radosławem Sikorskim], „Nasz Dziennik”, 31 X-1 XI 2009, http://www.naszdziennik.pl. 
Bober M., Rząd przekształca Polskę w kolonię [Rozmowa z Anną Fotygą], „Nasz Dziennik", 23 VIII 2010, nr 167.

Cichocki M. A., Polska polityka musi być świadoma własnej podmiotowości [Rozmowa Wojciecha Przybylskiego z Markiem Cichockim], http://www.teologiapolityczna.pl.

Czaputowicz J., Bazy USA z Niemiec do Polski - Zapraszamy [Wywiad Katarzyny Gójskiej z Jackiem Czaputowiczem], "Gazeta Polska”, 14-20 II 2018, nr 8.

Czaputowicz J., Dialog to nie ustępstwo [Wywiad Macieja Pieczyńskiego z Jackiem Czaputowiczem], „Do Rzeczy”, 29 I-4 II 2018, nr 5(258).

Czaputowicz J., Polska wie, jak ratować brexit [Wywiad Jędrzeja Bieleckiego z Jackiem Czaputowiczem], „Rzeczpospolita”, 21 I 2019, nr 20.

Czaputowicz J., Rosja wyczuwa słabość [Wywiad Jacka Karnowskiego z Jackiem Czaputowiczem], „Sieci”, 13-19 VIII 2018, nr 33(298).

Czarnecki R., Podwójna gra Berlina [Wywiad Marcina Makowskiego z Ryszardem Czarneckim], „Do Rzeczy”, 4-10 VII 2016, nr 27(178).

Duda A., Widzę próbę zablokowania dobrych zmian [Wywiad Tomasza Wróblewskiego i Mariusza Staniszewskiego z Andrzejem Dudą], „Wprost”, 15-21 II 2016, nr 7.

Fotyga A., Polska nie wpisuje się w nastrój antyamerykanizmu [Wywiad Wojciecha Muchy z Anną Fotygą], „Gazeta Polska", 18 VII 2018, nr 138.

Fotyga A., Polska-USA. Sympatia i młodość, „Gazeta Wyborcza”, 16 VI 2006, nr 139.

Kaczyński J., Bardzo potężne siły dążą do tego, żeby Polska nie była tym, czym mogłaby być. Trzeba się temu przeciwstawić [Rozmowa Jerzego Kubraka z Jarosławem Kaczyńskim], 7 VI 2014, http://www.wpolityce.pl.

Kaczyński J., Bezpieczeństwo kosztuje [Rozmowa Jacka Karnowskiego z Jarosławem Kaczyńskim], 19 IX 2006, http://www.polskieradio.pl.

Kaczyński J., I co dalej, Panie Premierze? [Rozmowa Ewy Milewicz z Jarosławem Kaczyńskim], „Gazeta Wyborcza”, 23 IX 2005, nr 222.

Kaczyński J., Mój brat chciał zbudować Polskę solidarna, [w:] Lech Kaczyński. Pamięć i zobowiązanie, PiS, Warszawa 2011.

Kaczyński J., Nie boję się o wartości [Rozmowa Jarosława Kurskiego z Jarosławem Kaczyńskim], „Gazeta Wyborcza”, 12 IV 2002, nr 86.

Kaczyński J., Odłączyć Rosję od kroplówki [Wywiad Pawła Majewskiego i Michała Sułdrzyńskiego z Jarosławem Kaczyńskim], „Rzeczpospolita”, 14 III 2014, nr 61.

Kaczyński J., Piłsudskim nie jestem, zgodzę się na przyśpieszone wybory, [w:] Dwa ognie. Wywiady [przeprowadzili Anita Werner i Paweł Siennicki], Wydawnictwo Literackie, Kraków 2010.

Kaczyński J., Polityka zagraniczna jest twarda grą [Rozmowa Pawła Lisickiego i Małgorzaty Subotić z premierem Jarosławem Kaczyńskim], 16 XII 2006, www.rzeczpospolita.pl. 
Kaczyński J., Polska naszych marzeń, Wydawnictwo „Drukarnia Akapit”, Lublin 2011.

Kaczyński J., Tusk powinien przyznać się do błędu [Rozmowa Jacka i Michała Karnowskich z Jarosławem Kaczyńskim], „Sieci”, 17-30 III 2014, nr 12(68).

Kaczyński J., UE powinna stać się supermocarstwem z prawdziwą armia, dużo silniejszą od rosyjskiej [Rozmowa Tomasza Grodeckiego i Agaty Jabłońskiej-Andrzejczuk z Jarosławem Kaczyńskim], 31 III 2017, http://www.forsal.pl.

Kaczyński J., Wstrzymuję się od krytyki PO [Rozmowa Ewy Milewicz z Jarosławem Kaczyńskim], „Gazeta Wyborcza”, 25 X 2005, nr 249.

Kaczyński J., Wywiad z prezesem Prawa i Sprawiedliwości [Rozmawiał Maciej Małecki], „Przegląd Europejski” 2003, nr 1.

Kaczyński J., Za Leszka z Polską się liczono [Wywiad Piotra Gursztyna z Jarosławem Kaczyńskim], „Do Rzeczy”, 7-13 X 2013, nr 37(37).

Kaczyński L., Historia stosowana, „Arcana” 2006, nr 70-71.

Kaczyński L., Jeśli Wrzodak, daję dyla [Wywiad Jarosława Kurskiego z Lechem Kaczyńskim], „Gazeta Wyborcza”, 3 VI 2003, nr 128.

Kaczyński L., Koniec dziwnej przyjaźni [Wywiad Józefa Tresnaka z Lechem Kaczyńskim], „Wprost”, 31 III 2008, nr 35.

Kaczyński L., Prezydent $w$ "Sygnałach dnia" o obchodach 70. rocznicy wybuchu II wojny światowej i podwyższaniu podatków [Rozmowa Henryka Szrubarza z prezydentem Lechem Kaczyńskim], 5 IX 2009, http://www.prezydent.pl/ archiwum.

Kaczyński L., Wspinaczka wśród spadających kamieni [Rozmowa Rafała Pazio z Lechem Kaczyńskim], „Najwyższy Czas” 2003, nr 11.

Kaczyński L., Wystawimy rachunek za krzywdy [Rozmowa Jarosława Kurskiego z Lechem Kaczyńskim], 11 III 2005, „Gazeta Wyborcza”, 21-22 V 2005, nr 117.

Kaczyński o Piłsudskim: Ja i mój brat uważaliśmy się za kontynuatorów jego myśli, 27 XI 2017, https://wiadomosci.dziennik.pl.

Krasnodębski Z., Prezydent nowoczesnego republikanizmu, [w:] Lech Kaczyński. Pamięć i zobowiązanie, PiS, Warszawa 2011.

Krasnodębski Z., Putin nie jest szaleńcem [Rozmowa Tomasza Terlikowskiego ze Zdzisławem Krasnodębskim], „Do Rzeczy”, 24-30 III 2014, nr 13(61).

Krasnodębski Z., Te wydarzenia zapamiętaja pokolenia [Wywiad Michała Karnowskiego ze Zdzisławem Krasnodębskim], „Sieci”, 27 IV-3 V 2020, nr 18.

Krasowski R., Czas Kaczyńskiego. Polityka jako wieczny konflikt, Czerwone i Czarne, Warszawa 2016.

Legutko R., Tusk nie jest jak żona Cezara [Wywiad Jacka Nizinkiewicza z Ryszardem Legutko], „Rzeczpospolita”, 13 III 2017, nr 60.

Macierewicz A., Elity trawi śmiertelna choroba [Rozmowa Dominika Zdorta z Antonim Macierewiczem], „Uważam Rze”, 15-21 X 2011, nr 42. 
Morawiecki M., Chcemy dać Polakom święty spokój i dostatnie życie [Wywiad Michała Szułdrzyńskiego i Andrzeja Steca z Mateuszem Morawieckim], „Rzeczpospolita", 6 III 2019, nr 55.

Morawiecki M., Pokazujemy naszą wiarygodność [Wywiad Katarzyny Gójskiej i Tomasza Sakiewicza z Mateuszem Morawieckim], „Gazeta Polska", 13 VI 2018, nr 24.

Morawiecki M., Pokazujmy naszą wiarygodność [Wywiad Tomasza Sakiewicza z Mateuszem Morawieckim], "Gazeta Polska”, 12 IX 2018, nr 37.

O dwóch takich... Alfabet braci Kaczyńskich. Rozmawiali Michał Karnowski i Piotr Zaremba, Wydawnictwo M, Kraków 2010.

Polityka zagraniczna. Bezpieczeństwo, [w:] Lech Kaczyński. Pamięć i zobowiązanie, PiS, Warszawa 2011.

Prezydent Duda: Od czasów marszałka Józefa Piłsudskiego nie było tak wielkiego przywódcy Państwa Polskiego jak Lech Kaczyński, 10 XI 2018, http://www. wpolityce.pl.

Rozmowa Doroty Gawryluk z Markiem Jurkiem, 4 VIII 2004, http://www.pis.org.pl. Rozmowa z Anną Fotygą na łamach „Przekroju”, 19 IV 2007, http://www.pis.org.pl. Rozmowa z Lechem Kaczyńskim w „Der Spiegel”, 6 III 2006, www.pis.org.pl.

Rozmowy w "Faktach" 15 I 2002, http://www.pis.org.pl.

Sikorski R., Nie uważajcie zgody Polski za oczywistość, „Polski Przegląd Dyplomatyczny", marzec-kwiecień 2007, nr 2(36).

Szczerski K., Chodzi o to, by politykę zagraniczną sprowadzić do realiów, 29 I 2016, http://www.wprost.pl.

Szczerski K., Cztery warunki Dudy dla Niemiec [Wywiad Jędrzeja Bieleckiego z Krzysztofem Szczerskim], „Rzeczpospolita”, 15 VI 2015, nr 137.

Szczerski K., Izrael powinien sobie cenić przychylność Polski [Wywiad Magdaleny Cedro i Grzegorza Osieckiego z Krzysztofem Szczerskim], „Dziennik Gazeta Prawna", 18 II 2019, nr 34.

Szczerski K., Moskwa nie ma powodu, by budować Fort Putin [Rozmowa Grzegorza Osieckiego i Zbigniewa Parafianowicza z Krzysztofem Szczerskim], „Dziennik Gazeta Prawna", 15 X 2018, nr 200.

Szczerski K., Nie będziemy walczyli samotnie [Rozmowa Grzegorza Osieckiego i Michała Potockiego z Krzysztofem Szczerskim], „Dziennik Gazeta Prawna", 12 VII 2016, nr 133.

Szczerski K., Nie przejmujmy się pieniaczami [Wywiad Grzegorza Osieckiego i Zbigniewa Parafianowicza z Krzysztofem Szczerskim], „Dziennik Gazeta Prawna", 13 I 2016, nr 7.

Szczerski K., Po Newport zmieniła się sytuacja [Wywiad Andrzeja Gajcy z Krzysztofem Szczerskim], „Rzeczpospolita”, 11 II 2016, nr 34.

Szczerski K., Polska droga na szczyt [Wywiad Piotra Goćka z Krzysztofem Szczerskim], „Do Rzeczy”, 7-13 IX 2015, nr 37(136). 
Szczerski K., Polska jest silna [Rozmowa Aleksandry Rybińskiej z Krzysztofem Szczerskim], „Sieci”, 27 XI-3 XII 2017, nr 48.

Szczerski K., Polską rządzą dzicy [Wywiad Jacka i Michała Karnowskich z Krzysztofem Szczerskim], „Sieci”, 27 X-2 XI 2014, nr 44.

Szczerski K., Prezydent nie jest zależny od PiS [Wywiad Grzegorza Osieckiego z Krzysztofem Szczerskim], „Dziennik Gazeta Prawna”, 21 VI 2017, nr 118.

Szczerski K., Skuteczna odpowiedź na prowokacje Rosji [Wywiad Marcina Makowskiego z Krzysztofem Szczerskim], "Do Rzeczy”, 23-29 V 2016, nr 21(172).

Szczerski K., Stawka większa niż Trybunał [Rozmowa Andrzeja Gajcy z Krzysztofem Szczerskim], „Rzeczpospolita”, 18 IV 2016, nr 90.

Szczerski K., Sukces szczytu NATO będzie sukcesem Polski [Wywiad z ministrem Krzysztofem Szczerskim dla „Do Rzeczy” przeprowadzony przez Piotra Goćka], 7 IX 2015, http://www.prezydent.pl.

Szczerski K., Wschodni protokół rozbieżności [Wywiad Michała Potockiego z Krzysztofem Szczerskim], „Dziennik Gazeta Prawna”, 24 VIII 2015, nr 163.

Szczerski K., Zapalimy polską latarnię [Wywiad Pawła Wrońskiego z Krzysztofem Szczerskim], "Gazeta Wyborcza”, 10 VI 2015, nr 133.

Szczerski K., Zarządzanie kryzysowe [Wywiad Jakuba Mielnika z Krzysztofem Szczerskim], „Wprost”, 20-26 II 2017, nr 8.

Szczygło A., Wozi mnie kobieta, „Wprost”, 9-16 VIII 2009, nr 32/33.

Szymański K., Długa droga do odrodzenia Unii [Rozmowa Jędrzeja Bieleckiego z Konradem Szymańskim], „Rzeczpospolita”, 14 III 2019, nr 62.

Szymański K., Premier niezmiennie inwestuje w region [Wywiad Grzegorza Osieckiego z Konradem Szymańskim], „Dziennik Gazeta Prawna”, 3 I 2018, nr 2.

Szymański K., Rosja i Chiny nie są alternatywą dla współpracy z USA [Wywiad Magdaleny Cedro z Konradem Szymańskim], „Dziennik Gazeta Prawna”, 6 VI 2018, nr 108.

Świat według Mellera. Życie i polityka - ku przyszłości, t. 2, Rosner \& Wspólnicy, Warszawa 2008.

Tożsamość i pamięć, [w:] Lech Kaczyński. Pamięć i zobowiązanie, PiS, Warszawa 2011.

Walicki A., Między polskim mesjanizmem a misjonizmem [Rozmowa z Andrzejem Walickim], „Teologia Polityczna” 2006-2007, nr 4.

Warto być Polakiem. Idea i myśl Lecha Kaczyńskiego, oprac. M. Łopiński, Kancelaria Prezydenta RP, Warszawa 2010.

Waszczykowski W., Chcemy Unii Europejskiej, ale innej [Wywiad Jacka i Michała Karnowskich z Witoldem Waszczykowskim], „Sieci”, 11-17 I 2016, nr 2(163). Waszczykowski W., Chcę się ułożyć z Białorusią [Rozmowa Elizy Olczyk i Jakuba Mielnika z Witoldem Waszczykowskim], „Wprost”, 8 I 2017, nr 1.

Waszczykowski W., Dość zacieśniania Unii [Wywiad Renaty Grochal z Witoldem Waszczykowskim], „Gazeta Wyborcza”, 25 VI 2016, nr 147. 
Waszczykowski W., Geopolityczne dylematy, czyli układanie się między Moskwa a Bruksela [Wywiad Grzegorza Osieckiego, Zbigniewa Parafianowicza i Michała Potockiego z Witoldem Waszczykowskim], „Dziennik Gazeta Prawna”, $26 \mathrm{X} 2015$, nr 15.

Waszczykowski W., Nie atakujemy już Tuska [Wywiad Jacka Przybylskiego z Witoldem Waszczykowskim], „Do Rzeczy”, 14-20 XII 2015, nr 51(150).

Waszczykowski W., Nie ujawniamy nazwisk z listy osób objętych zakazem wjazdu do Polski [Wywiad Grzegorza Osieckiego z Witoldem Waszczykowskim], „Dziennik Gazeta Prawna”, 13 IX 2017, nr 177.

Waszczykowski W., O trudnej drodze do NATO. Kilka wspomnień i refleksji, 12 III 2019, http://wiadomosci.onet.pl.

Waszczykowski W., Odnosimy sukces i świat to widzi [Rozmowa Jacka i Michała Karnowskich z Witoldem Waszczykowskim], "Sieci”, 3-9 VII 2017, nr 27(240). Waszczykowski W., Refleksje na temat polskiej polityki bezpieczeństwa, [w:] Rzeczpospolita na arenie międzynarodowej. Idee i praktyczne dylematy polityki zagranicznej, red. J. Kloczkowski, T. Żukowski, Kancelaria Prezydenta Rzeczypospolitej Polskiej - Ośrodek Myśli Politycznej, Warszawa 2010.

Waszczykowski W., Teraz to NATO wchodzi do Polski [Wywiad Grzegorza Osieckiego z Witoldem Waszczykowskim], „Dziennik Gazeta Prawna”, 7 VII 2016, nr 130.

Waszczykowski W., Tylko Jarosław może zastąić Lecha Kaczyńskiego, [w:] Dwa ognie. Wywiady [przeprowadzili Anita Werner i Paweł Siennicki], Wydawnictwo Literackie, Kraków 2010.

Waszczykowski W., Uchodźcy nie przyjda do Polski [Wywiad Marka Czarneckiego i Agaty Kondzińskiej z Witoldem Waszczykowskim], "Gazeta Wyborcza", 25 XI 2015, nr 275.

Waszczykowski W., Wysłaliśmy Rosji jasny sygnał [Rozmowa Marcina Makowskiego z Witoldem Waszczykowskim], „Do Rzeczy”, 18-24 VII 2016, nr 29(180).

Waszczykowski W., Zamelduję pani premier wykonanie zadania [Wywiad Jacka i Michała Karnowskich z Witoldem Waszczykowskim], „Sieci”, 6-12 XI 2017, nr 45(258).

Waśko A., Patriotyzm Lecha Kaczyńskiego, [w:] Lech Kaczyński. Pamięć i zobowiązanie, PiS, Warszawa 2011.

Wybranowski W., Powrót do konwenansów [Rozmowa Wojciecha Wybranowskiego z Pawłem Kowalem], „Nasz Dziennik”, 24 XI 2007, http://www.naszdziennik.pl.

Wywiad dla Polskiego Radia prezydenta Kaczyńskiego, 9 VI 2007, http://www.pap.pl. Wywiad L. Kaczyńskiego dla polskiego radia, 9 VI 2007, http://www.polskieradio.pl. Wywiad Lecha Kaczyńskiego dla „Naszego Dziennika”, 7 X 2005, http://pis.org.pl. Zaremba P., O jednym takim... Biografia Jarosława Kaczyńskiego, Czerwone i Czarne, Warszawa 2010. 


\subsection{Publicystyka polityczna i wypowiedzi publiczne}

Bernacki W., Wypowiedź, [w:] Wypowiedzi na posiedzeniach Sejmu RP, 8 kadencja, 60 pos., 21 III 2018, http://www.sejm.pl.

Bernacki W., Wypowiedź, [w:] Wypowiedzi na posiedzeniach Sejmu RP, 8 kadencja, 78 pos., 14 III 2019, http://www.sejm.pl.

Błaszczak M., Jesteśmy zaporą przed Rosją dla całej Europy, 4 IX 2014, http://www. wiadomosci.dziennik.pl.

Błaszczak M., Wystapienie w czasie dyskusji na temat informacji ministra spraw zagranicznych o założeniach polskiej polityki zagranicznej w 2011 roku, [w:] Sprawozdania stenograficzne z posiedzeń Sejmu RP, 6 kadencja, 87 pos., 16 III 2011, http://orka2.sejm.gov.pl.

Cedro M., Bałkany nie znoszą próżni. Albo Unia, albo marsz na Wschód, „Dziennik Gazeta Prawna", 17 V 2018, nr 95.

Cichocki M. A., Prawica, sfera polityczności i złudzenia, [w:] Partie i zmiany granic polityki, Fundacja im. Stefana Batorego, Warszawa 2009.

Czabański K., Za nic z Rosja, ostrożnie z Niemcami!, „Uważam Rze”, 15-21 X 2013, nr 42.

Czaputowicz J., Informacja ministra spraw zagranicznych o zadaniach polskiej polityki zagranicznej w 2018 roku, [w:] Sprawozdania stenograficzne z posiedzeń Sejmu RP, 8 kadencja, 60 pos., 21 III 2018, http://orka2.sejm.gov.pl.

Czaputowicz J., Informacja ministra spraw zagranicznych o zadaniach polskiej polityki zagranicznej w 2019 roku, 13 III 2019, http://www.gov.pl.

Czaputowicz J., Wystąienie, [w:] Sprawozdania stenograficzne z posiedzeń Sejmu RP, 8 kadencja, 78 pos., 14 III 2019, http://orka2.sejm.gov.pl.

Czarnecki R., Bałkański kociot - polska szansa „ "Polski Przegląd Dyplomatyczny”, marzec-kwiecień 2008, nr 2(42).

Duda A., Wystapienie Prezydenta RP Andrzeja Dudy podczas Dubrovnik Forum 2016, 25 VIII 2016, http://www.prezydent.pl.

Dwa przemówienia prezydenta L. Kaczyńskiego na Westerplatte, 1 IX 2009, http:// hej-kto-polak.pl/wp.

Dziubka M., Wystąienie, [w:] Sprawozdania stenograficzne z posiedzeń Sejmu RP, 1 kadencja, 4 pos., 23 XII 1991, http://orka2.sejm.gov.pl.

Fotyga A., Informacja ministra spraw zagranicznych o zadaniach polskiej polityki zagranicznej w 2007 r., [w:] Sprawozdania stenograficzne z posiedzeń Sejmu RP, 5 kadencja, 41 pos., $11 \mathrm{~V}$ 2007, http://orka2.sejm.gov.pl.

Gęsicka G., Wystąpienie w czasie dyskusji na temat informacji ministra spraw zagranicznych o założeniach polskiej polityki zagranicznej w 2010 roku, [w:] Sprawozdania stenograficzne z posiedzeń Sejmu RP, 6 kadencja, 64 pos., 8 IV 2010, http://orka2.www.sejm.gov.pl.

Głębocki K., Wypowiedź, [w:] Wypowiedzi na posiedzeniach Sejmu, 8 kadencja, 35 pos., 9 II 2017, http://www.sejm.pl. 
Głębocki K., Wypowiedź, [w:] Wypowiedzi na posiedzeniach Sejmu, 8 kadencja, 78 pos., 14 III 2019, http://www.sejm.pl.

Gosiewska M., Wypowiedź, [w:] Wypowiedzi na posiedzeniach Sejmu, 8 kadencja, 10 pos., 29 I 2016, http://www.sejm.pl.

Gosiewska M., Wypowiedź, [w:] Wypowiedzi na posiedzeniach Sejmu, 8 kadencja, 35 pos., 9 II 2017, http://www.sejm.pl.

Gosiewska M., Wypowiedź, [w:] Wypowiedzi na posiedzeniach Sejmu, 8 kadencja, 60 pos., 21 III 2018, http://www.sejm.pl.

Gosiewska M., Wypowiedź, [w:] Wypowiedzi na posiedzeniach Sejmu, 8 kadencja, 78 pos., 14 III 2019, http://www.sejm.pl.

Informacja rządu na temat polskiej polityki zagranicznej w 2008 roku przedstawiona przez ministra spraw zagranicznych Radosława Sikorskiego na posiedzeniu Sejmu 7 maja 2008 roku, „Roczniki Polskiej Polityki Zagranicznej” 2009.

Jach M., Nie ma bezpiecznego świata bez NATO, 7 VII 2016, http://www.polska-zbrojna.pl.

Jach M., Wypowiedź, [w:] Wypowiedzi na posiedzeniach Sejmu, 8 kadencja, 60 pos., $21 \mathrm{III}$ 2018, http://www.sejm.pl.

Jach M., Wypowiedź, [w:] Wypowiedzi na posiedzeniach Sejmu, 8 kadencja, 78 pos., 14 III 2019, http://www.sejm.pl.

Kaczyński J., Chrześcijańska demokracja w Polsce dzisiaj, 28 III 1992, [w:] Nowe państwo. Porozumienie Centrum w dokumentach (1990-2001), wstęp, wybór i oprac. A. Chmielecki, Patria Media, Gdańsk 2020.

Kaczyński J., Jaka reforma UE, 8 XII 2011, http://www.rp.pl.

Kaczyński J., Musimy wrócić do dużej armii w Polsce, bo bez tego nie będziemy bezpieczni, 15 III 2015, http://www.wpolityce.pl.

Kaczyński J., Przedstawienie przez prezesa Rady Ministrów programu działania Rady Ministrów z wnioskiem o udzielenie jej wotum zaufania, [w:] Sprawozdania stenograficzne z posiedzeń Sejmu RP, 5 kadencja, 22 pos., 19 VII 2006, http:// orka2.www.sejm.gov.pl.

Kaczyński J., Przemówienie po informacji prezesa Rady Ministrów na temat stanu realizacji programu działania rządu w rok po jego powołaniu, [w:] Sprawozdania stenograficzne z posiedzeń Sejmu RP, 6 kadencja, 29 pos., 20 XI 2008, http:// orka2.www.sejm.gov.pl.

Kaczyński J., Przemówienie w dyskusji nad informacją rządu na temat polskiej polityki zagranicznej w 2003 roku, [w:] Sprawozdania stenograficzne z posiedzeń Sejmu RP, 4 kadencja Sejmu, 40 pos., 22 I 2003, http://orka2.www.sejm.gov.pl. Kaczyński J., Reperowanie reparacji, "Gazeta Wyborcza”, 1 IX 2004, nr 205.

Kaczyński J., Silna Polska w świecie, „Nasz Dziennik”, 31 XII 2010-2 I 2011, http:// www.naszdziennik.pl.

Kaczyński J., Sojusznicy i wartości, 30 IX 2010, http://www.old.pis.org.pl.

Kaczyński J., Testament polityczny prezydenta, „Nasz Dziennik”, 9 IV 2013, nr 83. Kaczyński J., Tuska zupa z buta, „Gazeta Wyborcza”, 22 II 2011, nr 43. 
Kaczyński J., Wystąpienie na konferencji prasowej PiS, 11 VII 2016, http://www. tvn24.pl.

Kaczyński J., Wystąpienie w czasie dyskusji na temat informacji rządu na temat polskiej polityki zagranicznej w 2003 roku, [w:] Sprawozdania stenograficzne z posiedzeń Sejmu RP, 4 kadencja, 40 pos., 22 I 2003, http://orka2.sejm.gov.pl.

Kaczyński L., Pojednanie możliwe tylko dzięki prawdzie, „Rzeczpospolita”, 1 X 2009, http://www.rp.pl/artykul.

Kaczyński L., UE potrzebuje własnej armii, 6 XI 2006, http://www.wiadomosci. wp.pl.

Kaczyński L., Wystąpienie $w$ debacie nad informacją ministra spraw zagranicznych o podstawowych kierunkach polityki zagranicznej Polski w 2004 roku, [w:] Sprawozdania stenograficzne z posiedzeń Sejmu RP, 4 kadencja, 67 pos., 21 I 2004, http://orka2.sejm.gov.pl.

Kloc I., Wypowiedź, [w:] Wypowiedzi na posiedzeniach Sejmu, 8 kadencja, 60 pos., 21 III 2018, http://www.sejm.pl.

Kloc I., Wystąienie, [w:] Sprawozdania stenograficzne z posiedzeń Sejmu RP, 8 kadencja, 35 pos., 9 II 2017, http://orka2.sejm.gov.pl.

Kloc I., Wystąienie, [w:] Sprawozdania stenograficzne z posiedzeń Sejmu RP, 8 kadencja, 78 pos., 14 III 2019, http://orka2.sejm.gov.pl.

Kobosko M., Koncepcja Trójmorza ma sens, 15 XII 2016, http://www.rp.pl.

Kowal P., Wystąpienie w czasie dyskusji na temat informacji ministra spraw zagranicznych o założeniach polskiej polityki zagranicznej w 2008 roku, [w:] Sprawozdania stenograficzne z posiedzeń Sejmu RP, 6 kadencja, 15 pos., 7 V 2008, http://orka2.sejm.gov.pl.

Kowal P., Wystąienie $w$ czasie dyskusji na temat informacji ministra spraw zagranicznych o założeniach polskiej polityki zagranicznej w 2009 roku, [w:] Sprawozdania stenograficzne z posiedzeń Sejmu RP, 6 kadencja, 35 pos., 13 II 2009, http://orka2.sejm.gov.pl.

Krasnodębski Z., Jaki model prawicowości?, [w:] Partie i zmiany granic polityki, Fundacja im. Stefana Batorego, Warszawa 2009.

Krasnodębski Z., Lech Kaczyński - niepokorny polityk w świecie „postpolityki”, [w:] Lech Kaczyński - portret, oprac. M. Karnowski, Wydawnictwo M, Kraków 2010.

Krasnodębski Z., Wielkie spetnienie, czyli postliberalizm po polsku, 23 I 2012, http:// www.fundacjarepublikanska.org.

Krasowski R., Dwie formuły prawicowości, [w:] Partie i zmiany granic polityki, Fundacja im. Stefana Batorego, Warszawa 2009.

Krzemiński A., Pamięć i pamiętliwość, „Polityka”, 29 VIII 2009, nr 35(2720).

Legutko R., Trzy konserwatyzmy, http://www.omp.pl.

List Putina do Polaków - pełna wersja, http://wyborcza.pl.

Maciążek P., Za Kijów nikt nie chciałby zniszczyć świata?, http://www.psz.pl, 21 IX 2010. 
Magierowski M., Decyzje podjęte na szczycie to sygnat, jakiego Rosja nie dostawała od lat, 9 VII 2016, http://www.telewizjarepublika.pl.

Matyja R., Druga..., trzecia..., czwarta..., czyli o państwie Polaków, 7 VIII 2004, http:// www.newsweek.pl.

Matyja R., Konserwatyści - rzecznicy zmian, „Debata” 1998.

Meller S., Informacja ministra spraw zagranicznych o zadaniach polskiej polityki zagranicznej w 2006 r., [w:] Sprawozdania stenograficzne z posiedzeń Sejmu RP, 5 kadencja, 10 pos., 15 II 2006, http://orka2.sejm.gov.pl.

Memches F., Berlińska prowokacja Sikorskiego była potrzebna, 9 XII 2011, http:// www.wpolityce.pl.

Michałek M., Wielki plan małych państw. Jak Trójmorze wzmocni lub podzieli Unię, http://www.tvn24.pl.

Miłosz M., Będzie więcej sił NATO na wschodniej flance, „Dziennik Gazeta Prawna", 15 VI 2016, nr 114.

Morawiecki K., Wypowiedź, [w:] Wypowiedzi na posiedzeniach Sejmu, 8 kadencja, 35 pos., 9 II 2017, http://www.sejm.pl.

Morawiecki M., Przedstawienie przez prezesa Rady Ministrów programu działania Rady Ministrów z wnioskiem o udzielenie jej wotum zaufania, [w:] Sprawozdania stenograficzne z posiedzeń Sejmu RP, 8 kadencja, 54 pos., 12 XII 2017, http://orka2.www.sejm.gov.pl.

Morawiecki M., Wystąpienie, [w:] Sprawozdania stenograficzne z posiedzeń Sejmu RP, 8 kadencja, 54 pos., 12 XII 2017, http://orka2.sejm.gov.pl.

Mularczyk A., Wypowiedź, [w:] Wypowiedzi na posiedzeniach Sejmu, 8 kadencja, 60 pos., 21 III 2018, http://www.sejm.pl.

Mularczyk A., Wypowiedź, [w:] Wypowiedzi na posiedzeniach Sejmu, 8 kadencja, 78 pos., 14 III 2019, http://www.sejm.pl.

Nosowski Z., Zawrotna kariera „ulicy i zagranicy”, 5 IV 2018, http://www.wiez. com.pl.

Nowak-Jeziorański J., Rzeczpospolita atlantycka. Czym jest polska racja stanu?, [w:] Polska polityka wschodnia. Materiały konferencji w dniach 28-29 października 2005 roku we Wrocławiu, Kolegium Europy Wschodniej, Wrocław 2005.

Noworoczne spotkanie Pary Prezydenckiej z korpusem dyplomatycznym, 15 I 2020, http://www.prezydent.pl.

Orędzie nowego prezydenta, 6 VIII 2015, http://www.tvn24.pl.

Osiecki G., Potocki M., Duda aktywny w regionie, „Dziennik Gazeta Prawna”, 18 VIII 2015, nr 159.

Ostrowski K., Wypowiedź, [w:] Wypowiedzi na posiedzeniach Sejmu, 8 kadencja, 78 pos., 14 III 2019, http://www.sejm.pl.

Parafianowicz Z., Polsko-rumuńska reanimacja Sojuszu, „Dziennik Gazeta Prawna", 5 XI 2015, nr 216.

Partyka M., Duda i Trump podpisali deklarację ws. zwiększenia obecności wojsk USA w Polsce, 23 IX 2019, http://www.rmf24.pl. 
Parys J., Spotkanie Duda-Trump to nasza polisa ubezpieczeniowa, 24 IX 2019, http:// www.dorzeczy.pl.

Paweł Zalewski w „Poranku Radia TOK FM", 5 VII 2006, http://www.pis.org.pl.

Poczobut A., Białoruś. Minister Waszczykowski spotkał się z Łukaszenką. Ten się skarżył: „Droga ministra z Warszawy do Mińska była długa”, 23 III 2016, http:// www.wyborcza.pl.

Prezydent: Polityka historyczna jednym z obowiązków państwa, 4 IX 2009, http:// www.prezydent.pl/archiwum.

Przemówienia na Westerplatte, http://www.tvn24.pl.

Przemówienie premiera Putina na obchodach 70. rocznicy wybuchu II wojny światowej, 13 VII 2016, http://www.dzieje.pl.

Przemówienie Prezydenta na obchodach 70. rocznicy wybuchu II wojny światowej, 1 IX 2009, http://www.prezydent.pl/archiwum.

Putin W. W., List do Polaków, „Gazeta Wyborcza”, 31 VIII 2009, nr 203.

Pyzik P., Wypowiedź, [w:] Wypowiedzi na posiedzeniach Sejmu, 8 kadencja, 78 pos., 14 III 2019, http://www.sejm.pl.

Radwanowicz P., Grzegorz Schetyna:Będziemy opozycją totalną. Będziemy przeszkadzać w niszczeniu kraju, 26 II 2016, http://www.polskatimes.pl.

Sellin J., Wystąpienie w czasie dyskusji na temat informacji ministra spraw zagranicznych o założeniach polskiej polityki zagranicznej w 2011 roku, [w:] Sprawozdania stenograficzne z posiedzeń Sejmu RP, 6 kadencja, 87 pos., 16 III 2011, http://orka2.sejm.gov.pl.

Seminaria lucieńskie 2006-2007. Referaty wprowadzające do dyskusji, Kancelaria Prezydenta RP, Warszawa 2008.

Semka P., Lech Kaczyński. Opowieść arcypolska, Czerwone i Czarne, Warszawa 2010.

Sienkiewicz B., Pochwała minimalizmu, „Tygodnik Powszechny”, 24-31 XII 2000, nr 52-53.

Sienkiewicz B., Pożegnanie z Giedroyciem, „Rzeczpospolita”, 29-30 V 2010, nr 124.

Sikorski R., Lekcje historii, modernizacja i integracja, "Gazeta Wyborcza”, 29 VIII 2009, nr 202.

Sikorski R., Polska a przyszłość Unii Europejskiej, Berlin 28 XI 2011, http://www. scribd.com.

Sikorski R., Polska i Niemcy w jednoczącej się Europie, [w:] Modernizacja-Centrum - Peryferie. Księga jubileuszowa z okazji 70. rocznicy urodzin Profesora Ryszarda Stemplowskiego, red. W. Borodziej, S. Dębski, PISM, Warszawa 2009.

Sikorski R., Rosja w NATO? Czemu nie, "Gazeta Wyborcza”, 31 III 2009, nr 73.

Soloch P., Wokół przyszłej bazy USA w Polsce pojawia się wiele manipulacji, 16 III 2019, http://www.demaskator24.pl.

Szatkowski T., Postanowienia szczytu NATO w Brukseli kluczowe dla strategii wzmocnienia, 17 VII 2018, http://www.defence24.pl. 
Szczerski K., Nie jesteśmy niemieckim zasobem [Wywiad Mariusza Staniszewskiego z Krzysztofem Szczerskim], „Wprost”, 17-23 VIII 2015, nr 34.

Szczerski K., Pierwszy raz od końca zimnej wojny zwiększamy obecność wojskowa USA i NATO równocześnie, 12 VII 2016, http://www.prezydent.pl.

Szczerski K., Przepraszam za wolny świat [Wywiad Mariusza Staniszewskiego z Krzysztofem Szczerskim], „Do Rzeczy”, 17-23 III 2014, nr 12(60).

Szczerski K., Wszystkie instalacje $w$ ramach Fort Trump będą otwarte dla naszych partnerów, 10 VI 2019, http://www.tvp.info.

Szczerski K., Wypowiedź, [w:] Wypowiedzi na posiedzeniach Sejmu, 7 kadencja, 3 pos., 15 XII 2011, http://www.sejm.pl.

Szczerski K., Wypowiedź, [w:] Wypowiedzi na posiedzeniach Sejmu, 7 kadencja, 91 pos., 23 IV 2015, http://www.sejm.gov.pl.

Szczerski K., Wystąpienie w czasie dyskusji na temat informacji ministra spraw zagranicznych o założeniach polskiej polityki zagranicznej w 2012 roku, [w:] Sprawozdania stenograficzne z posiedzeń Sejmu RP, 7 kadencja, 11 pos., 29 III 2012, http://orka2.sejm.gov.pl.

Szczerski K., Wystąienie $w$ czasie dyskusji na temat informacji ministra spraw zagranicznych o założeniach polskiej polityki zagranicznej w 2013 roku, [w:] Sprawozdania stenograficzne z posiedzeń Sejmu RP, 7 kadencja, 36 pos., 20 III 2013, http://orka2.sejm.gov.pl.

Szczerski K., Wystąienie w czasie dyskusji na temat informacji ministra spraw zagranicznych o założeniach polskiej polityki zagranicznej w latach 2014-2015, [w:] Sprawozdania stenograficzne z posiedzeń Sejmu RP, 7 kadencja, 79 pos., 6 XI 2014, http://orka2.sejm.gov.pl.

Szczygło A., Waszczykowski W., Jakiego NATO chcemy, „Gazeta Wyborcza”, 15 III 2009, nr 62.

Szydło B., Przedstawienie przez prezesa Rady Ministrów programu działania Rady Ministrów z wnioskiem o udzielenie jej wotum zaufania, [w:] Sprawozdania stenograficzne z posiedzeń Sejmu RP, 8 kadencja, 1 pos., 18 XI 2015, http://orka2. www.sejm.gov.pl.

Szymański K., Odpowiedź na interpelację nr 30610 w sprawie wyhamowania działań polskiego rządu na rzecz rozszerzenia Unii Europejskiej i NATO, 17 IV 2019, http://orka2.sejm.gov.pl.

Szymański K., Unia polskich oczekiwań, [w:] Myśląc Polska. 5-7 lipca 2019 r., Katowice. Konwencja Programowa Prawa i Sprawiedliwości oraz Zjednoczonej Prawicy, PiS, [b.m.w.] 2019.

Szymański K., Wystąienie, [w:] Sprawozdania stenograficzne z posiedzeń Sejmu RP, 8 kadencja, 61 pos., 13 IV 2018, http://orka2.sejm.gov.pl.

Szymański K., Wystąienie, [w:] Sprawozdania stenograficzne z posiedzeń Sejmu RP, 8 kadencja, 81 pos., 13 IX 2018, http://orka2.sejm.gov.pl.

Szynkowski vel Sęk S., Wystąpienie, [w:] Sprawozdania stenograficzne z posiedzeń Sejmu RP, 8 kadencja, 61 pos., 13 IV 2018, http://orka2.sejm.gov.pl. 
Śpiewak P., Koniec złudzeń, „Rzeczpospolita”, 23 I 2003, nr 19.

Świerczyński M., Co zostało z amerykańskiego Fort Trump w Polsce?, 13 VI 2019, http://www.polityka.pl.

Tarczyński D., Wypowiedź, [w:] Wypowiedzi na posiedzeniach Sejmu RP, 8 kadencja, 10 pos., 29 I 2016, http://www.sejm.pl.

Ujazdowski K. M., Informacja ministra spraw zagranicznych o podstawowych kierunkach polityki zagranicznej Polski, [w:] Sprawozdania stenograficzne z posiedzeń Sejmu RP, 4 kadencja, 16 pos., 14 III 2002, http://orka2.sejm.gov.pl.

Ujazdowski K. M., Wystąienie, [w:] Sprawozdania stenograficzne z posiedzeń Sejmu RP, 4 kadencja, 16 pos., 14 III 2002, http://orka2.sejm.gov.pl.

Warzecha E., Lech Kaczyński. Ostatni wywiad, Prószyński i S-ka, Warszawa 2010. Waszczykowski W., Długa droga do pokoju, „Rzeczpospolita”, 12 XII 2017, nr 268.

Waszczykowski W., Informacja ministra spraw zagranicznych o zadaniach polskiej polityki zagranicznej w $2016 \mathrm{roku}$, [w:] Sprawozdania stenograficzne z posiedzeń Sejmu RP, 8 kadencja, 10 pos., 29 I 2016, http://orka2.sejm.gov.pl.

Waszczykowski W., Otwarte drzwi dla Ukrainy, , Rzeczpospolita”, 13 IX 2016, nr 214.

Waszczykowski W., Refleksje na temat polskiej polityki bezpieczeństwa, http:// www.omp.org.pl.

Waszczykowski W., Wypowiedź, [w:] Wypowiedzi na posiedzeniach Sejmu, 7 kadencja, 36 pos., 20 III 2013, http://www.sejm.gov.pl.

Waszczykowski W., Wypowiedź, [w:] Wypowiedzi na posiedzeniach Sejmu, 8 kadencja, 60 pos., 21 III 2018, http://www.sejm.pl.

Waszczykowski W., Wypowiedź, [w:] Wypowiedzi na posiedzeniach Sejmu, 8 kadencja, 78 pos., 14 III 2019, http://www.sejm.pl.

Waszczykowski W., Wystąpienie w czasie dyskusji na temat informacji ministra spraw zagranicznych o założeniach polskiej polityki zagranicznej w 2012 roku, [w:] Sprawozdania stenograficzne z posiedzeń Sejmu RP, 7 kadencja, 11 pos., 29 III 2012, http://orka2.sejm.gov.pl.

Waszczykowski W., Wystąpienie $w$ czasie dyskusji na temat informacji ministra spraw zagranicznych o założeniach polskiej polityki zagranicznej w 2013 roku, [w:] Sprawozdania stenograficzne z posiedzeń Sejmu RP, 7 kadencja, 36 pos., 20 III 2013, http://orka2.sejm.gov.pl.

Waszczykowski W., Wystąpienie w czasie dyskusji na temat informacji ministra spraw zagranicznych o założeniach polskiej polityki zagranicznej w 2014 roku, [w:] Sprawozdania stenograficzne z posiedzeń Sejmu RP, 7 kadencja, 67 pos., $8 \mathrm{~V}$ 2014, http://orka2.sejm.gov.pl.

Wypowiedź A. Macierewicza do żołnierzy polskich wracających z Afganistanu, 24 VI 2017, http://www.pap.pl.

WypowiedźJ. Kaczyńskiego na konferencji w 20. rocznicę "Nocnej zmiany”, 7 VI 2012, http://www.tvn24.pl.

Wystapienie M. Błaszczaka w bazie lotnictwa z okazji pikniku NATO, 9 III 2019, http://www.tvp.info. 
Wystąpienie Prezydenta podczas 2. sesji plenarnej na szczycie Grupy Arraiolos, 11 X 2019, http://www.prezydent.pl.

Wystąienie Prezydenta RP na spotkaniu noworocznym z Korpusem Dyplomatycznym, 11 I 2018, http://www.prezydent.pl.

Wywiad J. Kaczyńskiego w "Sygnałach dnia", 15 II 2019, http://www.polskieradio.pl.

Zalewski P., Dyplomacja w imię wartości, „Polski Przegląd Dyplomatyczny”, listopad-grudzień 2006, nr 6(34).

Zalewski P., Wystąpienie w imieniu KP PiS w dyskusji nad informacją Ministra Spraw Zagranicznych o zadaniach polskiej polityki zagranicznej w 2006 r., [w:] Sprawozdania stenograficzne z posiedzeń Sejmu RP, 5 kadencja, 10 pos., 15 II 2006, http://orka2.www.sejm.gov.pl.

Zenderowski R., Polityka zagraniczna państwa wobec megatrendów cywilizacyjno-kulturowych w polityce światowej, [w:] Myśląc Polska. 5-7 lipca 2019 r., Katowice. Konwencja Programowa Prawa i Sprawiedliwości oraz Zjednoczonej Prawicy, PiS, [b.m.w.] 2019.

Ziemkiewicz R. A., Myśli nowoczesnego endeka, Fabryka Słów, Lublin-Warszawa 2017.

Żurawski vel Grajewski P., Bić się czy nie bić? Oczywiście bić, „Sieci”, 8-14 VI 2020, nr 24.

Żurawski vel Grajewski P., Prawda o traktacie lizbońskim, „Gazeta Polska Codziennie", 4-6 I 2014, nr 3.

Żurawski vel Grajewski P., Zasady polskiej polityki zagranicznej, 7 III 2013, http:// www.niezalezna.pl.

\subsection{Materiały internetowe}

IV Rzeczpospolita, 15 XII 2005, http://www.wiadomosci.wp.pl.

Amerykanie w szoku. Nie wierza, że Waszczykowski to powiedziat, 31 III 2016, http:// www.fakt.pl.

Anty-PiS jest koniecznościa, http://www.wyborcza.pl.

Białoruś: Spotkanie marszałka Karczewskiego z prezydentem Łukaszenka, 5 XII 2016, http://www.kresy24.pl.

Błaszczak M., Jesteśmy jednym z liderów NATO i kształtujemy jego oblicze, 12 III 2019, http://www.polskieradio24.pl.

Błaszczak M., Konferencja prasowa MON, 21 VI 2018, http://www.pap.pl.

Briefing w Bąkowej Górze, 7 V 2016, http://www.pap.pl.

Czaputowicz J., Gruzja zasługuje na członkostwo w NATO jako najlepiej przygotowany kandydat, 24 X 2018, http://www.polskieradio24.pl.

Czaputowicz J., Opowiadamy się za szybkim rozpoczęciem negocjacji akcesyjnych z Albanią i Macedonią Płn., 8 IX 2019, http://www.radiomaryja.pl.

Duda: NATO powinno pozostać przy polityce otwartych drzwi, 8 VII 2016, http:// www.gazetaprawna.pl. 
Erdogan do Dudy: Jeżeli nie chcecie nas w UE, powiedzcie nam o tym, $17 \mathrm{X}$ 2017, http:// www.gazetaprawna.pl.

Hipokryzja Sikorskiego! Zrobiliśmy laskę Amerykanom, 23 VI 2014, http://www. fakt.pl.

Ile kosztuje wolność narodów, 23 I 2012, http://www.naszdziennik.pl.

Kaczyński J., Wypowiedź dla „Dziś wieczorem” w TVP Info, 3 IX 2014, http://www. tvp.info.

Kaczyński: „Kondominium rosyjsko-niemieckie w Polsce”. PO, SLD i PSD oburzone, zwołują konferencję. Wszyscy przeciw PiS, 8 IX 2010, http://www.wpolityce.pl.

Kaczyński mówi wprost: Powinniśmy dogadać się z Żydami ws. odszkodowań od Niemiec, 4 IV 2018, http://www.wiadomosci.radiozet.pl.

Kaczyński o reparacjach: Mamy sygnał, że Niemcy traktują tę sprawę bardzo poważnie, 30 I 2018, http://www.wiadomosci.gazeta.pl.

Kaczyński odpowiedział na pytanie, czy Putin stał za zamachem na jego brata, 25 I 2020, http://www.fakt.pl.

Karczewski: Łukaszenka to taki ciepły człowiek, 7 XII 2016, http://www.tvn24.pl.

Kondominium, stan europejski czy wolna Rzeczpospolita. „Kwestia suwerenności rozwiązuje się w naszych głowach", 16 I 2012, http://www.wpolityce.pl.

Konferencja bezpieczeństwa w Monachium, 10 II 2007, http://www.fakty.interia.pl.

Konferencja L. Kaczyńskiego po powrocie ze Stanów Zjednoczonych, 17 VII 2007.

Konferencja po spotkaniu premiera $z$ premierami państw bałtyckich $w$ Wilnie, 9 III 2018, http://www.premier.gov.pl.

Konferencja po spotkaniu szefów państw NATO, 26 V 2017, http://www.pap.pl.

Konferencja prasowa, 24 VI 2016, http://www.pap.pl.

Konferencja prasowa Antoniego Macierewicza w Brukseli, 9 XI 2017, http://www. pap.pl.

Konferencja prasowa B. Szydło z premierem Danii, 18 IV 2016, http://www.defence24.pl.

Konferencja prasowa M. Błaszczaka, 15 III 2018, http://www.pap.pl.

Konferencja prasowa MON, 14 VI 2016, http://www.pap.pl.

Konferencja prasowa MON, 20 VI 2016, http://www.pap.pl.

Konferencja prasowa MON, 28 IX 2017, http://www.pap.pl.

Konferencja prasowa MON, 9 VII 2016, http://www.pap.pl.

Konferencja prasowa MON A. Macierewicza, 20 VI 2016, http://www.pap.pl.

Konferencja prasowa po posiedzeniu sejmowej komisji obrony, 21 IX 2016, http:// www.pap.pl.

Konferencja prasowa prezesa J. Kaczyńskiego, 10 VII 2016, http://www.pap.pl.

Konferencja prasowa w Brukseli, 9 XI 2017, http://www.pap.pl.

Konferencja prasowa $w$ Londynie, 12 X 2017, http://www.pap.pl.

Konferencja prasowa w Waszyngtonie, 18 I 2018, http://www.pap.pl.

Konferencja prasowa z okazji szczytu NATO, 8 VII 2016, http://www.pap.pl.

Konferencja prasowa z premierem Wielkiej Brytanii, 5 II 2016, http://www.pap.pl. 
Konferencja prasowa z sekretarzem generalnym NATO, 15 VI 2016, http://www. pap.pl.

Konferencja premier B. Szydło, 11 VII 2016, http://www.premier.gov.pl.

Konferencja premier Beaty Szydło po spotkaniu z kanclerz Angelą Merkel, 7 II 2017, http://www.pap.pl.

Konferencja premiera M. Morawieckiego, 14 VII 2017, http://www.premier.gov.pl. Konferencja premiera M. Morawieckiego, 28 VI 2018, http://www.premier.gov.pl.

Konferencja premiera po szczycie Rady Europejskiej w Brukseli, 23 III 2018, http:// www.pap.pl.

Konferencja premiera z premier Wielkiej Brytanii T. May w Londynie, 20 XII 2018, http://www.gazetaprawna.pl.

Konferencja w Bukareszcie, 13 III 2018, http://www.pap.pl.

Konferencja z okazji rocznicy wstąpienia do NATO, 13 III 2017, http://www.pap.pl.

Konferencja z okazji szczytu NATO, 9 VII 2016, http://www.pap.pl.

Konferencje bilateralne, http://www.gov.pl.

Kto pisał berlińskie przemówienie Sikorskiego? Brytyjski ślad, 5 I 2015, http://www. tvn24.pl.

Kuchciński w Wilnie: Są sprawy Polaków na Litwie, ale sprawa zasadnicza to bezpieczeństwo Polski i Litwy, 20 XII 2018, http://www.kresy24.pl.

Lech Kaczyński dobre stosunki z sąsiadami i USA; wcześniejsze wybory parlamentarne są możliwe, 26 I 2006, http://www.pap.pl.

M. Kuchciński w Turcji m.in. o bezpieczeństwie, kryzysie migracyjnym i gospodarce, 28 X 2016, http://www.radiomaryja.pl.

M. Morawiecki na spotkaniu z żołnierzami wielonarodowego batalionu NATO $w$ Bemowie Piskim, 29 III 2018, http://www.radiomaryja.pl.

Macierewicz A., Konferencja prasowa przed szczytem NATO, 8 VII 2016, http:// wiadomoscidziennik.pl.

Macierewicz A., Konferencja prasowa w Żaganiu, 14 XII 2016, http://www.pap.pl.

Macierewicz A., Konferencja z okazji szczytu NATO, 9 VII 2016, http://www.pap.pl.

Macierewicz A., Wywiad dla TVP, 16 XI 2018, http://www.pap.pl.

Macierewicz na konferencji prasowej w Brukseli, 9 XI 2017, http://www.pap.pl.

Marek Kuchciński spotkał się z prezydentem Turcji, 27 X 2016, http://www.wprost.pl.

Marszałek Karczewski w Mińsku: Polskę i Białoruś dzieli granica, ale ta granica powinna nas łączyć, 7 VI 2019, http://www.kresy24.pl.

Marszałek Sejmu z pierwszą oficjalną wizytą w Wilnie z okazji 630-lecia chrztu Litwy, 27 IX 2017, http://www.marekkuchcinski.pl.

Marszałek Senatu Karczewski na Białorusi, 29 VII 2018, http://www.narodowcy.pl.

Miller zazdrości Dudzie? Zdumiewająca teza Jacka Sasina ws. spotkania z Trumpem, 24 IX 2019, http://wideo.wp.pl.

Minister Czaputowicz na spotkaniu z szefami dyplomacji Rumunii i Turcji w Bukareszcie, 11 IX 2018, http://www.gazetaprawna.pl. 
Minister Waszczykowski leci do Turcji z szefem rumuńskiego MSZ. Czy chodzi o broń atomową?, 23 VIII 2016, http://www.pch24.pl.

Minister Witold Waszczykowski o priorytetach polskiej dyplomacji, http://www. msz.gov.pl.

Monachium: Putin atakuje Zachód, Gates nie chce zimnej wojny, 11 II 2007, http:// www.pb.pl.

Morawiecki domaga się reparacji wojennych od Niemiec: Nie można tego tak zostawić, 22 VIII 2019, http://www.wprost.pl.

Na czym ma polegać korekta Dudy? „Przekonać partnerów, aby zmienili swoją politykę", 8 VIII 2015, http://www.tvn24.pl.

NATO uchyla drzwi krajom Bałkanów Zachodnich, by osłabić wpływy Rosji, 5 XII 2018, http://www.pap.pl.

NATO's Strategic Concept 2010, Active Engagement, Modern Defence, http://www. nato.int.

"Newsweek" ma nagrania Schetyny. "Naszą aktywnością będzie ulica, wyprowadzimy milion ludzi", 3 I 2016, http://wiadomosci.wp.pl.

Nic o nas bez nas - zasady polskiej polityki zagranicznej, 6 III 2013, http://www. salon24.pl.

Nie odtwarzajmy Cesarstwa Niemieckiego. „Polski minister wybrał metodę uzgadniania z rządem Niemiec", 9 XII 2011, http://www.wpolityce.pl.

PESCO: rusza współpraca obronna 25 państw, 11 XII 2017, http://consilium.europa.eu.

Piknik żołnierzy NATO w Piotrkowie Trybunalskim, 28 III 2017, http://www.pap.pl.

„PiS realizuje rosyjski scenariusz", 20 I 2011, http://www.wprost.pl.

Poland's vision for Europe, 30 IV 2019, http://www.politico.eu.

Polska, Rumunia i Turcja - nowy sojusz strategiczny w regionie?, 13 IV 2016, http:// www.forsal.pl.

Polska za utrzymaniem polityki otwartych drzwi NATO, 27 V 2016, http://www. biznesalert.pl.

Powitanie żołnierzy USA w Polsce, 14 I 2017, http://www.pap.pl.

Pożegnanie Polskiego Kontyngentu Wojskowego, 12 II 2018, http://www.pap.pl.

Premier po Radzie Europejskiej w Brukseli, 28 VI 2018, http://www.premier.gov.pl.

President Donald J. Trump Announces a National Security Strategy to Advance America's Interests, http://www.whitehouse.gov.

Prezydenci Duda i Trump rozmawiali w Nowym Jorku. Podpisano szczegółową deklaracje, 23 IX 2019, http://www.pch24.pl.

Prezydenci podpisali porozumienie o partnerstwie strategicznym Polski i Rumunii, 7 X 2009, http://www.bankier.pl.

Prezydencki Szczyt Energetyczny w Krakowie, 11 V 2007, http://www.prezydent.pl.

Prezydent: NATO musi zostać paktem obronnym, 12 III 2009, http://www.newsweek.pl. 
Prezydent Duda: Polska popiera starania Turcji o wstąpienie do UE, 17 X 2017, http:// www.tvp.info.

Przemówienie premiera M. Morawieckiego podczas posiedzenia ZP NATO w Warszawie, 25 V 2018, http://premier.gov.pl.

Przypominamy! Lech Kaczyński w 2009 r. na Westerplatte: „Nie wolno ustępować imperializmowi!", 1 IX 2019, http://www.wpolityce.pl.

Putin atakuje Stany Zjednoczone, 10 II 2007, http://www.wprost.pl.

Rozmowa M. Błaszczaka w TVP Info, 12 III 2018, http://www.pap.pl.

Rozmowa ministra Błaszczaka w programie "Sygnały dnia", 7 V 2018, http://www. pap.pl.

Rozmowa z Radosławem Sikorskim w „Sygnałach dnia”, 29 XI 2006, http://www. pis.org.pl.

Sesja Rady Północnoatlantyckiej z Wysoką Przedstawiciel UE ds. Zagranicznych F. Mogherini, 5 XII 2017, http://msz.gov.pl.

Sikorski: Rosja powinna być w NATO, 5 II 2010, http://www.tvn24.pl.

Słowa, które powstrzymały Rosję. 10. rocznica wystąpienia Lecha Kaczyńskiego w Tbilisi, 12 VIII 2018, http://www.tvp.info.

Spotkał się z Kaczyńskim przy kuflu piwa. I jest efekt!, 2 VIII 2017, http://www.fakt.pl. Spotkanie premiera Litwy i prezesa PiS w Warszawie, 5 IX 2017, http://www.telewizjarepublika.pl.

Spotkanie premierów V4 w Wesołej, 10 III 2019, http://premier.gov.pl.

Spotkanie szefów dyplomacji Polski, Rumunii i Turcji w Ankarze, 19 IV 2019, http:// www.gov.pl.

Spotkanie szefów dyplomacji Polski, Rumunii i Turcji w Bukareszcie, 10 IX 2018, http://www.msz.gov.pl.

Spotkanie z internautami A. Macierewicza, 6 XI 2017, http://www.pap.pl.

Spotkanie z żołnierzami w bazie w Mińsku Mazowieckim, 9 III 2019, http://www. pap.pl.

Szczyt NATO - sukces czy porażka?, 7 IX 2014, http://www.tvp.info.

Szczyt NATO w Brukseli (11-12 lipca 2018), 11-12 VII 2018, http://www.consilium. europa.eu.

Szczyt NATO w Bukareszcie, 2-4 IV 2008, http://www.lechkaczynski.org.

Szczyt NATO w Warszawie, 8-9 lipca 2016, 8 VII 2016, http://www.consilium. europa.eu.

Szczyt szefów Parlamentów Państw Europy Środkoweji Wschodniej, 16 V 2017, http:// www.parlamentarny.pl.

Szczyt Trójmorza z udziałem prezydenta USA, 6 VII 2017, http://www.prezydent.pl.

Szef BBN o „Fort Trump": Poczekajmy na ostateczne rezultaty rozmów, na stole leża różne kwestie, 13 III 2019, http://www.polskieradio24.pl.

Szef MSZ w Rumunii o bezpieczeństwie i współpracy dwustronnej, 23 XII 2015, http:// www.defence24.pl. 
Terlikowski M., PESCO:Unia Europejska zacieśnia współpracę obronną, 28 VI 2017, http://polska-zbrojna.pl.

The Alliance's Strategic Concept, http://www.nato.int.

Trójmorze, http://www.gov.pl.

Ukraina i Gruzja muszą stać się członkami NATO - szefowie MSZ Polski, Rumunii i Turcji, 19 IV 2019, http://www.jagiellonia.org.

W Sejmie szczyt szefów parlamentów państw Europy Środkowej i Wschodniej, $18 \mathrm{~V}$ 2017, http://www.pap.pl.

Ważny tekst prof. Krasnodębskiego w „Rzeczach Wspólnych”. Wielkie spełnienie, czyli postliberalizm po polsku, 8 II 2012, http://www.wpolityce.pl.

Wiceminister Konrad Szymański w programie „Horyzont” TVN24, 7 I 2017, http:// www.msz.gov.pl.

Witold Waszczykowski w „Poranku Radia TOK FM", 6 VI 2007, http://www.pis. org.pl.

Wizyta $w$ Warszawie wicepremiera do spraw europejskich Macedonii Północnej, 20 IX 2019, http://www.gov.pl.

Wypowiedź J. Kaczyńskiego na Śląsku, 6 XI 2006, http://www.bankier.pl.

Wypowiedź ministra Błaszczaka w Polskim Radiu 24, 22 XII 2017, http://www.pap.pl. Wypowiedź ministra W. Waszczykowskiego, 5 XII 2017, http://www.msz.gov.pl.

Wypowiedź ministra Waszczykowskiego na konferencji $w$ Waszyngtonie po obradach koalicji walczącej z IS, 22 VII 2016, http://www.pap.pl.

Wypowiedź premiera po konferencji bezpieczeństwa w Monachium, 17 II 2018, http:// www.premier.gov.pl.

Wypowiedź premiera po spotkaniu z kanclerz Niemiec A. Merkel w Brukseli, 19 VI 2018, http://www.premier.gov.pl.

Wypowiedź Prezydenta dla PAP, 23 IX 2009, http://www.pap.pl.

Wypowiedź prezydenta L. Kaczyńskiego dla polskiego radia, 13 III 2009, http://wiadomosci.dziennik.pl.

Wypowiedź prezydenta L. Kaczyńskiego na szczycie NATO w Bukareszcie, 2-4 IV 2008, http://www.lechkaczynski.org.

Wypowiedź W. Waszczykowskiego, 18 IV 2019, www.defence24.pl.

Wypowiedź W. Waszczykowskiego, 7 VII 2016, http://wiadomosci.dziennik.pl.

Wypowiedź W. Waszczykowskiego dla PAP, 29 XI 2015, http://www.pap.pl.

Wywiad A. Macierewicza dla TVP, http://www.pap.pl.

Wywiad B. Szydło w programie I PR, 7 VII 2017, http://www.pap.pl.

Wywiad dla programu I PR, 13 VI 2018, http://www.pap.pl.

Wywiad min. M. Błaszczaka dla PAP, 28 IX 2018, http://www.pap.pl.

Wywiad premiera dla tvp.info, 27 III 2018, http://www.premier.gov.pl.

Wywiad prezydenta Kaczyńskiego, 12 III 2009, http://www.bankier.pl.

Wywiad prezydenta Lecha Kaczyńskiego dla PAP na tematy międzynarodowe, 24 I 2006, http://www.pap.pl. 
Wywiad W. Waszczykowskiego w polskim Radio, 2 XI 2018, http://www.polskieradio24.pl.

Wywiad z W. Waszczykowskim, 18 IV 2018, http://www.defence24.pl.

Wywiad z W. Waszczykowskim, 7 VII 2016, http://www.wiadomosci.dziennik.pl. Zachód nas nie obroni, 18 IX 2014, http://www.nowakonfederacja.pl.

Zadanie, http://mndne.wp.mil.pl.

Żagań. Amerykańskie wojsko przyjechało na dłuższa wizytę, 13 I 2017, http://www. regionfan.pl.

\section{6. Źródła audiowizualne}

Europa Środkowa wobec zmian w UE - komentarz Jarosława Kaczyńskiego, http:// www.youtube.com.

Lech Kaczyński przemawia na Westerplatte 1.09.2009, http://www.youtube.com. Prezydent Lech Kaczyński na Westerplatte, http://www.youtube.com.

\section{PRASA}

„Debata”, 1998.

„Do Rzeczy", 2013-2019.

„Dziennik Gazeta Prawna”, 2015-2019.

„Gazeta Polska", 2018.

"Gazeta Polska Codziennie", 2014.

"Gazeta Wyborcza", 2005, 2006, 2009, 2011, 2015-2019.

„Nasz Dziennik”, 2007, 2009, 2010, 2011, 2013.

„Polityka", 2009.

„Rzeczpospolita", 2003, 2009, 2010, 2015-2019.

"Sieci", 2014-2020.

"Tygodnik Powszechny”, 2000.

„Uważam Rze", 2011-2012.

„Wprost", 2008, 2009, 2015-2019.

\section{LITERATURA}

\subsection{Opracowania zwarte}

Alden C., Aran A., Foreign Policy Analysis. New approaches, Routledge, LondonNew York 2017.

Ancona M. de, Postprawda, Wydawnictwo Krytyki Politycznej, Warszawa 2018.

Ankersmit F., Narracja, reprezentacja, doświadczenie. Studia z teorii historiografii, Universitas, Kraków 2004.

Bertalanffy L. von, Ogólna teoria systemów. Podstawy, rozwój, zastosowanie, Wydawnictwo Naukowe PWN, Warszawa 1984. 
Breuning M., Foreign Policy Analysis. A Comparative Introduction, Palgrave Macmillan, [b.m.w.] 2007.

Bryc A., Cele polityki zagranicznej Federacji Rosyjskiej, Wydawnictwo Adam Marszałek, Toruń 2004.

Buksiński T., Prawdy w polityce, Oficyna Wydawnicza Epigram, Bydgoszcz 2018.

Buksiński T., Racjonalność współdziałań. Szkice z filozofii polityki, Wydawnictwo Naukowe Instytutu Filozofii UAM, Poznań 1996.

Burchill S. i in., Teorie stosunków międzynarodowych, Książka i Wiedza, Warszawa 2006.

Cenckiewicz S., Chmielecki A., Prezydent. Lech Kaczyński 2005-2010, Wydawnictwo Fronda, Warszawa 2016.

Changing World Order. The Republic of Turkey's Rise as a Middle Power, ed. N. Grimsel, Stellenbosch University, [b.m.w.] 2014.

Chmielnicki P., Minich D., Gorzki smak kiełbasy wyborczej. Obietnice wyborcze i ich realizacja w latach 2015-2016, Wolters Kluwer, Warszawa 2019.

Chodakiewicz M. J., Międzymorze, 3S Media, Warszawa 2019.

Ciżewska E., Filozofia publiczna Solidarności. Solidarność 1980-1981 z perspektywy republikańskiej tradycji politycznej, Narodowe Centrum Kultury, Warszawa 2010.

Cywiński B., Szańce kultur. Szkice z dziejów narodów Europy Wschodniej, Wydawnictwo Trio - Centrum Europejskie Natolin, Warszawa 2013.

Czachór Z., Kryzys i zaburzona dynamika Unii Europejskiej, Dom Wydawniczy Elipsa, Warszawa 2013.

Czaputowicz J., Teorie stosunków międzynarodowych, Wydawnictwo Naukowe PWN, Warszawa 2008.

Czaputowicz J., Teorie stosunków międzynarodowych. Krytyka i systematyka, Wydawnictwo Naukowe PWN, Warszawa 2007.

Czechowska L., Wewnątrzunijni partnerzy strategiczni Rzeczypospolitej Polskiej, Wydawnictwo Mado, Toruń 2013.

Domańska E., Historia egzystencjalna. Krytyczne studium narratywizmu i humanistyki zaangażowanej, Wydawnictwo Naukowe PWN, Warszawa 2012.

Ehrlich S., Dynamika norm, Wydawnictwo Naukowe PWN, Warszawa 1988.

Ehrlich S., Dynamika norm. Podstawowe zagadnienia wiążących wzorów zachowań, Wydawnictwa Szkolne i Pedagogiczne, Warszawa 1994.

Fernández-Armesto F., Historia prawdy, Wydawnictwo Zysk i S-ka, Poznań 1999.

Filipczak-Białkowska A., Mechanizmy manifestowania orientacji ideologicznej w dyskursie politycznym, Wydawnictwo Uniwersytetu Łódzkiego, Łódź 2018.

Fleischer M., Polska symbolika kolektywna, Dolnośląska Szkoła Wyższa Fundacji TWP, Wrocław 2003.

Flint C., Wstęp do geopolityki, Wydawnictwo Naukowe PWN, Warszawa 2008. 
Gałkowski S., Barbarzyńcy i obywatele. Myślenie polityczne wobec wartości, Wydawnictwo KUL - Krakowska Akademia im. Andrzeja Frycza Modrzewskiego, Lublin 2012.

Gawin D., Rewolucja czy konstytucjonalizm? Dwuznaczne dziedzictwo polityczne oświecenia, http://omp.org.pl.

Gostkowska J., Brukselski szczyt NATO: wschodnia flanka między USA a Europa, "Analizy OSW", 9 VII 2018, http://www.osw.waw.pl.

Gostkowska J., W stronę sojuszu wojskowego? Perspektywy Europejskiej Unii Bezpieczeństwa i Obrony, OSW, Warszawa 2019.

Grochulska B., Małe państwo wielkich nadziei, KAW RSW „Prasa-Książka-Ruch”, Warszawa 1987.

Habuda L., Prawa i Sprawiedliwości Rzeczpospolita Polska. Aksjologia, ustrój, uprawianie polityki, obywatelskie społeczeństwo, Wydawnictwo Uniwersytetu Opolskiego, Opole 2010.

Jackson R., Sørensen G., Wprowadzenie do stosunków międzynarodowych. Teorie i kierunki badawcze, Wydawnictwo Uniwersytetu Jagiellońskiego, Kraków 2006.

Kmiecik S., Przemysł pogardy. Niszczenie wizerunku prezydenta Lecha Kaczyńskiego w latach 2005-2010 oraz po jego śmierci, Wydawnictwo Prohibita, Warszawa 2013.

KołodziejJ. H., Wartości polityczne. Rozpoznanie, rozumienie, komunikowanie, Księgarnia Akademicka, Kraków 2011.

Koszel B., "Nowe otwarcie”? Stosunki polsko-niemieckie w okresie rządów koalicji PO-PSL (2007-2009), Instytut Zachodni, Poznań 2009.

Krasnodębski Z., Demokracja peryferii, Wydawnictwo słowo/obraz, terytoria, Gdańsk 2005.

Krasnodębski Z., Drzemka rozsądnych. Zebrane eseje i szkice, Ośrodek Myśli Politycznej - Wyższa Szkoła Europejska im. ks. Józefa Tischnera, Kraków 2006.

Krasnodębski Z., Już nie przeszkadza. Szkice polityczne III, Ośrodek Myśli Politycznej, Kraków 2010.

Krasnodębski Z., Większego cudu nie będzie. Zebrane eseje i szkice IV, Ośrodek Myśli Politycznej, Kraków 2011.

Krzymowski M., Jarosław. Tajemnice Kaczyńskiego, Ringier Axel Soringer Polska, Warszawa 2015.

Lech Kaczyński. Biografia polityczna 1949-2005, S. Cenckiewicz i inni, Wydawnictwo Zysk i S-ka, Poznań 2013.

Legutko R., Antykaczyzm, Wydawnictwo M, Kraków 2013.

Lewandowski P., Mit polityczny Lecha Kaczyńskiego, Wydawnictwo Adam Marszałek, Toruń 2014.

Lipiński A., Prawica na polskiej scenie politycznej w latach 1989-2011. Historia, organizacja, tożsamość, Dom Wydawniczy Elipsa, Warszawa 2016. 
Machaj Ł., Za i przeciw Europie. Integracja europejska w polskiej myśli politycznej w latach 1989-2001, Wydawnictwo Uniwersytetu Wrocławskiego, Wrocław 2006.

Maj C., Wartości polityczne w stosunkach międzynarodowych, Wydawnictwo UMCS, Lublin 1992.

Maj P., Lewicowość, centrowość i prawicowość w nauce o polityce, Wydawnictwo Uniwersytetu Rzeszowskiego, Rzeszów 2018.

Menkiszak M., Strategiczna kontynuacja, taktyczna zmiana. Polityka bezpieczeństwa europejskiego Rosji, OSW, Warszawa 2019.

Nowak A., Idea jagiellońska w polskiej pamięci i wyobraźni politycznej, http://studylibpl.com/doc/1243941.

Nye J. S. jr, Konflikty międzynarodowe. Wprowadzenie do teorii i historii, Wydawnictwa Akademickie i Profesjonalne, Warszawa 2009.

Och J., Polskie elity partyjne wobec przyszłości Unii Europejskiej - perspektywa 19892008, czasopisma.bg.ug.edu.pl, DOI: 10.5604/01.3001.0013.1592.

Orzelska-Stączek A., Ministrowie spraw zagranicznych Polski w latach 2005-2015. Stefan Meller, Anna Fotyga, Radosław Sikorski, Instytut Studiów Politycznych PAN, Warszawa 2016.

Özkan M., Pivotal Middle Powers and World Order. Toward a New Understanding of International Politics?, http://www.eisa-net.org.

Paruch W., Myśl polityczna obozu piłsudczykowskiego 1926-1939, Wydawnictwo UMCS, Lublin 2005.

Polityka zagraniczna Rosji, red. S. Bieleń, M. Raś, Wydawnictwo Difin, Warszawa 2008.

Piotrowski M. A., Zmiany w głównych założeniach Strategii obrony narodowej USA, „Biuletyn PISM", 26 I 2018, http://www.pism.pl.

Ricoeur P., Pamięć, historia, zapomnienie, Universitas, Kraków 2006.

Samsonowicz H., O „historii prawdziwej”. Mity, legendy i podania jak źródło historyczne, Novus Orbis, Sopot 1997.

Sanecka-Tyczyńska J., Państwo obywatelskie i wspólnota polityczna. Studium o myśli politycznej Prawa i Sprawiedliwości, Wydawnictwo UMCS, Lublin 2011.

Sanecka-Tyczyńska J., Racja stanu we współczesnej polskiej myśli politycznej 20012015, Wydawnictwo UMCS, Lublin 2019.

Schmitt C., Teologia polityczna i inne pisma, Wydawnictwo Aletheia, Warszawa 2012.

Skarzyński R., Anarchia i policentryzm. Elementy teorii stosunków międzynarodowych, Wydawnictwo Wyższej Szkoły Ekonomicznej w Białymstoku, Białystok 2006.

Skarzyński R., Geoekonomia. Kryzys czy upadek teorii stosunków międzynarodowych?, Instytut Badań nad Bezpieczeństwem, Energetyką i Klimatem, Warszawa 2017. 
Skarzyński R., Mobilizacja polityczna. Wspótpraca i rywalizacja człowieka wspótczesnego $w$ wielkiej przestrzeni i długim czasie, Dom Wydawniczy Elipsa, Warszawa 2011.

Skarzyński R., Podstawowy dylemat politologii: dyscyplina nauki czy potoczna wiedza o społeczeństwie? O tradycji uniwersytetu i demarkacji wiedzy, Wydawnictwo Temida 2, Białystok 2012.

Stolarczyk M., Rosja w polityce zagranicznej Polski w latach 1992-2015, Wydawnictwo Uniwersytetu Śląskiego, Katowice 2016.

Sykulski L., Ku Nowej Europie:perspektywa związku Unii Europejskiej i Rosji. Spojrzenie geopolityczne z Polski, Wydawnictwo Instytutu Geopolityki „Alfa 24", Częstochowa 2011.

Szczerski K., Dynamika systemu europejskiego. Rozważania o nowym kształcie polityki w Unii Europejskiej, Wydawnictwo Uniwersytetu Jagiellońskiego, Kraków 2008.

Szczerski K., Utopia europejska. Kryzys integracji i polska inicjatywa naprawy, Wydawnictwo Biały Kruk, Kraków 2017.

Tinder G., Myślenie polityczne. Odwieczne pytania, Wydawnictwo Naukowe PWN, Warszawa 2003.

Vall M. du, Neokonserwatyzm w Stanach Zjednoczonych. Od Żywotnego Centrum do epoki Reagana, Krakowskie Towarzystwo Edukacyjne sp. z o. o. - Oficyna Wydawnicza AFM, Kraków 2011.

Warzecha Ł., O wypetnianiu przez Polskę jej potencjału, Ośrodek Myśli Politycznej, http://omp.org.pl.

Wendland M., Filozoficzne i metodologiczne podstawy historii komunikacji, Wydawnictwo Naukowe UAM, Poznań 2014.

White H., Poetyka pisarstwa historycznego, red. E. Domańska, M. Wilczyński, Universitas, Kraków 2000.

Wołek A., Słabe państwo, Ośrodek Myśli Politycznej - Instytut Studiów Politycznych PAN, Kraków-Warszawa 2012.

Wróbel S., Władza i rozum. Studia rozwojowe krytycznej teorii społecznej, Wydawnictwo Naukowe UAM, Poznań 2002.

Zielonka J., Koniec Unii Europejskiej?, PISM, Warszawa 2014.

Zięba R., Główne kierunki polityki zagranicznej Polski po zimnej wojnie, Wydawnictwa Akademickie i Profesjonalne, Warszawa 2010.

Zuba K., Polska scena polityczna. Ciągłość i zmiana, Wydawnictwo Sejmowe, Warszawa 2012.

Zuba K., Polski eurosceptycyzm i eurorealizm, Wydawnictwo Uniwersytetu Opolskiego, Opole 2006.

Żurawski vel Grajewski P., Bezpieczeństwo międzynarodowe. Wymiar militarny, Wydawnictwo Naukowe PWN, Warszawa 2012.

Żurawski vel Grajewski P., Geopolityka - siła - wola. Rzeczypospolitej zmagania z losem, Ośrodek Myśli Politycznej, Kraków 2010. 
Żurawski vel Grajewski P., Polska polityka wschodnia 1989-2015. Wymiar narodowy i unijny, Ośrodek Myśli Politycznej, Kraków 2016.

Żurawski vel Grajewski P., Motusic A. B., Adriatic-Baltic-Black Sea. Visions of Cooperation, ed. K. Redłowska, Institue of Eastern Studies, Warszawa 2017.

\subsection{Artykuły naukowe}

Bachmann K., Z perspektywy Brukseli: czy UE ma świadomość geopolityczną?, „Rocznik Strategiczny" 2004/2005.

Balcerowicz B., Powrót siły, „Rocznik Strategiczny” 2006/2007.

Bieleń S., Pozycja geopolityczna Polski, [w:] Polska w stosunkach międzynarodowych, red. S. Bieleń, Wydawnictwo Aspra-JR, Warszawa 2007.

Bonikowska M., Przyszłość Unii Europejskiej w kontekście prowadzonej obecnie debaty, [w:] Kształtowanie się nowego ładu międzynarodowego, red. A. Chodubski i inni, Fundacja Rozwoju Uniwersytetu Gdańskiego, Gdańsk 2007.

Bryc A., Europejska Polityka Sąsiedztwa w perspektywie rosyjskiej, [w:] Europejska Polityka Sąsiedztwa Unii Europejskiej. Geneza, doświadczenia, perspektywy, red. J. M. Fiszer, Dom Wydawniczy Elipsa, Warszawa 2012.

Burakowski A., Czy Rumunia może być partnerem Polski?, [w:] Polska w grze międzynarodowej. Geopolityka i sprawy wewnętrzne, red. J. Kloczkowski, Ośrodek Myśli Politycznej, Kraków 2010.

Chase R., Hill E., Kennedy P., Pivotal States and US Strategy, „Foreign Affaires”, January-February 1996, vol. 75, no. 1.

Chmielecki A., Antykomunizm praktyczny, czyli zarys historii i programu Porozumienia Centrum, [w:] Nowe państwo. Porozumienie Centrum w dokumentach (1990-2001), wstęp, wybór i oprac. A. Chmielecki, Patria Media, Gdańsk 2020.

Cichocki M. A., Szkice z polskiej podmiotowości, „Teologia Polityczna” 2009-2010, nr 5.

Cichocki M., Szkice z polskiej podmiotowości, [w:] Rzeczpospolita na arenie międzynarodowej. Idee i praktyczne dylematy polityki zagranicznej, red. J. Kloczkowski, T. Żukowski, Kancelaria Prezydenta Rzeczypospolitej Polskiej - Ośrodek Myśli Politycznej, Warszawa 2010.

Cichocki M. A., "Więcej Europy" jako przykład strategii antykryzysowej-próba oceny efektywności, "Studia Europejskie” 2017, nr 2.

Collingwood R. G., Istota i cele filozofii historii, "Roczniki Filozoficzne" 2018, nr 4(66).

Czachór Z., 2019. Powrót do przyszłości, "Instytut Idei” 2019, nr 6.

Czachór Z., Unia Europejska w stanie krytycznym. Nowe sytuacje - nowe konstelacje - nowe orientacje, „Przegląd Europejski” 2018, nr 1.

Czajowski A., Władza polityczna: analiza pojęcia, [w:] Studia z teorii polityki, t. 1, red. A. W. Jabłoński, L. Sobkowiak, Wydawnictwo Uniwersytetu Wrocławskiego, Wrocław 1999. 
Czaputowicz J., Globalna strategia UE - koniec Unii Europejskiej jako potęgi normatywnej?, „Przegląd Europejski” 2016, nr 4(42).

Czaputowicz J., System międzynarodowy jako poziom analizy w nauce o stosunkach międzynarodowych, http://ptsm.edu.pl.

Dyner A. M., Rosja wzmacnia potencjał wojskowy na zachodzie państwa , „Biuletyn PISM" 2018, nr 173, http://pism.pl.

Europa Wschodnia między nostalgią a inercja, "Rocznik Strategiczny" 2009/2010.

Feldman S., Wartości, ideologia i strukturyzacja postaw politycznych, [w:] Psychologia polityczna, red. D. O. Sears, L. Huddy, R. Jervis, Wydawnictwo Uniwersytetu Jagiellońskiego, Kraków 2008.

Fiszer J. M., Polityka zagraniczna Polski w XXI wieku:cele, wyzwania, kierunki, szanse i zagrożenia, "Myśl Ekonomiczna i Polityczna” 2019, nr 2(65).

Fiszer J. M., Zadania i cele polityki zagranicznej Władimira Putina, „Myśl Ekonomiczna i Polityczna" 2016, nr 1(52).

Gaczoł K., Narratywizm historyczny Haydena White'a $w$ badaniach nad historia prawa, „Folia Iuridica Universitatis Wratislaviensis” 2018, vol. 2(7).

Galent M., Kryzys systemowy strefy euro w cieniu traktatu z Maastricht $i$ traktatu z Lizbony, „Politeja” 2018, nr 3(54).

Gawin D., Kowal P., Polska polityka historyczna, [w:] Polityka historyczna. Historycy, politycy, prasa. Konferencja pod honorowym patronatem Jana Nowaka-Jeziorańskiego, Pałac Raczyńskich w Warszawie, 15 grudnia 2004 roku, red. A. Panecka, Muzeum Powstania Warszawskiego, Warszawa 2005.

Gawin D., Przekleństwo 1709 roku. Czy Polacy moga wybić się na podmiotowość?, „Teologia Polityczna” 2009-2010, nr 5.

Gniazdowski M., Bałkany Zachodnie: sprawa środkowoeuropejskiej solidarności, „Polski Przegląd Dyplomatyczny”, marzec-kwiecień 2008, nr 2(42).

Gorgosz A., Kto i z kim? Analiza rozbieżności stanowisk w głosowaniu w Radzie Unii Europejskiej w latach 2009-2014, "Przegląd Europejski” 2018, nr 2.

Gostkowska J., Niemiecko-amerykańskie spory o bezpieczeństwo. Konsekwencje dla wschodniej flanki, „Analizy OSW”, 22 II 2019, http://www.osw.waw.pl.

Grosse T. G., Kryzys demokracji w Europie, „Przegląd Europejski” 2014, nr 3.

Grzesik-Robak A., Wzmocnienie czy osłabienie suwerenności państwowej w kontekście integracji europejskiej w opinii wybranych polskich partii politycznych, „Studia Europejskie" 2007, nr 1.

Habowski M., Platforma Obywatelska wobec zagadnień polityki zagranicznej, [w:] Polityka zagraniczna Polski w latach 2004-2011. Struktury, koncepcje, sąsiedzi, Izrael, red. M. S. Wolański, Dolnośląska Wyższa Szkoła Przedsiębiorczości i Techniki, Polkowice 2013.

Habowski M., Prawo i Sprawiedliwość wobec zagadnień polityki zagranicznej, [w:] Polityka zagraniczna Polski w latach 2004-2011. Struktury, koncepcje, sąsiedzi, Izrael, red. M. S. Wolański, Dolnośląska Wyższa Szkoła Przedsiębiorczości i Techniki, Polkowice 2013. 
Hajduk-Nijakowska J., Proces mityzacji współczesnych bohaterów, [w:] Mit, prawda, imaginacja, red. P. Kowalski, Uniwersytet Wrocławski, Wrocław 2011.

Huczek A., Zastosowanie analizy systemowej jako metody badawczej w naukach politycznych - perspektywa porównawcza, http://bibliotekacyfrowa.pl.

Jachymek J., Paruch W., Wstęp, [w:] Więcej niż niepodległość. Polska myśl polityczna 1918-1939, red. J. Jachymek, W. Paruch, Wydawnictwo UMCS, Lublin 2001.

Kaczmarski M., Realizm neoklasyczny, [w:] Teorie i podejścia badawcze w nauce o stosunkach międzynarodowych, red. R. Zięba, S. Bieleń, J. Zając, Wydział Dziennikarstwa i Nauk Politycznych Uniwersytetu Warszawskiego, Warszawa 2015.

Kaluziński B., Idea prawdy jako korespondencji w filozofii późnego Wittgensteina, „Diametros”, wrzesień 2012, nr 33.

Karnowska D., Polityka zagraniczna Prawa i Sprawiedliwości w latach 2005-2011. Próba bilansu, „Nowa Polityka Wschodnia” 2012, nr 2(3).

Karolewski I. P., Mehlhausen T., Między polityką kreowania a asertywnością. Polskie debaty o Europie na przykładzie europejskiego traktatu konstytucyjnego i wojny na Ukrainie, „Przegląd Politologiczny” 2017, nr 2.

Kieniewicz J., Czy Europa Wschodnia jest możliwa?, „Arcana” 1999, nr 29.

Klatt M., Polska - jako „średnie państwo": możliwości i perspektywy, [w:] Polska na arenie międzynarodowej - współczesne wyzwania, red. J. J. Piątek, R. Podgórzańska, Wydawnictwo Adam Marszałek, Toruń 2009.

Kleinowski M., Wpływ traktatu lizbońskiego na siłę Polski w Radzie Unii Europejskiej, „Myśl Ekonomiczna i Polityczna” 2015, nr 1.

Kloczkowski J., Gra bez wyjścia, czyli nic pewnego w geopolityce poza problemami, [w:] Polska w grze międzynarodowej. Geopolityka i sprawy wewnętrzne, red. J. Kloczkowski, Ośrodek Myśli Politycznej, Kraków 2010.

Kloczkowski J., Żukowski T., Polityka polska:czas na poważną debatę, [w:] Rzeczpospolita na arenie międzynarodowej. Idee i praktyczne dylematy polityki zagranicznej, red. J. Kloczkowski, T. Żukowski, Kancelaria Prezydenta Rzeczypospolitej Polskiej - Ośrodek Myśli Politycznej, Warszawa 2010.

Kontynuacja w polskiej polityce zagranicznej, „Rocznik Strategiczny” 2009/2010.

Koralewski J., Rozpad ZSRR a powstanie Federacji Rosyjskiej. Mocarstwowość utracona?, [w:] Mocarstwowość na przełomie XX i XXI wieku. Teorie - analizy - prognozy, red. S. Wojciechowski, M. Tomczak, Wyższa Szkoła Nauk Humanistycznych i Dziennikarstwa w Poznaniu, Poznań 2010.

Kornat M., Nie wyrzekajmy się "doktryny Giedroycia”, „Nowa Europa Wschodnia” 2010, t. 5 .

Kowal P., Wielki powrót geopolityki i wschodnia idea Lecha Kaczyńskiego, [w:] Polska w grze międzynarodowej. Geopolityka i sprawy wewnętrzne, red. J. Kloczkowski, Ośrodek Myśli Politycznej, Kraków 2010.

Koziej S., Amerykański system obrony przeciwrakietowej, „Rocznik Strategiczny” $2007 / 2008$. 
Kozub-Karkut M., Realizm neoklasyczny - główne założenia i możliwości, [w:] Mapa współczesnego realizmu. Założenia i zastosowania badawcze, red. E. Haliżak, J. Czaputowicz, Wydawnictwo Rambler, Warszawa 2014.

Krasnodębski Z., Republikanizm po komunizmie - utopia czy alternatywa?, [w:] Władza w polskiej tradycji politycznej. Idee i praktyka, red. J. Kloczkowski, Ośrodek Myśli Politycznej, Kraków 2010.

Kristol I., Konserwatywne państwo opiekuńcze, [w:] Neokonserwatyzm, oprac. I. Stelzer, Wydawnictwa Akademickie i Profesjonalne, Warszawa 2007.

Kristol I., Neokonserwatywne przekonania, [w:] Neokonserwatyzm, oprac. I. Stelzer, Wydawnictwa Akademickie i Profesjonalne, Warszawa 2007.

Kubera J., Polska „piastowska" vs. „jagiellońska". Odmienność wizji relacji z Niemcami jako determinanta poglądów na polską politykę zagraniczną, „Acta Politica Polonica" 2016, nr 4(38).

Kubin T., Głosowanie większością kwalifikowaną w Radzie Unii Europejskiej w Traktacie z Lizbony, „Polski Przegląd Dyplomatyczny”, lipiec-sierpień 2008, nr 4(44).

Kuczyńska-Zonik A., Wilczewski D., „Polska i Litwa podaja sobie dłonie”. Polska perspektywa współpracy bilateralnej, [w:] Stosunki Polski z Litwa, Białorusia i Ukrainą. 450 lat po unii lubelskiej, red. T. Stępniewski, B. Surmacz, Instytut Europy Środkowej, Lublin 2019.

Lasoń M., Zagrożenia dla bezpieczeństwa Polski w XXI wieku w świetle analizy porównawczej kolejnych Strategii Bezpieczeństwa Narodowego „ „Bezpieczeństwo. Teoria i Praktyka", Czasopismo Krakowskiej Szkoły Wyższej im. Andrzeja Frycza Modrzewskiego, 2016, nr 10/3.

Legro J. W., Moravcsik A., Is Anybody still Realist?, „International Security" 1999, nr 24(2).

Legucka A., Dylemat bezpieczeństwa w stosunkach polsko-rosyjskich po 2014 roku, „Studia Politologiczne" 2018, vol. 49.

Łoś R., Siła współczesnych państw. Ujęcie teoretyczne, „Przegląd Politologiczny” 2018, nr 2.

Łoś-Nowak T., Paradygmat realistyczny - projekcje porządku międzynarodowego u progu XXI wieku, [w:] Porządek międzynarodowy u progu XXI wieku. Wizje, koncepcje, paradygmaty, red. R. Kuźniar, Wydawnictwa Uniwersytetu Warszawskiego, Warszawa 2006.

Macała J., Polish Geopolitical Codes Illustriated with the Example of the Electoral Programs of the Major Political Parties in 1991-2011, „Athenaeum. Polskie Studia Politologiczne" 2017, vol. 56.

Madej A., Świeżak P., Informacja na temat doktryny wojennej Federacji Rosyjskiej, „Bezpieczeństwo Narodowe” 2015, nr 36.

Malinowski K., Polityka Niemiec wobec Europy Wschodniej: Russia first? , „Przegląd Politologiczny" 2015, $\mathrm{nr} 4$. 
Marciniak W., Rosja w Europie: utopia i antyutopia modernizacji, [w:] Polska w grze międzynarodowej. Geopolityka i sprawy wewnętrzne, red. J. Kloczkowski, Ośrodek Myśli Politycznej, Kraków 2010.

Markiewicz G., Kontrowersje wokół "numeracji” Rzeczypospolitej Polskiej - zarys problematyki, [w:] Idea ustrojowa a rzeczywistość "IV Rzeczypospolitej", red. J. Kornaś, Kraków 2010, „Studia i Prace Uniwersytetu Ekonomicznego w Krakowie", 2010, nr 9.

Master B., Unia Europejska w programach głównych polskich ugrupowań politycznych po 2004 roku, "Studia Politicae Universitatis Silesiensis” 2014, t. 12.

Mazurek K., Europejska ofensywa w obszarze obronności - EDF, PESCO i CARD, Fundacja im. Kazimierza Puławskiego, Warszawa 2018.

Migalski M., Polityka zagraniczna w programie i działalności Platformy Obywatelskiej, [w:] Platforma Obywatelska, red. M. Migalski, Wydawnictwo Adam Marszałek, Toruń 2009.

Minkner K., Problem polityczności jako metateoretyczne wyzwanie dla politologii, "Athenaeum. Polskie Studia Politologiczne" 2014, vol. 43.

Nalewajko E., Eurosceptyczne partie i ich liderzy w publicznej debacie o integracji wprowadzonej w latach 2000-2003, [w:] Przed referendum europejskim - absencja, sprzeciw, poparcie, red. L. Kolarska-Bobińska, Instytut Spraw Publicznych, Warszawa 2003.

Niedźwiecki A., Polska polityka europejska w latach 2005-2007. Zarys problemu, "Athenaeum" 2008, vol. 19.

Nowak A., Europa Wschodnia - polskie pytania o Europę i jej Wschód (po 10 kwietnia 2010 roku), [w:] Polska w grze międzynarodowej. Geopolityka i sprawy wewnętrzne, red. J. Kloczkowski, Ośrodek Myśli Politycznej, Kraków 2010.

Obszar WNP: broń gazowa Rosji, „Rocznik Strategiczny” 2006/2007.

Obszar WNP: długi cień Rosji, „Rocznik Strategiczny” 2007/2008.

Obszar WNP. W stronę nowego ładu? Rosja: na rozdrożu, „Rocznik Strategiczny” $2009 / 2010$.

Orzelska-Stączek A., Inicjatywa Trójmorza w świetle teorii realizmu. Polityczne aspekty nowej formy współpracy dwunastu państw, „Sprawy Międzynarodowe" 2019, nr 1.

Orzelska-Stączek A., Uwarunkowania polskiej polityki zagranicznej w okresie urzędowania ministra Stefana Mellera (31 X 2005-9 V 2006), „Myśl Ekonomiczna i Polityczna" 2016, nr 2(53).

Özkan M., A New Approach to Global Security. Pivotal Middle Powers and Global Politics, „Perception. Journal of International Affairs”, Spring 2006.

Pacześniak A., Eurosceptycyzm polskich partii politycznych - ile w tym przekonania, a ile pragmatyzmu?, „Politeja” 2015, nr 33(1).

Paruch W., Dwie koncepcje bezpieczeństwa Polski - neorealistyczne refleksje o narodowych strategiach bezpieczeństwa państwa (2007 i 2014), [w:] Bezpieczeń- 
stwo Europy - bezpieczeństwo Polski, red. E. Maj i inni, Wydawnictwo UMCS, Lublin 2016.

Paruch W., Między romantyzmem a realizmem - Prawo i Sprawiedliwość o polityczności, „Annales Universitatis Paedagogicae Cracoviensis”, Studia Politologica, 2015, nr 15.

Paruch W., Między wyobrażeniami a działaniami. Wybrane aspekty przedmiotowe badań politologicznych nad myśla polityczną, "Polityka i Społeczeństwo" 2004, nr 1.

Paruch W., Myśl polityczna - refleksje metodologiczne o pojęciu, „Annales Universitatis Mariae Curie-Skłodowska", Sectio K: Politologia 1999, vol. 6: Państwo - ludowcy - myśl polityczna, red. Z. J. Pietraś, A. Wójcik, W. Paruch.

Paruch W., Polska w Sojuszu Pótnocnoatlantyckim. Koncepcja Prawa i Sprawiedliwości bezpieczeństwa państwa (2015-2019), [w:] Sojusz Północnoatlantycki w środowisku niepewności i zmiany. Dwadzieścia lat członkostwa Polski, red. W. Paruch, M. Pietraś, B. Surmacz, Wydawnictwo Sejmowe, Warszawa 2020.

Paruch W., Przeszłość w myśli politycznej Prawa i Sprawiedliwości: polska wersja neorealistycznej doktryny stosunków międzynarodowych, [w:] Pomiędzy pamięcią zbiorową a historią. Rekonstrukcje przeszłości w Europie Środkowo-Wschodniej, red. P. Bałdys, I. Jakimowicz-Ostrowska, J. Charuta-Kojkoł, Wydawnictwo Naukowe Katedra, Gdańsk 2016.

Paruch W., Regionalne czynniki bezpieczeństwa Polski. Powrót do doktryny realistycznej w myśleniu politycznym, [w:] Współczesne bezpieczeństwo ekonomiczne i społeczno-kulturowe. Wymiar międzynarodowy, red. M. Gębska, Wydawnictwo Akademii Sztuki Wojennej, Warszawa 2017.

Paruch W., Romantyzm celów i pozytywizm środków. Piłsudczycy o warunkach potęgi Rzeczypospolitej w środowisku międzynarodowym, [w:] Sen o potędze. Bezpieczeństwo-suwerenność-mocarstwowość. Rzeczpospolita Polska 1918-1939, red. E. Maj i inni, Wydawnictwo UMCS, Lublin 2014.

Paruch W., „Wprowadzenie Sojuszu Północnoatlantyckiego do Polski”. Studium o polityce transatlantyckiej większości parlamentarnej Zjednoczonej Prawicy (2015-2019), „Przegląd Sejmowy” 2020, nr 2.

Paruch W., Źródła orientacji eurorealistycznej w Polsce. O myśli politycznej Prawa i Sprawiedliwości, [w:] Integracja europejska. Polska perspektywa, red. Z. Czachór, T. Grosse, W. Paruch, Wydawnictwo Sejmowe, Warszawa 2018.

Paruch W., Trembicka K., Wprowadzenie, [w:] Wizje i realia. Studia nad realizacja polskiej myśli politycznej XX wieku, red. W. Paruch, K. Trembicka, Wydawnictwo UMCS, Lublin 2002.

Pełczyńska K., Polska wobec Rosji. Radykalizm bez polityki , „Sprawy Międzynarodowe" 2018, nr 3.

Pękala M., Stanisława Ehrlicha decyzyjna koncepcja prawa: próba rekonstrukcji, „Państwo i Prawo" 2012, nr 10. 
Pietrzyk-Reeves D., The Revivals of the Jagiellonian Idea. Political and Normative Contexts, „Politeja” 2017, nr 51.

Pietrzyk-Reeves D., Tradycja republikańska, respublica, republikanizm, „Horyzonty Polityki" 2013, nr 7.

Piotrowski M. A., Wiśniewski B., Strategia bezpieczeństwa narodowego USA. Podejście administracji Trumpa, „Biuletyn PISM”, 21 XII 2017, http://www.pism.pl.

Piwnicki G., Syndrom reintegracji w stosunkach Polski z Unią Europejska po roku 2015, „Środkowoeuropejskie Studia Polityczne” 2017, nr 3.

Pleśniarska A., Integracja europejska w obliczu eurosceptycyzmu, "Zeszyty Naukowe Uniwersytetu Ekonomicznego w Krakowie" 2017, nr 966(6).

Podolski A., Czy Polska ma doktrynę integracyjną?, [w:] Czy Polska ma doktrynę integracyjną?, Ośrodek Myśli Politycznej, Kraków 1998.

Polska polityka historyczna, „Biuletyn Instytutu Pamięci Narodowej”, maj 2006, nr 5.

Polska polityka zagraniczna: jeden krok - dwie odsłony, "Rocznik Strategiczny" $2007 / 2008$.

Polska polityka zagraniczna - U.S. First, lecz także więcej Europy, „Rocznik Strategiczny" 2004/2005.

Polska polityka zagraniczna w 2006 r., „Rocznik Strategiczny” 2006/2007.

Przegląd sytuacji strategicznej - aspekty globalne i regionalne, „Rocznik Strategiczny" 2006/2007.

Reykowski J., Myślenie polityczne, [w:] Podstawy psychologii politycznej, red. K. Skarżyńska, Wydawnictwo Zysk i S-ka, Poznań 2002.

Rosja aspiruje do statusu supermocarstwa i zawiesza CFE, „Rocznik Strategiczny” 2007/2008.

Rubisz L., Platforma Obywatelska - tradycje i inspiracje światopoglądowe, [w:] Platforma Obywatelska, red. M. Migalski, Wydawnictwo Adam Marszałek, Toruń 2009.

Rubisz L., Prawo i Sprawiedliwość - konserwatyzm tu i teraz, [w:] Prawo i Sprawiedliwość, red. M. Migalski, Wydawnictwo Adam Marszałek, Toruń 2010.

Sabat M., Stosunki polsko-rosyjskie. Rozbieżności interesów strategicznych, [w:] Polityka zagraniczna Federacji Rosyjskiej. Wybrane aspekty stosunków z Polska, Ukrainą i Białorusią, red. L. Zyblikiewicz, M. Czajowski, P. Bajor, Wydawnictwo Uniwersytetu Jagiellońskiego, Kraków 2010.

Sajduk B., Tradycyjne metody analizy polityki zagranicznej, [w:] Podmiotowość geopolityczna. Studia nad polską polityką zagraniczną, red. K. Szczerski, KSAP, Warszawa 2009.

Sałajczyk S. P., Wizje rzeczywistości międzynarodowej, [w:] Stosunki międzynarodowe. Geneza, struktura, dynamika, red. E. Haliżak, R. Kuźniar, Wydawnictwa Uniwersytetu Warszawskiego, Warszawa 2006.

Sanecka-Tyczyńska J., Model bezpieczeństwa zewnętrznego państwa w myśli politycznej Prawa i Sprawiedliwości, „Zeszyty Naukowe WSOWL” 2011, nr 3(161). 
Sienkiewicz M., Koncepcja Trójmorza w polityce zagranicznej Polski po 2015 r., „Dyplomacja i Bezpieczeństwo" 2016, nr 1(4).

Słomczyński W., Zajączkowski K., Kompromis Jagielloński-system głosowania dla Rady UE, "Międzynarodowy Przegląd Polityczny” 2007, nr 2(18).

Snapkouski U. E., Białoruś-Polska:jak wyjść z błędnego koła w rozwoju wzajemnych stosunków, [w:] Stosunki Polski z Litwa, Białorusią i Ukraina. 450 lat po unii lubelskiej, red. T. Stępniewski, B. Surmacz, Instytut Europy Środkowej, Lublin 2019.

Sokołowski J. K., Od sojuszu do skrajnej wrogości. Ewolucja zachowań parlamentarnych Platformy Obywatelskiej i Prawa i Sprawiedliwości w latach 2001-2013, "Annales Universitatis Paedagogicae Cracoviensis", Studia Politologica, 2015, nr 15.

Soloch P., Pietrzak P., Szczyt NATO $w$ Warszawie: uwarunkowania, rezultaty, wnioski dla Polski, http://bbn.gov.pl.

Soroka J., Stępniewski T., The Three Seas Initiative. Geopolitical Determinants and Polish Interests, , Rocznik Instytutu Europy Środkowo-Wschodniej” 2019, nr 3.

Stanisławski W., Polska na Bałkanach Zachodnich - życzliwy, roztargniony kibic, "Polski Przegląd Dyplomatyczny", marzec-kwiecień 2008, nr 2(42).

Stelmach M., Charakter i podstawy "metanauki” Ludwika Wittgensteina, „Zagadnienia Naukoznawstwa” 2011, nr 1.

Stępniewski T., Inicjatywa Trójmorza. Uwarunkowania geopolityczne i nowy model regionalnej współpracy, „Studia Europejskie” 2018, nr 2.

Stolarczyk M., Główne problemy w stosunkach polsko-niemieckich na początku XXI wieku, [w:] Problemy polityki zagranicznej Polski i stosunków międzynarodowych na początku XXI wieku. Wybrane aspekty, red. M. Stolarczyk, Wydawnictwo Uniwersytetu Śląskiego, Katowice 2008.

Stolarczyk M., Stosunki polsko-niemieckie w latach 1998-2009 (wybrane aspekty polsko-niemieckiej współpracy), [w:] Stosunki Polski z sąsiadami w pierwszej dekadzie XXI wieku, red. M. Stolarczyk, Wydawnictwo Uniwersytetu Śląskiego, Katowice 2011.

Stolarczyk M., Wrost kontrowersji w stosunkach transatlantyckich i ich implikacje dla bezpieczeństwa europejskiego, [w:] Bezpieczeństwo Polski i bezpieczeństwo europejskie na początku XXI wieku. Wybrane aspekty, red. M. Stolarczyk, Wydawnictwo Uniwersytetu Śląskiego, Katowice 2004.

Szczerski K., Analiza neogeopolityczna (neo-geo), [w:] Podmiotowość geopolityczna. Studia nad polską polityką zagraniczną, red. K. Szczerski, KSAP, Warszawa 2009.

Szczerski K., O nieistnieniu i warunkach zaistnienia. Unia Europejska a problem demokracji, [w:] Politikon III: kto jest suwerenem? Kontrowersje wokół Traktatu Lizbońskiego, red. M. Burzyk, M. Podniesieński, M. Rysiewicz, Koło Nauk Politycznych UJ, Kraków 2012. 
Szpak K., Założenia programowe polityki zagranicznej koalicji rządowej PO-PSL w latach 2007-2011, [w:] Główne kierunki polityki zagranicznej rządu Donalda Tuska w latach 2007-2011, red. P. Musiałek, Wydawnictwo eSPe, Kraków 2012.

Świeboda P., Polski powrót na Bałkany - za i przeciw, „Polski Przegląd Dyplomatyczny", marzec-kwiecień 2008, nr 2(42).

Tosiek P., Polska wizja „rekonstytucji" Unii Europejskiej: nowy model integracji zróżnicowanej?, „Przegląd Europejski” 2017, nr 3.

Uniwersytety sa podstawa suwerenności dzisiejszego państwa. Rozmowa z prof. dr. hab. Ryszardem Skarzyńskim, "Geopolityka” 2012, nr 5 (14).

Waltz K. N., Structural Realism after the Cold War, „International Security”, Summer 2000, vol. 25.

Warzecha Ł., Czy możliwa jest realistyczna polityka zagraniczna nie na kolanach, czyli o fałszywej interpretacji realizmu, [w:] Rzeczpospolita na arenie międzynarodowej. Idee i praktyczne dylematy polityki zagranicznej, red. J. Kloczkowski, T. Żukowski, Kancelaria Prezydenta Rzeczypospolitej Polskiej- Ośrodek Myśli Politycznej, Warszawa 2010.

Wągrowska M., Wraz z tarczą - nowe dylematy w polityce bezpieczeństwa, „Rocznik Strategiczny" 2007/2008.

Wedel J. von, Polska polityka wobec Niemiec 2005-2007: polityka historyczna czy nowa polityka europejska?, [w:] Polityka zagraniczna Polski w warunkach członkostwa w Unii Europejskiej, red. R. Podgórzańska, Wydawnictwo Adam Marszałek, Toruń 2009.

Weremiuk S., Polska wobec Rosji w latach 1992-2014. Od zależności postimperialnych do trudnych relacji. Analiza wybranych aspektów, „Przegląd Bezpieczeństwa Wewnętrznego" 2015, nr 13.

Węc J. J., Reforma wspólnej polityki bezpieczeństwa i obrony Unii Europejskiej w latach 2016-2017, „Politeja” 2018, nr 54(3).

Węgrzecki J., Teoria polityki - powszechność interpretacjonizmu na przykładzie rekonstrukcji, „Teoria Polityki” 2020, nr 4.

Więcławski J., Hans Morgentau, realizm klasyczny i jego rekomendacje dla polskiej polityki zagranicznej, „Myśl Ekonomiczna i Polityczna” 2011, nr 3.

Wildstein B., Czy Polaków stać na niepodległość?, [w:] Rzeczpospolita na arenie międzynarodowej. Idee i praktyczne dylematy polityki zagranicznej, red. J. Kloczkowski, T. Żukowski, Kancelaria Prezydenta Rzeczypospolitej Polskiej - Ośrodek Myśli Politycznej, Warszawa 2010.

Witkowski P., Plany umieszczenia "tarczy antyrakietowej" na terenie RP a bezpieczeństwo Polski - wpływ, znaczenie, analiza krytyczna, [w:] NATO w dobie transformacji. Siły zbrojne $w$ transatlantyckim systemie bezpieczeństwa początku XXI wieku, red. K. Kubiak, P. Mickiewicz, Wydawnictwo Adam Marszałek, Toruń 2008.

Wodzińska K., Polskie dylematy strategiczne. Debata na temat uczestnictwa Polski w amerykańskim systemie obrony rakietowej, [w:] NATO na początku XXI wieku, 
red. S. Zakrzewski, Wydawnictwo Wyższej Szkoły Nauk Humanistycznych i Dziennikarstwa, Poznań 2008.

Zając-Frąs M., Teorie i modele integracji europejskiej, „Zeszyty Naukowe Uniwersytetu Ekonomicznego w Krakowie" 2011, nr 852.

Zalewska M., Gstrein O. J., Parlamenty narodowe $i$ ich rola $w$ procesie integracji europejskiej. Deficyt demokracji w UE w czasach kryzysu ekonomicznego i niepewności politycznej, "Studia Europejskie” 2013, nr 1.

Zieliński T., Europejska Unia Obrony wyzwaniem dla wschodniej flanki NATO, „Zeszyty Naukowe ASzWoj" 2017, nr 4(109).

Zięba R., Implikacje stosunków polsko-amerykańskich dla polityki zagranicznej Polski, „Przegląd Politologiczny” 2015, nr 2.

Zięba R., Teoria bezpieczeństwa państwa w ujęciu neorealistycznym, „Studia Politologiczne" 2018, vol. 49.

Zuba K., Europejska polityka Polski, „ETE Working Paper” 2015, t. 1, nr 1.

Zuba K., Polska, [w:] Doktryny integracyjne państw europejskich, red. K. Zuba, Wydawnictwo Sejmowe, Warszawa 2017.

Zuba K., Polski eurosceptycyzm w kontekście dylematów teoretycznych i porównawczych, „Politeja” 2015, nr 33(1).

Zuba K., The role of ideology and political partie in the proces of formulating Polish foreign policy, [w:] Poland's foreign policy in the $21^{\text {st }}$ century, ed. S. Bieleń, Wydawnictwo Difin, Warszawa 2011.

Żurawski vel Grajewski P., Czy Unia Europejska może/powinna mieć spójna politykę wobec USA?, [w:] Polska w grze międzynarodowej. Geopolityka i sprawy wewnętrzne, red. J. Kloczkowski, Ośrodek Myśli Politycznej, Kraków 2010.

Żurawski vel Grajewski P., Nicejska równowaga, „Polska w Europie” 2004, nr 1.

Żurawski vel Grajewski P., Polska wobec przywództwa Niemiec w Unii Europejskiej, „Przegląd Zachodni" 2014, nr 1.

Żurawski vel Grajewski P., Specyfika relacji polsko-ukraińskich po 2015 roku, „Sprawy Międzynarodowe" 2018, nr 1. 


\section{Indeks osobowy}

A

Alden Chris 96

Ancona Matthew de 86

Ankersmit Franklin 17

Aran Amnon 96

Arystoteles 8

B

Bachmann Klaus 368

Bajor Piotr 182

Balcerowicz Bolesław 100

Bałdys Patrycja 29

Bartoszewski Władysław 165

Băsescu Traian 292

Beck Józef 196, 201

Bell Daniel 325

Bernacki Włodzimierz 101, 103, 105 , 107, 109, 112, 119

Bertalanffy Ludwig von 32

Bielecki Jan K. 127

Bielecki Jędrzej 244, 248, 319

Bieleń Stanisław 89, 90, 97, 194, 399

Bierut Bolesław 78

C

Cedro Magdalena 232, 320, 321

Cenckiewicz Sławomir 20, 60, 193, 229

Błaszczak Mariusz 124, 128, 146, 161 , $181,212,214,228,237,250,256$, 290, 294, 295, 296, 305, 314-317

Bober Mariusz 116, 166, 212, 217

Bonikowska Małgorzata 336

Borodziej Włodzimierz 172

Bratkiewicz Jarosław 150

Breuning Marijke 96

Bryc Agnieszka 194

Buksiński Tadeusz 85, 90

Burchill Scott 64

Burke Edmund 383

Burzyk Mateusz 375

Bush George H. 128

Charuta-Kojkoł Janetta 29

Chase Robert 351

Chmielecki Adam 20, 37, 76, 193, 229 
Chmielnicki Paweł 24, 25

Chodakiewicz Marek 36, 37, 52, 171, 219, 290

Chodubski Andrzej 336

Churchill Winston 381

Cichocki Marek A. 36, 52, 69, 171, 201, 398, 414

Cimoszewicz Włodzimierz 164

Ciżewska Elżbieta 91

Collingwood Robin George 11

Comănescu Lazar 292

Crawford Charles 172

Creţu Corina 288

Cywiński Bohdan 104

Czabański Krzysztof 170
Czachór Zbigniew 29, 375

Czajowski Andrzej 40

Czajowski Michał 182

Czaputowicz Jacek 18, 19, 64, 97, 103, $111,112,143,144,158,220,224-$ 228, 232, 235, 239, 248-250, 254, 260, 261, 270-272, 291, 310-312, $317,319,321,335,358,367,375$, $378-380,382,393,394,400,401$, 405, 413

Czarnecki Marek 221

Czarnecki Ryszard 229, 261

Czartoryski Adam Jerzy 104

Czechowska Lucyna 140, 173, 174, 368

283, 284, 286-289, 292, 294, 296-298, 303, 304, 307, 308, 312, $314-316,318,319,323,326,351$, $355,360,365-367,369-373,378$, $379,381,383,385-388,391,395$, 397, 406, 407, 409, 410, 419

Dyner Anna 282

Dziubka Marek 125

Ehrlich Stanisław 83

Erdoğan Recep Tayyip 231

\section{$\mathbf{F}$}

Feldman Stanley 10

Fernández-Armesto Felipe 11

Filipczak-Białkowska Anita 24

Fiszer Józef M. 108, 156, 194, 255

Fleischer Michael 81, 82

G

Gaczoł Klaudia 17

Flint Colin 364

Fotyga Anna 18, 19, 70, 116, 137-139, $141,143,146,166,191,212,217$. 232, 239, 242, 243, 311

Fuller Buckminster 8

Gajcy Andrzej 264, 280 
Galent Marcin 407

Gałkowski Stanisław 18

Gawin Dariusz 47, 48, 122, 296, 383

Gawryluk Dorota 123

Gębska Marta 89

Gęsicka Grażyna 41, 95, 96, 114, 187, 277

Giedroyć Jerzy 104, 114, 115, 117

Gliński Piotr 121

Głębocki Konrad 109, 172, 257

Gniazdowski Mateusz 229

Gorbaczow Michaił 128

Gorgosz Adrian 400

Gosiewska Małgorzata 103, 106, 107, $109,127,167,168,188,195,208-$

\section{H}

Habowski Mirosław 168, 169, 216

Habuda Ludwik 192

Hajduk-Nijakowska Janina 48

Halecki Oskar 104

Haliżak Edward 68, 103

Handzlik Mariusz 150, 154

I

Iohannis Klaus 292

\section{J}

Jabłońska-Andrzejczuk Agata 247

Jabłoński Andrzej W. 40

Jach Michał 237, 261, 305, 306

Jachymek Jan 30

Jackson Robert 64

Jakimowicz-Ostrowska Iwona 29

K

Kaczmarski Marcin 97, 327, 353

Kaczyńska Maria 81

Kaczyński Jarosław 9, 11, 14, 18-24, $27,31,32,37-42,44,46,49,53$,
$210,212,213,227,231,260,272$, 288,320

Gosiewski Przemysław 154

Gostkowska Justyna 259, 260, 314

Gowin Jarosław 263

Gójska Katarzyna 271, 320

Grimsel Naadirah 327

Grochal Renata 248

Grochulska Barbara 53

Grodecki Tomasz 247

Grosse Tomasz 29, 403

Grzesik-Robak Anetta 335, 336

Gstrein Oskar Josef 403

Gursztyn Piotr 210

Gwiazda Andrzej 79

Hill Emily 351

Hitler Adolf 176, 196, 199, 200

Hobbes Thomas 40

Huczek Agnieszka 32

Huddy Leonie 10
Jan Paweł II 73, 93, 384, 389

Jelcyn Borys 128

Jervis Robert 10

Juncker Jean-Claude 288, 374, 405

Jurek Marek 15
$54,56,57,62,64-70,74,77,79$, $81,83,84,86,87,90,104,113$, $117,119-122,127,128,134,137$, $141,143,148,149,151,158,159$, 
$161,162,164-166,169-173,175-$ $177,180,181,184,188,190,191$, 193, 195, 198, 209-211, 216, 219, $221,233,243,245-248,250,251$, 263, 264, 267, 268, 270, 271, 273 , 274, 277, 292, 293, 301-304, 308, 312 , 325-327, 329, 335, 340, 341, $346,349,350,353-356,364,365$, $370,373,374,376,379,385,388-$ $390,392,396,401,411,414,418$, 419

Kaczyński Lech 9, 11, 18-22, 27, 32, $36,38-41,43,46,48,49,54-56$, $59-62,64-66,68,73,74,77$, 81-84, 86, 87, 90, 91, 97-99, 108, $109,113,117,118,122-124,129$, 133, 137-139, 141-147, 149, 150, $157,168,172,173,179,189$, 191195, 197-203, 207, 209, 211, 215, 216, 220, 223-228, 232-235, 240, 242, 246, 247, 269-271, 276, 285, 286, 289, 292, 293, 311, 321, 338, $340-343,345,346,349,351,360$, $364,366,367,370,373,377,378$, $388,389,391,409,412,413,421$

Kaluziński Bartosz 11

Kant Immanuel 341

Karczewski Stanisław 266, 267

Karnowska Danuta 330, 331

Karnowski Jacek 57, 180, 188, 215, 222, 226, 302

Karnowski Michał 9, 36, 180, 188, 215, 222, 302, 325

Karolewski Ireneusz P. 388, 400

Kennedy Paul 351

Kieniewicz Jan 104, 105

Klatt Małgorzata 120, 351

Kleinowski Marcin 345

Kliszko Zenon 15

Kloc Izabela 253, 254, 399, 404

Kloczkowski Jacek 16, 64, 91, 105, 117,325
Kłoczowski Jerzy 104

Kmiecik Sławomir 73

Kobosko Maciej 369, 371

Koehler Horst 412

Kolarska-Bobińska Lena 337

Kołodziej Jacek H. 10

Komorowski Bronisław 34, 80, 109, 163, 165, 283, 298

Kondzińska Agata 221

Kopacz Ewa 26, 34, 45, 163, 165, 372

Koralewski J. 194

Kornaś Jerzy 73

Kornat Marek 116, 117

Koszel Bogdan 169

Kowal Paweł 16, 122, 186, 187, 192, 193, 211, 212, 370

Kowalski Piotr 48

Koziej Stanisław 140

Kozub-Karkut Magdalena 103

Krasnodębski Zdzisław 12, 13, 18, 36, $55,58,61,73,76,86,90-92,99$, $102,133,324,325,333,378,383$, 398

Krasowski Robert 20, 24, 83, 102

Kristol Irving 22, 88

Krzemiński Adam 198

Krzymowski Michał 20

Kubera Jacek 183

Kubiak Krzysztof 142

Kubin Tomasz 351

Kuchciński Marek 18, 19, 231, 263, 268-270, 376, 377, 379, 385, 391, 402-404

Kuczyńska-Zonik Aleksandra 268, 269

Kurski Jarosław 77, 195, 321, 340

Kurtyka Janusz 103

Kuźniar Roman 67, 68

Kwaśniewski Aleksander 23, 34, 163 


\section{L}

Lasoń Marcin 149

Legro Jeffrey W. 334

Legucka Agnieszka 190

Legutko Ryszard 11, 73, 84, 165, 166, 261

\section{$\mathbf{E}$}

Ławrow Siergiej 182

Łopiński Maciej 56, 118

Łoś Robert 120

M

Maas Heiko 288

Macała Jarosław 364

Machaj Łukasz 329

Maciążek Piotr 113

Macierewicz Antoni 18, 126, 127, 143, $144,146,157,161,170,180,190$, $236,244,248,255,256,279,295-$ 297, 299-303, 305, 307

Madej Anna 282

Magierowski Marek 305, 306

Maj Czesław 10

Maj Ewa 149, 325

Maj Przemysław 24-26

Majewski Paweł 264

Makowski Marcin 210, 261, 274

Malinowski Krzysztof 178

Małecki Maciej 340

Marciniak Włodzimierz 105

Marcinkiewicz Kazimierz 19, 137, 233, 267, 345, 349, 377, 378, 391

Markiewicz Grzegorz 72

Master Beata 335, 336, 377, 398

Matyja Rafał 71, 72

May Theresa 255, 256

Mazowiecki Tadeusz 28, 127

Mazurek Kamil 258, 259

Mearsheimer John 327
Lennon John 167

Lewandowski Piotr 48

Lipiński Artur 14

Locke John 40

Łoś-Nowak Teresa 67

Łukaszenka Alaksandr 265, 266-268

Mehlhausen Thomas 388, 400

Meller Stefan 19, 116, 138, 139, 141, 191-193, 226, 243, 244

Memches Filip 172

Menkiszak Marek 209

Michałek Maciej 369

Mickiewicz Piotr 142

Miedwiediew Dmitrij 277

Mielnik Jakub 102, 244

Mieroszewski Juliusz 104, 113

Migalski Marek 72, 95

Milewicz Ewa 70, 195

Miller Leszek 23, 34, 69, 79, 163-165, 309, 319, 372

Miłosz Maciej 297

Minich Dobrochna 24, 25

Minkner Kamil 35

Mogherini Federika 251, 259

Mołotow Wiaczesław 196, 201, 202

Moravcsik Andrew 334

Morawiecki Kornel 106

Morawiecki Mateusz 19, 101, 175, $190,215,244,248,249,253,255$, $256,258,263,266,295,296,314$, 319-321, 361, 422

Morgenthau Hans 327, 328

Motusic Andreana Baeva 286 
Mucha Wojciech 311

Mularczyk Arkadiusz 174, 176, 177

$\mathbf{N}$

Nalewajko Ewa 337

Nałęcz Tomasz 15

Niedźwiecki Artur 233

Nosowski Zbigniew 15

\section{0}

Obama Barack 142, 143, 206, 277, 311

Och Jarosław 335, 336

Olczyk Eliza 102

Olszewski Jan 9, 79, 124-128, 216, 349

ö

Özkan Mehmet 351

$\mathbf{P}$

Pacześniak Anna 334

Panecka Agnieszka 122

Parsons Talcott 40

Partyka Magdalena 318

Paruch Waldemar 10, 29-31, 89, 92, $149,217,325,335,369$

Parys Jan 126, 319

Pazio Rafał 340

Pełczyńska Katarzyna 210

Pękala Mateusz 83

Piasecki Bolesław 78

Piątek Jarosław J. 120

Pieczyński Maciej 225

Pietraś Marek 29

Pietraś Ziemowit J. 31

Pietrzak Paweł 282, 285

Pietrzyk-Reeves Dorota 91, 183

Piłsudski Józef 9, 31, 48, 58, 64-66, 78, 104, 107, 114, 184, 196, 198, 200, 201, 216, 219, 289
Musiałek Paweł 116

Nowak Andrzej 16, 104, 198, 254, 278,326

Nowak-Jeziorański Jan 114, 122

Nowak Sławomir 210, 211

Nye Joseph S., jr 359

Orzelska-Stączek Agnieszka 16, 28, 116, 119, 139, 140, 172, 191, 212 Osiecki Grzegorz 224, 225, 237, 239, $261,275,281,285,307,320$

Ostrogski Konstanty 268, 269

Ostrowski Krzysztof 286

Piotrowski Marcin Andrzej 253

Piwnicki Grzegorz 112

Pleśniarska Aleksandra 334

Pocock Agard John Grevill 254

Poczobut Andrzej 266

Podgórzańska Renata 120, 123

Podniesiński Michał 375

Podolski Antoni 331

Potiomkin Władimir 201

Potocki Michał 237, 239, 275, 281

Primakow Jewgienij 194

Przybylski Jacek 281

Przybylski Wojciech 69

Putin Władimir 14, 133, 150, 153-156, $165,167,180,182,184,190,192-$ 204, 206, 207, 216, 221, 264, 273 , $277,278,285,317,370$

Pyzik Piotr 109, 314 
$\mathbf{R}$

Radwanowicz Paula 39

Rasmussen Anders Fogh 189

Raś Maciej 194

Reagan Ronald 23, 158, 271

Redłowska Kinga 286

Reinfeldt Frederik 370

Reykowski Janusz 18

\section{S}

Saakaszwili Micheil 157

Sabat Martynika 182

Sajduk Błażej 97, 364

Sakiewicz Tomasz 320

Sałajczyk Sławomir P. 68

Samsonowicz Henryk 17

Sanecka-Tyczyńska Joanna 16, 51, 87$89,132,141,142,148,159,218$, $219,264,294,336,354,355,382$

Sapieha Lew 269

Sarkozy Nicolas 411

Sasin Jacek 319

Schetyna Grzegorz 15, 39, 166, 278

Schmitt Carl 12, 36, 39

Schwartz Shalom H. 23

Sears David O. 10

Sellin Jarosław 212

Semka Piotr 59, 65, 342, 351

Siemoniak Tomasz 298

Sienkiewicz Bartłomiej 114, 115

Sienkiewicz Marcin 28, 255, 289, 290, 381

Siennicki Paweł 184

Sikorski Radosław 114, 116, 137-140, $155,165,168-170,172,173,182-$ 189, 205-208, 212, 213, 268, 308, 415,422

Sikorski Władysław 48

Skarzyński Ryszard 36, 89, 348

Skarżyńska Krystyna 18

Skvernelis Saulius 268

Słomczyński Wojciech 346
Ribbentrop Joachim von 196, 201, 202

Ricoeur Paul 86

Rubisz Lech 16, 72, 95

Rybińska Aleksandra 265

Rysiewicz Maciej 375

Snapkouski Uladzimir E. 266

Sobkowiak Leszek 40

Sokołowski Jacek K. 95

Soloch Paweł 282, 285, 316, 318

Sørensen Georg 64

Soroka Jerzy 289, 290

Stalin Józef 188, 199

Stanisławski Wojciech 229

Staniszewski Mariusz 179, 236, 272

Stec Andrzej 320

Stelmach Michał 11

Stelzer Irving 22

Stemplowski Ryszard 172

Stępniewski Tomasz 28, 266, 289, 290

Stolarczyk Mieczysław 80, 116, 171, 175, 192, 205, 220, 221, 258

Sułdrzyński Michał 264

Surmacz Beata 29, 266

Sykulski Leszek 98

Szajnowicz Jerzy I. 391

Szatkowski Tomasz 283, 284

Szczerski Krzysztof 16, 18, 19, 45, 88, $96,97,110,111,167,179,188$, 207, 208, 213, 214, 235-239, 244, 247, 248, 263-265, 271, 274, 275, $278,280,281,283-285,289,292$, 294, 297, 298, 304, 307, 309, 310, $315,317,320,321,334,341,342$, $355,356,361,364-366,372,375$, 392, 395-401, 407, 410 
Szczygło Aleksander 141, 223, 251, 311

Szpak Konrad 116

Szrubarz Henryk 197

Szydło Beata 19, 101, 160, 215, 231, 255, 256, 263, 280, 293, 295, 296, 298-300, 304, 307, 310, 422

\section{T}

Talleyrand-Périgord Charles-Maurice de 412, 414

Tarczyński Dominik 92-94, 109

Terlecki Ryszard 266

Terlikowski Marcin 133, 259

Tinder Glenn 18

Tischner Józef 12

Tomczak Marian 194

Tresnak Józef 271

Trump Donald 253, 256, 257, 274, 277, $288,295,299,307,313-319,422$

$\mathbf{U}$

Ujazdowski Michał K. 104, 164, 343 , 372,373

V

Vall du Marta 23

Vanhanen Matii 411

W

Walentynowicz Anna 79

Walicki Andrzej 188

Waltz Kenneth N. 119, 327, 352

Wałęsa Lech 28, 127

Warzecha Łukasz 9, 40, 43, 46, 64, $65,77,98,99,109,123,143,155$, $165,172,173,179,184,198,225$, $346,364,370,388,413$
Szymański Konrad 230, 244, 248, 249, 261, 294, 295, 320, 321, 357. 393, 394

Śmigły-Rydz Edward 201, 202

Śpiewak Paweł 71, 72

Świeboda Paweł 229

Świerczyński Marek 318

Świeżak Paweł 282

Tusk Donald 21, 26, 34, 42, 45, 49, 68, $69,79,80,87,115,116,124,131$, $141,143,149,150,153,154,163$, $165,169,180,182,186,188,190$, 191, 197-199, 205, 208, 210, 211, 229, 246, 261, 271, 274, 277, 281, $301,308,311,312,368,372,415$, 422

Tymoszenko Julia 198

Vico Giambattista 11

Waszczykowski Witold 18, 19, 78, $101,102,111,121,125,127,132$, $133,138,139,141,145,148,149$, 179, 187-189, 206, 207, 209, 210, $213,215,221-225,230,231,238$, $239,241,244,248-251,253,255-$ $257,259,261,266,272,275,279-$ 281, 286, 291, 292, 295-302, 304, $305,308,309,311,314-316,320$, $359,363,413$ 
Waśko Andrzej 55

Wągrowska Maria 140

Weber Max 40, 327

Wedel Joachim von 123

Wendland Marek 16

Weremiuk Sławomir 182, 186, 188

Werner Anita 184

Węc Janusz J. 257

Węgrzecki Janusz 17, 20

White Hayden 17

Więcławski Jacek 327, 328

Wilczewski Dominik 268, 269

Wilczyński Marek 17

Wildstein Bronisław 348

Y

Yoko Ono 167

Z

Zając Justyna 97

Zając-Frąs Magdalena 333

Zakrzewski Stanisław 142

Zalewska Marta 403

Zalewski Paweł 156, 178, 179, 242, 251

Zapatero José Luis Rodríguez 267

Zaremba Piotr 9, 83

Zdort Dominik 170

Ż

Żukowski Tomasz 64, 117

Żurawski vel Grajewski Przemysław $16,28,34,60,120-122,150,173$,
Wiśniewski Bartosz 253

Witkowski Przemysław 142

Witos Wincenty 78

Wittgenstein Ludwig 11

Wodzińska K. 142

Wojciechowski Sebastian 194

Wolański Marian S. 168

Wołek Artur 353

Wójcik Alicja 31

Wróbel Sylwester 40

Wróblewski Tomasz 272

Wybranowski Wojciech 212

Wycech Czesław 78
Zenderowski Radosław 359

Zieliński Tadeusz 259

Zielonka Jan 398

Ziemkiewicz Rafał A. 42

Zięba Ryszard 97, 119, 126, 128, 136, $194,216,271,308$

Zuba Krzysztof 16, 326, 330, 331, 334, 337, 363, 399

Zyblikiewicz Lubomir 182

$178,182,189,208,239,245,252$, 286,346 



\section{Skróty}

$\begin{array}{ll}\text { AWS } & \text { - Akcja Wyborcza Solidarność } \\ \text { EWG } & \text { - Europejska Wspólnota Gospodarcza } \\ \text { FR } & \text { - Federacja Rosyjska } \\ \text { KP PiS } & \text { - Klub Parlamentarny Prawo i Sprawiedliwość } \\ \text { KPRM } & \text { - Kancelaria Prezesa Rady Ministrów } \\ \text { LPR } & \text { - Liga Polskich Rodzin } \\ \text { MSZ } & \text { - Ministerstwo Spraw Zagranicznych } \\ \text { NATO } & \text { - Organizacja Paktu Północnoatlantyckiego } \\ \text { NSZZ „Solidarność" } & \text { - Niezależny Samorządny Związek Zawodowy „Solidarność" } \\ \text { PC } & \text { - Porozumienie Centrum } \\ \text { PE } & \text { - Parlament Europejski } \\ \text { PiS } & \text { - Prawo i Sprawiedliwość } \\ \text { PO } & \text { - Platforma Obywatelska Rzeczypospolitej Polskiej } \\ \text { PO-PSL } & \text { - Platforma Obywatelska Rzeczypospolitej Polskiej-Polskie } \\ & \quad \text { Stronnictwo Ludowe } \\ \text { PSL } & \text { - Polskie Stronnictwo Ludowe } \\ \text { RFN } & \text { - Republika Federalna Niemiec } \\ \text { RP } & \text { - Rzeczpospolita Polska } \\ \text { SLD } & \text { - Sojusz Lewicy Demokratycznej } \\ \text { SS Sejm } & \text { - Sprawozdania stenograficzne z posiedzeń Sejmu RP } \\ \text { TSUE } & \text { - Trybunał Sprawiedliwości Unii Europejskiej } \\ \text { UE } & \text { - Unia Europejska } \\ \text { USA } & \text { - Stany Zjednoczone Ameryki (tłumaczenie) } \\ \text { UW } & \text { - Unia Wolności } \\ \text { WNP Sejm } & \text { - Wypowiedzi na posiedzeniu Sejmu RP } \\ \text { ZSRR } & \text { - Związek Socjalistyczny Republik Radzieckich }\end{array}$


Waldemar Paruch

Realizm i wartości. Prawo i Sprawiedliwość o polityce zagranicznej Instytut Europy Środkowej, Lublin 2021

https://doi.org/10.36874/M21443

\section{Recenzent}

Dr hab. Przemysław Żurawski vel Grajewski, prof. Uniwersytetu Łódzkiego

\section{Korekta}

Zespół Instytutu Europy Środkowej

@ Instytut Europy Środkowej

ISBN

978-83-66413-44-3

Wydawca

Instytut Europy Środkowej

ul. Niecała 5

20-080 Lublin

www.ies.lublin.pl

Druk

Drukarnia Akapit

www.drukarniaakapit.pl 


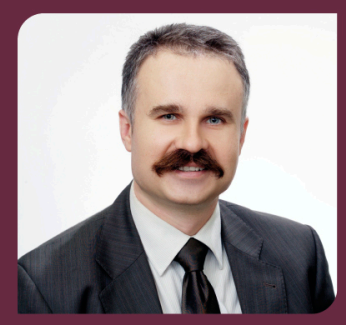

Prof. dr hab. Waldemar Paruch - profesor nauk społecznych w zakresie nauk o polityce i administracji, twórca i kierownik Katedry Metodologii i Teorii Nauk o Polityce i Administracji na Uniwersytecie Marii Curie-Skłodowskiej. Specjalności naukowe: metodologia badań politologicznych, teoria polityki, myśl polityczna, systemy polityczne (autorytaryzm), partie polityczne (ruch ludowy, obóz piłsudczykowski, Prawo i Sprawiedliwość), stosunki międzynarodowe (systemy bezpieczeństwa, polityka zagraniczna Rzeczypospolitej, Europa Środkowa). Autor ponad 240 publikacji naukowych, w tym około 30 publikacji zwartych, redaktor naczelny/przewodniczący komitetów naukowych kilku czasopism z zakresu nauk społecznych, w tym redaktor naczelny "Przeglądu Sejmowego". Pełnił funkcje doradcy Marszałka Sejmu RP (2015-2018) oraz szefa Centrum Analiz Strategicznych w Kancelarii Prezesa Rady Ministrów (2018-2019). Jest członkiem Rady Fundacji CBOS, ekspertem Sejmu RP, przewodniczącym Rady Polskiej Fundacji Narodowej, głównym ekspertem projektu „Europa Karpat”, analitykiem spraw publicznych, specjalistą w zakresie polityki zagranicznej. 